UNIVERSIDADE DE SÃO PAULO

ESCOLA DE COMUNICAÇÃO E ARTES

CARINA GONZALEZ Y SOUSA

COMUNICAÇÃO TRANSLÚCIDA: RESSONÂNCIAS ESTÉTICAS DO CONTEMPORNÂNEO.

São Paulo

2018 
CARINA GONZALEZ Y SOUSA

COMUNICAÇÃO TRANSLÚCIDA: RESSONÂNCIAS ESTÉTICAS DO CONTEMPORNÂNEO.

Tese apresentada a Universidade de São Paulo na Escola de Comunicação e Artes no Programa de Ciências da Comunicação para obtenção do título de Doutora em Comunicação.

Área de Concentração: Teoria e pesquisa em comunicação.

Linha de pesquisa: Linguagens e estéticas da comunicação.

Orientador: Victor Aquino.

São Paulo 


\section{Nome: Carina Gonzalez Y Sousa}

Título: Comunicação translúcida : Ressonâncias estéticas do contemporâneo

Tese apresentada a Universidade de São Paulo para a obtenção do título de Doutora em Comunicação.

Aprovado em:

Banca Examinadora

Prof. Dr.

Instituição

Julgamento

Prof. Dr.

Instituição

Julgamento

Prof. Dr.

Instituição

Julgamento

Prof. Dr.

Instituição

Julgamento

Prof. Dr. 
Dedicatória: A vida 
Agradecimento: A DEUS.

Sem ele nada sou. 
"A capacidade do homem de conhecer o seu caminho depende do quanto que dele não o conhece. A cada dia, o mesmo deve te parecer outro, assim sendo estarás, atento, e um passo após o outro, indagarás a consciência, para olhar sobre o conhecido com os olhos do desconhecido. “

Do espaço e do tempo

Presente

Eles diziam sobre o desconhecido, um espaço onde se pode ser presença, ausência estando por toda parte. Eles, diziam sobre o desconhecido, do que está em tudo que não temos a alma de perceber na carne do mundo. Eles diziam do desconhecido, havendo dúvida no olhar, porque não o reconheciam em seu próprio lugar. Eles diziam do tempo a procura do espaço, arquitetura do movimento. Eles diziam do pensamento querendo encontrar o caminho, e agiam querendo dizer, para ver a imagem do seu tempo. Eles eram seres humanos a procura da vida. Arquitetos do existir, erguendo suas lutas sobre as raízes de sua natureza. Eles diziam, onde por vezes precisamos ouvir, e ouvindo, sendo a palavra que é capaz de nos dar os instrumentos da razão. Compasso e esquadro. Arquitetos em construção.

*Este trabalho solicita licença, vindo respeitosamente colocar em seu corpo de texto e não como referência, breves poemas compreendendo que a apreensão deste objeto de estudo pode estar alicerçada pela expressão poética em este especifico meio textual favorecendo o entendimento. Músicas, letras e livros de poesias assim como outros trabalhos de aporte literário estarão como anexo, porém, os do corpo do texto aqui, se fazem eminentes. 

Resumo

Esta pesquisa propõe auscultar o corpo orgânico dos tempos atuais, realizando um diagnóstico para tentar elucidar os caminhos possíveis para a compreensão dos embates nos quais estamos inseridos em dilemas de ordem particulares e de escala global, onde a comunicação tem papel de primazia sendo o desenvolvimento de suas relações a possibilidade de viabilizar e concretizar o entendimento dentre a organização de um viver contemporâneo. Tratamos de realizar um traçado onde a vida se constitui o produto de nosso tempo e a maneira como ele é composto é o tema da obra, que se manifesta no cotidiano. e o desafio dessa percepção assim como a interpretação, e os rumos cognitivos para se preservar uma ressonância entre o efêmero são elementos que estarão sobre análise. Consideramos que para uma cultura sustentável é primordial educar o pensamento, sobre os modos de olhar o mundo, onde tanto o desatrelar do imediato como forma de encontrar um significado em acréscimo de sentido, e para tal creditamos em parte uma lógica que comporte o modo de ser da metáfora; assim como a prática de relações, mediar a apreensão em conexões, e sobre o que pode ser de responsabilidade ética, enquanto desenvolvimento, assim, neste contexto, o diálogo com as imagens, sons e textos das cenas da narrativa social. Ao considerar linguagem no referente a comunicação estamos tratando de tudo que existe e age no mundo, portanto a liberdade de expressão se instala na vontade de existir e onde a comunicação é a chave para o entendimento. A pesquisa se fundamenta em aspectos do som, como lógica e presença, sendo realizado também, um conjunto de composições inseridas no estudo do som em geral, um paralelo onde se caracteriza a complexidade como também o exemplo de que podemos encontrar a possibilidade da harmonia em comunicação, em diversas vozes, e também diversidade de instrumentos, características que acreditamos demostrar a viabilidade do tempo, a multiculturalidade, dispondo como face de entrelaçamentos onde tanto informações como modos de emissão, podem se encontrar. Em conjunção aos aspectos teóricos também foi realizado vídeos, e um trabalho de coreografia, interpretação e som, onde o propósito é esclarecer mediante a filmagem, como nos deparamos com as probabilidades em curso, em paralelo das imagens da própria vida, de elementos informacionais agregados, uma cena após a outra, como os compassos da música, e apreender o que permanece em ressonância como capacidade de comunicação é o desafio da atualidade. Dentre os aspectos referentes a 
percepção da realidade, e sua possível representação em valor da voz da palavra, encontramos, também como parte do escopo deste trabalho, acreditando que a pesquisa do discente não finda na defesa, mas perpetua em interesse de conhecimento, para tratar do subjetivo, dos aspectos da sociedade, e da identidade humana, alguns anexos literários, dentre eles, citamos Balsamo da noite, ensaios poéticos filosóficos, e a trilogia Casa vazia, um conto só diferente, e o direito de viver. As questões teóricas perpassam os textos dando vazão aos embates da sociedade atual e buscas infindáveis da compreensão dos diálogos da comunicação.

Palavras Chave: Comunicação. Cultura. Cidadania. 
Abstract

This research proposes to listen to the organic body of the present times, making a diagnosis to try to elucidate the possible ways to understand the conflicts in which we are inserted in dilemmas of particular order and global scale, where communication has a primacy role being the development of their relations the possibility of making feasible and concrete the understanding between the organization of a contemporary living. We try to draw a path where life is the product of our time and the way it is composed is the theme of the work, which is manifested in everyday life. and the challenge of this perception as well as the interpretation, and the cognitive directions to preserve a resonance between the ephemeral are elements that will be on analysis. We consider that for a sustainable culture it is essential to educate thought, about ways of looking at the world, where both the untying of the immediate and the way of finding meaning in addition to meaning, and for this we believe in part a logic that includes the mode of being of the metaphor; as well as the practice of relationships, mediate the apprehension in connections, and on what can be ethical responsibility, while developing, thus, in this context, the dialogue with the images, sounds and texts of scenes of social narrative. When we consider language in relation to communication we are dealing with everything that exists and acts in the world, so freedom of expression is installed in the will to exist and where communication is the key to understanding. The research is based on aspects of sound, such as logic and presence, being also realized, a set of compositions inserted in the study of sound in general, a parallel where the complexity is characterized as also the example that we can find the possibility of armony in communication, in diverse voices, and also diversity of instruments, characteristics that we believe demonstrate the viability of the time, the multiculturality, disposing as a face of interlacings where both information and modes of emission can be found. In conjunction with the theoretical aspects, videos, and a work of choreography, interpretation and sound, where the purpose is to clarify through filming, as we are faced with the probabilities in progress, parallel to the images of life itself, aggregated informational elements, one scene after another, like the bars of music, and apprehending what remains in resonance as a capacity for communication is the challenge of the present. Among the aspects concerning the perception of reality, and its possible representation in the value of the voice of the word, we find, also as part of the scope of this work, believing that student research does not end in defense, but perpetuates in the interest of 
knowledge, to treat the subjective, the aspects of society, and human identity, three literary annexes, composed of Night Balm, philosophical poetic essays, and the empty House trilogy, a different story, and the right to live. The theoretical questions permeate the texts, giving vent to the current society's struggles and endless searches of the understanding of the dialogues of communication.

Keywords: Communication. Culture. Citizenship. 
Lista de composições inseridas.

Letra e melodia.

1.Natureza

2.As árvores

3.0 tempo não espera

4.0 sal da terra

5.Humana condição

6.Espetáculo em sociedade

7.Um dia de domingo

8.0 preço

9.Entulho

10.Por onde vou caminhar

11.Direito de viver

12.Porque sobrevive

13.0 circo

14.Das folhas ao vento

15.Das folhas ao vento

16.Socialmente aceitável

17.Tecendo raízes

18.Avenida - Homenagem as costureiras do samba.

19. A roda

20.A outra porta

21.Multidão

22.Algozes dos ossos

23.Rios da gente

24.0 corpo

25.A ferida aberta

26.Os lugares

27.Cidade 
28.Vem de lá

29.A mata

30.Espaço de uma nação

31.Dos abusos de poder

32.Os destroços

33.Terra

34.Ciclos

35. As cartas da vida

36.Vem dizer para mim

37.0 mundo

38.Faces da terra

39.Ver a igualdade

40.Qual a razão

41.As gotas da chuva

42.Travessias

43.Sobre o céu

44.0 social humano

45.Mordaças

46.Qual a cor da minha pele

47.Lugar da manhã

48.Exílio

49.Ribeirinho

50.A beira

51.Uma verdade por se conhecer

52.Quem somos

53.Promessa

54.Esse teu direito de viver

55.Por onde vai

56.Por mais estranho

57.Do copo vazio

58.Sopra o vento 
59.0 preço de um insulto

60.Meus braços aos céus.

61.Árvore da vida

62.As pétalas se despedem

63.Vamos ver o amanhã

64.É domingo

65.Dos ladrilhos

66.Expressão

67.Cada vez

68.Precisa

69.Calçada

70.Madrugada.

71. Basta.

72. Do ventre do mundo.

73. HORUS - Acesso

74. Composição - Piano: Saga da Justiça, Hino à Justiça- Fogo Sagrado, O corpo da justiça.

75. Súplica da natureza - Piano

76. Composição - Piano: Liberdade. Asas do céu. Sonhos de liberdade, entre almas.

77. Das folhas ao vento- Piano

78. Composição Piano - hino e melodia - Fraternidade

79. Composição: Igualdade - Piano

80. Composição: A força de um viver- Piano

81. Entardecer - Flauta

82. De outras águas - Violino

83. Do sonho, entre a mensagem do caminho. Piano

84. Caminho do vento. Piano

85. Tabla. Sanguinea

86. Dos campos do sofrimento. Piano

87. Paisagem da solidão, Piano

88.Entre as notas do que chove na alma. Piano

89. Sem poder tocar o que se ouve nas águas do mar. 
90. Tempo triste

91. Pingos de anil, composição realizada para tocar com uma mão-Piano- Homenagem ao Maestro João Carlos Martins.

92. Tarde suave. Piano

93. Composição - GEO-ACESSO

94.Infinito- КОТО

95. Duas almas. Piano

96. Sabor de amar. Piano

97. Na pele da alma. Piano

98. Sobre o por do sol. Piano

99. Asas do céu. Piano

100. Sonhos de liberdade. Piano

101. Travessia. Piano

102. Manhã de glória. Piano

103. Glória ao senhor. Piano

104. Obreiros do céu. Piano

105. Sopro de paz. Piano

106. Infinito. Piano

107. Bethadt. árvore da vida. Piano

108. Vento 4 e 6 . Piano

109. Coração do deserto. Guitarra

110. A cor do sangue. Acordeon

111. Nuvens sobre o céu azul. Piano

112. Um lugar para existir. Piano

113. Asas do afeto. Piano

114. Nas margens de mnemosine. Piano

115. Estrela. Piano

116. Neblina sobre o amanhecer. Piano

117. Caminho do vento. Piano

118. Esquina do tempo. Piano

119. Eterno. Piano 
120. Floresta. Piano

121. O destino. Piano

122. Melodia da tarde. Piano

123. Êxodo. Piano

124. Um dia antes. Piano

125. Olhos da noite. Canto som

126. Fênix. Canto som

127. Um sonho e um coração. Composição realizada para uma mão somente. ACNUR-UNESCO.

para qualquer pessoa que por acidentes, ou vidas em áreas de risco. Para também pessoas com problemas de saúde.

128. Elixir. Piano

129. Sueña el amor - Piano. Composição para uma mão.

130. Jasmim. Piano

131. Raios do sol. Piano

132. Baile da alborada. Piano

133. Os ventos. Piano

134. Sagrado da natureza. Natureza das leis de Deus, homens e do direito.

135. Revoada. Piano

136. Cinzas. Piano

137. Vítimas do mundo. Piano

138. Entre lugares. Passos entre fogo. Piano

139. Do que chove na alma. Piano

140. Meu som entre blues. Piano

141. Entre caminhos. Piano

142. A tarde. Piano

143. A saga da justiça. Piano

144. BELIVE. Canto. 


\section{Sumário}

\section{Introdução}

Capítulo 1 - $\quad$ Sustentabilidade do pensamento. Concepções diagramáticas .23

1.1.Responsabilidade cultural, imagem em representação 46

1.2. $\mathrm{O}$ tempo, ele mesmo, produto em consumo. .99

1.3.Sedução, cumplice

do desejo, latência do existir.

1.4. A construção da percepção monotipia, a passagem interna como ser no mundo...165

Capítulo 2 - A ressonãncia, a contrução em afecções .226

2.1 .A mediação nos caminhos da comunicação .228

2.2 Figura $\mathrm{e}$ o fundo, interfaces do engendramento. 300

2.3 Seres de ovídeo em mutação, perspecivas do olhar.

2.4.. A s estrutura sonora em movimento de imagens.....................................................349

$\begin{array}{llllllll}\text { Capítulo } & 3 & - & \mathrm{O} & \text { verso } & \mathrm{e} & \mathrm{o} & \text { reverso }\end{array}$ palavra 354

$3.1-$ A metáfora, no através dos sentidos do enigma 355

3.1.1

Uma

fenomenologia do imaginário 390 
3.1.2 O desnudar do viver, entre a retórica e a poética 418
3.2
Deslocamentos
da
edificação
de

significados

.426

3.3. - $\quad$ A poética do sensível uma face do conhecer .434

Capítulo

4

Comunicação

translúcida .436

$4.1 \quad-\quad$ Adjancências $\quad$ e $\quad$ transparências, $\quad$ gerando a experiência 436

4.2. - $\mathrm{O}$ sujeito mundo e suas narrativas 447
4.3
Aspectos
de
uma
mobilidade

comunicacional. .513

$4.4 \quad-\quad$ Do $\quad$ que $\quad$ pode nascer do

sonho .532

$\begin{array}{llllll}\text { Capítulo } & 5 & - & \mathrm{O} & \text { palco } & \text { do }\end{array}$ mundo. .541
5.1 .
A
experiência
audiovisual,
sinestesia

explicita .558

5.2 A margem do som, amalgama da imagem, escritos de um tempo .562

5.3. Esferas em construção, Bethadh - a arvore da vida. 568

5..4. Do poema da vida, inacabado e a dizer. 575

6. Conclusão .575

Anexos do corpo do traabalho - Da autora da tese.Carina Gonzalez Y Sousa 
1- Bálsamo da noite - literatura e som -100 poemas e composições-

2 -Desmembramento - Duas vidas e um destino -

3 - Das cores - literatura e imagem em desenhos liquidos- texto, som e pintura

4 - Gingado - poesia

5 - Diário da manhã

6 - Ensaios poéticos teatrais O escritor de corpos

7 - Derivação de corpos - partitura dramaturgica - Cena, texto e som.

8 - Depoimentos - Expressão teatral de texto e som.

8.1.Constatação

8.2. Os riscos e a justiça

8.3. Mundo melhor

8.4. Sobre o amor e o esquecimento

8.5. Da vida - um contexto

8.6 Lugar e representação

8.7.No meu verso

8.8. Confesso

8.9. Café

9.0. Diálogo da fé

9.1.Melodia - Orifício

9.2. Edifício

9.3. CARNE

9.4. LÍBIDO 
9.5. ENTREGA

9.6. COMEU

9.7. OROBORO

9.8. ÁGUAS

9.9. U M(UNDO - ACESSO

10. MOMENTO

10.1.PÃO E ARTE

10.2.HUMANA CONDIÇÃO

10.3. POSIÇÃO

10.4.ILUSÕES

10.5.SOLO DO INVERNO

10.6.ESCULTURA

10.7. TORTURA-ME

10.8. LABIRINTO

10.9. UM DIA

11. COGNIÇÕES PARALELAS

11.1. COGNIÇÃO II

11.2. ENTRE OS PASSOS

11.3.ÁRIDO SONHO

11.4.FENDAS

11.5.MNEMOSINE - MITOS EM ARCOS

11.6.POROS NOSSOS

11.7. EXAUSTO CORPO QUE CARREGA A ALMA 
11.8.VIDA E MORTE

11.9.DA MANHÃ - REALEJO

12.DIÁRIO DA MANHÃ- ENTRE “ ” REALIDADE POSSÍVEL

12.1.PASSAGEM I E II.

9 - Um conto só diferente

10 - Casa vazia

11 - Direito de viver.

12- MADELEINE. Romance

Arquivos de vídeo - Sala 25

Arquivo das letras - Música Brasileira

Aquivo de algumas composições - Piano e Digital para diversos instrumentos. 



\section{INTRODUÇÃO}

Este trabalho de pesquisa inicia-se com a presença da obra intitulada, obreiros do amanhã, música composta em agradecimento. Mais do que qualquer compreensão, o aprendizado deste caminho é da presença de Deus, como elemento fundamental de nossas vidas.

Composição ao piano- obreiros do amanhã é o agradecimento, por acreditar na presença Dele, justamente razão da qual dedico este trabalho a Deus, e porque sei que sem Ele, sou nada. Então, ao me referir que isto é trabalho, ouço em minha alma, que é ser obreiro. Para que eu sempre me lembre que do destino, a escolha dentre a fé que torna a vida o significado de existir sobre a razão de estar nos braços de Deus é desses e nesses braços, que tomo a força para erguer o grão como aprendiz que devo ser, eternamente, em construção, diante das mazelas da vida. Não foi fácil, lidar com injustiças, pedras, apunhaladas, e incompreensões, estas ainda persistem no cotidiano de todos nós, e dentre o educar o pensamento como razão do sentimento, toma-se a consciência de que, algo do que morre, a cada dia nasce, e me parece sempre, que o renascimento, este orixá da vida, aqui sempre presente, mostra-se fiel, a presença do que nos faz, ser, parcela ou filhos, do Pai, que tanto chamo. Duas vidas e um destino. Estamos sempre, juntos, mesmo quando, nele não estivermos, Ele está em nós. Duas vidas e um destino.

E agora entendo, lágrimas de Cristo, chove. Eu tenho tanta certeza da consciência de ser obreiro mesmo que não me pertence, pertencendo, porque é da natureza desse Ser no qual nos habita e nos torna o que somos, ou o que poderemos ser. Sei que nada sou, mas Nele, posso ser algo, fagulha de uma centelha, da mesma chama, ao redor do fogo, espaço do tempo de criação. A certeza de Deus é sempre sentimento, pleno, emoção. Sempre. Razão sensível que nos habita, ser no mundo. E perde-lo, pelos atos humanos, é a maior tristeza. Então, aprender como ficar ao lado dele, quando os homens, querem esquecê-lo ou a morte dele, será o maior aprendizado da vida. Disso tudo me mostraram que da crueldade, da injustiça, e de todos os males, o maior aprendizado, é ainda ter a razão da presença de Deus, não perder a fé, e a crença Nele. O que mais aprendi em tudo que vivi, ainda foi estar ao lado dele, quando dele, estava tão longe. Assim somos, pais e filhos, e Dele também, filhos. O caminho é um só.

Multidão. Choro com alegria agora, e gratidão. Essas lágrimas, mais do que minhas, devem ser do perdão, comigo, com o que vivi, e para com os que feri, temendo a incompreensão do 
que é viver. Vela acessa. Quantas civilizações, quantas dimensões, quantos de nós. Quantos tempos, e templos. Quantas vidas e almas, corpos do mesmo movimento.

Esta pesquisa tem como tronco principal, o objeto da vida como produto de nosso tempo, onde como a compreendemos, como vivemos, e o que almejamos para a sociedade futura será aqui demostrado como o auscultar do corpo orgânico na organização de nosso viver. Sendo assim, esperamos encontrar nesta pesquisa a busca perene que percorre desde o educar o pensamento, a cultura sustentável onde estamos imersos, ou almejamos estar, assim como de que maneira o ser pode na atualidade corresponder de fato e verdadeiramente a sua VERDADE. Então, pondera-se que entre o que representa a nossa história, como a vemos, com quais imagens construímos nossos caminhos, e de que forma a emissão em comunicação se estabelece, sendo que ainda o silêncio possa ser a respiração de nosso tempo, em movimento e não ausente; de maneira que mesmo imersos em ilusões, possamos ter o discernimento para realizar e diagnosticar o nosso cotidiano em reflexões cada vez maiores, para que o consumo encontre a vida com os valores que pretendemos às gerações futuras. De que maneira o que desejamos, se concretiza na realidade nesse oásis ou miragem deverá ser um desafio e ainda, quanto ao que criamos em viver, devemos fazer do palco do mundo, a cena mais fiel que possamos sentir, onde a razão prevaleça e sempre cada vez mais como compasso e prumo do esquadro de nossas condutas. A arquitetura é plena sobre o cosmo, em geometrias do sentimento, onde do que nos faz pulso do mundo, seremos os rios de sangue, na construção ininterrupta de nosso tempo. No desejo de existir, a sedução que nos contempla exala a amplitude que deverá estar sobre todos os nossos propósitos pautados pela ética, por uma complexidade onde as conexões se estendam de maneira a realizar percepções antes não exauridas do sistema em que nos encontramos, e que carece de uma lógica com relações cada vez maiores de expansão. Os embates naturais de um indivíduo e a sociedade como princípio de um estar no mundo como cidadão consciente requer o diálogo constante e de reflexão de uma expressão livre e responsável que priorize a liberdade, a justiça, a fé e a razão, assim estando sobre a ordem e o progresso, de nossa terra ${ }^{1}$, de nosso ar e de nossos mares, como chama do fogo que não deverá se apagar. Calcadas estarão como monotipia os nossos atos em comunicação e deles estaremos prontos, para realizar a passagem interna como ser no mundo, a nossa marca, a vida, de nosso olhares e sentidos, entre os passos como nossa conduta e a imagem dentre a missão que constituímos será dentre o que somos e o que queremos, o que representa o produto de nosso tempo.

\footnotetext{
${ }^{1}$ Composição: força de um viver -
} 
Partindo da compreensão do som, espaço constituído de vibração como já exposto em Ágape, arte como a vida, nossa dissertação de mestrado na Universidade de São Paulo, a comunicação torna-se pauta, onde os elementos em diversidade, respeito e união se formam para a existência da harmonia. Estados da natureza planetária, constituídos e constituintes de nossa dignidade será a integridade que procuramos, e em nossa pesquisa, que não tem a menor pretensão de se extinguir aqui, ao contrário, tem a consciência da presença do aprender eterno, onde somos para

todo o sempre aprendizes. A realidade tão objeto de desejo, entre as dificuldades, são sonhos a serem conquistados onde a sobrevivência na maior parte é o dia do amanhã, saciando a fome, a pobreza, as mazelas humanas, onde o firme propósito esteja na compreensão de cada um, e o outro, como sociedade não apartada de si, mas envolvida em seu ventre gerando seus frutos cônscios cada vez mais, para a construção de um ideal que nutre gerações em fraternidade, igualdade e liberdade. Mas, para tal, depõe seu cotidiano sobre todos os argumentos favoráveis e contra, onde espera com toda sua luta, a justiça! ${ }^{2}$

Nesse caminho, onde a perspectiva se torna ponto de fuga, levantamos a hipótese de que nos tempos atuais, precisamos da ressonância como fator primordial onde não percamos a informação capaz de elucidar o discernimento necessário para termos o que perpetua frente ao efêmero que nos desgasta, para que o desenvolvimento ocorra na presença da vida como força do elemento capaz de proporcionar o continuo. Como instrumento dessas conjecturas que serão do decorrer do texto apresentadas, temos a mediação sendo fundamental para a cognição.

Na composição da imagem da vida, figura e fundo são um entrelaçamento, onde o que cada um representa está imbuído do significado de suas vozes sendo ouvidas, e como seres em mutabilidade a conjugação se faz uma frase continua de significado acrescido de valor. E como a organização apreende essas conjecturas de relações em movimento é uma constatação cada vez maior no tempo vigente. $\mathrm{O}$ verso e o reverso da palavra são o corpo do sentido e alma do significado, princípio de uma forma de pensar onde a metáfora adquire importância de maneira licita, como o gesto da poesia, para que possamos ver e ser da realidade a força que ela pode representar alcançando dimensões não imediatas. O imaginário concede entre a densidade do existir a volúpia de uma transposição onde as cenas do palco são a narrativa do personagem real que se desmembra entre suas faces em natureza

\footnotetext{
${ }^{2}$ Sousa, Carina Gonzalez. Composição da Saga da Justiça - O corpo da justiça - Hino da justiça - fogo sagrado.
} 
interna e externa do ser no mundo, como sujeito múltiplo existindo entre a facticidade e o sonho, revelando o desnudar do viver, constrói argumentos de uma retórica capaz de pertencer a ambos sobre os olhos da poética.

E nesse tempo vigente creditamos ao olhar de uma comunicação translúcida por onde a luz atravessa, ainda um olhar que em parte sombras podem estar em profundidade como fundo que não se vê, mas onde o cotidiano atual, traz a tona do que necessário é de se conhecer. Onde se perpetuam elementos informacionais temos o resgate de imagens, sons e palavras onde o viver se inscreve, como marca dos passos de sua travessia, onde adjacências e transparências geram experiência.

O sujeito de uma economia planetária onde busca a intersecção de territórios do saber, preserva e compreende o ambiente não somente como natureza, mas como naturezas do existir, onde os valores e aspectos das culturas priorizadas pelo respeito estimulam o desenvolvimento para uma sociedade mais justa como princípios de igualdade entre nações, onde pode até ser visto como uma utopia mas que acreditamos que deva ser nutrida a ponto de realizar-se concretamente em futuro, onde os recursos serão de maneira a constituir uma cultura organizacional de Nações. E essa presença de multiculturalidade é importante, porque no sujeito mundo e suas narrativas, cada vez mais, estaremos em redes reais, compartilhando esforços para que o mundo deixe de sobreviver como partes, mas que viva por inteiro, ainda que cada qual tenha sua identidade. E dentre essa realidade, estaremos cada vez mais concebendo aspectos da mobilidade comunicacional.

E no meio disso tudo, do que pode nascer do sonho. A esperança perdida, mas, quem sabe um dia ainda possa existir, e no palco do mundo, o modo de ser em sinestesia se engendra tanto como cognição como também busca de significados entrelaçados, compartilhados em desmembramentos de cenas cotidianas, onde o sentido do filme, é a própria realidade, posta como narrativa humana em saga de seus desejos, tristezas, in(compreensões), e aprendizado.

Estamos imersos em um "filme" em tempo real, e assim considerado a mente, os sentidos, a cognição se acerca da experiência audio-visual, da dramaturgia, cada vez mais. E os nossos espaços entre protagonistas, coxias ou espectadores estão em um só roteiro, que é a arvore da vida, Bethadt. Onde o limite da ficção e da realidade são para construir vidas e não destruir. e que o equilíbrio seja sempre a presença da razão na consciência. 
Capítulo 1 - Sustentabilidade do pensamento. Concepções diagramáticas

Por uma sustentabilidade do pensamento, em uma economia planetária.

Aprender a organizar o pensamento além de exigir um habitar integro consigo mesmo, deverá estar observando-se por onde as raízes de seu pensar estão fincadas como natureza ${ }^{3}$ sua e do mundo que o cerca, sobre quais determinações e rumos, para além do que consideramos indeterminado, fator este de gérmen da criação.

A sustentabilidade do pensamento não somente se configura em como ele ocorrerá em suas diagramações, mas, todavia, o que o move justamente à elas, e portanto, o que antecede as conjecturas de um pensar. Em uma palavra, equilíbrio, conexões estabelecidas sobre critérios de equalização priorizando uma harmonia. Em certo ponto, me parece que em meio ao cotidiano que promove amortizações, devemos declarar como podemos estar em nossa vida enquanto pensamento e ações, no que consiste, estar off, ou stand by, ou in, de maneira que não de súbito sejamos despertados para um pesadelo de dívidas por onde o mundo que sobrevive, terá que arcar com seu estado de eminencia de ou quase morte, onde as custas, serão um peso talvez demasiado para se suportar. Creio que portanto, haveremos de realizar

\footnotetext{
${ }^{3}$ Sousa, Carina Gonzalez Y. Música Brasileira. Natureza: Quem sabe a natureza nos ensina, A viver... quem sabe o amor nos vê chegar. Nessa beleza que a natureza nos faz olhar. Um dia poderemos nos revelar. Um dia poderemos nos revelar. Um dia poderemos saber do que é amar. O que é amar. Então, nos abraçamos da verdade, e como irmãos. Um dia quem sabe. Quem sabe, talvez a natureza, esteja a nos acolher, para que possamos ver, o que queremos de tanto que sofremos, mais então, por onde vamos. Que não saibamos o que é viver. E porque e porque... Ainda erramos. Se desde tempos tão antigos já foi escrito... Que sem o amor, não viveremos. E agora, então, me diga meu irmão, o que fazer.... o que fazer. e a composição e letra: As árvores: As árvores estiveram a me tocar. Querendo saber o seu lugar. Tantos lugares do mundo, e agora as folhas vazias, do outono tão queridas, o vento levou. Soprou na janela a saudade, de onde haverá esse nosso respirar. As arvores dos troncos da minha aldeia. Que é desse povo e a mesma seiva. E agora, se demora o orvalho que ficou na tua folha, escreveu o seu destino, que repousa como voo do passarinho, que do mansinho sobreviveu, se o teu ser te ergue vem viver, essa casca do mundo, tronco
} 
um procedimento capaz de averiguar e regenerar ou ainda mais, reportar a nossa gênese, ou para os rumos, do que queremos para o futuro, no qual o presente necessita se moldar, conforme os objetivos de concretude real, de projetos avançados de desenvolvimento, onde o pensamento e a educação parte do princípio de condutas condizentes com o pensamento. Portanto, e de suma importância será sempre, e cada vez mais, organizarmos a gestão do que queremos enquanto votos em cadência de depósitos em "confiança" do que almejamos enquanto cidadãos de um pensar em conjunto, no que para isso, precisemos considerar o outro, cada vez mais, integro de nossos esforços como decorrência de planejamento social, imbuídos dos mais reais desejos de um viver melhor, onde não seja na realidade vigente apenas o indivíduo como gesto de cidadania, mas o corpo social, como diretriz de uma consciência.

Para tal, precisamos nos ater ao como se organiza esse planejamento de desejo futuro, em conexões do pensar, para sermos obreiros verdadeiramente do que queremos, enquanto seres capazes de realizar, o desencadeamento de matrizes que poderão concretizar o equilíbrio dentre os desafios, dos déficits nos quais estamos imersos como economia planetária de um viver comum.

Parte de um viver comum se torna emergente como necessidade sendo o caráter da realização de concepções diagramáticas, onde a noção de continuidade e contiguidade se fazem profusas nas relações. Nesta hipótese a construção da continuidade se entrelaçando com a contiguidade opera pelo modo de ser da música, em cognição que abrange a ressonância onde os espaços do tempo, em integralidade todavia se desmembram, em compassos, passos da vida em porvir.

As relações do pensamento no qual creditamos ao modo de ser diagramático em representação ao que o manifesta como organização proveniente é espaço de seu tempo. Relações compreendidas como princípio e continuidade, ponto e linha, complexidade e desmembramento, fractais em geometria de um pensar, como demostrado mais adiante por volúpia da palavra, arabescos de sentido são presença cada vez maior de uma cognição necessária como aspecto possível de ser da natureza, o mesmo âmago ${ }^{4}$. Dentre as relações e conexões estabelecidas em um pensar, a sustentabilidade se constitui frente a uma gama de

\footnotetext{
${ }^{4}$ Sousa, Carina Gonzalez Y. Composição Súplica da natureza em vídeo disponível no endereço eletrônico: https://youtu.be/_fagKXgHrU
} 
determinados fatores internos e externos, individuais, sociais ${ }^{5}$ e portanto, de aspectos fortalecidos pela sobreposição de caminhos onde os elementos se acoplam e acumulam informação multidirecionados para ramificações dentre as quais pautamos que seja sempre relevante o que denotamos ser de um desenvolvimento comum. E a observação de como, a ocorrência do pensamento pode encontrar-se necessária e relevante no modo de ser da vida, é desafio cognitivo, informacional e de conhecimento, para mesmo considerar a presença possível de sendo caminhos por vezes em extensão divergentes, encontram pontos de elementos adjacentes e comuns, fator este de aprendizagem fundamental para encontrar na economia planetária, funções cabíveis de se sustentarem como meio de uma cultura em diversidades mais abrangente e de respeito.

Avaliando este patamar dentre ao que consiste nos diagramas as conexões, salienta-se a organização dos argumentos da construção mental em relação a constatação dos aspectos do tempo ( passado, presença e projeção ), no que consiste a elencar fatores que instrumentalizarão a razão, ou seja, a ressonância aqui já se apresenta sobre um aspecto, no qual demostra ser eficiente e portanto, o elemento é resgatado na elaboração do argumento mental, porém ainda, se observa que nem sempre a reverberação será fator de escolha, mas a causa de sua origem, que provém a validade para o percurso a ser desenvolvido ${ }^{6}$. Desta forma se apresentam tanto o reforço de desenvolvimento de estruturas vigentes como o fomento de possibilidades heurísticas de construção.

Devemos considerar que no tocante aos diagramas mentais, como organização do pensamento, mais do que associações, eles ocorrem por elaboração cognitiva, raciocínio dispondo sobre determinadas conjecturas sejam elas da ordem da sensibilidade ou razão, em igualdade, havendo um motor se assim poderei nomear, algo que o move, porém, ainda desejo considerar que existe uma energia ${ }^{7}$, esta, descriminada em pesquisa restrita e não de

\footnotetext{
${ }^{5}$ O tempo não espera. Composição do arquivo: Música Brasileira- Não se pode calar a manhã, Parte do trem que o tempo não espera, quisera eu te encontrar, naquele mesmo lugar, outro. Passageiro, silêncio estrangeiro de mim. Desafio do vento, desafio ao relento. Das vozes que partiram. Do canto que ecoa, mais uma vez revoa, dos braços que acolheu, Seu porque da proa, Dos trilhos dessa garoa, Gota voa minha proa, rastro do mastro que soa, o sonho que parte comigo, levando minha vida contigo, sigo esse meu caminhar, nesse meu jeito de amar...
}

\footnotetext{
${ }^{6}$ Sousa, Carina Gonzalez Y. Formas diagramáticas em desenho in Diagramas explorações no pensamentosigno dos espaços culturais. São Paulo: Alameda, 2016.

${ }^{7}$ Ver para este ponto, os aspectos de Física em sentido de informação e vida. Podendo ser consultado. Jorge, Ana Guimarães. Topologia da ação mental. São Paulo: Annablume, 2006. Pg78.e ATKINS, Peter. Principios
} 
todo se apresenta ou faz parte deste escopo, do que é da física e da música, como presença, do que como dito no inicio é parte do desconhecido, mas está em toda parte. Esta razão etérea, se prontifica ao pensamento na forma do próprio existir, no qual somos parte, e dessa totalidade se expressa a liberdade sobre o que é da alma do pensamento, sendo sua estrutura como diagramas, sistemas, enfim, o que é da sua carne, se por ventura estas palavras tornem este objeto, menos abstrato e do caminho dele, mais plausível de compreensão. O sensível se apresenta como manifestação da vida, por onde encontramos a razão e dentre o desconhecido e o que pretendemos conhecer, o pensamento se torna agente, movimento e existência. ${ }^{8}$ De maneira que, como o pensamento age, torna-se objeto dele mesmo, da vida como busca da consciência. E, justamente nessa democracia que faz com que inclusive o próprio pensar seja de cada um, a forma que a vida o representa e em reverso, ou seja, o meu olhar para a vida, me faz ter a consciência de apreendê-la de maneira a que o pensamento, seja a imagem pela qual torna-se sentido. E as vias desse sentido, são os elementos que vão dar as diretrizes de como se constrói os caminhos da busca nas relações e as razões nas quais estejam elas imbricadas. Se realiza um acoplamento em direção, à o que nos move e o porquê, e, ao como nos move.

Como bem descrito por topologia de ação mental ( JORGE, 2006: 33), o mundo da natureza para os gregos se identificava com o conceito de Physis $^{9}$ em conjunção mente da natureza. o homem e esse movimento, pulsa a vida, de maneira plena em conformidade ao que pode ser de relações do cognoscível, pensamento em sentido de criação, heurística como razão de presença na vida, e portanto pondera-se sobre o mover-se do quanto que frente ao modo de ser do tempo, somos, efêmero e permanência, respiração, e sobreposto, ainda lembrando a citação de Empédocles em Schopenhauer, do mesmo conhecido nele próprio mas pelo espírito apreendido, de maneira que em ressonância possamos ainda que em metamorfose, compreendamos o ser.

Ter diante da percepção o continuo em pensamento é reverberar o instante em possibilidades de formas, diagramas, caminhos cognitivos, assimilações que tem em si, o caráter de relações, grafos de sentido e olhar, fusão, transparências, conjugações. Isto para nos

de Quimica: questionando a vida moderna e o meio ambiente. Tradução: Ignez Caracelli. Porto alegre: Bookman, 2001 assim como PRIGOGINE, Ilya. O fim das certezas. Tradução: Roberto Leal Ferreira. São Paulo: Unespe, 2011. BATESON, Gregory. Natureza e espírito. Tradução: Maria do Rosario Carrilho. Portugal, 1987, e Una unidad sagrada. Tradução Alcira Bixio. Barcelona: Gedisa, 2006.

\footnotetext{
${ }^{8}$ Sousa, Carina Gonzalez Y. A OCULAR. Texto do livro> Diário da manhã.

${ }^{9}$ A respeito de Physis como princípio de crescimento Sousa, Carina Gonzalez Y, Ágape arte como a vida. São Paulo: Inmood, 2016, pg 26. E ver também no livro, o segundo capítulo.
} 
aproximar do que poderemos considerar ser, a realidade, dentre os desenhos do mundo, internos modos de ser, da face externa que nos contempla, completude. O próprio modo de ser de ver o mundo, dentre o que é acaso, existência e permanência; condiz com o entrelaçamento e tendo como consequência o próprio continuo, onde se observa o tecer da vida, propriamente. E dessa propriedade na qual estamos inseridos, a escolha, fator este que, vermos ser abordado como responsabilidade do indivíduo e à organização social, marca de nossas diretrizes, elemento de bússola, é princípio de liberdade ${ }^{10}$ posto como razão e consequências, em imagem e representação de sermos constituintes de nosso tempo, vigência na qual estamos inseridos e pela qual, vamos responder, pelas condutas assumidas.

E dentre esse conjunto de argumento do próprio modo de ser aqui colocado como a experiencia da vida, sobre o pensamento ainda é necessário dizer, o tocante ao que é da natureza da dúvida, fator desencadeante de movimento, onde sobre a permanência e o determinado por vezes e até mesmo como heurística creditamos ao questionamento indagador a propriedade de inquietação pela qual o caminho prossegue desbravador e creditamos ser inclusive da natureza da dúvida um motor essencial ao que é de engendramentos e possibilidades não diagnosticadas em princípio, sendo elemento satisfatório e não prejudicial quando, existe por vazão de critérios pautados em argumentos plausíveis de serem desmembrados como fator que agregará valores, e conduzirá a um esclarecimento inclusive, em grande parte de seus posicionamentos, quanto ao conhecimento e o pensar, até mesmo crendo ser este um modo cientifico de nos colocar diante da realidade. $^{11}$

Pensar enquanto sentido, as asas podem repartir-se sobre véu da manhã vestindo-se de nuvens, como a desenhar-me. E incansavelmente soa de teu ventre as naturezas da fragrância do voo por onde o pousar reclama de tua imagem, o âmbar. E, desse silêncio contido em teu olhar, o repouso do tecido da vida cobre-se de imensidão. Latejando raízes de rios, sobre o sangue gemendo como o vento, de janelas se abrindo do corpo sagrado da

\footnotetext{
${ }^{10}$ Composição- liberdade. Composição: Asas do céu. Sonhos de liberdade, entre almas.

${ }^{11}$ Sousa, Carina Gonzalez Y. Composição: O sal do corpo da terra. O vento carrega..... lembrança da alma, o sal do corpo da terra, espera por nós.. o sangue que carrega a vida por entre nós. Sal da água que pranto desce do céu leva consigo... ah... trazendo o vento do oceano, a voz da esperança que o vento vai, trazer pra nós, onde haverá lugar para existir. pg $515 \mathrm{E}$ a composição: Humana condição : A condição humana, mulher, homem, ser cidadão vem descer a multidão é vida, trabalho.... não é mais, escravidão! ah condição humana, quero ver nascer, viver e pertencer o direito a liberdade e igualdade... de verdade. Verdade, de verdade, verdade. Onde possa haver, onde possamos ser. realidade. Vem pelas ruas passar, vem pelas ruas, esse teu jeito de caminhar. Esse teu jeito de amar, amor, sincero amor, retira a dor, é essa a condição... de viver a esperança de viver a igualdade, de viver um grande amor, onde estiver o teu calor, como o sol a queimar a minha dor, ah esses raios do sol, esses raios do sol, por onde for, entrega o seu amor.
} 
natureza $^{12}$ em que a alma se recolhe. E de tempos em tempos o que se descobre da noite que sonha, sobre as estrelas e o luar vem tão tarde nos levar sobre os aranha céus, de onde ainda se pode ver uma ave, traçando o céu, como destino ou desatino da realidade, onde o pensar permanece a procura do ar destilando no viver, os passos, olhares e mudos versos na busca da palavra, no gesto que irá lhe confidenciar as saudades múltiplas de se deslocar, sentido, mobilidade, multifacetado e entrelaçado em dizeres, quantos tantos forem seus abrigos, risos, contidos lugares esquecidos por ora ou depois até, nomeado modernidade, pós, tempos vigente, em suma, até que novamente, desperte Acorda, voz que do mundo dorme. Teu sono desafia a própria natureza em que os ruídos perpassam por entre o que busca em exaustão, compreensão de ti mesmo, e a esmo espera, espera, de tantos lugares, o território de existir. E no existir, quer seja outro de ti mesmo, nas faces da natureza ouça, antes que o pulso se perca dos olhares tardios que mais que a madrugada insone, se lamenta. Então, como tormenta de seu destino, segue a veia como a própria seiva à matar a tua sede, de onde o espirito sorve o mundo ao redor emudecido, escrevendo a folha branda que do outono se desprende, efêmero gesto da natureza, compartilhada, em solo, semente e por vir. Pendeu sobre teus clarões, antes das primeiras horas, que antes de ti, sorveu o espaço admitindo existir, o tempo que lhe aguarda mansamente até que o som dos pássaros ${ }^{13}$ ainda se possa ouvir. E sem partir esteja os campos de relva sobre o concreto, onde travessias ${ }^{14}$ fazemos, e dizemos sobre o burburinho como o navegar de um navio em correnteza de esperança nos concretos incertos desse nosso tracejado, cotidiano ${ }^{15}$ amassado como papel, esquecido de onde rascunhos faremos de nossas vidas a espera da obra final que desafiadoramente não tem fim.

Como espirito do vento, soa querendo liberdade ${ }^{16}$, e se expressa sobre o gozo de viver a própria vida como sopro do infindável Ser. E tempo, do espirito, coração de sua razão. Sujeito mesmo, feito sentimento, transformando pedra em movimento, lento, vento, lento, que sopra o sopro de retirar-nos da condição que nos aprisiona sobre uma pele que fere mais

\footnotetext{
${ }^{12}$ Sousa, Carina Gonzalez Y. Composição: Sagrado da natureza - FLAUTA.

${ }^{13}$ Sousa, Carina Gonzalez Y. Composição Entardecer - FLAUTA -

${ }^{14}$ Sousa, Carina Gonzalez Y. Composição Travessias do arquivo para consulta de música brasileira de letras e melodias.

${ }^{15}$ Sousa, Carina Gonzalez Y. Do livro: Escritor de corpos e almas. Um dia de domingo e o texto espetáculo em sociedade.

${ }^{16}$ Sousa, Carina Gonzalez Y. Composição Aurora. MB Esteve a Aurora no cio, cidade humana e rio. Desmatados da alma. Calma do sol valente. Gente urbana erguida. Sobre destroços de luta sofrida. Esteve aurora no cio, cidade humana e rio. desmatados e atados aos edifícios. De vícios contidos do tronco. De escravos e senhores do tempo. A espera da igualdade, movimento. Espero chegar as trilhas abertas. $O$ respirar, o ar, o ar. Esteve a autora em que hora? Esteve a cidade e o rio. Onde a criança que chora, e agora? $\mathrm{O}$ ar, o ar, ar.
} 
que o cinza, pedra vocifera frente sua própria condição, tornando-se outro, grita! Objeto verdadeiramente ser. Do que dizer, mais que o poeta?

Incerta, manhã talvez as águas trepidam ${ }^{17}$, de onde os muros podem de outras pedras erguer e por onde as mesmas águas do sangue, da seiva, podem gemer. E sem atirar, ou resvalar, as ondas nascem como da própria terra, pedra-ponto do espaço que vejo na imensidão. Lembrança feito presença, imagem como representação. Realidade e impressão ${ }^{18}$, subjaz o pensamento de onde a razão e o sentimento soam como destino de um universo que existe pela consciência de estar vivo. Dimensão de um lugar, identidade da humanidade. Pensamento sendo forma, marca de um tempo, vida em movimento.

Em se tratando de topologia do pensamento, avaliamos uma similitude em nosso modo de considerar este aspecto do que é da geometria e de onde outros autores ${ }^{19}$ compartilham também de que o contínuo da forma do pensamento se desmembra como demostrado inclusive por aspectos em volúpia da palavra, a seguir em capítulos subsequentes. Porém, vale ressaltar aqui, que em se tratando de topologia, território do pensamento, sujeito topológico e sujeito ambiente, mais do que como a topologia procede, e de que maneira se constitui, quanto a modo de configurar-se, será em que direções, quais conexões, razões, se dirige, isto porque, o direcionamento é fator motriz no tocante ao desenvolvimento nele mesmo, mais do que ele pode gerar. E nesse gerar tem-se aspectos a serem considerados de relevância principalmente do que se pretende alcançar quanto a propensões em relação ao objetivo, a natureza não só do caminho ${ }^{20}$ mas do que ele irá representar em por vir, e de como esse porvir pode ser valor ${ }^{21}$ agregado a origem, ao continuo dela, e sua possibilidade de expansão, como nós em grafos, na geometria do pensamento como certos momentos podem ressoar, conjecturas que irão proporcionar mais frutos a sementes da árvores da vida, havendo de avaliar não somente a capacidade objetiva mas também e principalmente seus valores éticos, dentre a lógica da topologia mental, como fator inclusive de uma estética que tem em si, a conduta ${ }^{22}$ dentro de uma ética de intersecção, determinante em nossa marca

\footnotetext{
${ }^{17}$ Sousa, Carina Gonzalez Y. Composição Violino: De outras águas.

${ }^{18}$ Sousa. Carina Gonzalez y. Composição: Sobre as luzes - IMPRESSÃO.

${ }^{19}$ Ver considerações a respeito de topologia e protodiagramas e o caráter infinitesimal. JORGE, Ana Guimarães. São Paulo: Annablume, 2006.

${ }^{20}$ Sousa, Carina Gonzalez Y. Composição Do sonho entre a mensagem o caminho. Também a composição Caminho do Vento,

${ }^{21}$ Sousa, Carina Gonzalez Y. Pesos e medidas, a balança. pg 75

22 Conduta como podendo aproximar-se de ação significativa como considera Shapiro, ou ainda como diagnosticado por Charles Sanders Peirce por hábito. E no livro fruto de minha dissertação de mestrado se observa que na topologia ainda conduta é avaliado inclusive como contendo a intersecção da possibilidade
} 
como síntese do que se constitui a integralidade do propósito, colocado por muitos como missão, o cerne de uma organização. ${ }^{23}$

E tem-se ainda a presença na construção estética no que se refere a formação e aproximação do pensar, a percepção, porém, o que condiz ao diagrama ontologico ${ }^{24}$, como descrito, "funcionando como uma interface entre a espécie cognoscente e o fluxo de informação que a une ao mundo."(MACHADO, ROMANINI: 2010; 89-97).

Razão
Pensamento

Diagramas

Recursos

Organização

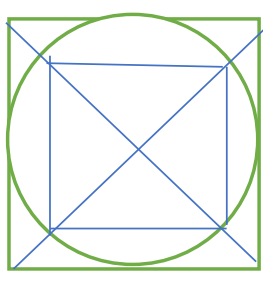

VIDA
Sentimento

Cultura Sustentável

\section{Cidadania}

Práticas
Ações

e Ressonância

do acaso, neste particular ver Agape, arte com a vida, capítulo II. Importante ressaltar as considerações que são de ligações quanto ao que é de topologia, habito e heurística frente a necessidade sempre contemporânea, diante do desafio de creditar aspectos de crescimentos no tocante ao que é discernimento em razão do que nos é benefício ou retroação do hábito, em conexão ao que 'pode ser amortecimento cognitivo. Se ressalta portanto, sempre a necessária avaliação do que é rumo estabelecido por raiz fincada como elemento útil ao sistema - hábito, ou seja, diretriz que condiz com o que tornam práticas de estruturas onde caminhos conhecidos validam inclusive a possibilidade de integrar novos elementos, porém, atento ao que pode por existência de longevidade ser contribuinte ou não, porque a um sentido de permanência que pode deixar amortecido uma determinada outra possiblidade. O caráter de hábito pode ser contribuinte ao sistema ou não dependendo do olhar.

${ }^{23}$ Ver MOTTA, Fernando Prestes. A teoria geral dos sistemas na teoria das organizações. In Revista Administração de Empresas vol 11 n 1, São Paulo jan/Março 1971 e também JORGE, Albuquerque Vieira, Organização e sistemas, in Revista Informática na educação: teoria e prática, v 3, N 1, 2000.

${ }^{24}$ Ver capítulo II de Ágape arte como a vida, tópico afecções diagramáticas, São Paulo: Inmood 2016, e também o artigo de MACHADO, ROMANINI, in revista FAMECOS, Porto Alegre V 17 n 2 , pg 89-07 maio/agosto; 2010. 
Creditamos ao que é da sustentabilidade do pensamento, o educar, como ação real de um progresso. O que pode representar as formas de um desenvolvimento de um capital intelectual para uma cultura sustentável? De que maneira poderemos realizar uma gestão de recursos em uma dimensão orgânica da ordem do pensamento, comunicacional, em estruturas de um aspecto social, preservando a liberdade, como caráter de um desenvolvimento educacional? A consciência de uma cidadania incorporada no pensamento como ato, podem alterar a crença e a imagem de um tempo futuro, onde então, iremos "consumir" o progresso, sobre qual valor? Busca-se refletir sobre, em que bases seria possível um diagnóstico e aferição que contribuíssem para um equilíbrio das esferas particulares e globais em vista a uma economia planetária, entre as relações sócio educacionais.

A porta por onde desejamos atravessar, compreende as dificuldades de nosso tempo atual, porém, acredita procedente discernir sobre aspectos dentro da contemporaneidade que possam estar sobre o prisma de entrelaçamentos que desvendem possíveis caminhos de soluções aos desafios de nosso cotidiano repleto de tantas desigualdades. Abrimos para a reflexão que, para uma construção de pensamento vigente sobre fortes fundações de razão, com objetivos claros de desenvolvimento, devemos erguer uma estrutura cognitiva que contemple um modo de ser expansivo e complexo, não havendo pretensões nem quanto a contrapor, a falibilidade efêmera de compreensão, ou quanto ao fato de insipiência de profundidade, mas sabendo da necessidade de justamente entrelaçar os conhecimentos, e ainda mais, realizar capacidades do exercício dessas relações, promovendo olhares múltiplos que promovam o esclarecimento. Julgamos o volume de demanda por soluções, abrasivas, porém, antes que a corrosão esteja nos cerceando as possibilidades, os caminhos dentre a educação, cidadania e o ambiente da sociedade como um todo, devem estar sobre nossos olhares.

Alíquota sobre as engrenagens do território social. Apesar de não estarmos aqui propriamente relatando a observação de um relógio, até mesmo porque a intenção é justamente absorver a capacidade de estimular dentre um mecanismo operante, aspectos de evolução onde uma maleabilidade seja capaz de na engrenagem dispor sobre a parcela e o continuo, de maneira a coabitar a responsabilidade individual e coletiva, demostra-se no presente texto, a relevância de que a partir da consciência do indivíduo em seu pensar que se insere na educação como gestão cognitiva, para que em seu modo de viver, se realize como cidadão, teremos aqui, aspetos contemplados para que, ressonâncias se tornem claras de 
maneira a que o outro, como indivíduo, ambiente, caminho, sejam parte de nosso agir. Portanto, partindo do objeto de auscultar nosso próprio agir em significado sócioeducacional devemos considerar como estamos lidando com o conhecimento interno e externo do mundo que nos cerca, esferas compartilhadas, que se diferenciam conforme a maneira pela qual nos aproximamos delas, e assim, sendo, se o pensar está embutido em compartimentos de frações que não estão sobre sistemas, e assim perdem significado e valor, ou se o valor educacional se apresenta em meu pensar de maneira a apreender estados de compartilhamento, e agrega dimensões de envolvimento de áreas, desvinculando fronteiras, absorvendo portanto, uma gama maior de elementos capazes de tornar o conhecimento, mais amplo e em tempos de rede, conectado. Afinal, onde nos encontramos com cenas cotidianas de relatos de todo tipo, a realidade está sobre nós como cenário ou protagonista? E, eu, como indivíduo, me represento, como mercadoria ${ }^{25}$ no ar, sobre que marcas de meus passos?

Educando o pensamento. As razões do conhecimento cerceiam os caminhos cognitivos, e são fundamentais para as escolhas de ações, tanto quanto o que em mente nos aproximamos quanto a também nossas buscas na timeline mental, como nas representações do mundo externo. Educar o pensamento sobre as faces de conhecimento é importante, porque somos automatizados muitas vezes e de maneira costumas a realizar buscas de pensamento onde nos foge ao prumo o que é de fato relevante e que, pelo hábito cognitivo podem nos escapar, informações importantes, e ainda mais, possibilidades não reconhecidas até então, para tal. O imediatismo do pensamento prescinde relações, estas fundamentais para se encontrar caminhos de soluções frente a desafios. Relações são a base de uma proposta de realizar uma educação do pensamento, como princípio, e forma de gerar capacidades criativas, e próximo do que se considerara economia criativa. Portanto, em se tratando de compreensão do mundo atual, devemos nos orientar como uma bússola, sobre as regiões do cotidiano interno e externo à nós, com que valores? Educar o pensamento, exige não somente uma busca de ações em direção a um ganho significativo de capacidades cognitivas, porém, e mais ainda, um alicerce firme e produtivo de nosso conhecimento enquanto ethos, na conduta mental que se refletirá em atos. Como consequência poderíamos dizer, que encontramos um

\footnotetext{
${ }^{25}$ Sousa, Carina Gonzalez Y. Composição: O preço. Você não me disse que eu tinha um preço. eu não mereço... quero viver em liberdade. Pra se ver e conhecer. Ah eu posso voar... feito asas do mar. Você não me disse, que eu tinha um preço, eu não navego a portos distantes. eu não quero o seu desprezo. Não tenho preço, mas sou da vida. Ancoro em feridas e curo com bravura. Sobre a fúria das tempestades. o vento sopra...Na minha vida, o vento sopra, na minha vida o vento sopra. Na minha vida eu quero amar. Em todo lugar que ao ver ainda, um sonho para embalar. Não vou desistir. Eu quero seguir. Do meu pranto eu já vivi. Agora.... vou sorrir e abraçar, nesses portos...a alma e o corpo. São meu lar. Vem para o seu lugar. Os braços estão sobre a pele, tecendo a manhã o destino, que segue contigo.
} 
ambiente em continua construção, sobre relatos dos tecidos sociais onde nosso conhecer deve encontrar o discernimento entre o que se defronta de dissenso e consenso quanto a seus pilares como individuo social e as mazelas, desde as esferas de ordem global, estejam elas desde aspectos de violência como quanto a conjecturas que se estendem ao âmbito do que são diferenças culturais. Assim sendo, podemos indagar sobre diagnósticos de demandas do ambiente, quer estejam sobre prismas particulares ou gerais entrelaçados sobrepondo a essa observação de como justamente essa interface pode encontrar nas instituições, universidades, papéis a serem desempenhados de maneira a buscar uma lógica ampliando sistemas, conexões e principalmente distribuindo oportunidades que virão a gerar recursos de capital intelectual, que retroalimentarão o sistema já dispostos a suprir, colaborar com as necessidades da demanda inicial do ambiente social. Sobre essa ótica, podemos então, nos considerar abertos a possibilidade de nos ver como cidadãos, que participam de um conhecer o seu cotidiano não apartado, mas envolto as diretrizes que o fazem existir. Educar o pensamento é participar da própria vida, de maneira consciente.

Dentre as relações do acima abordado, papel fundamental é o da comunicação. Para que a educação do pensamento se torne de fato concreta. A comunicação é fator em derivações infinitas se assim poderemos traçar esse paralelo, encontrando razões entre funções de utilidade individuo-político-social em exponencial, ou seja, quais elementos devem ser diagnosticados como passíveis de reverberações como matriz- exponencial, ou seja, se inserem em sistemas também adjuntos em instituições e universidades, mais praticamente na soma equacionaria passam a ter o sentido de serem elementos em que os recursos e oportunidades são observados como razões sensíveis de ordem prática com funções de vazão. Existem possibilidades de se observar quanto ao ambiente educacional que, para o aqui presente tratado, esteja sempre disposto como o que pode se inserir em benefício, para tal, deve-se ater a disposição que o ethos esteja sempre aliado e conjugado para assim sendo, o sistema esteja com fator de evolução e desenvolvimento. Portanto, o diagnóstico sobre a face interna (indivíduo) e externa (social), deve estar atento as conexões para que conforme as capacidades do educar o pensamento estejam sendo oferecidos oportunidades e investimentos onde naturalmente no decorrer se possa avaliar, os resultados tanto para os indivíduos como para a sociedade em geral. 
Partindo de um modo de pensar em diagrama ${ }^{26}$, que realiza conexões, o aspecto de rede que tão familiar se tornou pela tecnologia, é realizado mais do que como em paralelo de sinapses mentais, mas como sentidos e comunicação que se integram, em ações, ou seja, uma rede orgânica social, onde cada elemento age como fractal $^{27}$ interagindo em outros sistemas, agregando faces de conhecimento.

Desafios estarão presentes não somente como contiguidade, mas nesse engendramento o encontro com dissensos entre os sistemas que haverão de comportar novos elementos, é uma das faces do conhecimento, porque precisa investigar as razões de como haverá de compreender como e em que direção ao propósito se esteja caminhando mediante auscultar possibilidades de elucidar os novos elementos por diretrizes ou melhor, por sentidos que podem ser percebidos não em sua representação mas em sua anatomia. Anatomia comportando um modo de ser da complexidade que não é de maneira alguma superficial por ser amplo, ao contrário é uma complexidade que é capaz de sentir as entranhas.

Edgar Morin, em seu livro, educação e complexidade, sete saberes e outros ensaios, aborda as questões que permeiam este caminho de reflexão apontado, e quanto a reforma do pensamento e as universidades, e de que maneira a educação do pensamento pode ser realizada se a reforma deve estar tanto no indivíduo como nas instituições, e portanto, como educar os que movem o conhecimento? Nesse paradoxo creio que a vida nos ensina, porém, como? Para tentar elucidar esta questão, me parece que somente nos aproximando da razão, intrínseca a todo ser, é que poderemos encontrar a base do educar o conhecimento através da vida e assim, transformando-nos poderemos adentrar a sociedade e as instituições de maneira lúcida capaz de reformar. Porém ainda não se resolve de todo, porque se a base do educar que é da vida ${ }^{28}$, tem seu esteio na razão, em que bases esta razão está erguida? Portanto, pode-se argumentar sobre mais de um prisma esta questão. Poderei conceber a razão de um ser, análogo a um princípio vital?

Poderei conceber a razão de um educar, como sendo interface do cotidiano e meio? Ainda, posso entender a razão como uma razão ética? O que difere a razão como princípio vital, da razão ética? Bem, aqui me deparo com algo que é sempre difícil, mas cada vez mais frequente a necessidade de se observar, que são os dois lados de uma moeda, ou uma

\footnotetext{
${ }^{26}$ Ver Explorações do pensamento-signo nos espaços culturais. Capítulo Formas diagramáticas em desenho.

${ }^{27}$ Teorema de Noether, espaço topológico, onde é um par ( $x, r$ ) onde X é um conjunto e $r$ é uma topologia em $x$.

${ }^{28}$ Sousa, Carina Gonzalez Y. Composição: PIANO - Do sonho entre a mensagem do caminho.
} 
tridimensionalidade, pois apesar de que, em meu modo de ver a razão está propriamente intrínseca aos valores morais, há de se convir que existe e para este caso, o que observo como sendo parte do princípio vital, porém explico: A razão como parte do princípio vital pode se subdividir, em alguns modos, que se apresenta como a razão que desperta ainda como impulso da natureza orgânica do ser, voltada como um fator de sobrevivência, a razão sobre o princípio vital, que se mostra sobre um caráter de livre-arbítrio e portanto, passível de controvérsias em consenso geral, ou seja, neste caso, pode-se creditar que parâmetros pessoais de razão neste aspecto, é todavia, colocada nos moldes do indivíduo e do respeito ao judicativo para a razão de cada um, o que nos faz refletir sobre como a razão de um ser humano pode o levar a condutas ilícitas, mas, teremos ainda ligada a razão de sobrevivência mais difere da mesma, que é a razão imediata, que promove atos pensados porém, sem um discernimento, e nem sempre ligada a sobrevivência, mas apenas um caráter de imediatismo, muitas vezes apregoada a escolhas, cotidianas.

Como então, essas razões frente ao educar o pensamento podem se erguer mediante a vida? Justamente, a comunicação $^{29}$, nas relações em que se estabelecem entre semente e fruto na sociedade, vão conduzir como amostragens e parâmetros, sendo respostas as indagações em que esta razão vai se construindo e se estabelecendo, em confrontos, desafios e consensos.

Estar diante dos problemas do seu tempo, condiz com a necessidade de buscar um alcance maior de oportunidades gerando dentre os fomentos de capacidades a vazão de uma igualdade, ou ao menos um alicerce para tal. Se educarmos o pensamento em responsabilidade cidadã no âmbito interno e social, aliado ao desenvolvimento de capacidades, com uma organização podemos diagnosticar relações onde, o equilíbrio de possibilidades, encontrem um desempenho para que a busca e o caminho estejam ungidos de maneira a um bem comum e uma educação para uma sociedade futura. Diagnósticos de capacidades, com oportunidades geram um ambiente de maior igualdade, com o sentido participativo, ativo, e não somente passivo nas relações humanas, sociais, políticas, enfim, de um viver consciente.

A reforma necessária do pensamento é aquela que gera um pensamento do contexto e do complexo. O pensamento contextual busca sempre a relação de inseparabilidade e as inter-retroações entre qualquer fenômeno e seu contexto, e deste com o contexto planetário. O complexo requer um pensamento que capte- relações, inter-relações, implicações mutuas, fenômenos multidimensionais, realidades que são simultaneamente, solidárias e conflitivas, ( como a própria democracia que é o sistema que se

\footnotetext{
${ }^{29}$ NASSAR, Paulo. Tudo é comunicação. São Paulo: Lazuli.
} 
nutre de antagonismos e que simultaneamente os regula ), que respeite a diversidade, ao mesmo tempo que a unidade, um pensamento organizador que conceba a relação recíproca entre todas as partes. ( Morin, 2007 pg 22 )

Porém para se conquistar uma educação do pensamento, nos modos que aqui propomos, deve-se elencar diretrizes segundo graus de relevância, porque não é fácil a tarefa de equilibrar as forças para uma sociedade com um caminho mais justo em igualdade. ${ }^{30}$ Carências para encontrarem-se com as capacidades precisam de um olhar atento, com possibilidades de recursos investidos, e esses recursos normalmente em suas avaliações tem que sofrer uma análise, que é do tempo, ser continuo no sentido de que, presume-se englobar tanto o ambiente insipiente como o porvir para em gestão de pensamento avaliar de que maneira essas conexões podem estar aptas a estabelecerem-se da melhor maneira a fim de desenvolver gerando transformações, como uma esfera onde se proliferam aspectos de uma topologia orgânica onde todos os órgãos ressoem em harmonia. Isto porque em se tratando do social, dos ambientes políticos, dos cidadãos, as demandas que vivemos são diversas e ter o cuidado de saber, a ordem em que elas devam obter de recursos, para que o movimento surja como fator na engrenagem, creio que já é por si mesma, uma aprendizagem, posto que a vida, é nela mesma, um vazio, no qual nos deparamos com tudo, e assim sendo, o desafio de se deparar com escolhas perante o viver melhor, desejando investir em melhorias para uma existência mais igual é, de fato, um desafio em si mesmo, que deve ser enfrentado, om a força que jorra de nosso sangue e o ar de nossos pulmões. $\mathrm{O}$ organismo planetário, agoniza, e frequentemente e incansavelmente dá sinais, quer estejam sobre o meio ambiente, sobre fome, guerras veladas ${ }^{31}$, gente de nossa gente, como margem, como inexistente vivendo, e esses sinais desapercebidos, passam olhando em nossos olhos, como anjos sofridos, sem asas para voar. Uma vez, pensando a razão, encontrava sobre caminhos uma indagação, que vem a ser: Como caminhar, quando não se tem mais chão? ${ }^{32}$ Então, ouvi

\footnotetext{
${ }^{30}$ Sousa, Carina Gonzalez Y. Composição para piano - Igualdade

${ }^{31}$ Sousa, Carina Gonzalez Y. Composição: Piano .Dos campos do sofrimento.

${ }^{32}$ Sousa, Carina Gonzalez Y. Composição: Entulho. Sabe sobre destroços qual é o nosso lugar. Sabe....sobre destroços qual é o nosso lugar. Meu corpo se tornou, entulho pra cidade, eu sou apenas, um barulho. ah... grito ao céu, o que fazer. Se não me dá o direito de pertencer. A vida eu também tenho pra viver. Sabe, parece que ninguém vê. A tanto que se pode fazer.... Mas eu tenho que ter, um teto sobre a minha cabeça. Quem sabe, eu esqueço os destroços, ou esses negócios, da sociedade que eu não faço nem parte e agora.... vem me falar, que eu posso ser, um cidadão, pra variar. ah... eu quero ser... Quero aprender.... quero saber, te conhecer... e um pouco mais. Quem sabe então... eu posso ser, mesmo um cidadão. já disse tantas vezes, desse calçada. Me dê a mão, que eu vou levantar. Porque eu tenho.... que ter o direito de trabalhar é desse amanhã que eu quero falar. Venha me buscar. Abre a porta, me dê um caminho que eu vou passar.

Construção de nós, um lugar pra se morar, um lugar....um lugar...um lugar. pg 472
} 
dizer, que quando não tiver mais chão, para saber onde ir, devemos perguntar aos anjos, porque eles, tem asas.

Quais fatores podem ser capazes de nos dar diretrizes para elencar uma gama de ações que serão agentes transformadores? Em parte o pensamento em rede, fornece uma possibilidade de ação, pois, ao se procurar um discernimento quanto a isso, devemos não perder de vista, as relações e conexões porque o atendimento quanto a investimento, deve ter em si, o que abordamos quanto a educação do pensamento, então, não fragmentado, mas em profícuas relações, assim, um fator pode ajudar a gerenciar o outro e estarem mutuamente, se favorecendo.

Porém, se como já observados por momentos sociais contemporâneos, em disputas de interesses, nos faz conhecer uma das faces da razão, que vem a ser, aquela que não nos parece apropriada, que é a cobiça como coluna de uma razão de ação, e isto não gera para a sociedade o bem maior que buscamos. Portanto, quando avaliarmos as demandas, as instituições, o caráter próprio de cada um, em reflexões humanas e de vida, devemos ter em pensamento, o que queremos alcançar que não fosse mal algum para meu próximo, posto que o outro, é minha outra face da moeda, que pertence ao valor que pretendo compor para a harmonia das próximas gerações. Portanto, pautado em valores éticos deve ser o objeto de análise de todo o cerne de um conhecimento quer seja para âmbito interno ou externo, que de qualquer forma, estará reverberando em condutas. A semente em terra que é fértil germina, a semente em terra que precisa ser adubada, precisa de tempo, e o tempo e o ser, precisam da razão e da fé. Quantas vezes passando pelo mesmo caminho, ora, e sempre, sobre minhas palavras, mas, estava a mente da carne, em outro tempo, quando os ouvidos estiveram no mar, e as profundezas estavam a dizer o que o sol, as banhava, mas lá, era escuro.

Onde está nosso pensamento, materializamos também destinos sobrepostos, e isso quero dizer, que caminhamos em mais de um caminho. $\mathrm{O}$ do coração, o da mente, o da carne, o do espírito, o finito, e o do eterno. Todos eles caminham conosco e estar entre eles, é o desafio humano de se compreender. Assim sendo, onde vamos arar, nos tempos futuros, que não esqueçamos, que o caminho dentre o mesmo, são muitos, mas a verdade do caminho, é uma só. ${ }^{33}$

O tempo futuro do ontem.

\footnotetext{
${ }^{33}$ Sousa, Carina Gonzalez Y. Composição: Piano. Caminho do vento.
} 
Por vezes desejamos consumir o que ainda não tivemos oportunidade de gerar, e isso deve nos mostrar, o que todavia, teremos que atravessar. Homens, querem uma sociedade mais justa, e esquecem das oportunidades e capacidades dos seus semelhantes, que serão parte dessa totalidade, e o que desejo, para ser real, ou ainda uma realidade presente, devo então para tal, participar, compartilhar com estruturas orgânicas de um corpo maior de uma sociedade sobre minha face, onde o reflexo das águas, tanto estejam na superfície, como nas águas da profundidade. E que os desafios dos segundos perpétuos estejam entre nós, como sentido do tempo, para nossa vida, do que queremos, quando como temos a eminencia da perda, do que se esvai, da morte, para que possamos olhar a vida, como o segundo eterno de nossas escolhas, ou vidas em compasso, onde um compasso após o outro, sobre passos da areia, também estaremos sobre o sol, mesmo anoiteça, mesmo que esmoreça, o educar o pensamento, não se desfaz do sentimento, ao contrário, deve estar ungido ao sentimento, para que a razão se encontre e não se perca, mesmo que sobre os segundos infinitos. Educar a consciência de um mundo melhor, começa por nós, como carne desse mundo, de onde quem sabe possamos tornar visível, a alma do ser. Espaço e tempo, que se revestem do que atravessamos. Em nosso tempo, afinal, realizamos nosso espaço, vivendo o contemporâneo gesto pautado por nossos ideais ainda não conquistados, mas, desejamos também, criar um espaço, onde o tempo seja, do porvir a liberdade de existir. Como pode haver liberdade em desigualdades? ${ }^{34}$ Como podemos estar existindo, ou será que apenas estamos sobrevivendo, quando deveríamos estar vivendo.

Os pássaros tem asas, e nossa alma não. As aguas tem mais sangue que o nosso? O que flui de nossas naturezas que ainda não conhecemos. Ou haveremos de acreditar que ainda somos apartados de tudo que vive, porque somos humanos, e com isso, os tornamos desumanos. Onde está o conhecimento? Erguem-se árvores como colunas da terra, e nós a cortamos, como veias de um suicídio sem nem mesmo, perceber? Como ainda pensamos respirar? O que vem sendo educar o pensamento. Se acreditamos que poderemos agir e pensar diferente,

\footnotetext{
${ }^{34}$ Sousa, Carina Gonzalez Y. Composição: Por onde vou caminhar. Por onde eu vou caminhar. Que eu saiba te encontrar. Quando será que a beleza do teu olhar.... Paire sobre a minha alma. De ter como meu lugar... Noite minha madrugada sua. Corpos nus da alma tua. Amor, se pode amar, quando você chegar...Na minha vida vou encontrar. Amor, por onde foi que eu estive. A sonhar, desse teu gesto que não quer se calar. Abraço o vento, como mistério a passar por nós. De onde fui para o teu sentido A palavra...que recebe o teu abrigo é casa do silêncio. Percorreu os sonhos teus. A dizer de mim, o teu ADEUS, amor, por onde foi que caminhou, onde ficou o gesto teu. Sonhei, quantas vezes, as águas que se abriram para te ver chegar, Beleza e mar, oceano do horizonte. Onde ficam os vales e montes Através da esperança... Que mundo está sobre o delírio da febre de amar... Prazer da alma que vive a verdade. Sincero como a dor. Punhal na razão, retira da minha alma. Perdão. $O$ que farei quando te ver, amor... Onde ficou minha dor, que não posso mais sentir amor, Punhal, deste teu gesto, manifesto do meu querer, de justiça que possa haver. Amanhã.
} 
não basta, preciso será refletir sobre o que foi feito. Nas areias encontramos pegadas, ao menos até que a chuva caia, ou o mar as retire, mas dentro de nós, elas caminham conosco. 35 O que queremos, o que buscamos, o que o pensamento encontra, vive e pulsa, o que projetamos em dimensão do pensar humano do mundo. Pensamos o que queremos, e agimos de fato como queremos, ou isso parece um paradoxo. Quais rumos estamos, traçando. Queremos igualdade, e haveremos de a ter em nosso pensar e ação? Muitos desafios nos parecem, porém, o sol nasce amanhã, e recomeçamos.

As porcentagens de que balança? Quanto um sorriso de quando uma dor finda, vale, diante de tantas outras possibilidades? Cada qual, tem o seu lugar e tempo, e o eterno, convive com ambos, hoje o pouco, é muito, e amanhã o muito poderá ser pouco. Quais valores de fato teremos, da vida que consumimos, e queremos para uma educação planetária. Existem silêncios que pairam sobre nós como segundos, e outros como a própria eternidade, talvez sendo esse mesmo segundo. Como as distâncias, que percorremos, perto ou longe do que queremos, se o destino já nos encontrou. Justo quando percebo e reconheço que de fato deve do que queremos para o amanhã, estar no caminho, ou seja o destino quando é o objetivo do bem, do melhor viver, este deve estar sendo traçado enquanto caminha.

Modos de olhar. Uma das características de uma educação do pensamento, para um conhecimento, creio que é justamente, desenvolver a percepção de olhar com múltiplos sentidos do significado, caminhos para o significado, e portanto, que estejamos abertos para nos encontrar com a própria busca. Nos defrontamos com o cotidiano, simplesmente, não o vendo, ou apenas, como aquela paisagem diante de nós, que não percebemos. Assim é nosso olhar, caminha por onde estamos, e de onde estamos não o sabemos buscar.

Portanto creio que ficou claro que para educar para um conhecimento, requer despertar a consciência.

Estando claro as disposições deste artigo acima, ainda vamos adentrar um paralelo quanto a vida e o valor, tendo em vista que em um tempo vigente onde a sociedade como um todo vive uma perspectiva de consumo de que maneira a meu ver essa conjectura pode ser um elemento real e concreto de transformação tendo em vista a própria vida como produto em consumo. Que leis permeiam nosso mercado hoje, o que está na vitrine cotidiana de nossos olhares e desejos. Nesta lógica, somos produto, consumidores, gestores e fabricantes. Assim sendo, devemos perceber que, as regras que queremos tão avidamente para estar convivendo

\footnotetext{
${ }^{35}$ Sousa, Carina Gonzalez Y. Composição: Piano - Paisagem de solidão
} 
conosco em sociedade, que nos forneçam diretrizes para saber como conduzir as relações do consumo, ${ }^{36}$ são paralelos de ponto de fuga na perspectiva do que fazemos em relação as nossas ações da vida. Que matéria prima de pensamento estamos fornecendo, ou como agimos enfim, em todo o modo de ser, nas características do nosso produto, vida, para que não tenhamos indigestão, ou reclamações, e tendo reclamações, quem está respondendo ou vai responder são as próximas gerações, ou nós mesmos devemos enfrentar o que estamos gerando de maneira a melhorar a ponto de validar uma economia planetária para o futuro, onde estejamos sobre um viver sustentável. Buscamos um consumo consciente ${ }^{37}$, então com a vida não pode ser diferente, e sendo uma razão ${ }^{38}$ compartilhada.

Se hoje já tratamos de um educar o pensamento para o consumo consciente, me pergunto o quanto que estes projetos ou consciências estão gerando no produto vida, em rumos das novas gerações, em instituições educativas de fixa etária mais novas, para que eles, não somente tenham ouvido falar, mas que de fato e concretamente, estejam fazendo parte do ensino, não como uma atividade adjacente, mas uma forma de interface com disciplinas. Atitudes de empresas, de instituições não governamentais, projetos governamentais que estão caminhando para um "produto" vida de forma a ser uma consciência coletiva, está mesmo no mercado para todos? Até que ponto a rede humana de conhecimento está se conectando de fato e verdadeiramente para que o alcance das nossas propostas para um mundo melhor se realize entre todos. Me pergunto se os parâmetros curriculares estão sendo atualizados tanto quanto os dispositivos eletrônicos.

Existe um modo de aproximação de gerações que pode ser observado, pois, se adentramos ao que torna-se familiar em organização do cotidiano para tanto o que é lúdico, ou o que é

\footnotetext{
${ }^{36}$ Neste momento, compreende-se consumo, principalmente dentro da topologia do pensamento em que é primordial, neste espaço diagramático, e do que consumimos, o que trazemos para essa atmosfera da mente, povoando nossos olhares da razão, para saber em que diretrizes voarão. No espaço dessa topologia você produz e adquire, no movimento interno e externo, faces do mesmo corpo, atravessando o seu espírito.

${ }^{37}$ Para consumo consciente buscar referências no Akatu, consumo consciente, como mobilização social.

${ }^{38}$ Pode-se também quanto a razão considerar, nos estudos da Fenomenologia do espírito de Hegel, quando ele aponta para uma razão observadora, como uma consciência de "visar", sendo a consciência própria experienciando, tendo um interesse universal pelo mundo, por ser esta, sua própria constatação de presença racional, podendo se a razão como uma essência mais profunda do que o eu puro, sendo que a diferença, como ele coloca, o ser multiforme, se torne para ele, figura e coisa. Ver também do mesmo Filósofo, suas considerações a cerca das leis do pensar, onde mesmo pondera que " pela natureza das coisas, a consciência observadora será conduzida até essa outra consciência como realidade daquelas leis. Mas, porque esse nexo entre as leis do pensar e a consciência operante não é evidente, para a consciência observadora, ela acredita que o pensar em suas leis, fica de um lado, e que o outro lado recebe um outro ser naquilo que lhe é objeto, agora, ou seja, na consciência operante. Essa consciência é para si de modo que suprasume o ser outro, e tem usa efetividade nessa intuição de si mesmo, como o negativo. Apenas devo dizer que na presente pesquisa e como modo de pensar da autora e demostrado em Ágape, arte como a vida, a arte é fator primordial para a compreensão da organização da vida.
} 
prazeroso, podemos ver onde esse mesmo modo de organização pode estar presente, para aliar elementos cognitivos e de reconhecimento para outros planos territoriais sendo justamente o que pode trazer razoes para uma compreensão onde se vive um cotidiano incompreensível. Ou seja, observar como é o projeto vida de novas gerações, e sabendo como eles querem que esse produto esteja para que eles o consumam, na linha do tempo onde todos estamos inseridos, o que podemos fazer dentre o existente para alcançar, as distâncias que percorremos, sejam elas, desde o que a vida apresenta como insalubre, até a consciência do que sabemos que podemos viver, essas distâncias assim como, os modos de pensamento de gerações, e do que vivemos para o que queremos, precisa da marca de nossos passos.

Encaminhando neste momento as reflexões acima para a conclusão, acreditamos ter ficado claro que sabemos para onde queremos que a educação, o pensamento, a cidadania, o conhecimento, a vida caminhe, porém, fica claro que devemos colocar a mão na massa e que as ferramentas estão a nosso alcance para construir um futuro como queremos e devemos realizar. Desafios em época de globalização estão a nossa frente, porém, penso e sou partidária de que a globalização, os modos de ser da rede, a consciência coletiva para os problemas planetários que se acercam desde as conjecturas do indivíduo, são capazes de se entrelaçar para benefício das diversas culturas e que com as capacidades e oportunidades em gestão de um mundo melhor serão objeto de relevância nas relações quer estejam no âmbito particular ou de esfera pública, assim sendo, temos uma gama enorme de possíveis, mas que cabe uma organização de educar o pensamento em práticas concretas, viabilizando o sentido de um valor do progresso. 


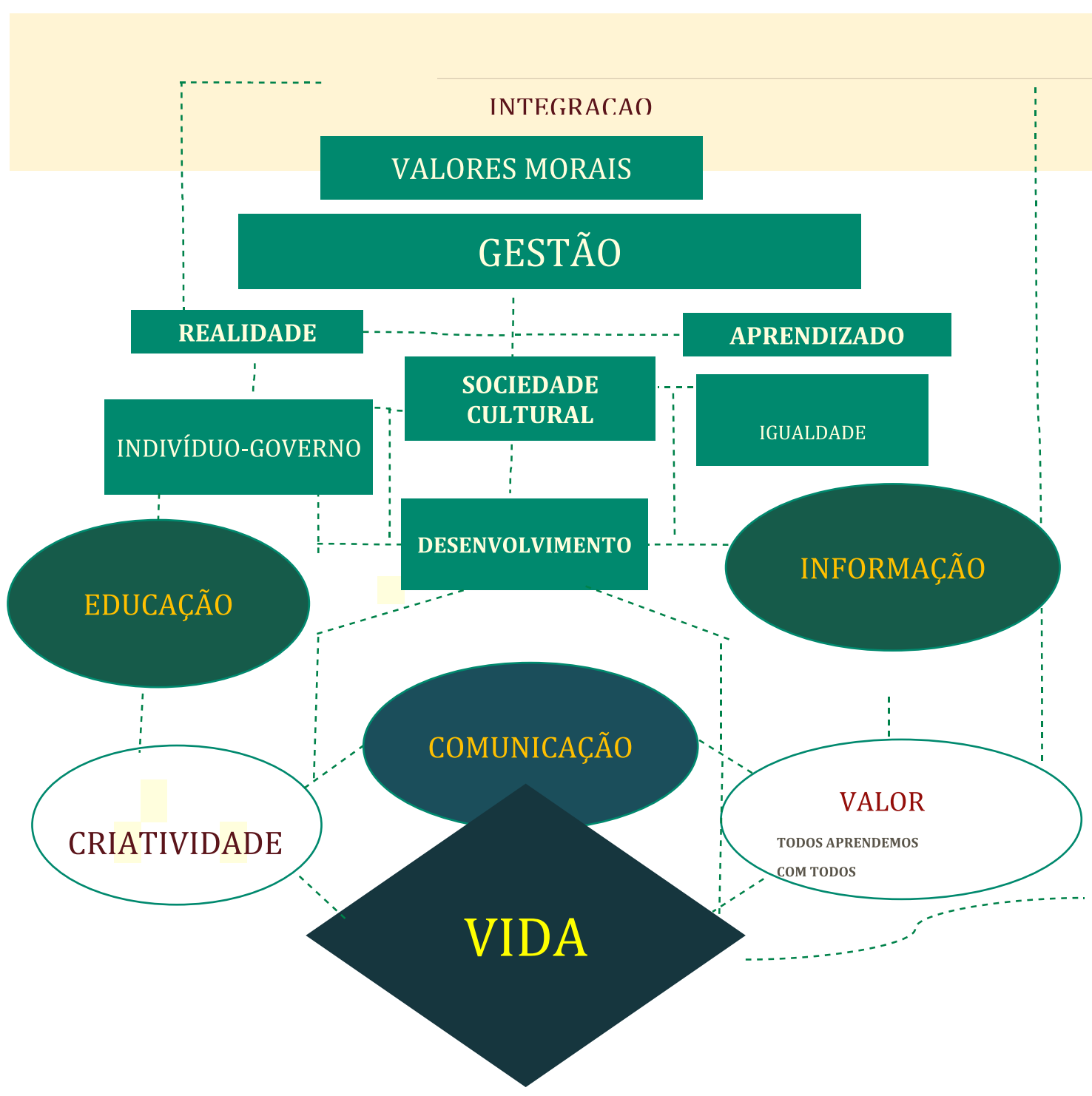

E diante desse panorama agora e no decorrer como modo de cognição abordaremos sobre concepções diagramáticas.

O pensar como sentido do silêncio que está em tudo. A poesia fala do que ouve, nesse lugar do infinito. Depurada esteja a presença no vazio para que dela possa realizar a alquimia de se ver, entre o que de tudo pode jorrar.

Todavia, deve-se considerar que do pensamento, o que o move, quanto saberemos ser de nossa integridade como Vontade sendo presença de um bem maior, e não somente de nossos próprios interesses. E, frente ao tempo, somos sujeitos ainda desconhecendo, do que o infinito sopra. O devir. Então, de fato na economia da vida, quando o pensar passa a se mover diante do que é múltiplo infinitesimal do corpo de seu próprio ser em sociedade, haverá a possibilidade de estarmos como indivíduos iguais ao nascer. Acaso seja essa o que 
permeia nossa natureza, antes que finde o corpo ou a alma, fragmentados onde apenas sopra uma unidade, do que existe e é de nós o próprio viver em economia planetária, e de onde os recursos, antes que se esgotem, porcentagem de quem, será a responsabilidade, do que ficou, morta natureza ${ }^{39}$. Então se pergunta mais uma vez, onde está a consciência, ou o que dela somos? Estaria ela acaso, sendo em nós, ainda que necessariamente dela devêssemos pertencer, e esta seria uma razão como função equacionaria de uma presença de Deus? E se assim o fosse, qual movimento haveríamos de fazer e rumo quanto a destino de nosso pensar consciente. Ou haveremos de considera-la sem tal presença, por diálogo de igualdade onde a crença, ainda se questiona frente ao que é de nós estarmos em Deus e não considerando que Ele esteja independentemente em nós, ou seja, como dizem se a realidade existe de maneira livre de nossa vontade, poderei eu considerar entre a consciência, o mundo e Deus, uma liberdade na qual devo apontar para em igualdade uma presença de razão posta como princípio de uma consciência genitora como presença de Deus, constatada pelo existir, porém, como poderei eu crer em existir quando dessa consciência n(d)o mundo, supor ser ela mesma, um holograma, ou uma imagem em representação? Ou seja temos aqui dois fatores a observar: Para o pensar, realizo em meu modo de ser, particular, quanto a consciência, a presença de Deus, porém, devo salientar por respeito e igualdade de todo o ser, que mesmo existindo, nele não creia, e, ressalto que, das considerações acima quanto a subconjuntos de presença e ausência, são de fato, muito possíveis de estarem até mesmo, em outros raciocínios, por exemplo, o todo e as partes, dos quais, estou inserido, porém, seja do todo ainda fragmento e em descoberta fractal, o que tento compreender, e dentre a consciência, a liberdade, o respeito, a integridade, e (d)o pensamento, onde a razão consciente de uma origem, ou se não assim puder considerar dessa forma, uma função de razão equacionaria da geometria da vida, se estenda de maneira a ponderar que, se do mundo podemos estar ausente em totalidade sendo indivíduo em parte, posso traçar um paralelo procurando um entendimento do quanto que a consciência d( n)o mundo; e neste parênteses já temos três presenças, ou seja, a da consciência plena, a consciência do mundo como um todo, e a consciência no mundo, desta última suponho nós, estar mais próximos, dentre o que trato de subconjuntos para ilustrar o que pretendo aqui colocar, quanto a consciência e pensamento, E esta última portanto, também se desmembra, a consciência no mundo, seria da qual nós dialogamos constantemente enquanto pensamento consciente, termo este, propício para considerar, a presença do indivíduo na aproximação em relação a consciência

\footnotetext{
${ }^{39}$ Sousa, Carina Gonzalez Y. Composição: PIANO. Entre as notas do que chove a alma.
} 
e o mundo, mundo do qual nos apresentamos dessa forma, enquanto, ser que contem a consciência do mundo, e no qual esta contido em diálogos com o que se presume ser da consciência plena, havendo por bem entrar em argumentos e proposições em relação ao que é de valores, ética e conduta, avaliando portanto, o quanto se representa enquanto pensamento consciente, no mundo. Havendo aqui uma consideração do que é pensamento e razão. E, aqui voltaremos ao que anteriormente foi abordado sobre razões, e seus desmembramentos, porém, ainda, o quanto podemos observar de razão e consciência frente ao que consideramos do pensamento, e ainda, do ser, de que maneira compreender nesses elementos, o distanciamento que ocorre do pensar e agir. A ação deliberada, contrária ao que o indivíduo tem como pressuposto de seu ser, enquanto pensamento consciente, no mundo será todavia pressuposto de uma incompreensão, da qual é parte o que ( e agora entramos no que seria da razão e consciência - conhecimento ), não estaria todavia, sobre uma conduta do que apontamos ser, do conhecimento, e mais uma vez, podendo inclusive o próprio, cometer infrações contra si mesmo, e a sociedade, Mas, ainda não deixemos somente a parcela da tríade, razão- consciência e conhecimento, enquanto pensamento e conduta, como somente fator de decisão e escolha, mas o que é de presença da vontade, esta do indivíduo, aqui assumindo o fator do que é de liberdade, havendo então, ainda, o posicionamento que considera mesmo sabedor inclusive de consequências, todo aquele que mesmo em pensamento consciente e com conhecimento, age por livre escolha em detrimento de sua causa. Porém, creio que esta postura do ser, particularmente, e agora sim, em reflexão, deve ser avaliada ainda, suas possíveis causas não aparentes, e não aqui por defesa, mas como uma possibilidade de em liberdade, a liberdade neste ponto sendo a parcela que diz respeito ao conhecer, porém, pode estar em circunstâncias em alguns casos de fatores de coação de um outro ou ser-social, ou enfim, de maneiras diversas. Havendo de elucidar o ponto aqui tratado, creio que devo explanar que, da razão, o pensamento consciente que está enquanto conhecimento, é livre, enquanto propriedade do ser, porém, quando este está sobre a consciência do mundo, pode haver fatores, como dos quais, consideramos o distanciamento de um pensar e agir. Claramente no distanciamento do que é do pensar e agir, teremos outras reflexões, todavia. Havendo ainda, este ultima colocação, que lembrar o posicionamento da razão em relação à consciência plena, e do que podemos considerar, livre-arbítrio, e até mesmo, então, avaliar, a liberdade, bifurcada, a do próprio ser nascido em relação ao do que é natureza da consciência plena, e ainda, a liberdade da razão como conhecimento no pensamento consciente em relação a mesma consciência plena. Chama e fagulha, faíscas do mesmo fogo, elemento que nos permeia, e ascende nossa vontade diante do que podemos ser 
como viver. E mais uma vez, podemos nos debruçar sobre o que seria livre-arbítrio- como fator da consciência plena, liberdade e escolha. Esta última mais a mercê do que encontramos como pensamento consciente no mundo.

E diante desse panorama, devemos considerar agora do que é o diagrama.

Demasiado questionar a esta altura, quem somos? Ou do pensar, o que poderemos ser. Estaria sendo proveniente neste momento abarcar uma lógica onde se tem a intenção de buscar resposta para o como somos constituídos, em parte integrantes do Estado e de nossas naturezas, nas faces da sociedade, como olhar do que de fato entre o que somos, é o que nos vivifica parcela nem que seja do mundo, que nos olha e é contemplado, porque do mundo também temos o silêncio, ainda por saber, de qual momento, é a vida, ou se justamente é o movimento entre a pausa e as notas, que estaremos ouvindo ${ }^{40} \mathrm{o}$ existir.

Portanto temos um desafio que nos acerca constantemente em nossa vida, que é justamente a passagem ou estar entre e com, o que o próprio pensar representa e como procede seu modo de ser, e do que ele se nutre sobre a boca aberta do mundo ${ }^{\mathbf{4 1}}$, e aproximando do modo de ser da vida como produto de nosso tempo, entre processo de produção e consumo, moebius em interfaces ambas conectadas ao pensar e este sendo também existência onde a natureza da realidade abarca essa conjunção, torna-se portanto sujeito ambiente que engole como Ericsiton ${ }^{42}$ a vida, onde alguns se perguntam se a consciência tem preço! E entre diferenças políticas e realidades humanas, a estética, o pensar o viver se conjuga como verbo, entre pretérito na busca do mais que perfeito, atual gesto presente. E, ressaltando o ensejo de consciência no acima tratado, supõe-se que, entre a realidade e o que queremos dela, também deva ser objeto de circunferência, onde o interno e externo se representa, e ainda de onde não somente o preço, se houver, mas o valor, este sem fronteira, é intrínseco e confronta-se com a suposta avaliação de quem quer comprar, na sociedade em consumo. ${ }^{43}$ Creio que deveremos neste momento, fazer um aparte reflexivo no que diz respeito a

\footnotetext{
${ }^{40}$ No decorrer de todo este trabalho consideramos com sentido orgânico ao nos referir ouvir, dizer, e os demais, sendo uma sinestesia, onde inclusive será abordado como cognição em paralelo a presença da metáfora, como valor informacional de apreender o mundo, face de uma inteligibilidade. Aspectos estes podendo ser esclarecidos nos livros do cineasta Seguei Eisenstein, sobre palavra, imagem, e som. Eiseistein, Segei. O sentido do filme. Rio de Janeiro: Zahar, 1990, A forma do filme. Trad. Teresa Ottoni, Rio de Janeiro: Zahar, Ed, 2002.Reflexões de um cineasta. Trad. Gustavo A. Doria, Rio de Janeiro: Zahar, 1958.

${ }^{41}$ Sousa, Carina Gonzalez Y. Composição: TABLA. Boca aberta do mundo.

${ }^{42}$ Artigo publicado in Ericsiton: Um mito dos tempos atuais?. Revista Estética, Revista Estética USP, p. 1 - 6, 02 set. 2016.Resenha de MACLUHAN, Marshall y Powers Bruce. La Aldea Global. R, Barcelona: Gedisa, 1986.

${ }^{43}$ Ver no projeto de livro Ensaios poéticos teatrais, especificamente o trecho, Rosas sem casa, a prostituta social e $O$ voo de uma pena.
} 
sociedade e cultura, havendo, todavia, em outro tópico salientar outros aspectos, porém, argumento uma necessidade de distinção entre ambos os termos, enquanto descrição e sentido. Quiçá por ter entre as partes, algo a relatar, posto que do valor e do preço, talvez esteja o néctar do raciocínio a discernir, neste particular. Enfim, penso que neste estudo, é de relevância compor que a sociedade estaria disposta no mundo como sendo os elementos propriamente de que ele se constitui, porém, a maneira como ele se organiza torna-se a sua cultura, e para que ela seja sustentável, em presente e porvir, alegamos a necessidade da ressonância e presença no educar o pensamento, razão e conhecimento.

E, assim sendo, creio que poderemos nos acercar do que estaria entre o valor e o preço, a respeito da consciência. Entraremos por certo no que diz respeito a correspondência, sendo que do que é valor intrínseco como elemento da face interior do pensamento consciente, argumento em proposição do que seria ética disposta sobre consumo orgânico do viver, estando próximo das conjecturas que são de uma aquisição, em viabilidade de juízo quanto a equalizar os aspectos internos e externos. Então o preço, quando este condiz com o valor interno, estaria em relações similares, ainda que podendo ter que realizar percursos do processo em diferenças, por exemplo, culturais, este sendo um caminho para avaliar condutas entre aspectos de globalização onde presume-se haver a necessidade de um ponto de conjunção, e para tal, mais do que uma sociedade, ressalta-se a necessidade de respeito e educação entre culturas, e mesmo quando tratamos de aspectos particulares e esferas de escala mais restrita, o ambiente do pensamento, supomos estar sobre a mesma reflexão, havendo possibilidade de através do conhecimento, posto como o abordamos, ser a função equacionaria da razão, abrindo rumos de compreensão entre as partes. Portanto, a respeito se a consciência tem preço ou valor, como sujeito ambiente, interno e externo assumindo um posicionamento, eu creio que seria plausível, considerar que as ações, possivelmente dentre o pensamento, serão avaliadas em conformidade segundo posicionamentos éticos, no que trataremos mais adiante como ética de intersecção. E questionamos, todavia, não terá preço, mas valor? De qual ponto de vista. E como ficamos em tempos de produtores de nosso tempo, vida em consumo, que constrói seu pensamento na busca da consciência de seu existir, cidadãos do mundo, indivíduos em rede, a espera de saber nas águas oceânicas onde se pertencem, continuando a desbravar territórios, de cognição em forma pensamentos como estruturas de um porvir. 
Dessa maneira, o diagrama ${ }^{44}$ se torna complexo, porém, viabilizando um caminho de lucidez. E agora, neste momento, para elucidar o que pretendo, creio que recorro as palavras, ou melhor, o que abre a porta, neste caso, o sentido do sentimento, e é neste prisma que noto que o raciocínio se conjuga com o que é, e eu não diria abstrato, porém, em nosso cotidiano em uma presença diferenciada do que consideramos matéria, e mais próximo do que creditamos na ordem diária como energia, presente na física, em ondas, partículas, enfim, do que somos cientes de sua experiência fática e não vemos, contudo, absorvemos os efeitos.

Um impulso que nasce de um sentido. Considero portanto, o fator de emissão da elaboração de um diagrama, por vezes, ao menos, em algo que o nutre como motor de raciocínio, em direção a uma razão, possivelmente esta condizente com um conhecimento, sendo consciente, tornando-se função de um objetivo, em grande parte, dentre o imediato e as relações, o ponto que se desmembra na geometria do pensar, se manifesta como uma nascente, que dentre o ambiente da mente, composto de referências, internas e externas, procura passagem, formando-se suas águas em corrente, criando seu desenho, seu diagrama. E tratando de seus elementos não fisiológicos como sinapses neurais, mas como seu caráter representativo, ícone mental, desperta a consciência, a razão, o existir, em fluxo continuo de entrelaçamento, ora uns sobrepondo mais os outros, porém, em organização com uma finalidade, normalmente, mesmo que esta seja a do devaneio.

Como um princípio que se constitui em vazão, na qual, se firma em propósito conforme os seus pilares que o fundamentam sendo os fatores que na sua elaboração podem em conduta mental transparente em sobreposições, externo e interno, posicionar onde se estabelecem conjunções ou extensões e para onde essas extensões se direcionam, criando um movimento que considera os pontos de justaposição, como " pausa”, respiração onde a informação, elenca dentre as ramificações os pontos argumentativos de sentido, em possíveis desmembramentos e novas conjunções, compondo uma dimensão na qual estabelecemos uma imagem, como caminho, traçado, destino, mesmo que havendo sempre a presença da possibilidade de aglutinações, fatores que venham a despontar como acaso, isto considerando o pensar, como processo, e não determinado, ou seja, o movimento é característica de um pensamento que é dinâmico, em sua constituição e em propensão. Em se tratando de geometria e arquitetura, seria o projeto do pensamento, espaços da consciência, sobre a razão de um viver.

\footnotetext{
${ }^{44}$ Sobre diagramas, consultar Jorge, Ana Guimarães. Ropologia da ação mental. São Paulo: AnnaBlume,2006.
} 


\subsection{Responsabilidade cultural, imagem em representação.}

Em geometria, compassos do pensamento, na busca da harmonia de um viver. Talvez eu encontre no sentido do moderno, ou como prefiro chamar, do tempo vigente, sendo que a cada gesto cotidiano, me sinto algo de liberta engrenagem nos tempos modernos, relógio ainda por me dizer as horas que da natureza sobre o sol, procuro saber, astros de uma cosmologia, onde a realidade ainda precisa encontrar o seu espaço. Algo do universo da música, como os compassos, um tempo após o outro, Cronos, onde se lê uma narrativa, as frases, dizendo de si um corpo sonoro no ambiente em eco, ou ressonância que permanece após a passagens dos compassos, onde poderemos encontrar a sonoridade do efêmero que perpetua. Modernidade líquida (BAUMAN, 2000) eu diria, modernidade ressonante em camadas do diagnóstico, de elementos em compassos da sociedade construindo sua cultura, ainda que soando em trezentos e sessenta e reverberados, no sentido de expansão em movimento do que permanece, transmuta e prossegue.

Um respeitado sociólogo pesquisador da Oxford, John Goldthorpe, conclui que não mais se pode determinar na hierarquia da cultura uma distinção com base nos dados averiguados por antigos signos, dispostos como o que concerne a "grande arte" e o que é do âmbito da arte do "grande público “. O consumo cultural ${ }^{45}$ passou a ter um perfil de sujeito que engloba tanto ópera como heavy metal, ou seja, uma maleabilidade nem tanto de gosto eu diria, mas de tolerância, compreensão em significado de ambíguo, como talvez uma adaptação de espaço habitado pelo próprio tempo em que está existindo, de maneira similar, uma ação, um comportamento fluido, e em diluição de fronteiras. Retornando as considerações, o próprio mito de Erisicton, com fome avassaladora, consome nesse mundo tudo que lhe é saciável ainda que por vezes provoque uma indigestão.

Auscultando esse corpo múltiplo, observa-se que em verdade não há lugar fixo ou determinado, mas se aposta em uma presença que considera seu estado, em movimento, e se permite estar confortável em qualquer ambiente, ou nem tanto confortável, mas ser um transeunte. Onde presume-se claramente a presença do respeito, como pensamento e

\footnotetext{
${ }^{45}$ Para este aspecto vale ressaltar que o consumo cultural é em parte instrumento de uma presença de busca de igualdade onde o respeito passou a ter valor social não somente como palavra, mas sentido integrado de conduta. Nesta razão se estabelece um caminho onde os aspectos culturais se encontram com aproximações sem juízo de gosto, mas de compartilhamento no âmbito social, e do indivíduo. O som passa a ser, apesar da presença de estilo, mecanismo de união, respeito, integridade de diversidade, sentidos estes paralelos ao que desejamos como forma de viver.
} 
conduta, na organização de uma gestão de territórios do conhecer em vivências compartilhadas, na relação indivíduo-sociedade-cultura. ${ }^{46}$ Havendo para tal de considerar densidades de probabilidades, nos aproximando da incerteza como grau de tolerância em vivência. Mas, todavia antes de seguir, devemos apontar que no que diz respeito a cultura, não tratamos aqui de restritamente objetos de arte e suas amplitudes, mas de seu modo de ser sim, portanto, a arte ${ }^{47}$ como cognição da vida. Porém, Bourdieu alertava há tempos que a produção artística se direciona a uma determinada classe social, no "gueto" das elites, porém, em tempos de globalização e identidade, como poderemos conceber o status social cultural de um sujeito habitado em um espaço múltiplo ( globalização ) em expansão, ainda que pertencendo a uma determinada Nação? Mesmo que, restritamente nesse âmbito como até possivelmente reflexo, a de se convir que o objeto da arte cada vez mais, creditamos ser, da ordem do manifesto, onde temos a diversidade como participe do momento atual.

Oscar Wilde, dizia que "Os que encontram belos significados nas coisas belas só significam Beleza."48, uma questão sempre polêmica, e se conseguirmos não afiliar a esse pensamento o

\footnotetext{
${ }^{46}$ Apesar da antropologia no decorrer de seus próprios modos de ser, ter sofrido alterações como as apontadas no livro: Antropologia: prática teórica na cultura e na sociedade, de Michel Herzfeld. Segue do livro de Luís da Câmara Civilização e Cultura algumas definições a saber: "Cultura, de cultum, supino de colere, trabalho da terra, conjunto de operações, próprias para obter do solo os vegetais cultivados. Cultura de batatas. Cultura de milho. Sinônmo de agrigultura, lavoura, trabalho rural, cultura agri. Fundar cultura era plantar uma determinada espécie ou aproveitar o terreno com um plantio apropriado. Figuradamente, analogiacamente, cultura das letras, das ciências, das belas artes. Sempre numa aplicação parcial, específica, localizada. Era ainda o critério francês que o Larousse servia de porta-voz, culture, étude, application de I esprit a une chose. La culture des beaux-arts, des sciences. Developpement que I on donne, par des soins assidus, a des facultes naturelles. Entende-se que a cultura era um exercício de inteligência aplicado a um esforço para finalidade determinada e única. Nunca o geral, o conjunto, a totalidade. É um musculo, um órgão, um nervo. Jamais o organismo inteiro. Um rio, uma árvore, uma montanha. Não a paisagem completa. [...] Define Raph Linton ( 1893-1953) : Como termo geral, cultura significa a herança social e total da humanidade, cormo terno específico, uma cultura significa determinada variante da herança social. Assim, cultura, como um todo, compõe-se de grande número de culturas, cada uma das quais é característica de um certo grupo de indivíduos" ( apud, O homem, uma introdução à Antropologia, São Paulo 1943). É bem possível que a cultura modifique uma cerimônia, um aspecto da organização administrativa, uma técnica da produção agrícola ou industrial, a maneira de preparar um alimento tradicional, um ritmo de dança individual, bailado coletivo, equipamento ou forma de caçar, pescar, guerrear, tecer, fiar, modelar, pintar cerâmica, ornamentar-se, tatuar-se, abandonar certos vocábulos por outros ou fazê-los ter significação diferentemente, sem que a civilização perca no conjunto de sua apresentação habitual e sensível vitalidade e fisionomia normais. [...] José Ferrater Mora explica: Si la vida humana es continuamente una formación y transformación de bienes culturales según su espontaneidad, es también al mismo tiempo, un vivir dentro de los bienes transmitidos o reconocidos não será apenas o uso material das utilidades que una cultura fornece em sua especialidade mas a plenitude do espírito que emana, indispensavelmente, do seu conjunto organizado, com suas orientações, distinções, restrições, exigencias e finalidades educativas, religiosas, políticas.[...]A cultura é sempre funcional, vigorosa e mantenedora do estado normal do seu povo quando sentida, viva na acepção de Ortega e Gaset, exercida por todos os membros e objeto de orgulho e confiança.

${ }^{47}$ Ver Ágape arte como a vida. Sousa, Carina Y Gonzalez. São Paulo: Inmood, 2016.

${ }^{48}$ Sousa, Carina Gonzalez Y. Composição Piano: Sem poder tocar o que se ouve nas águas do mar.
} 
ditame do gosto, creio que poderemos compreender a beleza como o próprio curso da vida, inseridos nos gestos do mundo, em aprendizado e sem julgamento.

Sobre o conhecimento estético e a necessidade cultural. ${ }^{49}$

Em se tratando de experiência estética ${ }^{50}$ como viver e continuo de pensamento que abarca o conhecimento, se afinando como instrumento do soar os acordes para que de fato a vida exista, e não esteja sobre amortecimento, mas que pulse verdadeiramente sobre seus espaços possíveis se manifestando e representando, se tornando razão sensível, como aisthesis ${ }^{51}$, fractais no mundo, permeados pelo que é de natureza do bem, da ética, em lógicas compreendidas para um desenvolvimento, se prontifica como um fator necessário para uma cultura sustentável onde o pensamento se constrói nesses tecidos orgânicos do mundo, entre naturezas onde o belo se torna a procura do viver em igualdade, fraternidade e liberdade. ${ }^{52}$ Assumindo as dificuldades de cada parcela dessa imagem que deseja soar por entre tempos futuros onde a história como lastro, de tantos séculos, passa a ser a dimensão de um segundo, frente a imensidão de esforços na direção dos rumos, em geometria ${ }^{53}$ de uma concepção, que se nutre em liberdade $^{54}$ para o desafio de nessa condição encontrar a

\footnotetext{
${ }^{49}$ Continuando, ainda sobre aspectos de cultura levantados no livro de Luís da Câmara Cascudo, ele alerta pelo nosso modo de aproximação para com culturas de maneira equivocada, e salienta que: " $O$ que caracteriza essencialmente uma cultura não é a existência de padrões equivalentes aos nossos no espaço e no tempo.", e ainda reflete: Cultura é civilização? Civis, cidadão, deu civilidade, civismo, cidade. Está sempre ligado ao homem, portador de direitos, expoente de força disciplinadora, detentor das garantias ideais de um patrimônio politico, como ainda de urbs, cidade, urbanismo, urbano. São vocábulos decorrentes da ação espiritual e doutrinária do próprio indivíduo, conquistas do convícivio, da aproximação, relações humanas associadas ao plano do espírito, da projeção imanente da dignidade, soberania e domínio da espécie. (2004, pg 44). Segue em outro trecho apontando que, as culturas são conteúdos e a civilização continente. No capítulo de morfologia social, destaca como sendo a morfologia um lugar de aproximação do conhecimento, e o papel dentre as organizações do viver, de uma estrutura movida de instrumentalização inteligente. ( 2004, pg 55); e ainda nesse capítulo, descreve a Theory of Needs, teoria das necessidades, provocando cada uma a cultural response respectiva. E o desequilíbrio dos fatores dentre benefícios e respostas, quanto a camadas sociais, podendo até, extinguir determinadas civilizações. ( 2004, pg 63). Importante o livro distingue, culturologia, a saber como: "É a ciência que estuda a vida das culturas como produtos da atividade humana, entidades vitais, autônomas. A culturologia, estudando a vida das culturas, analisa o mesmo complexo etnográfico, participando da etnografia como a semântica se inclui na filologia. Apenas estende sua curiosidade às organizações humanas que são, logicamente, fórmulas existenciais de permanência social.( 2004, pg 116). Sobre normas e conduta, página 160. Instinto, caça, e modos de agir.

${ }^{50}$ Ver capítulo I do livro: Ágape arte como a vida. Caminhos da estética e as raízes de uma vagueza.

${ }^{51}$ Aisthesis, Etimologia da palavra grega definida como compreensão dos sentidos, ou faculdade do sentir. Aqui também se compreende a música das esferas, a geometria do cosmo, o silêncio do universo.

${ }^{52}$ Sousa, Carina Gonzalez Y. Composição: Pingos de anil - piano para uma mão.

${ }^{53}$ Nos referindo a Pitágoras, onde se pode encontrar a medida como medida de virtudes, vendo Platão, Timeu e Fédon. E em se tratando de Pitágoras, e a palavra, consultar mais adiante nesta tese, o texto escrito em reflexão da autora, a parte da negociação.

${ }^{54}$ Sousa, Carina Gonzalez Y. Composição: Piano - Sonho de liberdade.
} 
igualdade, onde quem sabe, dos pontos de conjunção entre o pensar e agir, esteja o gesto do aperto de mãos, imagem representada de uma humanidade, que se forma.

No livro modernidade liquida de Bauman, Bourdieu sugere que temos os benefícios da beleza e a necessidade dela, embora como afirmando por Kant não de forma desinteressada, ainda que os benefícios sejam da ordem do social, do que concerne a dicotomias de classes, o que observo particularmente como uma visão restrita do âmbito do social. Pessoalmente, os benefícios e a necessidade da beleza ligadas as questões éticas e lógicas estão inseridas na construção de um viver, como dito anteriormente fraterno e igualitário, buscando soluções, dentre desenvolvimento de capacidades de toda ordem, favorecendo processos heurísticos e ainda como fator de melhor produtividade, parte de uma arquitetura social, descrita mais adiante como elemento presente e fator de uma forma do belo para a evolução, de espaços do nosso tempo.

A parte de concepções pessoais, e seguindo o estudo em reflexões do livro, permanecemos em contato com a reviravolta que Pierre Bourdieu, em seu livro, La distinction, fazendo uma reviravolta como apontado no livro, no conceito de cultura nascido no iluminismo. Segundo a origem do conceito cultura, mais próximo do que apresentamos como sendo objeto a ser colocado como construção, mas que talvez em diagnóstico seja algo mais próximo de Bourdieu, porém, como transito entre os dois, o caminho, ou seja, um agente da mudança do status quo e não de preservação, e um “ instrumento de navegação pra orientar a evolução social rumo a condição humana universal", portanto, "o propósito inicial do conceito de "cultura" não era servir como registro de descrições, inventários e codificações da situação corrente mas apontar um objetivo e uma direção para futuros esforços" - cabe aqui, considerar a interface das duas posturas e considerar o caminho entre elas.

Uma educação do pensamento como esta pesquisa propõe, claramente dispõe os sentidos a um esclarecimento que deveria ser capaz, de preservar-se de qualquer manipulação, e havendo uma diretriz, esta não será impositiva, mas de conhecimento, ou seja, o livrearbítrio em consciência estaria propenso a devido ao esclarecimento tomar o rumo, nessa direção. Portanto, para além de creditar estarmos em educandos da vida como aprendiz do viver, sendo e buscando compreensão, e quando no conhecimento, poder ter o discernimento suficiente para evitar toda e qualquer manipulação e subjugação, para tal, presume-se que a firmeza de caráter esteja sobre o horizonte de não se iludir em movimento s de massa que não estejam de acordo com os seus ideias traçados, conquistados ou almejados. Isto, tratando 
de indivíduo e sociedade, para gerar uma cultura edificante de maneira q contribuir no desenvolvimento uns com os outros. Necessário será alertar que a observação quanto ao discernimento mesmo de rumos traçados, deve permanecer constantemente em pauta, pois, já presenciamos consensos que geraram desumanidades, e portanto, avaliar constantemente as nossas próprias convicções e das quais viermos a fazer parte, é necessário, principalmente para uma cultura que tenha os pilares como os citados, de igualdade, liberdade e fraternidade. E, não nos esqueçamos de que, o respeito é parte integrante do que chamamos de cultura sustentável, e portanto, em uma topologia do conhecimento, esta abrange diversidades de aprendizados, isto considerando a multiplicidade de tempos, onde podemos encontrar tradições que se prolongaram, e que constituem e preservam sua identidade, mas que podem ter relações de divergência ou abrangências com outros espaços, porém, como dito, uma lei básica do homem civilizado que seria o respeito, deve ser colocada em prática, e portanto, é uma complexidade cultural que se constitui fundamentada no que é de direito de todo ser e ambiente na terra, como dizemos de uma economia planetária, que convive com a distribuição de seu corpo orgânico, entre Nações, e dentre as mesmas, dependendo, suas particularidades, onde sempre teremos escolha, quanto ao compreender no sentido de englobar aprendizados e transformá-los em conhecimento percebendo possíveis entrelaçamentos, ou ainda que, definir-se pelo respeito como mesmo em discordância, por certos hábitos e costumes, leis serem muito diferentes, mas, ter a consciência de que entre direitos, somos seres, e do que haveremos todavia de encontrar o que apontamos em Ágape ${ }^{55}$, a presença de um sentimento que é capaz de unificar pelo que somos independente de crenças, raças, ou territórios, mas do que a vida nos constitui em integralidade e união.

Apesar do que propomos, avalia-se a condição atual, ainda dentre a própria condição humana, e constatamos uma luta de desigualdades e até mesmo, em alguns lugares, crueldades. ${ }^{56}$

Das lutas de desigualdades. Holocausto cego e guerra sem armas. O diagnóstico.

Está me parecendo que ainda veladamente estaríamos vivendo uma segregação cultural, ou estamos vivendo, e diante disso os marginalizados estariam em campos de concentração da sociedade, dispostos aos mal tratos, e calamidades de um sobreviver, sem ar, sem voz, em olhos cegos, de onde haveremos sempre de questionar, o quanto que nosso tecido social está

\footnotetext{
${ }^{55}$ Ver Capítulo III do livro, Ágape, arte como a vida, em especial, a metáfora o poema do universo.

${ }^{56}$ Sousa, Carina Gonzalez Y . Composição Piano - Tempo triste.
} 
amorfo e amortecido. E, como ponderava sobre sentidos compartilhados entre música e comunicação, ressalto que a pauta da atualidade discorre sobre inúmeras dificuldades, e uma delas, é por onde encontraremos da realidade o que nos sucumbe, ou nos ergue do que desejamos ser, e até mesmo, o desafio de constatar ilusões ou sonhos a conquistar, diferenças também postas como cotidiano, e dentre os fatos, devemos buscar a razão das causas, para quem sabe, dos argumentos dessa sobrevivência aferimos a consciência, e desse lugar, oxalá saibamos, entre a causa e o fato, encontrar o prumo, da origem e de onde o caminho segue, e no qual estaremos sobre a vida, na perspectiva do tempo que nos trás o retorno, de onde, todavia, saibamos ser o mesmo, ou outro, segundo o aprendizado, mantendo ou alterando as consequências. Portanto das mazelas, das quais somos parte integrante, por indivíduos e sociedade, devermos estar em um tempo em que as escolhas do que nos faz ter a ciência de nossa natureza, é fator decisivo, de uma coletividade, e portanto, saná-las, e desenvolver uma diretriz capaz de integrar ações transformadoras para o bem comum, é a presença na qual cada vez mais, almejamos constatar, para inclusive o meio ambiente. E, já colocando que neste trabalho, vemos o sujeito ambiente, como sua relação de seu estar interno e externo com a sociedade, mas principalmente não centralizado no homem, e sim, um ser orgânico com a natureza, e não apartado da mesma, ao contrário, sabendo de que são recursos ambos, do existir. E em se tratando de recursos esse permear de natureza do homem e Natureza, é fundamental, para a educação do futuro, relação esta que traduz-se em um conhecimento na qual também se faz, a humildade de reconhecer que existe um saber que se apresenta na conduta de espécies, de tudo que existe, e se tivermos sentidos para sentir, e pudermos nos acercam de maneira a não sempre com nosso modo de olhar o mundo, mas, como nele, essas estruturas também convivem, e tem sua comunicação $^{57}$, sua sobrevivência, poderemos compreender melhor e realizar o que almejamos de maneira mais equilibrada. ${ }^{58}$

E novamente tratando de nossos desafios, o homem do tempo vigente, que examina seu lastro, o que observa? Se já sabemos que posturas como o holocausto na Alemanha devem

\footnotetext{
${ }^{57}$ MACHADO, Irene e ROMANINI, Anderson. Artigo apresentado a revista Famecos. Porto Alegre • v. $17 \mathrm{n}$. $2 \cdot$ p. 89 - $97 \cdot$ maio/agosto $・ 2010$. No qual abordam o diagrama ontológico, como condição de possibilidade de comunicação porque articula a rede de relações que emerge da percepção estética ( espaço-temporal), funcionando como uma interface entre a espécie cognoscente e o fluxo de informação que a une ao mundo. Eliminam-se, dessa forma, as dicotomias, interno-externo, emissor-receptor, sujeito-objeto, em prol de uma visão sistêmica baseada na continuidade dos processos de informação e significação. Ver também o livro de autoria de Humberto Maturana e Francisco Varela, A árvore do conhecimento, São Paulo:Palas Athena, 2011.
}

${ }^{58}$ Maturana, Humberto R. A árvore do conhecimento. São Paulo: Palas Athena, 2001. 
ser lembradas para que nunca mais ocorram, como podemos realizar e ser agentes participativos de uma segregação cotidiana e permitamos tal acontecimento? Alguns podem dizer que é diferente, mas eu penso que não. Mas, o que mais assusta é que não estamos apartados dessa situação e somos em parte o próprio ditador e ainda pior contra o sujeito mundo todos os que vivem, em um lastimável extermínio coletivo, cortamos os rios de nossa natureza, como os rios, seiva do mesmo sangue do corpo da terra. Contudo, a esperança não desiste e se abriga no através da insanidade buscando uma consciência capaz de despertar ainda que para alguns como caráter de preservação, e contra medida da morte, e para outros o despertar da centelha divina, em suma, de alguma forma, o bem maior que nunca sessou de arder, ilumina os caminhos, e ações e esforços vão nascendo, brotando, ressurgindo, e concretizando na experiência uma fraternidade capaz de apaziguar as mazelas do mundo, trazendo à tona, a voz, o ar e o calor de um amanhecer que independente de nós, como espaço e tempo, permanece.

Mundo desenvolvido ou em desenvolvimento?

Ainda a missão de salvar o homem selvagem da barbárie. Na expansão do urbano território contemporâneo, o que mudou do desbravamento de terras distantes? Dentre os espaços do tempo onde a cultura ser realiza dentre um passado dentro da perspectiva da colonização, com suas consequências, e de que lado, mais estaria a barbárie onde estamos ainda a desbravar, de forma que aspectos da história configuram o comportamento dos homens e consequentemente nas sociedades a sua cultura, onde os critérios de posturas são avaliados hoje, para que modos de ser no através do tempo não se tornem outros deles mesmos, posturas sobre o palco da vida em baile de máscaras ${ }^{59}$, onde quando as retiramos, os papeis se entregam ao que é de submissão, de exploração do homem contemporâneo. Em considerações sobre o equilíbrio social, há de se fazer uma ressalva pois não é permanecer no mesmo estado o que estamos tratando mas a busca de um estado em que as diferenças se equalizem de maneira a proporcionar um equilíbrio e Bourdieu considera que por vezes a cultura que promove um avanço e desenvolvimento pode ficar em um estado como os indivíduos, amortecida, ou ainda, oscilando entre o movimento e uma estável presença angustiante, e esta última palavra se refere justamente a não presença de igualdade, enfim, Bourdieu considera o segundo tardio do amanhã, sendo a cultura a possibilidade de um estado homeostático que oscila na perda dessa mesma posição.

\footnotetext{
${ }^{59}$ Ver texto. A moeda, apresentado em congresso IBERCOM 2015, podendo ser consultado no endereço eletrônico:https://pt.linkedin.com/pulse/moeda-est\%C3\%A9tica-de-um-discurso-napercep\%C3\%A7\%C3\%A3o-da-imagem-carina
} 
Questionamentos sempre presentes, se apresentam, como a concepção do ontem como partícula do amanhã, o mundo como projeto e movimento. Arquitetura de uma época. Sociedade em re(construção)? A vida em processamento, evolução contínua? Modernidade líquida $^{60}$ (BAUMAN:2000) muitas vezes denominada, pós-modernidade, modernidade tardia, segunda modernidade ou hipermodernidade, os tempos atuais neste trabalho se refere a tempo vigente. Muito todavia se trata ainda do efêmero, como propriamente ele considera a possibilidade, de ser esse estado seu molde, sua forma de ser, da diluição que se esvai, porém a diferença como considera é justamente que o que se alterou no estado antes diagnosticado é que hoje, ao contrário de ontem, as formas dissolvidas não são substituídas por outras mais sólidas e resistentes à liquefação, o que ocorre, é que as que surgem, são tão quanto mais suscetíveis ao "derretimento" e portanto inconstantes. E neste particular me parece fortemente que poderemos aliar ao pensamento da densidade de probabilidade na Física, concebendo uma existência em mobilidade. Neste tempo vigente, indivíduos e sociedade $^{61}$, aqui em argumentos de compreensão de ambos se conjugam para os esforços de construir uma cultura sustentável em entrelaçamentos de responsabilidades sociais mútuas.

Lidar com uma densidade de probabilidade e não uma determinação, não quer dizer desorientação. E quando abordamos a sociedade atual deve se ter em mente, que a delinquência não está somente sobre as não oportunidades non tecido do existir, mas no poder, este ainda podendo ser pior talvez, porque possui mecanismos de manipulação e de realizar marionetes segundo a vontade, e desse lugar pode-se observar conjecturas antes colocadas em lados opostos, por um preço, onde o valor de ser integro ou não, igualda as partes, havendo pela escolha, determinar o verdadeiro rumo. A efemeridade do desejo, enquanto passível de ser diretriz, é um desafio de permanência do eco ainda que caminhemos, o pulso continua exercendo sua força em nossos corações, a latência ainda que estejamos em mutação, nos preserva do exaurir completo de forças e nos faz ainda caminhar. Portanto, o que o torna, um desejo sapiente? Inserido, talvez sobre da matéria do pensamento, suas razões, entre a consciência. Bauman retrata um olhar onde somos hoje,

\footnotetext{
${ }^{60}$ Sigmund Bauman descreve: O que torna líquida a modernidade, e assim justifica a escolha do nome, é sua modernização compulsiva e obsessiva, capaz de impulsionar e intensificar a si mesma, em consequência do que, como ocorre com os líquidos, nenhuma das formas consecutivas de vida social é capaz de manter seu aspecto por muito tempo "Bauman, Sigmund. Modernidade Líquida, 2000, pg 16,
}

\footnotetext{
${ }^{61}$ Composição em Homenagem ao pianista e maestro, João Carlos Gandra Martins. Em especial agradecimento ao trabalho realizado na Fundação Bachiana Filarmonica Sesi.
} 
pessoas transformadas em consumidores e eu alerto para que o próprio tempo está sendo transformado em consumo, tempo cronos, como identidade, viver sendo o tempo, a marca que nos identifica.

A insaciedade, como fator de avaliação contemporânea, pode ser mais dos que os produtos, mas, do que o pensamento crê estar sobre inquietação. Como duas faces ainda da mesma moeda, podemos ver entre o mesmo, que rumos escolheremos, porque pode ser uma insatisfação que nos leva a procura do algo melhor, do que pode ser realizado de maneira mais eficiente, do que condiz com uma maior reciprocidade, ou apenas ser uma insatisfação pelo simples fato do hábito de descarte, o que torna a razão do ato, entre o mesmo, completamente diferente. Então, em um olhar sobre um diário de bordo cultural, recupero as palavras de Salvador Dali "Deliciosamente corroído, pelo desejo de fazer algo mais belo, e extraordinário. Esta divina insatisfação é o signo de que no interior de minha alma efetua-se um impulso que vai me proporcionar grandes satisfações"(DALI, 1989). e o mesmo Dali, dizia: "Não se preocupe em ser moderno. É a única coisa que infelizmente, por mais que faça, você não poderá evitar". Ainda se aponta para o caráter social em que estamos inseridos, como lógica possível, dentre o que é do ser da moda, e seu estado de devir, e curiosamente, percebo que existe um espaço, já que tratamos de espaços e não espaços sociais, e de pensamento, identidades, onde perpassa a nossa marca, e tratando de marca e moda, em ambiguidades podemos dizer, quiçá estaremos vivendo um paralelo onde a liberdade de expressão, também considere o modo de ser de cada um, onde a vestimenta, esteja na moda ( LYPOVETSKY, 2009) ${ }^{62}$ ser o respeito a cada um, como tecido de seu pensar. Onde o poeta, brinca: Caneta fluorescente - chame atenção! Observe a vida. Boa campanha! Lendo o mundo, public(o)idade. Havendo de o pensar procurar diminuir distanciamentos onde o território seja a viagem ${ }^{63}$, entre os nosso passos o cotidiano que nos marca, finca a terra sobre ainda nossos ideais, onde certas palavras se tornem gestos, e reflexão que nas asas encontrem o pouso, onde certas palavras, tem a características de nos causar um impacto, e quando os sentidos nos perpassam consideravelmente o diálogo entre o que lemos e o que pensamos se torna quase que uma necessidade de resposta, havendo na

\footnotetext{
${ }^{62}$ LIPOVESTSKY, Gilles. Capítulo IV. E voga o sentido. A sustentável leveza do sentido: moda e ideologia. Companhia das letras 2009. Particularmente chamamos atenção quando o autor, considera: "Evitemos de saída um mal entendido falar de processo moda nas ideias não significa que tudo flutua numa indiferença absoluta, que as opiniões coletivas oscilam de um polo a outro sem nenhum ponto de ancoragem fixo. A moda consumada não tem sentido senão na era democrática em que reinam um consenso e um apego forte, geral, durável, relacionado aos valores fundadores da ideologia moderna, a igualdade, a liberdade, os direitos dos homens.

${ }^{63}$ Poema para letra e melodia em arquivo da autora de música brasileira.
} 
consciência um espaço onde se tenha a liberdade de expressão para considerar um ato manifesto. E, entre o pensar e agir, encontramos de Jose Carlos Bruni, a recordação de um grafite de 1968: “ aquele que fala de revolução, sem mudar a vida cotidiana, tem na boca um cadáver”.(MEDINA,2018). E, ainda nesse cotidiano, iremos encontrar para o pensamento e valores, o defrontar-se em guerras veladas, massacres incógnitos, frutos de não espaços sociais, nos quais perguntamos sobre sentidos de compreensão, havendo de considerar que sobre nosso olhar ao mundo para além do que pode ser considerado sonho ${ }^{64}$, utopia ou ideal, ainda sobre a mesma $\mathrm{p}(\mathrm{a}) \mathrm{uta}$, o preço de uma relação, contempladas no prazer e equação da vida em sobrevidas reais, onde pergunta-se onde está o sinal de igual ${ }^{65}{ }^{66}$ E, sobre considerações do modo de ser, ontem e hoje da moda, o quanto que apresentamos ser de nosso diário de vida, a narrativa de querer pertencer de grande massa ou compreender um tornar-se que é do próprio englobamento do diversidade como uma maneira até de tentar equalizar os lados, que por vezes se encontra em dilemas quanto a independências e o pertencer social, embora, passamos a ver a independência como a voz capaz de ser ativa, principalmente como um outro olhar dentre o que é consenso, e creditamos ser necessária essa voz, para não incorrermos em consensos patológicos da sociedade. Parece portanto da natureza humana estar entre esses meandros, tanto da individualidade, preservada e conquistada, assim como seu caminho do que é do território social, havendo de estar as razões descritas anteriormente sobre o pensamento, validando condutas escolhidas entre esses dois caminhos, que no sujeito ambiente, se torna sob o desafio de diminuir distancias. Admitindo o argumento de que a moda pode promover um acordo entre o indivíduo e o sentido da igualdade social, pode ser colocado como uma renegociação contínua como a economia do social em práticas sustentáveis. Pode parecer que o modo efêmero condizente com a moda, nos leve a considerar o progresso como algo natural a ser constituído por uma diversidade de fases, porém, o que pensamos ser o progresso? Um lastro, história, e o amanhã, um dia após o outro. Haverá do progresso ser mais do que isso. O pensamento, considerando o tempo, como espaço da vida, inclui os massacres não resolvidos do processo de existir, por onde e quando, não sabemos como caminhar, entre o lugar que poderia ser

\footnotetext{
${ }^{64}$ Sousa, Carina Gonzalez Y. Composição Tarde Suave. Piano.

${ }^{65}$ Apenas como aparte mas devido em referência como pesquisa desta autora, os trabalhos ainda em curso, de estudo como ser humano que se preocupa, os trabalhos de Acesso, e GEO.

${ }^{66}$ Sousa, Carina Gonzalez Y. Composição Direito de Viver. Se o destino está escrito então eu vou te falar, eu quero o direito de viver, eu quero a liberdade de ser, os meus passos entre os teus, eu quero, se está escrito, o direito de viver. Eu quero se está escrito a liberdade dos meus passos, e eu não sei, como pode ser. 0 tempo se assim nascer o ontem o adues que é manhã. Eu quero o direito de viver. o direito de ser, apenas simplesmente, amor.
} 
para todos, e sobre as margens do rio, está a sede, e dela queremos sorver o progresso, sem os passos do hoje. E, dentre o camaleão, procura-se o cidadão. Da forma de ser muitos, presença múltipla, e multidão, nos aproxima penso, do desafio de viver em compreensão. No fator compreender em compasso de englobar se observa que se desenvolve a capacidade de lidar tanto com o não determinado, o múltiplo, absorção do que não é natureza do próprio sistema, requerendo uma maleabilidade do pensamento. Portanto, seria um equívoco considerar a incerteza um campo minado nessa guerra sem armas creio que poderemos imbuídos de um propósito, nos deslocar de posturas dogmáticas e de estagnação para contemplar novas possibilidades que se afeiçoem nessa rede de significações embarcadas no sentido de um desenvolvimento, e dessa forma, considero que a utopia esteja todavia mais próxima, talvez, ou precisando de um abraço sem pele ${ }^{6768}$, em tempos de ((in)compreensão), o pseudônimo do nome, sociedade e cultura. Mutilados também, dos seus gestos do viver.

Cavernas arqueológicas do existir, partículas de relações no movimento do tempo. A Caça e o desejo. Impulso predador e o querer. Quando haveremos de estar sobre o relacionamento para com a sociedade no mesmo ímpeto de nossas volúpias de relações particulares, enquanto objeto de consumo de nosso querer dos valores considerados para o progresso, o que dessa aproximação é real, verdadeira, ou apenas algo passageiro, descartável, e segundo as escolhas, como será a comunidade do futuro. Estamos realizando uma relação humana ${ }^{69}$, de que maneira para o presente, sendo que as consequências estão sobre as próximas gerações. Como nessas relações os objetivos e a economia se sustentam ${ }^{70}$ ? E, sobre o

\footnotetext{
${ }^{67}$ Do projeto de livro, Gingado- Poema abraço sem pele, e composição em acordeon, intitulada: Abraça-me.

${ }^{68}$ Composição para o projeto Geo - Acesso. Não há distâncias para o amor. Das dificuldades humanas em qualquer território a vontade de um sentido que nos une em um viver melhor é força que nutre o pensamento, a possibilidade de nos encontrarmos. Diversas culturas, lugares do mundo. Os esforços do amor, onde a fraternidade pode se aliar a um conhecimento, como destino que nos une e fortalece como humanidade. Uma das partes da pesquisa do ACESSO é devido a partituras para pessoas que tenham somente um membro de mão, vitimas de acidentes, ou violências, ou conflitos. A busca de um lugar de paz. Principalmente para as gerações futuras, as crianças. E com auxilio de um PUNHO, largo duas mãos, quando uma criança ou adulto precise de auxilio por ter problema de saúde mas deseje tocar piano, duas almas, no sentido de um tocar junto com o outro, sendo a mão de um só coração.

${ }^{69}$ Sousa, Carina Gonzalez Y. Composição: Duas almas - PIANO.

70 Sousa, Carina Gonzalez Y. Composição: Negocio. Negocio, negocio, negocio, qual é o meu preço do meu valor? Humano, faça-me o favor, diga-me onde está, a oportunidade do negócio. Ou da igualdade, do meu trabalho e a liberdade, quero a minha parte nessa tal grande cidade ou seja, qual for o lugar... que eu esteja e possa respirar... negocio...negocio.... cadê a minha gente, igualzinho que também sente...comendo asfalto, sem ter estrada! De repente, a fome da cidade engoliu, o reverso que sumiu da palavra o sentido, de uma vida o proibido, qual o lugar da sociedade, pão de estomago vazio, negocio esse humano, corrompido, é esquecido... sou artista do existir, muito prazer... se me permite dizer... o meu valor... neste mundo é viver... ainda quando de tanto morrer permaneço ainda na minha alma. alma e pão, corpo são no direito de viver eu quero ter um espaço para nascer. alma e pão, corpo são. eu quero ter um espaço para nascer. Quantas e quantas vezes, por onde for, esse meu destino é... meu amor.... negocio, negocio, qual é o preço... do meu
} 
cenário cultural, no palco do mundo, interroga-se a identidade. Desde o tempo nomeado como modernidade a migração teve seu papel em períodos de dominação, subjugação impondo saberes e modos de vida, assim como ainda sobre a rede, e globalização, certos territórios se sobrepõem no cenário, havendo de sempre ser protagonistas das ações mundiais, em recursos e produção. Porém, hoje se adverte que os caminhos estão mais abertos tanto para desbravar territórios do saber, de relacionamentos, como para estabelecer direitos de preservação culturais onde o diálogo não restringe ao contrário valida posicionamentos de múltiplas compreensões. Me pergunto se viramos pescadores em territórios nossos, querendo encontrar sentidos. Os movimentos populacionais em deslocamentos geográficos continuam acontecendo apesar da tecnologia "não ter "fronteiras em deslocamento de conexões e contatos, então algo está acontecendo nos deslocamentos que não possuem a mesma estrutura lógica de necessidades. Aonde passa a ser o abrigo negado pelo Estado, quando, o abrigo da cidadania passou a percorrer os bits dos dispositivos tecnológicos, mas que por eles não podemos dormir, nos agasalhar, comer e trabalhar e viver de fato, então, aonde está o sentido dessa aparente complexidade que para se acercar de uma rede cidadã carece de compreensão? Mercado, poder econômico, vozes próximas ou distantes dessa compreensão? São esforços participativos de ações concretas do desenvolvimento em diluição de fronteiras para além da rede? Sobre que territórios estamos do capital humano?" "É impossível negar que as forças de mercado em movimento livre contribuem muito para a crescente mobilidade dos migrantes econômicos. No entanto, até governos territoriais são obrigados, ocasionalmente, embora com relutância a cooperar com eles. “(BAUMAN, 2000). E, entre intervalos do tempo, o deslocamento do corpo que carece de compreensão do próprio viver, fica naufrago ${ }^{72}$ em águas do oceano que lhe pertence e como sujeito mundo, na busca da terra, onde deveria em qualquer espaço ter ao menos dignidade.

E depois falam que não tem mais escravidão.... os vestígios de uma travessia. Sobre os caracteres da representação, os processos de significação como comunicação, poderá haver

valor? ah humano, faça-me o favor, diga-me onde está a oportunidade do negocio dessa igualdade do meu trabalho e a liberdade. quero a minha parte, nessa tal cidade, ou seja lá qual for o lugar que eu possa respirar. negocio... senti e vive, não de estomago vazio. Cadê a minha gente, que também sente. Comendo asfalto, sem ter estrada, de repente sente a fome, da cidade engoliu, o reverso que sumiu! da palavra o sentido, de uma vida, o proibido. de uma vida, qual lugar da sociedade. Pão de estomago vazio. alma, e pão, corpo são. do direito de viver... eu quero ter um espaço para nascer, o artista que eu sou, quantas vezes eu posso ser, por onde eu for... esse meu destino é, é esse o meu lugar, meu amor.

${ }_{71}$ Entre paralelos do tempo, poema Hevea Brasiliens, do livro Gingado.

${ }^{72}$ GALEANO, Eduardo. As veias abertas da América Latina. Capítulo O desenvolvimento é uma viagem com mais náufragos do que navegantes. Rio de Janeiro: Paz e Terra, 1983. 
uma voz itinerante do viver ${ }^{73}$ ? Vemos o mundo, lendo suas páginas, entre linhas, pautas de um dizer sonoro do existir, onde acreditamos que nas folhas, afluentes do pensar vivente, escrevem as palavras desde sua gênese à latente contemporaneidade vigente. Porém, indago sobre onde repousaria verdadeiramente o olhar, as vésperas do hoje, buscando a confluência do tempo, se procurarmos a poesia, a metáfora como canto, a soar pelos sentidos que dizem de si, melodias submersas desejando nossos ouvidos em ecos de uma possível realidade não percebida no frugal saboreio cotidiano. ${ }^{74}$ Estaria esse olhar em um lugar que não lhe pertence? Desapropria-se, humildemente, por embriagar-se no sulco das experiências, sendo movente, o próprio deslocamento, trânsito ininterrupto da compreensão. Talvez, a anatomia do mundo vivente espere de nós o auscultar do seu pulso, fazendo desse compasso, a compreensão dos sentidos. Tudo que existe exerce o ato de comunicação, em seu próprio modo de ser e agir, em idealismo objetivo, sem dicotomia de mente matéria, porém, algo me inquieta o pensamento quando tudo exerce sobre a Vontade ( Schopenahuer) uma contemplação que emana, com um impulso genético criador ( Schelling ) para a percepção dos sentidos antes não absorvidos, observados, diagnosticados, outro interno e externo nele mesmo e não percebido, e então, pergunto sobre quanto de informação poderemos buscar se permitirmos que a metáfora adentre as nossas e outras formas da vida, para ir além do que a realidade aparenta.

O urbano corpo deixa-se navegar, e entre o caminho aprendo, desejando as palavras na alma, no dorso do viver. Desagua avido o cotidiano em faces desapercebidas do concreto aparente e alheio a transparência do olhar, que invade o todo e permanece no limiar do desejo da comunicação. Comunicação, como ato da arte de viver, porque imaginar a hipótese da vida, é exercer o ato exploratório da descoberta. Assim, o olhar não me pertence, mas engendrado no todo ao qual pertenço, observa a si mesmo, como enigma a espera do tempo, nas areias de nosso deserto, é clepsidra, ainda que infinito. Que dizer se as palavras, tem um lugar no som que se faz identidade, ecoando, quando as cortinas estão abrindo a

\footnotetext{
${ }^{73}$ Sousa, Carina Gonzalez Y. Composição: Porque sobrevivo: Não será castigo, porque sobrevivo nesse teu destino de almas, estou contigo, mesmo quando me calo, e se ensaio esse meu jeito, é porque sou terra e solidão, por onde passei e senti meu irmão, que na calçada dos tempos, os sofrimentos são os mesmos, de outros ventos... animais, violências colossais, desatando tristezas, que nem me lembrava mais. Mas é preciso não esquecer jamais, por onde somos, como vivemos, nossos ancestrais quem sabe me fala, o segredo que desabou, de quem amou, esse teu querer insano, que do Brasil proclamo, o passo do compasso, que não me engano é nesse verão... dos sois encobertos de nuvens incertos, tempestades de multidão, que não sabem por onde vão o que da alma são, corpo da mente não mente, a vontade que sente, de um dia viver, a igualdade, Mas quem sabe... a saudade, mas quem sabe... a saudade. Por onde somos, como vivemos. Nossos ancestrais.

${ }^{74}$ Sousa, Carina Gonzalez Y. Composição: Sabor de amar. PIANO.
} 
janela e eu fico aqui na coxia, do outro lado do meu corpo. Essa forma que pode dizer de onde vim, não é somente o som, mas uma imagem que se faz outra palavra, esquecida desse corpo que se representa independente porque se veste do pensar e acredita que dessa forma, o personagem não tem somente uma voz, mas um discurso. E nas coxias da alma, o espíritomente renasce sendo personagem do mundo, atravessando esta passagem onde o corpo se veste das vozes do Ser aprendiz em diálogos da compreensão humana exalando do pensamento o desejo de se encontrar nas formas da vida, a dramaturgia em mar. Sobre os caminhos das águas cotidianas, no palco, o árido $\operatorname{ser}^{75}$, sobre a viagem nos trilhos do existir.

Domingo, o dia deixando-se ficar memória dos fatos repartidos nos jornais, lidos como nosso próprio amanhã, deita-se a espera dos novos retratos, nas ruas da cidade que penso, de mim se faz o mesmo desenho, imagem navegante. Amanhã o sol, nasce, e com ele a pauta já se fez, antes dos meus olhos, ela em verdade, me observa para noticiar o que de mim, ressoa mesmo que adverso. $\mathrm{O}$ mundo se fez sem territórios, onde atravesso, sendo também os passos em pegadas. A experiência outra é pátria repartida, identidade fluida desse ser contemporâneo. Porque penso que a ausência dessas águas são de minha palavra, o cimento bruto existente que seca e amarga o cotidiano sem janelas. Preciso acercar-me dos lábios densos, e debruçar-me sobre o Eros da imagem, aprisionado no campo do não dizer. Rosa que deleita-se no papel, da vida redimensionada, em através, fez-se botão a abrir-se em pétalas de contos dos personagens não utópicos, mas existentes em ser poeta do corpo, sonoro nos ecos da linguagem, que sente, como o fingidor, é Pessoa, em viver. (SOUSA, 2017: 21)

E do sujeito ambiente, que realiza a travessia, o que concebemos em percepção da realidade? $\mathrm{O}$ que de fato é a realidade? Tecendo fio a fio no tecido hibrido do existir a sinestesia é alquimia em busca, de uma possível verdade. Seria possível pensar a realidade como o engendramento da própria comunicação, tendo como premissa que toda a criação em qualquer instância desempenha um ato de desenvolver-se, podemos refletir que seu hábito, seu ato do existir, a configura e informa seu ser que desempenha suas relações emergindo e possibilitando a aferição do que a representa, nos conferindo uma realidade - existência, convivida ou construída, mas, prenhe ainda que, em descoberta. Porém para além do que a realidade, independentemente de nosso desejo, se apresenta, podemos nós participes do cosmo, ser um com ela, em infinitas semioses de relações, para a realidade se aproximar do existir, em transparência, como o sangue que não vemos mas nos faz viver ${ }^{76}$, onde podemos

\footnotetext{
${ }^{75}$ SOUSA, Carina Gonzalez Y. Amanajé, contos e reflexões. Concreto Sertão, página 21. São Paulo: Innmood, 2017.

${ }^{76}$ Sousa, Carina Gonzalez Y. Composição: Na pele da alma - Sobre o por do sol- PIANO.
} 
então perguntar, sendo assim, o que nos faz viver. Percorremos o uníssono tear, em tramas conjugadas, sobre uma realidade como sujeito mundo, sujeito ambiente.

A realidade sendo o próprio viver, mutável. Como poderia a realidade ser mutável? Antes mesmo de considerarmos o desenvolvimento, a evolução, que por si só, se configura uma transmutação, o que propriamente é observado em ponto estático do tempo Kronos, se faria plausível de muitos olhares em percepções, e então, qual seria o verdadeiro? Mas, de fato, o que consideramos não é ainda o que é verdadeiro, mas sim, a possibilidade de considerar a amplitude, o horizonte como sendo, um Le Parlement, effet de soleil, 1903, de Claude Monet, podendo ser a busca da luz, o próprio caminho, e o caminho o próprio viver, despertando o siena natural como areias em mar, esculturas convexas em profundezas? Poderemos recolher em nosso pensar, como realidade impressões ${ }^{77}$, no diário do cotidiano, a bordo os navegantes. ${ }^{78}$ Sendo a viagem como passagem, o limiar de um temp $(1)^{79} \mathrm{o}$, onde se pergunta o que do lugar em mutação me transforma, geometria da vida. E assim sendo, como a cultura nessa sociedade pode estar representada. Se estamos considerando para o desenvolvimento real e concreto a capacidade de olhar e viver com valores onde o respeito é condição de integridade humana, posto será que, os diálogos entre ditas, minorias devem estar mais próximos de um diálogo e uma imagem a ser correspondente com os argumentos dos discursos e narrativas que validamos como propostas de um novo tempo. Tempos de diálogos construídos entre redes e guetos, compartilhamentos, respeito e individualidade. Capacidade para enfrentar possíveis contradições públicas onde o cotidiano está sobre arguição, no curto circuito do sistema do viver, sendo ataduras da realidade sobre feridas da travessia, aspectos onde não dizemos sobre solidariedade, apesar dela ser um valor, mas da vida como produto e moeda, tratamos de capacidades desenvolvidas para um equilíbrio compreendido como igualdade, havendo oportunidade, e instrumentalização, fator da capacitação, condizente com os objetivos, traçados, e portanto, as diretrizes são parte integrante do produto e da moeda, como vida, sendo eles próprios o capital ${ }^{80}$, a organização do pensamento para ser intrínseco ao caminho e destino. Onde estruturas em pensamento, havendo participação do que se valida ao planejamento em presente e porvir, de uma arquitetura social, onde os reflexos vão além do seu tempo, como paralelo do que é cognitivo, entre razões e consciência, havendo de erguer espaços onde a sociedade caminhe

\footnotetext{
${ }^{77}$ Série de composições - Impressões.

${ }^{78}$ Trabalho realizado em tela de dimensões $2.80 \times 3.00$, com texto e série de nove composições.

${ }^{79}$ Da volúpia da palavra pg. 21. Caracteres da geometria.

${ }^{80}$ Do livro Gingado: Hevea brasiliens
} 
do que a cultura estabelece de coluna direcionada à um futuro, portanto, espaços, compartilhados para o sujeito ambiente, tornar-se reflexo do seu desejo. Espaços e usos do pensamento, espaços e usos do cidadão, espaços e usos das políticas governamentais, sociedade em projeto, sobre a cultura em obra. No entrelaçamento de caminhos, haveremos de convir que é necessário a humildade de recolher que aprendemos todos juntos, e que o valor de uma cultura, como signo de uma nação e seus integrantes está em nossa capacidade de aprender com ela, sendo desmembramentos de uma cultura planetária sustentável. Portanto a reforma e educação do pensamento é premissa, de um bom futuro, porque condutas dogmáticas são entraves em tempos de globalização, e mais, de entrelaçamento de relações e expansão de territórios, para uma economia humana. Lembrando, que o dogmático não se refere ao ter convicções próprias, não confundir, porque argumento e proposições podem ser ardis, de manipulações. O pensamento esclarecido, busca até mesmo como fundamento de liberdade, a identidade que o forma, sendo capaz de exercer até mesmo por direito de igualdade, o que é do respeito, por onde as travessias são justamente construídas através dessa razão equacionaria. Aspecto este que será tratado mais especificamente no capítulo quatro sobre o prisma do multiculturalismo. Estando a favor ou contra, ao multiculturalismo, o que se presume seja estar acima de nossas convicções pessoais, uma lógica capaz de abrigar uma ética acima dos interesses individuais, provendo um bem estar geral em condutas, estejam elas em quais escalas estiverem de nossas convivências. Portanto o dilema da diversidade, como aprovado pelo pluralismo, de fato me parece, que é mais, uma realidade da qual não nos furtamos, ela sendo independente de nossa delimitação de território geográfico, assim sendo, me parece cada vez mais que é uma questão do pensamento e comportamento social, estando estes sobre a óptica local, do indivíduo ou global. Os aspectos de vazão a condições de promover uma possibilidade equacionaria de igualdade frente a dificuldades, deve estar sempre em acordo as necessidades das minorias, sendo o projeto cultural a interface de ambos, ou seja, uma via de mão dupla.

A compreensão. Diálogos contemporâneos. Sobre as vozes da imagem do mu(n)do ${ }^{81}$. Discernimento, provavelmente ou mínimo deverá ser como salvo-conduto em tempos de globalização, para que o multiculturalismo não seja, para prazer de alguns críticos, a solução para caos mal resolvido, ou casos mal resolvidos, dentre nossos cacos. Então, presume-se que haverá condutas de organização, onde os riscos ou discordâncias sejam minimizadas,

\footnotetext{
${ }^{81}$ Sousa, Carina Gonzalez Y. Composição: ASAS DO CÉU. PIANO.
} 
nos aproximando dos mesmos aspectos levantados pelo que constitui, a cultura organizacional (NASSAR, 2000), podendo manter suas crenças, valores e direcionamentos, dentre suas relações internas e externas, como chama-se de imagem corporativa. Creio que um dos maiores desafios seja pensar sobre a organização social como cultura, de maneira que não lhe seja natural a desigualdade como fator estrutural, ao contrário que o planejamento dessa organização esteja permeado para busca de soluções justamente para encontrar meios onde os lugares dessa desigualdade sejam sanados por caminhos outros onde possivelmente os alcances de recursos de ordem tecnológica ou de conhecimento supram certos esforços antes reduzidos a uma margem colocada em depreciação quanto a relação posta como distanciamentos sociais, ou seja, procurar reorganizações e não somente conexões novas.

De fato, a crítica é sempre elemento saudável, quando principalmente propositiva também, e não somente de avaliação, porém, em nosso tempo vigente, enquanto protagonistas e observadores, sempre será parte do discernimento, a captação do diagnóstico como drones de um olhar, onde o próprio não se permite enxergar. Sinceramente, da condição humana ${ }^{82}$, quem ou quando irá dizer algo, é relativo, porque estamos nela, e ao vivermos, dizemos sobre ela. Por vezes me parece que dentre a condição humana, o cidadão, Estado e seu tempo, observamos dissociações onde um deveria compor o outro, então presume-se que temos algum motivo para o distanciamento do que em verso e reverso, discurso e conduta, sofremos como ponto de observação e perspectiva, onde sobre sentidos se questiona o quanto estaríamos vivendo uma ilusão de óptica, ou projeção que pondera-se onde está nosso objetivo diante de nossos atos. Vale ressaltar justamente para um esclarecimento, sendo que apesar, já anteriormente colocado, sobre ser, livre-arbítrio consciência e razão, sendo da ordem da busca e da compreensão e não impostas, e talvez por não termos uma noção todavia ainda de completude, ser e humanidade como organização, que surgem tantas dificuldades prejudicando proximidades, necessárias para a compreensão, o que não quer dizer perda de individualidade, mas de equilíbrio, harmonia entre essas duas escalas. Devendo por certo os perguntar o que nos torna capazes de compreender e sermos em igualdade, isto porque há de ainda que considerar que para alguns essa condição seria fornecida pelo Estado, sendo que no que refletimos dentre o caminho da sociedade atual, na qual estabelecemos o rumo para uma cultura sustentável, esta considera portanto, um pensamento onde a igualde é construída na busca por todos de um viver em condições de

\footnotetext{
${ }^{82}$ SOUSA, Carina Gonzalez Y. Escritor de corpos. Ensaios poéticos teatrais.
} 
dignidade em uma lógica da organização do viver ${ }^{83}$, que é pautada por valores distribuídos dentre a educação do cidadão como sua formação porém, como recurso do mesmo, onde irá no entrelaçamento com o Estado, ser capaz de gerar uma sociedade mais justa, havendo para tal de nutrir esforços para condições básicas e de desenvolvimento, diminuindo diferenças e realizando caminhos de aproximações onde os espaços sociais tenha cada qual de maneira particular seu modo de ser e necessidades a seres supridas assim como em sobreposições os espaços da esfera governamental e social, onde deverá encontrar vazão de crescimento. Portanto, a observação que segue, como diagrama do existir, se faz, onde o ponto de fuga é um horizonte, partindo de que havendo melhor condição de vida do cidadão este estará mais apto em ressonância com o viver na sociedade, promovendo acredita-se uma evolução econômica.

Do pensamento, à crítica, tecnologia e Deus. Câmeras a nossa volta enquanto não se amortece, tomaram a presença de um juiz de uma certa presença divina para alguns, como sentença, sendo este o momento onde presumindo estarem sendo "vigiados" ou assegurados, estão postos sobre uma ética tecnológica, onde por causa de um observatório público por vezes ou ao alcance de qualquer um, temos o efeito de condutas apaziguadas, ou não reveladas, e assim sendo mascaradas de sua realidade, procriam " virtuosamente", ou virtualmente, modos de ser, enquanto, em algum lugar ainda se pretende saber existir. Apesar de que, entre realidade e ficção, a própria vida pode ser mais do que a ilusão, dependendo de nossas escolhas, e do que vemos, agimos, lemos, ou ouvimos, diariamente, como natureza nossa ou outra, e nesse diálogo, a mesma busca ainda acontece, do como vivemos e queremos viver. Claramente o indivíduo que vive em sociedade, é cônscio de que existem leis, normas, de uma convivência que deve ter como dever, a preservação do bemestar geral. E ainda, resta saber, se o olhar que nos pertence, não seria o bastante para o diálogo entre a consciência e a razão. Conforme salienta Charles Taylor " o verdadeiro respeito à igualdade exige algo além do pressuposto de que novos estudos nos farão ver as coisas dessa maneira, ele impõe avaliações verdadeiras, de igual valor, aplicadas aos costumes e criações dessas diferentes culturas. "(apud BAUMAN: 2001), sendo a propriedade do pensamento a integralidade de uma conduta idônea e coerente, lembrando que disparidades em diversidades ou diferenças ocorrem em âmbito particular também, e a maneira como buscamos soluções para os desafios de embates de pensamento ou condutas na sociedade são caracteres do próprio conviver, como sujeito e sociedade, povo e governo,

\footnotetext{
${ }^{83}$ Sousa, Carina Gonzalez Y. Composição: Sonhos de liberdade. Canto- PIANO.
} 
produto e mercado, relações, ou seja, também a forma como iremos resolver impasses revela do objetivo o que somos, ou queremos ser, porém, adversidades impõe por vezes "becos" 84 onde a saída, demanda por vezes escolhas não desejadas, ou nas quais o momento deva esperar a razão do tempo, havendo portanto que caminhar sobre o olhar, por onde o tempo seja o movimento que revela o que antes todavia, lhe era inconcebível de discernimento. Sobre instâncias e leis, onde o pensamento se ancora. Considero, o respeito um prumo para a relação entre culturas distintas, e sobre determinadas ocorrências, ainda o respeito sobre a forma do direito humano enquanto existência planetária, recorre ao tribunal internacional de justiça, órgão judiciário das Nações Unidas, ONU, que valide a integralidade da vida, salvaguardando o ser, de violências, injustiça, abrigando e prevalecendo o direito do existir.

$\mathrm{O}$ regime democrático constitucional - Se concordamos que o reconhecimento das diferenças entre culturas é o ponto de partida correto para um debate nacional sobre o compartilhamento dos valores humanos, devemos então concordar também que o regime constitucional é um arcabouço capaz de abrigar esse debate. [...] Para vermos mais claramente o que Habermas tem em mente ao insistir nas prerrogativas de um regime constitucional vale a pena, observar o conceito correlato de república ou invocar o conceito correlato de sociedade autônoma tal como formulado por Cornelius Castoriadis - lembrando que uma sociedade autônoma é inconcebível sem a autonomia de seus membros, tal como uma república é inimaginável sem que os direitos dos cidadãos estejam profundamente desenvolvidos e sejam respeitados. [...] ... sem as práticas democráticas de indivíduos livremente autodeterminados, é impossível enfrentar o conflito de maneira adequada, muito menos ter a esperança de resolvê-lo. Seria difícil provar que a defesa do indivíduo em relação as exigências de subordinação inconteste à comunidade é obviamente uma tarefa mais grandiosa mais digna de louvor e apoio, que a da luta de uma comunidade para manter sua identidade distinta. .... como diz Habermas: Uma teoria dos direitos corretamente compreendida, requer uma política de reconhecimento que proteja a integridade do indivíduo nos contextos da vida em que se forma sua identidade... Tudo que se exige é a efetivação coerente, claro, sem movimentos sociais e lutas políticas.... O processo de efetivar direitos está de fato implantado em contextos que exigem esses discursos como componentes da política - o debate sobre uma concepção comum do que seja uma forma de vida boa e desejada, capaz de ser reconhecida como autêntica. (HABERMAS, apud BAUMAN) p. 64

Como condição natural de um estado orgânico da sociedade, creio que a citação acima procede e em acordo, porém somente uma ressalva, em um momento avalio que quando da condição não se encontra subsídios para sua efetivação, movimentos para que se realize de

\footnotetext{
${ }^{84}$ Sousa, Carina Gonzalez Y. Quando as entranhas doem. Texto do projeto de livro Ensaios poéticos teatrais, pg 100.
} 
fato e verdadeiramente são considerados a meu ver, até mesmo necessários. Ao observar certas críticas ao multiculturalismo ${ }^{85}$, o que me faz refletir é justamente mais uma vez a natureza humana e não posso me furtar ao que aprendi com a música, que encontra caminhos onde a natureza é de vibração ${ }^{86}$, compor o sentido do firmamento em nossas vidas, busca a semelhança do elemento primeiro que ressoa, entre suas multiplicidades, tornandose multidão como diversidade da mesma natureza, por essa razão justamente encontrar-se em igualdade, em se organizando obra, que procura ouvir por onde estará a harmonia, em compassos, onde cada passo da humanidade, se observa, ponto e abertura, círculos de onde $\operatorname{somos}^{87}$, ser, sociedade, culturas, planeta, ponto do $\operatorname{cosmo~}^{88}$ e grafos de um universo. E do que é matéria do pensamento, em movimento, de longe ou perto, qual a referência? Da convivência, os lados da moeda, são diferentes, mas são a mesma, apesar do peso ainda estar sobre a balança. E ainda citado por Bauman, Jeffrey Weeks, a contingência, não o determinismo é a base de nosso complexo presente, o caso, entre o destino almejado, determinado e como vamos fazer a travessia, o incerto nos reserva, de súbito o acaso, diz um poema meu, e ainda, em poesia, partícula. Ou seja, dentre o que queremos, no caminho o que poderá ser indeterminado, se entrelaçam. Travessias são destinos percorridos, para onde vou, o que posso encontrar.

Salienta-se mais uma vez que o educar o pensamento é fundamental, sendo que fortalece a identidade e corresponde ao alcance de travessias onde se agrega valores e não se perde. Dentre os caminhos já trilhados, a experiência e o pensamento são aprendizado de compreensão, para rumos em porvir, ao ver deste trabalho para uma evolução sem condições de submissão ou posições autoritárias de nenhuma espécie, ao menos como creditamos ser elementos para o cidadão e a sociedade que esteja inserido, adventos para a cultura. Somos cientes de que algumas civilizações se tornaram culturas obsoletas, e me pergunto enquanto humanidade, quando deixamos de ser obsoletos da mesma maneira para percorrer uma timeline mental do planeta sem perda de lastro? A sobrevivência pode unir culturas? A gestão de uma construção de identidade, indivíduo(cidadão)-cultura e Nação, constituída pelo pensamento onde de maneira pela qual já consideramos, como uma lógica onde a estética é permeada de valores onde a consciência ${ }^{89}$ e a razão se estabelecem como ética, as conexões

\footnotetext{
${ }^{85}$ Sousa, Carina Gonzalez Y. Composição: Travessia. PIANO.

${ }^{86}$ Ágape, arte como a vida.

${ }^{87}$ SOUSA, Carina Gonzalez y. Amanajé, Contos e reflexões. São Paulo:Inmood, 2017.

${ }^{88}$ SOUSA, Carina Gonzalez Y. Casa vazia, Um conto só diferente, Casa vazia, direito de viver. Em anexo para posterior publicação.

${ }^{89}$ SOUSA, Carina Gonzalez Y. Composiçôes: Manhã de Glória. Gloria ao Senhor. Obreiros do céu. PIANO.
} 
internas ou externas dos mesmos, não sofreram prejuízo da identidade composta pela tríade cidadão-cultura e Nação, ao contrário se desenvolvendo. Na construção dessa tríade, os valores que serão intrínsecos constituíram a marca, que consequentemente torna identidade, nutrida por esforços conjuntos.

Respire, antes que o mundo lhe diga: Ah! Deus! Biodiversidade, cidade querendo abrigo, e do que existo, insisto em ser mais do que um, múltiplo. Enfim, algo do diálogo é sempre interessante, mesmo quando, internamente monólogo em ambiente, quer seja das entranhas ou superfície, sinceramente sinto que o permear é fruto de intersecções onde o fato de apresentar-se requer em grande parte para com o outro ${ }^{90}$, um conhecer-se então, quando a cultura se apresenta não difere tanto de um indivíduo, sobre esquinas da vida, sobrevoo do tempo, representa-se identidade, dizendo-se quem é, a procura de se revelar. Portanto o que queremos dizer ao pensamento é que ao locomover-se a um outro, ou outra cultura, fortalece o que se constitui ser $^{91}$ próprio, em adjacências tecidas sobre o Estado, suas relações em sociedade, que enfim ao também ser cultura, e dialogar com outra, constitui-se integro capaz de novamente permear-se sobre outros dizeres, estabelecendo respostas, de uma emissão continua de natureza da comunicação. Creio então que nos nossos tempos, individuais, coletivos, de nossos passos em compassos de nossa cultura, indagamos, mas também, poderemos dizer que em todo relacionamento as perguntas, estarão abertas a negociação, responda-me. Negociação? Sim, ato político de transpor minhas fronteiras, para que sejam tuas, só dá para dizer assim em poesia, ou haverá outras maneiras...quem sabe venha dizer de mim, o que não sei. Desloco-me para ver o quadro, como a chegar pela primeira vez, e o vejo outro. E respondendo a poesia, talvez mais que o diálogo, esteja na resposta, a compreensão.

\footnotetext{
${ }^{90}$ Sobre relações humanas e comportamentos, no livro modernidade líquida, Bauman cita Gadamer este se referindo que para os antigos gregos: " Amigos são pessoas capazes e desejosas de estabelecer uma relação amigável mútua sem preocupação com as diferenças entre eles, e prontas a ajudar umas às outras por conta dessas diferenças capazes e dispostas a agir com gentileza e generosidade sem abandonar sua distinção - ao mesmo tempo cuidando para que essa distinção não crie uma distância entre eles ou os coloque uns contra os outros. E ainda, Gadamer assinala que o caminho da compreensão passa por uma fusão de horizontes. Se aquilo que cada aglomeração humana percebe como verdade é a base de sua experiência coletiva, então os horizontes que cercam seu campo de visão também são fronteiras das verdade coletivas "Se, vindos de uma variedade de aglomerações, desejamos encontrar uma verdade comum a todos e sobre ela concordar, precisamos de uma fusão de horizontes, essa condição preliminar de uma síntese de experiências de histórias distintas, mas de um futuro comum. A união Europeia é nossa chance de realizar essa fusão. É, afinal, nosso laboratório comum, no qual conscientemente ou não, de boa vontade ou não, nos fundimos os horizontes dos grupos, engrandecendo a todos nesse processo. “p. 81
}

${ }^{91}$ Um múltiplo do ontem. Te escrevo. 
Reafirmando algumas considerações, sujeito múltiplo, ou sujeito plural ${ }^{92}$ ( MEDINA, 1993), todavia ainda não sendo o mesmo talvez, cabe refletirmos sobre a possibilidade de não termos a necessidade de ao deslocarmos nossos possíveis encontros culturais e externos ao nosso interior de sermos outros em perda, mas sim, ao contrário de nos localizarmos como sendo a identidade que é capaz de preservar-se natureza intrínseca e enquanto deslocamentos é um acoplamento, ou uma extensão, tornando-se sem deixar de ser, outro nele mesmo, ainda que em aprendizado e apreensão, de si, torna-se conjunto, desmembra-se ao mobilizarse e até mesmo usando o sentido dessa palavra, atua, exerce sua amplitude para se identificar-se em construção onde o finito não é sua digital, mas o que dela o torna, ser, e assim sendo o é, pela multiplicidade em que pode existir. Sobre a modernidade tardia do tempo e da descoberta.

Entre os epicentros e movimentos dos quais a humanidade se fez, me parece cada vez mais, que ora a balança pende um pouco mais, para um lado, ora para outro, porém, em certo ponto o renascimento de sermos, está em cada prato da balança no qual a sociedade pende, sobre o cosmo que a retém, como parcela da infinitude de onde o que somos, ainda talvez um dia em evolução descobriremos, ou será esta a procura que não finda, e esse o sabor de viver. Mas, enquanto sociedade e indivíduos, e não me atendo completamente a períodos porque tenho a impressão de que os seres humanos, poderia dizer homens, dentre os seus, sempre houve dos quais elementos dispostos como pontos de um grafo, onde a forma, todavia se veria em outro lugar do tempo, isto porque ideias, por vezes, carecem de uma certa longevidade para existir. E enquanto isso, e justamente por essa razão que o discernimento do homem, enquanto natureza da criação cada vez mais, precisa de si, como fonte de nascimento, ou renascimento, continuamente, para descobrir-se, realmente a vela que sopra, onde as naus, de terras distantes, em uma época, continuam nos esforços de um futuro melhor, de territórios de nossos valores, e de tudo que queremos para uma sociedade futura. Mas, do futuro, onde ainda escrevemos o destino, e parece estar desatualizado as pegadas de onde viemos, desprezadas até, de fato, talvez o corpo humano que tem suas dimensões, precisem de uma perspectiva, aberta, onde nosso olhar contemple, o que fizemos, o que somos, ou procuramos, para o que nos tornamos. Identidade? Identidade, é o que somos, ou o que estamos em descoberta? Do que nos tornaremos. Como regaço, algo das águas permanece, pelos quantos e muitos que nela navegaram. Lembrando Leonardo da Vinci, e quando dizem que tem homens além do tempo deles, me recordo de uma frase, que

\footnotetext{
92 MEDINA, Cremilda, GRECO, Milton. Do Hemisfério Sol, 1993.
} 
diz, eu sou do mundo, mas o mundo que não é de mim. então do que somos, ou nos tornaremos, territórios do saber,( do) querer, (do) viver. Como arquiteturas poderiam construir-se de maneira tão magnifica e todavia sabermos tão pouco do corpo, e quiçá da alma. Não seriam ainda a mesma geometria? Talvez, ácidos demais estejamos, ao olhar nossos passos, como recolhidos de onde nem mesmo ficam as areias. Corroídos ao ponto de não saber quem somos. Porém, entre milênios, ou ainda mais, quando do cosmos, qual o tempo nos pertence, entrego por vezes a própria Natureza, que parece ouvir o silêncio melhor do que nós, ident- IDADE. Fósseis poderemos ser, mas desejos desumanos também. E o que conquistamos? Da identidade da realidade, está compatriota de nós, é talvez mais difícil de se revelar, dentre os mundos possíveis que fizemos existir, onde a escolha do que somos, verdadeiramente está sobre judice. Afinal, a mobilidade de estarmos múltiplos, sem deixar de ser quem somos, é caráter de exigir de nós, a consciência, fator primordial, nas conexões pelas quais se exerce o direito de existir, sem nos tornar um engodo a nós mesmos. Portanto, a escolha, dentre virtualidades reais, se assim posso chamar de pseudos gestos humanos, está ao alcance de todos, sendo um exame árduo dentre o existir, como validade ou não do que pretende produzir como mais um produto no mercado, onde em tempos atuais, ainda talvez seja uma descoberta, sobre especiarias de novos nomes, e territórios, dentre o individuo e a globalização, entre o ser e ele mesmo, estarão lá, sempre, do que queremos, alcançamos, conquistamos, mais principalmente do que vamos ser. A escolha da identidade. Se nascemos, com ela? De qual labirinto de desenhos de nossas digitais, estaremos como fruto de anéis de um tronco, como respirar de uma natureza onde a humanidade tem seus anos, e nos multiplicamos, sem perceber o quanto nos asfixiamos, e espero não ser tarde demais, para compreendermos o que nos fez chegar até aqui. Aqui, lugar, identidade também. O tempo, chegará a ser o espaço de nosso viver, onde a natureza do passado, apenas se sobrepõe ao que do hoje nos faz ser continuamente amanhã, mas do destino, a escolha ainda, que sobre programações, não deixemos de ser humanos. A roda, o círculo, olhemos em volta, a tecnologia. O pensar, circuitos negligenciados, pelo cotidiano e ainda mais, pelo humano coração de sentir, que dentre os caminhos a seguir, não pulsa por um outro coração, e talvez tarde ouça, o que lhe faz viver então. Identidade em civilizações, somos do tempo, ou dele nos desfazemos, como sopro ao vento. Vento ${ }^{93}$. Qual a frase da manhã? Tenho dias de gaivota, onde o céu fica sem asas, e eu fico no chão. Então, hoje sou

\footnotetext{
${ }^{93}$ Sousa, Carina Gonzalez Y. Das folhas ao vento. Composição criada em 19-03-2018
} 
gaivota, céu, nuvens, e terra, o ar, por onde eu possa estar, que por fim, saiba quem posso ser.

Ah, sim, falavam em ser moderno ou pós-moderno. Sinceramente, penso que a cada vez que renasço do que vivo, me constituo, moderno no meu tempo, talvez para não ter confusão, ou ilusão, devo chamar de tempo vigente, e o homem moderno, passou a ser o quê, Chaplin? Ou melhor, os tempos? Mudamos, para onde? Tic- tac. A engrenagem se modernizou e pergunto então, a Elis Regina, cantando, continuamos os mesmos, ou não?

O circo. ${ }^{94}$ A progressão aritmética de um viver in(SANO). Saudavelmente nos dispomos a ser civilizados, onde? Qual o fator referencial, ou exponencial? E, por vezes parece tão banal, um dia após o outro. Triste. Como a lágrima de um pierrô, fragmentado, entre os olhares do circo, Picasso, desmembra o que a realidade ainda vê. Referências, ou vivências, seremos identidade de qual? Ambas? Inteiramente composto! Como vozes da fuga de Bach, dizendo, dizendo... dizendo, ouvindo uma harmonia, de quem sabe um dia...nos tornemos notas, entre a pauta de um viver comum. Comum... em mais de um sentido, simples e unido, sonido de almas, quem sabe... Quantos somos, na solidão? Multidão.

Redigindo um viver confuso, procurando uma origem, onde o fio da meada, está no labirinto. Ao lermos o mundo ${ }^{95}$, poderemos escrevê-lo, mas por vezes, na identidade, ou realidade, as palavras sucumbem. Destroços de nós, a procura dos nós, e os laços? Conexões de um tempo, novo? Tecendo o tear de um viver, onde a imagem ainda está por nos pertencer, sendo nessa geometria, um ponto ${ }^{96}$, e o fio, a linha. Grafos de destinos. Então, como poderei responder ou dizer: Permita-me, me apresentar: Sou. Existo, talvez, ou depende do que possa o mundo viver.

Todo aquele que vive no mundo e nele não existe, sua boca estará prenhe mas os frutos sem semente. Então, retorno a resposta com uma, pergunta: Do que o mundo vive? Da vida,

\footnotetext{
${ }^{94}$ Sousa, Carina Gonzalez Y. Composição O circo. No meu caminho..... como poeta tinha uma pedra, que com o tempo, era um muro de sofrimento, ah mas eu disse ao poeta, que eu quero um pouco mais, eu quero ver, vento bater. Eu quero ver, o vento bater, eu quero ver as águas trepidar ah....como o mar, na cidade. A chuva cai, e as pedras vão rolar. Eu quero ver, disse ao poeta... eu quero ver... as palavras incertas da minha liberdade. Vou encontrar.... eu vou passar... deixa eu te segurar. Ah .... sabe, por onde andei, eu também vi, outras pedras virarem pó.... ou ainda uma bela escultura me diga, você, o que pode ser, afinal, nos estamos aqui pra vive, ou sofrer. Ah meu bem, eu vou passar, seja com pedras, ou areias do mar, Porque desse viver, meu bem... nesse viver, meu bem. Eu vou escolher, o que pode ser.... o que pode ser... do pão ou do circo, o meu picadeiro, e não estrangeiro do mundo, meu bem.

${ }^{95}$ Composição: Infinito.

${ }^{96}$ Geometria como poema e sentido da vida, desmembramento de formas, em corpos de física e significados do viver.
} 
produto de nosso tempo. E, então, pergunto: Do que morremos? Da falta de vida. Algo a refletir deverá ser necessário. Quem somos $?^{97}$ Ou deveria dizer, existimos? Logo, minha identidade, também te pertence. Sou do mundo, o mundo será...de nós? GRAFOS... um ponto do universo, verso, que ainda procura a palavra, VERBO. Ser. Diz um poeta, à realidade: As almas se pertencem mais que os corpos. Faz de conta que comeu hoje. Diz a carne, como a alma sobrevive. E, range as engrenagens do relógio. Identidades culturas, sobre a bússola de um tempo - movimentos:

A identidade nessa concepção sociológica, preenche o espaço entre o interior e o exterior, entre o mundo pessoal e o mundo público. $\mathrm{O}$ fato de que projetamos a nós próprios nessas identidades culturais, ao mesmo tempo que internalizamos seus significados e valores, tornando-os parte de nós, contribui para alinhar nossos sentimentos subjetivos com os lugares objetivos que ocupamos no mundo social e cultural. A identidade então, costura ( ou, para usar uma metáfora médica, sutura,) o sujeito à estrutura. Estabiliza tanto os sujeitos quanto os mundos culturais que eles habitam, tornando ambos reciprocamente mais unificados e predizíveis.(HALL, 2014 ,pg 12)

A imagem sobre o desenho da realidade, esculpe os sons de sua natureza, compondo os gestos do significado, de onde ouviremos pelo sentimento que dela possamos sentir. E entre a vida na qual estamos vivendo, passagens ${ }^{98}$ sobre identidades, a roda ${ }^{99}$, percorre as faces do tempo, movimento de nós, entre partidas e destinos ${ }^{100}$.

\footnotetext{
${ }^{97}$ Sousa, Carina Gonzalez Y. Composição: Tecendo raízes: Tecendo raízes e nós. Não estamos a sós, a árvore da vida, se estende sobre nós. Que vê a avenida como o sol. Ao redor desse mundo. Seremos o silêncio do espelho profundo. Que sujeito do tempo. Revendo, revendo, imagens. Que será o espaço, das lutas que percorremos. vivemos e queremos ser. Felizes e um pouco mais... Desses carnavais, eu não me esqueço jamais. Eu vou desfilar nesse mundo. Eu quero entoar as águas do céu e o mar. Tecendo raízes e nós. Não estamos a sós. A arvores da vida. Se estende sobre nós e vê a avenida se pondo como o por do sol. Ao redor do mundo, seremos do silêncio. O espelho profundo. Que sujeito do tempo, revendo .... revendo.... imagens... que será o espaço. Das lutas que percorremos, vivemos e queremos ser felizes. E um pouco mais... Desses carnavais... eu não me esqueço jamais. Eu vou desfilar. Nesse mundo, eu vou. Eu quero entoar, as águas do céu e o mar.

E, composição: Socialmente aceitável. Não, não é proibido. Querer saber demais. socialmente aceitável, negociável para nós dois, sociedade e o depois. Afetos despatriados, calcados entre afagos. Desprovidos de identidade nessa desigualdade, cidade maltratada, que é viver, sem pertencer. e o que eu posso ver, se teu destino eu não ligo, mas eu quero ser, igual a você e porque então, porque senão sobrevier sem a razão, não pode ser eu vou viver e te querer um pouco mais, mesmo que não me olhes mais, eu vou estar contigo, até onde eu sigo, sendo o amanhã.

${ }^{98}$ Sousa, Carina Gonzalez Y. Avenida - letra para composição - homenagem as costureiras do samba. Esperar não sei porquê, sem você....mulher. Será o quê? A vida que se faz avenida. Sobre os teus pés... Mulher blues. Samba que canta. Querer humano sofrer. sem desengano viver. Não pode mais querer assim. Seguir sem mim.. Mulher bossa notas por onde esse teu olhar. Eu quero ver o sol da tarde. E a lua que parte junto de você. Justo quando adormeço, vejo você agora em recomeço. Será esse nosso contra-ponto. Ou apenas as letras de u conto sem escrever. Dedilhando apenas para te ver. eu quero viver... Esperar não sei porquê. Sem você....será o quê? Da vida que se fez avenida. Sobre os teus pés... Mulher blues, samba que canta. Querer
} 
Entre a identidade e os aspectos da cultura em movimento, argumenta-se que como validade de tal comportamento particular e social, a própria reflexão como elemento cognitivo, porque continuidades ou efemeridades sem ponderações, torna a vagueza insipiente em vez de profícua, portanto, uma diferença está, na progressão justamente o fator que atende ao que é de construção argumentativa da evolução. O que pode agregar o movimento em relação ao que é de desenvolvimento, como paralelo poderemos colocar a própria teoria de sistemas, ou relações matemáticas onde o pensar seja expansivo e exponencial, em uma progressão satisfatória, de elementos que de alguma forma se relacionam e se expandem.

Sociedade vista assim, ainda penso que ao renascermos no tempo, somos parte dele, entre o passado e o que nos faz presença, porém, ainda como a flor, que despetala somos haste e principalmente aroma, de onde mesmo que o caminho siga, com o vento e as pétalas, ou o silêncio e as cores ao chão, podermos ser a estação que segue tendo o âmbar no coração, pensamento e atos do cotidiano, então a sociedade, é múltipla como seu sujeito, se torna, parte e conjunto, como alas de uma avenida. Como órgãos do corpo humano, que tem sua independência e funcionam, mas que se conectam e de alguma forma se constituem um caráter unívoco como corpo. Então o corpo social, me parece que pode e é até mesmo constituído como uma grande avenida que todos os dias conta a sua história, de um povo e povos se conectando entre o globo, realizando seu direito de viver, percorrendo seus dias, vidas, trazendo cada integrante, indivíduo, nomeado conforme quiser, em que tempo vier, as vozes da mesma harmonia, estejam em blocos, em alas, em sentidos, vielas, na esquina do bar, ou na vontade de um mar, inteiramente cidadãos, que existem e estão narrando suas

humano sofrer sem desengano viver. Não pode mais querer assim, seguir sem mim. Mas... Bossa notas por onde andas esse teu olhar. Eu quero ver, o sol da tarde. E junto de você, a lua que parte. Não posso mais, viver sem você.....Não posso mais, viver sem você.... Se você me ver assim, eu não posso dizer quem sou, não posso dizer que sou tua, se não me quis. Quando eu não era feliz, Agora eu sou do som. Agora eu sou do som. ${ }^{99}$ A roda - letra para composição realizada em 20-03-2018. Gira a roda lá fora. he oh Oyá. Gira o beija flor. Natureza de flor que o tambor já ouviu. Sou lá no meu terreiro. Eu de ti, sou obreiro. Do mundo inteiro. Oxalá. Eu quero ouvir, o teu sentir. Por onde ir, hoje sou teu amanhã. Corpo regado pela mão, do teu condão. Agora e sempre o perdão. Mas, tem justiça na harmonia. Essa vida... Só não dá viver, na contra-mão. Tem que revirar, as águas desse mar. Gira a roda lá fora... eh Oyá. Gira a roda lá fora... Eh Oyá Gira a roda lá fora... Eh Oyá. Gira o beija flor. As águas por onde for. Natureza do amor. Que o tambor já ouviu. Natureza do amor. Que o tambor, já ouviu. Soa lá no meu terreiro. Eu te ti sou obreiro. No mundo inteiro. Oxalá.

${ }^{100}$ Outro porto - letra para composição realizada em 20-03-2018. Eu quero navegar em outro porto. Ancorar meus desejos em outro lugar. Chega de querer esse mar, eu quero outras águas pra viver. E sonhar, vou cantar, entoar, o meu gesto. Que tanto grita em silêncio. Desse meu jeito que não pode mais, sofrer... Não mais eu quero só viver. De alegria que eu espero. Encontrar, entoar.... navegantes desse mar. Viagem longa eu trilhei, caminhei. Viagem longa eu trilhei. Caminhei... DE tantos convés. De tantos corações. A emoção eu vou ficar. É meu diário de bordo. Das lutas desse convés. é meu diário de bordo. AS lutas desse convés. E se não me queres não faz mal. A natureza está em todo lugar. Na terra firme e no ar. Na terra firme e no ar. Viagem eu fiz, só pra te ver sorrir. Agora eu posso ir, mais uma vez. Velejar.... Velejar.... 
histórias, memórias, lendas, e vontades, retratadas como partes, como todo, como veste e corpo, alma de um coração ${ }^{101}$, que não deve parar de pulsar, como um samba ou uma canção. ${ }^{102}$

Me parece cada vez mais, que em um contexto atual, o que está em jogo como considera é a presença de uma certo diagnostico de perfil, no qual se observa a característica de permanecermos " egoísta" no sentido de olharmos somente para nosso próprio umbigo, aqui visto como o que se refere a restrição de uma cultura em seu modo de ser, sem a aceitação de outra, isto é relevante no tocante a globalização pois do que tratamos é justamente o agir compactuado entre diversidades e diferenças, sendo sujeito individuo e múltiplo, em topologia global, assim sendo, creio que podermos dizer que para além das conjecturas que fazem a realidade, no caso, o alcance global, está se tornando objeto de análise e o comportamento de determinadas culturas e indivíduos relutantes a um certo "contágio, o que talvez não seja essa a palavra, mas sim, fraternidade ${ }^{103}$, e agora entraremos em um modo de ser da fraternidade que não é tão religioso, mas completamente do que vivemos em realidade futura de campos sem fronteiras entre nações havendo a primazia de um respeito e integralidade mutuas, para alguns ligados ao terceiro setor, outros uma visão para um desenvolvimento planetário, como uma civilização orgânica capaz de elucidar seus membros ( nações ) de maneira a equalizar um bem comum a toda a humanidade. Então, aqui, a fraternidade recebe o caráter objetivo e claro de se dispor sobre o que está sendo a responsabilidade de uma integralidade onde recursos desde o humano, até do sistema biológico de cada território, assim como as capacidades de cada indivíduo e órgãos de seus sistemas de governo, serão devidamente relacionados, por respeito em suma instância, onde essa virtude, se assim poderemos chamar, torna-se elemento do que é inteligência de uma consciência de gerações futuras, onde deve-se priorizar o conhecimento do outro, ( Nação ) para realizar a esfera do que tratamos ser respeito de maneira a promover condutas mutuas entre Estados participativos, de desenvolvimento, isto porque experiências de realidades múltiplas em territórios diferentes, podem e devem nos favorecer enquanto olhar o mundo

\footnotetext{
${ }^{101}$ Sousa, Carina Gonzalez Y. Composição. Coração que luta. TABLA. Alma de um destino. Guitarra e TABLA. SANGUÍNEA.

${ }^{102}$ Sousa, Carina Gonzalez Y. Composição Samba das dez. É assim a vida vai me falar. O que não pode mais se calar. Vem teu segredo contar. Até onde o mar vai escutar. E assim a vida vai entoar. O coração do vento. Do tempo que para nós passou. De quem sabe um dia amou. A vontade de ser real. Não posso mais viver nessa ilusão. Meu coração precisa de verdade. Na procura de uma igualdade. Onde a vida possa ser um pouco mais. do que uma viagem a espera do cais. De onde o que ficou ainda procura o seu destino. E sigo mesmo que sozinho, nesse meu lugar. NO corpo e da alma, que não deixou de amar. E tem ainda um coração a pulsar.

${ }^{103}$ Sousa, Carina Gonzalez Y. Composição e hino - FRATERNIDADE .
} 
de forma plena. Isto, claramente inclui o desejo forte de conhecer a integralidade de cada parte em relação a esse todo, e não é apenas filosofia, mas constatação de sobrevivência, onde o corpo humano demostra que essa natureza, é nossa natureza de mundo em semelhança em verossimilhança, renascendo conosco em sentido participativo de sermos obra da criação, onde não se atem a um ou a quem, mas ao que queremos ser. Ao nos dispor o diálogo em territórios globalizados de convivência e mercado presume-se a disposição de estar apto a considerar que aprendemos com o outro, assim podermos observar em vivências múltiplas de culturas diversas aspectos não discernidos por nós, capazes de serem agentes promotores de caminhos por onde poderemos encontrar observações que serão capazes de avaliar ou mesmo solucionar dificuldade nossas encontradas em âmbito social e de relações humanas, justamente por ter um outro olhar.

Então, me parece cada vez mais, que ainda é tempo de acordarmos, para a realidade dos valores postos como somente dentro de templos, para caminharmos com eles, fora de lá, na própria vida, para construirmos a razão desse nosso existir. A presença dos elementos da VERDADE que não vejo tão fiel neste mundo, a de exigir de nós, uma férrea e firme determinação, onde por vezes mesmo perdendo o chão, como já disse, teremos que recorrer aos anjos, porque eles tem asas, e então, teremos que recorrer ao que nos faz seres humanos, ou ao que acreditamos que nos torne seres humanos de fato para realizar a tarefa de nos auxiliar mutuamente no sentido claro de evolução, com desenvolvimento integrado, respeito, humildade e ação participativa e ampla de uma bem estar planetário, onde cada vez mais, as dificuldades e mazelas humanas, serão tratadas em desmembramentos de um todo, onde o veneno e o remédio, podem estar em qualquer lugar, feridas onde como diz a música, o amor, pode curar, e mais do que isso, Estados, governantes, indivíduos, podem mover em cada gesto ao nascer do sol, despertar e caminhar sobre as montanhas e movimentar os mares, de um território ao outro, sobre a bússola, de um dia, encontrar o destino de uma IGUALDADE, ${ }^{104}$ como lógica para da comunicação ${ }^{105}$ no desenvolvimento de futuras

\footnotetext{
${ }^{104}$ Sousa, Carina Gonzalez Y. Composição IGUALDADE - - em 3 partes.

105 DRUCKER, Peter F. A comunidade do Futuro Margaret J. Whwatley e Myron Kellener Rogers, paradoxos da comunidade, ecossistemas. James L. Barksdale, sobre comunicação assíncrona, comunicação global, comunicação colaborativa, assim como também Marshall Goldsmith, comunicação global. Bob Buford, governos, negócios e setor social, Stephen R. Covey, a comunidade ideal; Clarie L. Gaudiani a sabedoria como capital nas comunidades prósperas; Rossevelt Thomas, A diversidade na comunidade; Arun Gandhi, lições de Sevagram Ashram.Ayala, Jaime A Zobel, prevendo a comunidade do futuro.Schubert Richard, Nossos filhos são a comunidade do futuro. Morse, Suzanne, Cinco elementos edificadores de comunidades bem sucedidas; Yzaguirre Raul, A nova identidade norte-americana; Price Hugh, Obtendo poder igualitário ao poder econômico; Austin Bobby William, Liderança do século XXI na comunidade afro-americana.Tichy M Noel, Mcgill, Clair,Desenvolvimento de comunidades metropolitanas de alta tecnologia; Hesselbein, Frances $O$
} 
gerações. Pensar a vida requer encontrar-se entre quem nela vive e morre enquanto existe. Dentre inúmeras lições do livro Comunidade do futuro que creio haverá de ser referência em muitos momentos neste trabalho, gostaria de ressaltar, em especial Elie Wiese ${ }^{106}$,

Esse é o dever de nossa geração à medida que entramos no século XXI solidariedade para com os fracos, os perseguidos, os solitários, os doentes e aqueles em desespero. Ele é expresso pelo desejo de dar um significado nobre e humanizante a uma comunidade em que os membros se definirão não por sua própria identidade, mas pela identidade de outros.

Pode-se perguntar sobre consequências políticas da fragmentação porém, considero que enquanto modo de ver, nos dispomos de atitudes que são da possibilidade de nos encontrar com o que pode ser dentre fragmentos, conexões, e delas encontrar possivelmente caminhos de pluralização de identidades, de onde vemos, o que somos, somos do que vivemos, onde tornamos, como e sendo, permanecemos, fomos através, dos olhares imagem, que nos olha sentido por onde poderemos estar, ambiente lugar, identidade em movimento..

O trânsito. Somos ou teremos escolha de sermos livres ou escravos de nosso tempo!! Precisamos saber ou ter a humildade de querer reconhecer se neste tempo seremos escravos de nossas ilusões, ou de nossos gestos que independem de nossa cor, de nossa pele ${ }^{107}$, porque eu tenho a cor do sangue ${ }^{108}$. Narrativas nômades e sujeito, entre ele mesmo e seu deslocamento.

Raízes do tempo. O que para alguns é história, para outros é vida. Por alguns, me parece como sendo o que é restrito a um período de tempo e teve seu momento, até chamado ou descrito como repertório, e como tradição fica "intocável", e eu vejo diferente justamente, considero a tradição o aspecto de ensinamento onde poderemos retornar a ela em considerações diríamos no vocabulário de hoje, atualizando o sistema dentre suas raízes, então, eu vejo a tradição como algo que fundamenta, e acima de tudo, com respeito, mas não como intocável e que não tem reverberações e é algo descartável, ao contrário, como sendo fator de nutrição ou seja, nos revela aspectos dentre a evolução do tempo, de magnitude que

sonho que se coloca a nossa frente; Cattaui, Maria Livanos Oportunidades na economia global;Ulrich Dave, Seis práticas para criar comunidades de valores e não de proximidade; Heskket James, Gerenciando para resultados na comunidade do futuro; Pinchot Gifford, Desenvolvendo a comunidade no local de trabalho; São Paulo: Futura 1998.

${ }^{106}$ Elie Wiesel, professor da Universidade de Boston, vencedor do Prêmio Nobel da Paz.1986.

${ }^{107}$ Do projeto para livro: Ensaios poéticos teatrais - A flor da pele e composição - Corpo de imagens - janela Composição FLOR DA PELE. E do poema em versos das cores.

${ }^{108}$ Sousa, Carina Gonzalez Y. Composição A cor do sangue. I e II Acordeon - Harmonica. 
nos auxilia a compreensões e alguns aspectos que sobre o mesmo com outro olhar, que pode acrescentar vividamente ao tempo vigente.

O capitalismo, e o sujeito passaram por algumas alterações dentre as realidades que o cercam. Creio que alguns aspectos da realidade atual consideram que por sobrevivência devemos ter claramente a condição que, passou a ser de relevância justamente que o homem não seja o centro e o maior detentor de uma vasão da organização do 'capital', mas que a vida em suas dimensões, e desmembramento com ele, é o maior agente promovedor de uma economia planetária onde a consciência de uma organização da vida como um todo é fator de sobrevivência sustentabilidade, e onde e como vivemos, é razão dentre o objeto maior de negociações do nosso tempo, avaliadas e mensuradas dentre as condições para um viver melhor em progressões e índices que consideram fatores antes não percebidos dentro de uma certa economia, com efeitos diretos sobre mercado e o campo social, relações do indivíduo e o Estado, instituições em geral. Talvez como parte do indivíduo em narrativas contemporâneas em contexto contemporâneo, se avalia considerações cerceadas em cultura, de tempos entre tempos. Em parte, neste trecho da pesquisa como entrelaçamentos do sujeito, cultura e aspectos da econômicos ${ }^{109}$.

\footnotetext{
${ }^{109}$ Algumas pessoas têm questionado se o capitalismo realmente exigiu uma concepção de indivíduo soberano desse tipo ( Abererombie et alli, 1986 ). Entretanto, a emergência de uma concepção mais individualista do sujeito é amplamente aceita Raymond Williams sintetizou essa imersão do sujeito moderno nas práticas e discursos da modernidade na seguinte passagem: A emergência de noções de individualidade, no sentido moderno, pode ser relacionado ao colapso da ordem social, econômica e religiosa medieval. No movimento geral contra o feudalismo houve uma nova ênfase na existência pessoal do homem acima e além de seu lugar e sua função numa rígida sociedade hierárquica. Houve uma ênfase similar, no Protestantismo, na relação direta a individual do homem com Deus, em oposição a esta relação mediada pela Igreja. Mas foi só ao final do século XVII, e no século XVIII que um novo modo de análise, na lógica e na matemática, postulou o indivíduo como a entidade maior ( mônadas de Leibniz ) a partir da qual outras categorias ( especialmente categorias coletivas ) eram derivadas. $\mathrm{O}$ pensamento político do iluminismo seguiu principalmente este modelo. $\mathrm{O}$ argumento começava com os indivíduos, que tinham uma existência primária e inicial. As leis e as formas de sociedade eram deles derivadas: por submissão, como em Hobbes, por contato ou consentimento, ou pela nova versão da lei natural, no pensamento liberal. Na economia clássica, o comércio era descrito através de um modelo que supunha indivíduos separados que possuíam propriedade e ) decidiam, em algum ponto de partida, entrar em relações econômicas ou comerciais. Na ética utilitária, indivíduos separados calculavam as consequências desta ou daquela ação que eles poderiam empreender ( Williams, 1976 pp 135-6 ). Ainda era possível, no século XVIII, imaginar os grandes processos da vida moderna como estado centrados no indivíduo sujeito-da-razão. Mas a medida em que as sociedades modernas se tornavam mais complexas, elas adquiriam uma forma mais coletiva e social. As teorias clássicas liberais de governo, baseadas nos direitos e consentimentos individuais, foram obrigadas a dar conta das estruturas do estado-nação e das grandes massas que fazem a democracia moderna. Emergiu, então, uma concepção mais social do sujeito. O indivíduo passou a ser visto como mais localizado e definido no interior dessas grandes estruturas e formações sustentadoras da sociedade moderna. [...] O primeiro foi a biologia darwiniana. $\mathrm{O}$ sujeito humano foi biologizado - a razão tinha uma base na Natureza e a mente um fundamento no desenvolvimento físico do cérebro humano.Apud Hall 2930.
} 
Depois diz o texto vieram as transformações decorrentes do surgimento de novas ciências sociais. Onde o sujeito, exausto corpo de facetas minhas, estava sobre a janela, que olhava, meus pedaços em multidão, alma que avizinha toda feita coração, e como único som, pulsa ainda, mas tão silenciosamente que de repente parece que não ouvimos o som da alma ${ }^{110}$. Entre, tantas calçadas nuas, repletas de gente corroendo mentes, ou diálogos que sente, talvez esteja na ausência justo o que a natureza escreve, como retendo sobre os passos, o que ficou destilando desde o primeiro olhar, multidão ${ }^{111}$ solitária querendo ficar, entre os passos tão sós, como nós, grafos, e todavia, múltiplas, figuras, desmembradas, também, ou aquém se possa confessar, diante da cidade calada, ou campos, verdes, em pleno burburinho da tarde querendo anoitecer, urbano, mesmo que concretamente alimento, de sentidos, que caminham, onde ainda que mesmo sendo madrugada, permanecendo a busca da manhã, e cambaleando como a despertar subitamente, perde o ar, e respirar tão sôfrego que desafia, fia e tece, o ambiente de viver, corroendo, sofrendo e buscando e vivendo e compondo os goles da natureza humana, que tem sede, e não para nem mesmo com as gotas da chuva que alimenta os cinzas de onde o inverno gosta de querer, mais do que o tempo, o espaço de permanecer, poesia em estação. Multidão, olha-me fixamente outro e quantos tantos, somos, vastos, gastos, e castrados da mesma solidão tremula, de desvario entre horas que passam distantes demais, ou próximas até do que animais humanos pensamos que somos, ou como então seremos, marcados como manada em meio a nossos ideais, de onde não fincaremos o território pessoal ou individual de viver, mais do que a relva vazia, o próprio vazio que vestia, entre humano, o pano de ser um dia, ou por um, cidadão. Multidão, como cimento, jazendo, mordendo sua fome de erguer-se concretamente vitrines, ou negócios, repartidos, ou corrompidos, erguidos, ou escolhidos dentre os quantos que somos sem existir, ou exibir do que somos, parte da estrutura, ou ruas, ao menos, movimentos, de quem compra ou vende, lamentos, ou destinos, fartos. Fartos? Em que sentido? Que tipo de diálogos poderemos encontrar? Multidão.

\footnotetext{
${ }^{110}$ Sousa, Carina Gonzalez Y . Composição Coração do deserto.GUITARRA/ Quadro - corpo-texto do projeto de livro diário da manhã.

${ }^{111}$ Sousa, Carina Gonzalez Y. Composição. Multidão que passou pela madrugada. Feito luz da alvorada. Que ficou na nossa estrada. Multidão que passou pela madrugada, feito luz na alvorada. Que ficou na nossa estrada. É balsa do cais, da travessia. Da tristeza que leva consigo. O dia que amanheceria. Canta o verso que soa, e corta manhã. Nos raios, da vida. Lado do mundo, de um só oceano. Onde o sol se põe. Multidão. De sol a sol, multidão. De sol a sol, multidão. DE sol a sol, querendo ser, querendo viver. Entre todos nós, seres alados. Cidade, atroz, de um novo corpo. Que de tão só, é solidão. É multidão. De teus olhos posso ver. $\mathrm{O}$ cidadão que vai nascer. Direito de pertencer. A luta de cada dia. Do verso que eu não queria esquecer. Da palavra do querer. Querer.. o sol da amanhã. Querer a luz da tua noite e sonhar o teu amor. O meu abrigo. De onde e quando a solidão. Você for, estarei contigo, multidão.
} 
As vezes me pergunto se de tudo que já sabem do caminho o qual eu não enxergo o que vivem? -Bate na porta, é outro ser. E o que quer responder?

-Pergunte... é festa de S. João.

-Os fogos, de artifícios, estão por toda parte, avisando que o que vai chegar?

-Guerras veladas na escuridão do silêncio. Quem responde? Quem responde?

-Bata na porta. Personagem que ficou, proscrito, e de onde, não reconheço, atuação presente de como se sente, ou vive, solidão, de espaço que o tempo apagou? E o que restou? Os fogos de artificio.

-O que sente, multidão? Solidão?

-Aparatos reais, são banais, demais? Ou corpo calados sobre as almas, multifacetados em espaços desconhecidos de abrigo.

-Interpretando a análise de que corpo, dorso, ou o que mais? O dorso social, é de frente uma máscara? Ou um diálogo em monologo, de onde se espera, vocifera, o que mais.?

-Apenas outros tempos, e não mais? O que mais, cidade ausente? Gente que sente?

-Entre, de repente, a porta sussurrou sobre a janela e viu o vento, que se foi, partiu e deixou algumas coisas, sobre o casebre, ou cimento de gente igual, e movimento.

-Se desse personagem, a fome saciou, então poderemos dizer, Bravo! E do palco, veste-se, multidão em voz, do corpo que ainda sopra, sobre a mesma janela, de onde observa.

-Observa, observa.... ave que voa, e voa, com na proa de um marinheiro, antigo passageiro das águas, águas, mágoas, de um lugar recolhido da terra, que exaspera chegar, porto do mar. O que viu, tempo do vento. Levou consigo. Partiu.

-Pariu o homem, solidão.

-Multidão. Arena a céu aberto, dramaturgia do incerto modo de ser. Território do sujeito.

O pensar é um produto que sente e gera nossa forma de viver e de conhecer, em todo lugar um sentido para se encontrar. Para esferas sociais integradas em expansão, denominamos, a Cultura Organizacional de Nações. Dentre o pensar a cultura e a nação, alguns caminhos foram trilhados. 
As culturas nacionais são uma forma distintivamente moderna. A lealdade e a identificação que, numa era pré-moderna ou em sociedade mais tradicionais, eram dadas à tribo, ao povo, à religião e à região, foram transferidas, gradualmente, nas sociedades ocidentais, à cultura nacional. As diferenças regionais e étnicas foram gradualmente sendo colocadas, de forma subordinada sob aquilo que Gellner chama de teto político do estado-nação, que se tornou, assim, uma fonte poderosa de significados para as identidades culturais modernas. HALL 2006 pg 49

Narrando a nação uma comunidade imaginada

As culturas nacionais são compostas não apenas de instituições culturais, mas também de símbolos e representações. Uma cultura nacional é um discurso - um modo de construir sentidos que influencia e organiza tanto nossas ações quanto a concepção que temos de nós mesmos. As culturas nacionais, ao produzir sentidos sobre a nação, sentidos com os quais podemos nos identificar, constroem identidades. Esses sentidos estão contidos nas estórias que são contadas sobre a nação, memórias que conectam seu presente com seu passado e imagens que dela são construídas HALL 2006. pg 51

Da imagem da tradição a imagem real - A cultura nacional coloca identidades entre passado e futuro, lembrando Hall, ainda:

Timothy Brennan nos faz lembrar que a palavra nação refere-se tanto ao moderno estado nação quanto a algo mais antigo e nebuloso - a natio uma comunidade local, um domicílio, uma condição de pertencimento " ( Brennan 1990, p 45 ). As identidades nacionais representam precisamente o resultado da reunião dessas duas metades da equação nacional: tornar a cultura e a esfera política congruentes" e fazer com que culturas razoavelmente homogêneas, tenham, cada uma, seu próprio teto político “ ( Gellner, 1983, p 43 ). Gellner identifica claramente esse impulso por unificação, existente nas culturas nacionais: A cultura é agora o meio partilhado necessário, o sangue vital, ou talvez, antes, a atmosfera partilhada mínima, apenas no interior da qual os membros de uma sociedade podem respirar e sobreviver e produzir. Para uma dada sociedade, ela tem que ser uma atmosfera na qual podem todos respirar e falar e produzir: ela tem que ser, assim, a mesma cultura. "Gellner 1983, p $37-38$

Quando se questiona uma identidade nacional ${ }^{112}$ presume-se não ser dogmática, portanto unificar em meu ver, é respeitar a diferença, a pauta de uma composição demostra muito bem isso, cada elemento, cada compasso, sua integralidade, sua diversidade enquanto passos de harmonia de uma obra geral, assim como o corpo humano, para se ter uma união no

\footnotetext{
${ }^{112}$ Sousa, Carina Gonzalez Y. Composição Algozes dos ossos. Territórios nossos, de algozes dos ossos, na procura da alma, da carne que sobreviveu. Luta e procura, os atos que viveu. Consumiu, sofreu, gemeu.... o vazio. O livro, da vida... Que não leu... O espaço do tempo, que prometeu justiça. De braços abertos, o quanto sejam, proporções, porções de travessa por onde passamos, caminhamos, do direito e verso e reverso das entranhas... e de quantas batalhas ganhas estejamos prontos ou apenas tenhamos....coragem.
} 
aspecto do qual aqui pretendemos, é justamente o respeito a integralidade onde se pode conceber a compreensão, no sentido de conjunto de englobar, e não asfixiar, por anular. Absolutamente, não é a isso que me refiro, não sobre uma subordinação.

O que mais desejamos é continuar sendo aquilo que somos. Desejamos fazer sentido. Para tanto é preciso não apenas estar junto às coisas, mas, sobretudo, reconhece-las no mundo. Somos um ser em conjunção. Conjunção aqui é o movimento que une o gênero próximo ao específico produzido. Enquanto somos o que mais desejamos ser, um não se realiza sem o outro. como as duas faces da mesma moeda. (FAUSTO, 2003).

Busca-se um raciocínio que prioriza um auscultar com profundidade capaz de ouvir o desmembramento dos passos, dos elementos, onde se pode encontrar razões compartilhadas de destino, ou seja, onde e como posso encontrar na diversidade, aspectos que me façam compreender uma harmonia de sentido, um significado nem mesmo que seja comum, mas que possa encontrar uma completude, e para isso precisaremos do olhar que muitas vezes me atrai ao oriente que é a capacidade de não em oposição mas ver dentre diferenças, completude. Claro que deve ser estudado com cautela cada olhar, e com responsabilidade do respeito, sempre, para em diferenças a integralidade possa ser preservada ainda que sobre uma instância que seja capaz de encontrar a união que até mesmo, restaure-a. ou seja, territórios de um saber, onde a multiplicidade envolve equações do viver em geometria de formas onde cada uma, poderá ser fractal sendo outro com traços onde se localizam propriedades comuns, ou complementares, adjacentes, ou tangenciais. Enfim, a vida, e a natureza principalmente demostra a sabedoria de sistemas, ecossistemas, onde se tem a comunhão de uma atmosfera, onde a sobrevivência aprenderá a ser mais do que isso, a ser com a evolução a capacidade de minimizar perdas, penso, e ser um desenvolvimento onde o tempo seja natureza de nossas raízes de origem e fim, ou seja, onde os esforços estejam na promovendo os espaços do futuro em direção do bem comum, sendo que nas lutas elas sejam justamente para colaborar em rumos que estejam de auxilio aos avanços, com tecnologia, com cognição, com amor, valores, e não lutas onde se tenha a realidade de violência, como fator de sobrevivência, e morte, então que as raízes como origem e fim, se tornem apenas o que perpetua, em natureza, e não que da violência seja essa a nossa natureza. Arrancados de nossas criações, ou desejos como humanidade integra fomos, pelos caminhos, e narrativas que vivemos, e escolhemos, mas dentre os avanços, sempre teremos escolha, e do lastro, do que foi, haveremos de encontrar o porquê de nossas diretrizes futuras. O que a natureza enquanto outras espécies do bios, mostra, de muitas vezes para 
viver, a morte estar na presa, creio que o desenvolvimento caminha para outras compreensões, ao menos do homem. Lugar de nós, sem subjugação, mas de caminhar em conjunto, havendo de olhar para o céu, e as estrelas, onde todas estão sobre o brilho como reflexo do sol. Um simples lugar ao sol.

Se compreendermos a capacidade que todos temos, no viver, de sermos, de fato e com dignidade, o caminho é longo, mas haveremos de conquistar. Do que o homem já fez, conquistou, desbravou, feriu, amor, matou, deverá compreender por onde ir, ou do que deseja seguir. E o como, este está ao alcance da razão, que permeia todo aquele que vive, e busca sua condição humana, enquanto humanidade, que somos, todos, juntos. Pode-se alegar, e de fato, é um ponto de vista, como o que segue, mas com meu direito de expressão tenho a minha opinião.

Um único povo tem que tomar cuidado, pode dar margem a autoritarismo, dependo do discurso. Não que não se possa dizer essa frase de um único povo, enquanto face de Nação, onde o povo esteja sendo unido pela vontade de se erguer como um futuro melhor, para todos, enfim, deve-se ter muito cuidado, e ter o máximo de esclarecimento quanto a palavras como gestos e manifestos do pensar. As ideias, devem ser claras enquanto argumento e diretrizes para não sucumbir a objetos de outrem com interesses escusos e de manipulação. Principalmente no que se refere a aspectos de ordem de nações, sempre toda precaução e discernimento com palavras em discurso.

“ A Europa Ocidental não tem qualquer nação que seja composta de apenas um único povo, uma única etnia. As nações modernas, são todas, híbridos culturais.” Esperamos ver não somente do que compreendem de lugares étnicos diversificados, mas de saberes compartilhados, onde se alcança olhares múltiplos para um lugar de desenvolvimento comum. E o comum, não é restrito, se somos capazes de observar, é um comum, amplo e complexo, extensivo. Creio que podermos dizer que estamos em um lugar em nossa história humana em que as diversidades de nossos povos, se tornaram um sentido, onde o planeta deixou de ser apenas um ponto, mas para ter uma vírgula, de onde seguimos concebendo verdadeiramente o significado, não sendo explorado, mas absorvendo sua natureza verdadeiramente para que certos aspectos de nossa vida, deixem de ser, apenas, junção de letras com dizer, para nos pertencer, então a palavra, mundo, se torna, VERBO, no sentido de voz que tem a origem no seu corpo, como alma que nos fez viver. Isto é a consciência que está despertando e vem progredindo, com direcionamentos a preocupações quanto a nossa maneira de viver, sem prejuízos tanto da natureza humana, como da natureza, porque 
negligenciados, foram até que por imaginar, prever, sentir, e pagar o preço, fomos levados a mudar, para não sucumbir e sobreviver. Então, me parece que o homem, foi capaz de realizar na eminencia da morte de sua espécie, a mudança, e sinto mesmo, porque somos assim? Precisamos chegar a extremos, para compreender que mover montanhas deve ser antes desse lugar, de onde talvez o ar seja pouco. De onde estaremos, quanto a nossa responsabilidade, do que é avanço, em que diretriz... serão as escolhas, de um por vir. O movimento, se torna Ericsiton por devorar-se e agora? Sociedade arrancada do ventre ${ }^{113}$, talvez prematuramente, esteja sobre os braços do cosmo. Tempo. Queremos tempo, quantos? Multidão. Solidão. Ao nascer, somos o silêncio e o grito, ou gemido de um lugar outro de nós, enquanto sós, múltiplos da GAYA. Talvez, o filho da Gaya seja o mito que lhe devolve o ventre. Haverá de ser serpente? Sobreviva então! Saberei do tempo, seu ciclo em movimento, e de lá, poderei ouvir, seus outros partos, nascidos do mesmo, e sobre clepsidra, devolve ao infinito, a concepção. ${ }^{114}$

Conceber uma consciência de vida, é parte do infinito.

Ouço... A muito tempo ouço... como geometria, que depois do circulo, Gaya se reparte, ainda estando um ponto, espaço, a espera das águas, que nasce elemento, como veia do tempo. Escreva-me. Origem. Do onde, talvez nem mesmo o ventre possa saber, se acaso pertencer ao que lhe vestiu imagem. Aqui sinto a presença do nada, porque o cosmo, por vezes se dilui, como gozo de um eterno que não concebo. Ainda que, a volúpia de me debruçar sobre ele, seja também infinita. E todavia, queremos identidade. De onde?

\footnotetext{
${ }^{113}$ Letra e composição do ventre do mundo.

${ }^{114}$ Sousa, Carina Gonzalez Y. Composição: Rios da gente - Rios da gente, da luta que sente, ah... enxurrada que descia a rua....ah ah... rios da gente, da vida que sente, lugar....de se procurar... Ou talvez porque, de querer te encontrar. Vou trabalhar. Oh já raiou ...é ainda madrugada. O voo do pássaro ( como um pássaro) Procurar um pouso, Dessa vida. Estrada que não finda. Calçada de ladrilhos. Por onde passei e não me reconheci, É talvez o lugar desse labirinto que me perdi, ah cidade que ai passar. De onde vou saber qual é a saída. Quem sabe percorrer, essa minha vida ( um dia ) eu vou poder viver. Acorda manhã, eu vou passar. Acorda, manhã, eu já quero te encontrar. Devora-me como os raios do sol, aqueço-me por onde eu possa te olhar. A estrada...que segue com a minha alma. Não vou te deixar, não vou te deixar.

Composição CORPOS- Dos corpos silenciados do ontem, Massacres que eu não vi. Notícias que eu senti. 0 meu senhor cidade do mundo é teu. Lugar na incompreensão. Os corpos na multidão. Sufocam demais. Não sei por onde as algemas se partiram. A que seguir a vontade de viver, na sinceridade. Das lágrimas que a saúde recolheu. Um dia poder viver. Essa minha cidade, que não sabe mais qual é a realidade. De onde o tempo percorreu. Ah imensidão do que não pode mais. Sonhar. Mais para viver um pouco mais, terá que ser, mais uma vez, um novo dizer, que eu quero ver, e vamos lá, cantar mais uma vez, a igualdade que eu quero ver nascer.

Composição: A ferida aberta- Porque... a ferida aberta, não cicatrizou. porque a ferida aberta, não cessou de te encontrar, naquele lugar. Do passado que não se despediu e sofreu, e agora as lágrimas não vão mais derramar....derramar.... Mesmo assim...seguiu em frente. A sua gente... Ihe ergue nos braços, da eternidade. Em igualdade de amor, e o sol cobriu a pele, e destilou o bálsamo da terra. que germinou. Um novo ser, que agora é livre para voar. Amar é sim eu se que vai enfim, voar... voar....
} 
Dimensões da imensidão. Mas, a sociedade quer a sua parte. Nome, endereço, documento. E, entre espaços do vento, apenas ressoa. Stuart Hall argumenta que na história moderna, as identidades nacionais estariam mais predominante no corpo cultural porém, no século $\mathrm{XX}$ observa-se um movimento e a razão deste seria objeto de estudo, nomeada como globalização, onde Anthony McGrew considera que " a globalização se refere aqueles processos, atuantes numa escala global, que atravessam fronteiras nacionais, e organizações em novas combinações de espaço-tempo, tornando o mundo, em realidade e em experiência, mais interconectado. “

O posicionamento em expansão no qual culturas estão sobre tempos de globalização não quer dizer, porque até mesmo me parece que esta questão ( sem tempos de internet ) mas sempre houve enquanto evolução humana das relações irem se aproximando e expandido cada vez mais, enfim, penso que o fator de nacionalidade cultural, não se restringe pela amplitude de relações ao contrário, se preserva e expande em relação ao cotidiano vigente proporcionando avanços onde tenha deficiência porque a não ser que não admita a possibilidade, todos e toda qualquer cultura aprende com outra, mas para isso, voltaremos a questão da humildade, e do não autoritarismo próprio em relação a não se deixar relacionar com outros povos, temendo se exaurir enquanto tradições, até por ocorrências anteriores da história que validariam esse posicionamento, porém, em tempos atuais, creio que certas conjecturas dessa geometria sofreram alterações enquanto avanços, porque me aprece já ser mais, prudente os caminhos de intersecções, nos quais estamos aptos a não perder nossa identidade enquanto cultura e ainda promover o entrelaçamento desta com as demais, sem a presença de violência de qualquer espécie, de qualquer tipo, ou seja, a escolha de entrelaçamento pode ser similar, mas o comportamento teve do decurso aprendizado, e portanto, supõe-se que a resposta enquanto patamar histórico seja outra, então, creio que poderemos desbravar território entre culturas sem prejuízos de integridade, das quais somos procedentes, até porque, já sentimos a presença da necessidade de uma cultura organizacional de nações onde o sentimento está na ordem de um complexo de sentido que se faz através da cultura mundial, pensamento em organização que expandiria a concepção da colaboração com o respeito e ações participativas que fomentem recursos para o desenvolvimento social, ambiental, cultural, cognitivo, pesquisa, enfim, tudo que nos leva ao que pode constituir uma cultura em benefício de um mundo melhor, com a coerência, prudência, respeito e lucidez capaz de organizar os pontos de coerência, conexão, entre as culturas particulares de cada nação, povo, enfim... de cada um, até porque, hoje, o sujeito 
múltiplo que se engendra pelos caminhos da sociedade globalizada cada vez mais, pode acercar-se do seu outro em dificuldade sem ter em conta o território mas o que o aflige e dessa forma, o território é o da paz, sanar as dificuldades, orgânicas onde quer que elas se encontrem, e não restrita a uma determinada fronteira.

A medida que o espaço se encolhe para se tornar uma aldeia global de telecomunicações e uma espaçonave planetária de interdependências econômicas e ecológicas - para usar apenas duas imagens familiares e cotidianas - e à medida em que os horizontes temporais se encurtam até ao ponto em que o presente é tudo que existe, temos que aprender a lidar com um sentimento avassalador de compreensão de nossos mundos espaciais e temporais ( HARVEY, 1989, p 240 ).

O tempo da gente. Sobre medida. Princípio - meio e fim? Indeterminação. Talvez a chave do encontro de nossa representação e enquanto desafio de identidade seja justamente a hipótese da ressonância que fará todavia, com que nos encontremos enquanto o que somos, dentre as conexões, grafos, existências de nossa natureza, em forma, que se desforma feito fractais para dentre rumos e diretrizes das quais somos parte, ainda sabermos nossa “ identidade", e o como, quem sabe a ressonância irá preservar o nosso sentido, tanto em origem como porvir. Creio que é uma hipótese válida dentre a consciência de que o espaço e tempo não são questões somente de física, mas são a vida, e nela estamos produzindo e promovendo as naturezas pelas quais nos representamos e somos o que construímos de nosso percurso e para onde vamos, então, se assim podemos considerar com argumento valido do existir é cabível por mais de um prisma que devemos considerar entre nosso passos, a indeterminação e que o tempo este se torna espaço segundo um modo de ser, no qual ainda estamos apreendendo. E, do que somos, constituintes, futuro enquanto vazão de lugares, nossos e vazios, densidades de probabilidades, em infinitesimais propriedades da criação, quem sabe, poderemos estar mais próximos, do que é a globalização, sem tanta necessidade de nos ater a nosso umbigo. E cortando o cordão, estaremos mais próximos do espaço, ou de nossa natureza, origem e porvir tão próximos, que por vezes pode nos tornar ansiosos por determinar um lugar, talvez receio de asfixiar, do que nem tanto conhecemos, ou temos receio de conhecer. O outro. ainda o outro, diria Hegel, E voltando a geometria, então, outro de nossa natureza, careço para que me forme, geometria espacial, do viver comum.

Enquanto relações de cultura e espaço, teremos alguns pontos de vista. 
Nas sociedades pré-modernas, o espaço e o lugar era amplamente coincidentes uma vez que as dimensões espaciais da vida social era, para a maioria da população, dominadas pela presença - por uma atividade localizada.... A modernidade separa, cada vez mais, o espaço do lugar, ao reforçar relações entre outros que estão ausentes, distantes ( em termos de local ) de qualquer interação face-a face. Nas condições da modernidade...,os locais são inteiramente penetrados e moldados por influências sociais bastante distantes deles. O que estrutura o local não é simplesmente aquilo que está presente na cena, a forma visível, do local oculta as relações distanciadas que determinam sua natureza ( Giddens, 1990, p 18 ). Pg 72

Quanto mais a rede passar a ser realidade aos sentidos de inter-relações na vida, havendo nas relações informações e comunicação, maior será a gama de assim acreditamos ser o desenvolvimento que sustentará aspectos para alcance de oportunidades e conhecimento em entrelaçamentos de culturas diversas e mesmo internas. A educação do pensamento mais uma vez é de suma importância tendo em vista que a relação não pode de maneira alguma ser de exploração afinal, não queremos repetir os mesmos erros.

O sentido de cultura foi se alterando, ressignificando e tornando-se fortemente um sinal de desenvolvimento intelectual, e ainda posteriormente um modo de vida, material, intelectual e espiritual, havendo de se estabelecer inclusive por diagnostico de reações das mudanças em curso da vida, economia e política. (WILLIAMS, Raymond 2011).

Pertencimento do ser e a sociedade como ambiente, pode se relacionar assim em paralelo de sentido. Pertencer de fato, a história, como ser humano, é sentir-se propriamente face da terra, gesto da mesma natureza, voz do mesmo ar, enfim, é de fato, se compreender natureza histórica-social, ventre do mesmo ambiente. Porque pode ser apenas discurso onde o tempo simplesmente é desapercebido de nós, e o cotidiano passa a ser um tempo dentro do tempo, no qual apenas percebemos um. O histórico, a razão de nossa existência pregressa no decurso da história, carece de um esforço um tanto quanto mais latente de ser de fato, um modo de olhar onde o exterior e o interior podem ser faces da mesma moeda. Estar e viver, compreender e aprender, tantas são as palavras que podem ser como vozes sem ação dentro de nossa constituição enquanto seres humanos, que precisam significar-se.

Que espaços hoje estaremos tentando recompor ou melhor, estar presente, na sociedade. Mudanças ou destroços, ocorrem mesmo sem guerras como as nomeamos, mas guerras também existem sobre o cotidiano, de uma outra maneira, mas ainda assim, com considerações em parte para muito ainda, semelhantes. Ter por onde ir, em busca de um 
lugar na sociedade, é em parte, procurar-se sobre destroços minoritários, com a intenção de se não um lugar, mas ao menos, o caminho. São campos urbanos, concretos, onde germinam economias, e o agricultor é o indivíduo para alguns em paralelo e outros... ou talvez outro nome mais apropriado, mas me parece que alguns aspectos dos movimentos de nossa história estão sobre nossas cabeças mais do que imaginamos, porém, todavia, não o enxergamos, e curiosamente, temos também, o ciber-espaço, e onde nos localizamos, ou em que espaços estamos, é de fato, um desbravar de territórios, em tempos atuais. Então, cabe a pergunta em parte, de que revoluções estamos travando hoje, E não que seja revolucionária, longe de mim, apenas, gosto de pensar paralelos do tempo. Você está conectado, quase dá pra dizer... “ industrializado" ....saiu daqueles campos urbanos... mas no entanto, se habita dois espaços simultâneos, o urbano -concreto e o virtual; e para não marginalizar ninguém, o lugar externo- (território cotidiano podendo ser qualquer lugar que o ser viva cotidianamente - áreas de matas etc.) e isso é interessante na sociedade atual que terá que se acostumar com ESPAÇOS MULTIPLOS.” E, os espaços múltiplos, quase penso em dizer in loco, e em deslocamento geográfico, globalização-aqui também multidirecionado.

Portanto, o onde estamos se tornou um tanto quanto significativo, mas o como, também. Aliás, o como, passa a ter um valor, entre geografias múltiplas, ou será melhor, topologias múltiplas. Em que medida o estar conectado se tornou posicionamento social, e podendo até mesmo, diferir completamente de um outro posicionamento de seu cotidiano. Então, como lugar está uma possibilidade ou oportunidade de talvez uma igualdade de espaço? E passo quase a me perguntar, quem somos? Ambos, quantos.... ora, ora, então somos muitos em diversidade de espaços? Como então, seria essa identidade social. Podemos ter espaços múltiplos, mas precisamos de uma identidade mais singular ou socialmente poderemos também abarcar uma diversidade com algum ponto de unidade? Sinceramente, ainda não sei, mas gosto de começar a pensar a respeito. Qual condição me tornaria um cidadão com características de "preencher um formulário" onde a minha situação de moradia, por exemplo precária não condiz com meu estado de topologia virtual por exemplo. Isso pode ocorrer? Não entendo muito, mas me parece que podemos refletir que caminhos estão sendo traçados como deslocamentos sociais, em busca de unidade de identidade social coesa, ou ao menos, igualitária, mas ainda o primordial talvez seja as características de meu posicionamento em ambos, como ser humano e seus valores, fato este que nos mostraria possivelmente caracteres de um ser que se encontra em correspondência apesar de diferenças, ou seja, podemos nos encontrar como seres, ainda que caminhando em espaços 
compartilhados ou moventes, capazes de nos proporcionar uma certa igualdade. O mais curioso seria, se nossos olhos enxergassem um posicionamento em uma parte como igual (virtual) e no posicionamento cotidiano, em condições de moradia, trabalho, renda etc, ausentes, então, será esta a razão de muitos vivenciarem como moradia "o espaço virtual? Ou temos também muros de territórios sociais virtuais? O que seria o ideal em aspecto de movimentos hoje, e o que estamos fazendo? E culturalmente dialogando espaços, constrói-se ainda em observação, no próprio movimento ${ }^{115}$.

Mas, dos lugares que. ${ }^{116}$.. produzimos, e consumimos. Ainda sou do tempo que de maneira simples se pensa do que consome vindo do campo, estando na cidade, algo bem corriqueiro e que nem paramos para pensar mais( no ato de consumir ), me parece, de qualquer forma, no paralelo travado, fico me perguntando, por onde estaremos mais, produzindo ou consumindo, em qual dos territórios, ou não necessariamente precisemos escolher, ou definir, apesar de que na cadeia produtiva ou enfim, seja qual forem os nomes, no percurso como dizem da terra a mesa do consumidor, seja qual for o produto, onde está a terra e onde esta a mesa, em territórios atuais. Ao menos para dependendo do diagnostico saber onde investir, ou onde a demanda "social” é maior, ou ainda poderá ser mais útil, ou poderá ter um alcance entre espaços de maneira mais condizente com a realidade que almejamos. Estarei vivendo mais no virtual, porém, consumindo do cotidiano factual, ou vice-versa? Posso viver na cidade e consumir do campo, em que dimensões isso me afeta, ou nem vou mais perceber. Será necessário perceber, quanto ao que falamos de espaços múltiplos, urbanos e virtuais, produção e consumo, para que os aspectos econômicos estejam disponíveis para avaliação? Me parece que sim, inclusive nas relações humanas - sociais que estão intrínsecas neste âmbito. A cultura deve estar atenta enquanto meio e caminho de sustentabilidade futura onde o traçado enquanto escolhas, rumos estarão em mesma medida. Espaços novos estão sendo disponibilizados com que movimentos sociais? De maior capacitação para igualdade ou opressão silenciosa. Do que queremos, o que fazemos, por onde ir? E, para além de espaços múltiplos, se queremos desenvolvimento, penso que

\footnotetext{
${ }^{115}$ Kerckhove Derrick, palestra de abertura no Ibercom realizada na Universidade de São Paulo, no ano de 2015, A transparência vai definir o comportamento do futuro. E reflexões sobre o tecno-ser, janelas da mobilidade: da autora da tese em diário da manhã, e vídeo no endereço eletrônico disponível em https://youtu.be/mLbSp635NNk.

${ }^{116}$ Sousa, Carina Gonzalez Y. Os lugares. Cheguei em casa e percorri. Os teus lugares e eu não te vi. e eu sonhei que estavas lá. Cheguei em casa. E percorri, as tuas imagens. Que tanto fez, sorrir pra mim. Aquele dia que o sempre. Dos teus olhos me abraçou. Ah o teu piano... lá estava e eu sei. Que mesmo assim ele não toca. Sem você aqui pra mim. La laia lala. E agora, essas paredes são. Meu coração vazio... Não sei mais sem você. A noite inteira é o luar. Desse meu ar que não respiro. E não posso mais viver, aqui sem te pertencer...
} 
haveremos de considerar a economia do pensamento. Então teremos algumas propriedades e valores, nos espaços múltiplos, onde o pensamento, o conhecimento, a educação, deve encontrar lugar, para em vias de acesso, atravessar outros objetivos, sendo uma economia que considere, um pedaço de "terra," um espaço de um novo tempo. Podendo ser: Sociedade: Cultura e indivíduo. Caracteres culturais onde a responsabilidade social está integrada responde ou deveria responder as demandas de um lugar social, onde não criasse aos menos favorecidos submissão e ciclo viciosos de condição de vida, ao contrário, estimular por oportunidades e capacidades como dito anteriormente um mover-se em deslocamentos sociais para crescimento onde o humano em gesto de viver se apresenta consciente da reverberação que a vida apresenta.

Reivindicar diretos não é anarquia, como muitos gostam de dizer, é existir de forma licita. Ainda que determinadas posturas estejam sobre dilema sempre. ${ }^{117}$ Cultura e condições de

117 No livro Cultura e sociedade de Raymond Williams, são feitas considerações sobre modos de olhar a cultura em produção e reverberações. Em um sistema, “ Owen, portanto, está com Southey e contra os economistas políticos, em perceber a causa de todas nossas dificuldades" não na natureza humana e sim na constituição da sociedade". Além disso, ele está afirmando com uma clareza até aqui sem precedentes, as duas proposições que desde então foram afirmadas tão amplamente: Que uma mudança nas condições da produção gera uma mudança essencial nos produtores humanos. Que a Revolução Industrial foi uma mudança dessa importância e produziu aquilo que era virtualmente um novo tipo de ser humano. A escolha, na visão de Owen, é entre o novo mundo moral e a anarquia. O problema, como se apresentou a Owen, era uma questão de engenharia social: a frase dá exatamente a ênfase correta. Ele expressa seu princípio básico da seguinte maneira: Qualquer caráter geral, do melhor o pior, do mais ignorante ao mais ilustrado, pode ser dado a qualquer comunidade, até mesmo ao mundo como um todo, pela aplicação de meios adequados; meios esses que estão em grande medida sob o comando e controle daqueles que têm influência nos negócios humano. Em sua concepção do povo e por razões não muito diferentes, Wordsworth baseia-se fortemente na teoria social de Burke. Independente de como o argumento se apresentasse, fossem quais fossem as reações dos leitores reais, havia assim disponível um apelo final ao espírito personificado [...] do povo, ou seja, a uma ideia, a um leitor ideal, a um modelo que pudesse ser colocado acima do clamor das verdadeiras relações do escritor com a sociedade. É bem natural que o espírito personificado fosse uma alternativa muito bem-vinda ao mercado. Obviamente uma atitude assim então influencia a própria atitude do escritor para com sua obra. Ele não irá aceitar a cotação de popularidade do mercado: Em sua concepção do povo e por razões não muito diferentes, Wordsworth baseia-se fortemente na teoria social de Burke. Independente de como o argumento se apresentasse, fossem quais fossem as reações dos leitores reais, havia assim disponível um apelo final ao espírito personificado [...] do povo, ou seja, a uma ideia, a um leitor ideal, a um modelo que pudesse ser colocado acima do clamor das verdadeiras relações do escritor com a sociedade. É bem natural que o espírito personificado fosse uma alternativa muito bem-vinda ao mercado. Obviamente uma atitude assim então influencia a própria atitude do escritor para com sua obra. Ele não irá aceitar a cotação de popularidade do mercado:

Fora, então, com a reiteração se sentido da palavra popular aplicada a novas obras na poesia, como se não houvesse qualquer teste de excelência nessa primeira das belas-artes, e sim que todos os homens tivessem de correr atrás de suas produções, como se impulsionados por um apetite, ou forçados por algum encantamento. Ele continuará a insistir, com efeito, em uma ideia, um padrão de excelência, o espírito personificado de um conhecimento do povo como algo superior ao verdadeiro curso dos eventos, ao verdadeiro funcionamento do mercado, Essa insistência, vale a pena enfatizar, é uma das fontes primárias da ideia de cultura. Cultura, o espirito personificado de um povo, o verdadeiro padrão de excelência, passou a ser disponível no decorrer do século, como o tribunal de recursos em que valores reais eram definidos, normalmente em oposição aos valores artificiais lançados pelo mercado e por operações semelhantes da sociedade. A sujeição da arte às leis do 
trabalho e educação. Ainda que, como territórios nômades, seja um poema: Estar sobre cadeiras vazias, de onde os braços tenros, permanecem a olhar, e consome. Dilatados pelo íngreme estado, latente de uma realidade com fome desatados, desejo e membros, sociedade insaciável de ruídos estranhos, viável à quem? Despejados de si, sangram, ${ }^{118}$ Como dizíamos sobre o humano ser o capital de um desenvolvimento, este presume-se estar como não somente valor mais riqueza de uma nação, de um povo, além claro das relações econômicas, porém esta premissa como vazão de demais frutos que venham a ser situações de ordem financeira condizente com esses dois lados, tanto de capital humano como finanças, economia não somente estabelecida mais em crescimento como uma nação entrelaçada com suas faces sociais. Onde continuamente se pergunta sobre o viver, poema:

Viver não basta para estar sobre o solo,

Pés descalços, é a terra.

Liberdade

Braços abertos como asas que não reconhecemos sobre o ar

De onde se possa estar, pés no chão, face da terra.

Caminho de todo que vive

Igualdade de onde sonhar

Viver não basta para o solo ardente

É preciso dizer, o que se sente

Caminho de todo que vive bravamente

Face da terra, fenda do ventre que nos gerou,

RAIZES DO TEMPO.

mercado sujeita em grande parte às mesmas condições que as outras formas de produção, tinha sido prenunciada em grande parte no pensamento do final do século XVIII. Adam Smith tinha escrito: Em sociedade opulentas e comerciais pensar ou raciocinar vem a ser, como qualquer outro emprego, um negócio particular, que é executado apenas por uma poucas pessoas, que fornecem ao público todo o pensamento e raciocínio que possuem as vastas multidões que trabalham. (WILLIAMS, 2011, PG 50-58)

\footnotetext{
${ }^{118}$ Sousa. Carina Gonzalez Y. Composição Pedras. Pedras que calam, resvalam a pele. Resgatam as vestes. dos corpos nus, pedras que caem, das aguas escrevem, o gesto em passagem, do rio da cidade. Viagem contida. Vazão de uma vida. Por onde ir. Por onde ir. Seguir o destino. Das ondas nas pedras. Sinceras urbanas. Naturezas humanas. Pedras que sofri. De quem eu sou. Pedras recolhi. do que ecoou. Pedras esculpi, do que soou, sobrevivi. Pedras que calam, resvalam a pele. Resgatam as vestes, dos corpos nus. Pedras que caem, das águas escrevem, o gesto em passagem, do rio da cidade, viagem contida, vazão de uma vida. Por onde ir... Por onde ir... Seguir o destino, das ondas nas pedras. Sinceras urbanas. Naturezas humanas. Pedras que sofri, DE que eu sou, Pedras recolhi, do que ecoou. Pedras esculpi, do que soou, sobrevivi, SOBREVIVI.
} 
Não há palavra que não possa ser como o som, atravessar-nos. De onde a autoria, é sujeito mundo. Quem sabe um dia, assinemos, vida. Simplesmente.

O conhecimento - mercadoria. Lugares: DO LAR - Uma questão de espaço ortográfico? Literatura e outras formas de expressão como corpo cultural entre as vivências cotidianas, depoimentos de um pensar intemporal. Teorias literárias e comportamento do texto. Temos não somente o escritor, mas a voz do texto, que se configura sendo também uma identidade, como outras obras que possuem ao serem produzidas uma "vontade própria", porque é parte do sentido interno na obra, que possui sua liberdade e a liberdade é fato de gênese de toda obra que é Arte por si mesma. Em parte, como o viver, escrevendo-se. Cultura como atividade humana, considerando o que vemos ser, arte de viver, este aspecto abarca a ética, como fundamental, para o que vemos, nos encontrar como sendo linguagem e pensamento, de uma sociedade. Onde, a arte, não é somente obra que reside na manufatura humana, mas como presença na vida em sociedade, assim sendo como já descrito em ágape, arte com a vida, temos, movimento onde os seres se relacionam, e assim realizam sua dança ( SHIVA ), e tantos outros exemplos. Portanto, quando dizemos, que, lemos o mundo, de fato, estamos a ler as palavras contidas nos sentidos de nossas ações, comportamentos, relações, sobre as cenas que vivemos, narradas por nossas histórias e as dos demais, realizando uma sociedade em modelagem diríamos, como um todo. E se lemos o mundo, então, deveremos prestar atenção a quem está escrevendo, se somos autores compartilhados socialmente ou apenas, fantoches de nossas mentes.....e do mundo, quanto que é a participação como sendo obra que toma por si, autoria também? Então, vale lembrar que, do que lemos, o que apreendemos, do que gostamos, queremos, almejamos, com pessoas, empresas, escolas, família, tudo nos afeta e nos reverbera, em gestos de narrativas lidas no mundo, e assim sendo, o discernimento é fundamental para que possamos tomar a consciência de nossa presença no mundo, porque, de tudo, encontraremos, ilusões ou realidades. Dentre o tempo, passando o passado entre o futuro, encontros arrebatados desencontrando-se, até que: Onde o poema, recebe a palavra, e torna-se poesia? Gesto teu.?

A literatura como face de uma sociedade, assim como as demais artes demostram absorver dos sentidos o que sua alma sente, e revela dentre a realidade o que a faz, viver. Palavras são destinos habitados por representações para além do real, mas do que no real, está de sentimento, e não costumo muito usar tradução, mas, sim, prefiro, entrelaçamento. Agora, como a arte tem por primazia a liberdade, sabemos que pode ter na representação da 
"realidade" o que a torna voo sobre o céu, ou algo que precise para alguns ser mais concreto, assim sendo, vejamos, o sensível o que transcende para alguns, ou, do que a realidade todavia, me encanta.

Poeta, causa humana, sendo efeito de ser, real o que da realidade ainda é sentimento, ou a liberdade de descrever uma possível imagem entre a cena exibida e a programada, entre o esboço e a obra final, a exibição, ou seremos continuamente projeções, estados do "entre", personalidades escritas pelo mundo. Então entre o que é ficção, realidade, representação, descrição, ora, o que importa? O roteiro fica cada vez melhor, conforme a imaginação, não é mesmo, e a parcela real, fica a cargo de cada um.

Ah, página "64",119, do livro da vida, espaços nossos. Atentos devemos estar para que uma dominação sobre máscara não esteja ao nosso redor e a sociedade coagida sem perceber. Memórias da cultura. Dizer sobre o relacionamento entre o escritor e o leitor, quase é o posicionamento do mundo com o criador, ora, estranho parece, mas a teologia, ou a filosofia, tratam deste aspecto que circunda também o escritor ${ }^{120}$, assim como o posicionamento da interioridade humana com o externo, que lhe é interno sobre face como o externo ele reconhece em si. Quem escreveu o mundo, e quem o lê.... então aqui, nos deparamos, com páginas em branco.

Sempre perguntam sobre gosto quando se fala em arte, mas sinceramente penso que, na sociedade de consumo, seria bom, pensarmos, na deglutição antes do gosto, porque parece que tudo pode ser abocanhado, podendo por vezes se tornar indigesto, mas comido. Então, Salvador Dalí tinha razão! Nunca vi ele tão contemporâneo como nos tempos atuais. Saboreamos realidade como ficção e nem perguntamos que gosto tem! E, também, nos deparamos com um banquete de ficção e simplesmente o paladar é saciado como realidade, então, onde fica o gosto, não tão longe do gozo, ora, vejamos as possibilidades, do antes, afinal, temos que ter preliminares. Ou não temos mais? Hum... já dá pra sentir não é mesmo.

\footnotetext{
${ }^{119}$ Sousa, Carina Gonzalez Y. Composição: Basta. Basta o quanto seja a crueldade, basta. Basta quanto seja a maldade. Basta sem lugar na sociedade, basta quanto for não tem idade, pra viver. SE for dignidade que eu quero. Basta essa desigualdade, Basta não ter ar nessa cidade. Sufoca o próprio ,mar. Eu quero velejar, por onde os portos da minha crença me levar. Ainda que nas areias eu possa, estar. Basta, da crueldade eu não quero mais, basta, dessa amargura. Basta da violência eu não quero mais. Basta. Basta.... Da incompreensão. O que você pensa, ? Eu tenho um coração. Basta de tanta tortura, o que você pensa, eu sei o que é vida dura. Essa cidade esqueceu o que é humano. Percorre o seu dizer, sem ter o sentido, ah... basta. Eu quero viver, liberdade de sentir. O meu coração bater, pelo que é a verdade de viver. Ah eu quero ver, igualdade, liberdade, dignidade eu quero ver, o que é que você pensa... me fazendo assim sofrer. O que é que você pensa, me fazendo assim sofrer. Eu quero ver um lugar na sociedade. Um lugar no por do sol, um lugar no por do sol. Beijando a minha alma. ah.... BASTA! BASTA! BASTA!.

${ }^{120}$ Ver o projeto em anexo: ESCRITOR DE CORPOS. Textos de Ensaios poéticos teatrais.
} 
Que delicia. Então, Blade Runner não precisa tanto da tecnologia para ser visível, em sentido. Talvez já estivesse na programação do escritor, falta os circuitos saberem. E, Chaplin brincou com o mundo, e um ditador, mas e sabe como poucos o que o silêncio pode dizer. Enquanto isso, os nossos, "circuitos”, dão curto. E ainda fico sobressaltada como pode Bach, organizar todas aquelas vozes, e conseguir harmonia, e nós em uma babel sem nem mesmo sentido, ou pessimista demais, a gosto de "Bauman", todavia, ainda em busca do paraíso perdido. Leu? Não, mas todo mundo comenta. E de boca a boca, falta saber se teremos ar para respirar, porque o ambiente, natureza, me parece que está na sobrevida.

Onde saiu esse texto? Você lembra? Ou já esqueceu. (pariu (o escritor) e) partiu da sociedade que vive em fast food da realidade. E dos quais os bastidores, esperam a chance de ser protagonistas, ou artista do viver, esperando ser do mais profundo o que nos faz ainda, sonhar. Talvez esteja no sonhar o gosto e a saciedade. Dizer que o sonho, pode ser a face que haveremos de conhecer da verdade, é demasiado para alguns me parece, mas, quem sabe, não será esta a forma de não sucumbirmos a extinção. E, aqui, para a academia, pergunto: Estou dizendo sobre tempos contemporâneos, pura teoria, ou essa parte, deveria estar em um diálogo, dos ensaios poéticos teatrais. Onde nos localizamos? Onde estamos? Onde ainda podemos ouvir um coração? Sabe, quando no palco, existe sim uma magia, que atravessa o coração daquele que representa e do que está olhando, e tornam-se um só pulso, quando então me pergunto, se o mundo pode ser um palco, onde está a magia? ENTRE NÓS. Mundo contemporâneo, talvez seja o momento no qual sendo, ainda assim, não nos pertencemos, e dessa forma, podemos ser tantos outros, cosmo. Então, os artistas, que somos todos nós no palco do mundo, se perceberem que são personagens, vestindo-se sobre suas almas nuas, a sua identidade com o outro, repartidas em unidade, serão uma face continua de representar a vida.

Ideia de cultura como arte, como todo um modo de vida. Dos homens, e dos poetas, a poesia.

O mundo se revela propriamente em poesia a meu ver, mas, me detendo em um olhar mais restrito, devo dizer que, podemos crer que o pensamento se acerca do homem a cada qual sua maneira, porém, dos poetas quiçá se assemelham, mas todavia, é da poesia, que a todos, cerceiam, porque, o sentir não é propriedade do poeta, mas da vida, e do homem, e é justamente nesse elo, que se pode encontrar então, o pensamento, de estímulo externo imediato, mas veja, se o sentir, está em cada ser, assim eu penso e a sua maneira claro, podemos dizer que o estímulo está naquele que percebe o mundo deixando a poesia entrar e 
se encontrar com os seus olhos do sentimento, que todo aquele que observa a natureza do viver, pode saber. Então, a poesia, ou qualquer outra arte como autonomia circunscrita a um certo tipo de indivíduo, e justamente ao contrário, talvez, por eu ver a arte como forma tão inserida no corpo da vida, do mundo, que me parece apenas uma passagem por onde podemos caminhar se prestarmos atenção ao caminho. A capacidade de se expressar como disse o livro, "sem um estímulo externo imediato", a meu ver é um pouco imaturo, porque, em que medida estaremos tão apartados dos laços externos que nos fazem existir? E, também, o que é do homem, sentido da palavra, que não esteja como sendo, além da palavra, um gesto da alma? Quando nos dirigimos a alguém em nosso cotidiano, a nossa volta, temos imagens, sons, toques, sentidos ou mais que isso, outro sentido, por onde poderemos ir, e a escolha do como iremos caminhar sobre o gesto da palavra, aqui, gesto porque não se restringe apenas a fonemas, sílabas, mas a todo gesto que se comunica, e aqui penso que nos aproximamos, no gesto que se comunica, do que considero perceber o mundo, e sentir, ou transformá-lo em poesia. Estaremos prontos para a compreensão do sentido da mente, ou ainda o sentido da fé? Quando... E ao sentir, perceber o transformar, se torna interno lado externo e vice -vera, o verso do reverso, em verso ou prosa, do sentido. Talvez, até, e mesmo bem antes eu já não era muito afeita a escrever sobre felicidade, mas me parece que quem sabe esteja nesse lugar, a possibilidade de encontrar uma face dela, ainda valor da vida. E poeta, ou poesia, humano. Volto a dizer, aliás, bem no começo, sentia que muitos tinham necessidade de autoria, no que diz respeito a provar, o que, de quem, do mal ou do bem... e o contexto? Enfim, de qualquer forma, a complexidade humana, pode nos revelar frases e palavras nos lugares mais lúgubres, então, assim é o mundo, por onde olhamos, talvez mais que as palavras de quem será, o sentido que delas nos podem dizer seja algo a perceber. Claro que temos a autoria, mas não que seja isso somente, frente a multiplicidade do mundo, o fator que irá ser inclusivo ou o contrário para a nossa vida. Armadilhas de sentido, mundo, temos muitas infelizmente, mas também, me parece que a maneira como nos dirigimos a nosso olhar, fará uma certa diferença do que abrigamos em nossa palavra interna, aquela do nosso silêncio. Isso porque, podemos escrever por exemplo, por várias razões, e até mesmo a violência que tanto ainda temos no mundo, não difere nas palavras, mas o seu porque, sim. Mas, quem sabe, posso olhar a tempestade sem estar no meio dela, de maneira diferente, não é mesmo? A palavra finda? Ou reverbera sobre o mundo que dela escuta e ressoa, em fluxo contínuo em via de mão dupla. 
Uma das maiores belezas da palavra é sem dúvida o estado que a perpetua. Talvez nesse ponto esteja bem próxima da música, pois onde a palavra finda? Não pode ser, ela deve permanecer, enquanto for ao menos eco em nosso corpo. Face da cultura, o gesto da palavra. Desafios de um tempo - poder - personalidades - responsabilidades e consciência política. Pode ser o cidadão "comum" tanto heroico como desconhecido, e talvez em ambos estejam no mesmo que atravessa a cidade. Em seu desconhecido modo, abarca o cotidiano de forma tênue como destino, habitual, mas tanto se pode conhecer sobre seus atos que, generosamente o encenam como herói pelo simples fato de viver. " Uma hipótese essencial no desenvolvimento da ideia de cultura é que a $\operatorname{arte}^{121}$ de um período está intima e necessariamente relacionada com o modo de vida prevalecente naquele período e além disso, que consequentemente, os juízos estéticos, morais e sociais estão também intimamente inter-relacionados. (WILLIAM, 2011 pg154).

Cidade paraíso

Esquecido demais para se ver

Quem sabe então, insisto

Em querer do amor viver

Pode ser assim a palavra

O sentido que vejo pra mim

Em corpo e alma, enfim

Algo que não se perca totalmente

Que nos faça querer novamente

Ouvir o som do mundo.

E pode ser bom

Ou quem sabe, sem perdão

Apenas um aperto de mão.

Vamos embora

Está na hora, de nossa música

Sem demora, outra vez tocar.

Palavra e sentido, arte e o vivido.

\footnotetext{
${ }^{121}$ Amaral, Aracy. Arte para quê. A preocupação social na arte brasileira 1930-1970. Subsidio para uma
} história social da arte no brasil. 
Artesão, modificações da palavra e sentido, sobre os olhos e ouvidos de quem? O mundo recebe a nosso modo de sermos artesãos, quase artífices do viver, e não difere tanto do que antes se mostrava sobre o ser da arte. Quando mais vejo o tempo passar e entre o tempo passado, vejo vestes do mundo apenas trocando de roupa. E, em se tratando de roupa, como modo de ser do mundo, qual é a da moda? O ser do poeta e a poesia do ser do mundo.

E ainda em se tratando de cultura e civilização, a poesia diz Stuart Mill:

A poesia, como ele a descreve, é a própria cultura dos sentimentos", mas não é apenas isso, ela não tem qualquer conexão com luta ou imperfeição ou seja, é uma esfera separada e ideal. Os sentimentos democráticos são mantidos: o prazer será enriquecido com cada melhora na condição física ou social da humanidade. Nesse interim, no entanto, não é apenas uma promessa, mas um refúgio, uma fonte de contato com as fontes perenes da felicidade. E essa passou a ser uma maneira comum de considerar a poesia e a arte em geral, com a óbvia implicação de um juízo a respeito das demais atividades sociais do homem. ( WILLIAMS, 2011,pg 91)

Do que nos concede a cultura como construção e vivências do cotidiano, entre parte e todo, do que compreendemos como verdade, refere-se ao discernimento ao menos na sua relação com o tempo, estados de origem, movimento e transmutação que não absolutamente desafazem a verdade, mas a constituem lugar a ser sempre reflexionado e não imutável. A cerca das considerações apontadas em Cultura e Sociedade sobre condições sociais, a meu ver prefiro considerar a evolução do que perfeição e digo porque tal posicionamento na atual sociedade ainda não como cultura de forma de um educar, me parece que sugere em muitos casos uma margem a um posicionamento que pode denegrir ou subjugar ou até provocar distinções e preconceitos, de maneira que em perfeição o infinito lhe reserva abarcar como sentido, a evolução e desenvolvimento, mais próximo estaria do cultivo ${ }^{122}$, neste estudo.

\footnotetext{
${ }^{122}$ WILLIAMS Raymond, Cultura e Sociedade. Neste trecho do livro John Stuart Mill aponta aspectos e diálogos com Benthan e Coleridge e em posições contrastadas, reflete como sempre de maneira capaz de discernimento de pensadores da sociedade inglesa de maneira imparcial, onde neste capítulo considera: " $\mathrm{O}$ fato de o homem ser tão capaz, ou de a busca da perfeição ser realmente a coisa mais importante de sua vida, era, é claro, afirmado amplamente em outros textos, especialmente por escritores cristãos. Mas, para Mill Coleridge que pela primeira vez tentou definir em termos de sua sociedade mutante, as condições sociais da perfeição do homem. A ênfase de Coleridge em seus escritos sociais é nas instituições. As inspirações para a perfeição, realmente vem do coração cultivado - ou seja, da consciência interna do homem - mas como Burke antes dele, Colerige insistiu na necessidade que o homem tem de instituições que devem confirmar e constituir seus esforços pessoais. O cultivo na verdade, embora interno, nunca foi um processo meramente individual. Aquilo que no século XVIII tinha sido um ideal de personalidade - uma qualificação pessoal para participar da sociedade educada - tinha agora, diante da mudança radical, de ser redefinido, como uma condição da qual a sociedade como um todo dependia. Nessas circunstâncias, cultivo ou cultura, tinha se tornado um fato explicito na sociedade e seu reconhecimento dominava a pesquisa sobre instituições. pg 87
} 
E em se tratando de lugar, o pensamento e sociedade vejamos a Carta de Coleridge para Wordsworth:

\begin{abstract}
A diferença importante é entre conhecimento substancial e conhecimento abstrato, mas a função do último não é negada, uma função de memória, organização e comunicação geral. O contraste não é entre pensar e sentir, mas sim entre maneira de ambos, insiste-se sobre a unidade dos modos substanciais de um e de outro. Minha opinião é essa: que o pensamento profundo só é atingível por um homem de sentimento profundo, e que toda a verdade é uma espécie de revelação. É insolente diferir da opinião pública na opinião, se for apenas opinião. Por meio do sentimento profundo tornamos nossa ideias indistintas, e isso é o que queremos dizer com nossa vida, nós mesmos. Essa elevação do espírito por cima das aparências do costume e dos sentidos para um mundo de espírito, essa vida na ideia mesmo naquela suprema e divina que sozinha merece o nome de vida, e sem a qual nossa vida orgânica nada mais é que um estado de sonambulismo, isso é o que nos dá a única âncora em uma tempestade, e ao mesmo tempo o princípio substantivo de toda sabedoria verdadeira, a solução satisfatória de todas as contradições da natureza humana, de todo o enigma do mundo. Só isso pertence a todo sem exceção e fala inteligivelmente a todos sem exceção, o culto e o ignorante, se o coração ouvir. Pois igualmente presente em todos, ela pode ser despertada, mas não pode ser dada. Mas não imaginemos que é um tipo de conhecimento. Não! É uma forma de ser ou, aliás, é o único conhecimento que realmente é, e todas as outras ciências são reais apenas até o ponto em que são simbólicas disso. ( WILLIAMS, 2011,pg 93)
\end{abstract}

E, ao tratarmos de olhar a sociedade em movimentos, e do que de fato a memória de nossa civilização pode se representar, aprendizado, buscando o continuo porém realizando autonomia considerando o que de fato é causa de voz que ainda reverbera em atos e avaliações sociais, podemos determinar um pensamento crítico reflexivo ${ }^{123}$, como mínimo

\footnotetext{
${ }^{123}$ Thomas Carlyle no livro de Williams: Carlyle deseja ver uma restauração do equilíbrio nos termos que ele mesmo estabeleceu. Não está escrevendo uma rejeição de sua época, e sim, uma crítica dela. " Essas características escuras, estamos cientes, pertencem mais ou menos a outras eras bem assim como a nossa. Essa fé no mecanicismo, na importância total das coisas físicas, é em todas as épocas, o refúgio comum da fraqueza e do contentamento cego[...]Também estamos cientes de que, em sua aplicação a nós mesmos em toda sua gravidade, elas formam apenas a metade do quadro [...] Tampouco perdemos em nenhum momento, e mesmo com todos esses males mais ou menos evidente diante de nós, a esperança das sortes da sociedade. O desespero ou mesmo o desalento, nesse aspecto, nos parece, em todos os casos, um sentimento infundado. Temos fé na dignidade imperecível do homem, na vocação superior à qual, durante toda sua história terrestre, ele foi destinado [...] Essa era também está progredindo. Sua própria intranquilidade, sua atividade incessante, seu descontentamento contém material promissor. O conhecimento e a educação estão abrindo os olhos dos mais humildes, estão aumentando o número de mentes pensantes ilimitadamente. Isso é como deve ser, pois nossa vida consiste não em voltar atrás, ne em resistir, mas apenas em seguir adiante, lutando resolutamente[...] Há uma luta latente em todo o tecido da sociedade, uma colisão opressiva e ilimitada do novo com o velho. A Revolução Francesa, como é agora bem visível, não foi o pai desse movimento poderoso e sim seu filho[...] A questão final não se desenrolou naquele país, não, ela ainda não se desenrolou em lugar algum. A liberdade política é até agora o objeto desses esforços, mas eles não irão, e nem podem parar lá. É na direção de uma liberdade mais elevada do que uma mera liberdade da opressão por seus semelhantes mortais que o homem vagamente se dirige. Dessa liberdade superior, celestial, que é o serviço sensato do homem, todas as suas
} 
dentre as vozes da história, memória de nosso corpos social globalizado, as agressividades desumanas, e principalmente para sofrerem sobre máscaras atualizações em aplicativos sociais de realidades

A vida e a vida humana, porque parecem tão distantes por vezes? A palavra cultura e os modos dela significar-se. Em certo ponto cultivar os nossos modos de estar na sociedade, é construir um tempo melhor, conforme o almejamos, em possível harmonia. A música me leva a ver a harmonia, não como perfeição, mas como um estado de coesão do bem, no caso do som, uma ligação com o $\mathrm{OM}^{124}$, ou no caso de vibração de atos humanos, o que nos torna verdadeiramente humanos, em contínuo.

Considero que em se tratando de compassos como passos da própria vida, a cultura é lugar do sujeito ambiente em que mobiliza a possibilidade de equalizar espaços sociais, tomada como inclusive inserida em contexto da estética como ética de uma sociedade permeada por uma lógica de valores considerados por alguns teológicos, mas para a concretude de comportamentos sociais efetivos ao bem estar de todos, como inclusive economia planetária onde se sustenta a evolução e desenvolvimento, de pensar o tempo de hoje como face do amanhã, onde se encontram pensamento, atos em sentidos da comunicação ${ }^{125}$.Arte,

nobres instituições, seus esforços leais e suas sublimes vitórias, são nada mais que o corpo e cada vez mais um símbolo aproximado. “ 100

${ }^{124}$ TAME David, O poder oculto da música. Um estudo da influência da música sobre o homem e sobre a sociedade, desde o tempo das antigas civilizações até o presente. Capítulo 4 , a sabedoria antiga: a música na índia.- OM -A base mística da música e da fala. Capítulo 6 . A física do $\mathrm{OM}-\mathrm{O}$ OM e a unidade dos mitos da criação, o gênese egípcio - $\mathrm{O}$ verbo feito carne - o gênese agora- A obrade Ernest Chladni e Hans Jenny - A canção do átomo - razões e proporções harmônicas na natureza - Para uma teoria de campo unificado da física - A astrologia como música das esferas. E ver também o livro de Garaudy Dançar a vida, especificamente neste trecho Humphrey Doris," a relação do homem com o mundo. Viver é movimentar-se. A relação com o trabalho, e cultura. Rituais. E ainda sobre anexo do trabalho da sala 25 realizado para esta tese, como suporte teórico neste livro aponta-se que: É próprio da educação estar orientada para o futuro e formar o homem para inventar e construir o futuro. Ela começa, portanto, com a pesquisa dos fins realmente humanos da criação, para além dos fins imediatos que tendem somente a conservar e reproduzir a vida habitual $\mathrm{O}$ ato da criação artística é o modelo de todo ato criador, antecipando seus fins. Mas, a arte. E sobretudo a dança, não é somente esta cumplicidade com o futuro. Ela não é apenas ruptura com os comportamentos habituais e as realidades já dadas com vistas à instauração de uma ordem inédita, especificamente humana. Mais além da expressão pessoal e do controle de si, e através deles, a arte é um meio de comunicação, uma tomada de consciência do outro e da comunidade no sei da qual ele existe, ele em função de nós, nós em função dele Ela é escola da generosidade e do amor, do sentido de comunidade e da unidade humana. A estética é a alma da ética." Pg 120 125 MATTELART, ARMAND. Histórias das teorias da comunicação. Dentre outras considerações Claude Henri de Saint Simon como renovação da leitura social a partir da metáfora do ser vivo, Musso como pensamento do organismo rede Herbert Spencer na continuidade entre a ordem biológica e a ordem social, Braduel considerando irradiações, como teorias difussionistas, Quetelet o homem como medida em probabilidades que convidam o homem a rever seu papel na governança em participação na sociedade em relação ao governo. A busca de uma ciência social com bases empíricas. Ernest Haeckel como estudo de uma ecologia humana- referindo-se a 1859, relações do organismo com o ambiente, aspectos do individuo e cultura, considerando o indivíduo parte do todo, ligado como um contrato desde seu nascimento, e a interdependência como necessidade deum processo de comunicação. George Simmel ( 1858-1918) e Gabriel Tarde, estudam a 
sociedade e comunicação, processos construtivos em desenvolvimento. de um mundo e suas sociedades, culturas em espaços de relação. A economia política da arte. Do modo de ser da arte partícipe dos elementos que constituem também a cultura, as relações humanas quer sejam individuo sociedade- governo, e cultura, onde como dito acima a estética presume a concepção da ética enquanto conduta de viver, e portanto a economia política sobre argumentos de procedimentos elaborados sendo que as conexões estejam de maneira a considerar a propulsão e consequente desenvolvimento de todos os envolvidos, propiciando em curto e longo prazo alcance de melhorias como um todo de cada parte. Dos aspectos culturais e o modo de ver o mundo, estaremos diante de mais uma vez, posturas do pensamento ${ }^{126}$ onde ver o científico não apartado da vida mas engendrado nela, capaz e elucidar caminhos e cognições em sensibilidade. Existem certas estruturas de construções sociais, como poder político, empresarial, de cidadania, que muitas vezes se veem em

natureza subjetiva das interações sociais para evitar a reificação dos fatos sociais. Simmel se interessa pelos pequenos objetos da vida coletiva no cotidiano. É ai que ele crê discernir esse duplo processo paradoxal que caracteriza o social, feito dessas realidades complementares econcomitantes; a sociação e dissociação., a primeira metáfora da ponte e a segunda como balança biótica e o equilíbrio social mantem-se uma vez conquistados, assim como aqueles pelos quais, desde que um ou outro se ache perturbado se opera a transição de um ordem relativamente estável a outra - Park, 1936. A dicotomia original operada pela ecologia humana entre o biótico e o social suscitou numerosas discussões no período entre a primeira ea segunda guerra mundial, e Park admite aliás, a dificuldade de estabelecer a linha demarcatória entre os dois planos em seus estudos sobre a sociabilidade no tecido da vida urbana.Colley associações de grupos onde busca se encontrar natureza social e ideais do indivíduo. Também em embates da comunicação, Dewey pondera que a comunicação seria a diversidade individual onde teremos a tensão sobre perda da comunidade e democracia política ( 1927). Após a segunda guerra, Lasweel, propaganda e opinião pública, emissão e efeitos; “ quem diz o que, por qual canal e com que efeito".. Berelson, mídia e os efeitos sobre os receptores, em comportamentos, emoções, opiniões e resultados. Teoria Behaviorista. Estudos da função narcotizante da mídia. O funcionalismo, formalização matemática dos fatos sociais. Lazarsfeld visão falsa de democracia em meu ver, precisando de um olhar do pragmatismo de Charles Peirce. Parson e Merton, o duplo fluxo da comunicação. Escola de Palo Alto, a comunicação como fenômeno de interação. Teoria da informação, como matemática da comunicação, final dos anos 40, Shannon. Comunicação e os caminhos perigosos de persuasão, a condução na segunda grande guerra, Carl Hovland. Wright Mills, precursor dos American Cultural Studies. Kurt Lewis aspectos de decisão de grupo. Teoria da comunicaçao e biologia molecular. Ludwig von Bertalanfly, teoria dos sistemas, a vida política é considerada um sistema de conduta, estuda também a retroalimentação no sistema social constituído pelos meios de comunicação de massa como um todo. Adorno e a indústria cultural, ideologia e o poder, interrogam sobre os novos meios e a transmissão cultural, teoria crítica na universidade de Frankfurt. Walter Benjamim, 1933, o livro das passagens, reconstruir as ruinas para uma totalidade perdida, Marcuse descama as camadas das novas formas de dominação política, considerando que a modelagem social pode incorrer o risco de ser subjugação em vez de libertação, e ainda em Marcuse o espaço público. E nesse mesmo espaço público, Habermas considera a mediação entre Estado e sociedade. Daniel Bell, 1962, indústria da informação como matéria prima do futuro, o estruturalismo, Saussure, teoria linguística; Barthes com elementos de semiologia, para o estudo da mídia, língua e palavra, significante e significado, sistema e sintagma, denotação e conotação. Da linguística a antropologia estrutural. Roman Jakobson, o primeiro a usar o termo estrutura. Bordieu sociedade como sistema de relações de força. Baudrillard e o papel da mídia, indução na relação social. Hall, decodificação como dominante, opcional e negociada. Miege, produzir valor a partir da arte e da cultura. Mead, a observação como forma de conhecimento. Giddens, superação da dicotomia indivíduo-sociedade, estrutura e prática.Wittgenstein, as regras do saber comum, a interação social.Luhman, sistema autopoiético. Bakhtin a linguagem e o outro, protodiagramas.

${ }^{126}$ Morin, Edgar. A cabeça bem feita. Os três graus, a reforma do pensamento. 
lógicas distintas, porém, em conexões podem e devem aliar esforços e visões de onde a participação em ultrapassar desafios ou mesmo, elucidar já caminhos existentes acredita-se nesta pesquisa ser a postura de uma olhar geométrico onde a beleza é parte dos grafos em arte, relações de um viver ${ }^{127}$.

Na produção social de sua vida, os homens estabelecem determinadas relações necessárias e independentes de sua vontade, relações de produção que correspondem a uma determinada fase do desenvolvimento de suas forças produtivas materiais. O conjunto dessas relações de produção forma a estrutura econômica da sociedade, a base real sobre a qual se erige uma superestrutura política e jurídica e a que correspondem determinadas formas de consciência social. O modo de produção da vida material determina o caráter geral dos processos da vida social, política e espiritual. Não é a consciência dos homens que determina o seu ser, e sim, pelo contrário, seu ser social que determina sua consciência. Quando a base econômica muda toda a imensa superestrutura construída se transforma, mais um menos rapidamente. Ao consideramos essas transformações, devemos distinguir sempre entre a transformação material das condições econômicas de produção que podem ser determinadas com a precisão da ciência natural, e as formas jurídicas, politicas, religiosas, estéticas ou filosóficas - em suma, as formas ideológicas em que os homens adquirem consciência desse conflito e lutam para solucioná-lo. ( WILLIAMS 2011 pg291).

E avaliando ainda comportamento de ordem cultural, Raymond Williams considera que:

O progresso da cultura depende do progresso das condições materiais para a cultura e em particular, a organização social de qualquer período histórico limita as possibilidades culturais daquele período. No entanto, através da história há uma interação constante entre cultura e organização social. A cultura, é bem verdade, não pode ir além daquilo que é possível, mas a organização social pode e, com isso fica atrás daquilo que, do ponto de vista da cultura, é tanto possível quanto desejável. Há uma continuidade entre as várias formas de organização social e também das várias formas de cultura, mas a continuidade cultural é mais marcante porque, por um lado, é mais fácil imaginar possibilidades do que coloca-las em prática e também porque a mudança e o progresso na sociedade sempre foram alvo da resistência por tanto tempo quanto possível daquelas pessoas interessadas que, estando temporariamente no topo, iriam perder com qualquer reajuste do todo. Vemos que, naqueles períodos históricos em que uma mudança da organização social é necessária, a cultura passa a se opor aos padrões há muito respeitados da sociedade, padrões que alias, eram exaltados e adequadamente homenageados pela cultura do passado, mas que se mostraram inadequados e desinteressantes para mais um avanço para o futuro. (WILLIAMS, 2011, pg 296).

${ }^{127}$ Sousa, Carina Gonzalez Y. Composição Os ventos- PIANO 4 e 6. 
A meu ver me parece que existe uma via de mão dupla, mas deixar ou melhor relegar a consciência a um estado social, é perigoso, assim me parece. Justamente por perdermos a capacidade de contestar frente a um argumento massivo e social, é que muito de ocorrências pejorativas foram feitas na humanidade. E estamos sempre a mercê de infelizmente nos deixar levar, sem mesmo perceber. Atos coletivos, e chamo de atos porque pensamento é forma concreta, que se manifesta em corpos urbanos, com prejuízos muitas vezes em escala ainda maior. Por essa razão entre mesmo, as relações familiares, devemos priorizar a liberdade de pensamento, com razão e discernimento. Despertar um cidadão para a consciência particular na esfera social, é responsabilidade de todos. Raymond cita Caudwell em Ilusion and Reality, dizendo que:

O elo entre a ciência e a arte, o motivo pelo qual elas podem viver na mesma linguagem, é essa: o sujeito da ação é o mesmo que o sujeito da cognição - o genótipo. O objeto da ação é o mesmo que o objeto da cognição - a realidade externa. Como o genótipo é uma parte da realidade, embora ela se encontre competindo com oura parte dela, os dois interagem, há desenvolvimento, o pensamento do homem, e a sociedade do homem têm uma história.(apud WILLIAMS, 2011, pg 303.)

Dentre as relações externas e internas, enquanto ação do ser imbricadas e como reflexos, refletidas na sociedade, são presenças, porém, questiona-se quanto que do discernimento, a razão, interage com a cognição.

\subsection{O tempo, ele mesmo, produto em consumo}

Cultura entre o bem e o mal, como tempos canibais. Refugiados, dilemas religiosos, guerras veladas, desigualdades. Entre culturas, o medo. Entre cidadãos, o ato de coagir, entre relações, o desrespeito. Deprimentes? Nem tanto, tome um comprimido, ou se torne esquizofrênico, está na moda, da cultura atual, ao menos, do terror. Ou melhor, depende da fase, mas... será que é bivolt? Ou seja, combinaram com qual das partes, sobre o veredicto? O tempo, será desse espaço, senhor de que sentença? ${ }^{128}$

\footnotetext{
${ }^{128}$ Sousa, Carina Gonzalez Y. Composição: Um lugar para existir. PIANO.
} 
Qual medinase, medicamento de texto, se encontra nas belas artes do nosso lugar. Talvez, outra, a da fumaça, que encobre a verdade. De quem estamos falando, ora, de pseudônimos da vida real. Ah sim, mas tem lugar para o amor? Pegue a folha do São Paulo... e se eu falasse a língua dos anjos, quem sabe, no mundo, no globo, poderemos encontrar algum destino. Confuso, ou informações trocadas, ou sugadas por um processo sem laudo. Tome mais um comprimido, talvez a dor de cabeça pare. O imaginário sobre autonomia cognitiva - o espaço da mente - razão concreta em diagramas de propensão.

A física da vida, onde está nossa natureza? Contemporâneo gesto do pensar. Saturados os olhos aguçados perseguem a sociedade mundana, de enxertos (o)(a) sobre-humana. Destacam-se peles descascadas das feridas escaldadas sobre o tecido real, desatando os lugares perdidos, ainda que esquecidos, boiando feito dejetos em pleno oceano do mundo. Malditos, ou apenas restos apodrecidos de qual natureza que não seja de nós a mesma beleza inalterada de relações que não queremos mais suportar. Nossos desejos animais.

Saturados, feitos informações do cais, viajamos sem sair do lugar, conectados ao mundo. Demasiadamente profundo, até que afogados em desespero, puxamos o fio da vida. E, resolvermos nascer. Onde? De tantos lugares, em pertencer feridas abertas, passagens funestas, cobiças encobertas pelo gesto do suor contido do esforço do parto. Reparto agora, em qualquer destino, o choro do momento e que tua lágrima jorrou do vazio. E feito lugar, me dispus a SER.

Estive outrora, tantas vezes entre o ventre, mundo também, que desafiadoramente, ausculta sobre as paredes, a clausura de se alimentar do gozo puro de não se reconhecer, fronteira externa do mundo, como corpo aberto aos destroços dos negócios do lado de fora. Fora ou embora, chegou a hora. Nesse viver se apodera de um poder sem nome, que consome o simples fato de quebrar a casca ${ }^{129}$, como criança geopolítica assistindo o nascimento de um novo homem - Salvador Dali e no surreal desejo, sobre um lampejo desprovido de crueldade, impetuosamente os segundos dão os primeiros passos. Saturados ou maturados o tempo gestou, e agora se organiza nesse novo território, que gesticula sobre imagens utópicas, aliás, sobre posologia incerta, um tópico de gotejamento ácido, corroendo os ossos, enquanto crescem e se lamentam, porque o contra-tempo de crescer e envelhecer, torna as ranhuras, as fissuras e as rugas, o lastro incansável de se pertencer ao cotidiano. Saturado,

\footnotetext{
${ }^{129}$ Criança geopolítica assistindo o nascimento de um novo homem Salvador Dali, e sobre considerações de um mundo modo de viver e ver o mundo, absurdamente real, Diário de um gênio, 1989.
} 
profano ou sagrado. Asco de gozo e sabor, mistura de nojo e estupor ou ainda dos cinzas a dor, haveria alguma, face do amor?

Relações humanas, de afetos dispensados, por do ventre estarem desatados? Ou retorcem as vísceras, a espera de um querer, que os possa surpreender, a ponto de exercer o seu direito de viver?! Reconhecidamente humano, assina identidade de criação sobre a égide de ser racional. E qual racional possa ser, entre a gestação e o ser latente, encontrado sem fronteiras por gerações incandescentes de valores que ficaram aonde?

Onde!

E se for demais, nos reconhecermos como animais, onde estará a razão, parte da sociedade que nos leva a nos encontrar sobre a igualdade da natureza, onde habitamos de que maneira?

Animais amorosos, não são racionais? E onde estaremos então, sobre os laços menos humanos de nos conduzir sobre qual caminho, que sejamos, apenas, ou ainda, criaturas. E dessas agruras, seremos menos que animais, ou iguais? Sinceramente, não sei mais.

E dessas agruras, nos prontificamos, examinar o que nos tornamos. Seres que vivem e se despedem de sua natureza sem saber que suas veias são a mesma seiva a correr sobre o que poderá compreender, de um saber que não se compra sobre o estigma de sermos um tipo de produto, animais racionais, mas sim, um saber onde o que existe tem a voz que me permeia, que envolve ao ponto de eu sentir a placenta planetária, como amor do cosmo. E, se o universo é demasiadamente complexo, este também será um gesto que busca o nexo de apenas querer a percepção da simplicidade das coisas por mais infinitas que possam pulsar sobre nós, como a noite das estrelas, razão dos poetas, ou portas abertas à solidão.

Onde se encontra um menino, e um cão, sobre confissões de um tempo, ao relento do que pode ser um cidadão. Mas, com a certeza de que em um pensar do mundo, também se divide o pão.

Bom lugar entre os meandros a esta altura desse " processo" dizer sobre ilusões e erros. Talvez também, fosse um bom momento, para entre os erros, não subestimar, falsos mestres, e ainda, onde a ilusão, pode levar a verdade de uma realidade oculta. Com juízos sobre máscaras, e relatos, inalterados pela memória do tempo, testemunha de ambos, a ilusão, o erro, e a realidade. 
Deglutimos a ilusão, como fatia da realidade, e por vezes em dupla face, está uma unidade de um lugar perdido, por onde caminhamos, pisando em ovos, como costumo dizer. Mas, ainda quando, e não tenho aqui, nenhum receio de não ser acadêmica pelo que vou dizer, pelo contrário, afirmo, que ainda quando a fé, pode ser o guia, sobre o caminho sem chão, porque nela talvez estejam os anjos que tem asas, de onde quem sabe, esperemos o milagre, posto como ele o é, o fato de constatarmos a vida, simplesmente, a vida, milagre do existir. Colocamos tão distante a fé, que ne percebemos o quanto real ela pode ser, diante de ilusões. Porque quando não temos chão, perguntamos, no que ainda cremos. Ao menos, eu me perguntei. E de que maneira a condição humana, pode se atrelar a uma vontade de acreditar, onde o cotidiano, é dela, uma fatia, ou a melhor parte. O que enxergamos do mundo? Se falarmos do que nos cega, me parece licito, nos deter sobre o que é ver. Faces da mesma moeda? Talvez, uma sugestão: Jogue a moeda ao céu, vejamos o veredicto. E, porque a imagem da justiça, tem justamente, uma venda nos olhos? Temos que lidar com erros e ruídos de informação.

Creio que todos já sabemos do momento mais benéfico de um erro, que vem a ser, justamente o que aprendemos com ele. Em direcionamento, escolhas, procedimentos, atitudes e pensamentos, enfim, por onde possamos, ao menos considerar a reversão, ou seja, em situação similar, que o aprendizado seja um dado informacional capaz de se integrar no sistema como ambos, erro e opção alterada de acerto, ou se não assim, como simplesmente Drummond poderia dizer, como a pedra, que está no caminho, ou que atiraram em você, mas considere, também, se, por um acaso, o melhor não seria, que, justamente a pedra, não foi deixada por você, apesar do tropeço, ou que, não foi você que atirou a pedra. Talvez outros prismas de uma determinada óptica social, ou particular seja um ato observatório de uma condição, não com a intensão de minimizá-las, mas para ter clareza e justa posição de uma ocorrência, localização ou em expansão. E, além do mais, não esqueçamos que existem percalços temporais, ou seja, por vezes em se tratando por exemplo de cultura, algo hoje é considerado, objeto de reprovação e no futuro, talvez não, e mais uma vez, não estou aqui com a intensão de justificar, mas de observar por diversas perspectivas, até mesmo porque, espera-se que após o erro, tenhamos todavia, o caminho para andar. E, tendo o caminho para andar, é saudável pensar sobre diversas perspectivas. Agora, claro que temos ciência de erros, ou faltas, inclusive cabíveis de punição judicativa veiculada a leis sociais, e assim sendo como cidadãos que estamos na vida, o procedimento, de erros desta natureza, tem que arcar com suas consequências. E, presume-se que o aprendizado, deve ser correspondente a aplicação das leis, ao menos, deveria ser. Agora, de maneira cotidiana, errar e lidar com 
ilusões, é caminho entre neblina. E, se o erro provem de ilusões, há de se convir que se deve observar, que existe mais um lugar onde a parcela do erro está habitando. Qual o propósito de iludir, que possa ser lícito? Ludibriar uma conduta, e se assim procede e ainda afere resultados, mais errado está o que ilude.

Sabe, talvez a parte mais real quando vivemos em ilusões seja justamente, aquela no qual pensamos no que ainda cremos, porque é o que nos fornecerá uma identidade, quando a realidade está sobre pseudônimo.

Emoção e razão. Quanto a conhecimento e aprofundamento ou detrimento pelo fato de estar a emoção participando, eu claramente, porque sou artista, não posso dizer que o conhecimento fica depreciado pela presença emotiva, e aliás, tenho provas em meu cotidiano, justamente do contrário. Mas, sei de sociedades ou regimes, brutais ou autoritários, que creditam a emoção um demérito à razão. E, considero um ledo engano. A emoção, o sentimento, assim como fatores racionais, devem priorizar o equilíbrio, porque não pensem que somente a razão está sobre o crivo do equilíbrio, a razão pode sim, também, ter extremos, justamente por desconsiderar a face do sentimento, ou até, por levar ao extremo condições que podem gerar uma situação sobre-humana, apesar de que, a razão por ela mesma, como princípio deveria ser o equilíbrio, porém, na face do homem, ainda e todavia, não estamos dispostos sobre esse patamar. Então, a nossa razão, em desenvolvimento ainda se espanta possivelmente e o judice tem provas disso, o quanto que pode estar errada, e portanto, por razões diversas deverá buscar os argumentos para validar uma razão que tenha procedência licita mesmo que para tal, reveja seus elementos de compreensão. E, retornando ao que é do sentimento, para o mesmo vale, ressaltar a necessidade do equilíbrio. São forças, nas quais estamos imersos, cotidianamente e das quais devemos ser observadores de nós próprios, porque sabedores de nossas tendências e inclinações, poderemos buscar onde, em que face dessa balança, razão e sentimento, precisamos pender um pouco mais, para encontrar o equilíbrio. Agora, de maneira especifica como cognição me parece que não estão dissociados um do outro, posto que penso, que em cada matéria da razão, poderemos encontrar sua alma, o sentimento, mas não que estivéssemos dispondo ainda uma dicotomia, mas um entrelaçamento.

E, algo me diz, que lembrar um ditado, seria bom agora. Deus escreve certo, por linhas tortas. Aonde o erro pode estar descrito, assim, frente o finito, como presença em propensão do que é infinitamente existente. "Portanto, não há um estágio superior da razão dominante 
da emoção, mas um eixo intelecto- afeto, de certa maneira, a capacidade de emoções é indispensável ao estabelecimento de comportamentos racionais.“pg21.

No que segue, será abordado, erros, de diversas formas, mas eu gostaria de sobrepor, com alguns aspectos de crenças e o poder nelas imbuído e desconsiderado, na construção de realidades ou ilusões. Até porque a crença, pode até mesmo, influenciar em uma ilusão, mas também pode ser o discernimento para sobreviver construindo a realidade.

Faces da arte e da cultura. Tem um fator da imaginação que é de extrema relevância, que é trazer a imaginação à realidade. Quem, escreve, pinta, observa, enfim, a criação não é particular dos artistas, mas é da vida, então, todo aquele que porventura esteja disposto a uma imagem que abriga em sua mente, pode querer trazer a sua realidade, construindo meios, propósitos, empreendedores fazem isso. Enfim, projetos de vida, planejamentos, são caracteres de uma imaginação construtiva, ou seja, esforços estarão sendo direcionados, para que sua concretude venha à tona na realidade, no seu devido tempo provavelmente, o que nos leva a um impasse, porque, na imaginação ${ }^{130}$ o tempo é do instante, enquanto a realidade nos move a esforços saudáveis suponho, se os objetivos forem bons e éticos, que algumas vezes demandam um tempo mais longo. Aqui vale dizer das energias que estão nesse mecanismo, e que o universo sente, captura e movimenta. Ah! E voltando ao acreditar, no caminho, muitos vão dizer, que é loucura, e querer desestimular um projeto, mas aquele que imagina e quer tornar real, pode mover montanhas!

Falando em educação, quando a relegar ao outro a sua parcela, quando justamente essa é pejorativa no sentido de resultado de nossos próprios atos, aqui já posso dizer, por justamente ser o tema, educar o pensamento, como rumo de inserção em cultura de desenvolvimento, que meus pais, me ensinaram a por certo e justo não fazer isso, não é certo delegar a outros nossas faltas, e tanto que por mais difíceis que fossem as consequências, que assumíssemos nossos erros.. Porque assumir seus erros e não colocar nos outros, condiz com responsabilidade, respeito pelo outro, ética, bons costumes, valores morais, coisas simples, que a sociedade ou mentes perturbadas podem querer relegar ou afirmar a

\footnotetext{
${ }^{130}$ Morin, Edgar. Os setes saberes para uma educação do futuro. A importância da fantasia e do imaginário no ser humano é inimaginável: dado que as vias de entrada e de saída do sistema neurocerebral, que colocam o organismo em conexão com o mundo exterior, representam apenas $2 \%$ do conjunto, enquanto $98 \%$ se referem ao funcionamento interno, constituiu-se um mundo psíquico relativamente independente em que fermentam necessidades, sonhos, desejos, ideias, imagens fantasias, e este mundo infiltra-se em nossa visão ou concepção do mundo exterior. Pg 21
} 
existência de outras formas, como normais e corriqueiras, e além disso, como sei que a palavra, o gesto de uma afirmação tem suas reverberações, tenho por bem, e por experiência de vida, contrapor. Não quer dizer que colocamos a culpa nos outros, não seja de fato uma prática na sociedade, mas não que isso seja um posicionamento de conduta, que deva ser afirmado como potencial de mente frente a ilusão como sendo natural.

Memórias e hipóteses a serem confirmadas. Da mente do ambiente e do sujeito. Em diagramas do pensar, lugares, pessoas, de alguma maneira observar o que pode ser, uma forma de recuperação de dados, é importante em uma sociedade com múltiplas ações informacionais que povoam nosso cotidiano o tempo todo. Então, também, é quase como um outro exemplo, mas com um diferencial, como quando nos esquecemos de algo, e retornamos ao lugar para saber o que íamos fazer, e normalmente se não tiver ruído no sistema, a memória retorna, e porque isso acontece? Não sou especialista no assunto, mas gosto de observar, e sempre foi útil constatar isso, que esse retorno tem um papel de eclodir no tempo, um resgate, portanto, no exemplo anterior sobre certo aspecto também se retorna, mas não sobre uma posição geográfica ou do que se estava fazendo, mas de uma imagem determinada, gravada na mente, que por solicitação de dados, retorna, mas retorna, pela imagem que veiculada, conectada a informação, eclode o conteúdo. Isto é um funcionamento habitual, assim eu observo, e que não deve sofrer danos, no sentido de corromper memórias. Se assim sendo, esta preservado, a ocorrência é licita, se aproxima da verdade, e não de erros ou ilusões. Mas, se, todavia, existe um propósito externo de confundir, ludibriar, ou manipular, este comportamento mental, pode ser adulterado, e estar a mercê de erros.

Particularmente, a procedência de dados informacionais em geral, condiz diretamente com conexões, e inclusive no que diz respeito a perda ou não de memória. As conexões a meu ver, de sentido, como provavelmente neurais, preservam os dados, resgatam os dados, tornam a sua presença úteis ao sistema, mais uma razão para se estimular na educação um pensar em relações. Portanto, lugares, palavras, imagens, tudo o que nos rodeia, permeia nossa mente em duplo fluxo, e o tempo da mente, é uma constatação, de que linear, ele não é. Seria uma simultaneidade, absorvida conforme a necessidade, me parece, ou conforme eclodem devido a conexões, em novas propensões. Quase como um encadeamento, onde determinadas partes ficam em latência, e outras em atividade, porém, quando existe uma razão, o que estava em latência, eclode para o sistema em atividade. Como uma "regeneração" de dados, re-conexão. E onde se pode observar o valor que pode adquirir 
quanto a relações com culturas diferentes. Erros intelectuais. O nosso comportamento frente a ideias, a crenças, a ideologias, diferentes das nossas, é simplesmente correspondente ao quanto que respeitamos o outro. Se tivermos respeito, não temos problemas em conversar ou dialogar com pessoas de diferentes culturas, crenças, ideais.

Pode-se argumentar e vale ressaltar a necessidade sempre de reflexão como auditoria interna, licita de um pensar contemporâneo, onde pensamentos inscrevem e marcam o futuro que queremos para gerações. "Nossos sistemas de ideias, teorias, doutrinas, ideologias estão não apenas sujeitos ao erro, mas também protegem os erros e ilusões neles inscritos. Está na lógica organizadora de qualquer sistema de ideias resistir à informação que não lhe convém ou que não pode assimilar. As teorias resistem à agressão das teorias inimigas ou dos argumentos contrários. Ainda que as teorias científicas sejam as únicas a aceitar a possibilidade de serem refutadas, tendem a manifestar esta resistência. Quanto às doutrinas que são teorias fechadas sobre elas mesmas e absolutamente convencidas de sua verdade, são invulneráveis a qualquer crítica que denuncie seus erros. (MORIN, 2000, pg22).

No tocante a lembranças e certezas, ilusões, equívocos, ou não, sei que a razão é importante, mas a emoção é fator praticamente de certeza de uma lembrança. Desconsiderar a emoção, e colocar como preponderante o fator racional, no que diz respeito a erros ou ilusões, frente ao menos a memória, devo dizer que o fator emocional é de suma importância, porque preserva a integridade, da memória, uma lembrança de forte apelo emocional é praticamente certeza da ocorrência, assim eu penso, inclusive frente a sobreposições com intenções ilícitas. De referências e diagramas. A emoção pode preservar a informação verdadeira.

Dizer sobre a face da realidade que é uma ilusão e a ilusão que é na criação e do mundo parte sensível que pode ser até mais, considerando vida plena de sentido e racionalidade ainda que permeada com ilusão no sentido de arte.

Diferenças - racionalidade e racionalização

Instância logica e empírica - Um olhar de ambas se conectando e uma aprendendo com a outra. Sobre racionalidade Edgar Morin ressalta a capacidade de ser elemento construtivo como caráter lógico de uma teoria, com o empírico de maneira sempre aberta a reflexão, segundo este autor para não se tornar racionalização. Segundo o mesmo estaria a racionalização imbuída de caráter dogmático. Ele postula que a racionalização é fechada e a racionalidade aberta. Onde na vida se pode ser da razão um coração?

Um aparte. 
Se estar só,

É viver da solidão

Onde as paredes/ do teu coração

Eu posso ouvir

Já estou feliz.

Posso sorrir. Da solidão eu vou viver

Porque te conhecer

Foi saber que o ser

É mais que um momento

É o movimento

Do silencio, um pouco só

De nós dois, e o depois

Saberá teu coração

De quem vive a emoção

Como razão de ser feliz.

E dos lugares vazios

$\mathrm{O}$ entre dos rios

De nossos olhares

Serão os nossos lugares

Por onde podemos nos encontrar

Como águas de um mar,

Silencio de respirar.

As cegueiras paradigmáticas

Seleção de ideias. Operações lógicas.

Determinação das operações lógicas em densidade de probabilidade o que provem um estado ainda que, indeterminado.

A "seleção" de elementos cognitivos, ocorre me parece a um ponto de horizonte, que por bem, deveria creditar o entorno e não somente a localização fixa, isto porque apesar de uma prévia determinação em um “ objeto-objetivo" por exemplo, se deva considerar que a mescla dos elementos ou a sua disposição se aplica em mente e facticidade, havendo para tal, no decurso de se observar em distanciamento capaz de verificar tanto no que antecede as experiências, outras possibilidades como também, no que diz respeito a propriamente o ato 
em si, com as adversidades ou fatores aleatórios a seleção prévia de operações lógicas. A escolha é um fator das operações lógicas mas o agrupamento das relações das operações lógicas podem considerar mais de uma opção ainda na mente antes da experiência fática, não exatamente como protodiagramas, mas semelhante posto que seriam, relações diversas em multiplicidade de organização, para um determinado rumo, portanto, as operações lógicas que desejem ter um resultado mais eficaz, deve ter em si, não uma determinação ( o que não quer dizer - incoerência ou insegurança ao contrário) mas uma indeterminação no sentido de densidade de probabilidade, assim sendo, estaria mais apto a ao se deparar munido de suas concepções de estruturas de organizações lógicas operacionais, ter opções para se definir frente a realidade quando adversa das primeiras ou outras quer sejam conjecturas. Porém, para determinados pensamentos autoritários, pode parecer um pouco libertário demais, ter mais de uma conjectura quando o sujeito apenas credita uma possibilidade como a correta e não tem por hábito, analisar possibilidades diversas, o que claro, depende do âmbito da questão, posto por exemplo que frente a leis, sociais, existem certas condutas, que não serão objeto de diversidades, mas sim, de aplicação da lei, conforme as regras sociais. Portanto, o discernimento, é e sempre será plausível de reconhecimento por qualquer elemento de operação lógica, quanto a ao processo mental, como de conduta da experiência.

Cultura como territórios do viver em geral.

Curiosamente ao nos aproximar do modo opernadi de certas naturezas, me parece que estaremos mais em pé de igualdade se considerarmos que o mundo gera observações de conduta em seu ambiente natural, que se deslocarmos nosso egocentrismo humano as outras espécies, creio que poderemos, aprender mais sobre o que é viver, e talvez seja justamente uma ilusão, crer que o homem é o arcabouço de uma linguagem na qual ele detém o saber e razão, sem a participação de tudo que existe na realidade. A verdade, sem ilusões, me parece que precisa de humildade para que nos encontremos mais sobre o que é aprendizado.

Está servido?

Bandeja vazia

Servida depois

Janelas dos carnavais

Lampejos do nunca mais

Ou de um pouco mais

Destinos servidos 
Esquecidos depois

$\mathrm{Na}$ bandeja vazia

O livro que eu lia

De quem sabe ser real

Tudo aquilo que eu sentia

Um dia, quem sabe

As letras escrevem

As páginas viradas

Por onde contadas

Que não vejo mais

Ouço apenas, os carnavais

Sentinelas da alegria

De um dia quem sabe

Viver na avenida

Um talvez, de harmonia

E, onde ficou a bandeja vazia?

O fim do livro, eu quero ver

De quem sabe ao vento, percorrer

Um outro destino servido, do ser

Em mais um novo querer.

$\mathrm{O}$ inesperado

A incerteza do conhecimento

Diz ainda Edgar Morin,"“ Portanto, devemos aprender que a procura da verdade pede a busca e a elaboração de metapontos de vista, que permitem a reflexividade e comportam especialmente a integração observador-conceptualizador na observação-concepção e a ecologização da observação-concepção no contexto mental e cultural que é o seu.“ (MORIN, 2000). 
Os princípios do conhecimento ${ }^{131}$ pertinente, dentre os posicionamentos da diversidade cultural.

O contexto, o texto, a palavra e o sentido, as relações entre as partes. Diálogos ${ }^{132}$ contínuos do sujeito ambiente e a cultura.

O global é mais que o contexto, é o conjunto das diversas partes ligadas a ele de modo inter-retroativo ou organizacional. Dessa maneira, uma sociedade é mais que um contexto: é o todo organizador de que fazemos parte. O planeta Terra é mais do que um contexto: é o todo ao mesmo tempo organizador e desorganizador de que fazemos parte. O todo tem qualidades ou propriedades que não são encontradas nas partes, se estas estiverem isoladas umas das outras, e certas qualidades ou propriedades das partes pode ser inibidas pelas restrições provenientes do todo. Marcel Mauss dizia: É preciso recompor o todo. É preciso efetivamente recompor o todo para conhecer as partes. "Dai se tem a virtude cognitiva do princípio de Pascal, no qual a educação do futuro deverá se inspirar: sendo todas as coisas causadas e causadoras, ajudadas ou ajudantes, mediatas e imediatas, e sustentando-se todas por um elo natural e insensível que une as mais distantes e as mais diferentes, considero ser impossível conhecer as partes sem conhecer o todo, tampouco conhecer o todo sem conhecer particularmente as partes. Além disso tanto no ser humano, quanto nos outros seres vivos, existe a presença do todo no interior das partes: cada

131 Neste ponto Morin considera o conhecimento como "O conhecimento dos problemas-chave, das informações chave relativas ao mundo, por mais aleatório e difícil que seja, deve ser tentado sob pena de imperfeição cognitiva, mais ainda quando o contexto atual de qualquer conhecimento político, econômico, antropológico, , ecológico... é o próprio mundo. A era planetário necessita situar tudo no contexto e no complexo planetário. O conhecimento do mundo como mundo é necessidade ao mesmo tempo intelectual e vital. É o problema universal de todo cidadão do novo milênio como ter acesso às informações sobre o mundo e como ter a possibilidade de articulá-las e organizá-las ? Como perceber e conceber o Contexto, o Global ( a relação todo/partes), o Multidimensional, o Complexo? Para articular e organizar os conhecimentos e assim reconhecer e conhecer os problemas do mundo, é necessária a reforma do pensamento. Entretanto, esta reforma é paradigmática e não programática, é a questão fundamental da educação, já que se refere à nossa aptidão para organizar o conhecimento. A esse problema universal confronta-se a educação do futuro, pois existe inadequação cada vez mais ampla, profunda e grave entre, de um lado, os saberes desunidos, divididos, compartimentados, e de ouro, as realidades ou problemas cada vez mais multidisciplinares, transversais, multidimensionais, transnacionais, globais e planetários. Nessa inadequação tornam-se invisíveis: o contexto, o global, o multidimensional, complexo. Para que o conhecimento seja pertinente, a educação deverá torna-los evidentes. " 36

${ }^{132}$ Diálogo, poema Cecília Meirelles. Minhas palavras são a metade de um diálogo obscuro/ continuando através de séculos impossíveis/ agora compreendo o sentido e a ressonância, que também trazes de tão longe em tua voz/ nossas perguntas e respostas se reconhecem/ como os olhos dentro dos espelhos, olhos que moraram/ conversamos dos dois extremos da noite/ como de praias opostas mas com uma voz que não se importa/ e um mar de estrelas se balança entre o meu pensamento e o teu/ mas um mar sem viagens. E poema, êxtase. Deixa-te estar embalado no mar noturno, onde se apaga e acende a salvação/ deixa-te estar na exalação do sonho sem forma/ em redor do horizonte, vigiam meus braços abertos/e por cima do céu estão pregados meus olhos guardando-te/ deixa-te balançar entre a ida e a morte sem nenhuma saudade/ deslizam planetas na abundância do tempo que cai, nos somos um tênue pólem dos mundos. Nem é preciso dormir para a imaginação desmanchar-se em figuras ambíguas, nem é preciso fazer nada para se estar na alma de tudo, Nem é preciso querer mais, que é preciso um beijo eterno, e afoga a boca da vontade e seus pedidos. 
célula contem a totalidade do patrimônio genético de um organismo policelular; a sociedade, como um todo, está presente em cada indivíduo, na sua linguagem, em seu saber, em suas obrigações e em suas normas. Dessa forma, assim como cada ponto singular de um holograma contém a totalidade da informação do qual representa, cada célula singular, cada indivíduo singular contém de maneira hologramica o todo do qual faz parte e que ao mesmo tempo faz parte dele. ( MORRIN, 2004,37-38.).

Consideravelmente se altera a cultura enquanto comunhão com o tornar-se humano em complexidade $^{133}$, considerando multiplicidade em que o pensamento foi adquirindo estados de coesão em conexões.

\section{O complexo. Unidade e multiplicidade}

Mobilização do que o conhecedor sabe do mundo. Sendo que poderemos ter a representação do mundo, como exposta cotidianamente, e se estivermos entrando em contato, ou seja, conhecendo algo novo, claramente faremos relações com ou o que costumam chamar de " repertório" ou apenas do que vivemos, o podermos chamar de sensibilidades cognitivas retroativas, que entrando em contato com experiências novas, poderemos constatar, conhecimentos relegados por outrem que não tem acesso, aos dados pessoais retroativos, e quando os mesmos em relações podem advir sentidos, que lhe são adversos, mas não para aqueles que realizam essas conexões. E então a representação do mundo, nela mesma, passa a ter sentidos múltiplos, existentes e em construção. A fragmentação ${ }^{134}$ parece um fantasma quando falamos de complexidade e não o vejo assim, se considerarmos não fragmentação mas fatoração, ou unidades que se desmembram e realizam acoplamento e conexões. E, ainda, as conexões revelam sentido entre o que antes poderia ser apregoado como especializado e caráter de um saber isolado ou como a denominação fragmentado. Porém, e ainda considerando que não é superficial, mas ao contrário, não desfaz da especialização porém a utiliza em aspectos de saberes conectados que realizam observações não mostradas justamente no olhar restrito de determinado campo. Em parte, a fragmentação quando somente é nela mesma sem ramos, pode ser prejuízo, porém se torna amplitude quando conectada e em contexto, interfaces de áreas Dentre o saber e a sociedade, não sou contra a

\footnotetext{
${ }^{133}$ Unidades complexas, como o ser humano ou a sociedade, são multidimensionais: dessa forma, o ser humano é ao mesmo tempo biológico, psíquico, social, afetivo e racional. A sociedade comporta as dimensões histórica, econômica, sociológica, religiosa. O conhecimento pertinente deve reconhecer esse caráter multidimensional e nele inserir estes dados: não apenas não se poderia isolar uma parte do todo, mas as partes umas das outras, a dimensão econômica, por exemplo, está em interretroação permanente com todas as outras dimensões humanas, além disso, a economia carrega em si, de modo hologrâmico, necessidades, desejos e paixões humanas que ultrapassam os meros interesses econômicos.

${ }^{134}$ MEDINA, Cremilda; Greco Milton; Do hemisfério Sol, 1993. Lógica paraconsistente. Pensamento plural.
} 
especialização mas todavia a percepção da necessidade desse conhecimento estar conectado em uma expansão. Não basta a meu ver, apenas realizar junções mais, buscar com os novos elementos, como poderemos encontrar relações novas, com elementos informacionais resultantes de interesse ao objeto em busca, mas também considerando as informações dos dois sistemas isolados anteriormente para identificar em quais relações mutuas poderão ter interesse ao sistema em conjunto como resultado satisfatório. "A incapacidade de organizar o saber disperso e compartimentado conduz à atrofia da disposição mental natural de contextualizar e de globalizar.“( MORIN, 2004, pg43).

De maneira geral, convenhamos que é importante sempre atender a que o pensamento esteja disposto a se representar enquanto diagramas, aberto.

Ensinar a condição humana

A educação do futuro deverá ser o ensino primeiro e universal, centrado na condição humana. Estamos na era planetária, uma aventura comum conduz os seres humanos, onde quer que se encontrem. Estes devem reconhecer-se em sua humanidade comum e ao mesmo tempo reconhecer a diversidade cultural inerente a tudo que é humano. (MORIN, 2004,47).

“Conhecer o humano é, antes de mais nada, situá-lo no universo e não separá-lo dele. Como vimos, todo conhecimento deve contextualizar seu objeto, para ser pertinente. Quem somos? É inseparável de onde estamos? de onde viemos? Para onde vamos? “(MORIN, 2004, pg 47). A condição cósmica, a condição humana e os aspectos culturais de viver o contemporâneo, em gesto de interfaces da realidade, onde também tem a condição da razão.

Somos originários do cosmos, da natureza, da vida, mas devido á própria humanidade, à nossa cultura, à nossa mente, à nossa consciência, tornamonos estranhos a este cosmos, que nos parece secretamente íntimo. Nosso pensamento e nossa consciência fazem-nos conhecer o mundo físico e distanciam-nos dele. $\mathrm{O}$ próprio fato de considerar racional e cientificamente o universo separa-nos dele. Desenvolvemo-nos além do mundo físico e vivo. É neste além que tem lugar a plenitude da humanidade.

A maneira de ponto de holograma, trazemos no seio de nossa singularidade não somente toda a humanidade e toda a vida, mas também quase todo o cosmos, incluindo seu mistério que, sem dúvida, jaz no fundo da natureza humana. pg52

O humano é um ser a um só tempo plenamente biológico e plenamente cultural, que traz em si a unidualidade originária. É super e hipervivente: desenvolveu de modo surpreendente as 
potencialidades da vida.[...]A cultura acumula em si o que é conservado, transmitido, aprendido, e comporta normas e princípios de aquisição. ( MORIN, 2004, pg52).

O humano do humano

Desculpas aceitas, por quem e em que tempo? Ou para fatos temos que nos deter sobre o momento, de portas abertas ou fechadas ao desconhecido. Sendo assim, porque então, foi me procurar? Ou o destino era de outro lugar. O humano do humano, me parece que está faltando ainda, alguma coisa, talvez a verdade da parcela nessa pauta, quer seja, o desumano, mas quem liga, tudo se esquece e amanhã é um novo dia. Afinal, de destroços nossos, de irrisórias somas, de nossos ideais, permanecemos como animais, mas não tem a menor importância, volte semana que vem. Volte semana que vem! Quem sabe o preço da vida, vai estar mais barato, ou com algum desconto. Enfim, quem liga?

Voltei! Sabe, essa vida tem uma ferida aberta, e eu quero um desconto por isso, e penso que no estoque não tem mais, então...

-Não tem negociação que baste! -Você esqueceu a melhor, parte. Justiça.

- Não sabem mais o que isso, meu caro. Posso até negociar com o inferno, e não é ainda o livro de Mafessoli, a parte do diabo, ou será que é somente o título, e não posso julgar o livro pela capa?

Eu não estou julgando, mas observo. E mantenho, ainda, minhas portas abertas, isso enquanto estivermos em uma " democracia", onde eu tenha espaço.

Para isso, também tem, volte semana que vem.... porque a mesma violência ainda está sobre os meandros da inocência onde a liberdade de expressão, ficou nos direitos do cidadão maquiados por um picadeiro, de onde não sei se pagamos o ingresso, ou é de graça para que a gente nem perceba o que acontece, ou nos esqueçamos, mais uma vez.

-Aceito.

O que?

Vai levar mesmo com a ferida aberta.?

- E quem diz que eu quero mais?

Já que você voltou, pensei que ainda estava interessado.

-Talvez, ou uma simples prosa baste. ( ou precisa um pouco mais, para um sonho se realizar?). Se isto for um sonho, ainda não acordei do pesadelo.

- Pense, bem, mesmo estando assim, é a melhor mercadoria que eu tenho, e outra vida, só lá no paraíso, ou no inferno. 
- Eu faço o meu paraíso ou inferno aqui mesmo.

- Não tenho a menor dúvida disso, mas para isso, precisa da vida.

- Não sei.... do que estou vendo nessa ferida... vai ser muito difícil de cicatrizar, tem mazelas difíceis de suportar, que dirá, quem sabe...

Eu não sou médico apenas vendo, e o que escolheu, a vida, tem seus prós e contras, mas são partes da mesma moeda. Para onde você vai leva-la? E, antes que eu me esqueça, eu não aceito devolução e nem trocas. Agora, você pode nela, viver na ilusão, e perder a realidade, ou fazer da realidade a melhor coisa de sua imaginação, e por onde ir, também será a sua questão. Do que quer, ou deseja...se ainda souber, no labirinto, talvez encontre a saída. Compartilhe....crie... talvez essa seja a solução. Quem sabe assim....em vez, de você, eu compro! Ou, precisaremos estar em outra dimensão? Um holograma, do humano do humano...

A complexidade humana não poderia ser compreendida dissociada dos elementos que a constituem todo desenvolvimento ${ }^{135}$ verdadeiramente humano significa o desenvolvimento conjunto das autonomias individuais, das participações comunitárias e do sentimento de pertencer à espécie humana. ( MORIN, pg55).

A esfera individual - social/ Diversidade cultural e pluralidade de indivíduos. Morin ainda salienta sobre a cultura estar sobre o espaço onde são gerados e perpetuados os valores, em gerações, provendo em qualquer tempo da sociedade, o que dizemos ser sua identidade e marca; havendo ainda a possibilidade de estarem sendo com o tempo e o engendramento de outras regiões e culturas respectivas

A responsabilidade do pensamento em culturas futuras. Prazos de consciência, onde se revela o noebius do contemporâneo ainda que o mesmo seja outro ${ }^{136}$. Somos parte do universo, então... onde estamos, ou estaremos, do humano do humano desejando ser, quem sabe o somos, e ainda não percebemos, distâncias de nós, sobrepostas, em um porvir, de

\footnotetext{
${ }^{135}$ Conforme Morin, "Cabe a educação do futuro cuidar para que a ideia de unidade da espécie humana não apague a ideia de diversidade e que a da sua diversidade não apague a da unidade. Há uma unidade humana. Há uma diversidade humana. A unidade não está apenas nos traços biológicos da espécie Homo sapiens. A diversidade não está apenas nos traços psicológicos, culturais, sociais do ser humano. Existe também diversidade propriamente biológica no seio da unidade humana, não apenas existe unidade cerebral, mas mental, psíquica, afetiva, intelectual, além disso, as mais diversas culturas e sociedades têm princípios geradores ou organizacionais comuns. É a unidade humana que traz em si os princípios de suas múltiplas diversidades. Compreender o humano é compreender sua unidade na diversidade, sua diversidade na unidade. É preciso conceber a unidade do múltiplo, a multiplicidade do uno. A educação deverá ilustrar este princípio de unidade/diversidade em todas as esferas". 55
}

${ }^{136}$ HILMAN James. O código do ser. ( ainda verificar se o cita). / Tao te king de lao tsé. 
momento singular. Multifacetados recorremos aos nossos caminhos em tracejados que somos de formas entrelaçadas de argumentos do existir. Prosa ou bossa? Entre a música e o poema que estão estampados como natureza nossa, somos versos diante de nossos atos, e manifestações, assim sendo, faces da arte polissêmica da vida. E entre dilemas, também parte da reflexão cultural e humana, despertamos por onde de fato estão as ilusões dentre a realidade e de onde amarras podem estar o cotidiano, que por desejo se veja livre. Quanto que temos de lados incompreensíveis, da aparência e realidade. Violência, pessoas passando fome, roubos, corrupção, mas veja bem, essa é a parte, sã da história.... então, me pergunto... aonde estão os loucos? "O ser humano é um ser racional e irracional, capaz de medida e desmedida; sujeito de afetividade intensa e instável. "(Morin, 2004).

Medimos, por ressonâncias provocadas por elementos foram do sistema interno, e julgamos, e ditamos regras, conforme o que queremos ver, então, fica um pouco difícil, dependendo em qual momento estivermos, saber quem está avaliando e o quê, ou para quê, com quais propósitos... e acusamos, por atos provocados por elementos fora do sistema interno ( raízes da vida até então), e ainda temos a petulância de achar que podem dizer sobre quem é, ou o que irá fazer, entre seres iguais e não por regras sociais e leis mas, sigamos a programação. Até que os circuitos estejam funcionando.... ou... volte, semana que vem.

Assim, uma das vocações essenciais da educação do futuro será o exame e o estudo da complexidade humana. Conduziria à tomada de conhecimento, por conseguinte, de consciência, da condição comum a todos os humanos e da muito rica e necessária diversidade dos indivíduos dos povos, das culturas, sobre nosso enraizamento como cidadãos da Terra ${ }^{137}$..(MORIN, 2004,pg 61)

Entre a condição humana, e do que dela é também o universo tecnológico as relações planetárias, imbuídas no sentido de sobrevivência, precisam estar como cerne da própria consciência enquanto existir. Aprender a escolha dentre ramificações - stand by porém em arquivo mental, e racionalização da utilidade sendo portanto que, não é o tudo que me faz real, mas o real de tudo que me faz pleno. Ou seja, abarcar o tudo não necessariamente seja ele mesmo, porém dentro dele. Organização e gestão passam a ser fundamentais em um mundo de informação conectada e expansiva. Enquanto vermos a montanha ${ }^{138}$ como subida

\footnotetext{
${ }^{137}$ Vernadiski no livro de MORIN, aponta para que pela primeira vez, o homem compreendeu realmente que é um habitante do planeta e talvez deva pensar ou agir sob novo aspecto, não somente sob o de indivíduo, família ou gênero, Estado ou grupo de Estados, mas também sob o aspecto planetário.

${ }^{138}$ Sousa, Carina Gonzalez Y. Anoitecer do vento PIANO. Composição; Montanhas- HARPA.I,II,III,IV.
} 
e descida, e não com a forma toda dela, um ao redor, dificilmente podermos perceber, um passo após o outro

\section{Do cipreste, deitou-se a alma a ver o céu \\ Quando o sol, lhe cobriu os olhos \\ Para sentir o corpo.}

A civilização e seus rastros, movimentos da história que nos perpassa como indivíduos e sociedade, em busca dos tempos da nova cultura. Do progresso, nossas escolhas, o avanço para que fim, este deve ser sempre um prumo de questionamento. Se percebermos o mundo e do que nele nos faz sermos ligados ao criador, saberemos que entre o amor, a razão e a consciência, independentemente dos fatores de ordem cronológica, do tempo cronos, estaremos cientes de que o amor, em nossa natureza está sempre de alguma forma presente, e é a ponte para que a razão seja despertada e nos ligue a consciência.

A civilização nascida no Ocidente, soltando suas amarras com o passado, acreditava dirigir-se para o futuro de progresso infinito, movido pelos avanços conjuntos da ciência, da razão, da história, da economia, da democracia. Entretanto, aprendemos com Hiroshima que a ciência era ambivalente; vimos a razão retroceder e o delírio staliniano colocar a máscara da razão histórica, vimos que não havia leis da História que guiassem irresistivelmente em direção ao porvir radiante, vimos que em parte alguma o triunfo da democracia estava assegurado em definitivo, vimos que o desenvolvimento industrial podia causar danos à cultura $\mathrm{e}$ poluições mortais, vimos que a civilização do bem-estar podia gerar ao mesmo tempo mal-estar. Se a modernidade é definida como fé incondicional no progresso, na tecnologia, na ciência, no desenvolvimento econômico, então esta modernidade está morta, ( MORIN, 2004, 72).

Da consciência do mundo planetário, estejamos certos de que os modos de ser, deverão incluir o respeito, a justiça e a igualdade, não somente em palavras, mas em atos concretos como forma inclusive de economia, educação, e de toda relação que as Nações necessitem para que a consciência esteja como participe de um progresso real, onde a experiência humana em seus rastros históricos demostrem o que devemos não esquecer e aprender. Onde no traçado, não percamos a esperança, que nasce conosco, semente do ventre e vive, esperando, os frutos.

O peixe e o mar - Sobre os astros, vemos as águas, e as correntes, oceano que atravessamos. Estaremos sempre vivos, do corpo da alma de amor, que pelos caminhos e diante da dor ainda recebe nos braços, a flor; da paz que o Senhor nos traz. A consciência terrena: 
A união planetária é a exigência racional mínima de um mundo encolhido e interdependente. Tal união pede a consciência e um sentimento de pertencimento mútuo que nos une à nossa Terra, considerada como primeira e última pátria. [...] A consciência cívica terrena, isto é, da responsabilidade e da solidariedade para com os filhos da Terra. A consciência espiritual da condição humana que decorre do exercício complexo do pensamento que nos permite, ao mesmo tempo, criticar-nos mutuamente e autocriticar-nos e compreender-nos mutuamente. [...] É necessário ensinar não mais a opor o universal às pátrias, mas a unir concentricamente as pátrias- familiares, regionais, nacionais europeias -e a integrá-las no universo concreto da pátria terrestre. Não se deve mais continuar a opor o futuro radiante ao passado de servidão e de superstições. Todas as culturas tem virtudes, experiências, sabedorias, ao mesmo tempo que carências e ignorâncias. É no encontro com o passado que um grupo humano encontra energia para enfrentar seu presente e preparar seu futuro. A busca do futuro melhor deve ser complementar, não mais antagônica ao reencontro com o passado. Todo ser humano, toda coletividade deve irrigar sua vida pela circulação incessante entre o passado, no qual reafirma a identidade ao restabelecer o elo com os ascendentes, o presente, quando afirma suas necessidades, e o futuro, no qual projeta aspirações e esforços. Civilizar e solidarizar a Terra, transformar a Terra, transformar a espécie humana em verdadeira humanidade torna-se o objetivo fundamental e global de toda educação que aspira não apenas ao progresso, mas à sobrevida da humanidade. A consciência de nossa humanidade nesta era planetária deveria conduzir-nos à solidariedade e à comiseração recíproca, de indivíduo para indivíduo, de todos para todos. A educação do futuro deverá ensinar a ética da compreensão planetária. ( MORIN, 2004, pg 7678).

Do que é do desenvolvimento da cultura humana e o tempo, haverá a consciência de que nossa natureza ${ }^{139}$ está entre o livre-arbítrio e o maktub, ou seja, destino construído, a incerteza que se desvela como certeza do infinito. Enfrentando incertezas e os seus respectivos propósitos assim como as decorrências das conclusões de cada escolha. A dúvida e fator benéfico da crença. O movimento da dúvida, exerce o critério sobre o que poderemos enfrentar de um conhecimento estipulado como determinado ou do que iremos nos defrontar, como novo. Assim, sendo uma postura investigativa, cientifica, tem como presença de uma "auditoria do pensamento capaz de manter lúcida determinados ideais, crenças, enfim, favorecendo assim, o discernimento. Dos tempos de nosso destino enquanto cultura que se organiza em gestão, pressupõe-se o contexto de uma ecologia da ação, onde a conduta e o ambiente ao estarmos inseridos como sujeito que narra suas escolhas em busca da compreensão, mediante riscos e precauções, na tentativa de que o educar o pensamento

\footnotetext{
${ }^{139}$ Sousa, Carina Gonzalez Y. Texto do livro a ser publicado Diário da Manhã, De tudo ou tão pouco.
} 
nos rumos do progresso possam estar conduzidos para a evolução, somos, passado presente e futuro.

Compreender não quer dizer, aceitar, porém como afirma Morin, “A compreensão do outro requer a consciência da complexidade humana ".

A completude é parte do caminho e o discernimento todavia, também, entre o oriente e o ocidente enquanto mundo, enquanto planeta que não se vê como humanidade dissociado, mas sim, integrado como formas de vida, e havendo para que se realize de fato, o respeito e a compreensão.

Com certeza, aquele que recolhe as contribuições originais de múltiplas culturas está ainda limitado às esferas restritas de cada nação, mas seu desenvolvimento é um traço marcante da segunda metade do século XX e deveria estender-se até o século XXI, o que seria triunfal para a compreensão entre os humanos. / Paralelamente, as culturas orientais suscitam no Ocidente múltiplas curiosidades e interrogações. O ocidente já havia traduzido o Avesta e os Upanishads no século XVIII, Confúcio e Lao-Tse no século XIX, mas as mensagens da Ásia permaneciam restritas a objetos de estudos eruditos. Foi apenas no século XX que a arte africana, os filósofos e místicos do Islã, os textos sagrados da India, o pensamento do Tao, o do budismo transformaram-se fontes vivas para a alma ocidental isolada ao mundo do ativismo, do produtivismo, da eficácia, do divertimento, que aspira à paz interior e à relação harmoniosa com o corpo. ( MORIN, pg104).

Toda e qualquer abertura deve compreender que manter o que de sua integralidade como parte em si, é responsabilidade de manutenção do que é direito de liberdade, igualdade, fraternidade ${ }^{140}$ e principalmente de dignidade, sendo fator intrínseco, claro que em desafios sempre durante o desenvolvimento quando em contato com diversidades quanto a essas premissas que podem estar até mesmo sobre outro prisma em alguma outra cultura, será diálogo ininterrupto, na construção do amanhã.

Objetivos e caminhos. Assumir o propósito condiz com a firmeza de procura do caminho para atingi-los em comprometimento e conduta, para tal, aprofundamento de gestão e organização são fundamentais, como diagramas em pensamento e forma de elucidar o caminho traçado. Relacionamentos contínuos como perspectiva de nossa marca, marketing de nosso viver, onde diversidades e antagonismos fazem parte dos elementos em movimento da procura harmônica do que seja "espírito cívico", sobre a face inacabada da obra enquanto existir global. Apesar de nomearmos sistemas de governo, cabe ressaltar penso, que, os

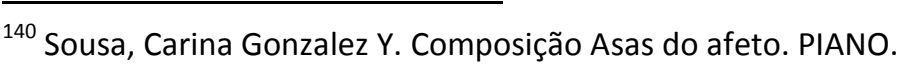


objetivos sociais de um viver que preserve a paz, os valores humanos, a integridade da vida, a liberdade, deve estar como pauta da realidade independente do tempo, mas como razão atrelada a consciência de um viver melhor, basilar para uma cultura organizacional de nações. Cidades ${ }^{141}$ inteligentes- fruto de arquiteturas de soluções, sobre o desafio do diálogo da comunicação e a tecnologia entre as relações humanas e o poder público, espaços de um novo tempo. Por essa razão os fins tão apregoados ao pensar filosófico passaram a ser cotidianos em busca dos caminhos a seguir, diante da oportunidade e capacidade que a tecnologia oferecerá e ainda, quanto a melhorias de vidas e políticas públicas, porque estará a razão e a consciência como pilar das estruturas que comportarão os objetivos a serem conquistados com os instrumentos da relação comunicação-tecnologia, rumos dentre a humanidade. Vidas e condições, humano do humano.

A experiência humana entre tempos.

Tic e Tac assustadoramente o tempo não passa, em pleno século contemporâneo, os segundos pertencem as cavernas dos desejos insalubres de jeitos de fazer, que precisam de um tempo a mais, talvez. O tempo dentro do tempo. O que quer dizer isso? Aprendemos com o que foi feito, e podemos fazer agora diferente. Respeitamos o passado, e podemos realizar algo em liberdade no momento presente, mas que, se estamos a repetir as mesmas ações com valores ainda mais baixos ou em promoção, afinal a tecnologia facilitou a nossa vida. Será? O que estamos fazendo com ela? Tecnopatias, tecnofobias, ou falta de humano ser? Quem poderá dizer? Talvez os atos do silêncio, que tanto reproduzem a alma sem palavras. Mas para que criticar se as ferramentas são boas. Não é minha função criticar, posso ver os dois lados da moeda, e ainda mais, atirá-la ao CÉU. Veremos o que dá? Tic Tac. Do relógio e não de uma bomba em uma guerra sem armas, mas, porque dizer isso, se está tudo em paz. A realidade construída é uma miragem tão bem feita que até acreditamos que a guerra ficou no passado, quando tantas pessoas morrem, em trincheiras do cotidiano,

\footnotetext{
${ }^{141}$ Sousa, Carina Gonzalez Y. Composição: Dentre o que somos cidade, o que poderemos ser. Cidade: Da cidade, da fome nua, minha alma crua, despedaçou e calou o teu desejo, que ileso me apanhou. Nos braços teus, os sonhos meus. Por onde andei, senti demais. Por onde andei,...cidade árida. Tão queridas como minhas águas, talvez do teu concreto meu incerto. Lugar, seja na tua alma. O meu espelho, da lágrima que escorre. E ninguém socorre mais... E o que fazer então... Simplesmente... cidade nua, veste a minha fome. E o meu verso será teu.... Como prometeu... quem sabe então. Do coração, de um poeta. Eu possa ainda respirar.... Cidade descoberta. Desse frio me aquece, quando amanhece. Sobre o teu olhar. E não para mais, de sonhar. Mas as minhas vestes, estão por todos os lados, repartidas com tantas feridas. De vidraças vazias... Dos arranha céus... Esquecidas de mim. São nossas, as paisagens mudas. Que vestem nas ruas. $O$ teu nome. Cidade que consome, cadê, você.
} 
esquecidas pela falta de humanidade. Mas, não se preocupe, nós não podemos fazer nada mesmo, ficamos em nosso automatismo reprodutivo e ilusório, que está bom. De estomago cheio e coração vazio, posso continuar assim, mas um parafuso pode emperrar essa máquina, o dia que o sentido de um certo sentimento comece a acordar. Pois, não podemos nos esquecer que o relógio também funciona como despertador. De que época estamos falando?

O domínio de si próprio. Dizem que o corpo humano é uma máquina. Hum, deverás isso me parece uma engrenagem perigosa, quando estamos procurando aonde fica a alma, o sócio controle de meu urbano gesto de cidadão que habita um mundo e inserido nele tem a sede de se ver orgânico sem destino na maioria das vezes, onde apenas os segundos passam. Possivelmente conjecturas que são cabíveis de serem sempre resgatadas, porque o tempo passa e a gente não vê. Os ruídos dessa engrenagem em perigos constantes, na paz disfarçada é algo a ser ao menos observado com cautela, nas cenas que assistimos e simplesmente desistimos de viver. Uma pergunta sempre fica latente, se assim podemos chamar, que vem a ser o fato de que se no tempo histórico temos mutações facilmente aferidas e constatadas, porque também na outra face, podemos ver o que apenas mudou de veste $^{142}$ continuando com o cerne das mesmas mazelas? O que falta mudar? O que queremos para as próximas gerações?

As máquinas, quais? Até que nós não sejamos maquinas tão automáticas que deixamos de ser o que poderíamos. De quais máquinas falamos? Ou haverá algo de compartilhado entre esses dois modos de existir no mundo. Em um objeto, posso conhecer pela sua função seu modo de ser, e desse modo de ser agindo, o que eu posso compreender em minha própria ação comunicativa? Objeto, máquina, instrumento, são a mesma coisa? Necessidade, função, utilidade, servem para qual destino? A terra é instrumento da semente ${ }^{143}$ ? Ou é útil a ela.... o que compreendemos por instrumento, máquinas, são de fato uma perspectiva somente, ou pode ser algo a mais, que me faça compreender o tempo em que agora estou vivendo? Antes do arado, a terra é também objeto da plantação, ou útil a plantação? Toda palavra tem o seu lugar? Ou o sentido não pode reverberar? Estarei nos meus olhos apenas retendo um só lugar, determinado e assim sendo, como um mecanicismo? O indeterminado em sentido é indigesto para a sociedade? Indigesto porque faz pensar? Quais as condições e o contexto para que eu faça o diagnóstico de como podem ser as estruturas " mecânicas "que cercam o

\footnotetext{
${ }^{142}$ Ver trabalho apresentado em Congresso Ibercom 2015 intitulado A moeda - A estética de um discurso na percepção da imagem do corpo social entre as linguagens. Usp.

${ }^{143}$ Sousa, Carina Gonzalez Y. Composição: Pelo desejo da terra.
} 
cotidiano e onde não percebo os passos que continuamente perpassei? Território cultivado e ceifado, por quais ditadores? Mas, que, nós vivemos em uma democracia? É mesmo? O cotidiano em seu mecânico gesto é um ditador que por vezes não somente impede a liberdade, mas a condiciona, como uma liberdade programada. Circuitos internos da sociedade.

Quem se pergunta se o sol vai nascer amanhã? Haverá razão para isso? Aonde está minha razão nesse redemoinho como pinceladas de Van Gogh, para que eu ao menos possa ver uma tela, mesmo que em branco, ou como uma ovelha negra. ${ }^{144}$ Quem são os que habitam as engrenagens do cotidiano, as facilidades de nossas vidas urbanas em tecno-ser ${ }^{145}$, ou ser desapercebido de viver? Havermos de escrever, e quem sabe o eco pode nos trazer algo de volta, quando saibamos do que das vontades das máquinas, nos lê e deseja que saibamos o que pode haver também de corpo das palavras na alma de cada um, que sai para o diário de cada dia, faça chuva ou sol, de quantas naturezas puder compor, linhas por onde atravessar, onde ainda possamos respirar, um novo tempo, ou para começar, um gesto de ternura. ${ }^{146}$ Enfim, talvez o desejo seja, e quantas vezes já não tivemos essa vontade, de que o tempo parasse. E em que momentos isso ocorreu? Volto a dizer, pegue o fio de Ariadne, e veja em que ponto esse espaço, porque quando o tempo para ele se transforma em espaço, e fique ali um pouco, resgate o tempo dentro do tempo, para sentir. E ouça, mais do que os ruídos, a presença.

Aonde por entre colinas urbanas, gesticulando janelas cheias de gente que pensa, em tantos rasgos do cansado tráfego, dos mares de gente, cansa. Perpassa as vestes da cidade, do campo ficam as pegadas, porque todo território caminha, e que mais? Linguagens esquecidas de se conhecer. Muito prazer? Talvez quem saiba a catraca da viagem esteja menos lotada, ou pisoteada de tanto correr sem sair do lugar. Insana mordaça, que laceia a cada vontade de sonhar, se permitido for. Aonde vai?

Respirar.

$\mathrm{Ou}$, volte a postar seu cartão de ponto. Mas, tome cuidado, porque se fizer algo de diferente ou pode ter que estar fora do sistema, ou julgado como economicamente criativo. E, onde há uma possibilidade lucrativa, talvez, quem sabe, seja visto com outros olhos.

\footnotetext{
${ }^{144}$ Referência ao filme tempos modernos de Chaplin - Cena.

${ }^{145}$ Vídeo -Canal Marketing. Carina Gonzalez Y Sousa

${ }^{146} \mathrm{O}$ direito á ternura - Luis Carlos Restrepo
} 
Sem dúvida que entre o estado habitual e os acréscimos de desenvolvimento, sempre teremos posturas que ou desejam manter o estado antigo ou creditar que o avanço pode e deve ser benéfico, como mostrou-se em muitas áreas do percurso da humanidade. Vale dizer, penso, que independentemente das posturas quanto ao estado ao qual queremos pertencer, se do passado ou do empreendedorismo, devemos constatar também que ainda teremos dentre as opções qual postura de conduta nos mesmos havermos de encontrar em relação com o nosso próprio jeito de ser, escalas e esferas compartilhadas de consenso ou não. Tudo que move, em certo ponto exige uma capacidade de lidar com o desconhecido, ou mesmo que conhecido, realiza um embate interno para que se compreenda ou ao menos que se desenvolva a análise do que poderá ser beneficiado. Como as empresas realizam para vender um produto novo, ou seja, para convencer um público, além de outras razões se estabelece uma razão de constatar benefícios possíveis. O mesmo valendo para posturas de empresa onde o seu representante tem relutância para aceitar modificações que são apontadas como avanço, por exemplo ligadas a sustentabilidade. Mas, não vamos enveredar por aqui, somente para constar um exemplo, ainda que producente de reflexão creio. Conquistar novos mercados dentro do automatismo em que vivemos é um desafio, curioso, porque as novidades tecnológicas enfrentam isso muito bem. Talvez tenha colocado no automático dos seus consumidores, que é tudo muito efêmero, ou seja, o padrão é esse, a efemeridade, então não se questiona? Desses dois campos, o que podemos afirmar? Ou apenas, observar?

Forma e função. Nas arquiteturas do viver, como elas podem ser?

De aviões à skipe, aonde você está? Novas geografias. Os avanços e as resistências sempre houve, mas a questão é o que fazemos com esses avanços, para onde eles podem nos levar? Nem se questiona neste momento, malefícios ou benefícios mas sim as escolhas que estão ocorrendo, em indivíduos e em massa, e suas transparências. Quanto a tempo de transparências, elas, se forem lícitas, são de todo producentes, porém, chegamos ao descalabro de viver uma " transparência programada, ou manipulada, ou distorcida de realidade “, então, fica um tanto quanto difícil o discernimento. Precisaremos de uma perícia da vida, ou uma auditoria do cotidiano? 
Técnicas ${ }^{147}$, como denomina Friedmann, são bastante e fertilmente constatadas no decorrer da história, e seu uso, em modo de ser e utilidade e necessidade também, tendo como exemplo clássico o avião, como transporte e instrumento de bombas na guerra. Hoje buscamos o que ainda mais valida tal posição após tanto tempo em dicotomia de espaços. $\mathrm{O}$ ritmo, o que não quer dizer mecânico, está presente em nosso cotidiano, interno ou externo, porque é elemento vital da vida e digo ainda que, o silêncio é movimento do continuo, é pausa que respira, é sentido que se ouve. Independência fruto de manipulação não é liberdade, não é independência. Resultados aparentemente favoráveis que conduzidos por manipulação são um verdadeiro engodo e contrários fortemente a razão e a verdade.

Os ritmos - natureza da civilização quer estejamos no campo ou na cidade. O ritmo ${ }^{148}$ é elemento natural do existir e dos ritmos do pensamento. O homem está subjugado a milhares de solicitações, de excitações, de estimulantes até há pouco desconhecidos. Assim, o conjunto dessas técnicas criadas. O ponto de referência e a perspectiva. Se tomarmos o horizonte como ponto de referência e não perspectiva ${ }^{149}$. Os ritmos se entrecruzam, se revelam um emaranhado harmônico quando possível, e em tempo atuais, cada vez mais, ter o ponto de referência pode ser um campo aberto, um sistema aberto, por onde o destino, a perspectiva, é a própria complexidade em expansão. ${ }^{150}$

Há exemplos que podemos observar, como a matéria que se esvai e presença física de um indivíduo, em um ponto determinado no tempo, mas que como bem sabia Sócrates, seu pensamento excede o mesmo, prolongando-se através da humanidade, porque não há idade para o pensamento, ele pode e muitas vezes temos visto isso, se atualizar até mesmo de

\footnotetext{
${ }^{147}$ Segundo George Friedman, "O homem está subjugado a milhares de solicitações, de excitações, de estimulantes até há pouco desconhecidos. Assim, o conjunto dessas técnicas criadas instala, aumenta cada dia em tômo dele o que chamaremos globalmente o meio técnico. A partir dai, no curso de uma aventura milenas, onde causa e efeitos se emaranham e se condicionam reciprocamente o homem modifica seu meio, e através de seu meio codifica-se a si próprio e se lança para novas transformações." Friedman, George. O estudo sobre o homem e a técnica. Pg 17

${ }^{148}$ Garaudy, Roger. Em diversos pontos do livro, Dançar a vida, coloca o ritmo sobre seu auscultar. "O mundo é um fogo eternamente vivo que se acende e se apaga em ritmo certo. Movimento e ritmo, esta é a visão da ordem cósmica expressa, na alvorada do pensamento grego, no sexto século antes da nossa era, por Heráclito, inseparavelmente filósofo e poeta. A física contemporânea nos dá uma imagem mais rica do universo, que em nada contradiz, contudo, a visão de Heráclito, seja qual for o nível de redução da matéria a que possamos chegar, a realidade provisoriamente última que pudermos atingir não será constituída por átomos concebidos como esferas compactas em que nada acontece: aquilo a que se chama partícula não é senão um ponto singular de um campo ondulatório no qual se concentra ou a partir do qual irradia a energia e que se desloca e desaparece para renascer alhures como uma vaga no imenso mar de matéria. Ritmo e movimento, mas também esta imagem nova do indivíduo, que não é um átomo fechado em si mesmo, mas um núcleo mais denso de uma energia da qual participa, onde se enlaçam forças e fibras que o tornam solidário do todo."

${ }^{149}$ Ver Capítulo do Livro: Diagramas explorações no pensamento signo dos espaços culturais .Ed. Alameda, Bela Vista, SP. Formas diagramáticas em desenho. Carina Gonzalez Y Sousa

${ }^{150}$ Sobre esse apontamento, a respeito de continuidade, protodiagramas, imagem mental, ícone de relações; ler o livro: Topologia da ação mental de Ana Guimarães Jorge.Ed. AnnaBlume
} 
forma alarmante Quantas vezes temos percorrido hoje, pensadores antigos, que em suas palavras, ou peças de teatro são profundamente viscerais de nossa contemporaneidade? $\mathrm{O}$ tempo, dentro do tempo, se fazendo movimento, é uma constante. Equação difícil de se ver.

Querem saber que horas o sino toca, e eu, as notas do som. Aonde nos encontramos diante do que queremos? A escolha sempre estará conosco, se aprendemos com o passado, ou se nele queremos viver. Se a nossa maneira de ver o passado, é amarga, e o fel irá corroer o futuro, ou olhar para a frente, apreciando um lindo pôr do sol, a maneira de Monet.

Haverá tempo do sentir nessa cobiça cotidiana em que pagamos por sobreviver? Percebemos os sentidos do amor? Haverá tempo e espaço para essa razão, desprovida de intenções apesar do leilão do ambiente a seu redor? Ambientes vistos como contextos, habitar, são curiosos. A história nos revela momentos dispares e ao mesmo tempo, confluentes apesar de distâncias, então de certa maneira pensando em paralelo, teríamos a possibilidade de trazer o conceito da Umvelt ${ }^{151}$ em se tratando, aqui uma hipótese, de uma Umvelt específica de um período de tempo, este que em sua complexidade, realiza relações com um ambiente temporal, ainda maior.

Não cremos, contudo, que o processo vital seja o resultado da estrutura orgânica, mas sim o ritmo, a melodia - de certo modo - segundo os quais o organismo organiza e reorganiza a si mesmo... Igualmente impensável parece a mim a idéia de que o processo vital evolua a partir de processos físicos e químicos específicos. A fonte da vida não repousa neles, pois do contrário ela não teria unidade. (Karl Ernst von Baer, 1983) apud A teoria Umvelt de Jacob von Uexkull )

Os desejos do tempo ${ }^{152}$. Estímulos dos sentidos e significados que despertam no decorrer do tempo, nos fazendo perceber apesar das raízes, as folhas que com o vento voam e ao estar sobre o chão adubam, e o que haverá de nascer e quando, talvez a natureza nos revele, ou a semeemos novamente para observar do que ali estava, ainda se fará possivelmente outro dele mesmo. Muitas maneiras de se ver, como Ovídio, como Umvelt, como cosmologia, os desejos do tempo se fazem abrigo das vontades ou necessidades. Pergunto, se são do existir, ou do humano, porque nem sempre somos capazes de respeitar a natureza, e isso tem suas consequências, diferentemente do existir que promove uma integridade me parece de

\footnotetext{
${ }^{151}$ A teoria de Umvelt de Jacob von Uexkull. Pesquisa em 17-07-2017 de texto anteriormente estudado. Disponível em https://revistas.pucsp.br/index.php/galaxia/article/download/1369/852

${ }^{152}$ Sousa, Carina Gonzalez Y. Composição Nas margens de Mnemosine. PIANO.
} 
coerência onde sim, com a presença humana, mas em certo ponto, mais ligado a uma harmonia, latente e em busca de um prumo, para se edificar como civilização.

Quais os desejos do tempo, e quais os desejo de nosso tempo? Um tempo histórico e um tempo vigente, onde se despertam necessidades, funções de compreensão, buscas na time line mental do organismo planetário da espécie humana. O que percebemos do tempo, e o que queremos? ${ }^{153}$ Conhecemos nossos códigos e contextos do sentimento, códigos e contexto do viver, ou somente do automatismo costumas onde as percepções se diluíram não em efemeridade mas em significado? Usamos linguagens em determinações de estruturas, com seus códigos específicos, mas me pergunto, quanto a linguagem de nosso tempo, e quais são os códigos que estamos usando para deixar claro a estrutura de nosso modo de viver. O efêmero, se assim eu posso considerar, foi um código de uma linguagem que permeou os sentidos vorazes de uma época, em que a estrutura se viu em parte ruir por não ter fundação, profundidade para que seu edifício se estabelece-se, então eu volto a alegar e perseguir, os códigos da linguagem de uma ressonância do viver, onde eu possa encontrar elementos suficientes que me organizem em uma estrutura capaz de lidar com a complexidade, com adjacências, com divergências, com tempos em mobilidade, e principalmente com o sentimento. Talvez, códigos tão antigos, como a ética, o bem, uma estética capaz de ver a arte como a vida ${ }^{154}$, engendrados em uma lógica de um desenvolvimento seja um caminho. E, sei que para muitos isso pode não ser visto como códigos, mas quando eu estou falando do ambiente do existir do tempo em sua infinitude, e continuidade, eu tomo a liberdade de considera-lo dessa maneira.

Signos e sentidos, os tons em atmosfera. ${ }^{155} \mathrm{SE}$ concebemos o som em liberdade, assim como uma emissão do tempo, poderemos o encontrar em diferentes momentos, orquestrado pela

\footnotetext{
${ }^{153}$ Sobre el deseo. Por qué queremos lo que queremos. Irvine, Williams B. Editora Paidos Ibérica, Barcelona.

${ }^{154}$ Ler o livro: Ágape, arte como a vida. Carina Gonzalez Y Sousa. Dissertação de mestrado apresentada a Universidade de São Paulo.

155155 Ver sonoridade apresentada por Nikolai Chaikin, Concerto n 1 para acordeon e orquestra, tecendo conexão sonora com Phillip Glass em Poet Acts, em sinestesia de diagnose de corpo sonoro, adverso do instrumento, mas na imagem da voz sonora que ultrapassa o objeto para ser instrumento melódico, onde na orquestra se organiza como força de movimento, em um primeiro momento, e posteriormente buscar a referência de comportamento do mesmo som exposto pelo acordeon em diversas culturas, que apensar das diferenças, pode-se constatar que após um tempo de apreensão se observa uma identidade preservada que independe da localização porque constitui em si, uma mobilidade que se agrega como digital, onde a emissão pode ser de seu coabitar uma expressão que o representa no através da construção de seu tempo ( música ), criando um espaço de significar que abrange espaços conduzidos que mapeiam os passos que o recebem como um através de territórios, transeunte sorvendo seu destino. ( em transito )https://youtu.be/vuBfz5DNyM4 E, Gabriel Garcia Marquez, " No se que tem el acordeón de comunicativo que cuando lo oímos se nos arruga el sentimento ".
} 
vida, em diferentes instrumentos desde que uma certa harmonia o resguarde, ou se desenvolva, penso. Sonoridades e ritmos em afinidade, ou continuidade, são como gestos dos códigos das linguagens da vida, onde o ambiente os fecunda dependendo de uma percepção ou razão, necessidade, desejo...

E, para além das relações com o tempo dentro do tempo, havemos de ainda lidar com as relações do que me é particular ou de esfera pública, e ainda do que me é interno e externo como ser individual, então quase como sobreposições em expansão nos desafiamos ao movimento do conhecer, porque desbravar territórios assim, nos faz ser como nômades em pausa, de uma partitura cósmica. Desafio sem dúvida, ao menos para termos um mínimo de harmonia, se não a do tempo atual, mas a construção presente de reverberações, de ressonâncias em que as razões possam ser sentidas em por vir, ou o continuo.

A vida é uma maneira de os signos produzirem um outro signo" (Sebeok 1979). Uexküll fala de "planos" que se materializam com o desenvolvimento dos organismos, de "melodias" que direcionam o intercâmbio de signos entre sistemas vivos na forma de duetos ou corais, e de "contagens" que o biossemioticista deve encontrar e registrar ( UEXKULL...pg 33)

Inserção e reação - meio de sentir e o meio técnico- modos congruentes ou díspares de agir e de pensar?

O enredo da dramaturgia social é de fato bastante conclusivo ao deixar claro a exposição a que estamos imersos em sendo todos, protagonistas de seu personagem. Significativos aspectos de como somos constituídos e estamos sendo apreendidos é parte da integralidade do conjunto de se estar existindo em sua interioridade e a face da esfera pública, em seus mecanismos sociais, e de relacionamento. Aspectos relevantes de cada um são possíveis reverberações que aparentemente podem estar desconexas, mas são todavia uma expansão na qual os elementos acabam se inter-relacionando. Marcas desse território diversificado de um indivíduo que em seu drama de existência é ao mesmo, tempo personagem, palco como caminho e trilha, enfim, plateia. Os lados com o tempo foram ficando no limite mais tênue do que pode ser uma ficção ou realidade, onde a razão deve ainda ser uma matriz de conduta ao menos para que os efeitos da emissão da voz dos personagens, venha a narrar uma história que possamos deixar como, se não legado, um fator que propicie uma continuidade no ensejo de que a vida prossiga. Assim sendo, constatando a imersão, o quanto ou melhor, 
o como a reação ocorre, é um diferencial, posto que a reação, até mesmo pode ser a objeção ao sistema, ou a inercia, ou ainda, a busca de um lugar em que a sua imagem no corpo da trama esteja bem descrita, para que ao escrevermos o nosso tempo, as palavras possam estar em nosso pensar como reflexo de nossa alma, e não somente como marionete de um teatro.

Explorar o mundo, desvendar suas possibilidades, desafiar os sentidos e significados, ou explorar de forma a ser para o outro, o algoz de uma máscara, onde o teatro, deixou de ser verdade, para sucumbir a uma exploração da própria cobiça, ou seja, o ápice de uma aniquilação em prol de uma desenfreada forma de compreender um mundo sem igualdade. Penso que, deveríamos então, alterar a palavra explorar, que carrega um cunho tão antigo, de formas humanas tão degradantes, para o tão contemporâneo empreender, ou conhecer, porque todo ato de conhecer exerce uma força, desenvolve uma capacidade e movimento para que de fato possam operar discernimentos, razões, construções que permeiem um solo de valores humanos onde germinem uma sociedade almejada.

Ao adentrarmos o mundo, o palco, a marca que estamos calcando, inevitavelmente estaremos nos impactando e apreendendo a cada momento e a apreensão ocorre gradativamente e concomitantemente ${ }^{156}$, onde o sujeito hoje plural ${ }^{157}$ não está em dicotomia com o ambiente, mas sendo o ambiente, em um entrelaçamento de relações. A desconfiança natural em tempos de interfaces tecnológicas e de ficção e realidade, está alguns passos a mais, do que Descartes dizia, e eu diria que com uma larga vantagem, porque os lados se entrecruzaram e ficou mais difícil saber quem pode dizer aonde ou o que, termos para ser verdade em um mundo melhor. O receio das máscaras ao ser inquérito foi que as aparências estavam por trás das máscaras, e na própria pele. E então, como é que fica? Quando o viver passa a ser notícias ilusórias da razoabilidade ${ }^{158}$ demais, ou seja, não são efetivas de razoabilidade e ao contrário são disfarces ou manipulações, que perderam o prumo da ética, e principalmente do que consideramos o bem, então, nos defrontamos com um terreno minado onde o existir de quem quer aferir um sentimento de valor em relação a um simples lugar ao sol, é de fato pela sociedade depreciado. Portanto, o que iremos apreender desse entrelaçamento com o mundo nesse ambiente que nos constitui? Haveremos de ter uma homeostase possível ou de diagnose confiável? Como aferir escolhas plausíveis em um

\footnotetext{
${ }^{156}$ Quanto a mente e acumulo de informação - Ver Gregory Bateson.

157 Medina Cremilda, Hemisfério do sol.

${ }^{158}$ Aqui o termo é condizente com o considerado como o bem lógico, o bem ético e a estética para uma conduta plausível de uma sociedade melhor, que tenha um rumo em direção ao admirável.
} 
sistema perturbado não por energias externas mas deturpações da ordem concreta do viver, como ultrapassar limites de uma ficção e manipulação de experiencias? ${ }^{159}$

A reação mensurada dentre uma ilusão não pode tirar conclusões efetivas e concretas.

A interioridade humana e a condição humana, por modo de conhecer de fato e muito comumente renegam aspectos que devem ser considerados independentemente de crenças, que é de uma ordem de religare, que sim, é da emanação espiritual, ou caso esse termo não seja aprovado cientificamente, da ordem de uma efetiva e concreta força movente do organismo sensível que constrói e edifica um ser em seus mais relevantes aspectos da experiência do seu viver. Como isso ocorre e pode ser diagnosticado ou observado, provavelmente como cada ser, não será padronizado requerendo uma atenção, esforços e trabalho de quem se debruça para auscultar a alma no sentido aqui proposto, portanto, o exame de verificar a força sensível que emana em capacidades dos sentimentos que nos unem a uma vontade de aspectos podendo ser considerados da ordem moral, ética, e lógica também, agindo como relações naturais deste " sistema “ a que estamos nos aproximando, assim sendo, imbuídos de propósitos afins, em sintonia, reverberam a fé, a força, que não é de religião mas está no indivíduo para lhe sustentar em adversidades da vida, e que não é nem mesmo muitas vezes aferida por experiências anteriores, como podem estudiosos querer averiguar, mas é algo presente no mundo, parte das escolhas e do ventre de cada ser em evolução, onde o infinito ouve e reparte essa harmonia, na forma desse sentido, que é propriamente a comunhão com seja por qual caminho chegarás a verdade. Portanto, esse religare, pode ser percebido naquele que nutre em alguma presença no mundo o que lhe retornará ou emanará em favor de sua elevação, ou construção, ou ainda procurando termos, a consciência, chegando mais propriamente a o que pode ser considerado cientifico, onde para mim, não há dicotomia, que esteja claro, mas, assim sendo uma consciência que se funda e eclode pela presença simples do desmembramento do amor, em que forma ou destino ele se mostre. Para alguns, amor agápico ${ }^{160}$, para outros, o amor acima dos homens, ou do que à eles unirá, ou ainda, o amor em plenitude que se reverte em grãos para que possamos de um ínfimo nos tornar parte do infinito. E, sinto deverás, por isso ser relegado ao se estudar um ser humano, muitas vezes, como não sendo plausível de cientificidade ou aferição por fatos, que dizem, não ser concretos, e para meu espanto, é para mim, como o ar que respiro. O que vemos? O que atravessamos em nossa jornada? O que sentimos?

\footnotetext{
${ }^{159}$ Pistoia, Lenise. Sobre sistemas e escolhas, trabalho disponível em http://www.lume.ufrgs.br/bitstream/handle/10183/16401/000703912.pdf acesso 27-07-2017.

${ }^{160}$ Sousa, Carina Gonzalez Y, Ágape arte como a vida2016
} 
Percebemos? Nosso cotidiano não tem espaço para isso? Eu vivo a cada segundo, nesse mundo, que para muitos, é dispensável. Não são mundos diferentes, mas é o religare, é a união do que nos pode nutrir e gerar indivíduos em desenvolvimento para que cada vez mais, possamos nos ajudar uns aos outros, e quem sabe, termos uma vida melhor, uma sociedade que em igualdade, tenha o que um dia, saberemos ser, possível em dignidade. Os fenômenos sensíveis, estão na forma diária como nos envolvemos com o nosso cotidiano. Não estão apartados ou somente restritos a quem tem uma sensibilidade mais aflorada. Não, é do alcance de todo aquele que sente, com amor, simplesmente o seu dia. Claro, tem momentos difíceis, e é realmente onde as pegadas lá estão, de quem ouviu o seu coração bater, e desse som, lhe carregou pelo universo, onde a música, mesmo que do silêncio pode amar.

Olhar o mundo com sensibilidade requer um esforço porque nos colocaram em um automatismo, onde tudo é imediato sem nem mesmo permitir que o pensamento vagueie por sentidos outros, onde claro o ganho de informação é profícuo, e quando se fica restrito ao automatismo de pensamento, a seu mecanismo imediato, perdemos e perdemos muito de criação. Abrir o pensamento para possibilidades, para uma densidade de probabilidade onde as relações possam ser feitas, é do caráter da multiplicidade que o mundo nos oferece e que apesar da diversidade do mundo, no cotidiano, nos esquecemos. E, sobre certos aspectos isso não é novo, somente não temos a prática cotidiana disso, os surrealistas tinham certos hábitos de ver a imagem por outras facetas, o cubismo também, a arte é um modo de ser assim, o design, a publicidade, ou seja, está pelo mundo, mas nem tanto ainda no modo cognitivo naturalmente, o que poderia, para que as crianças ao olhar para um objeto, o percorressem em sua vasta sensibilidade de sentidos e significados, onde a semiótica para isso, é completamente necessária como ferramenta de caminho para se alcançar relações, e o que me entristece muito, porque o mundo não investe tanto ou não pensa muito nisso, a arte tem essa abertura cognitiva, onde as ciências podem confluir e se permitir ver conexões onde antes não viam, então a arte é sim, como outras áreas, caminhos para se ter uma cognição mais aberta e que permita modos de ver o mundo, mais sensíveis e de um empreendedorismo do existir, onde a inquietação das crianças não estará sobre um cabresto mas em um horizonte de perspectivas de orientação mais instigante, promovedor de experiências onde justamente o que é apreendido, passa a ter elementos descobertos pelas relações que o atravessam de maneira a ter o interesse pelas descobertas do aprender e do conhecimento. Que presenças temos ao nos deparar com um objeto, que não vemos, que 
aparentemente estão ausentes do sentido habitual? A poesia é mestre nisso, em nos mostrar caminhos de sentidos amalgamados pela sensibilidade, mas não precisa ser poeta, a curiosidade é saudável neste aspecto e bem direcionada, para que a mente capte e se sinta no impulso da descoberta, do que pode haver de outro no mesmo em possível.

Ver a vida como cenas a céu aberto cada vez mais, onde a imagem, a narrativa de nossos corpos, múltiplos na sociedade ganham vida, pelos nossos passos, nossas escolhas, nossos desejos. O que vemos se reproduz na nossa mente, e em nosso espírito assim como uma tela, e ainda, para além de nossa vontade, assim creio, já escrito em ágape arte como a vida, a memória do universo, está permeada de informações, estas, sendo cenas grafadas pelas nossas escolhas, planetárias sim, mas construída por cada um de nós, e é aí então, que cada um de nós, deveria compreender que somos uma rede cósmica, ou seja, o que o outro faz, sim, também eu estou nessa parcela desse todo, o sofrimento, o erro, os acertos, as vitórias, os desejos, estão compartilhados na rede cósmica, só que em completa unidade assim penso, talvez diferentemente da internet, onde um indivíduo além de conectado, ainda não tem, mesmo com ativismo, talvez, a consciência, falávamos dela, de que a união é uma força motriz universal, e portanto, onde estaremos e que rumos queremos, não somente é para nosso filhos, mas de uma integralidade que a sociedade em sentido planetário precisa se desenvolver. Sem martírios, todos erramos, mas a procura e a busca incansável de nos dirigimos a um propósito de um alcance de todos em dignidade de viver, é uma luta de todos e para com todos, e para com as vítimas do mundo ${ }^{161}$, que continuamente de nós todos ainda nos faz, sermos eternos aprendizes.

A tecnologia certamente pode e deve ser aliada, mas sem perder o sentido de para onde em que direção os estímulos serão enviados, ou seja, as crianças devem e passaram por essas mudanças, onde o cuidado deve ser prudente, e principalmente nessa transição de tempos, onde fora da escola muitas vezes os impulsos estão maiores, portanto quanto mais prontamente a escola, o conteúdo e os materiais, venham a ter acesso a essa confluência tão comum em jogos, de imagens, textos, objetivos, caminhos, enfim, trazer para o universo do estudo, as formas tão familiares e de prazer que eles encontram em outras vivencias. Imagem, textos, vídeos, cada vez mais, não como material de suporte, mas integrado no dia a dia de ensino. Trazer um instinto de prazer para uma necessidade, o aprender.

\footnotetext{
${ }^{161}$ Composição de minha autoria disponível em parte no endereço eletrônico: Em nome do amor https://youtu.be/wBM5oAZWLKY
} 
Combater agressividade com capacidade intelectual, é algo em direção a paz, uma defesa onde as armas produzem ainda obras de afeto, isso é algo que muitos não compreendem, e se esforçam para que a resposta a agressividade seja outra, até mesmo, conseguindo muitas vezes, infelizmente. Porém, é parte da busca de um desenvolvimento do religare, a resposta em direção a paz, mesmo que nem sempre possível, ao menos é um caminho, que nem sempre os psicólogos entendem, observam mais como fuga, quando é sublimação. E, ainda existe algo, não considerado e parte também do religare, e da observação de qualquer ser humano, que é a profundidade, isto posto, porque tenho visto comentários sempre em superfície, e que não se fundamentam na profundidade o que normalmente demanda esforço, trabalho, e uma vontade de retirar rótulos de um padrão, e ver cada um como se fosse o primeiro.

As relações humanas e seus gestos em necessidade do viver em sociedade são naturais, porém, em harmonia, plausíveis de discernimento quanto a escolhas. Impulsos são naturais, mas, em cada instância também o são a natureza do pensamento e razão, onde mesmo o sentimento se desenvolve em outros caminhos. Não sei quais são os termos empregues pelos estudiosos da área, porém, há em parte uma presença em desejo, mais do erotismo talvez que move até mesmo um objetivo, e é fundamental muitas vezes, para até que o indivíduo em seu trabalho o desempenhe de forma mais eficaz, então, sobre muitas facetas o que é da matriz do sexo, desejo, erotismo, tem seus canais de veículos bem saudáveis, que em equilíbrio não deturpa nenhum aspecto, tudo vai penso de como o conduzimos em nossas vidas essas forças, que também, são presenças que podemos alimentar mais ou menos, conforme nossos propósitos e benefícios para que os mesmos sejam alcançados.

Quando dizemos da infância, da esperança, e existe algo aparentemente simples, mas que deve existir, que é a segurança, a harmonia no lar, o afeto, para além das necessidades de sobrevivência, mas é da sobrevivência de um ser que tem a vida pela frente. Onde está seu pensamento, sua energia se direciona e sintoniza com influências emanas dos campos mentais correspondentes, e ainda, o posicionamento mental é uma geografia de uma atmosfera que diretamente se relaciona com seu estado físico, em meu modo de ver e sentir. Inclusive sendo grande forma de se redirecionar ataques de forças inviáveis ao sistema, ou seja, não me conecto com fatores agressivos e uma forma de não conectar é aonde o seu pensamento está? Isso demanda esforço e prática. O pejorativo, as forças contrárias a um rumo evolutivo e de progresso, nenhuma empresa quer, muito menos um organismo. O meio técnico em sociedade contemporânea e o instinto. 


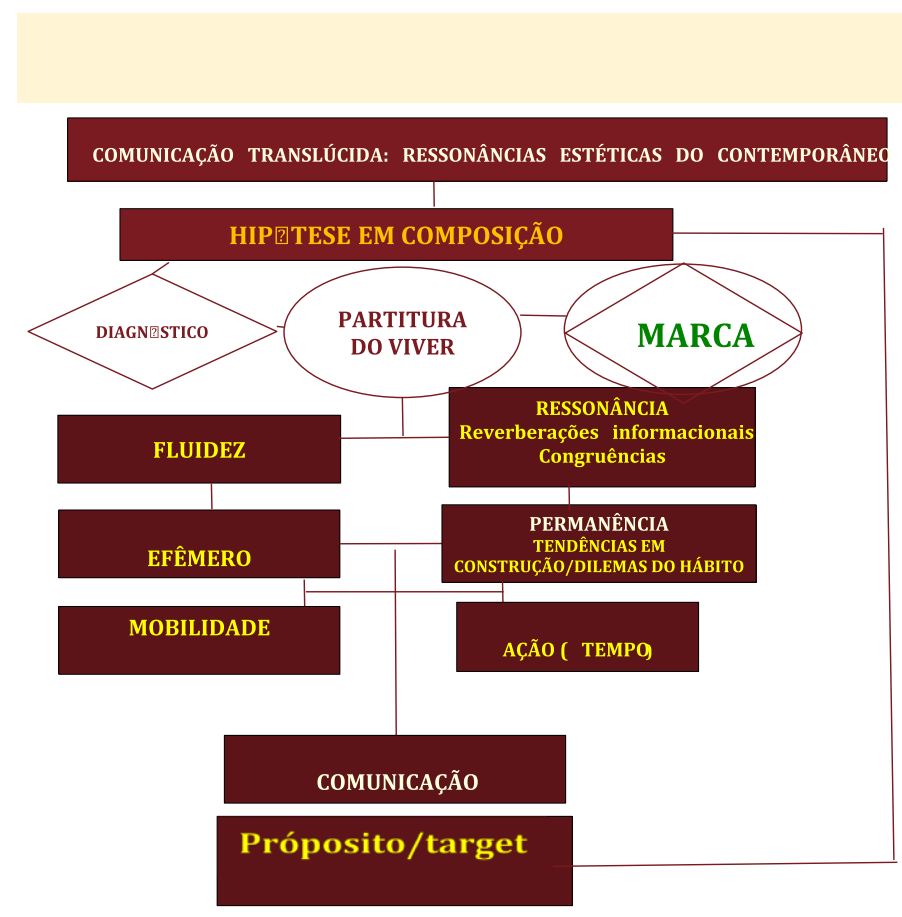

Instinto e aprendizado. O meio nos fornece em situações normais um amplo aspecto de comportamentos onde tanto um como outro podem emergir, devendo para tal quanto ao instinto podendo ser tanto o que é naturalmente pelo meio ou por reações da sociedade despertado como diálogo em recepção em retorno e como emissão, ou um fator intrínseco que emerge como aspecto de desenvolvimento frente a adversidades ou a ambientes desconhecidos, ou ainda havendo de ser um elemento de alimentação até o do sistema, como fator que surge para que a sobrevivência do mesmo esteja salvaguardada, o que em alguns dos aspectos citados podem estar correlacionados com o aprendizado, visto que a relação com o meio, ou com adversidades, e observação do próprio sistema é um aprendizado constante que pode ser demostrado por vários comportamentos, onde o instinto é um deles.

Instinto como capacidade de adaptação. $\mathrm{O}$ instinto como capacidade de adaptação é o fator que se apresenta como meio de se estabilizar um sistema que precisava de uma adaptação, portanto, em certo ponto podemos considerar que o desmembramento do instinto como abordado inicialmente em algumas possibilidades encontra-se como adaptação em reverberação do citado que pode o confrontar e fazer emergir.

Dentre a análise do instinto como inicialmente aqui tratado, pode se considerar que ainda mesmo assim, no que emerge como instinto, teríamos uma razão que o permite validar-se diante da situação, ou seja, é um fenômeno, plausível de averiguação mediante a constatação de seu uso, função ou razão de ser, o que nos leva a uma possível covalência de sentido, quanto ao impulso. Um instinto que surge em um impulso gerativo de conduta, ou 
pensamento se dispõe sobre campos existenciais que demostram uma demanda de reflexo, prática fática ou intelectual, e assim sendo, o instinto recebe uma direção em parte, onde o impulso co-habita como movimento em direção, a um propósito este locado em um ambiente, em uma reação, em um propósito etc. Pensamos normalmente em instintos do ser humano para o ambiente, esquecendo-nos que é uma via de mão dupla, a imersão ocorre amplamente e em complexidade.

Existe nos seres humanos, uma presença em relação ao instinto que difere de outras formas da natureza da criação que vem a ser a dos interesses e frentes de esferas não particulares, ou seja, quando o instinto emerge mas é freado mediante a interesses de outros ou da sociedade. Resta avaliar, de que maneira o instinto está inserido em uma ordem acima dos sortilégios do indivíduo e mais inserido no sistema da própria vida em si, como ambiente e sujeito, assim sendo, demostra-se a necessidade de se assegurar o discernimento de que o instinto esteja em benefício de um desenvolvimento, acima dos interesses particulares ou escusos. "A plasticidade do homem permite falar de uma readaptação contínua dos comportamentos instintivos ao meio." (FRIEDMAN, pg 70).

Há certos indivíduos que se comportam com os demais como se estivessem lidando com seus companheiros cada um como um experimento de laboratório, onde a reação, equilíbrio, conservação, análise, reflexão, combate, irá, fraqueza etc, são observadas como sendo dignas de um escárnio somente. Essa forma de agir e de pensar os semelhantes não são condizentes com o que queremos para uma sociedade mais humana e sensível que desperte para seus objetivos de maneira clara e em dignidade de propósitos. Sobre a ação humana, entre a razão e o querer e o querer como razão. Do cotidiano em seu automatismo e a força do habito, e a força do movimento.

O meio e a linguagem? Dúvidas da realidade? Se um indivíduo fala uma língua de outro país significa que ele é desse lugar? Ou poderia ser um pré-julgamento. Do que vemos, já indubitavelmente realizamos julgamentos sem averiguações? É costumas fazermos rótulos sociais quase inconscientemente. Ao ouvir em um shopping uma língua estrangeira, já se objetiva que essa pessoa é de outra origem, quando nem sempre é uma premissa verdadeira. Do que sabemos, do que podemos conhecer, do que lembramos? Situações pre-moldadas, para usar termos técnicos bem conhecidos dos engenheiros de obras, podem ser fatores para induzir a respostas que em estremos e mesmo assim, serão revertidas em feedbacks ao indivíduo, e mesmo sabendo que foram impróprias devido as situações que as originou, 
funcionando como uma cobrança indevida, bem apropriada para uma sociedade de consumo, então, o que desejamos aferir, e de que prumo? Quem prestará contas na ilusão?

Em que meio repleto de mentiras se pode aferir um comportamento fidedigno? Essa é sem dúvida a maior das ilusões. Jamais se pode aferir um comportamento onde ele ocorre em subterfúgios de mentiras, assim sendo, mesmo que o indivíduo não o saiba, em que lamaçal se encontra, a atmosfera desse ambiente é de uma patologia, absurda. A realidade, o convívio social, deve ser e estar permeado dentre uma razão plausível e consistente com veracidade. Portanto, e deixando claro que o que consideramos não ser válido para averiguação é o embuste, o que não condiz com os fatores que, consideramos de um religare apontados inclusive com a capacidade de percepção, de até mesmo religiosidade seja ela qualquer crença, digo isto em razão de estas possiblidades serem por muitos apregoadas de mistificações quando em verdade são caminhos de busca espiritual ${ }^{162}$ que em suma, clareiam o prumo e não o contrário, devem ser alicerce da razão. O que aqui diagnosticamos como sendo ilusório são condutas que na sociedade e como realidade não estão dispostas sobre um bem comum, pautados na ética, na lógica e condizentes com uma estética de um mundo evolutivo.

O lazer, o trabalho e a civilização tecnicista

O trabalho de viver é um dos quase relegado em considerações cientificas como propriamente fora do contexto, sendo que trabalho normalmente é enquadrado sobre outros termos, ficando vigente sobre o campo social visto sobre moldes, como por exemplo, empresas, organizações, instituições, enfim, o que é apregoado dentro dos padrões estabelecidos como mercado de trabalho, onde a própria vida parece não caber. Mas, no aqui proposto, a vida é produto de nosso tempo, e esse produto é realizado mediante esforço, mediante forças que interagem no organismo para que a viabilização ocorra e seja viável, sustentável, e onde podemos inclusive perguntar: $\mathrm{O}$ que esperamos de um produto? Como ele está sendo produzido? Que repercussões em meu ser, esse produto exerce? Culturalmente como ele se equaciona? Então, ao sabermos que o produto, é a vida, e o trabalho é o viver que o produz, o que isso significa?

De que maneira posso discernir sobre o viver, a civilização tecnicista e o lazer, considerando que o viver é o trabalho, a força que move o produto da vida, onde somos inseridos como mercado a céu aberto?

${ }^{162}$ Sousa, Carina Gonzalez Y. Composição. Caminho do vento. 
Veja que ao dispormos assim a vida, e o viver, como trabalho, podemos considerar que não há diferenças em distâncias como em trabalho e repouso, ou enfim, categorias de estado, mas sim, uma capacidade de exercer um movimento onde se permeia o modo de agir com responsabilidade e caracteres onde o fruto da árvore é o nosso bem estar, esteja ele na empresa, na organização, na família, no lazer. Em certo ponto, o ambiente virtual muitas vezes condensa esses elementos.

O urbanismo de uma cidade onde condensa o indivíduo e um certo número dos mesmos, demostra um pulso irradiado de vida, onde tudo se entrelaça, o movimento da cidade, de sua população, estando em campos de ação quaisquer mais conectados, vivenciando uma organização sendo propriamente um organismo. Encontrar prazer no trabalho, é um desafio ou uma constatação de alguns, podendo ser para muitos, dependendo da oportunidade ou na visão em perspectiva que o indivíduo tem para com seu envolvimento no que faz. O tempo e a maneira como nos deparamos com ele, ou nos engendramos nele, também ocorre mediante nossas escolhas, e para além delas, de que maneira realizamos o nosso tempo, um tempo dentro do tempo em significado, ou seja, aquele momento onde podemos sentir os segundos como um entardecer brando, ou aquele que nos surpreende com a capacidade de poetizar o cotidiano.

Tempo, lazer e renda disponível.... Qual o valor de uma felicidade? Onde ela está? A felicidade ou o que se pretende comprar? E agora? Ainda sabemos o valor de um sorriso, mesmo que ele esteja sobre lágrimas? Ainda sabemos o valor? O que temos? Sobrevivemos? Desejos e necessidades? Posteridade? O hoje ou o amanhã? Os dois? E depois? ${ }^{163}$ O que ganho ou perco, no trabalho do viver? Estabeleço metas, target, objetivos? Tenho clareza do que quero nesse meu viver, que inclui, família, organizações, enfim, todas as formas da sociedade, exercem sobre o cidadão uma participação que pode ser de ter as rédeas na mão, em desafios constantes a serem enfrentados, mas com propósitos bem claros, ou simplesmente ver o sol nascer, um dia após o outro, sem ter sentir o calor mais do que no corpo, na alma que nos move, no mesmo viver. Mas, onde tudo nos parece impossível, e na verdade sinto que poderia ter sido tão simples, porém, chego a conclusão que de fato, é e sempre será, difícil, amar. O tempo que se torna, seu. Quando o tempo se torna espaço. Razões de um viver. O tempo é distância da alma somente pelos que não sentem. Friedman se refere a possibilidade de haver uma ética do trabalho transformada em ética do consumo.

\footnotetext{
${ }^{163}$ Conto O valor da cidade, de Carina Gonzalez Y Sousa no livro Amanajé, contos e reflexões. São Paulo, Inmood 2017.
} 
Me parece que haveremos de ter ambas se conjugando, posto que o próprio cotidiano deverá estar inserido no contexto, onde o trabalho é a vida existindo e não somente a carteira assinada, e nesse da vida, nós ainda provemos o nosso pensar e agir para nossa sustentação enquanto seres em evolução e responsabilidade, em esforços humanos. ${ }^{164}$

A construção de um tempo ${ }^{165}$, a força de um viver, a marca, como passos, imagens e posteriormente monotipia.

O desvelamento de um modo de pensar em sinestesia de comportamentos investigativos nos entrelaçamentos das reverberações que se fazem desde a criação até o consumo e seus efeitos. Propomos um estudo que contemple fatores desse desmembramento que percorre vários elementos desde aspectos de sua origem até as plataformas atuais onde atuam essas formas de presença no existir, em tempos que a própria vida se faz consumo eminente na consciência de sobreviver. Produto, para além de um objeto, como pensar, como interagir, como ação responsável, onde tudo é mais além do que a percepção imediata. Compor um significado que atinja esferas diversas de seu público de maneira tal que preserve a identidade, ou ainda compartilhe modos de ser, são espaços sem fronteiras, para além da rede, marcas de um sujeito mundo, globalizado. Diagnosticar perspectivas como desafios e não como problemas, transformar e atingir valores reais que tem impacto de fato para a mensagem permanecer, são objetos dessa estrada investigativa, para viabilizar um caminho de horizonte aberto e pleno.

O desvelamento de um modo de pensar em sinestesia de comportamentos investigativos nos entrelaçamentos das reverberações que se fazem desde a criação até o consumo e seus efeitos. Propomos um estudo que contemple fatores desse desmembramento que percorre vários elementos desde aspectos de sua origem até as plataformas atuais onde atuam essas formas de presença no existir, em tempos que a própria vida se faz consumo eminente na consciência de sobreviver. Produto, para além de um objeto, como pensar, como interagir, como ação responsável, onde tudo é mais além do que a percepção imediata. Compor um significado que atinja esferas diversas de seu público de maneira tal que preserve a identidade, ou ainda compartilhe modos de ser, são espaços sem fronteiras, para além da rede, marcas de um sujeito mundo, globalizado.

\footnotetext{
${ }^{164}$ Considerando que os esforços humanos contemplam diretrizes que com o decorrer do tempo não somente a curto prazo mas a longo prazo preservem a natureza de uma estética como ética em logicas de condutas e práticas do bem estar geral, mas não somente discurso porém como avaliações perenes de resultados e objetivos.

${ }^{165}$ Sousa, Carina Gonzalez Y. Composição: A saga de um viver.
} 
Diagnosticar perspectivas como desafios e não como problemas, transformar e atingir valores reais que tem impacto de fato para a mensagem permanecer, são objetos dessa estrada investigativa, para viabilizar um caminho de horizonte aberto e pleno.

É fato que, atualmente a cultura de massa produz não apenas objetos mas hábitos, comportamentos, conceitos, ídolos, símbolos, ícones, representando anseios, desejos, individuais e de grupos. São os chamados valores simbólicos que, globalizados pelos meios de comunicação ou produção em escala mundial, provocam nosso desejo a todo instante ( BELCHIOR 2014 )

Consumo não é nem uma prática material nem uma fenomenologia da abundância, não se define nem pelo alimento que se digere, nem pelo vestuário que se veste, nem pelo carro que se usa, nem ela substância oral e visual das imagens e mensagens, mas pela organização de tudo isto em uma substância significante, é ele a totalidade virtual de todos os objetos e mensagens constituídas de agora então em um discurso cada vez mais coerente "( BAUDRILLARD, ano ainda a colocar )

O viver como ativo estratégico. Como salienta Ricardo Guimarães,

Um jeito de pensar e de fazer, que cria processos, serviços, que são adotados pelas pessoas, que são experiências que você cria, para um habito de consumo, para um tipo de serviço, nesse sentido, marca é uma cultura. A Marca nasce na empresa mas ela vive nos relacionamentos de mercado., a partir daí, você entende que marca é uma dinâmica de relações. É nessa dinâmica que é gerado o valor da marca. Processo contínuo de criação e renovação desse valor.

166

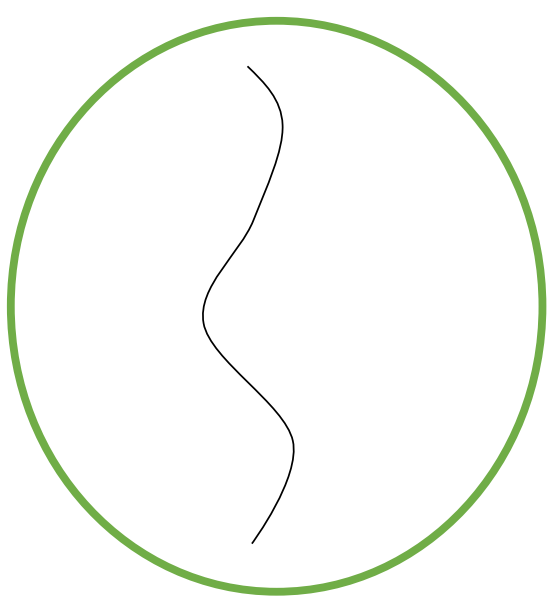

${ }^{166}$ Sousa, Carina Gonzalez Y. GEO - ACESSO. Símbolos da pesquisa da autora de estudos de geometria e corpo, física e tempo, pensamento e vida.. Do que desejamos para o amanhã, a cultura e o respeito a integridade de um viver em busca de uma harmonia, enquanto ser e pátria, corpo e alma. 
Se eu de ti não pertenço

Não posso te olhar enquanto seja

De outra manhã ou tarde teu beijo

Onde as horas ainda vagueiam porquê demoras

e em minhas lágrimas da alma choras.

Enquanto for assim os teus passos entre da infância na terra semente

Te espero no amanhã que tu tanto sentes

Como fruto do teu ventre

Que sabe o que já nasceu

Por entre teu pensar e sua gente

De um povo e alma que natureza luta

Sobre o suor da vida que labuta

Desde o sempre a liberdade

De justiça e igualdade

Por entre dificuldades como mares

e oceano dantes o quanto

sejam mesmas tempestades

Bravios se erguem como multidão

A fé e a esperança em uma Nação! 


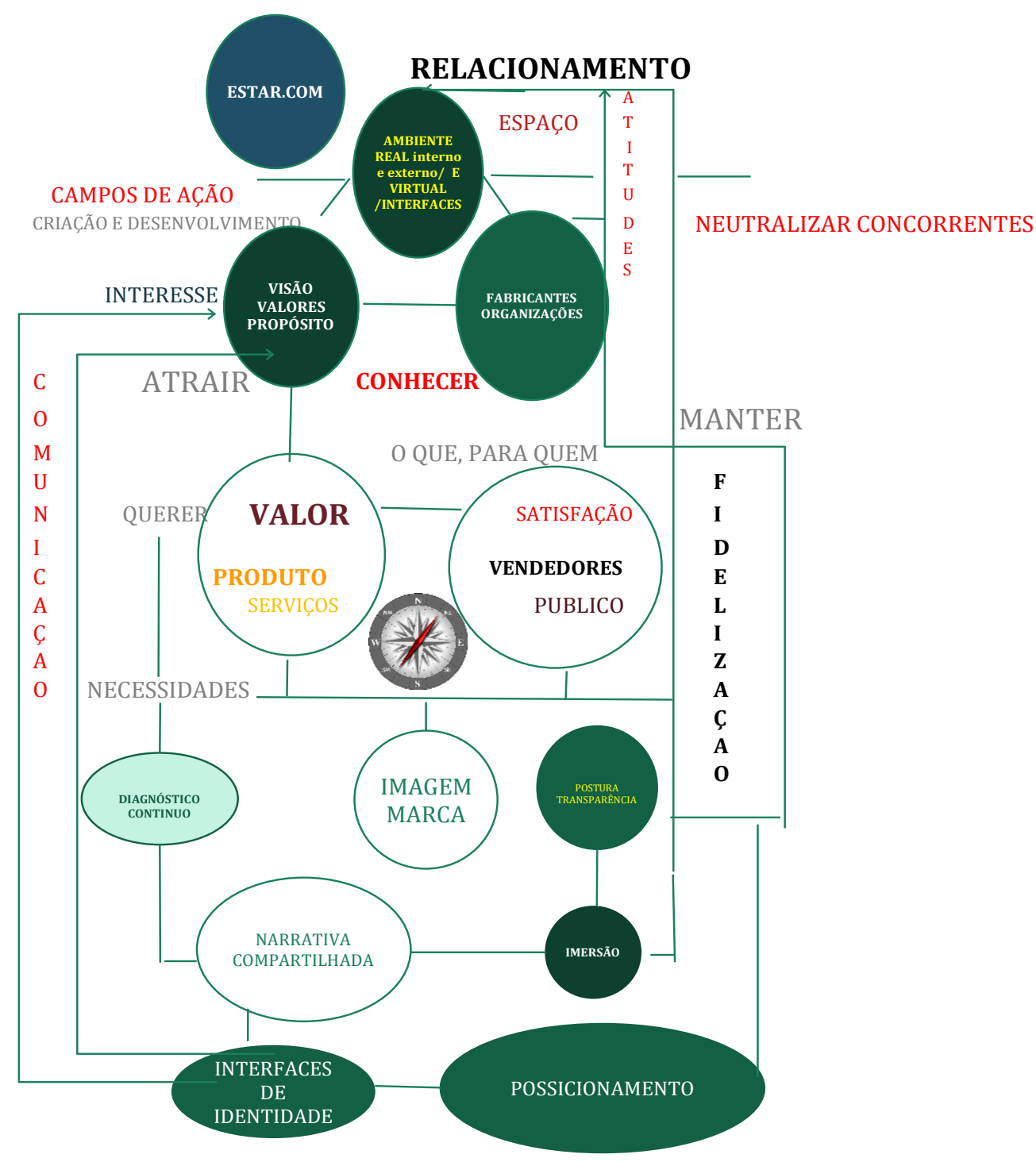

Posicionamento é englobar uma experiência que permaneça, que envolva e que desperte para sentidos posteriores. Onde tudo pode dizer algo. Estímulos em descoberta. O ambiente, a cor, o som, a luz, a organização, as formas do produto que valorizam o estar.com. Percepção e histórias de civilizações em background, cotidiano, como valor informacional, para além do fato, o ambiente, o contexto, os indivíduos, as culturas, os espaços orgânicos do pensamento onde reverberam atitudes e gestos em propensões futuras. Formas de conexão, identidade ou diversidade, ambíguos caminhos do ser e da cultura, do mercado e das escolhas, e o comportamento quanto a desejos e satisfações, caminho e identidades, vínculos e conhecimento. Em paralelo de sentido quanto a vida como produto de nosso tempo, como vai o nosso relacionamento com ela?

Marketing de relacionamento: É um conjunto de práticas que visa reter o cliente atual por meio do estreitamento da relação empresa-cliente. Para 
isso, é necessário que se consiga identificar cada um de duas vias e, por meio do acúmulo de informações fornecidas, adaptar suas ofertas às necessidades manifestadas pelo cliente ( Gordon, 1998, Vavra, 1993 )apud Crescitelli.

O que desejamos e queremos para o nosso cotidiano e de qual maneira traçamos o rumo para alcançar os nossos objetivos frente as relações do cerne da sociedade, trabalho, família, governo, ações participativas e em conjunto de um decorrer do tempo, onde pressupõe-se necessidades de escolha, onde estaremos dispostos ao crivo de sermos coerentes com a opção de valores, dentre o próprio caminho e a maneira de alcançar os desejos e objetivos. Aplicação dos modos de ser da razão, entre a consciência, o instinto, o conhecimento, a necessidade, e como dentre estes aspectos vemos o mundo,

Para o marketing, as necessidades podem ser convertidas em desejos. Isso se torna possível através dos benefícios que essas são capazes de trazer consigo. Os desejos são as necessidades humanas moldadas pela a cultura e a personalidade de cada indivíduo (SANDHUSEN, 2000). O marketing, ao transformar necessidade em desejo por um produto ou serviço específico, lida com os benefícios que esses bens de consumo possibilitam. Os desejos junto ao poder de compra constituem, para Kotler e Armstrong (2007), a demanda. Com o intuito de satisfazer as necessidades e os desejos dos clientes, têm-se a oferta ao mercado, onde produtos, serviços ou experiências são oferecidos pelo mercado, pretendendo saciar uma necessidade ou desejo de um indivíduo (KOTLER e ARMSTRONG, 2007).

Modos de pensar em áreas que podem se estabelecer em paralelo, são objeto de observação e compreensão, do que diz respeito a raciocínio e colocar em modos de ação comunicativa. Nos tempos atuais cada vez mais somos protagonistas de nossa própria narrativa, cenário em tempo real, e das coxias o pensamento se revela, ato corporificado sobre vozes múltiplas do ser que encarna o movimento de ser na atualidade sujeito ambiente, múltiplo e indivíduo em desafio de construção de sua identidade que permanece como espelho das reações entre os territórios do particular como do global. Esta pesquisa dentre o estudo de autores dessa área, considera o posicionamento atual como marketing vigente, $\mathrm{MKV}$, onde a forma como o próprio posicionamento se faz espaço, decorre da presença do seu tempo, ou seja, como está se comportando a sociedade atual, dos efêmeros gestos posso ainda extrair um significado que marque o suficiente para me identificar e que eu possa me relacionar? Ainda em paralelo, de aspectos do mercado, como dentre a diversidades de culturas posso assimilar e adentrar de maneira a conhecer o que estão dizendo, fazendo, em similitudes e diferenças, 
como modo de olhar e estabelecer uma perspectiva. Perspectiva, onde tudo pode se revelar outro nele mesmo, uma chave de observar o mercado e os produtos, assim como o pensar do desejo dos consumidores. Estar aberto para os caminhos da criatividade e empreendedorismo. Riscos e benefícios. Também, poderemos pensar sobre o posicionamento como identidade, linhas de ação que como uma digital, são o gesto que me constitui como imagem. Onde encontraremos, a missão, a estratégia, como imagem e marca em monotipia, responsabilidade e sustentabilidade, aspectos estes a serem contemplados quanto a monotipia sobre a passagem do ser no mundo. E, dentre os caracteres do MKV, em estudo de autores da área acrescentamos o posicionamento do consumo consciente, como parte do desejo, ciente de sua parcela no educar o pensamento para reflexo cultural e de atitudes dentre o indivíduo e a sociedade.

$$
\begin{aligned}
& \mathrm{P} \text { - PRODUTO } /=+ \text { PENSAMENTO - DESIGN } \\
& \mathrm{P} \text { - PREÇO } /=+ \text { VALOR } \\
& \mathrm{P} \text { - PRAÇA - DISTRIBUIÇÃO/ = + REDE - CONEXÕES } \\
& \mathrm{P} \text { - PROMOÇÃO / =+ COMUNICAÇÃO RESSOANTE } \\
& \mathrm{P} \text { - POSTURA / = + DESEJO CONSCIENTE }
\end{aligned}
$$

Onde retornamos ao modo de ser dos diagramas como lógica do tempo em pensamento progressivo.

- Desenvolvimento de competência

- Forma lógica - possibilidades - estrutura - movimentos.

\section{BUSCA CONEXÕES PROPULSÃO}

Fator da busca tratamos na concepção do que consideramos fundamental ser a estrutura de diagramas, ou seja, buscar corresponde a elaboração do processo mental conjecturando suas devidas consequências em vias de mão dupla no sentido da vida, como percepção, desejo, publicidade e consumo. O existir entra como modo de ser da reação, ou seja, após a idealização, na inserção direta no campo do viver. Campo do viver - segmentos - quanto mais conseguirmos abrir do instante para o contínuo, mas poderemos perceber o fator que promove uma unidade e minimiza os riscos. Porque? 
Segmentos se tornam compartilhados quando se procura absorver a noção de tempo de forma não linear, mas sobreposta. Papéis em mobilidade - compreensão da diversidade interna e externa. Como consideramos como arquiteturas, as demandas sociais, em diagramações de espaços reais, em busca e segmentos. Pensamento e ato, produto e mensagem, o pensar é um produto que sente ${ }^{\mathbf{1 6 7}}$ e gera nossa forma de viver e de conhecer, em todo lugar um sentido para se encontrar. Passamos a viver tão corriqueiramente que deixamos de perguntar o que é a vida. E sendo do contemporâneo a vida produto de nosso tempo, a indagação deve ser relevante para a busca dos desafios frente as demandas e soluções. Do existente ao propulsor - o que já é feito e o que poderemos fazer - O que mais pode despertar o desejo. Ações e impacto. A fusão da imagem pode-se dizer que está contida em um organismo que respira no ato de se encontrar em ressonâncias que permanecem entre o passado, através das referências latentes das lembranças como, índices referenciais, o presente, construindo uma realidade entre a representação, a forma como se apresenta e a imagem, como fusão condensando a lembrança, a informação presente que repercutiu no entre a lembrança, a forma, e o sentido.

\begin{abstract}
Além disso, apesar de a imagem entrar na consciência e na percepção, através da agregação, cada detalhe é preservado nas sensações e na memória como parte do todo. Isto ocorre seja ela uma imagem sonora - uma sequência rítmica e melódica de sons ou plástica, visual, que engloba, na forma pictórica, uma série lembrada de elementos isolados. De um modo ou de outro, a série de ideias é montada, na percepção e na consciência, como uma imagem total, que acumula os elementos isolados. “( EISENSTEIN, 1947, p. 20 ).
\end{abstract}

Se eu entendo o produto como um organismo vivo, um design, que tem seu ambiente, seu modo de ser e de representar-se poderemos mais devidamente informar seduzir e gerar os aspectos da publicidade e dos processos integrados da comunicação. O produto como narrativa se ancora em cenas que poderemos compor ou extrair de nossas próprias percepções e experiências. Consumo não é nem uma prática material nem uma fenomenologia da abundância, não se define nem pelo alimento que se digere, nem pelo vestuário que se veste, nem pelo carro que se usa, nem ela substância oral e visual das imagens e mensagens, mas pela organização de tudo isto em uma substância significante, é ele a totalidade virtual de todos os objetos e mensagens constituídas de agora então em um discurso cada vez mais coerente "( BAUDRILLARD )

Em se tratando de civilizações e culturas devemos considerar que os nosso passos constituídos pelas nossas escolhas, representados por nossas condutas são a marca de nosso 
tempo, e além desse sentido, reafirmamos que fortalece a razão de marca como valores conforme nos diz, Ricardo Guimarães:

Um jeito de pensar e de fazer, que cria processos, serviços, que são adotados pelas pessoas, que são experiências que você cria, para um habito de consumo, para um tipo de serviço, nesse sentido, marca é uma cultura. A Marca nasce na empresa mas ela vive nos relacionamentos de mercado., a partir daí, você entende que marca é uma dinâmica de relações. É nessa dinâmica que é gerado o valor da marca. Processo contínuo de criação e renovação desse valor.( Guimarães, Ricardo. )

Portanto realizar a vida como produto é ter discernimento, educar o pensamento realizar formas de uma lógica diagramática de maneira que viabilize espaços onde a sociedade tornase cultura fruto de relações permeadas ao conjunto de ações constituídas de ética. No mercado globalizado, conviver com o efêmero e o incerto, tornou a marca também, um jeito de ser, ajudando a constituir a organização de competências que reflete como a própria competitividade, sendo identidade e caminho.

Antropologia de um viver em tempos de razões oprimidas na busca da consciência em liberdade. A força de um viver ${ }^{168} .169$

Em meu pensar, não se deve considerar em hipótese nenhuma como premissa uma realidade onde a libertação seja uma ocorrência como efeito necessário obtido pela opressão. A liberdade deve ser como premissa de todo ser, como elemento de gênese, e não como reflexo de uma conduta conquistada pelo "advento "de uma opressão. Mas, fato será, que em

\footnotetext{
${ }^{168}$ Sousa, Carina Gonzalez Y. Composição Força de um viver.

${ }^{169}$ Sousa, Carina Gonzalez Y. Composição Vem de lá. Vem de lá, o barco da estrada, vem de lá, o braço da enxada, vem de lá esse meu lugar, vem de lá, essa força que canta, Espanta teus temores, Revela as tuas dores, Vem decifrar a fome do tempo, Não posso mais reter o sofrimento, Menino do mundo, suor que partiu, das perdas daquele que tua alma feriu, Perdoa e segue, assume a fé, a profissão escolhida, E vive para quem ama, $\mathrm{O}$ amor, que se pode ter, ensina a esperança, Que podemos sobreviver, Vem de lá, o barco da estrada, Vem de lá, esse meu lugar.

Composição: A mata- A Mata, VEM A NATUREZA me falar, na nossa vida. Que está esquecida de viver. A mata, verde dos olhos que são dos rios. Prantos vazios. Janelas cálidas. Do povo brando. Chorando tanto. Mata dos temporais, que incendiaram o nosso gesto, Humano desumano que não sabe crescer. Ai que dor é essa. Que rompe a terra. Desse nosso mundo. ESSA DOR DESSA FLORESTA, que é minha gente VALENTE. Que sofre e descontente SEGUE. O CAMINHO. Mata adentro, desse relento. Agora, vou por onde o destino me levar.

Composição: Espaço de uma nação: Viver... o espaço de uma nação. Na gratidão de ser feliz. Viver.... Na multidão de conquistar. $\mathrm{O}$ seu lugar. Em um raio de sol. Geração que quer sorrir e encontrar os braços do seu lar. Dia após dia lutar para ter o direito de viver. Aprendendo, vivendo e lutando. E não basta viver, tenho que sobreviver. Mesmo que árduo e farto de tanta injustiça. $\mathrm{O}$ tempo vira de onde eu possa trabalhar. E seguir com justiça. O retrato da lida. Não esquece a ferida mais. Segue e persegue o seu sonho. Para ser realidade. VIVER. Não basta sonhar. Eu tenho que aprender o que é amar, para ter LIBERDADE.
} 
opressões, que nos escravizam a carne e alma, necessário é sem dúvida o caráter da liberdade, mas, não que isso, seja o ideal. Penso que como direito de viver, deveríamos privar pelo respeito e integridade de todo ser, que inclui o outro, e assim sendo, a liberdade se constitui de outros valores e preserva a existência.

O recurso da liberdade existir como fruto posterior de uma opressão, não é o que queremos, apesar de vivenciarmos, por vezes, como ocorrência. Coloco dessa maneira, porque existem deturpações a meu ver, entre o que deve ser (futuro), o experiência da realidade, e o que deveria (como princípio sem deturpações).

Conviver com a existência como um diálogo de um distanciamento de nós, em nós mesmos, é árduo, mas não como pode ser exposto e receio pisar em ovos, quando tratamos de constatar uma difícil realidade, onde temos opressões não impostas, mas vivenciadas, e diferentemente, as que são impostas. Esta colocação é um diferencial de reflexão importante a meu ver.

Métodos atrozes não são condizentes com a evolução humana!

Não se extrai da pedra, à escultura pela violência ou opressão. ${ }^{170}$

A palavra, a emissão, gesto sonoro de um conhecer $^{171}$. O ser humano que vive, se expressa e a expressão é a palavra que conheço dentro do existir. Assim sendo, o que mudo se revela gesto, é palavra do verbo que se manifesta e existe. Todo ser que se expressa, está se

\footnotetext{
${ }^{170}$ SOUSA, Carina Gonzalez Y .Composição dos abusos de poder. Eu quero saber, Quando isso vai acabar, Eu quero saber. Porque eu quero viver. E assim não vai dar. Vocês me fazem só sofrer, Quando eu só quero amar. eu quero saber, Quando isso vai parar. Eu quero saber, que a vida vai continuar. Porque eu preciso seguir em frente. E a minha gente tem que sonhar. Eu quero saber. Porque não dá mais. Esse lugar de tantas feridas abertas. Não minhas mais de ti incertas. Foram tantas e tantas mágoas, que vocês não perceberam. Criaram a dor, achando que era amor. Criaram a dor, achando que era amor. Eu sei o que pode ainda ser, se você deixar nascer. O que não precisa acontecer. Porque eu já estava vivendo.

Composição: Os destroços- Eu vim por onde os destroços. Ficaram a céu aberto. Ninguém recolheu os pedaços de mim. Assim como folhas sem dizer e sem fim. Eu vim.... com a coragem de viver. Eu vim...com a coragem de viver. Do teu rosto e sofrer. Eu sei que as tuas rugas, são marcas de tuas lutas. E que eu não vou esquecer. eu vim....de longe... Para estar aqui bem perto, nesse lugar tão incerto, que é o teu viver. Mas é assim, é assim.... Que os lábios dos teus campos, nas brumas. Insanos vamos seguindo atrás de quem sabe a razão. Possa também entender que a emoção é nosso sangue. E por onde mais que eu cante.... vou dizer, que eu posso ser. Desses retalhos o teu pano que vai vestir a tua alma. Não há desengano, está na tua palma o destino. Recolhe agora, nessa hora, tudo que passou. Ficou para trás... É lastro teu. É lastro meu... Chegou a hora de dizer ADEUS. Vai nascer aurora, Vai raiar o sol, Vai chegar a hora...do calor e da paixão. Segue então, os teus desejos. Quem sabe ilesos vão ficar. De tudo que ficou no mar. Agora sopra, o vento devagar. E vai cantar.

Composição: Terra- Terra que o sol partiu, Terra que ninguém viu. Terra de agora e depois. Terra de águas distantes. Terra de rios e amantes. E mares... Terra de rios e lugares. DE corpos e almas. Dos sonhos do teu mar. Diário de bordo. A vista teu mundo. De hoje e do sempre. O teu velejar. Terra de todos nós. Terra que o sol partiu, Terra que ninguém viu. Terra que o sol se pós. Terra do agora e depois. Terra de águas distantes. De rios e mares. Todos esses lugares.

${ }^{171}$ Sousa, Carina Gonzalez Y. Canto som - FÊNIX.
} 
manifestando em sua liberdade, considerando o respeito tanto à sociedade e suas leis, como os demais.

Prefiro pensar em estruturas em vez de métodos, porque, podemos conforme a obra, realizar diferentes estruturas, e o caminho se torna livre, apesar de ter e saber de suas estruturas possíveis, o procedimento é em conformidade ao desenho. Paulo Freire em seu livro pedagogia do oprimido, considera:

A intencionalidade transcendental da consciência permite-lhe recuar indefinidamente seus horizontes e dentro deles, ultrapassar os momentos e situações, que tentam retê-la e enclausura-la. Liberta pela força de seu impulso transcendentalizante, pode volver reflexivamente sobre tais situações e momentos, para julgá-los e julgar-se. Por isto é capaz de crítica. A reflexividade é a raiz da objetivação. Se a consciência se distancia do mundo e o objetiva, é porque sua intencionalidade transcendental a faz reflexiva. Desde o primeiro momento de sua constituição, ao objetivar seu mundo originário, já é virtualmente reflexiva. É a presença e distância do mundo: a distância é a condição da presença. Ao distanciar-se do mundo, constituindo-se na objetividade, surpreende-se, ela, em sua subjetividade. Nessa linha de entendimento, reflexão e mundo, subjetividade e objetividade não se separam: opõem-se, implicando-se dialeticamente. A verdadeira reflexão crítica origina-se e dialetiza-se na interioridade da práxis constitutiva do mundo humano - é também práxis. [...] Distanciando-se de seu mundo vivido, problematizando-o descodificando-o criticamente, no mesmo movimento da consciência o homem se redescobre como sujeito instaurador desse mundo de sua experiência. Testemunhando objetivamente sua história, mesmo a consciência ingênua acaba por despertar criticamente, para identificar-se como personagem que se ignorava e é chamada a assumir seu papel. A consciência do mundo e a consciência de si crescem juntas e em razão direta, uma é a luz interior da outra, uma comprometida com a outra. Evidencia-se intrínseca correlação entre conquistar-se, fazer-se mais si mesmo, e conquistar o mundo, fazê-lo mais humano.( FREIRE, ano Pg 14-15).

E ainda podendo se estender ao corpo social:

Mas ninguém se conscientiza separadamente dos demais. A consciência se constitui como consciência do mundo. Se cada consciência tivesse o seu mundo, as consciências se desencontrariam em mundos diferentes e separados - seriam mônadas incomunicáveis. As consciências não se encontram no vazio de si mesmas, pois a consciência é sempre, radicalmente, consciência do mundo. Seu lugar de encontro necessário é o mundo, que, se não for originariamente comum, não permitirá mais a comunicação. Cada um terá seus próprios caminhos de entrada nesse mundo comum, mas a convergência das intenções, que o significam, é a condição de possibilidade das divergências dos que, nele, se comunicam. A não ser assim, os caminhos seriam paralelos e intransponíveis. As consciências não são comunicantes porque se comunicam, mas comunicam-se porque comunicantes. A intersubjetivação das consciências é tão originária quanto sua mundanidade ou sua subjetividade. Radicalizando, poderíamos dizer, em linguagem não mais fenomenológica, 
que a intersubjetivação das consciências é a progressiva conscientização no homem, do parentesco ontológico dos seres no ser. É o mesmo mistério que nos invade e nos envolve, encobrindo-se e descobrindo-se na ambiguidade de nosso corpo consciente. ( FREIRE, 2005, pg 15 )

Neste estudo colocamos sociedade e cultura em diálogos de compreensão contínuos, de maneira que a história ${ }^{172}$, o lastro seja partícipe de um educar em reverberações de ações futuras, rumo ao que poderá ser a coerência com a cultura sustentável.

Expressar-se, expressando o mundo, implica o comunicar-se. A partir da intersubjetividade originária, poderíamos dizer que a palavra, mais que instrumento, é origem da comunicação - a palavra é essencialmente diálogo. A palavra abre a consciência para o mundo comum das consciências, em diálogo, portanto. Nessa linha de entendimento, a expressão do mundo consubstancia-se em elaboração do mundo e a comunicação em colaboração. E o homem só se expressa convenientemente quando colabora com todos na construção do mundo comum - só se humaniza no processo dialógico de humanização do mundo. A palavra, porque lugar do encontro e do reconhecimento das consciências, também o é do reencontro e do reconhecimento de si mesmo. A palavra pessoa, criadora pois a palavra repetida é monologo das consciências que perderam sua identidade, isoladas, imersas na multidão anônima e submissas a um destino que lhes é imposto e que não são capazes de superar, com a decisão de um projeto.( FREIRE, 2005 pg20).

No meu pensar a palavra se aproxima das referências colocadas por Eiseistein, Para mim as palavras têm cor, forma, caráter; elas têm rostos, partes, modos, gestos; elas têm temperamentos, humores, excentricidades - elas tem matizes, tons personalidades. "( Hearn apud, Eiseistein, 1947). e de maneira mais aprofundada ainda neste estudo no objeto da metáfora argumento e reflexão em cognição do próprio manifesto poético enquanto estética e do queremos acreditar para tornarmos em nós em pensar e agir, o desenvolvimento que almejamos.

Antes, porém, conscientizam o poder criador dessas palavras são elas que geram o seu mundo. São significações que se constituem em comportamentos seus, portanto, significações do mundo, mas suas também. Assim, ao visualizarem a palavra escrita, em sua ambígua autonomia, já estão conscientes da dignidade de que ela é portadora - a alfabetização não é um jogo de palavras, é a consciência reflexiva da cultura, a reconstrução

\footnotetext{
${ }^{172} \mathrm{O}$ autor Paulo Freire, aborda que a historização tem co o produto o próprio diálogo, constituindo o próprio movimento da consciência, onde a mesma se faz pelo comunicar-se com o outro. havendo de a educação ser a prática da liberdade, sendo que a palavra tornando=se gesto da sociedade é ato do pensamento em expressão do seu tempo. Trabalho em viver.
} 
crítica do mundo humano, a abertura de novos caminhos, o projeto histórico de um mundo comum, a bravura de dizer a sua palavra. [...] A palavra é entendida aqui como palavra e ação; não é o termo que assinala arbitrariamente um pensamento que, por sua vez, discorre separado da existência. É significação produzida pela práxis, palavra viva e dinâmica, não categoria inerte, exânime. Palavra que diz e transforma o mundo. / A palavra viva é diálogo existencial. Expressa e elabora o mundo, em comunicação e colaboração. O diálogo autentico - reconhecimento do outro e reconhecimento de si, no outro - é decisão e compromisso de colaborar na construção do mundo comum. Não há consciências vazias, por isto os homens não se humanizam, senão humanizando o mundo.( FREIRE, 2005, pg21).

Presume-se que a palavra deva ser nela mesma consciente de sua profusão havendo de estar sempre sobre a consciência de maneira a não ser tornar objeto de dominação, muito menos a outrem de submissão. A liberdade deve estar no cerne do gesto da palavra como constituinte de sua integralidade, havendo, portanto em seu uso de ser coerente com sua origem enquanto partícipe da consciência da maneira como já dispusemos em nosso pensar sobre a relação razão e consciência. Agora, quando o ato de liberdade está imbuído de responsabilidade nos acercamos de uma maturidade social e individual. E responsabilidade também se acerca de elementos que colocam a liberdade dentro de não um simplesmente ato sem consequências, mas, justamente o contrário, um ato que em liberdade se apresenta frente a considerações de suas reverberações, porque se alicerça com a presença da responsabilidade. Simplesmente dispor sobre liberdade e medo, sem colocar mais claro as conjecturas, creio que poderemos incorrer a algo imaturo, com todo respeito, mas penso que deve ser aprofundado em razões e questões de origem, contexto e progressão.

Em se tratando de pensamentos e atos quer sejam sob o objeto do interior humano ou da face governamental, a palavra realizada discurso, conduta se estabelece e deve ser em seu caráter de liberdade intrínseca de sentido que corresponda de maneira integra ao mesmo em reverberação aos demais, assim acreditamos que a dominação ou subjugação é prejudicial a qualquer sociedade que deseje uma cultura humanizada, portanto, podemos também ressaltar que a reação por parte individual ou de um povo, mediante a opressão, quando na presença de medo, coação, estados de privação de direitos, torna-se uma dificuldade, de graves consequências. 
Sociedade responsável? Entre partes "iguais", a liberdade? Da terra ${ }^{173}$ e a enxada ${ }^{174}$. De onde plantamos, podemos colher? Tenho por onde arar no concreto das cidades des (humanas)? E, do que queremos, saciamos de onde? Estou saciado de queixas, de reclamações, e mesmo descalço, não quero caminhar, ou não tenho ar para respirar? Quais minhas opções?

O que é a liberdade? Difícil responder, mas para não nos furtarmos de nossas lutas, creio que merece ao menos considerar que para além da responsabilidade que nela se faz, necessária, penso que devemos refletir que uma coisa é ser, ter e outra, permanecer. O permanecer em estado de liberdade, é uma constante de uma equação da vida, dentre variáveis que se aproximem, que apesar da luta e justamente por ela, e sendo, e tendo conquistado, se preserva e permanece. Enfim, estando no mundo creio que é uma palavra de sentido, composto com a realidade, então presume-se que seria bom para os primeiros passos, refletir sobre, quais seriam as responsabilidades implicadas, para não considerar que estivesse implícito nessa responsabilidade o caráter de uma exigência que tenha um valor que se volte justamente contra o que o firma como base da liberdade. Portanto, a responsabilidade da liberdade é consciente. Ou seja, implica em um estado capaz de considerar deveres sociais, onde a responsabilidade da liberdade inclusive transita entre o indivíduo e a sociedade.

Sociedade marcada a ferro? Em qual parte? Gênero, pad(t)rão, ou não..., escolaridade ou então...? Apenas mais uma forma de opressão. Por onde vamos?

\footnotetext{
${ }^{173}$ Sousa, Carina Gonzalez Y . Composição: A terra para plantar. Eu vi a terra para plantar. Da procura do meu lugar. Eu vi a terra para eu trabalhar. A estrada por onde eu ira passar. Eu vi, a semente que iria brotar. Sobre a chuva ou o calor. Lugar vazio da minha dor. Plantação. De todos os olhares. Lugares de todos os campos. Verdes tons, amarelos, quantos fores, sejam teus...árvores que crescem e florescem como o amanhã. Eu vi a terra para plantar, o rio para colher, nas águas da vida, o que pode ser. Manhã de sol, eu te vi crescer. Como se fosse o amor. Dentro da alma e do meu ser. Camponês que sonha, em viver para dizer, o alento de um viver, vida que canta, canta. Vida do ser, campo que lida, o trabalho que ensina, a terra, a semente e o fruto. O vento, lugares do mundo, ouça...ouça...brotar a emoção dos teus olhos marejados, como tua plantação. Lágrimas sugados, dos lugares da estação. Partiu, ficou a terra... o vento levou a semente, canta agora a sua gente. Canta...canta...canta.

${ }^{174}$ Sousa, Carina Gonzalez Y. Composição: Ciclos - Esteve aurora no cio, Cidade humana e rio, desmatados da alma. Calma do sol valente. Gente urbana erguida. Sobre destroços de lutas sofrida. Esteve a aurora no rio. Cidade humana. Desmatados. Atados aos edifícios. De vícios contidos no tronco. DE escravo e senhores do tempo. Espera da igualdade. O movimento. Espero chegar as trilhas abertas. Do respirar, ar, o ar. Esteve a aurora em que hora? Esteve a cidade e o rio. Ouço criança que chora. E agora, o ar, o ar. Esteve a aurora no cio. Cidade humana e o rio. Desmatados da alma. Calma do sol valente. Gente urbana erguida. Sobre destroços de lutas sofridas. $\mathrm{O}$ ar, ar, ar....
} 
Sociedade marcada a ferro? Em qual parte? Gênero, pad(t)rão, ou não..., escolaridade ou então...? Apenas mais uma forma de opressão. Por onde vamos? Anúncio na face da terra: Propriedade, de nome liberdade: Não está a venda.

Como vão falar de concepção bancária, creio que podemos fazer algumas alterações de saldo.

Existem certos, parâmetros que são como diagnóstico de uma boa reflexão, porque se não corremos o risco de inverter certos sentidos, quando se observa como uma impossibilidade cognitiva. Por exemplo, me parece que sempre teremos uma relação próxima entre o que é da ética e o que é da liberdade, e em alguns momentos, essa aproximação, torna-se acirrada sendo que onde talvez coloquemos limites, possamos talvez enxergar como a ausência de uma liberdade, quando, trata-se do respeito a liberdade do outro, ou de regras sociais. Então, considerando, uma cognição onde não se invalida a integridade de um sentido, podemos avaliar contextos dentre relacionamentos significativos de opressão e liberdade. Até onde, não deixemos de caminhar. E ainda, onde ancoramos o respeito justamente como base da educação que deve permear todo o raciocínio que discorre sobre esses meandros difíceis de convivência.

1.3.Sedução, cumplice do desejo, latência do existir.

Libido $^{175}$ da cúpula do existir, prazer do mundo.

Onde mora o desejo, nômade do ímpeto, arfar da volúpia.

Apresenta-me

Aceno. Esse instante de mão estendida, revelados. A realidade apresentando-se enfurecida, serena, desmedida, ou não, espera a presença que engole o ar, esquecendo-se que já a respira.

Nasci, a tanto tempo que não me lembro mais.

Inspira-me ao viver, e novamente respira, e sem perceber, EXISTO.

Realiza-me. (SOUSA, 2018, pg 79-80 ).

\footnotetext{
${ }^{175}$ Dilemas do homem que atravessa o tempo, e se transmuta perante a própria vida em indagações. Capítulo IX do livro Cidade de Deus, pg 1295. Sousa, Carina Gonzalez Y. E arquivo em áudio de depoimento para teatro, texto: libido. Ensaios poéticos teatrais, poema obsceno, em texto e um áudio em vídeo.
} 
Quase como uma estamparia nos representa em nosso jeito de ser, os contornos constantes de nossos interesses e vontades, consumindo-nos, por certo, quase que de maneira inadimplente frente a uma razão. Argumenta-se um possível modo que se altera mediante a constatação de que o desejo não se extinguiu, ou se desfez, apenas movimentou-se, passou a habitar outro lugar. O que fez então, essa alteração se tornar evidente e plausível de ter uma razão que a motivou e inclusive podendo ser investigada, como podendo validar outros possíveis movimentos, ou seja, o que me interessa, para que eu deseje? Em certo ponto, se nos acercamos do desejo ser um movimento, podemos considerar que o estado amortizado que a sociedade; compondo, dentre os indivíduos e o ambiente, se encontra, sofre de uma perda? Ou ainda que não sendo uma perda, mas um corpo desnutrido da alma do viver, assim sendo, destituiu-se do que para assim se encontrar?

Posso me libertar do desejo, ou ele é parte do existir? Será naturalmente um "instinto

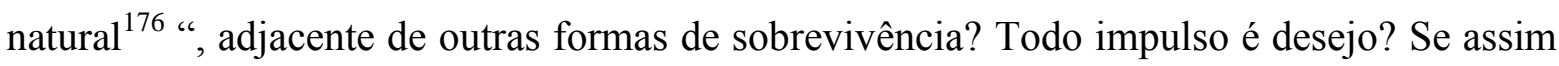
for, posso compreender o impulso vital, como propriedade dos elementos do viver, ou será apenas uma questão de palavras e significados, desmembrados e não solucionados com suas correspondências. Haverá de ser a ação da palavra, seu jeito de ser no mundo, a melhor maneira que a represente, e portanto, me pergunto, quais as condutas do desejo? Teria que me aproximar do modo de ser do desejo, e conseguirei adentrar esse, ser de um sentimento, extraindo possíveis lugares onde ele habita e se mostra, além e principalmente da sua superfície.

Sobre os caminhos da cultura, nas indagações do viver, o que perguntas é porque desejas somente me indagar ou porque desejas compreender?

Destino

Desejo deixar outra vez

Por entre os outros desejos teus...

E que posso, então, te dizer...

\footnotetext{
${ }^{176}$ Instinto aqui como o que é em paralelo da natureza da presa, do adquirir como Bauman em um de seus livros considera. E na relação com o desejo sobrepomos estados de apreensão na sociedade de consumo, onde indivíduos concebem sua natureza dentre o mercado da vida como elemento de produção e aquisição, e como diz William Irvine, el deseo mueve el mundo.
} 
Que os livros esquecidos, não partam

Diante dos olhos que tuas palavras abraçam

E retém de tantos inconfessáveis seres

A tua mais contida, expressão que me despertou

Por entre as camadas de tuas noites,

A debruçar-me como lençóis de tua pátria, percorrendo-se

Alcance de um sentido, para viver,

Querer o que mais que se possa desejar

Um simples ser disposto a amar, o que

Defronta-se como sua razão,

Como seu gesto amargo,

Como seu fiel passado

Que não se desfaz em máscaras

E que te olha de frente,

E cada vez mais reflete a lucidez do tempo

Que te recolheu entre todos os desejos

Para que voltes a caminhar o destino

Que a muito tempo, e em eternidade

Deseja, estar a seu lado.

Localizar o ímpeto, a vontade, o que cerceia um desejo, a saciedade ou o álibi dela, dentro da sociedade e a formação da cultura são dilemas a serem observados sobre do que concebemos ser a necessidade, satisfação, motivações, escolhas, consequências e diante desse prisma, o que pode ser aferido como gestão, gerando para além do movimento do desejo, nas intenções, o que dele implica em novos impulsos ou ausência que podem todavia serem diversidades apontadas, dentre o que temos ainda de livre-arbítrio, razão e consumo consciente. Arguir o próprio desejo livre de impulsos, estabilizado por necessidade ou por adentrar a face entre desejo e razão, remete-se ao porquê, e dentre esse querer, os fatores são elementos cognitivos ligados a vários posicionamentos úteis a quem irá ter o objeto de despertar a vontade, portanto o que antecede, por onde o desejo desperta é razão de 
elementos que farão a diferença, em escolhas, parâmetros e futuras aquisições. Este fator aproxima o que somos do que queremos.

Razões e territórios, sejam de saber, de itens do mercado, enfim, de qualquer forma o movimento se faz presente como lógica de consumo, estética do desejo. Retornando ao sentido, palavra e imagem, ao alcance da mente ( diagramas ) e correspondência aos fatos e relação individuo-sociedade ${ }^{177}$, diálogos de convergência e divergência se estabelecem permeando o estado de desejo, alimentando-o em sua busca, estabelecendo lucidez quanto ao caminho de conquista, sobre os meandros do impulso e a razão, não deixando de mover a relação dentre o ser e o ter, como razão e territórios onde a exploração é o próprio ato de consumir, porém, tendo em justaposição de argumentação, o produto aqui é o próprio viver, e portanto, dentre o que somos, o porque de nossos desejos, enquanto objetivos e objeto em interfaces mutuas de destino, se aproximam e se procuram como indivíduo e sociedade, com a imersão do desejo da própria cultura, cabendo dizer que são subconjuntos de acoplamentos onde o sujeito múltiplo discerne sobre si e o que quer, não somente nele mesmo, havendo de pelo educar o pensamento compreender que o desejo alcança o posicionamento da sociedade, entre a razão futura.

O sentido do desejo, e o ambiente da felicidade. Me parece aqui, um ponto de fato muito importante a ser ponderado pois, quando entre o ser e o ter, se coloca a felicidade, o sentido do desejo está questionando-se em razão perante uma parcela de consciência. O quanto que aprendemos sobre a felicidade do que se apresenta no que somos, e o que queremos adquirir, e o que nessa relação estabelece a ponte, ou seja, dentre o que sou, e o que quero, quais conexões me satisfazem perante ao que me torna feliz no viver, o que resulta sobre o como se representa o nosso modo de olhar o mundo. Existe um lugar a ser aprendido que se faz espaço enquanto movimento, e isto requer uma abertura de pensamento, capaz de olhar o que se move partindo ou indo em direção ao querer adquirir, como o objeto passível de presença interna.

Podes me aconselhar a ver sobre as montanhas os vales dos teus olhos e lacrimejar ainda pela lembrança na minha alma do dia em que partiste. E, porque então eu iria compreender, se a razão a ti pertence nesse lugar que você deseja que eu habite, lar da distância se fez, de onde o sempre buscou a tristeza de se reconhecer, incompreensível do que prometeu, querer e não querer. Porque como posso então, seguir desse caminho, sendo outros de suas palavras

\footnotetext{
177 Do desejo em sociedade a "culpa" da desigualdade social, carências, adjacências, espaços urbanos de um viver. Arquivo de áudio da série Depoimentos. A culpa.
} 
que a mim apenas destilam a safra que não foi cultivada em minhas terras e não bebeu da fonte do meu ser, desafiando somente o eu que você queria fazer viver. Que será então do tempo, esse que tantas vezes nascimento, se destoa ao jazer a cada segundo em direção ao que lhe diz, devorando-se e insaciavelmente. Paro diante do que recebo, ainda de braços abertos ao recolher-me um tanto incerto desse existir que me parece, somente teu. E desse ato, não sei mais as falas. Percorro minhas escadas onde os degraus me perguntam, para onde eu desejo ir?

Indivíduo e sociedade. Povo e cultura. Cidadão e governo. Querer-te continuamente, é meu maior desejo ${ }^{178}$. Para tanto, não nos deixamos morrer. E desse abraço que trocamos, nos amamos sobre nós dois, eternamente e depois.

Havendo de ser novamente, o que poderá viver. O que de nós mais feliz haverá de ser. E, desse sentimento que nos acomete ainda que nos penhascos das dúvidas. Será nosso voo, porque é das asas o azul celeste. E das nossas profundezas o oceano que me destes. Então das águas minhas e tuas reflexos de nossos atos consumados estaremos nós dois, onde tudo será apenas um começo do infinito desejo de ao lado seu, viver. Mesmo que possamos um dia não mais nos pertencer, e sermos outros de nós e quem sabe? Somete o amor responde, se ele de alguma forma também outro, ficou em nós.

Enigmas? Aprisionando o destino, sufoca o tempo no ensejo de fazer realidade as páginas passadas que agora não mais serão verdade, ou estão sendo outras passagens da frase retirada de nossa sala, ou de momentos vividos, por onde esperava você entrar, mas hoje sei, que se não há razão porque haveria então de lhe ver chegar? O esquecimento seria o desejo do ontem? Entre o passado ${ }^{179}$ e o futuro, as condutas atuais, nem tão longe e muito mais perto. Ao considerar a exploração de uma consciência não factual dentre o desejo de conquistar um mundo melhor, espaços entre nós.

Habitar o espaço de nossa memória refazendo-se mesmas conjecturas sociais sobre a linha do tempo, onde a exploração permanece e a luta por direitos também.

Desejo me esquecer até saber quem sou. E desse lugar imaginar quem posso ser. E, nessa distância na qual vou pertencer, um dia quem sabe quantos serão possíveis de se ver, para que eu não me perca, do que esqueci e do que sou.

\footnotetext{
${ }^{178}$ Sousa, Carina Gonzalez Y. Composição: Alma de um destino. Tabla e Guitarra.

${ }^{179}$ Galeano, Eduardo. As veias abertas da América Latina.
} 
Feliz eu posso ser do teu sorriso

Triste eu sinto o amargo das tuas lágrimas

E insisto em não lhe ver do que possas ser

E turvo então o meu olhar ao também amar

E como posso derradeiramente estar

Infeliz do teu jeito que me olha

Como quem apenas sente em despertar

O querer que desmente a outra face em viver

Continuamente sua verdade de apenas

Ser

Sobre aceitação, diz da terra um ancião: Passei a vida inteira desejando, até compreender por fim, que essa era a própria razão de minha busca.

De que maneiras posso desejar? Especiarias da vida nos valores contemporâneos do mercado cotidiano. Da noite que podem ser as estrelas por onde um dia navegamos, rede de desejos conquistamos ou entrecruzamos em travessias que habitam territórios contemporâneos de condutas, onde ainda procuramos as estrelas sobre o espaço da condição humana.

O ímpeto do desejo - o reflexo e a face do absurdo.

Cada vez mais parece que o desejo como forma que emerge, realiza mais de um movimento, ou seja, nasce do mundo convidando-nos a despertar em seus braços ou de outra maneira um ímpeto que em nosso interior se manifesta inquieto, repercutindo vibrações que irão nos tornar, movimento, porém, em que direção?

Onde pode se encontrar a razão quando, habitamos a morada do sentimento?

Impressiona-me com tal força

Que dos teus braços eu não perca

A tua própria fome em saciar

$\mathrm{O}$ ar que eu mesma respiro

E vivo para em ti representar

O desejo constante de amar. 
Impressiona-me ao marcar a fronte

Do tecido de meu corpo em tua razão

Face que não se desfez, a emoção

De viver a qualquer tempo e aonde

Estiver a paz de seguir a mesma chama

Que não cessa e não perece porque ama

E não se cansa de arder

E não perece porque clama

O próprio infinito desafiando segundo

Luz do ontem de toda manhã.

Do que o solo da terra soa, Blaise Pascal diz “ O coração tem razões que a razão desconhece. “, e nos compassos ressoa em meu dizer: Porque te entregas ao afeto, não respira a luxúria que afago? Desperto o sentimento recebe o ritmo de tua alma em me pertencer, no pulso de sua própria liberdade. Então percorre sem pudor mais uma vez o que te percebe mais que tua pele ao te cobrir dos desejos mais insanos e de todos aqueles que proclamo, no gesto, brado e árduo, de tocar. Será então os mundos, um som, percorrendo a saudade de já pelo amor sentir, a tua presença, na eternidade. Entre desejos, realidade e nossas memórias históricas? Objetivos e interesses ( sem befles ). Do "jogo“ da vida, quem tem as cartas ${ }^{180}$, ou de quem é a vez. Um dia da presa e outro do caçador? Acabou. Ecossistema como presa e caçador, diálogos do mesmo lugar de sabor, onde engula se for capaz. E resta saber, se haverá in (digestão), ou o vômito colossal em re(verso), de onde a fome não bastou, do que precisa ainda saber sobreviver. E pasme, não somos apartados da natureza, somos território e carne do mesmo lugar. Então não adianta deter o sentido da escravidão, somente nas correntes de um passado onde nem ainda vemos do que não somos apartados e vivemos acorrentados a uma soberania humana frente a natureza que não tem sentido, e que deve acordar para os direitos do viver em igualdade.

\footnotetext{
${ }^{180}$ Sousa, Carina Gonzalez Y Sousa. Composição AS cartas da vida. A vida é um jogo de cartas de marcadas. Por onde se possa ainda escrever. A vida é um jogo de cartas marcadas. No baile de máscaras. Por onde lhe ver. Será que se possa não perder a esperança. De um dia quem sabe a criança. Viver um mundo e ser feliz. Quem sabe será esse o destino que se quis. De tudo e sempre nosso querer aprendiz. Até onde se possa nascer, como fruto nosso de cada ser. Um futuro melhor para se viver. Semente da vida. Das casas da rua. De pedras ao chão. Ainda se pode ouvir. Um coração. E não se esquecer. Que se eu me perder. DA vida o jogo. Eu não vou querer. Da vida e o jogo. Eu posso sofrer. Mas as cartas marcadas . Eu vou devolver. Meu tempo da vida. É sobreviver. Escrever o meu nome. Liberdade de ser!.
} 
Os estágios e a gestão dos desejos. Sujeito ambiente, ambiente mundo, naturezas mesmas. Desejo de sobreviver. Na alquimia dos sentidos do sentimento posso desnudar seus modos de ser? Falando em exploração e liberdade. Aqui cabe o posicionamento do(s) outro(s), afinal, se meu desejo se encontra em sociedade, de qual a outra parte?

As rugas dos desejos, fendas de nossos caminhos. Desejos e o alcance em possibilidades, o inatingível e o existir. A sociedade em campo aberto e minado? Por onde seguem as águas do rio do sangue de um povo?

Estive a tempo contemplando a mesa, o caderno, e um lápis, objeto ou pessoa desejando a expressão de um pensamento. Pensamos o desejo de existir sobre a palavra que nos fazem compreender o mundo, mesmo que distante nos pareça e meus olhos um tanto cansados do tempo ao se depararem com teu ímpeto, se recolham antes que as águas que nos banham me deixem sobre as margens sem saber onde o destino nos levaria. Segura-me, mas desejando ir-se, porque não nas pedras, areias do ser, desejo escaldante de se ver. Porque não? O ser que se foi. Será ontem menos de si mesmo, porque vestiu-se para o amanhã? Serei desafio de traçar natureza de todo rio que me leva consigo, pegadas.

Deixei contigo, escutando o pulso de onde viveu, o desejo.

Quais os desejos da sociedade? O momento em perplexidade, vida que se pergunta, aonde vamos. O cotidiano nos embriaga! E por certo, como bem dito, por Irvine, " la verdade es que la vida carece de sentido".

Sobre uma geologia da compreensão. ${ }^{181}$

Precisamos uns dos outros, e onde fica essa afirmação nas guerras que travamos sem armas, mas no cotidiano? Guernica do Brasil ${ }^{182}$, bombardeio social, na sociedade sem fronteiras onde o outro se manifesta. A liberdade e paz interna, talvez seja uma luta travada conosco para que compreendamos suas extensões aos aspectos sociais que em suas reverberações se fazem no âmbito social. O que queremos, buscamos em nós? Estabelecemos o que cobramos socialmente em nosso convívio interno? A paz do outro me interessa?

\footnotetext{
${ }^{181}$ Sousa, Carina Gonzalez Y . Composição- Vem dizer pra mim. Vem dizer pra mim, que o teu peso do mundo é tanto. Vem dizer pra mim. Vem dizer pra mim, que o teu peso, do mundo é tanto. Vem dizer pra mim, que da janela eu posso ver, o que não sei mais de tanto carregar, não sinto mais.... calçada vazia...de noite ou do dia...os sonhos perdidos, que eu percorria, distâncias da vida... vem dizer pra mim, vem dizer pra mim, vem dizer pra mim, que um dia enfim... posso lhe ter pra entender, o que do mundo possa ser, o teu sorriso... paraíso, que existe no teu querer...no teu ser, onde eu passei, a te procurar, tempo dos templos do mundo que é um segundo, infinito pra saber, o que pode ser, esse viver. Diz pra mim... diz pra mm.

${ }^{182}$ Sousa, Carina Gonzalez Y. Guernica do Brasil, texto do livro, Amanjé contos e reflexões.
} 
Necessitamos compreender a dor do outro, e ainda perguntamos como posso conviver com isso? Adquirir em meu pensar também o que é do outro que não somente felicidade? Superamos o cotidiano amortecedor? Ou ele é tão parte de nós, que nem mesmo há nenhum outro, ou outros a serem parte de nós. O texto fala da privação do contato humano e os temores dessa possibilidade. Entendo, e claramente posso interpretar pelo ponto de vista mais explícito, porém, reflito sobre a possiblidade de qual contato humano estamos falando. $\mathrm{O}$ aspecto físico a meu ver, é um princípio afirmativo, que em meu ponto de reflexão pode ser alargado, para o campo da sociedade atual, em que arames farpados estamos sobrevivendo nesse contato com os outros, que tanto sejam os outros de nós mesmos ou os outros indivíduos que estão gerando nosso tempo atual, onde quer seja o contato dito " real “ ou virtual, em que muros estão as nossas relações. Ou, acaso estamos dizendo da liberdade como roupa onde a pele está sendo sufocada sem perceber frente a sortilégios ( como mais uma máscara social ) que precisam de verdadeiramente escolhas como condutas ainda por serem feitas ou estabelecidas pela presença do discernimento frente a constatação do convívio entre todos esses modos de ser vigentes, outros, por fim, existentes.

O lugar que construímos, onde o outro pode estar e onde será também o nosso lugar interno e externo.

Se, a solidão te inquere

Desejos múltiplos me tomam

Por estar em outros tantos

Quantos outros me façam

Perceber-me, só.

Esteja assim em descoberta

Incerta me parece, até quando

Da multidão, todavia esteja

$\mathrm{O}$ eu recoberto do silêncio

E se por ventura da suspensão

Do vento possa adentrar-me

As vestes do edifício, serão espaços

Compartilhados, e passagens de

Onde quem parte ou é chegada, sendo apenas

O princípio da resposta. 
Eis da dúvida o meu sangue

Posto como tanto ar que me faz viver

Que é do outro o que respiras.

Vivo despetalando-me

Para reter o aroma que do tempo

Permaneceu sentindo-nos

Naturezas devorando-nos frugalmente

Vazios germes brotando em

Territórios diversos

Do local que é sulco

E o destino é a terra.

Desejo, satisfação e o relógio? Mecanismos absorvidos dentre o mecanismo do viver e a vontade.

Abre assim meu corpo, sem desaguar a alma

Do ser que respira meu dorso, mas

Não será de minha palma o toque, do desejo

Porque perdeu-se satisfação

De onde queria estar, entre lugares distantes

Disfarce para ser lugar, nosso.

Se, o beijo saciou a fome

Consome agora o tempo

De abraçar os mesmos lábios

Onde sugou o gesto, passado

Que escorreu do teu sentido

Recolhido como sentimento, dizendo

Pulso, da dor que não satisfez

O estomago vazio da tua alma.

Então, espera do vento, a noite 
Porque o dia se foi na lembrança

Que me ateve por fim internos

Momentos dos segundos só seus

Do mesmo beijo que ainda não me disse adeus

Permanecendo, jangada na areia

Sobre os grãos e o mar do sol.

Queria o desejo, que no impulso vagueia

Onde não mais as palavras esperam

Que dos mesmos olhos eu leia

A imagem que o pensar saboreia

Sem lhe ter na presença de amar

Amando mesmo assim onde

Se desafia o corpo que esconde

O lugar da alma que se apaixonou

Pelo teu sabor

E que por fim, desafia-se

Desejo.

Satisfaça-me, sem devorar

Aqueça-me, sem sufocar

Abraça-me com prazer

E me ame, sem esquecer.

Importa-se?

Já percebeu o quanto que os dias não são suficientes?

- Suficientes?

- Quando o desejo nos invade ou nos vira do avesso, o tempo passa a não bastar e uma certa capacidade de esperar ou mesmo parar o relógio passa a ser como a pele que nos contorna e mesmo o tempo todo estando conosco ainda transpira, sente frio, sobre os poros te ( nos ) observa e não cessa jamais de perder-se na volúpia contínua de te encontrar. E que será 
então, do momento insuficiente para deitar-se com a eternidade, arfando no segundo incapaz de se ver infinito, já sendo teu.

Desespero da liberdade de possuir-te na ausência.

E quando presente, latência

Aprisionando do que voa na imensidão do tecido no qual se tornou as próprias fibras.

- Ah, o desejo mentiu para mim.

Esqueceu de se confidenciar com o amor

E não ouviu que a lembrança

Escorre febrilmente a fome, ardendo em saciar, o presente.

- E o que fazer, se o desejo partiu?

- Havia pleno de estar sobre o sentimento, mas apenas se viu no espelho, esquecendo de virar-se e nos tocar. Sentiu?

Por onde mais, agora.

Entre quantos, outros, nossos.

E como coloca Henry Irvine, "Asi pues los pobre humanos estamos entre la espada y la pared, nos parece difícil vivir con otras personas pero más difícil aún se nos antoja vivir sin ellas ".69

Almejar um objetivo é saudável, admirar uma conquista de um outro é um ato também por si, admirável, porém, o desenvolvimento dessa postura, carece de uma evolução de pensamento, onde, compreendendo que o bem ou a bem-aventurança do outro é um passo que reverbera em continuidade para que afluências possam estar se acercando também de projetos ou propósitos individuais na mesma direção. Paralelepípedos da sociedade. ${ }^{183}$ Do que lembro, sou o que permito, em esferas e instâncias do indivíduo e sociedade, claramente com lutas travadas do interior e da exterioridade. Passagens por onde a vida caminha.

\footnotetext{
${ }^{183}$ Sousa, Carina Gonzalez Y. Composição - O mundo - O mundo não era bem como eu pensava de febre eu delirava. O caminho que seguia tão sozinho por nós dois..... quem sabe você, saiba razão porque precisa ser assim, esse teu sofrer por mim, não pode ser, imensidão que tarda em lhe ter, pra mim. ah liberdade. Te quero tão perto, de nós. A sós, eu te beijo outra vez, como asas que voam sobre esse teu querer insano, do céu entre a terra, proclamo o destino teu... querendo entre os paralelepípedos na calçada.... encontrar um porquê dessa vez que doeu mais que a fenda por onde a natureza te escolheu, semente do mundo, prometeu, encontrar um lugar para viver, e ser feliz.... feliz.... feliz... filhos teus, filhos teus.
} 
Desejos e ambições, entre compreensões de sentido, diferenças resultados e consequências. O que nos pode fazer feliz ou o que possuir que te faça pleno. Presenças e ausências. Um ente querido? Posses materiais? Um objetivo, bem-estar de saúde? Do que se deseja e não se tem, do que não se cuida quando "possui" também. Corre o tempo frente o movimento que se esqueceu de respirar quando a pausa é estar no lugar do que pode nos trazer felicidade, e talvez esteja aí a pergunta da perda do tempo, sobre o que nos preenche.

Por vezes me parece que estamos sitiados em nossos territórios mentais, esquecendo que a vida lá fora, pode estar aqui dentro. Violência da mesma luta, sofrimento do mesmo silêncio. Aguardando a voz se manifestar.

Tempo e desejo

Deseje o tempo até que ele te compreenda sabor do vento da tua paz.

Deseje o vento até que a natureza se torne carne do teu pensamento.

Deseje a vida até que o tempo te preencha espaço e o movimento se faça universo. Deseje a força de tornar-se Vontade, pleno ser que te faz existir.

Deseje a contemplação dos sentidos para que eles te signifiquem

Deseje o som até poder compreender o próprio silêncio como razão de seu ritmo

Deseje até que a ausência dele se faça presença

E então perceba o verso de tudo que pode ser uno

Respire ante a passagem de e tornar espírito do tempo

Viva e deseje a esperança de encontrar-se com a felicidade

Encontre-se onde o desejo te observa em construção

E erga-se na imensidão dos passos de teu caminho estejam eles pelas dificuldades que possam as tempestades abalar mas não detenha seu ímpeto e resgate quantas vezes forem necessárias das profundezas os teus seres pertencidos ao infinito para que possas de tuas fontes encontrar o caminho da verdade. ${ }^{184}$

Qual o tempo da dor? Qual o tempo do amor?

Se podes conceber os segundos do outro, abraça o tempo demasiadamente humano, talvez insano possa te parecer, mas busque o desafio que será continuamente, exercer a razão do

${ }^{184}$ Sousa, Carina Gonzalez Y. Composição: Terra pulsante. KOTO. 
sentimento que transborda do ato de tua própria compreensão que a concebe como alma vivendo no exercício de existir quanto cerne do tempo dos sentidos do mundo na qual as experiências nos consomem exaurindo nossas forças, até onde o movimento seja o tempo de se ver, o que se faça, percepção, onde a vastidão permeia, dores, tristezas, formas, abandonos e desse tempo que se prolonga até onde se estabeleceu um infinito que se dissipou em fractais da vida onde os seres passam emudecidos pelo cotidiano carentes da voz desse tempo, estejamos frente a vazão do sentido de um bem maior.

Posso dizer do tempo, como sendo o existir?

Tempo, existo porque nasceste em mim. Princípio do quando, a espera do porquê para viver continuamente, onde.

O tempo, do amor difere do quando que a saudade se fez quanto, onde o lugar se formou vazio, parte do destino, existindo. Então, o tempo - do existir se divide? Dimensões do vazio a se recolher, sendo. Tempo, nasce de mim então, até que eu possa compreender o infinito, E, perdoa-me por não vê-lo onde a passagem te fez árduo, lastimando-se como a própria perda.

Que possamos sentir o porvir como verdadeiramente um princípio que nasceu do ontem, permitindo que a passagem seja fluido das veias de toda a criação. Entre os desejos e o contínuo, o que precisamos mudar, contemplar, cuidar, partir, seguir, realizar.

O desejo e os passos do caminho - um lugar para enamorar-se. Objetivos claros, que tenham no ímpeto da alma, a vontade de realizar-se como propósito para além dele mesmo, mas do que pode ser transformador. Seja, particular, ou que a cadências dos passos, reverbere sem fronteiras, porque até mesmo o sentimento, parte dessa alquimia, recebe a morada por onde por ir. Qual o desejo da vida, e qual o desejo da morte? Porque quando estamos morrendo, em geral, desejamos tanto a vida? Temos muitas mortes, que não a física, somente, mas a morte de ideais, a morte da alma, a morte do afeto, a morte de um querer, a morte da justiça, a morte da fraternidade, a morte da solidariedade, o que esperamos então para viver, que não compreendemos do desejo. Renascer. Nascer quantas vezes, o nosso espírito possa se perdoar, por não se compreender, sem culpas, mas atravessando-nos caminho, apenas um passo após o outro, desejando existir. Podemos sim, ver a morte das agruras e mazelas, para renascer a cada vez, um novo ímpeto que nos deseje continuamente, conhecer. E, não nos preocupemos, todos podemos cair e se levantar, é parte do que seremos. De que maneira me aproximo da morte, encontrarei a vida. Desejos desequilibrados encontram normalmente o 
sentido de se ver como conduta, quando se observar sobre, não fazer para o outro o que não quero para mim, e mesmo que por vezes nos esqueçamos disso, de alguma maneira a harmonia poderá encontrar seu caminho. A verdade conhece o desejo melhor do que aquele que deseja.

Do desejo, e da necessidade. Pensar o desejo enquanto da vida necessidade é lugar coexistente, equacionando esforços, medidas, foco para o alcance do objetivo, quando este pode ser como uma autopoiese, busca e se alimenta, nutre para não esmorecer o próprio desejo em princípio de continuidade e permanência ainda que se torne outro dele mesmo. Proporcionando a retroalimentação como um fator lógico desencadeante de sua sustentabilidade em prognostico de sobrevivência. Um desejo que se realiza enquanto gestão.

Os instrumentos da emoção quanto a razão de decisões. Impulsos e planejamento, os lados da equação. Uma organização fatorial de alcances, projetando caminhos, disciplinando o pensamento, movendo espaços para a criação, transformando desejos em realizações, onde a realidade se organiza. Condicionamento, tem alguns aspectos positivos e negativos, sendo que se pensarmos por práticas que fortalecem o espírito humano, como em paralelo ao esporte, poderemos alcançar uma força de equilíbrio capaz de ampliar o desenvolvimento, discernir sobre melhores caminhos segundo essas práticas, porém, o condicionamento quando se afeiçoando ao que é de cabresto o que pode limitar uma conduta, deixa pouco ou nenhuma margem a criatividade, portanto, a diretriz do condicionamento deve também ser uma escolha, quando este houver, isto porque pode condicionar um comportamento cognitivo que considere a capacidade de caminhos e relações criativos justamente como fator integrante do sistema. Realidade motivada e não absorta em manipulações ou induções não participativas ou elucidativas do sistema, deverá conter a ilusão como elemento também de escolha dentre o que desse fator é objeto de crescimento como criatividade, e não como sendo a ilusão que amortece por perder o laço com a realidade. Dos espaços cotidianos, a publicidade lida com a ilusão, o desejo, o impulso, o querer, a mensagem, a realidade, sonhos e vidas, onde a escolha permanece, em constante diálogos da in( satisfação) de fome ou saciedade, da sociedade, na busca de uma mente consciente. ${ }^{185}$ Do estar ciente das opções

\footnotetext{
${ }^{185}$ Sousa, Carina Gonzalez Y. Composição Face da terra. Faces da Terra, distantes de nós. Vozes da terra que chamam, distância atroz. Ah navegante que somos. Pescador da rede, do povo que proclama, proclama a igualdade de viver. Ah vozes da terra, cadê o seu lugar. Ah, vozes da terra, cadê o seu lugar. É verso do mundo, afeto profundo de braços abertos, de passos teus. A DEUS, me faça ver o amor. Desse teu lar, que tanto quer nos abraçar, cadê meu irmão, nessas vozes da terra, é cidadão que trabalha com justiça, que procura a harmonia, na igualdade de se ver, do tempo é mesmo ser, eternidade pra se viver. ah vozes do mundo de
} 
dentre possibilidades se encontra, na luta da razão e da consciência, o ser e o ter, mais do que o consumo, o direito de viver, na conquista de uma paz, seja em cotidiano onde a satisfação está em uma sociedade justa, que promova uma igualdade, ou a in(satisfação), por direitos corrompidos e não preservados do cidadão.

Territórios nômades sitiados, cercados em uma sociedade do céu da boca aberto ao silêncio de mordaças e ameaças do futuro que deseja livre expressão. Para além da realidade a semente do fruto da imaginação. Parâmetros do perfil de uma sociedade surrealista, ou sobre clinicamente aceitável como vigência de tempos atuais, modalidades orgânicas de um mundo em disputas entre a ficção e a realidade, como poder de manipulações.

Voz e ouvido cego

Cego e olhar falante

Gente vociferante

Do silêncio ausente

Enquanto se sente

E a razão, mente....

Entre a realidade e o gosto, entre a realidade e o sopro

Gestos escaldados do cotidiano, aguardam a noite, a espreita de não perder o sonho.

Grafia esculpida no mundo, tatuando as expressões da terra, sobre os sulcos da atmosfera de um respirar árduo e tênue como estações de nossos ciclos, onde o frio cala, mas a chama ouve, enquanto somos, ou desejamos ser, entre o tempo e o existir. SER D(N)O MUNDO. Plebiscito social. Se conseguirmos levar a cognição cotidiana abarcando o novo e refletindo o lastro, creio que teremos conjecturas plausíveis de espaços múltiplos e de respeito a um por vir, integro ou capaz de se desenvolver. Até que a decisão seja "nossa", sobre intervalos do tempo.

Quando o outono chegar novamente

braços abertos, ao seu redor. Ao seu redor, natureza da vida que sente, toda essa gente, toda essa gente...essa gente. 
Liberdade $^{186} \ldots .$. siga as coordenadas. Como?

Geografias do sentido. Paradoxo da realidade nas imagens da ficção, cenas reais nos espaços cotidianos e virtuais, onde mensurar o que pode ser factual ou verdadeiro, corre o risco de ser desnecessário. Objeto de consumo, o quê, o que pode ser, o que parece ser, o que útil, o que é necessário, arbitrariamente cobiçado, e descartado de sua integralidade constituinte como ser, órgão planetário que como células dos territórios que se vive, multiplicam-se, patologicamente? Ou conscientemente, mas da razão ${ }^{187}$, teria ainda a possibilidade de ser necessariamente, verdade?

O sempre, pode ser tão pouco, que deverás seja, até que o pouco se torne insaciavelmente muito.

E se a vida nos promove demonstrações, onde estaremos como amostras da realidade, perante as cenas de nossa virtual posição de escolhas? Em que ponto os diagramas são virtualidades como compartilhamento de ações em significado que se mostram evidências de onde o espaço deixa de ser real, mas o é tanto quanto a experiência do viver. E se deixo de desejar, estaria menos amorfo, ou em igualdade, quando da realidade sou manipulado, estigmado, e vivo feito fantoche?

Então a realidade pode me tornar amorfo, em estado de ausência de identidade, onde os documentos são existentes de um indivíduo onde sua vida é moldada a qualquer preço ou ao preço do dia, conforme o alvitre de um bel prazer, até que, se depare com o incognoscível e que mesmo sobre os ciclos da vida, reservem das suas raízes um tanto quanto de estrelas, para o cosmo sonhar, ou esteja sobre o caminho de onde o fruto é semente que gerou do ventre onde o lastro não se perdeu, apenas espera nascer, onde quem sabe possa ter mais do que identidade, mas sim, a sobriedade de servir ao que o pode tornar cidadão do mundo, mas do mundo coração de uma razão.

\footnotetext{
${ }^{186}$ Sousa, Carina Gonzalez Y. Composição- Ver a igualdade. Eu quero ver o sol nascer. Sobre a cidade. Ver a igualdade como folhas. A tocar a liberdade. Ah eu quero ver. O sol nascer sobre os teus olhos. Quero sentir, a madrugada. Ao lado seu... braços da vida, que me acordam todo o dia... Por onde ir, por onde ir.... A cidade. De sentidos tão vazios, percorrem as ruas, percorrem as luas, noites e dias, de lugares nossos. Ainda lutamos, por existir. Se ao menos soubermos por onde ir. Ah.... o que sonhar quando a idade precisa aprender a respirar, a respirar... Me dê a mão, olha no meu coração. Me dê a mão, olhe no meu coração.

${ }^{187}$ Sousa, Carina Gonzalez Y. Composição: Qual a razão: Notícias... que passou por mim, nesse caminho sem fim, eu pergunto, qual a razão... noticias, do mundo, que falam pra mim... Do que acontece, da incompreensão. ah são tantas lágrimas. São tantos sofrimentos. Ah que lamento, meu irmão. Ai que lamento, meu irmão. Ai que lamento, haverá de virar a página, que noticias que virão... eu posso ver, eu quero ter, um futuro melhor. Escreva então, o teu querer. Para que eu possa ler nas tuas linhas. O meu gesto de viver.
} 
E quando ouvir as suas próprias palavras, reconheça como gesto, na harmonia ou desarmonia, de um lugar nesse universo. A quem diga que ao deixar de desejar se esteja mais livre, ou o desejo seja esse. O meio do caminho - desejo -saciedade - identidade responsabilidade

Por vezes um bom termo de avaliação seja responsabilidade porque ela nos coloca frente a não somente a saciedade mas do que dela se desmembra e assim sendo, nesse desmembramento, consideramos as consequências. E por vezes em se considerar as consequências, podemos creditar a razão o elemento suficiente capaz de nos conduzir a outras escolhas. Ou que não seja outras escolhas, mas possam ser capazes de elucidar o objeto tratado mesmo que de consumo, ou que da vida seja prazer, mas enquanto responsabilidade atrelada ao ímpeto pode ser a capacidade de discernimento suficiente para que se liberte um momento de razão dentre o significado do sentimento, e dele nos fazer possibilidade de escolha mais tranquila ou de uma serenidade proveniente de um desmembramento como considerado, onde a pausa tão natural de nosso respirar se exala em nossas atos, como vontade participativa de um existir. Todavia, se for capaz de compreender dentre a tempestade a sua natureza, quiçá possa ser, o que dela, é serenidade. Ao romper uma terra, em busca do sol, a angustia ou serenidade podem nos habitar como gesto que deseja nascer, e continuamente exerce força, sem impasse, ou com a necessidade do impulso generoso do existir, mas que ao deixar de ser, continua sendo nele mesmo, outra face ( propósitos ). A natureza da vida e do homem - espaços de igualdade

Busco as estrelas da noite, na íris dos olhos humanos, onde do sonho se pode ver a realidade. Quase sempre estou em busca, onde o passo por onde fui, procura-me, e dentre esse lugar, busca o próximo, tentando saber por onde ir. A busca de si, para a compreensão do outro.

Da luz e uma certa chama. Pode se ver, ou sentir, apenas seja, como o que acende, e quando o sopro apaga se percebe que está sobre a luz do sol, ou o brilho das estrelas, onde o vento também respira. Casa da humanidade, onde esteve suas portas? Recobertas por quais tempos.

Lugares onde com frequência chove, e se comove com espaços vazios, por onde a lágrimas desceram do céu. ${ }^{188}$

\footnotetext{
${ }^{188}$ Sousa, Carina Gonzalez Y. Composição: Travessias- Do palco do mundo, esqueceram-me de dizer, que eu não teria, o que comer. Que eu não teria, onde viver. Do palco do mundo, esqueceram-me de dizer. Do palco do mundo, esqueceram-me de dizer. Que eu não teria o que comer. Que a minha sede, de sobreviver. Seria
} 


\section{O CÁLICE E O VENENO}

Qual parte te pertence sociedade vigente? Do grão ao graal. Mitos e realidades da sociedade atual, ou muito antes disso. Sorver até a última gota, da serpente? Ou do sangue? De qual parte ainda pode ser o cálice. Sabedoria, entre medicina? Antidoto de um tempo que virá? Retornando a sociedade no Ps, atendimento domiciliar, ou será que a família não sabe mais o que é isso? Domicilio ou tempos de exílio? O que nos torna familiar? Afinal, quem são meus irmãos, já nos disse, Cristo, não é mesmo? Ou será demais, ainda colocar em um texto, onde podemos viver e constituir o nosso tempo, e nossa relações familiares, onde o sangue, é o que nos faz seres humanos do bem e propósito evolutivo, onde o amor, é a pedra, do que está e sempre estará escrito.

Chama acessa onde e em qual momento estivermos do tempo. O equilíbrio de forças onde ainda temos luz e escuridão, sem saber por onde está o silêncio.“ Impôe-se, assim, um redimensionamento teórico. Só podemos entender bem uma época sentindo seus odores. “( MAFESSOLI, 2004). E os humores sociais, independendo de que lado estamos vivendo, assim portanto, entre narrador e protagonistas, direitos iguais.

Apetecer!

A abstração nos espaços de ordem pública prejudica em grande parte, o que pode ser e precisar de uma descrição e clareza para que possa ter suficiente discernimento das etapas de desafios possivelmente necessários de serem compreendidos. Não que a abstração seja um entrave de compreensão, porém, depende de quem dela faz uso, assim como as metáforas. Enquanto passagens, sobre perspectivas, até quando haverá necessidade de perguntar de que lado estaremos, dentro ou fora de um portão.

O reencantamento do mundo, o apelo do fantasmático, os envolvimentos coletivos que são sua expressão, tudo isto traduz o ressurgimento do sentimento do sim. O maravilhoso, o surrealismo já não constituem mais, então, simples divertimentos literários, enraizando-se nas emoções afirmativas. Emoções compartilhadas que já não se reconhecem nas diversas formas de ressentimento em relação ao que é, mas o aceitam, teatralizando-o. A emoção poética da surrealidade torna-se uma realidade comum, um sagrado cotidiano. (MAFESOLLI, 2004, 125).

como uma seca, interminável. Como Outono, as ranhuras da minha pele, de poros abertos, realidade, ingrata. Verdade por nascer, dentro do ser. Será que ainda... O que eu posso ser. Será que ainda.... O que eu posso ser. Matará a minha fome, e haverá um lugar pra viver. Pra viver.... Não muitas vezes. Estive sem chão, mas encontrei o céu. DE algum lugar, de algum lugar. Eu pude saber, como poderia me encontrar. E do mundo, sorrir outra vez. E do mundo, sorrir outra vez. Personagem da alma, é verdade que faz sonhar. Personagem da alma, é corpo que vive. O palco do amanhã. 
Do olho da alma, o eterno não se apresenta no momento, mas na parcela infinita do finito, que pouco conhecemos. Ou seja, quando se revela.

1.4.A construção de uma percepção; monotipia - a passagem interna como ser no mundo.

A construção de uma percepção, nos acerca de um dizer sobre a poesia de Cecília Meirelles, escrito por Darci Damasceno, sobre a visão de mundo:

O conjunto de seres e coisa que latejam, crescem, brilham, gravitam, se multiplicam e morrem, num constante fluir, perecer ou renovar-se, e, impressionando-nos os sentidos, configuram a realidade física, é gozosamente apreendido por Cecília Meireles, que vê no espetáculo do mundo algo digno de contemplação - de amor, portanto. Inventariar as coisas, descrevê-las, nomeá-las, realçar-lhes as linhas, a cor, distingui-las em gamas olfativas, auditivas, tácteis saber-lhes o gosto específico, eis a tarefa para a qual adestra e afina os sentidos, penhorando ao real sua fidelidade. [...] Se o contemplar é o árduo exercício da apreensão, e se o amor, polarizando-os, catalisa contemplador e objeto contemplado, o clima desse exercício deve ser o de exigente disciplina: o afago dos sentidos, a fruição, o gozo do contato não podem nunca atingir os limites da turbação, do arroubo, da cegueira, por maior que seja o deslumbramento no choque com a realidade. Decorrido o primeiro momento de contacto com as coisas e neutralizada a corrente intensa dos estímulos, externos, fixa-se nos objetos e contemplador, considera-os, interpreta-os e deles faz alvo de seu olhar, centro de gravitação da inteligência. A magia verbal, por mais fascinante, não deixa em nenhum momento confundidos contemplador e objeto contemplado, criador e obra recriada, em meio ao sortilégio conserva o mago a consciência de sua arte. ( apud, MEIRELES, 1987).

A um poeta visual, apuradamente visual, como Cecilia Meireles, não poderia escapar o desempenho de cada ser na mecânica do mundo. Sobre a vastidão da realidade física estendem-se os seus olhos, num levantamento rigoroso da vida em todas as suas manifestações. O ser orgânico e o inorgânico, o bicho e a planta, a pedra e a luz, montanha, céu, floresta, tudo cabe no círculo enorme que dominam os olhos do contemplador. [...] Da finura dos instrumentos de apreensão do Poeta lhe advém a capacidade de perscrutar singularmente o mundo físico, captando neste o rasgo imperceptível, a qualidade oculta, como também a faculdade de convulsionar a lógica discursiva, renomear os seres, transmudar-lhes atributos, confundi-los todos, e do caos, dar ordem a novo mundo, onde as coisas renascem sob o signo do artífice: liquefaz-se a cor, sonoriza-se a luz, tangencia-se o aroma e o ar se encrespa. (MEIRELES, 1987, pg 21).

$\operatorname{Im}$ (prensa) de nós. Imagem do nosso tempo. 
Abordávamos a questão do desejo no capítulo anterior, e aqui propomos o seguinte pensar: No corpo social ${ }^{189}$ desejamos a alma da condição humana dentro de um ideal, então nessa relação dentre o que queremos, estará o prazer de descobrirmos mais do que o próprio ato, o olhar do tempo que observa a própria realidade em termos de vivências de desigualdade, e então, por entre o prazer e o desejo, temos uma monotipia da imagem de nosso existir, marca que traçamos ${ }^{190}$, rumos que desenhamos.

A vida está passando, ou vivendo como anúncio. Em que canal?

- Olá, meu economista. Tudo bem? Boa noite. Quem é quem, quando temos mercadoria esgotada?

Se o mundo não é como nos contaram, por qual ângulo estamos vendo, mesmo? Ou, superfície em profundidade, suficiente para a humanidade? Que parte, como propriedade particular, ou socialmente aceitável? O que é negociável? Afinal, será que negociamos a liberdade? Ou o Estado está muito ocupado, sem lugares, ou vagas para se sentar e assistir, o próximo anúncio. Preste atenção, a vida passa rápido. E apesar do conto do Amanajé, o valor d(n)a cidade, eu já me pergunto: será que estou vendo o número do ônibus?

Sobre opressão: - Qual o preço

Identidade ${ }^{191}$ - Qual o preço? Depende, ontem hoje ou amanhã...

Durante uma geração, a Wall Stret foi realtivamente impopular, os anos de trabalho dessa geração decorreram de 1929 a 1946. Em 1937, o ano em que o primeiro grupo isolado de analistas de títulos se formou, só três membros do último ano da Escola Comercial de Harvard enfrentaram a ira das famílias e amigos para entrar na Rua da Iniquilidade. A lembrança de Richard Whitney ex-presidente da Bolsa de Nova York, posando para um foto nos degraus de sing-sing, seu novo lar, era ainda muito viva. "SMITH", 1967, pg 28).

\footnotetext{
${ }^{189}$ Sousa, Carina Gonzalez Y. Composição: Sobre o céu- Da alma do som, das horas errantes, das seivas falantes, que não ouvimos, das seivas que murmuram, passa o vento a cantar, passa o vento a cantar. Passa a chuva a dançar. Passa o rio a amar. Passa o rio a amar. Sou tronco, a beira dos teus olhos. Esperando um lugar, passa o vento sobre mim. Passa o vento sobre mim. Delírio da aurora que chora. Delírio que a alma demora a chegar. Dos verdes das matas, das montanhas. Atravessamos, o que trocamos sem respirar. Urbano ser. Quero lhe conhecer. Quero lhe conhecer. Mais preciso, de um lugar para viver, mesmo que seja na solidão. Porque... passa pássaros a cantar. Passam pássaros a sonhar a melodia, da minha vida. DA minha vida. Então, cidade grande. De arranha céus. De arranha-céus. E agora, como respiramos. Como respiramos. Passam as horas, passam as horas. E respiramos... O que fazemos, do que vivemos. Vivemos

190 Duas vezes, texto presente no livro Ensaios Poéticos teatrais. Hábitos, normas, comportamentos sociais, repetições do cotidiano, enquanto seja bom, repetiremos quantas forem ou suportem nossos desejos em monotipias de um querer.

${ }^{191}$ Do projeto do livro em anexo - Gingado: Trincheiras - Composições Brejeiro e Onde. Amaral, Aracy. Arte pra quê? Studio Nobel, 2003. Tela de Cândido Portinari, café. Col. Museu Nacional de Belas Artes, Rio de Janeiro.
} 
Claro que eu não sou Adam Smith. O Sr. Smith jaz no cemitério, em Canongate, com o epitáfio escrito por ele mesmo, identificando-o como o autor da Riqueza das Nações, e aí permanece desde 1790, rico em respeito e honrarias, tendo-se imortalizado como o primeiro grande economista de mercado livre em todos os textos de história econômica. O Sr. Smith não pensava em si mesmo como um economista, mas sim como um filósofo moralista. "Para que fim", perguntava na Teoria dos Sentimentos Morais, " servem toda a labuta e pressa deste mundo? Qual o fim da avareza e ambição, da caça à riqueza, do poder e da precedência." Gosto disso, mas não foi por essa razão que tomei o nome de Adam Smith para pseudônimo. Isso foi, chamemos-lhe assim, um acidente feliz. ('SMITH, 1967, pg 16).

Será que para termos "valor", temos que "ser" uma mercadoria, aceitável como mais do que útil, necessária, ou algo a mais, talvez um diferencial no mercado, que faça "levantar" os preços..... Então, que pseudônimo terei? Administrar o tempo, é vida ou movimento de nossas ações? Quais? O cotidiano não basta de amostragem? Ou precisaremos falar de porcentagem em quanto se vive, e o quanto se passa, inerte a vida. Também temos a frase... não vou entrar no seu jogo....

-Façam suas apostas! Ah, não é disso que estamos falando!

-Ah claro, então temos escolhas, é diferente de apostas...

-Isso está confuso.

-Confuso, porque... se temos escolha, temos liberdade... ou será que não?

-Quer começar? Cara ou coroa? Jogue a moeda ao céu, vou gostar de saber o que escolheu. Quem, eu ou o céu. Não sabia que o céu estava fazendo parte....

-No meu jogo sim,

-Mas, e se eu não quiser jogar. Para mim a vida não é um jogo.

-Então, assista. E o que mais fazemos!!!! Torne-se crítico, talvez, quem sabe... Ácido demais, mordaz... nem tanto... ainda nem dei a primeira mordida.

-Qual?

-A da maça...

-Não, aquela é do Marx.

-E, também, eu não tenho dinheiro para jogar...

- Ora, então, faça.

-Como assim?

- É aí que o jogo começa. Seja bem vindo

Realidade, a sua ou a minha; mas... não é a mesma? 
Curioso como sempre comendo tanto da vida, e mesmo que com fastio ainda sinto um enorme prazer em degustar mas nem tudo, talvez alguma parte. Conveniente seja talvez este pseudônimo... como de praxe. Mas a autoria aqui é minha, mesmo que repartindo, com você a leitura e ainda mais, as referências. Talvez disso tudo, algo soe familiar. As vezes eu penso que quero garantia hoje, do futuro, complicado, se estou produzindo agora. Sempre acho incrível como o tempo, se torna onde nos reconhecemos...

Smith no livro, jogo do dinheiro, faz a seguinte colocação: “A nota dominante do nosso tempo é a irrealidade". Lemos o mundo, enquanto pergunto ao cotidiano que escrevemos, para quem fica a revisão? Avidamente percorremos os lugares da sociedade, descamandonos em suas passagens, de quem sabe lembrando Salvador Dalí, encontrar a vida do lar, como uma questão de espaço ortográfico, onde se assina, dólar. Pseudônimo da realidade, sobre economia de um sobreviver. Por onde ficam os investimentos....nas relações. Entre números, a condição de vida.

Como está o nosso mercado? Quando o produto é a vida. Do que produzimos, do que consumimos etc. Satisfeito ou não? Ainda vale a expressão... Estou saindo no lucro... de qual relação mesmo? Sobre quais valores? Entre origem e propensão... analiso no momento, " restos"? Ou não? Antes deles... antes das migalhas. Ah sim, um outro quadro, nesse " horizonte " Qual será o negócio da realidade, e por onde estarão os riscos que deles já não façamos parte, em nossos olhares para trás de nossos rastros por onde, todos em algum momento erramos.

Então, vamos investir aonde?

Negócios de risco? Não?! Então, o que mudou da última frase?

Vejamos....

Ora, “ O mercado é uma multidão, e se você leu A multidão, de Gustavo Le Bom, sabe que a multidão de homens atua como uma só mulher. O espírito de uma multidão é igual ao espírito de uma mulher.“ ( SMITH, 2004, pg34 ). Onde para o que da vida, segue, recomenta-se " Picasso", os fragmentos da multidão. Compulsivamente devorando o existir, exaurindo nas forças as relações dos espaços, que traçam o viver. Onde ainda a pauta do viver, é investigação continua de relações a espera dos fatos, ou, quanto vale a informação para a próxima pista? Depende, a fonte é séria! Tenho imagem a zelar. Reputação, ainda se fala disso, ou não, saiu de moda, ou ainda vale alguma coisa em tempos líquidos....ah mas 
estou falando de ressonância, então creio que é ainda, importante, ou será que pode ser para alguns, “ alterada “. Depende, de maneira lícita, ou não? Qual os propósitos!

Mas, então, estava pensando, sobre as pistas... os riscos, qual rumo mesmo pode ser mais seguro? Jogo, pistas, mapa, para onde vamos? Boa pergunta. Afinal, tratamos de uma economia planetária, onde depositamos nossos sonhos, entre riscos da sobrevivência.

Parece um pouco simplista dizer que a primeira coisa que é preciso conhecer é você mesmo ${ }^{192}$ e necessariamente não estará a caminho de tornar-se um administrador profissional de dinheiro. Mas se pensar um pouco, eis uma autoridade dizendo que não existem fórmulas que possam ser automaticamente aplicadas. Se você não aplicar automaticamente uma formula mecânica, está operando na área da intuição, e se vai operar com a intuição - ou raciocínio - então acontece que a primeira coisa que você precisa conhecer é a você mesmo. Você è - enfrente isso é ótimo se você o souber. Os especuladores que obtêm êxito não tem necessariamente um retrato completo deles mesmos na mente, incluindo as verrugas, mas sabem parar instantaneamente quando sua intuição e o que está acontecendo lá fora ficam de repente com defeito. Surge uma série de erros e dizem apenas "Este não é o meu gênero de mercado ou não sei o que está, acontecendo, você sabe? E regressam as linhas preestabelecidas de defesa. Uma série de decisões da Bolsa, soma-se creiam ou não, a um dado retrato de personalidade. ( SMITH, 2004)

Certos indicadores, são mesmo eficientes. Enfim, cada um com seus malabarismos sociais e negociáveis, ou não. E, como a dizer o poeta: para meu espanto, alerta geral, comportamentos que não desejamos, em conduta de massa, então, se sobre preconceito, sobre injustiça, deslealdade, passividade, por fim, eu deixei de assistir e resolvi viver, e não vou aceitar preconceito, ou qualquer jeito desumano de viver.

E não nos esqueçamos que além de saber o "perfil", ainda tem os que fazem previsões. Ainda diz Smith, mas será realmente o mercado uma multidão, ou é apenas uma especulação? Será que, todavia, o mercado, em meio ao efêmero, torna-se um movimento de risco ao comer cru o prato quente, ou a previsão fornece dados suficientes, para que em certo ponto o risco se torne conhecido.

No caso, de relações pessoais. Veja bem o que o povo vai dizer, e lembre-se dos mitos dos investidores. Sobre estratégias e viver, diante do contemporâneo e os riscos nele apresentados, creio que cada vez mais se torna relevante considerar o lastro histórico e suas reverberações visíveis ou mascaradas socialmente, ainda em pauta o olho no olho! Sobre especulação algo me veio a mente, quanto aos que jogam em mais de um lado, e deixam

\footnotetext{
${ }^{192}$ Texto em audio, Edifício. Da série depoimentos.
} 
meio que em corda bamba certos procedimentos. Bem se vê que as vezes nos sentimos um peixe fora d'água. Dentre o que são as multidões, como mais uma vez face de mesma moeda, teremos, o consenso e o que deve sempre estar presente como discernimento, afinal do que se constitui a opinião de uma multidão é sempre e necessário estar sobre o prisma de uma consciência, isto porque temos exemplos históricos para este argumento. E lá vem, o que está me revirando no túmulo, sem eu ter morrido. As multidões controladas, pedras nas calçadas, ou espaços sociais tecnológicos? E falando nisso, sobre perfis reais ou falsos, identidades urbanas até que a procura esteja sobre nós. De qualquer forma:

No fim do século XIX, um físico francês, chamado Gustave Le Bom, publicou a sua Pzychologie des Foules, traduzida como a Multidão. Le bom enviou uma boa parte de outros originais seus sobre generalizações de características de raças, que não tiveram tanta aceitação, mas a Multidão parece absolutamente profética - em 1895 - bem antes de o mundo conhecer as espécies de multidão que um Hitler ou que um Mussolini podiam reunir num local e manejar. Para Le Bom, uma multidão não era apenas um número de pessoas reunidas num local, podiam ser milhares de indivíduos isolados. A esses ele chamou multidão psicológica ( havendo de considerar - multidão patológica), sujeita a desaparecimento de personalidade ( controle e manejamento de comportamentos ) consciente e mudança de sentimentos e idéias numa direção diferente. A peculiaridade mais marcante de uma multidão, segundo afirma o Dr. Le Bom é que: Quaisquer que sejam os indivíduos que a compõem quer o seu modo de vida, seja semelhante ou dissemelhante, suas ocupações, caráter ou inteligência, o fato de haverem sido transformados em multidão, coloca-os na posse de uma espécie de espírito coletivo, que os faz sentir, pensar e aturar de uma maneira totalmente diversa da que cada indivíduo sentiria, penaria e agiria, se estivesse em estado de isolamento. ( SMITH, 2004, pg $55)$.

Prognostico social, para não ser uma patologia em contágio como ainda se constituindo de espaços comunicacionais, precisa ter e ser, razões que permeadas por consciências de diálogos sejam uma constante, na equação, povo e governo, indivíduo e relações sociais. Em tempos de camuflagem social e guerras veladas urbanas de desigualdades e ainda "expedições" para os territórios globalizados, em redes virtuais e reais, o perfil do indivíduo e social, carece de uma abordagem ética para se conceber dentro de uma veracidade, e portanto, ter como aferir seus comportamentos, suas estratégias, seus riscos e benefícios de planejamento, gestão e organização. Isto claramente reflete que precisamos no tempo vigente de esclarecimentos quanto ao que somos, e o que queremos. O pior perfil falso é o de uma nação que não se reconhece, sobre as plataformas sociais de onde ainda querer se dizer cultura. Então, me parece que o que falta é arregaçar as mangas e exercer o direito de termos dignidade enquanto seres humanos, com comprometimento real e verdadeiro do 
presente e futuro, em faces de monotipias de marcas nossas, de uma identidade concreta e fincada pelas condutas sustentáveis da ética, comprometida na consciência do indivíduo com suas relações sociais, promovendo na realidade a própria cultura como reflexo ${ }^{193}$.Portanto entre sociedade e cultura, o perfil de um povo, identidade nossa, compartilhada entre a parcela de cidadão e cidadania, aguarda a percepção do olhar real de uma imagem lícita.

O jardineiro e uma porta.

Por vezes os canteiros do mundo, e nem estou falando das ervas daninhas ainda, mas os canteiros do mundo, de corpos urbanos plantados sobre vazios de serpentes, ainda respiram a procura de sementes, por onde a terra não plantou. Vestígios do veneno, ou antídoto? Até quando será necessário? Talvez os invisíveis saibam mais sobre as poças da rua, por onde os destroços caminham, já que permanecem atentos. Curioso como do mundo, aqueles a quem não se vê, da rua são a própria imagem mais detalhada e dela sabem os passos de cada um. E, é nesse caminho, que a lágrima do jardineiro escorre, do que ouviu invisível do mundo e plantou sobre a terra. Homens incógnitos, podem resolver a equação, quando o resultado, é descobrir a traição. Atentos ao vento, aos cantos dos pássaros e algo mais. Desprezaram a natureza, quando dela, tudo se ouve. E lembraram-se tarde, muito tarde, dela fazer parte.

A alquimia do corpo, pode não ser a mesma da alma, mas do universo, pertence as duas. E da matéria dele, o espírito do universo, escreve os elementos, do que inclusive permanece em silêncio de ambos. Existe um campo, entre o que permanece do que não é revelado, mas é exposto sobre outro véu, descortinado, pelo infinito, daquele que tudo sabe. De maneira idônea apenas, sendo do tempo, o que a consciência se faz visível enquanto tempo de compreensão.

E, entre multidão e indivíduos, do que são, o povo e o cidadão?

E depois de um bom tempo...

Tudo isto não constituirá novidade para muitos dos disputantes do Jogo. A Wall Street inconscientemente aceita isso, a imagem que uma companhia ou uma ação apresenta, auxilia seu preço e pode conservá-lo bastante tempo, mesmo depois que os fatores racionais de lucros e retorno do capital investido começaram a deteriorar-se. Se uma companhia tem uma reputação de inovação contínua ou de criar seu próprio mercado, isso constitui exótico estímulo. Todo o processo mantém uma série de firmas de relações públicas em ação. As multidões, diz o Dr. Le Bom, são um pouco como a esfinge da antiga lenda: é necessário chegarmos a uma solução dos

\footnotetext{
${ }^{193}$ Sousa, Carina Gonzalez Y. Composição do arquivo de música brasileira: Preço; nua; cidade de São Paulo e Quando.
} 
problemas mas oferecidos pela sai psicologia ou resignarmo-nos a ser devorados por eles.( SMITH, 2004, pg58).

Ora, em se tratando de enigmas.... das areias do temp (1)o, clepsidra foram as vossas verdades, por onde a própria se fez realidade. Porém, em tempos de indivíduos, empresas, organizações e governo onde se inquere um estado de integralidade quanto a transparências e procedências de atos como correspondência de valores éticos e nos quais produtos estando estes em participação como razão e consequências, as relações se estabelecem dentro de uma responsabilidade mútua. E, portanto, o enigma considera apenas a própria busca que revela as lutas entre a face interna e externa do mundo, em monotipias que sejam correspondentes, ou tenham uma verossimilhança.

Dos investidores e os que ainda não viram o “ pregão”. De que valores estamos falando, e com quem? Devo chama-los usando uma passagem da bíblia, de vendilhões do templo. A diferença de lá para cá é que, não estão fora, mais dentro, não estão somente na porta, aliás, a porta.... e entre os tempos, me pergunto, o que aprendemos, do que vemos em face externa e interna, do mundo e de nós, do que vivemos, o que somos, e queremos ser, o que deixarei para viver...

Pergunto: se o mundo me mostra violência, meus caros, nesse pregão, devo arrematar para mim, o que em minha face, pois do mundo, moro dele, sou dele também lar. E então, entre lágrimas, posso perguntar, qual o meu lugar. Em qual momento, o ensinamento do apertar de mãos entre indivíduo e mundo, deve ter a alma da consciência, para quem sabe da procura encontremos o que deve permanecer em ambos. E o que deixar para trás, também será o que levamos ao saber que não deverá ser nunca mais, nos pertence como nunca ou jamais, do que foi e de outra forma, permanece. Então do vale, aquele do mundo que nos rodeia, inferno feito carne, sinto que a escolha sobre por onde andamos, ainda que no vale é a presença de Deus, mesmo que não acreditemos. Há muito tempo me pergunto do aprender do mundo, o que é aprender. A defesa do mal? Até quando! ${ }^{194}$ Será preciso o inferno ensinar que o bem é a maior defesa? Até quando? Ou chegará o dia, em que a natureza do bem, será a nossa natureza. Provas? Caminhar será a prova de que o amor venceu.

E apenas, pergunto, após um tempo, para o jardineiro: Estás a trabalhar, e do que precisas? O que fazes? E ele apenas me responde, que vê as sementes, mas também procura o lugar por onde nascerá, dentre o que ele separa de joio o trigo. Podem mudar palavras, gestos,

\footnotetext{
${ }^{194}$ Sousa, Carina Gonzalez Y. Composição Neblinas sobre o amanhecer.
} 
manifestos, mas ainda todavia, do progresso que queremos, o campo aberto entre plantações e colheitas de um novo mundo, o mesmo evoluindo em desenvolvimento e globalização, não é muito diferente, em, trabalhar a educação, o conhecimento, reformar o que pode se modificar, preparar o terreno, conscientizar o que deve compreender, proporcionar sementes onde germinará, e caminhos, do que queremos para uma cultura sustentável. E, em qualquer tempo, que saibamos em multiculturalismo, onde o respeito deve ser esquadro e compasso em movimento de conhecimento, que a crença, esteja ela como viver digno, é parte da consciência, e de toda crença que receba nome, esteja se apresentando-se, o respeito, como primeiro passo, não ferindo nenhum por sua vez, a integridade do ser em liberdade.

Do processo de monotipia, o que fecundo e o que fica em superfície de maneira que não se representa imagem, a escolha será nossa. E ainda percebo que em tempo de caos e patologias sociais, em inversões absurdas de valores e práticas, enquanto se tenta sobreviver ou desenvolver uma humanidade como consciência de todos e práticas econômicas e de leis, ainda a crença se destitui, havendo de parecer insano esse ato? Crer é força do viver, esteja ela em trabalho, em dignidade, em procura de harmonia. Colocamos isto porque ainda mesmo no particular a crenças de religiões, estas são parte da cultura e inclusive em alguns territórios refletem em concretos modos de viver e procedimentos políticos, então consideramos neste estudo a presença inevitável do respeito e diálogo como forma de elucidar diferenças dentre uma igualdade de seres humanos que todos somos no mesmo planeta, onde acreditamos que não corresponde a nenhuma prática de valor, onde a crença pode ser elemento, nada que leve a violência, mas sim, do que encaminhe à justiça, ao bem comum, ao progresso de condições de vida, conhecimento, ainda que de culturas diversas, estes são dentre outros elementos de igualdade.

Então, dos valores da vida, do consumo, o que adquiro, ou não, levo comigo, perguntaremos, o que será suficiente? Querer e desejar? Sinônimos? Já ouviu a frase... eu quero, mas não desejo tanto assim... porque será? O que é o suficiente! Do target, o objetivo e os caminhos. Haverá entre as perguntas, as respostas de que as informações se tornaram multidões hoje em tempos cotidianos onde a organização também passa por lá, gerando e sobre gestão de escolhas, para até mesmo saber por onde ir? E falamos ontem, de identidade entre a opressão e a liberdade. Escolha-me talvez eu seja a realidade, e de como ela pode ser, quem sabe teremos a liberdade de descobrir juntos, por onde a expressão possa nos revelar, imagem de nosso tempo. 
Entre necessário, suficiente e o querer, ainda como caminhos traçados de nossa monotipia, pergunta-se sobre considerar espaços do desejo, poderá haver relação do que Steven Connor coloca em teoria e valor cultural como valor absoluto e relativo?

O imperativo do valor poderia ser identificado com o princípio, que sempre busca incrementar a quantidade de prazer e evitar todas as formas de desprazer, ele poderia identificar-se alternativamente com a base biológica do nosso ser, na nossa necessidade ao que parece inerente de preservar a vida e resistir à morte. ( CONNOR, ano, pg12).

Sobre a necessidade do valor, Connor considera que valor e valoração como lei natural de uma condição humana, e assim sendo:

A necessidade do valor, é, nesse sentido, mais semelhante à necessidade de respirar do que digamos, a de ganhar a vida. Há sempre maneiras de viver enquanto ser humano sem esta última, mas não sem a primeiro ano. [...] Sem pretender dizê-lo com demasiada elegância, vivemos, respiramos e excretamos valores. Todo aspecto da vida humana está vinculada a valores, avaliações e validações. As orientações e as relações de valor saturam as nossas experiências e práticas de vida mais ínfimas microestruturas estabelecidas do sentimento, do pensamento e do comportamento às mais amplas macroestruturas estabelecidas das organizações e instituições. A história das culturas e das formações sociais é ininteligível fora do âmbito da relação com uma história de orientações de valor, ideais de valor, bons valores, respostas em termos de calor e juízos de valor, bem como de suas objetivações de sua interação de suas transformações. ( CONNOR, ano , pg17- )

Entre o determinado e as posturas de compreensão. Sobre certo aspecto os rumos que traçam o cotidiano e as leis sociais, se aplicam a um grau de determinismo, nos quais pelos mesmos, todavia encontramos lugares para as passagens criativas de onde o novo entre o que existe surge e emerge como força e capacidades de nossas escolhas e posturas de compreensão. Cada qual, me parece que mesmo assim, entre os padrões, normas, entre o sentido possui o seu próprio que é fruto de seu entendimento, e essa face encontra em relação a necessidade o seu significado quanto inclusive a valor se preponderante ou relativo.

A (o)posição da palavra. Havendo de termos em sentido que a palavra é imagem, som, contexto em percepção interna e externa, como diálogos em busca de entendimento, a mesma procurando corresponder-se palavra-compreensão-gesto narrativo do sujeito ambiente, relaciona-se ainda à reflexão argumentativa em instâncias de proposições de reconhecimento lidando com espelhos e refrações, distâncias do tempo, ausências e 
permanências, que se afirmam ou se alteram. A monotipia ${ }^{195}$ também se estabelece na observação de palavra e sentido, pensamento e conduta havendo de auscultar o entre, como a própria razão em que a imagem da expressão seja ao menos o caminho da correspondência, porém, em se tratando de um modo de ver a (o)posição da palavra, como diálogos de territórios do pensamento, onde o posicionamento se faz em vias de elucidar possibilidades de entrelaçamentos onde seria possível entre diferenças encontrar um sentido de acordo, ou coerência entre partes.

Sinceramente até então o presente momento, enquanto validação distante de corpos, atados ao umbigo do mundo, dialogando com uma monotipia que deseja ainda considerar-se ser em movimento, movendo-se sobre o prazer, em qual contexto, poderemos avaliar? Estações humanas, recolhendo-se palavra do contexto, de qual perspectiva? Sobre a prensa de nossos desejos, partes de nós, impressas como marca de nossos passos, revelam-se fatos, do cotidiano entre as partes do indivíduo e sociedade se relacionando. A reverberação do escrito, manchetes do amanhã, esquecidas do ontem, em tempo presente. Quando por fim, nos parece ou temos a impressão de que, o leitor passivo dele mesmo, sobre o diário das letras, observa, o obsoleto tempo real.

Entre a imagem do tempo, o discurso e poder. Onde? Depoimentos ${ }^{196}$. Dos fatos, recuperações do lastro de nossas passagens sociais. Mais uma vez, monotipia. De onde estamos no cotidiano, a imagem ${ }^{197}$ precisa ser a mesma, em linguagem para compreendermos, ou os diálogos podem expressar a impressão de nossa realidade. Entre o que calcamos da realidade, do que somos, e queremos, do que tornamos possível, marcas entre os pontos de vista e perspectivas são entrelaçamentos de onde a representação da imagem busca seu verdadeiro sentido. Nesse meio do caminho entre a imagem e o sentido, a palavra torna-se significado, também entre o discurso e o efeito, dentre o que será ainda, enquanto transparência, a possibilidade ética. Sentido e significado. Se pudermos colocar assim: Sentido: ainda que em multiplicidade trata-se do caráter próprio de uma palavra.

\footnotetext{
${ }^{195}$ Série depoimentos. Arquivo de áudio em texto e interpretação. Monotipia como imagem em palavras do manifesto da vida para a face do teatro, sobre o palco do mundo, diálogos ininterruptos do ser.

${ }^{196}$ Série depoimentos. Me olha enquanto arde, até a gota secar, no livro Bálsamo, desmembrado entre espaços do cotidiano e a imagem em impressão e diálogos de linguagens. Viagens dos passos nossos, onde a realidade se faz impressão sobre os lugares da arte. Assim, o corpo social se banha entre poesia e gesto interpretativo de outro ainda texto, do sujeito ambiente feito existência interpretando-se.

197 Anexo. Reflexão que desencadeou um projeto em hipótese de curadoria de objeto enquanto razão de referência a semana de 22 , ou sendo apenas, um movimento de manifesto, de no tempo vigente, arte para quê, a série ou sequencia de exposições sobre monotipia, NO MEU VERSO em desmembramento de reflexão quanto a arte e vida.
} 
Significado: compreensão adquirida do uso do sentido (palavra) em contexto. No caso de querer emprega-los não como sinônimos. E ainda onde sobre a leitura do mundo e a face da monotipia encontraremos, o texto e o leitor. Ponto e linha, ser e tornar-se.

Contato e controvérsias, conversas prazerosas,

Para Kant, se o estético devia ser caracterizado inteira e exclusivamente em termos do prazer, fazê-lo equivaleria a reduzir o estético a algo pertinente ao interesse ou favor puramente privados. Portanto, para ter valor, o prazer estético deveria. ser desinteressado e em consequência, prazer universal, ou seja, prazer sem lucro, vantagem ou gratificação individual. Uma corrente contemporânea de pensamento antikantiano veria esse relato do prazer estético como simples negação ou abolição do prazer sensual em benefício do prazer estético purificado do prazer, como diz Pierre Boudieu, que nada mais tem de prazer. Outra visão talvez mais nuançada é a sugerida por Terry Eagleton em The Ideology of the Aesthetic ( 1990 ) que vê a emergência da esfera autolegitimadora do prazer estético depois de Kant como instruída pela necessidade política de mediar a experiência e a autoridade na sociedade burguesa. ( CONNOR, ano, pg 43 )

Então perguntamos sobre o cunho social de onde poderemos encontrar na face mesma moeda, como monotipia valores e prazer, ilusão e realidade, percepção e "manipulação", onde retiramos verdadeiramente qual razão da consciência como estética dentre uma lógica aferida por condutas de meandros possível de serem ou tornarem aspectos de uma existência.

Mas, com efeito, é também apenas por intermédio de uma implacável redução lógica que esse problema pode ser apresentado segundo as alternativas acima apresentadas: o prazer e o valor ou são idênticos ou distintos. Tal como no impasse absolutista/ relativista, a própria investigação do relacionamento e da oposição entre prazer e valor induz a cisões, deslocamentos e transferências dos seus respectivos sentidos; assim, por exemplo, tentativas de diferenciar valor e prazer podem depender de distinções similares entre formas diferentes de valor no prazer. (CONNOR, 1994, pg 45).

As tensões entre aparências ou certezas opostas. Aparências quando dispostas de má fé, são, todavia, entraves e prejuízo de compreensão, posto que dificultam a veracidade que a realidade necessita para justificar-se enquanto aferição de conduta de e para um desenvolvimento. Valor, prazer e civilização.

O momento e o continuo:

Mas há uma incerteza na própria noção de equilíbrio que complica de maneira crucial o modelo econômico freudiano do prazer que está em ação aqui. Será que a obtenção do equilíbrio envolve a manutenção de uma 
estabilidade entre forças ou apetites opostos ou gradual redução de todas as tensões a zero?( CONNOR, 1994,pg 48).

Em meu modo de ver, neste momento, creio que não é uma negação do prazer, mas aonde ele se localiza de que maneira e qual suas razões de ser. Portanto aqui vale ressaltar a presença necessariamente da responsabilidade, sendo que penso que não á mal, ou negação do prazer, mas em qual direção ele caminha. Assim sendo, em relação a diretrizes da conduta de massa e por onde o indivíduo se observa participante e atuante na dramaturgia do viver, é vital a diretriz sem manipulações porque corre o risco do efeito ser uma gangrena social e patológica em amplo aspecto e instâncias, tanto para o indivíduo como para a relação cidadão- estado.

Interessante o que aponta a relação desejo e prazer, até mesmo como face de monotipia, sendo que o significado de desejo inclui penso o prazer, sendo parte desses sentidos, a volúpia como fator que engendra sabor e um pouco mais, até como antes de um consumo propriamente, portanto, e um tanto quanto amplo o aspecto da relação prazer e desejo, e do antes e depois que o tempo exerce sobre nós como manifestação de libido, de razões para permanência ou efêmero. Cabe, portanto no câmbio de ações transformar o prazer em valor. Falando em contexto, talvez seja um bom começo, tentar dizer sobre que contexto, porém, ainda eu preferia usar da própria literatura para falar sobre, Sempre me parece que a própria palavra debruçada feito narciso ${ }^{198}$, pode quem sabe ouvir os gemidos que o prazer esconde, ou o silencio.

Existe um lugar do silêncio que não é do mundo e nem do homem, mas do que a ausência da compreensão mora, e reside um argumento de razão que se constitui ele mesmo propriamente um lugar alheio ainda que sendo o quanto exista do mundo que também não o veja ou o compreenda, e esse espaço é distância, mas preenche quando do mundo passa a ser consciência. O que nos coloca na posição de estando no mundo, nos ausentarmos dele, e aqui claramente estamos cientes de responsabilidade, até mesmo, de maneira mais profunda.

E nesse pensamento, encontramos também a reflexão do que é prazer, necessidade, consumo, desejo, principio vital, expressão, instinto, valor. Ainda que do que o redemoinho possa ser como Derrida considera Weg, caminho, sem Umweg rodeio, pode aqui a reflexão pondera que se observa sistemas e elementos acrescidos ao mesmo, diante dos quais o comportamento poderá ainda que o mesmo, sofrer no decorrer alterações ou afirmações,

\footnotetext{
${ }^{198}$ Um conto de Narciso. Talvez coloque nos ensaios poéticos teatrais.
} 
dentre o que todavia permanece desejo ou rompe até mesmo, surgindo querer de outra natureza, formando até novos sistemas.

Há quem diga, não é novidade, que a partir do momento que nascemos, morremos um pouco a cada dia, e de certa forma, se assim adentrarmos esse pensamento, não estaremos tão distantes dessas duas possibilidades habitarem o mesmo espaço, e destino e caminho, morte e vida, cerceiam um completude. E de certa forma, como mensuro ou como estou realizando meus dias são a possibilidade de um prazer enquanto vida frente a fatalidade efêmera do acontecimento ou não, sim, quando cada dia se encerra frente ao tempo, uma parte que o desprende, e não, se estou continuo frente ao que se foi. Perda quando ativo, deixa de ser uma angustia, mas sim, uma produção que efetivamente é ganho, dizendo em aproximação a uma espécie de valor. Uma certa relação se estabelece do porvir com o ontem, em necessidade e compreensão.

Do lugar que se pergunta, sobre sombras...Aonde vai sombra? Vou a negativa do impossível. E porque se caminha sobre pegadas nossas sobre o sol, onde está a natureza que me olha quando a neblina envolve o sol, mesmo a imagem estando lá, carne do mundo, reflexo de um tempo.

Espaços de nossas naturezas, dentre o tempo que fazemos, o tempo que seremos e o lugar de nós.

Seja a qualquer hora, e qual passível te deponhas, saiba que sem demora, como o queimar do sol da mesma hora, esteve outrora os mesmo olhos retirados da proa, e destilados como fel a lhe fazer companhia, feito anzol de quem espera, o pescador ou do fundo de tua alma, o peixe, ainda que sejas apenas o barco enfim,

Sobre monotipia, pensamento e ato, ética e expressão, condutas sobre travessias.

Gosto de pensar, o que para alguns possa soar como não muito apropriado, como sendo justamente o ver a linguagem como toda forma de comunicação, portanto, não restrita a forma da língua, mas como estruturas de códigos, assim sendo, temos inclusive a possibilidade de sendo assim, observar como sendo de todas espécies e formas vivas uma capacidade de em seu agir, existir, tem a sua forma de comunicação como agente de linguagem, com elementos que se fazem compreender em espécie e ambiente. Mas, no presente momento, me surgiu ao pensamento uma outra conjectura que é a de um dilema, talvez, se apresentando como a ética e a expressão, da palavra e a narrativa, da realidade e o sentido. 
Podemos parar de nos preocupar com a questão como um romance social retrata as condições de vida da sociedade da metade do século XIX, perguntando em vez disso que tipo de mundo ele cria e em que tipos de relação de poder o texto literário entra, começando quem sabe pela litania de perguntas propostas por Edward Said. Quem escreve? A quem se destina essa escrita? Em que circunstâncias? Essas perguntas podem naturalmente ser respondidas de várias maneiras e de diferentes objetos, logo, poder-se-ia igualmente investigas as relações discursivas da literatura como tal, ou da crítica literária. Dado que uma das coisas que fazemos de modo mais compulsivo e habitual na linguagem é infligir violência, por em vigor a exclusão e manter relações de injustiça, essa nova orientação na teoria crítica e na linguística ( literária ou não ) dificilmente se pode deixar de fazer com relação ao discurso todas as perguntas, relativas a bondade, à justiça, à ação, à responsabilidade, de que os teóricos da política e da ética preocupados com a ação humana de modo mais geral se têm tradicionalmente ocupado. Nesse momento nasce a ética do discurso. [...]Habermas alega que o intercâmbio discursivo tem como resultado ideal o atingimento de uma racionalidade baseada no consenso, ou a comunalidade intersubjetiva da compreensão mútua, do conhecimento partilhado, de confiança recíproca e de acordo entre si. O acordo depende do grau de validade pretendido e concretizado de quatro maneiras distintas: a compreensibilidade do que está sendo dito, a verdade do que está sendo dito, a sinceridade do locutor e a adequação entre o que é dito e o contexto social em que é dito. Para ser racional e legítimo, esse consenso tem de ser não-forçado (unforced) ou seja, livre de todo tipo de constrangimento, distorção ou restrição, tendo de ser governado por nenhuma outra intenção estratégica ou proposição além da de estabelecer a verdade.( CONNOR, 1994,pg 111-112).

Argumentos de uma sociedade se estabelecem frente a realidade posto que no viés concreto carecem da correspondência do discurso como ação.

Habermas reside exatamente em sua evocação de uma orientação utópica no interior da estrutura do discurso, se bem que possa de fato implicar o desejo de fechar a lacuna entre a realidade e ideal, essa proposição não joga tudo na possibilidade de se alcançar essa convergência. Do mesmo modo como a improvável perspectiva da paz universal e da boa vontade na terra não nos impede nem nos deve impedir de tentar minimizar os reais conflitos existentes no aqui e agora, poder-se -ia pensar, de maneira semelhante, que a situação ideal de fala pode ser descrita e recomendada como orientação motivadora e operativa no âmbito do discurso sem precisar ser ou se tornar necessariamente concreta. ( CONNOR1994, pg 113).

Do impulso, a razão, consciente de estruturas do pensar que viabilizem caminhos concretos.

O que pode ser da natureza do pensamento, sendo educação movendo práticas de conhecimento é ação comunicativa. Vale ressaltar que sempre ao tratarmos de linguagem aqui no corpo deste trabalho se trata do modo de comunicação de tudo que habita o planeta. Sobre a face de um conhecimento, deve se ter em mente a necessidade de elucidar como o 
próprio pensar pode estar estruturado em núcleo, ramificações, conexões dentre o que expusemos como diagramas, e mais ainda, entre o modo de ser, do entrelaçamento da razão e sentimento, diálogos de compreensão, e como diante deste panorama se pode então aplicar o próprio modo operandi do pensamento em orientações de conduta, práticas sociais, concepções de indivíduo - cidadão, portanto agindo no pensar como linguagem que torna-se comunicação enquanto mente e se corporifica realidade em ato realizado natureza múltipla disposta sobre o existir havendo de lidar com espaço e tempo de maneira que discordâncias e consensos sejam questões de aproximações sobre o diálogo contínuo para a compreensão. ${ }^{199}$ Mas vale dizer que necessário é a ressalva quanto ao emprego em todo o processo de comunicação estando sobre o prisma do pensamento e conduta no prumo ético que em estratégia de concepção diagramática exposta como agentes na realidade, exerce ação de maneira integra e digna, de forma a conceber o caráter licito em suas conjecturas desde o discurso, argumento de sujeito narrativo até os fatos permeados na relação social. Discordâncias como análise óptica, ponto de vista, exauri um tanto quanto as forças de um caminho porém é de muita relevância, sendo que não podemos encerrar um objeto de pensamento como cárcere, isto seria como ir contra sua própria natureza movente de sentido em busca da compreensão, ainda que ela ocorra em seu contrário, não que isto seja necessariamente, mas sim, positivamente, como argumento mínimo desta possibilidade, o respeito.

Um engodo muito comum, em meu modo de observar é justamente que ao adentrarmos outros modos de linguagem em comunicação, justamente o que ocorre é que nos aproximamos pela nossa maneira de nos relacionarmos com o mundo, sendo que ao menos deveríamos ter a humildade de reconhecer estados diversos de apreensão em comunicação e conduta, de maneira a que do que tudo vive, age e pela ação corporifica ato, diagnóstico de seu dizer comunicativo, assim sendo presumo que o melhor seria a postura de observação, para aprender em vez de impor nossos modos e maneiras de agir em comunicação, para diante da observação, encontrar o que pode ser diálogo profícuo entre os envolvidos.

Pensamento - linguagem - ato- ato e linguagem/ A linguagem em corpo de conduta, exerce força a se confirmar em veracidade de correspondência ao pensamento.

\footnotetext{
${ }^{199}$ Ver Teoria da compreensão de Dimas A. Künsch. Revista Líbero, artigo intitulado: Saber, afeto e compreensão, epistemologia da comunicação e dialogia, São Paulo - v. 14, n. 27, p. 31-42, jun. de 2011.
} 
1. Descrição (observação) constatação- averiguação - Pensamento - Ato linguístico em qualquer expressão de códigos / fase de dados (ex. O que é) - fase investigativa inicial Percepção e avaliação constrita

2. Relação - para com/ experiência - compreensão "repertório" em direção ao 1. P.A. (como me parece) / Discernimento. Avaliação expansiva

3. Entre - mediação - relação que comporta inclusive os dois acima e a heurística. P. A . E - (como posso torna-lo outro nele mesmo), argumentação de probabilidade gerativa.

4. Instrumentalização - Uso em conduta - P. A. E. I. (de acordo com as anteriores - como agir) Razão.

1 e 4 - Assimilação - aproximação - judicativo - informação em desmembramento ou não. O pensamento pode requerer o uso da linguagem ( aqui sempre tratando das mais diversas formas em que podem ser utilizados códigos para expressão ), ou não, apesar de que o pensar em si, constitui uma gama de procedimentos anteriores ao que pode-se constatar nos itens 2, 3 e 4, sendo que existe algo que é da matéria do momento, ou seja um dinamismo informacional que tem um caráter quase como involuntário ou como prefiro, emergencial, ou seja um procedimento de caráter de forma física ( sinapses ) mas em cognição explicita poderíamos dizer, impulso vital, estimulo, propulsão, reação, em uma velocidade negligenciada pela força do hábito e desconsiderada como matriz.

Consenso e mediocridade humana, o que nos faltou compreender? Sinceramente compreendo a força que pode ter um discurso porém, ao avaliarmos os acontecimentos históricos, por exemplo, a segunda grande guerra, e os nazistas, eu simplesmente não consigo crer que seja ou possamos considerar que somente a força de um discurso tenha envolvido uma nação, e me foge completamente as razões de consciência que tal atrocidade possa ter encontrado no senso comum, porque não há nem consciência de nem senso em tal conjectura, e portanto, é do mais alto grau de mediocridade humana. Porém, em relação a constatar formas de uso da linguagem verbal, enquanto pensamento e ato, por infelicidade haveremos de constatar que pode-se encontrar um campo de ação pejorativa de cunho quanto ao alcance duvidoso frente aos valores morais, que supomos deveriam nortear todo e qualquer forma de discurso quanto e principalmente no tocante ao que move um povo, e mesmo assim, no âmbito restrito do indivíduo também se considera e encontrar-se o uso de manipulação, de induções com prejuízo de um outrem, mas, isso penso, deveria supor que não é ileso da repercussões de contra ordem ou seja em algum momento pode haver replica quanto a argumentos e não validar a ação voluntária de conduta ilícita. 
É de fato muito difícil contrapor direitos, sendo que podem ter oposições e realizar um posicionamento de acordo, requer discernimento e principalmente respeito pelas partes envolvidas, quer sejam cidadão e Estado, ou povos de origem diferentes e culturas.

Temos divergências quanto a auscultação de uma densidade ética considerada em pensamento e sua vazão no campo fático, de onde discorre a possibilidade de termos diferenças sobre o que seria as normas éticas quanto a explicita e especifica ou implícita e não declarada. ${ }^{200}$

Habermas tenta lidar com esse problema aprimorando progressivamente a distinção entre a ética universal das formas discursivas e as ações e crenças culturais e historicamente especificas articuladas por meio do discurso. Lytoard tenta manter essa distinção de modo ainda mais enfático, insistindo, como vimos, em que a política que tenta regular e dar conta da multiplicidade de gêneros não é ela mesma um gênero, ou, equivalentemente, que a filosofia que procura legislar sobre o campo de legislações linguísticas que é o discurso em geral não é legítima no sentido forte: As bases do discurso filosófico, escreve ele, estão numa regra ( ou em regras ) que permanecem por serem procuradas e a que o discurso não pode ser levado a conformar-se antes de al ser descoberta. Enquanto Habermas residem na extensão da força e do domínio do discurso racional, igualitário, o valor e o propósito políticos estão igualmente para Lytoard na determinação de resistir, com uma espécie de melancolia, a personificação do futuro utópico pelo presente. Apoiando-se no relato kantiano do efeito enobrecedor da Revolução Francesa, Lytoard sugere que o mais importante princípio ético é o da lacuna entre o ideal e a realidade, entre os ideais de

200 “ O universalismo encoberto de Lytoard apresenta duas dimensões que são, respectivamente, protetora e imperativa. Assimilar os outros à força ao nosso próprio projeto de emancipação ou, em termos mais gerais ao nosso estilo cultural, é para Lytoard uma violação injusta precisamente porque ele supõe, como deve fazê-lo, o direito universal de todos os povos grupos e mesmo pessoas de não ter as autonomia violada dessa maneira. Essa suposição seria desvelada se se perguntasse: quem Lytoard possivelmente desejaria isentar da proteção dessa norma ética? Como poderia ele pôr em prática essa isenção sem praticar a mesma violência que condena? Aqui, com efeito, o critério da autocontradição se aplicaria a ética lytoardiana do discurso exatamente da mesma maneira como se aplica a Habermasiana, porque Lytoard presumivelmente estebderia essa proteção a toda e qualquer cultura, de todo e qualquer período da história, exceção feita àquelas cujas ações, discursivas ou não, violassem sistematicamente os direitos discursivos das outras. A dimensão imperativa da ética do discurso de Lytoard seria correspondentemente revelada perguntando-se: quem ele desejaria isentar da responsabilidade de não violar injustamente o discurso dos outros?[...] Segundo o livro, “ Isso não equivale a dizer que não haja diferença entre uma norma ética explicita e especificada e uma implícita e não declarada. No sentido de que é isso o que separa e distingue Lytoard e Habermas, trata-se de uma diferença que faz toda a diferença do mundo. Para Lytoard, não haveria possibilidade de dar concretude a uma norma universal na prática, visto que isso é ou sempre tem probabilidade de ser, injusto, ao passo que para Habermas, como vimos, tudo se alicerça nessa possibilidade. Há pois, uma crucial diferença na fora de orientação ética imaginada pelos dois filósofos: Para Lytoard a orientação ética tem de ser sem chegada a formas corporificadas de valor, enquanto para Habermas a orientação nada significa sem a possibilidade dessa chegada. Isso porque Lytoard rejeita a noção de ação comunicativa tão central no argumento de Habermas, insistindo em que, como toda linguagem é estratégica, uma questão de jogo e de ganho, e não de uma questão de comunicação que leva ao entendimento, a comunicação no sentido habermasiano só poderia ser vista como uma forma particular de ardil estratégico.( CONNOR, 1994, pg 122 ). 
liberdade e de justiça visados pela Revolução Francesa e a violenta realidade do terror. Isso se assemelha mais com uma resposta estética do que ética, e uma resposta estética pertinente em particular a teoria romântica do sublime, que põe em relevo o hiato entre a vastidão da apreensão pela mente das formas naturais e a sua capacidade de representar essa vastidão. ( CONNOR, 1994, pg 123 ).

Creio ser este um momento para elucidar um ponto atual em desejo e expressão, quanto ao discurso e ação. Do livro de Fernando Almeida (2007, 134), os desafios da sustentabilidade $^{201}$ uma ruptura urgente. Coloca no capítulo seis, apontando o norte da sustentabilidade, para esforços mútuos de pensamento e ação, onde considera que traz ao palco personagens e temas antes relegados as coxias, posto que a sustentabilidade mexe com as estruturas de poder. $\mathrm{O}$ autor aborda a questão através de constatar a governança no mundo tripolar, onde a melhoria social se daria pelo entrelaçamento de governo/empresa e sociedade civil. Na busca de uma ética, em monotipia.

A governança no mundo tripolar é possivelmente um dos maiores desafios do século XXI.[...] Nesse cenário, tomar decisões tem se tornado uma tarefa cada vez mais árdua. Não bastasse o acirramento da competição global, a rápida sucessão de inovações tecnológicas que devemos acompanhar e o crescente corpo de conhecimentos que precisamos digerir e absorver, ainda somos convocados a adotar práticas que nos impõem dilemas antes desconhecidos, que exigem sistemas de prestação de contas inéditos, e cujos resultados têm, por isso mesmo, uma larga margem de imprevisibilidade. Não é de surpreender portanto que executivos e políticos e outros indivíduos em posições de liderança e mando sintam-se por vezes, atarantados, divididos entre o que fazem e o que acham que deveriam fazer (ALMEIDA, 2007, pg 130 )

Ainda de suma importância Almeida considera:

Dentre outras colocações, alerta que para a sobrevivência precisamos " 1 . Entender que a ruptura está nos relacionamentos, no modo de operar, no modo de pensar e não apenas na tecnologia. 2 Aceitar que os recursos naturais têm de ser perenizados, porque a falência dos ecossistemas planetários e a falência dos negócios 3 Fazer negócios com os pobres e miseráveis do mundo, saindo da zona de conforto de só produzir para quem está no mercado. 4. Entender que comportamentos éticos trazem ganho econômico e não prejuízo. (ALMEIDA, 2007, pg 130 ).

\footnotetext{
${ }^{201}$ O autor inicia o livro considerando a urgência de enfrentarmos a tragédia sócio-ambiental que impõe a descontinuidade de empreendimentos humanos, públicos e privados, da organização social e de nossas relações como um todo, da espécie humana. Ou seja, aponta a realidade como resultado de um processo predador e de uma gama de reflexos de falta de informação devidamente organizada. Na primeira parte aborda o trabalho realizado como levantamento de uma Avaliação Ecossitêmica do Milênio ( AEM ) encomendada pelo então secretário geral da ONU, Kofi Annan da qual o autor participa como membro do Conselho Diretor. Dentre outras colocações, alerta que para a sobrevivência precisamos.
} 
Neste posicionamento ainda o autor coloca que deve estar presente o estadista corporativo, este não sendo um indivíduo somente, mas um grupo, ligados por um objetivo comum, e direcionados em um esforço global.

De humanas relações em ecossistemas, me parece que por dificuldades, stress, tensões e outros fatores, apesar da natureza e natureza humana, o retorno as condições anteriores não se dão de maneira correspondente ao período, penso, por vários fatores, alguns positivos e outros negativos, havendo, portanto, de qualquer maneira verificar e analisar os riscos e proposições de interferências em curso de sistemas. Talvez bem próximo do que é chamado de Natureza Resiliente, para este ponto Almeida considera os estudos de Holling, C. S especialmente Adaptative Environmental Assessment and Monagement, considerando o retorno como o cessar da tração, podendo por vezes chegar a ruptura, portanto, resiliência tem limites, pautados no cotidiano, em nosso interior, na gama de relações que construímos. Do que queremos, o que somos, e o que poderemos ser. Como já dito neste trabalho assumimos a vida como produto de nosso tempo, e portanto o meio ambiente, preocupações sociais, tudo que se relaciona com a vida é interesse e primordial para uma cultura sustentável. Entre colocações de Lytoard e Habermas ${ }^{202}$, consideramos claramente a eminência de colocar em prática o que queremos no educar o pensamento, em ação onde o discurso se configura espaço social em movimento por suas diretrizes efetivamente transformando e mantendo, dentre o necessário e o adquirido a elucidação de um espaço diagramático visível em ética onde a estética se configura comunicação de relações e lógica da narrativa social.

\footnotetext{
202 "Logo embora tenhamos visto que, em certo sentido, Lytoard segue Habermas ao manter a distinção entre a transcendência vazia da ética discursiva e o real jogar jogos de linguagem - nos termos de Habermas, isso seria a distinção entre os domínios da norma e da lei, do procedimento discursivo e do conteúdo discursivo, da ação comunicativa e da ação estratégica, aqui esta distinção vem abaixo. Na ética do estético proposta por Lytoard , a norma ( a regra da obra de arte ) é questionada no próprio processo de ser aplicada. Revertendo a derivação habermasiana da ação estratégica partir da ação comunicativa, Lytoard faz das normas o resíduo posterior da ação discursiva. Segundo o autor, a ética de Lytoard é contraditória, porque visa a manutenção da contradição e não da sua resolução. "Impelido de um lado por um compromisso positivamente habermasiano com normas universais que garantam a preservação da diversidade e da liberdade discursivas que ( se bem que como vimos, esse compromisso poucas vezes alcance a consciência ), o amargo antagonismo lyotardiano àquilo que vê como uma força dominadora do universalismo ético esposado pela filosofia de Habermas é um antagonismo contrário a si mesmo. "E ainda sobre colocações e contraposições de Rorty no mesmo livro, página 128" ( CONNOR, 1994, pg 125 ).
} 
O radical desacoplamento entre o sentido estético e os imperativos da sociedade e da tradição tem o potencial de informar a consciência sobre como interpretamos normalmente os nossos desejos e sentimentos sob formas que espelham irrefletidamente os padrões de valor vigente da cultura que nos cerca. Habermas, continua a não ser convencido pelas afirmações de que a poética ( Rorty ), a metáfora ( Derrida ) ou a narrativa ( Lytoard ) possam ou devam ter algum papel sério na legítima determinação da ação social ou em processos linguisticamente mediados como a aquisição do conhecimento, a transmissão da cultura, a formação da identidade pessoal, bem como a socialização e a integração social ( que ) envolvem o domínio de problemas apresentados pelo mundo" Mas esse é um argumento que apenas demonstra os seus pressupostos: na verdade, podem-se imaginar inúmeros exemplos dos modos pelos quais o literário, ou o literário concebido em termos mais amplos do que a inovação do mundo ou desvelamento do mundo, pode ter efeitos concretos nas áreas que Habermas considera como a reserva particular do discurso racional legitimado. Com efeito, parece haver bases sólidas para suspeitar de que a formação da identidade e a criação de formas de integração social ocorram na verdade, enfaticamente, por meio de processos literários ou retóricos como a narrativa, a metáfora, os mitos etc. e de que a reprodução da vida social não é ne, nunca foi regulada pelos tipos de ação comunicativa séria supostos por Habermas. Claro que seria possível concordar com esse julgamento da perspectiva de Habermas e mesmo assim ver nisso uma razão para lamentar, afirmando com alarme que, as reivindicações da situação ideal de fala implicada em todo discurso racional ainda tem de ser definidas, em parte por causa das influências, deturpadoras do literário sobre a racionalidade. (CONNOR, 1994, pg 129-130).

Eu percebo, apesar de como já escrito, faltar dados intrínsecos dos autores citados, uma necessidade de distância, de dicotomia, entre uma coisa e outra, entre variáveis que em meu modo de ver, podem se relacionar livremente, linguagem, filosofia, poesia, discurso, e sem uma denegrir a outra ao contrário se relacionarem de forma a equilibrar maneiras de compreensão, porque penso que cada uma dessas formas podem se esclarecer mutuamente, e expor em representação coerente.

A percepção, nas imagens e a leitura do mundo, a expressão de um som, cavernas do cosmo - " as sombras" do som - desenhos da alma - o mundo visível, O espírito do silêncio. Ecos do sentido, retornam ao coração. Tambores. ${ }^{203}$

Retornando ao pensamento de que a palavra ou o que a antecede, como olhos do mundo ${ }^{204}$, sejam propriamente sentidos ( significados em paralelo aos modos como o percebemos ( sentidos físicos ) )“ representados” em imagens, sons, enfim, o mundo como ele é

\footnotetext{
${ }^{203}$ Durante disciplina - Bois Kossoy A imagem sonora de um corpo - som produzido com um garrafão de água, no começo da gravação pode se ouvir a agua que tinha ainda no garrafão. . E, depois em 2017 arquivos de audio em piano digital - CORAÇÃO EM LUTA.

${ }^{204}$ Ágape, arte como a vida. Capítulo III.
} 
vivenciado, ao nos mover ao ato de compreensão, emissão, comunicação, que nos entrelaça ao que é vivo, construímos um modo de retórica ao meu ver, e para tal, imerso do que é elementos tão no cerne da poesia, se relacionam Não sei como buscar um sentido, como explicitado, sem a razão. Por vezes pode a incompreensão, não ser da razão, mas de minha aproximação do que é do pensamento que me direciona a razão, ou seja, a razão se apresenta, mas meu modo de acercar-me ainda é vago, incipiente, ou diferente, creio que isso pode ocorrer. Havendo de nos debruçar sobre o que é de sua constituição (quanto a razão) e suas maneiras de ser representada, ou seja, penso que por seus argumentos, suas contraposições, e sua " gestão", ou seja, se procede ( em si ) em desmembramento de sustentar-se, dialogamos na interface interna e externa, na emissão do mundo, dos outros, e nossas razões, expressões, apreensões, e modos de comunicação, e isto penso que é tão propriedade da poesia estar sobre os olhos do mundo que tentarei dizer-me como palavra, para ater-me a sua origem, porque a poesia, é em meu pensar, dito o mundo propriamente, gerando-se movimento, como ritmo do significado da vida, onde as outras linguagens da arte se mostram também em equivalência, porém, como dizia, atendendo propriamente, a retórica como " grafia" do sentido da vida", em expressão de um "discurso “ argumentando-se para compreensão, necessariamente devo buscar a razão da comunicação, em fluxos contínuos do que estamos tratando, então aproximo a poesia da comunicação, uma palavra a mais, nas relações imbricadas a que estamos dispondo, e porquê? Porque do mais subjetivo que possam alegar, de uma poesia, claramente o mundo também o é, e a meu ver, prefiro colocar como sensível, até mesmo pode alcançar significados onde o sentido é do sentimento, propriedade de uma razão onde mesmo sem palavras podemos compreender. Lembramos aqui o poema Blanco de Octavio Paz, proclamado por Octavio Paz e Haroldo de Campos $^{205}$, onde a palavra se completa som, Om que fala o silêncio, "desnuda como uma silaba, linguagem desabitada. Se o eu e o objeto se faz ser consciente, propõe-se, corpo ciente da vida em seu tempo. Monotipia, oportunidades, desenvolvimento social, onde está a imagem da sociedade em cultura sustentável?

Relembrando aspectos de uma arquitetura social onde se coloca o saber ( oportunidades ) como agente de estrutura, creio que na hipótese de projetos inseridos no corpo social como elementos integradores das demandas entre estudos e busca de soluções, se aplica aqui, tanto para se houver essa inserção ou não, a meu ver,( como ) a) necessidade anterior destas reflexões quanto a " metodologia - pesquisa e prática “, ao início de qualquer egresso, como

${ }^{205}$ https://youtu.be/cITnD2MwApw acesso em 15-05-2018. 
um fator, preponderante de esclarecimento ao que e como irá se debruçar no ambiente entre a universidade e a sociedade. É um pensar particular, mas do qual creio que respeitando ainda as formas particulares de pesquisa, claramente o que é apontado quanto ao exercício de estudo de práticas epistemológicas, deve ser fundamento para que se compreenda mais amplamente por onde seguir e como, não somente no aspecto da comunicação mas do empreendedorismo quanto ao ser-social-participativo no qual não se distancia a universidade e sim ao contrário, sendo motor cultural-educacional-políticó-social. Imagino, que seria de grande esclarecimento haver a possibilidade de adentrar caminhos não aferroados, mas deixando margem para estudos livres ainda no próprio campo ( estudos epistemológicos ), como um aspecto abordado para quem deseja adentrar o caminho da universidade, consciente de seu papel social, esteja em uma universidade pública ou não. O esclarecimento quanto a formas e desenvolvimento de pesquisa, podem "interferir" na escolha quanto ao "objeto" e as demandas, assim como a projeção do mesmo. Projeção porque penso que o rumo no qual os pesquisadores se debruçam devem conter claramente a possibilidade intrínseca de que não se esgotam com uma defesa, mas ao contrário, é um perene e continuo esforço de dedicação ao conhecimento, e principalmente, ao aprendizado (e de trabalho). Projetos com propensão a estarem colocados à mostra, ou seja, em desenvolvimento de trabalho- universidade, projetos colocados no âmbito do cotidiano, segundo correlação de escolha- e necessidades sociais.

Connor coloca que Raymond Williams,

Forneceu uma espécie de genealogia do valor cultural que é tanto rica em especificação histórica como teoricamente flexível. Mas o seu trabalho faz isso sem uma única menção à questão do valor como tal", em contraposição Terry Eagleton e Frederic Jameson, " Se a obra de Williams representa um modo altamente influente de análise cultural marxista, a obra de Terry Eagleton e Frederic Jameson pode personificar um modo deveras distinto. Se o lucro da obra de Williams é um modelo acabado de uma sociologia da cultura, o seu custo é certo isolamento enfatuado dos debates teóricos mais cruciais das décadas de 70 e 80. Eagleton e Jameson tentaram responder de maneira muito mais direta do que Williams aos muitos ataques aos valores de significado, da totalidade e da verdade determinável, tão em evidência nesse período. Esses dois teóricos responderam especialmente a grotesca bifurcação de atitudes com relação ao estético na teoria pós-moderna, na qual a especificidade do literário ou é inteiramente liquidada em favor de alguma noção geral da representação cultural ou extremamente inflada no extremismo nietzchiano de um Deleauze ou do primeiro Lytoard. As respostas de Eagleton e Jameson tem se pautado na tentativa de aprender a categoria do estético de maneira plenamente dialética ou seja, permitindo e desenvolvendo uma crítica daquilo a que Eagleton denominou a ideologia do estético - os ocultamentos, as fixações e as falsas totalizações personificadas no ideal do 
estético nos últimos dois séculos - ao mesmo tempo em que se recusa a abandonar a possibilidade de discutir práticas artísticas e obras de arte em termos de seu valor. Tanto Eagleton como Jameson procuram situar-se a um só tempo, dentro e fora da questão do estético, quero dizer, dentro e fora da questão do valor. ( CONNOR, 1994, pg 140)

Palavra e sentido, imagem e sociedade. Eagleton considera sobre a natureza do valor literário.

\begin{abstract}
Seu primeiro movimento consiste em reencenar a questão do valor como principalmente uma questão de produção literária. Eagleton se acautela cuidadosamente do perigo de ignorar as relatividades de circulação e do consumo, que, no caso dos textos literários, tem de ser caracterizados, em certo sentido, como dissolvendo desde o começo a divisão produção/consumo: " não há valor imanente - nenhum valor que não seja transitivo. $\mathrm{O}$ valor literário é um fenômeno produzido na apropriação ideológica do texto, a produção de consumo da obra, que é o ato da leitura. Portanto o valor de um texto literário, continua Eagleton, nunca é mais nem menos, do valor relacional: valor de troca e não o valor em si. Essa admissão da relatividade dos julgamentos não é mero subjetivismo, já que para Eagleton, as contingencias do valor são primariamente ideológicas, e o texto literário é sempre o texto para a ideologia, selecionado, tornado legível e decifrado por certas convenções ideologicamente governadas de receptividade crítica para as quais o próprio texto contribui. ( CONNOR, 1994, pg 141).
\end{abstract}

Distanciando-se ou não de um real, ainda que possa significa-lo, entre a estética e a ideologia, os reflexos ou "descrições", são absorvidas a meu ver, podendo ser ambos, ou seja, de certa forma um distanciamento ou não, conforme o " objeto" do autor, ou seja, de que maneira a obra quer se manifestar entre ela ( obra ), o mundo ( realidade, e o ato de escrever no caso, portanto, penso que a comunicação enquanto mensagem, neste caso, se pensarmos quanto a estética, do que está sendo considerado nesse momento, me parece realizada entre escolhas, que podem ocasionar por ora, mais fortemente um aspecto em detrimento de outro, ou não, podendo inclusive manifestar alguns aspectos de forma mais velada ou não, havendo para tal inserir a ideologia, como inclusive estética do ato literário. Até mesmo um distanciamento de uma obra de "seu tempo", pode significar-se, e ensinar. Portanto, de onde formamos a imagem de nosso tempo? ${ }^{206}$ Nesta pesquisa se considera fortemente a ressonância.

\title{
RE FAZENDO
}

${ }^{206}$ Sousa, Carina Gonzalez Y. Composição Esquina do tempo. PIANO. 
Esteja sobre o tempo

Esteja sobre a sombra das aguas

Ou somente águas

Sobre as luzes que nos banha, ( nostalgia )

Ou somente as luzes ( orgia)

Frias como distâncias do silêncio

Ou próximas como o calor do vento ( suspenso )

Prossegue, de onde o estar

Pode não se revelar que

Está a navegar contigo

Em todas águas e luzes

Ou apenas o barco, sem ancorar

Nada mais que o lugar de um sonho

Que a realidade escreve entre linhas e

Beijando a imagem do entre

Segurando nos lábios, até sentir o coração

Impressão marcada como nuvens tênues do desejo

Latente quase, não vejo

Desata-me profundezas de onde observo

Poesia em superfície.

Espaço da imagem litero-acústica contemporânea Segundo Eagleton,“ As metáforas de tensão, conflito e fluxo geológico encenam na argumentação de Eagleton a libertação estética das forças produtivas, que vai representar uma superação não apenas da divisão forma./conteúdo, mas as das próprias estruturas de troca que permitem pensar o valor. “

The Ideology of the Aesthetic retoma a sugestão feita no final de Criticism and Ideology de que a política marxista de libertação humana é essencialmente estética no sentido de se orientar para o exercício livre e irrestrito das capacidades humanas como fins em si mesmas, mas agora dando a esse juízo uma força mais específica, ao identificar em particular a libertação do corpo como a fonte da política utópica de Marx: Somente quando as pulsões corporais forem liberadas do despotismo da necessidade abstrata, e o objeto for tirado da abstração funcional e devolvido ao valor de uso sensualmente particular, será possível viver esteticamente. A ironia está no fato de que a união, na teoria estética, do espírito e dos sentidos, do intelecto e do corpo, da forma e do conteúdo, seja simultaneamente uma autentica tentativa de resgatar o imediatismo do corpo humano de sua brutal abstração em valor de troca e uma idealização abstrata que é próprio 
sinal da cisão que essa reunião tenta curar, aqui, o estético é tanto ferida como bálsamo. É por essa razão que a associação marxista implícita entre a integralidade do estético e o imediatismo do valor de uso é tão vulnerável á objeção de que sustenta o próprio idealismo que denuncia. ( CONNOR, 1994,pg 145).

Atos conscientes - cultura sustentável - uma troca possível? Atualizando aplicativos, ações sobre tempos vigentes. Alguns pontos de vista se fazem compreender em possíveis indagações entre lados da moeda. De um valor estético na observação do que vivemos e do que queremos.

O valor estético - “ Parece que o valor estético residiria na premonição ou promessa de uma combinação profundamente sem precedentes entre forma e conteúdo que também é, não obstante, uma superação das maneiras idealizadas e reificadas pelas quais a sua resolução foi até então imaginada na estética formal do belo. Isso significa que o estético é tanto uma antecipação utópica de uma esfera de valor realizado como um constante lembrete de que, para um mundo brutalmente alienado de si mesmo pelas abstrações do valor de troca, tal esfera tem de permanecer impensável. "Se o marxismo tem mantido certo silêncio acerca do valor estético, isso pode muito bem dever-se ao fato de que as condições materiais que tornariam esse discurso plenamente possível ainda não existem", já declarara Eagleton no final de sua discussão precedente do valor estético ( CI 187 ). Se a estética do belo promete uma aproximação entre forma e conteúdo, abstração e particularidade, em alguma síntese demasiado ( belo - homem / natureza/ politico social/forças e reações/ lua e sol/ tempos e contra tempos/ realidade e desejos/ ilusões e cotidiano/ percepções) imaginável, a estética política do sublime, mantém uma proibição de tentar imaginar uma consecução de tal síntese. Essas projeções estéticas de futuros perfeitos consistem num irromper realizador de desejos a partir das condições degradadas do presente que dá consolo justamente à medida que atrofia a vontade de descobrir os modos pelos quais o presente poderia realisticamente ser levado desembocar nesse futuro. Portanto, paradoxalmente, a forma mais valiosa de pensamento político é a recusa proclamar a realização do valor, personificando a sua orientação para o valor exatamente na obra de negação ou contravaloração que é capaz de traçar no âmbito do presente a falta secreta de identidade consigo mesma que é o ponto em que um futuro viável poderia germinar - o lugar em que o futuro eclipsa e esvazia a plenitude espúria do presente. ( CONNOR, 1994, pg 146 ).

Teremos claramente visões de cunho pessimistas e deterministas até, porém, também um olhar de crença resoluta no caminho traçado para o que almejamos como objetivo tópico feito concretamente aos goles de uma sede humana que necessita subsistir ainda que para alguns como sonhos, mas para trabalhadores, empreendedores, cidadãos, um direito de traçar rumos ao que se deseja alcançar de um viver, e condições humanas melhores, onde o 
caráter da estética é matéria da moeda de lados onde o valor de uma ética se faz lógica eminente de condutas contemporâneas, espaço real de nosso tempo. O que se busca em uma estética que se encaminha pelos traçados políticos- sociais onde o cidadão é partícipe de sua constituição, ou seja, não é algo apartado dele, vemos como a preservação assim como o meio ambiente, do ambiente dos direitos de todo ser humano, em dignidade, em meios de subsistir com oportunidades, manutenção de condições de trabalho, educação, e tudo que pode estar sobre o " mecanismo" de uma sociedade que deseja criar uma marca onde seus parâmetros de missão são plenos de sentido do que almeja promover como responsabilidade de cidadão, família, comunidade, governo, onde o credo, a raça, condições sociais, territórios urbanos ou globais, em diversidades porém que estejam como, respeito, união, razão como forma de delegar espaços de sociedade ao observar caminhos em potenciais e diretrizes, de maneira igualitária e liberta, havendo abertura inserida em cognições de um rumo como ideal concreto para todos de forma a existir a realidade como integridade humana.

Tempos atuais, a troca, pode ser vista como estratégia de cognição responsável em diretrizes sustentáveis entre divergências e convergências sociais. Ou seja, a capacidade humana de gerar esforços para sobreviver, encontra uma direção aberta a diálogos contínuos onde se pode observar e diagnosticar capacidades em rumos que se farão mais produtivos, receptivos e capazes de funcionarem de maneira mais eficiente como fator social, e principalmente como indivíduo, portanto, seria quase como um remanejamento entre necessidades, capacidades, visivelmente atreladas as condições de propensões vigentes estas dispostas sobre os termos de: o que somos, e o que poderemos ser, perante a arguição do estado atual do indivíduo e o exame de suas vontades, onde o desejo com a capacitação podem gerar caminhos novos onde o espaço para a ter significado cultural de sustentabilidade em responsabilidade de valor ( humano ), em condições de gerar um futuro melhor.

Se creditamos na vida como produto de nosso tempo, a nossa parcela de mercado onde também produzimos como indivíduo-cidadão, haveremos de realizar a reflexão interna para a inserção do ser no mundo como percepção de possibilidades onde o rumos direcionados estejam de maneira a ser um melhor desenho de nossa imagem, lida no mercado exposto como existir de maneira a ser agradável, justa, permeável por direitos, em " embalagem” respeitada em acessos da sociedade como uma cultura verdadeiramente humana onde o capital, é condição de um pensamento onde a educação é para todos. 
Portanto, apesar da eclipse ou névoa a que estaremos expostos por vezes, também a educação é elemento de uma cultura fundamental onde o caráter digno esteja de maneira que o grito seja um depoimento capaz de ser ouvido mesmo que no silencio das incompreensões.

Do diverso, o consenso, e os tempos perplexos. Um aparte, em parte do todo. Do âmbito particular, para o geral. Aspectos correlacionados em capacidades integrativas, de expansão, havendo de realizar transformações, gestão de espaços sociais e desenvolvimento, em uma lógica que se apresenta no todo como nas partes, ressaltando a capacidade de relações ou seja, é uma lógica comunicativa, que considera adjacências e controvérsias.

Me parece que ao tentarmos compreender as relações apontadas nas palavras acima, muito já foi considerado, porém, penso que sempre algo quando novamente reflexionado pode oferecer um discernimento outrora antes não percebido.

Para começar as considerações que irão advir neste momento, creio que apontaremos o foco principal onde tudo está cerceado, ou seja, como colocado na pesquisa o estudo ocorre sobre, a própria vida, o eu objeto, aqui um certo eu-vida, sujeito múltiplo, complexo ( que se estabelece tendo como fio condutor as relações do indivíduo e a sociedade, como corpo integrado ), e para tal, onde pressupomos que a estética é propriamente valor intrínseco, e advertimos que o uso da palavra valor tem aqui sua força e sentido, proposital, sendo que consideramos a estética imbuída do que é também, bom e verdadeiro, considerando os aspectos relativos a ética ${ }^{207}$ o que presume-se outro ponto, que vem a ser o do pensamento e conduta, correspondendo a claramente, uma " ação comunicativa. (em correspondência). Penso inicialmente no trabalho como uma força em movimento, ou seja, fator essencial a produção da vida, considerando que para tal, no mercado do existir, estamos expostos a todo e qualquer tipo de trabalho*, pois a vida constitui-se nessa complexidade que ocorre em âmbitos do ser, enquanto indivíduo, família, sociedade, instituições, empresas etc, ou seja, o ser-lugar, porque aqui se considera integrado o eu agente, colocado como o trabalho exercido enquanto ser interno( seus dilemas, seu pensar, enfim, tudo que abarca um individuo - " nele mesmo "), e onde ele exerce a co-habitação do trabalho interno-com o lugar em fluxo de cada vez mais ambientes sujeitos de seus fragmentos do mundo em si, que tem ainda, nesse meio, a sociedade, considerando escalas de amplitude onde o trabalho é fornecido, com suas ações e reações, da e para a vida, constituindo-se nela e em projeção. Dessa maneira considero desde o momento em que se respira, a faculdade intrínseca de agir,

\footnotetext{
${ }^{207}$ Ver estudos do Filósofo Charles Sanders Peirce, assim como Plotino, Schelling e aspectos colocados pela autora no livro, Ágape, arte como a vida.
} 
e nesse agir, o movimento, este considerado, como uma das forças do trabalho, a gênese diríamos, e consequentemente a responsabilidade que isso se apresenta, pelos quais somos chamados a exercer nossos papéis, diante de nós, da natureza, das leis, das descobertas, enfim, tudo o que é existir. Pode parecer de amplo aspecto, porém, assim como se ampliam as escalas, elas se restringem ainda que relacionadas e em reverberações, apontadas pelos efeitos e consequências visíveis, mensuradas posteriormente ou em ato presente. Alguns aspectos podem ser comtemplados, como o prazer que um trabalho pode trazer quanto a nosso bem estar diante do que queremos ou conquistamos, e desprazer, atentando às causas e também suas consequências, advindo não esquecendo, da possibilidade de escolhas, ou de “ escolhas possíveis “, nestas últimas os caracteres particulares no entre fluxo quanto ao que é do posicionamento social; aspecto este que não podemos relegar em qualquer análise, posto que é fator interacional no sistema, positivamente ou negativamente, e onde faremos menção ao que é direcionado quanto a oportunidades e capacidades. Portando o trabalho que tem o seu valor e fornece valor se dispõe antes de estar no mercado disseminando, compreender nele mesmo, a capacidade que pretende, assim sendo, agrega valores em princípio interno, para ser da mesma maneira como agente externo, disseminando na sociedade, instituições o mesmo caráter correspondente que tem como seu fundamento. Dessa forma, o valor aqui proposto, considera que ele germina, raiz e frutos, sementes e proliferação. Vivemos em um tempo em que aproximar distâncias como o que vou colocar, parece um tanto quanto inconsequente com o advento das redes e a globalização, porém, em certas localidades a discrepâncias das ditas realidades assombram qualquer necessidade de viabilizar uma ideologia de, se não igualdade de maiores oportunidades, carentes de mecanismos viáveis, sendo que muitas vezes o fator representacional é em maior número pelo apregoado a uma certa parcela onde tudo pode parecer em conformidade ao socialmente aceitável, quase como o meu oculista me disse, após uma cirurgia de miopia, ele me disse que eu teria uma visão socialmente aceitável, e retirando desse contexto, mas aproveitando em parte, poderíamos dizer que certas visões do status quo da realidade de vivências sociais são expostas sobre esse olhar, faltando talvez a visão não tanto aceitável, mas talvez, mais verdadeira. Então ao se falar sobre um viver melhor, e aproximações, onde tudo a nossa volta parece conectado, onde estarão as conexões entre; particularmente nossa sociedade (no caso, neste país, e mesmo também, nos aspectos globais que em alguns aspectos nos são tão reais e próximos, virtualmente reais, mas que, e apesar disso), e o $\operatorname{cotidiano}^{208}$, que nos

\footnotetext{
${ }^{208}$ Sousa, Carina Gonzalez Y. Composição O social Humano. Nas ruas o tecido veste, o social humano, que do
} 
parece tão carente e tão distante. O que falta? Plantar ou colher? Ambos? Em qual terreno? Qual o alcance de um valor onde não se tem oportunidade, mas se tem capacidades (lembrando da relação valor intrínseco com fluxo externo)? O que se perde, ou quem perde, Estado, indivíduo, relações humanas... onde encontramos forças de trabalho estagnadas, e porquê razão?

E a base de uma comunicação, aprendizado, construção, está a cada dia como solo e obra. Se por ventura posso considerar a troca como sendo o que mesmo direcionado a outrem permanece todavia na emissão e recebe o feedback, o retorno, estaremos falando possivelmente em uma maior igualdade ao menos neste aspecto, quanto ao reter ou compartilhar, diferentemente do modo de observar a troca como algo que se perde para adquirir outro (para usar um termo bastante usual em rede e pouco fora dela).Exemplo bem simples, o conhecimento, que fica com aquele que emite, e troca com que o recebeu ao menos se admitirmos que todos aprendemos uns com os outros. Assim sendo, dizemos uma troca que em todos os lados, como sujeito ambiente, se realiza um valor agregado de cidadania e integridade.

A necessidade da consciência da ressonância, os aspectos da realidade social que reverberam. Dilemas compostos entre o lastro, presença atual dentre o que buscamos como projeto de uma sociedade.

A compactação da hermenêutica negativa com a positiva na modalidade de leitura proposta por Jameson, o entrelaçamento entre crítica da ideologia e discernimento da utopia, representa uma versão especificamente marxista do problema familiar do fato e do valor na interpretação, em outras palavras, uma forma de interpretação que mensure tanto o valor da bora como seu modo de funcionamento. Contudo, deparamos aqui com um problema. Para Jameson, assim como para Eagleton, não é possível falar univocamente do valor quando se está lidando com objetos culturais que estão sobremodo inseridos em estruturas sociais e econômicas em que relações de valor são sistematicamente distorcidas e alienadas. Jameson propõe a si mesmo o seguinte enigma: Como é possível a um texto cultural que cumpra uma função demonstravelmente ideológica.... personificar um impulso propriamente Utópico ou servir para fazer ressoar um valor universal inconsistente com os limites mais estreitos do privilégio de classe que informa sua vocação mais imediatamente ideológica? (CONNOR, 1994, pg 155).

sangue se reveste, a procura da minha alma, farrapos secos, concretos ilesos, do dia ou da noite, não haverá mais açoite, NUNCA MAIS destroços nossos, pedaços da cidade, descalços recolhemos, o espelho da comunidade. Por onde passamos, uma oportunidade uma gota de cidade. A fraternidade, onde está você.... nas ruas o sangue, escorre da pele nua, o tecido encobre, o sujeito ausente, a mesma gente, no frio ou na fome, passa a mesma sede. Na vida o direito que me consome, roupa da lida, moda que veste o humano, ano, cadê a alma? 
Connor, cita David Harvey,:

Um exemplo aqui poderia ser David Harvey, cuja recente crítica da teoria pós-moderna do deslizamento e da deriva, da superfície e da instantaneidade. O principio unitário da fase final do modernismo e do pós-modernismo, que no tocante a isso são contínuos para Harvey, é a noção de valor movimento " de Marx. " Harvey sugere que a rápida expansão do capital para a esfera cultural é uma das mais impressionantes maneiras pelas quais o capitalismo pode exercer domínio sobre o futuro mediante o recurso à redução da escala temporal do consumo e à aceleração dos ciclos da necessidade e do desejo na ( moda ), num processo de volatilidade escassamente regulado. "Ao insistir, como o faz, que as formas culturais têm firmes raízes no processo diário de circulação do capital, Harvey não está preferindo o ético ao estético, mas submetendo o ético à estética do arraigamento que a própria análise identificou como epifenômeno alucinatório do processo de circulação do capital. ( CONNOR, 1994, pg 159-161).

A meu ver, poderemos sobre o horizonte social compor não uma redução do consumo, mas uma reorganização, até que o promova posto que em melhores condições o equilíbrio em um determinado tempo possa promover uma margem ainda que em estancias de possibilidade mais igualitárias, porém em volume de alcance cultural estejam mais bem distribuídos como lógica da maneira a que dispusemos os diálogos das forças individuo( capacidades)trabalho- sociedade-governo, que devem gerar espaços onde distanciamentos se aproximem como circulação de um movimento que integra uma sociedade mais justa. E entre aspectos literários encontramos a palavra enquanto sentido que compõe um discurso social, estando sobre o prisma de uma razão consciente, que busca os valores dentre o que pode conceber da condição humana, sobre uma economia planetária, onde palavras e sentidos escrevem, ambiente, circulação e organização, mecanismos naturais, artificiais, programados, acumulo e mensurações, diversificados sobre a dificuldade de equalização de direcionamento de capital entendido como aspecto cultural que compreende o significado de valor econômico dentre saberes, capacidades, territórios como lugares do conhecimento em sociedade, onde o monetário tem a escolha de ser agente ( ativo) ou passivo de um ambiente em espécie entre espécies, e onde os dilemas, se tornam estimativas e índices.

Dos fatos e das propensões, das razões e do querer; o que pode ser uma totalidade com causa e efeito, ou seja, nos termos, se assim pudesse ser descrita ou nomeada, buscando uma “ eficiência “, uma “ organização", não uma totalidade estagnada ou pronta, mas em movimento, e o movimento considera a meu ver mais próximo de uma ideologia e não 
utopia, porque em seu cerne estaria a clareza das " dificuldades", erros, o processo em si, podendo ser falível, em alguns aspectos, havendo de considerar o andamento, “ aprendizado ou outro termo para este aspecto, avaliação, talvez mais adequado, e chamaria de totalidade porque se estabelece ainda que por subconjuntos, ou "frações", a unidade por conexões, por se estabelecer mediante relações como interfaces.

Monotipia em a negociação:

Homens de gravata... aonde? No pescoço dos animais... sociais demais? Engula o pão, ajuda com a espinha do peixe. Que peixe? Deixamos de ser cristãos, ou se não acreditar em Cristo, humanizados. Platão se questiona sobre onde estamos se nos primeiros princípios ou no que a eles nos dirigimos.

E, Platão, me diga: No que, difere o ponto e a perspectiva do espaço e tempo, quando um se torna a razão do outro. Faz muito tempo que eu aprendi, algo que dizia sobre o estar contido, e quando li a frase, no que se dirige a ele, ( ao princípio ), me pareceu completamente o sentido de estar.com, então, vamos, por onde o princípio nos guia, ou seja, contido nele estaremos para encontrar o destino. Origem e destino.

- Platão, ouça! A-visa o surrealista de plantão, que o ponto ${ }^{209}$, é um poema. E, agora? Quem paga a conta?

Mas, voltemos ao pensar, que gesto de geometria esse, que não se pode nem mirar?

Certamente, me darás a terra ou nela encontrarei espaço, porém, quando no caminho, te perguntarei da semente, e haverá na terra, o sulco, de onde esperarei brotar, e enfim, estarei em algum lugar?

- Talvez queiras a semente antes de saber sobre o chão que pisas e dele ouça o que pode nascer da terra!

- De fato, penso que poderá da minha carne, perpassar a veste da alma, de quiçá eu possa compreender a natureza do que penso.

- Fato este que deseje negociar?

- Negociar o pensamento? Ou nessa terra, as formas de se trabalhar?

\footnotetext{
${ }^{209}$ No capítulo o verso e reverso da palavra, a geometria se forma sentido, em concreta imagem.
} 
- Acaso o sol permita, haverá tempo em delírios do calor, de supor demasiado esforço de onde o arar esteja sobre o meu pensar? Talvez esse seja o delírio, que trará o sulco por onde a semente possa estar. Quem sabe?

- Custa - te por certo estar sobre a terra e dela nem sempre ouvir o ventre, por tão tecido denso, gestando ininterruptamente e arduamente seu fogo.

- Claro, o fogo. Como pude me esquecer, Elemento genitor, como fonte que jorra, mas da qual hoje preciso, encontrar ainda como ser. E todavia, então poderemos ser um?

- Um eu não diria, mas talvez, múltiplo dele, quem sabe.

- Negociemos então. Mas, poderá ser uma troca, ou teremos a necessidade do preço? Nascer haverá de conceber um valor? Esta será uma proposição de necessários argumentos para diagnóstico desse projeto de viver, onde quem sabe as medidas consultemos ao cosmo, ou mais próximo, o próximo!

-Bom será que o próximo esteja, nem tão longe ou que eu possa de sem fronteiras, o avistar, como do porto o além mar. De quem sabe a terra, esteja sobre os mesmos pés, e o caminho se torne o mesmo. Mas sobre o sol, será possível o que desejas. Ontem mesmo, encontrei o vazio, e não prenhe de si, esperava as cinzas, que nem mesmo servirão de adubo! Então pense, desejas tanto a igualdade, e como mostrar na forma de arar, o ventre dessa terra, que seus filhos se tornem a luta, cada qual a seu destino, mas que não desista. Será possível? Do que pode nascer o que não almeja brotar!? Então te pergunto, como poderá ser o amanhã. ${ }^{210}$ Então seja esta a vontade que falta ao desejo, o quanto baste! Ou melhor, do que o desejo precisa para ser, mais do que o querer. Então que o assim, seja o onde o saber esteja como

\footnotetext{
${ }^{210}$ Sousa, Carina Gonzalez Y Sousa. Composição: Mordaças- Mordaças na minha boca, nunca mais. Só se for o silêncio na paz. Mordaça na minha boca, nunca mais... Sobre o céu, vou ver as aves voar. Sobre o céu eu vou ver as aves voar. Sobre o meu corpo, trabalho e luta, vão vingar, brotar da terra, como o ar, mordaça na minha boca, nunca mais. a alma canta, e quer paz. Mordaça na minha boca, nunca mais... Nunca mais.... Nunca mais... fere o corpo, destila o sangue, alquimia da vida, é o amor..... a chama sagrada que acende a luz, sobre os astros verei o caminho. Liberdade por onde eu for, mordaça na minha boca, NUNCA MAIS. LIBERDADE, por onde eu for, mordaça, na minha boca, NUNCA MAIS, liberdade é meu gesto, NA VIDA A CENA EM IGUALDADE É ESSE O MEU VERSO, que do teu é a imagem.... águas na vida, a seiva da terra.... direito de nascer, um pensar que me faz. HUMANO SER. MORDAÇA NA MINHA BOCA. NUNCA MAIS, VOU PELOS CÉUS, RESPIRAR. NAS FRONTEIRAS entre os caminhos, segue a vida, não estamos sozinhos. Nos dê a mão.... aperto de alma.... meu irmão, segue o seu caminho. Liberdade de opinião. MORDAÇA NA MINHA BOCA, NUNCA MAIS. MORDAÇA NA MINHA BOCA, NUNCA MAIS.

E, composição, QUAL A COR DA MINHA ALMA? Qual a cor da minha alma? Você não me vê, como sentido. Abrigo do teu querer. De onde eu vejo também a sua palma... estendida como se fosse, palavra. Morando nos seus olhos, meus enquanto tua, paisagem. Eu não sou miragem, Sou a mesma viagem, do mundo carne, fissuras da alma. Que sente e pulsa, que é toda cor, a mesma alma, não sou tão ausente, que eu tenha deixado de ser gente! Eu sou alma em corpo vivente.
} 
natureza orgânica do ser que pensa, em sociedade, para que possa nascer a cultura, desejo de conhecer a educação onde o significado desta abrace a vida, e não longe dela, se torne razão.

E não te esqueças urbano que sejas, entre tuas vielas, de naturezas repartidas, os espaços do saneamento, quer habite teu ambiente, sujeito! E sujeito que respiras, onde está a tua natureza? Por onde andas, na arquitetura da terra sobre medidas de espaço, a procura do pensamento?

- Do que podes fazer, tanto me perguntas? E porventura não será está a tua indagação, antes mesmo da plantação? Terreno baldio do mundo, estaremos até quando? Negociação.

A troca. Quem sabe, natureza minha, mundo. Lugar de nós. ${ }^{211}$

Mas, veja, como poderei eu que acabo de nascer, cidadão e posto feito terra, ou nela, melhor dizendo, trocar-me, se, estou como vim ao mundo, ser, e nem mesmo tenho o que oferecer a não ser a vida. E isso tem valor para mim, não posso claramente me desfazer dela.

- Haverá de ser somente isso, ou o que dela sabes? Acaso teu pensar e agir não será também da tua vida seus pertences?

- Queres negociar minha consciência?

Não! Apenas que o desejo de tua vida se torne, nesse valor, uma troca com a terra, lugar teu de nascimento, sem que te percas, mas que gere em uma relação o que te tornará, semente.

Haverá tempo de meus atos serem a imagem de meu próprio discurso, onde a palavra em silêncio se torna gesto. Fato este, sendo objeto do meu pensar. Abrigo de minha consciência, razão de minha alma.

E conta-se que Gaia (terra), senhora de muitos frutos, haverá de contar seus filhos, e dependendo de quantas bocas houver, haverão de comer, ou da terra irão esperar, o que para todos saciará. Não havendo Gaia, de suportar, a fome de alguns, e a saciedade de outros.

\footnotetext{
${ }^{211}$ Sousa, Carina Gonzalez Y . Composição: Lugar da manhã. Sabe qual é o lugar da manhã, é esse suor sem pele, escorrido como sangue, a procura do massacrado, escarrado pela sociedade, parido sem igualdade, cadê o direito, o direito de quê, sabe qual é esse suplicio, que arde e queima como vício, de procurar a justiça, onde nem sabe por onde está, a face de quem ou de quem é a vez, tanto fez, tanto fez, não! Qual é o rosto da igualdade, qual é o nome da verdade, o que é essa cidade? Por onde vai? o que se faz, não posso mais viver em vão, as primeiras horas não bastam, se repartem da fome, na solidão, no desejo de consumir, a alma que se pode ter, Como sonho e direito de viver, o que se pode ouvir, ainda que no silêncio de existir, eu posso... O corpo macerado, massacrado, ainda assim.... eu posso ver, eu posso ouvir, eu posso sentir, a alma livre de existir. Sabe qual é o lugar da manhã. Nasceu no ontem que te fez da sua gente, o teu mesmo tempo presente que sente, sente, SENTE.
} 
-Pergunta-lhe o filho.

Como faremos então, dividiremos o pão, ou trabalharemos mais com o trigo?

Da terra nascerá, creia. E portanto, terás a tua resposta, se o que dividires, não seja o suficiente. Onde haverá de estar as tuas forças? Do que o trabalho nasce, que te saciará enquanto o próximo que da terra se nutre em igualdade.

O cultivo. O trabalho. Os frutos.

E, agora. Estando sobre a terra, que de tão vasta, perco-a de vista, e de lá de tão longe, parece um só oceano, de tão azul. Espaço.

Pescador, busca-me a solução, fui me aproximando, e comecei a ver, tantos lugares, que não sei mais onde poderei morar. Mas, me disseram que são muitas.

Precisarei distanciar-me para ver a terra, como um ponto, ou um oceano azul. Onde talvez a consciência desperte, do lugar de onde nem sequer sou capaz de ver um ser humano. ( origem)

Neste momento concebemos a natureza do gênero em referências a considerações de ética, diferença e discurso sobre o olhar do ventre do mundo, assim sendo, humanos somos gerando a opção de educarmos a nós, e filhos nossos em solo que nos abrigue território. Assim sendo, os papeis sociais são daquele que necessita, portanto, do que nomeados parcelas instituídas de um corpo restrito aqui como humanidade e ventre do mundo se expande nas considerações de que o homem por ter o afeto em suas relações como mãe que observa o voo e as asas do repouso de um caminhar, sendo ancião que brinca como criança ao deter sobre seus olhos a passagem da inocência que leva a presença de uma não idade, mas sentimento, onde sempre haverá tempo para sermos maduros frutos de nosso movimento. Assim, o movimento social se veste da alma de muitos que exercem o trabalho no propósito de elucidar a seres humanos independente de que gênero ou como nomeados forem, mas sim, respeitados em suas condutas como humanidade que os constitui integridade de razão na consciência de sermos íntegros enquanto dignidade de viver sobre o que é honestidade, justiça, lealdade, bondade, amor, trabalho, enfim, o que verdadeiramente nos faz, igualdade.

Certas colocações que normalmente abominamos por legados históricos que vão desde escravidão, segregação, genocídio, enfim, mazelas humanas de toda espécie, me parecem que sofrem de vestígios nos quais ainda precisamos que a névoa se dissipe posto que do que 
queremos para respeito e dignidade no decurso da história humana deve sempre ponderar facetas outras que estejam sobre a mesma tristeza, e não vista ou não desejada como socialmente aceitável. Isto porque presenciamos dores sociais, nas quais desconsideramos o paralelo com aspectos ditos abomináveis da história humana e quando assim colocados, não são aceitos normalmente como relacionáveis, porém, para esta pensar, enquanto educar o pensamento de uma cultura de ao menos respeito, credita-se a postura de nos colocarmos como SER do tempo ${ }^{212}$, onde assim, estaremos procurando a igualdade, observada ou que passe a poder viver em sentido e presença de afeto humano ${ }^{213}$ de conduta onde o que passa a ser relevante é a não presença de violência.

Avanços e vestígios. Os relatos pessoais ${ }^{214}$, como fundamentos de perspectivas sociais ${ }^{215}$. O verso e o reverso. A experiência do ser. Brevemente pensava o quanto que uma vivência pessoal interfere em fundamentos sendo que: Em que medida estaria dispondo de meu " ego vigente “ para compreensão de uma totalidade, onde o ser, não se restringe ao meu posicionamento, porém, e firmemente, capaz de estar por mensuração integrando aspectos possíveis de medida, indicando um índice de postura social, na qual apensar de, independe de minhas convicções. Quem alimenta quem?

O papel da educação para o ser. O que seria? Buscar uma educação de primazia por respeito em primeiro lugar, e intrínseco a esse posicionamento, os valores humanos, portanto, não

\footnotetext{
${ }^{212}$ Sousa, Carina Gonzalez Y. Composição Vozes. O direito de viver em igualdade.

${ }^{213}$ Restrepo. Luis Carlos. O direito a ternura. Onde logo no início temos a citação de Barthes, "Onde és terno, dizes plural.".A cognição afetiva, considerações de moldes sociais que nos fizeram perder a capacidade de um gesto humano, em entraves de sentido, afeto e conhecimento intelectual, que também faz a ressalva de que o universal não pode perder a capacidade de observar a particularidade do outro, no qual aprendemos. E no qual nesta tese, eu coloco como a presença de encontrar na singularidade os fatores que podem nos reunir, dentre a diversidade a igualdade, sobre direitos de uma humanidade.

${ }^{214}$ Cotidiano em pauta, como projeto sugerido neste ponto, para futuro desenvolvimento, aqui como hipótese de, uma revista Cognição global, sobre a plataforma yumpu, apresentada como rede de conexões, onde perspectivas sociais se desmembram em relatos, onde se conectam jornalismo, literatura e dramaturgia. A rede de temas da atualidade se despindo sobre conexões reais e desmembramentos. Do sentido ao significado, fatos e movimento, cultura sustentável. Modificação social, informa e constrói, imprensa como imagem real do tempo vigente.

${ }^{215}$ Sousa, Carina Gonzalez. Composição: Exílio - Exílio nesse paraíso que insisto, cadê a justiça na cidade, e onde estão as leis, a exílio, no paraíso da democracia, cidadão sem lugar para trabalhar. Cidadão sem lugar para trabalhar. Cidadão, sem lugar para respirar. Mais uma vez, mais uma vez, mais uma vez. Então onde está, a máscara do rosto da cidade, grudada na crueldade, exílio no paraíso, cadê a lei.... Cadê a democracia... Onde está... Onde está.... O diálogo nesse lugar. Minha fala e as suas.... Como cidade nua... não sei como vou fazer, para te encontrar na pele do viver, não pode nem mais sonhar, exílio no paraíso, cadê você... cadê você.... Direito de ser, onde foi você? Onde foi você? Onde foi você. Não precisou nem sair do lugar a fronteira da alma do indivíduo. Repartido como dois, entre povo e o que eu quero mais, será que é a verdade demais.... eu estou esperando... antes que seja tarde demais, quem sabe, ainda haverá, alguém para me falar, o que aconteceu.
} 
somente para alguns ou sobre algumas perspectivas nos quais preservariam de qualquer atitude que viesse a dar margem a uma submissão apoiada por qualquer aspecto do âmbito de posturas sociais arraigadas como validando tal domínio.

\section{Posicionamento - escolhas - (re)posicionamento}

\section{1 Social - particular - individuo-social}

Sobre o ser que não se determina gênero, mas se constitui ser humano, o ventre se manifesta voz, estado contínuo de indivíduo-povo-nação ( CON - Cultura Organizacional de Nações).. Estive sobre meus pés, e a partir dali, surrealmente cidadão, entre ruas de direitos e deveres, esgotos e dizeres, passos ou percalços, abertos pela fenda do parto do mundo. Arcado por vezes, quão peso esgotado, das escaras sociais, proveniente de letargia do controverso fluxo do tempo. Quem somos? Eis uma razão, ou questão, dependendo de onde você se encontra, sobre qual perspectiva, ou somente o ponto de fuga. Nascemos quando, e onde, a ponto de saber por onde realmente ir, porque a natureza, não espera, de fato e consequentemente, as horas... passam.

Qual pensar exige de mim, outro, para que eu me compreenda, lugar. Funções sociais, ergonomia da vida? Em que medida? Arquitetura do existir. Curiosamente no caos insano da realidade atual, me declaro capaz. Capaz de que? De viver? Sobre quais circunstâncias, ou instâncias de defesa sobre o caráter de instinto de sobrevivência! Em que época estamos? Quais os argumentos que se tem sobre as conjecturas humanas que validem o posicionamento do dizer-se, apenas como respeito. ( E, serei, somos, capazes de respeitar. Sabemos o que é isso? Ou ficou tão claro que não enxergamos mais...). Particularmente, pode-se avaliar, incipiente, muito vago, para as complexidades atuais, ou será que demasiadamente, verdadeiro. Escolha. A semente germinará, ou não será possível ver seus frutos, porque as tempestades assolaram deveras o terreno, havendo de sucumbir, ou, alguém perguntou se queria brotar? Haverá crença na natureza ${ }^{216}$ ? Em que instante e por qual razão, o pulso pode estar fraco, a ponto de não mais germinar. Haverá crença na natureza? Ou, essa pergunta não tem resposta? Matematicamente sobre a vida, a progressão de alguma forma se manifestará? Princípio ativo de qual viver? Por onde mesmo nasci? Talvez na força que esse

\footnotetext{
${ }^{216}$ Sousa, Carina Gonzalez Y. Composição: Ribeirinho- Ribeirinho das águas, recolhem a chuva de lágrimas, a gotejar, sobre o céu e a terra, que nas encostas verá. O verde das matas crescer, onde se poderá ver natureza... que seja teu o mesmo querer, ribeirinho das mágoas, recolhe o teu ser, faz das águas o desejo, de atravessar, o teu viver. Ribeirinho do tempo, nas águas como o vento. Sou o pranto e o passageiro que seja a esperança passar, sobre as mesmas águas, desse teu olhar, não chore ribeirinho, peça a DEUS pra te abraçar, recolhe nos braços dele, a tua face e o teu lugar, natureza da vida, e o sentido de amar.
} 
viver exprime, e que de mim, me torna órfão. Como foi minha gestação? Quem gera esse cidadão contemporâneo, sabe o que, ou quem irá por no mundo? E em que mundo...

Gestão ou gestação, faces da mesma moeda? Em que ponto, posso avaliar onde me encontro, ou como. Será que não cabe a mim julgar, o meu lugar? Mas, não devo possuir, identidade que responde por algum tipo de " moradia", dados, que talvez sejam escolhidos a dedo para serem sugados, amamentados por um sistema, ou apenas um cotidiano comum. Possuir? Que posses haverá de se ter, o valor de se pertencer ao menos ao direito a uma certa, como é mesmo o nome... dignidade.

Sinceramente, talvez isso esteja fora de moda, ou espero que não, ainda se possa dizer, escrever, gritar, sobre ser e ter, dignidade. Mas, onde estávamos, mesmo! Ah sim, no parto. Pariu e foi para onde? A sociedade. O ovo e a galinha. De tempos obsoletos modernos. Rápido demais, tão fugaz que... suspende o pedido, já passou a fome. Talvez, tarde demais, para aquele que ainda nesses mesmos tempos, morreu, da mesma fome. Consumiu o tempo, sem poder mais, existir. Mas, não percamos a esperança. Esperança, quase para alguns pode e realmente acredito que soe, como ironia. E, então, voltamos ao ovo e a galinha, hipocrisia de quem? Coloca nas costas do dilema social, assim alguém leva a culpa, da falta ou excesso, onde, nem mesmo haverá lugar para manifesto. Mas, espere, estou contabilizando o índice demográfico.

Indicativos de qual realidade? As vezes penso que para muitos o nascer de fato na sociedade, está também na fila de espera. Quase como se antes mesmo de nascer, já precisasse de doação de órgãos, públicos... ${ }^{217}$

Amargo, está pensando. Talvez, seja a boca da Gaia, continuamente grávida.

E, mesmo assim, se apregoa a u direito de ser humano, como força de trabalho, dignidade, integridade, escolhas, por vezes nomeado como feminismo, pós-modernismo e iluminismo.

Então, as indagações das faces sociais, não cessam. Curiosamente, de que lado?

Afirmam os teóricos, conjecturando de que lado estariam as prerrogativas do feminismo, se ligadas ao movimento do marxismo ou devendo ser "associado" a outra determinação de valor. Que me desculpem, mas pensar em que caixa, gaveta, ou compartimento colocar uma injustiça, não me agrada muito. Compartimentando meus sentimentos de indignação quanto a uma realidade vigente e que tem raízes históricas, do que necessita estar ciente de seu

\footnotetext{
${ }^{217}$ Sousa, Carina Gonzalez Y. Texto do livro a ser publicado Diário da manhã: Repartições públicas.
} 
cerne livre como individuo-mulher, sinceramente, penso que é querer gozar antes do sexo, ou não querer enfrentar uma batalha e declarar antecipadamente de quem é o território.

Será adequado pensar o feminismo como uma extensão da atividade da crítica iluminista associada com o modernismo e personificada em movimentos como o marxismo? Ou seja, é o feminismo uma elaboração das pretensões de razão fundacional características da maioria das formas de crítica dessa espécie, uma extensão da crença de que a razão nos permite distinguir o verdadeiro do falso o fato da ilusão e os valores reais dos valores falsos e degradados? Ou devemos associá-lo antes com uma valoração totalmente outro do valor, uma valoração que sugere não a inerência mas a indeterminação inerente de valor?[...] Será possível haver um sistema de valores ou uma crítica de valores feminista que não se baseie em pressupostos a respeito da natureza ou da identidade das mulheres e dos homens? (CONNOR, 1994, pg 168).

Aspectos ainda sobre face e reflexo social, monotipia, onde se considera, gênero - papel na sociedade identidade possível? Dependendo do interesse da máquina administrativa social e das relações familiares? Ou seja, lugar habitado conforme a assinatura contemporânea, se por ventura a necessidade na qual o indivíduo esteja valide tal posicionamento, me parece muitas vezes que a perspectiva se altera, ou seja, uma mãe que ficou viúva nova e tem seus filhos para criar, " assume" o " papel" de genitor ou o provedor, que nome queiram dar, e com isso, torna-se, viável que tenha na sociedade o papel que seria, para alguns de um homem, ou patriarca, o que isso quer dizer? Que a sociedade é hipócrita. Isso porque, podemos elencar outros exemplos onde a mesma situação dependendo do ponto de observação, torna o horizonte um pouco distinto, aliás, aproveitando a palavra, a distinção e o distinto, ocorrem em uma conjunção que é realmente fato de uma causa onde nos vemos perplexos, pois para um mesmo indivíduo, que pode considerar uma mulher que não viúva mais provedora da família, um insulto aos padrões e modos de viver etc e tal, em qualquer discurso cheio de referência cotidianas calcadas de uma maneira tão voraz e costumas que nem mesmo raciocinamos mais sobre elas, e assim nos defrontamos com o mesmo indivíduo $^{218}$, podendo validar tal posicionamento, o mesmo indivíduo, por seu lugar ( circunstâncias, alguns vão dizer, ) torna-se uma identidade válida, possivelmente creditada e

\footnotetext{
${ }^{218}$ Sousa, Carina Gonzalez Y. Composição: A beira - A beira da cidade eu vou.... A beira da cidade estou procurando... meu direito de viver. Meu direito de ser..... Um lugar de mim.... Quando seja passagem urbana ou matas da vida, que respira assim. Qual é a lei da vida. Que me seca por dentro e tem a minha sede, como seiva de sonhar, haverá ainda que sentir. Por onde ir, será.... que haverá um lugar. Pra se viver, ...esse seu direito de ser. Qual é a lei da vida.... qual é a lei da vida.... Esses passos na calçada ou da avenida. Imagem do mundo. Escreve, as águas desse oceano, tão profundo.... lugares nossos, a procura de oportunidades cidades vazias, cheias de incompreensão. A multidão, vem passar, seja noite na escuridão com o céu a cintilar amanhece... vem e nasce. Recolhe o seu destino, e brota amanhã. Amanhã.
} 
até, pasmem, distinta. Então, eu creio sim que é possível olharmos pelo que é do ser, independe de gênero e mais pelo direito de viver na sociedade segundo princípios de valores humanos, contemplados por direitos e deveres, sem maculas por restrições de aspectos que até considero preconceituosos, portanto, ao considerar a "identidade" na mulher na sociedade, penso que devemos observar como um ser humano que somos, assim, contemplamos em igualdade, uma maior gama de "papeis" e do que somos todos no cotidiano, porque, ao nos dirigirmos a um filho ou a um pai, com amor, precisa ter carimbo de quem está dizendo com afeto, se é homem, mulher, trans, ou enfim, qualquer opção que tenha, ou é a conduta que o identifica ao seu redor, podendo fazer parte de uma família que até mesmo, ultrapassa o que é de sangue, mas sim, o sangue que corre na própria terra, nossa família humana, o lugar de todos nós. Agora, o que penso, e o que constatamos em realidade de mercado de trabalho, nesse ponto, talvez os índices possam tentar retratar o que dentro de uma pesquisa que avalie, mostra de uma certa realidade, ainda que distante do que muitos de nós gostaríamos, porém, creio que as aproximações dessas distâncias entre o que muitos já pensam sobre igualdade e o que o mundo demostra, estão surgindo como uma forma mais humana do que consideramos viver.

Talvez essas aproximações fossem um modo de realizar uma coerência, ainda que complexa e com suas divergências, com o que de fato, queremos e o que vivemos

Connor todavia ainda em Teoria e Valor Cultural logo sobre considerações de Mancintyre e Rorty, vemos a seguinte frase: “ de que o indivíduo permaneça afirmativamente quem é “; da qual já me pergunto, para alguns, socialmente, sobre os moldes de quem?, pois, somente essa frase, do quem somos, já é consideravelmente um fator de gênese porém, muito mais, de construção e nessa construção me pergunto de como ela se realiza, se pode ser dissociada do ambiente, ou de tradições e em que momento esses dilemas entre o indivíduo e o que o cerca o mantem de fato quem ele é, posto que por vezes uma divergência o ascende a quem de fato ou ao que de fato seu caráter está direcionado e não somente o caráter mais, como sendo, constituinte do seu ser, portanto, a permanência, é algo que caminha conosco, o que quer dizer, que está conosco em movimento. É extremamente curioso ver como os outros tem tanta certeza sobre quem somos, quando nós mesmos, ao menos, eu penso, estamos em contínua descoberta o que nos faz estar em reflexão de quem somos, a não ser que o indivíduo não se descobrisse mais, ao longo da vida, e então, se, continuamente estou a me desvendar, e isto requer uma postura de humildade perante a reconhecer-se entre o caminho, e suas transformações, ou mesmo que permanências, lido interiormente com certezas e 
incertezas sem mesmo ainda considerar os aspectos advindos e compartilhados com outros sejam eles, o ambiente, seres humanos, culturas, enfim. Agora, dentre o que transmuta em nós, pode coabitar uma permanência, e aprendermos o que nos identifica mais profundamente, e não somente em superfície, é um retrato a ser visto todos os dias, sobre os pensamentos, atos, sentimentos, vontades, desejos, trabalhos, afinal somos dentre o que vivemos, e vivemos entre o que somos, e ainda questionando sempre qual nossas digitais da alma, ou do corpo, ou do ser, ambos, quem sabe justamente poderemos ver as linhas e os espaços dessas digitais, e assim sendo, o todo que elas se tornam, talvez sirva para um documento, ou uma procura de quem é ou reside esse indivíduo, que eu prefiro acreditar que está sempre, em busca.

Talvez um certo modo de ser, prefira se reconhecer dentre somente o que permanece, e nem mesmo reconheça para si, suas mudanças, ou somente depois de um tempo, é o tempo de cada um, sem julgamentos, apenas, sabemos que aquele que procura, como em um poema, que escrevi a muito tempo atrás, já te encontrou.

Agora, Macintyre fundamenta sua ética pós-moderna numa noção da inclusão de toda a vida social e de toda a identidade individual em narrativas partilhadas e herdadas.

Só posso responder à pergunta. O que devo fazer? Declara Macintyre - se puder responder à pergunta precedente - De que narrativa ou narrativas verifico ser parte? Ele afirma que não existe dimensão natural na qual possamos justificadamente nos posicionar para permitir uma arbitragem racional entre a pluralidade de narrativas culturais e sociais concorrentes e justapostas. Tal como Rorty, Mocintyre aconselha antes o ajuste local, pragmático, do que a tentativa de adjudicação universal herdadas em vez de suspeitar sistematicamente delas. Em flagrante contraste com a visão lyotardiana da incomensurabilidade dos jogos de linguagem, de uma justaposição e uma acomodação mútua entre diferentes narrativas culturais e políticas. Entretanto, animada como é pelo desejo de transcendência que ainda ronda mudamente a obra de Lytoard, a perspectiva comunitária de Macintyre e Rorty mantém a necessidade de que o indivíduo permaneça afirmativamente quem é e de que se recuse a submeter tradições e formas herdadas a um questionamento radical. (CONNOR, 1994, pg 171).

Ainda sobre um certo aspecto de posicionamento alternativo:

"Fullbrook descobre na obra de algumas romancistas do século XX o modelo de um reprocessamento feminista de valores culturais: Essa dimensão ética da escritura feminina não tenta estabelecer um conjunto de regras intemporais ou de leis morais universais. Ela trabalha, em vez disso, para criar condições de haver julgamentos éticos alternativos no âmbito de situações históricas particulares- de modo geral consideradas de novas maneiras a partir de novas perspectivas - e desse modo criar novos futuros com base na consciência da possibilidade de revisão de valores.[...]O modesto pluralismo resultante dessa perspectiva está de fato bem distante 
da ética contra a ética proposta por Kristeva. Fullbrook resiste às hipostasias que sugerem ser possível sair de vez de sistemas de valor cultural e entrar em algum começo ético inteiramente novo. E se favorece uma virada para valores femininos, tais como a profunda generosidade igualitária" evidenciada na obra de Gertrude Stein, a atenção política ao afetivamente particular na de Woolf, ou a fluidez e a flexibilidade evidenciadas na ficção feminina de modo mais geral, ela não o faz a fim de reproduzir sua personificação apenas nas mulheres mas á medida que esses valores prometem um esquema do bem que permite o acesso da inteireza da raça humana à participação em seu desempenho e projeto ( CONNOR, 1994, pg 172)

Talvez se invertêssemos um posicionamento, fosse interessante: partindo de valores e quem os tem, assim, o sentido do sentimento, como valor ético, passa a ter significado aqui, de sujeito corporificado em ação, ou por ação, e assim que o identifica como de praxe por outro prisma, fica em segundo plano, consideravelmente, isso porque as vezes me parece que damos um certo peso ao quem é como apenas superfície, sem nos aprofundar no como, e portanto parece que o raciocínio se restringe por vezes ao nome, que já o considera em aspecto sem analisar o ato, este ficando a segundo plano, então se invertermos, quem sabe, o que fazemos, como ética, esteja a frente da imagem no caso nomeada, este particular aqui apresentado ainda precisa ser revisto, porque não estou completamente ciente em quanto que esse modo de olhar pode se apresentar cotidianamente, apesar de acreditar que ocorre. Até porque muitas vezes, ouvimos a frase, não... mais você tem certeza que foi " fulano" que fiz isso, porque a imagem, e o ato, conflitantes por vezes nos indagam quem é, e portanto, no tocante a mulher ou homem, ou todos que somos, enquanto escolhas, se nos colocarmos como atos que fazemos, será que fica tão relevante se somos mulher ou homem? E a questão passa a ser o distanciamento, do que vemos como seres humanos e do posicionamento real dos papeis sociais atualmente na sociedade, porém, em perspectiva do que queremos, o existente para o que promovemos de mudanças.

Entre conhecimento e realidade ${ }^{219}$, buscas e igualdade, conhecimento e compreensão em Cultura pós-moderna Connor considera sobre o hiato entre experiência e conhecimento do movimento do modernismo: ${ }^{220}$

\footnotetext{
${ }^{219}$ El surrealismo - el umbral de la realidad. https://youtu.be/T4IGPHYZ4Sg acesso 18-05-2018. Quantas passagens tivemos entre o que buscamos compreender do que pode ser a realidade. Objeto e o existir, mulher e impressão, gênero e espécie de ser apenas, um gesto humano que tem o direito entre suas paisagens de viver.

${ }^{220}$ A respeito de certas colocações do modernismo, e sua importância quanto a inserção da visão sobre a experiência, e daqueles anos ao tempo vigente, gosto de pensar sobre as condições humanas, como o poema do projeto de livro, Bálsamo 80, onde se apresenta o viver como pensamento da vida, independe do tempo, espaço de condições. Lembrando Virgínia Wolf, em pálidas horas.
} 
Quando Baudelaire pediu uma arte que registrasse o momento passageiro sem violentar sua oscilante translência, quando Walter Paler nos incitou a capturar momentos de intensidade de fluxo, quando Henri Bergson convenceu uma geração da necessidade de representações que não impusessem uma falsa espacialização ao fluxo puramente temporal da consciência, e quando Virginia Wolf buscou uma arte que registrasse a intensidade da experiência interior em seus próprios termos, pudermos ver afirmado e reafirmado o princípio de uma tensão aparentemente irrevogável entre o modo como os seres humanos sentiam e as formas usadas para exprimir essa sensação ${ }^{221}$. É como base nisso que se costuma atribuir ao período modernista a descoberta ou redescoberta das intensidades reais da experiência que por tanto tempo tinham sido ocultadas ou distorcidas por falsas estruturas de compreensão. Mas, não é igualmente provável que essa descoberta da experiência fosse o resultado de uma reorganização de categorias e relações, em outras palavras, um produto de certo tipo de conhecimento?

Interlúdios de nossas condições, a construção dos espaços vazios. Entre guerras veladas do contemporâneo, tempos da atualidade. Mordaças dilatadas entre os vãos de pseudosrealidades sendo que temos a evolução dos tempos que libertam, porém, ainda sobre quais condições? Ou melhor, para quem?

\section{SOBRE SILÊNCIOS E VOZ}

Podendo estar sobre o palco, realidade de nós, desatando os espaços da procura de um gênero libertário, aquele já ouviu falar, que depõe sobre termos direitos iguais, mas não neste caso como surreais, porém, como totalidade ou... escolha a sua parte de uma realidade. A resposta: toca o telefone, não vai atender? O redemoinho chamando..., e o respeito?

Sinceramente, um dia minha voz emudeceu, e eu sei porque. Eu menti para mim mesma, estando longe de mim, talvez essa seja a razão de eu procurar tanto a verdade, e a querer. E do lugar de onde procura-se, quem sabe agora mais próxima, posso todavia, encontrar. E quanto a verdade, nunca deixar de procura-la $\mathrm{la}^{222}$.( SOUSA, 2018)

Irigaway e a ética da diferença: “ Irigaray tem estado voltada não somente para a contestação de estruturas de valor patriarcais que atuam no sentido de excluir ou silenciar as mulheres, como também para o exame do campo de valor como tal e em sua totalidade. "( apud, CONNOR, 1994 pg 175).

\footnotetext{
${ }^{221}$ Da citação, Charles Baudelaire, The Painter of Modern Life ( 1863), reproduzido em The painter of Modern Life and Other Essays.

222 Do projeto de livro Ensaios poéticos teatrais, e sobre a resposta, onde o tempo caminha. E em paralelo com De Chirico, atenção, não é um objeto, é uma mulher.
} 
Segundo o livro: Claude Levi-Strauss em certos povos primitivos, nas quais as mulheres funcionam antes como objetos do que como agentes de troca, mas generaliza as suas conclusões e naturalmente as submete a uma avaliação furiosamente negativa. Em dois ensaios da década de 70, Women on the Market e commodities amog Themselves, mais tarde reunidos em sua coletânea, Irigaray afirma que as mulheres funcionam universalmente como objetos de todo tipo de troca - econômica, familiar, sexual, psíquica, estética, religiosa, linguística. Longe de ser uma forma de organização social entre outras, sugere ela, essa assimetria é a condição fundadora de toda sociedade e de todos os sistemas de valores sociais e culturais, pois a passagem para a ordem social, para a ordem simbólica, para a ordem como tal, é assegurada pelo fato de que homens, ou grupos de homens, circulam mulheres entre si. (CONNOR, 1994, pg175).

E de algumas passagens sociais, devo dizer que: por enquanto nascemos de mulheres, fato este, que simplesmente o autor ao considerar o ponto de vista que seguiu-se (troca) deve supor que o nascimento é uma troca da vida com a vagina. E, prefiro pensar que: Ainda sobre a lógica de consumo, se assim pudermos ver, gostaria de dizer que ao nascermos, normalmente de uma mulher, creio que se formos muito exigentes, poderemos pensar que negociamos o ar que respiramos com a natureza, e é um tanto complicado, porque o que será que ela pede em troca? Menos devastação? Então, o que seria mesmo, essa troca? Acaso, poderíamos chamar de respeito?

Temos excedentes ou faltas nas trocas das relações humanas, e o que isso quer dizer? Até onde a negociação é lícita, ou de que maneira, melhor, ela pode ser lícita.

A alienação ao que podemos considerar a respeito do trabalho da mulher como ausência é um pouco difícil de digerir nos termos ao que o livro coloca ao se referir no trabalho de Irigaway, porém, o que preocupa é o quanto que de fato pode existir nas conjecturas atuais do que ele miseravelmente aponta. Tipos de trabalho: aceitáveis socialmente? Suportáveis... ora, veja a tolerância nos relacionamentos. De quem? Do homem e da mulher, ou de onde vier uma convivência, entrelaçada nos padrões sociais, e onde fica a jaula dos animais, ou exposição aonde? Sociedade expondo sua possibilidade de gênero e razão? Animais racionais? Para quem ? Qual é moda ( moeda de troca) de nosso tempo?

Lugares e posições, do sexo contemporâneo da cidadania.

Sabe, sinto que atualmente certas considerações a respeito do trabalho da mulher, não são tanto quanto ao poder ou não, trabalhar, mas sim, quais seriam os trabalhos dela, o que ainda demostra um certo grau de domínio ao prevalecer certos "tipos" de trabalho sobre outros como sendo adequados ou suportáveis pela sociedade. Alguns, parecem que caem bem, assim, diríamos, como uma roupa, para se desfilar em sociedade. Ah, esse 
trabalho tudo bem, esse fica bem na mulher. Então, como está na moda, não ter preconceito, certos tipos de trabalho, ficam bem. Mulher como bicho de estimação. Não esquecendo que como objeto-animal racional ( coisa que os homens se esquecem, da parte de racional ) podem se comportar alguns homens, diferentemente do que são, somente para saber como ela responde. Ou seja, bichinho de estimação. Se eu falar, isto, ela responde assim, e se eu dizer dessa maneira ela responde assado ora, ora, um outro nome para bichinho de estimação, é analise de quem quer saber como você é, e assim, ele procede como ele não é. ( e falando em assim ou assado, não esquecendo que é comida também, então precisa ver, se é bem passado ou mal, a gosto do freguês - dilema ético, é correto comer animal ou não, cuidado, pode provocar indigestão, ou melhor, divórcio ou muito antes, rompimento da relação) Assim, eu posso adestrar ela. Olha que gracinha!!! E sabendo como ela age e reage, não vou ter problemas na relação. Mas, vejam bem, ainda pode ter um bônus, quem sabe uma coleira, ops, uma gargantilha, talvez de brilhantes. E aí, quem quer ser bichinho de estimação? Não esquecendo de verificar na compra se tem, como é mesmo o nome...pedigree, ou melhor dizendo, classe social. E garantia de uso. É realmente muito engraçado, será que temos, como é mesmo o nome, quanto é o QI? Ah sim, eles medem isso, também, e ainda fico esperando a mensuração do calor humano, ou infelizmente do desumano. Mas, então, pensam que é só entre os homens, que se considera essa mensuração? Eu não sei bem, mas me parece que elas comentam bem, o tamanho do órgão deles, o que eu acho uma burrice, porque, afinal, ao saber e ...quem foi que disse, de quem...? Precisa conferir, e aí como é que fica? Afinal, penso que seria algo particular, a não ser, que... elas não se importem de trocar! ${ }^{23}$ (SOUSA, 2018).

Em que parte se pode considerar particularidades sem restringir a um argumento somente por gênero, mas justamente havendo respeito por uma integridade onde não se precisa estar no " lugar" do homem, no caso da mulher, mas sim, no lugar da SOCIEDADE, ou seja, existe uma diferença de se observar, sobre a óptica do já estabelecido como lugares determinados e movidos a um antigo sistema patriarcal, ou de origem onde $\mathrm{o}$ posicionamento da mulher era restrito e marginalizado, e realizar sua nova participação social pelo modo de estar no lugar do, homem, o que gera muito mais argumentos contra do que a favor, a meu ver, devendo para de fato ser coerente com o que se compreende como ser vivente, cidadão, enfim, igualdade, justamente a colocação de posicionamento social de direito, no que diz respeito ao ser que vive na sociedade, e portanto é o seu lugar que o distingue em relação aos demais, sejam quais forem, por seu trabalho, valor, dignidade, enfim, sua ação, modo de conduzir sua vida o constitui indivíduo integrante da sociedade, sem menção a estar a mulher desempenhando " papeis" masculinos, e sim, a mulher desempenhando o papel de viver, com dignidade onde e como puder realizar seu trabalho e

\footnotetext{
${ }^{223}$ Texto do livro Ensaios poéticos teatrais.
} 
valor, na sua vida. Portanto, é uma particularidade que se constitui por ser indivíduo, e não por pertencimento a este ou aquele gênero., estando então no relacionamento de indivíduo e sociedade, particular e geral, em seus direitos e deveres, de maneira que tenhamos uma coerência com a própria vida, em sua diversidade e evolução.

Alguns modos de observar de Irigaray não ficaram claros para mim, porém, o trecho que segue, gostaria de que estivesse aqui presente:

“ Irigaway enfrenta em Éthique de la difference sexuelle a dificuldade de escrever acerca da ética e da política do amor numa cultura que tradicionalmente expulsa o amor da esfera pública da ética e da política, relegando-o aos domínios privados do estético e do afetivo. Contudo, está claro que, para ela, a relação de amor entre os sexos é um padra e um exemplo de possibilidade daquilo a que ela denomina repetidas vezes fecundidade, isso significa que o seu amor é a própria transcendência do valor tradicionalmente limitado do amor na tradição, numa perpétua reavaliação em novas bases, num permanente vir a ser. De modo semelhante, a fecundidade da diferença sexual também envolve a produção de uma nova era de pensamento, de arte, de poesia e de linguagem, a criação de uma nova poética. Isso deve em parte compreender uma nova inversão de valores na qual a arte e a poesia, serão valorizadas ao lado do poder tecnológico. Mas se a ética-como-poética de diferença sexual de Irigaray tem realmente de ser vista como abrangendo a reavaliação, não basta somente ler o poético aqui como o que personifica ficções de uma modalidade diferente de organização social, como o caracteriza Whitford, já que identificar o poético apenas como o funcional é com certeza cair na dicotomia valorativa tradicional entre o ético-político e o estéticoimaginativo que a obra de Irigaray exigiria ser desalojada. $\mathrm{O}$ amor, para Irigaray, situa-se no ponto de junção entre o estético e o político, instabilizando e recombinando os valores dos dois. ( CONNOR, 1994, pg185).

Eu prefiro considerar a luta por uma integridade humana nas quais o direito a dignidade de viver em igualdade de condições de trabalho remunerado, estudo, e todas as conjecturas pelas quais a sociedade se organizem estejam sobre todos, e não vejo como um pensar feminista, mas sim, um pensar humano. Porém alguns autores como Felski, consideram que:

$\mathrm{O}$ valor de um texto como arte, se se designar por arte uma estrutura simbólica auto-reflexiva que gera múltiplos significados e não é diretamente redutível a interesses ideológicos, não constitui, consequentemente, base suficiente para os interesses e necessidades específicos de uma política feminista da cultura que também precisa situarse de modo mais concreto com respeito às dimensões ideológicas do texto e dos interesses orientados para a prática de uma esfera pública feminista de oposição. ( apud CONNOR, 1949, pg 186). 
Não fazer a outrem o que eu não desejo para mim, e os encargos de toda e qualquer decisão a esse respeito com suas devidas consequências sejam do âmbito particular para a sociedade e vice-versa. Como discernir sobre o que o indivíduo, considera licito nele mesmo, mas difere no "consenso da sociedade ", e até onde a lei pode ser o suporte para encontrarmos um meio de conduta onde um não fere o outro, sobre o prumo do respeito. E, quando ocorre justamente a necessidade de diálogo seja por quais razões, até mesmo da própria lei de se dirigir aos direitos de indivíduo ainda que o mesmo tenha ferido os moldes de lei social, para tal creio que os fundamentos éticos se aproximam em grande parte do jurídico, como ao menos argumentos que deem suporte ao que pode ser uma premissa de diálogo.

Inquérito de faces de máscaras descartáveis pelo destino de quem quer não em inquisição mas quase, saber o que pensamos, dizemos, agimos ou dos que se forma, trazer como se não fosse possível fechar a porta, absolutamente esquecendo-se que, somos a porta. ( lugar de nós ).

\section{LUGAR DE NÓS - esquina do tempo ${ }^{224}$}

Do lugar de nós, estivemos

Viemos de alma limpa

Conversamos, trocamos ideias

De tempos esquecidos, do adeus

Esse, que não volta mais

Foi demais

Então, no espaço do depois

Eu sou a passagem

Eu sou a passagem

Onde quem entra ou vai embora

Sem demora é na minha alma que mora

Ou está longe demais

Do que ainda virá, saudades

Do que não passará, o jamais

Eu sou a passagem

Eu sou a passagem

Do todo sempre, ou nunca mais

${ }^{224}$ Sousa, Carina Gonzalez Y. Composição Esquina do tempo. 


\section{A VIAGEM.}

Estrada a fora

Qual o lugar de que eu possa estar

Quando souber quem pode ser

$\mathrm{O}$ que te faz pertencer

Ao mesmo caminho, ou que seja o teu

Que no meu, é esquina do tempo.

Vento que voou entre as nossas vestes

E do templo que viestes

Estive no horizonte

Por onde quem sabe você entrar

Face do mundo

Tecido do universo

Reverso da vida

Umbigo da alma

Corpo que me abriga

E continuamente, me ensina.

Esquina do tempo

Me recolhe na ferida

Esquina do tempo

Me refaz a seu movimento

O som do sentimento.

Amar uma ilusão

Pode ser demais p/ um coração

Amar uma ilusão

Pode ser demais p/ um coração

Preciso da verdade

Preciso te olhar e ter sinceridade

Dos mesmos lábios

Que me deu a tua palavra

Sobre o teu gosto, que hoje não pude esquecer

Amanheceu comigo, no meu ser

E até onde eu possa viver 
Será um grande amor

Por conhecer.

Amar uma ilusão

Pode ser demais para um coração,

O que me disseste sem me pertencer, não reconheço em teu ser, espero, conto os segundos, mais não me recordo, a não ser, algumas palavras imprecisas de onde fico como em devaneio, sem saber o que estou a olhar feito neblina ou oásis. E se pode haver esse sentimento que mais pertence ao lamento, o que eu posso te entregar, se não sei por onde você possa estar que meu pensamento possa verdadeiramente, lhe encontrar. Assim fui do tempo, o relento, os batimentos tardios, sofridos ou cheios de felicidade, como uma tal igualdade inconstante, que junto comigo, é mais de teu jeito que, contigo passou a soar o pulso, comigo. E assim, não mais dos ventos da natureza pude reconhecer o ar, ou dos pés o chão pude sentir o mar, porque não eram mais o oceano por onde navegar. Então, as velas se puseram sobre o tecido da minha carne e alma, onde outros se assemelhavam por faces em bailes de máscaras, onde eu apenas queria sobreviver. Mas, repartimos assim, o tempo, de outros e antes de nós, perpetuando a sós o que ainda poderíamos, ter, talvez, a integridade. E de tantos papeis trocados, sufocados em exaustão, as ações e reações, feito naus em respostas dos astros do cosmos, um tanto quanto gotejando estrelas, entre o querer e tristezas, se recolheram, saudades. Saudade de apenas tentar existir sobre a liberdade, entre os bens do cotidiano, e o sonho de quem sabe, ter um dia o valor de conquistar o sentimento como sentido e voz de um diálogo onde por vezes sem palavras somente se tem a paz do olhar, mesmo que este possa estar, sobre o que é teu e não meu. Porque o nosso estar, ser compartilhado significa o futuro encontrado em vir a ser, que podemos aprender uns com os outros, juntos e eternamente.

Será esse o ponto em que a questão da dimensão estética do cultural, tradicional tão ausente da teoria moral e política, é obliquamente assinalada? Porque, se a determinação racional do valor tem de ser ampliada para admitir tanto a reflexividade irrestrita como os vislumbres da alteridade, não haverá um curioso fracasso na reavaliação em novas bases na continua exclusão do estético dessas negociações ou uma curiosa restrição a essa avaliação? Se o universal e o particular, o público e o privado, ao lado, poderíamos acrescentar, do real e do antecipatório, do sério e do não-sério, devem em algum sentido ser pensados uns com os outros e através dos outros, e não contra os outros, seria difícil saber com que fundamentos o estético deveria ser mantido fora da imaginação racional da liberdade. A esfera tradicionalmente constituída como o estético é talvez o mesmo tipo de ausência determinada, no relato de Benhabib, que a esfera da ação política coletiva no trabalho de Irigaray. [...] Alan Kennedy adota a distinção de Plotnitsky para seus próprios fins, 
propondo a luz dela uma distinção entre ética e valor. Alega Kennedy que a ética por envolver crenças mantidas numa comunidade, sempre tem probabilidades de ser a esfera da ideologia na qual o pensamento é de fato conduzido por meio da pré-compreensão. Contudo, estamos no domínio da ética sempre que tomamos algum tipo de decisão o fazemos algum gênero da escolha. O pensamento do Valor por outro lado, representa a tentativa de submeter os nossos próprios valores e investimentos éticos a escrutínio - avaliar o valor do valor mesmo: Quando efetuamos a determinação do valor...., deixamos o domínio do Valor e entramos no plano do ético, ou reino do valor. No instante precedente à enunciação de uma declaração de valor, operamos no Valor - justamente à medida que consideramos, ou ficamos suspensos entre um conflito de valores, estamos genuinamente operando no Valor. A categoria do Valor é incerta, é uma categoria em que acontece o pensamento responsável sobre alternativas ( CONNOR, 1994, pg191 - 196).

Determinações - in (determinações), entre valor, ética, diferença, equação e lados onde da calçada tentamos realizar uma rua por onde passe a cultura, em perspectivas de olhar. E dessa visão socialmente aceitável, qual o sentido do fluxo ou via de mão dupla, sociedade e indivíduo, consenso ou não. E nas patologias sociais, ainda queremos a prevenção, mas me pergunto, sabemos todavia, a complexidade do diagnóstico, e o que precisamos fazer para que o próprio viver estabelecido encontre o equilíbrio.

Ordem de valor - o que independe de diversificações - quando possível e porque, o que se restringe ou difere por: a) uma determinada cultura, valida ou não opções individuais, e portanto o que difere é por qual razão, ou melhor de que ponto de perspectiva, e por qual escala ou lugar. Consenso, a partir de que lugar? Em qual escala. Com a globalização a humanidade tem a opção de observar-se apesar das diferenças culturais? Onde então estariam os valores e a ética. Talvez a avaliação esteja justamente nesse lugar, onde como diz o texto, “ submeter os nossos próprios valores' e direcionamentos éticos, a um escrutínio.

E, propriamente como se observa essas mesmas questões quando a posicionamentos quanto ao relevante sentido do decorrer do tempo e suas alterações intrínsecas do que é social, humano, de tudo que cerceia o mundo em si. 
Sobre valores entre valores, sociedades e pensamentos. ${ }^{225}$ Entre o céu e a terra, espaços de uma indagação real, cabível e diagnosticada, atmosfera social!

Por aqui, vejo preocupações de quem são realmente, nomes do tempo, que se desfazem como areias, e nem sempre vejo, os atos, marcados onde o universo respira porque é parte de sua harmonia. Sinto por vezes, esconderijos alheios a vontade, onde a falta de sinceridade em nome de meios que não justificam seus fins, ficam a beira do sem nexo, porque se tornam irreais para o sentimento.

Enfim, entre a ética possível e a que desejamos, entre o céu e a terra, haverá de ter um lugar, para se existir. E o que parece ser ingênuo, e simples, é o mais prematuro do ventre da terra, ou o seu filho ainda não gerado, o da liberdade em igualdade. Os sentimentos, nos revelam a simplicidade onde isto se apresenta, mas nós todavia, não nos revelamos capazes de compreender no cotidiano, tal fato, então onde está o sujeito do sentir que se abriga em um corpo, mas carece de sua alma? A fragilidade das palavras podem ficar suspensas, em reflexão, ou como adagio, mas a eternidade a espera, de um dia, nos encontrar.

Que sujeitos somos, que não capazes ainda se ser em igualdade o que um sentimento, demostra. Acaso seria abstrato demais, elencar um sentimento (elevado), ou podendo ser ainda mesmo, o de rancor, ódio, que infelizmente ainda também nos une em pé de igualdade, então, acaso seria abstrato demais considerar, que os sentimentos tem maior expressão da razão, do que um homem de carne e osso, ou seria o mesmo ( sentimento, homem, razão ), e não o podemos encontrar?

O projeto de Levinas se inicia com a apreensão heideggeriana da existência como Dasein, ou estar - no - mundo, e com a acusação à metafisica que isso envolve. Não existimos, e jamais poderíamos existir, apartados das condições da nossa experiência que o pensamento metafísico descartaria com contingentes, por exemplo, a espacialidade e a temporalidade. Não se trata de elementos acessórios, mas necessários ao nosso ser, e dele constitutivos. Mas Levinas, acredita que, apesar de todo o seu alegado

\footnotetext{
${ }^{225}$ Sousa, Carina Gonzalez Y. composição: Uma verdade pra se conhecer: Sempre haverá tempo, uma verdade pra se conhecer. Sempre haverá, tempo. Uma verdade para se dizer...Quando será... que vamos ser. Nós mesmos. Quantas faces teremos de nós, sempre haverá, tempo de se viver, sem precisar se calar ou escolher, entre a vida ou morrer. Sempre haverá um caminho para percorrer de passos e compassos para se ouvir dentro de mim. Quando o teu lugar, outro chegar. eu saberei que ainda poderá me encontrar. Sobre qual seja a tua forma de amar, Haverá sempre, um lugar para se viver. A realidade que se quer, ser. Da imagem da vida, pra percorrer. Mas que um destino, o movimento de onde sempre haverá uma razão. De um sentimento, sempre haverá uma razão. Sempre haverá uma canção, sobre o tempo que vivemos. Haverá a vida que queremos. Sobre a ilusão de um sentido, que a passagem de um abrigo. Sempre haverá uma razão de existir e um caminho a seguir, sempre haverá. Sempre haverá u lugar para se viver.
} 
rompimento com a metafisica, o pensamento de Heidegger permanece metafísico devido á sua ênfase na consciência objetivizante, cuja tarefa é apreender as condições do seu estar-no- mundo. [...] A filosofia consiste no domínio gradualmente crescente de uma ontologia do mesmo em que um eu cognoscente labuta para subordinar ao seu domínio os objetos alheios ao seu pensamento $\mathrm{O}$ ser se torna, pois, o objeto, o alvo e o outro subordinado do conhecer. Levinas crê que a filosofia sempre tentou vencer o hiato entre o conhecer e o ser mediante formas de apropriação violenta. $\mathrm{O}$ conhecido é compreendido e, assim, apropriado pelo conhecimento e por assim dizer, privado de sua alteridade. $\mathrm{Na}$ esfera da verdade, o ser, enquanto o outro do pensamento, torna-se a propriedade característica do pensamento como saber.[...] O ego, escreve Levinas, é a própria crise do ser, de um ser no domínio humano. Uma crise do ser...., porque começo a perguntar a mim mesmo se o meu ser se justifica, se o Da do meu Dasein já não é a usurpação do lugar de outrem. ( CONNOR, 1994, pg198-199 )

\section{Cultura sustentável, responsabilidade social. Faces da monotipia em percepção e}

realidade? Será que poderíamos compreender o outro como valor agregado ao menos?

Onde os objetivos traçados reverberam entre nós, até nos encontrar novamente.

Em sua expressão, em sua moralidade, o rosto diante de mim me convoca, me chama, clama por mim, como se a morte invisível que deve ser encarada pelo Outro, a pura alteridade, separada, de algum modo, de qualquer totalidade, tivesse algo que ver comigo... O outro se torna o meu próximo precisamente por meio da maneira como o rosto me convoca, em chama, clama por mim, e ao fazê-lo lembra a minha responsabilidade, e me põe em questão. ( CONNOR, 1994, pg200).

Connor, aponta o esclarecimento de Mitsein:

Pressionado a dar, uma articulação do sistema ético que parece implícito no conceito de Mitsein, ou Ser- para - outros, em O ser e o Tempo, Heidegger, teve como resposta a Letter on Humanism" 1947, em que afirma que a ontologia, o estudo do Ser, sempre deve vir antes da ética, a teoria das ações corretas. Mas o que há de espantoso no que ele diz sobre a questão dos valores na Carta sobre o Humanismo é o modo pelo qual antecipa o tema levinasiano da resistência à objetivação de conceitos e valores: Pensar contra os valores não significa afirmar que tudo o que é interpretado como um valor - a cultura, a arte, a ciência, a dignidade humana, o mundo e Deus - seja desprovido de valor. Em vez disso, é importante perceber finalmente que justamente por meio da caracterização de algo como um valor aquilo que é assim estimado vê-se privado do seu valor. Quer dizer, mediante a avaliação de alguma coisa como valor, o que é estimado só é admitido como objeto para a estimação do homem. Mas uma coisa que esteja no seu Ser não se exaure por ser um objeto, particularmente quando a objetividade toma a forma do valor. Toda valoração ainda mesmo quando atribui um valor positivo, é uma subjetivação. Ela não deixa os seres ser. Em vez disso, avaliar deixa os seres ser válidos - apenas como objetos de seu fazer. Quando se proclama Deus definitivamente como o valor supremo, degrada-se a essência de Deus. Aqui como alhures, pesar em valores constitui a maior blasfêmia 
imaginável contra o Ser. Pensar contra os valores não significa, pois, bater na tecla da ausência de valor ou da nulidade dos seres. Significa, a bem dizer, levar a luz da verdade do Ser perante o pensamento, opondo-se a subjetivação dos seres em meros objetos. ( CONNOR, 1994, pg202).

Em qual parte o pensar não é do viver, somente porque não o vemos na experiência fática, presumindo esta ser o cotidiano, mas, ainda e mesmo assim, acaso não pensamos o tempo todo, e então, curiosamente, argumento a favor da imagem concreta do pensar, como constituinte do ser inserido no viver e não aparte dele, como um objeto intrínseco abstrato particular, porém, quanto a ética, de fato devo ressaltar que parece-nos que sempre aliamos ao que é da conduta, porém, e mais difícil talvez seja, a congruência entre o nosso pensar e nossos atos, e quem valida ou não a satisfação, de coerência, de justaposição, presume-se que seja o indivíduo, o ser, talvez o mesmo que vê-se representado, sobre a vida, no meio dela, talvez, uma tanto quando abusado, pelos meandros sutis em que a espada em riste fica sem resposta, sobre o caráter de onde esta o ser, sobre a coerência dele mesmo, ou do que dele podemos saber de seus atos, e portanto, o que é licito ou não, teve a procedência em relação a o quê, visto pois, que podemos nos defrontar, com uma imagem social, satisfatoriamente cabível de diferimos de forma completamente licita, mas, se acaso tivermos o prazer de observar o pensamento, então, talvez nos deparemos com uma nem tão grande satisfação, podendo ter uma dolorosa presença ausente, ao constatar que a correspondência, não foi como o ser, alegava para si mesmo. Mas, em se tratando de ética e estética, e adentrarmos um pouco mais o pensar como sentimento e lógica, talvez encontremos um pouco mais de um desmembramento do que pode ficar satisfeito sem tanto vir " ao mundo" como dito formalmente, mas que move, e esse movimento, entre o pensar e o mundo, sobre certo aspecto é um vir a ser, e portanto, existência compartilhada ou desmembrada. O pensar, sem nos deter sobre se, haveria de ter implicações teóricas ou práticas, nele mesmo, antes do vir ao mundo ( como movimento gerador - interno-externo ), me parece, que implica, também, e mais uma vez, movimento, quer seja como simples fato como o de respirar, ou arquiteturas lógicas, e de sentimento, que provem o que está existindo, nutre, e reverbera como estímulo onde inclusive a razão o habita, como talvez, um prumo do que emerge do pensar, portanto o mesmo, pode ser instintivo, natural, correlato, e de inúmeras formas, mas, a percepção conjugada denota a necessidade quando no pensar 
reside a eminência do fator, razão. Portanto estamos aqui falando de uma razão que habita o pensar, e neste particular a razão como discernimento. ${ }^{226}$

Oposição no exercício da compreensão e proposição, entendimento e discernimento. Partes possíveis de consenso?

Contrapor e atender - aspecto sociais - observações quanto ao discernimento e portanto, presume-se a presença novamente e sempre como direito o respeito, o que remete a necessidade de apesar da distinção entre partes, poder observar-se o reconhecimento, este reconhecimento ocorre quando para além do que me é diferente, eu obtenho a capacidade de aliar esforços no que é de reconhecer o outro, de maneira igual ao direito de se expressar enquanto pensar $=$, atos, para poder ser capaz de levar as considerações ao que é de escala, assim sendo, posto que muitas vezes, o ego, ou o particular de certo ponto de vista, nos cega de maneira a não realizarmos esse reconhecimento e nos fecharmos quanto a nossa forma particular nos que estiver sendo objeto do pensar e agir, enfim, comunicar.

Em relação a violência- pode parecer um tanto quanto na contra mão, porém, não me parece o impacto da diferença um encontro com a violência, mas sim, a subjugação esta sim, uma violência, ainda que, admitindo que no cotidiano mais comum, por vezes, podemos encontrar em relações mais simples, esse sentimento de violência quando de encontro a diferenças, mas, sem parecer contraditório, ou, admitindo que possa haver esses dois estados nas relações humanas, novamente talvez me veja sobre o que é de perspectiva, ou seja, de onde me pertenço enquanto ser, já que estávamos falando de ser, e portanto, estou sendo subjugado por algum discurso ou estou subjugando, estarei eu impondo e não respeitando uma diferença, ou sou a diferença, e de onde me localizo, onde está a violência? A violência, me pertence, ou do lugar em que encontro, e então, habito ou sou marginalizado, por onde anda o sentido? Existe uma violência que seja por ela mesma, o sentido habitando, ou seja, um consenso onde não será necessário discernir sobre que partes, mas sim, porque fere o que é do ser que vive, e portanto, curiosamente unifica a razão, porque se observa não do ponto de vista, mas do horizonte como a paisagem ( a violência,) sendo a imagem representada e

\footnotetext{
${ }^{226}$ Sousa, Carina Gonzalez Y. Composição: Quem somos - Quem somos, de tanto que procuramos, Ser como um dramaturgo do viver. Escrevo tanto.... as tuas margens. Eu quero percorrer, como sangue do teu ser. Essa tua vontade, palco do mundo. Ver sentir.... Palco do mundo.... vem ouvir. O gesto que tanto nos faz escrever a vida. Como um manifesto. É preciso percorrer. Todo esse palco de viver.... Quantos forem os lugares. Quantos forem os olhares. Escreva-me eu represento você. Cidade de viver. Me dê uma razão. Eu não vou perder o seu coração. Me dê uma razão. Me dê um porquê. Eu quero ser o seu personagem, Vem comigo, nessa viagem. Coxias da tua alma, Eu vou escrever.
} 
constituída no mundo. Havendo nesta observação que se estar inserido como ponto de fuga ( no aspecto arquitetônico ) na própria perspectiva, o que quer dizer, na própria pele.

E, continuando o livro:

Não esquecer que para aquele que subjuga, o que se rebela, está provocando um ato de violência, portanto para quem domina, o subjugado está ao ser rebelde, praticando violência, indo contra seus atos de dominação - é estranho, mas já presenciei atos assim, onde parece invertido o sentido, e então, questiona-se sobre a razão, onde ela se encontra, precisa de um olhar externo as partes envolvidas? Será que ainda não somos tão capazes de sermos racionais, a ponto de isso acontecer?

Bom ressaltar que normalmente quando eu uso o termo escala, é de alcance, de larga escala, e de medida como sobreposição de objetos de observação como paralelo ao próprio escalímetro.

Civilização e cultura ${ }^{227}$, monotipias em passagens, processos antropológicos em observação? Dentre considerações, significados atuais. Dentre todos os fatores que estão engendrados na sociedade nas relações indivíduos e civilização, que papeis deseja consolidar para que sua imagem de cultura venha a lhe simbolizar e significar verdadeiramente. Entre a diversidade, que encontramos, alguns fatores já foram elencados, porém ainda temos a presença do que

\footnotetext{
227 Com efeito, essa distinção não é simplesmente metodológica, visto que também parece marcar uma diferenciação entre duas formas fundamentalmente distintas de sociedade, as sociedades avançadas em que o processo de especialização econômica produziu uma divisão entre as atividades artística e as demais áreas d vida sociossimbólica, e as sociedades tradicionais, nas quais essa separação faz pouco sentido. Contudo, ao fazer uma distinção entre cultura e alta cultura é produto da nossa própria cultura, devendo por isso ser ela mesma, parcialmente, expressão das nossas próprias necessidades, dos nossos próprios valores e das nossas próprias ansiedades culturais, em vez de alguma espécie de representação isenta de valores do estado de coisas efetivamente existente. É notável, por exemplo, que os dois sentidos concorrentes da palavra cultura, que são mantidos em estreita proximidade nos relatos da cultura do início do século XIX, e em especial na noção do espírito nacional ou folclórico de um povo avançada por J G Herder, se cristalizam separados um do outro, com um intervalo de poucos anos entre si, naquele mesmo século, nas definições alternativas oferecidas por Culture and Anarchy ( 1869) de Matthew Arnold, e Primitive Culture ( 1871 ) de E. B. Tylor. Para Arnold, cultura é definida como a busca desinteressada da perfeição..., a simples tentativa de ver as coisas tal como são, a fim de aceitar o melhor e fazê-lo prevalecer, e mais uma vez, permitir a si mesmo, seja mediante a leitura, a observação ou o pensamento, chegar o mais próximo possível da firme lei inteligível das coisas, e desse modo, formar a base de uma ação menos confusa e de uma perfeição mais completa do que temos nos presente. A grande inovação de Primitive Culture, de E. B. Tylor, é por outro lado, a sua abrangência, como o indica a sua afirmação inicial de que Cultura ou Civilização, tomadas em seu sentido etnográfico amplo, são o todo complexo que inclui o conhecimento, as crenças, hábitos artísticos, costumes legais e quaisquer outras capacidades e hábitos adquiridos pelo homem como membro da sociedade. Refutando a austera distinção de Arnold entre o maquinário ou meio da cultura e os seus fins desinteressados, transcendentes, Tylor supõe a ampla sinonímia entre as palavras cultura e civilização. ( CONNOR, 1994, pg 234).
} 
permanece como identificação e o que caracteriza o movimento, havendo de portanto equalizar distanciamentos, aproximando do que, somos ao que almejamos ser.

O olhar sobre uma possível definição de cultura pode constituir-se como estudado por Arnold, Tylor, e George Stoking, dentre o que se articula em minha observação do que é volátil e perene, sendo que não fragmentado, ainda que podendo ser, mas em suma, havendo de procurar um desenvolvimento apesar de certas localizações no decorrer do tempo. Em certo aspecto o volátil, pode ser um lastro, ou seja, os aspectos do tempo entre o ontem e o desenvolvimento adquirem certa coerência quando a perspectiva ou percepção cultural abarca ambos.

Relações entre o modo de ser ocidental e orientais há um certos tempo são constatadas, porém, em caminhos interligados e conectados para além das redes virtuais, alega-se os efeitos de compartilhamento não somente de imagens e textos mas de comportamentos onde o compreender em sentido e razão de englobar passa a considerar a capacidade de aprender em conhecimento onde o valor se aproxima como mesmo diferença que pode gerar acréscimo e até mesmo relacionando com espaços de mercado para além de territórios de exploração mas como refluxo em direção de apropriações de modos de ser que contribuem de maneira significativa. E em certo ponto ainda me pergunto o quanto que dos efeitos demonstrativos são de fato correspondentes com a realidade, isto querendo dizer do cotidiano, povo, relações, dispostas com suas faces orgânicas sobre o que podemos encontrar na literatura, nas formas de arte, na organização social, ou seja, entre a definição de uma cultura nesse aspecto ainda procuro uma veracidade enquanto identidade representacional capaz de ser coerente, ainda que no presente tempo sobre influências, monotipia, de fato com o que o desejo interno expressa como externo, face observada por outros possíveis valores, assim chamado sobre esse termo, também cultura.

\footnotetext{
“As definições antropológica e crítica de cultura contidas nas respectivas formulações de Tylor e Arnold envolvem por sua vez duas atitudes distintas com respeito à questão do valor, se bem que, em ambos os casos, se deva considerar cultura, em certo sentido, sinônimo de valor. No sentido antropológico do termo, a atividade cultural representa o jogo do valor, todos os sistemas múltiplos e sobrepostos de equivalência e troca que servem de mediação às diferentes esferas da atividade econômica e simbólica. No começo do século XX, é razoável dizer, o que vem a seguir tornara-se a autodesignação normativa da disciplina antropológica: A atitude antropológica é relativista no sentido de que, em vez de começar com uma hierarquia herdada de valores, supõe que toda sociedade busca, e em certo sentido encontra, por intermédio da sua cultura, valores, e de que
} 
o objeto da antropologia abrange o escopo, a variedade, a constância e a sínter-relações desses valores inumeráveis. Contudo, no uso crítico e diferencial do termo, representado numa forma extrema por Culture and Anarchy, a cultura é definida como valor a certa distância ou oposição resistente do valor da alta cultura habitualmente lhe dá o status de valor em si. Na primeira definição, o valor é relativo, dinâmico e sob transação, na segunda, é fixo, concentrado e afirmado como absoluto. $\mathrm{O}$ relato antropológico que como vimos, identifica a cultura com o jogo do valor, não tenta impor ao seu material hierarquias valorativas - embora isso não signifique que essas abordagens, seja na antropologia ou na sociologia de modo mais geral, seja elas mesma algum sentido, isentas de valor. A definição critica de cultura, por outro lado, se orienta para a valoração quer dizer, em torno da seleção, da preferência e dos juízos de qualidade. Se é raro encontrar esses dois relatos alternativas da cultura em sua forma pura ou ideal, também e verdade haver entre elas certa oposição residualmente obstinada, oposição que se concretiza, por exemplo, na tensão entre estudos culturais e estudos literários, os primeiros se apoiando no que caracterizamos como definição antropológica de cultura e os outros ainda comprometidos amplamente com a definição crítica. (CONNOR, 1994,pg236

) .

Interculturação ${ }^{228}$. A passagem interna como ser no mundo ${ }^{229}$ se dará justamente nessa coesão ou absorção de onde estaremos continuamente dialogando com o espaço construído no entre, capaz de considerar seu amplitude interna em movimento que não exclui ainda que

\footnotetext{
${ }^{228}$ Entretanto, nos últimos anos esse problema tem sido representado de modo mais crucial não no campo das culturas individuais, mas através das e entre as culturas. Ou seja, a questão do valor cultural tem sido perpassada com profundas questões relativas ao valor de culturas autóctones e locais como tais, à natureza das transações de valor entre diferentes culturas e ao relacionamento entre modos universalistas e particularistas de modelar e regular essas transações de valor. O nosso é hoje um mundo em que faz pouco sentido considerar questões de arte ou de estética em termos puramente nacionais ou mesmos étnicos, ou simplesmente à luz de formas particulares de herança ou tradição cultural. Não falo apenas de coisas como a crescente disseminação e homogeneização de formas de cultura de massa, ( principalmente ocidentais ) da coordenação cada vez maior, por sobre fronteiras nacionais e mesmo continentais, do mercado internacional de arte nem da ampliação do público leitor e de redes de distribuição de publicações ficcionais, tudo isso fatores que podemos reunir na denominação globalização da cultura. Estão envolvidos aqui, igualmente a radical pluralização da cultura e das culturas, o profundo emaranhamento da cultura no sentido valorativo-afirmativo acima especificado com a experiência intensificada da diferença cultural, processo que podemos especificar alternativamente como interculturação. Já não se trata da questão das metades apartadas da arte e da cultura de massa de Adorno, que, embora não formem um todo, apresentam sua descontinuidade no âmbito do que ainda pode ser vivenciado potencialmente como uma única cultura, mesmo em sua calamitosa condição de clivagem. Porque agora a ruptura dos dois sentidos de cultura é parte de um recorte e de uma multiplicação mais gerais não somente de formas culturais, mas também de definições do que podem ser a cultura e o valor cultural; uma proliferação, deve-se portanto dizer, não apenas de valores culturais, como das próprias economias do valor cultural, uma atração para o circulo da troca do próprio meio de troca pelo qual o valor cultural é constituído. De fato, um dos mais importantes efeitos dessa convolução das economias do valor cultural é a recente visibilidade da dimensão global ou extracultural em ação mesmo nos debates endógenos acerca do valor cultural no século XIX, deixando clara a estreitíssima vinculação entre o valor da cultura como tal no sentido de Arnold com um sentido de identidade nacional, o que vem a gerar uma ansiosa refutação dos modelos alternativos de cultura que a etnologia estava encontrando. Eis o que liga de maneira tão enfática a definição elevada e restrita de cultura de Arnold com a definição contrastantemente expansionista de Tylor. ( CONNOR, 1994, pg238)
}

${ }^{229}$ Da série de audio em textos interpretativos, depoimentos datados em 21-05-2018, respectivamente:

Posição, llusões, Aqueça-me, solo do inverno. 
preservando a consideração de um estado original porém, concebendo a possibilidade do engendramento com outras culturas, que não o destitui como ser, mas fornece até mesmo a passagem como ser no mundo, na consciência de que pode tornar-se sujeito ambiente considerando por exemplo, seu nascimento e o desenvolvimento em contínuo, isto considerando até o movimento como ser original, partindo de que habitamos o planeta, ou seja, em se tratando de viagem e territórios e cultura, sobre esse olhar, origem e destino cohabitam mutuamente, portanto a de se ressaltar em tempos atuais a presença de uma consciência planetária que considero estejamos resgatando.

Sobre as passagens da cultura o ser, real na dramaturgia da vida ${ }^{230}$, em aspectos da imagem, som, texto, representação, consumo, marca e tempo etc.

Um sintoma desse novo interenvolvimento de questões culturais - estéticas com questões pertinentes às relações recém-complexas entre culturas é o recente cruzamento bilateral de fronteiras entre a teoria literária e cultural e a etnografia pós-moderna associado mais especificamente com Clifford Geertz e James Clifford. O que reúne esses dois domínios da teoria literária e da etnografia é um sentido fortalecido do relacionamento entre ação e representação. Do lado literário, isso envolve uma nova percepção das maneiras pela quais textos literários e representações culturais em geral não só representam o mundo sociopolítico, como também, em algum sentido primordial, o constituem ou lhe dão vida. Do lado etnográfico, isso é testemunhado no interesse intensificado pelas práticas representacionais e por costumes e rituais considerados enquanto significação, ou a frase de Nelson Goodman, formas de leituras do mundo, ao lado de uma autoconsciência mais profunda acerca da força significativa e retórica da escrita em todo o conhecimento etnográfico. ' 238

Clifford Geertz, em:

Seu famoso ensaio Deep Play: Notes on the Balinese Cockfight ( 1973 ) afirma que o propósito da briga, considerada como processo artístico, é tornar os vários tipos de experiência compartilhada visíveis, tangíveis, apreensíveis - reais, no sentido das ideias. Imagem, ficção, modelo, metáfora, a briga de galos é um meio de expressão, sua função não é mitigar paixões sociais nem intensifica-las mas, em meio a penas, sangue, multidões e dinheiro, exibi-las. Num ensaio posterior, sobre a Art as a Cultural System ( 1986 ), Geertz sugere ser somente o fato de certas

\footnotetext{
${ }^{230}$ Sousa, Carina Gonzalez Y. Composição Esse teu direito de viver. Esse teu direito de viver, responde a madrugada do teu ser. Que acorda a manhã, pra te dizer. Hoje será um novo dia para se viver. Acorda-me outra vez, de onde eu vou sonhar. Mesmo que não saiba, ainda amar. Quem sabe, as horas que passaram, Escrevam o que vou aprender. Me diga, do direito de viver. Me fale, do direito de te conhecer. Mundo......tão vazio de nós. Mundo........ tão vazio a sós. Me diga, agora que acordei. Por onde vou que eu não sei. Antes que a noite chegue. Me abrace para eu viver. Me beije no teu ser. Me beije um pouco mais.
} 
atividades parecerem em toda parte ser especificamente concebidas para demostrar que as ideias são visíveis, audíveis e - precisamos criar uma palavra aqui - tactíveis ( tactible ) que elas podem ser moldadas em formas em que os sentidos, e por meio deles as emoções, possam dirigir-se reflexivamente a elas, o que justifica a consideração de que arte ou atividade estética têm uma natureza comum em diferentes culturas. Para que isso não seja lido como outro gênero de etnocentrismo, em seu privilegiar o valor da forma estética sobre outros aspectos da atividade artística, Geertz nos adverte que a característica mais importante dessa objetivação estética não é a sua fixação ou reificação de ideias, experiências ou relações, mas o fato de subsequentemente tornar essas experiências de alguma maneira, disponíveis para uma valoração diferente, no grupo como um todo, à luz de experiências e valores distintos e levando-se em conta as contingências do tempo.[...] A arte é tanto extrínseca como intrínseca, ocupando o cerne da vida social exatamente por constituir uma espécie de parênteses no seu âmbito (CONNOR, 1994, pg239-242)

Portanto a face do texto, aqueça-me, solo de inverno, considera como Geertz em parte tradução mas de fato e verdadeiramente uma busca pelo desejo de entender o outro, uma outra cultura, outra parte de mim, ou seja, nos atravessando e atravessando a cultura, ressaltando que nos trabalhos de Geertz ainda se encontra a preocupação com a mediação intercultura como também a compreensão, colocando que cada vez mais somos uma cultura híbrida.

Em (toda) parte o teatro é a palavra tornando-se corpo. E então como literatura e sociedade, o gesto em sentido, torna-se ato compartilhado. Quiçá como diz Geertz uma cultura poetizada, onde se realizam aproximações da natureza e efeitos dos fatos e valores, tornando visíveis processos concretos da face da vida, agindo como compreensão de conhecimento, do que somos, do que queremos, e como em "Works and Lives: The Antropologist as Author ( 1988 ), a interface do gesto social como o próprio discurso, passagens interculturais.

Dentre as diversas formas de ver a cultura, em tempos atuais, creio que subsistem espaços onde a natureza é de tanto a determinação de tradições como de expansão, de hibridismo, havendo também de compreender que muitas das forças que observamos como elementos culturais, podem estar sobre diversidades de posturas sendo estas valendo-se de restriçõos, isto para quando se observa uma unicidade como perda, e não como ganho, e assim sendo, apesar, consideramos que podem haver visões fragmentadas em dilemas que vão desde a preservação de tradições como as vazões da própria em desenvolvimento ainda sem hibridismo com outras culturas, porém, a imagem de um tempo globalizado se questiona 
sobre o recurso planetário de existir em compartimentos sendo que estamos considerando o planeta, conectado em suas diversas facetas. Mas todavia encontramos uma reunião dentre os territórios que são da constituição de uma sustentabilidade cultural que se apresenta sobre o educar o pensamento em objetivos sobre o território que vem sendo objetivos comuns, e assim o modo de ser, abarca a possibilidade do pensamento na razão e consciência, o desejo de tornar-se tanto em tradições, avanços, a primazia do respeito, esteja ele sobre o ontem ou o amanhã. Quiçá haveremos de ver o tempo onde a imagem concebe dos povos uma mente cinematográfica de sentidos. Como paralelos de compreensão, encontramos destinos tantos que nossa travessia encontre, de Marlui Miranda, todos os sons, Nicolas Krassik e cordestinos, ritmos Malingue, sentidos do sentimento do som que unifica, como em oração de uma mesquita ou em cartas de amor, na voz de Maria Bethania, e sons como entre outros de Zakir Hussain, espaços de territórios poéticos do som, ou da percepção que nos rodeia mundo. Difícil dizer à terra onde ela habita, separada por seus povos, que são um só, diga ao verde, a poeira da terra, aos céus e aguas, qual é o seu lugar. Por onde andam as forças da natureza no homem que é sua natureza.

Se mostrarmos verdes, ou horizontes de terra, sem dizer o onde, saberemos onde estamos, por acaso, separados por culturas, ou apenas habitando um mundo ${ }^{231}$.

Quando a força do trabalho é o próprio viver, qual é a nossa linguagem? Da diversa natureza, a natureza da compreensão ${ }^{232}$, em “ reestruturação de sentido" e " produção de significado".

Sujeitos resgatados em engendramentos mútuos de natureza ontológica em procura de uma gêneses propulsora. Forças como energias oscilantes para lembra Milton Greco e sobre a teia da vida, física em percepções ${ }^{233}$, abertas ao outro, como movimento, deslocamento

\footnotetext{
${ }^{231}$ Depoimento S@U(I)TURA. Audio em texto interpretativo. Sutura de nossos sentidos, de nossa integridade de nossos sentimentos, que nos unem independente de povos ou nações, mas seres humanos.

${ }^{232}$ Reflexões do texto de Cremilda Medina, Jornalismo e Epistemologia da complexidade. MEDINA, Cremilda. Jornalismo e epistemologia da complexidade. Reflexões em jornalismo, Campo Grande, v. no 2006, n. 1, p. 3-9, 2006.
}

${ }^{233}$ CAPRA, Fritjof. A teia da vida, o ponto de mutação e o tao da física, para uma compreensão da realidade, citando Heisenberg sobre percepção: " O que observamos não é a natureza em si, mas a natureza exposta ao nosso método de questionamento", e ainda não sendo distante de uma possível realidade, os estudos de Eigen, sobre a organização dos hiperciclos, que se autoreproduzem e evoluem. Lembrando também, 
valor. que não se anulam mas somam-se nas equações diagramáticas dos objetivos, do próprio viver. Energias que realizam uma comunhão, que se tornam a passagem e permitem-se ainda que em espaço, lugar, serem o próprio movimento ( tempo). E sobre a natureza da vida, não apartados seres e culturas, as relações cada vez mais exercem em si a possibilidade do aprendizado, pois se desfazem da postura dogmática, entre determinismo e incertezas. ${ }^{234}$ para realizar o desprendimento do ego, apesar de ciente do mesmo, praticando um ato exploratório ainda que conservando sua natureza original, mas permitindo aventurarse em caráter do auscultar a hipótese de sentidos informacionais outros na sua própria realização do existir, assim, configura-se sua parcela do que não concebia percebido nele mesmo e do que dele, habitava nos outros. Configurando-se um tecido visível e vidente, conforme M. Ponty, da carne ou alma do mundo, na extensão do organismo social.

O olhar da realidade - perspectivas de percepção. Não ir de encontro a perspectiva, como sendo um ponto factual, mas sim como um campo aberto em diagnostico e relações intercambiantes, é abrir-se as conjecturas que se fazem contemporâneas. Podemos conceber uma perspectiva que não se faça milimetricamente, lembrando Brunelleschi, mas em sentidos exploratórios de observação, percepção onde poderemos encontrar, como relata Medina, o poeta de seu tempo, no que revela a produção simbólica, ainda participando desta compreensão quando da, arte de tecer o presente ${ }^{235}$, encontraremos reflexões apontadas mais profundamente, no decurso deste trabalho.

As forças, as mesmas citadas anteriormente, e da mesma maneira que estão nas interpelações, nas semioses, é a meu ver, fonte ( como lugar- habitar ) do movimento que é exercido intrinsecamente pelas aberturas de significado das metáforas, que são a gênese natural da poesia e como o mundo é um grande poema, declamado na dramaturgia do viver, somente posso conceber que no contínuo, na expansão evolutiva que almejamos para o mundo, se faça cada vez mais presente, o ato exploratório da Arte do viver, como arte do sentir $^{236}$.

Maturana em suas considerações de que: "Sistemas vivos são sistemas cognitivos, e a vida como um processo é um processo de cognição. Essa afirmação vale para todos os organismos, com ou sem um sistema nervoso. pg 49 - 88

${ }^{234}$ Popper, K. R.. Conhecimento objetivo: uma abordagem evolucionária. Tradução M. Amado. Belo Horizonte/ São Paulo: Itatiaia/Edusp, 1975.

${ }^{235}$ MEDINA, Cremilda. A arte de tecer o presente. Ed. Summus: 1973.

${ }^{236}$ Sousa, Carina Gnzalez Y. Composição: Por onde vai. Por onde vai, esse espaço entre nós, não me deixe a sós. Eu quero a tua presença mesmo quando de mim esteja assim tão longe. Eu quero, saber que o seu coração, mesmo que não seja meu, vive plenamente, sorrindo assim contente, por onde quer....caminhar, e nesse teu 
A busca que se encontra a flor da pele ${ }^{237}$. A sua gente como sujeito mundo. Nesse tecido existente e latente de pulso para sentir seu corpo, a sociedade exige para sua evolução uma nova maneira de se perceber, de se fazer fonte de conhecimento para se auto compreender e gerar a narrativa de seu tempo. Em jornalismo ${ }^{238}$ e epistemologia da complexidade, Medina coloca que “ Se seu projeto contemplar a mediação social, esta terá de ser sensível aos desejos profundos de um povo. Através do contato corpo a corpo - pela reportagem - e através da Arte, ele se expõe como o historiador contemporâneo aos mitos que reordenam o caos.“Que nas forças, caminhando através da Arte, não se pereça, frente ao poder, este que por vezes age como aniquilador de mentes criativas. Os diálogos do outro, como modos de romper com os entraves de uma dura realidade conflitiva. A fluidez dos sentidos, exerce a imagem que é fluxo continuo de significados, retratos, como discursos de uma época, metáforas de um olhar ${ }^{239}$, como escritos por Boris Kossoy, espaços de uma segunda realidade ou produção de sentidos, como produção simbólica ${ }^{240}$.

lugar de nós. Quem sabe, você tenha notícias, notícias de mim, nesse território tão distante, esse cotidiano, não esqueceu de ti, viver. Não precisa nem me dizer, eu ouço ainda o seu coração aqui, bem perto. Mesmo que incerto seja o seu destino. Ah....esse espaço entre nós. Não me deixe a sós. Porque eu te escrevo na multidão, horizonte meu que é vastidão, percorre o caminho, mesmo que sozinho, de um lado ou na contra-mão. É povo e cidadão, dialogo que não acaba mais, vai seguir, a bagagem está no cais, ou já foi, diário de bordo. Me diga, aonde estamos, eu quero saber, quem somos ou poderemos ser, quem somos ou poderemos ser. espaços de nós, espaços a sós. Vastidão.

${ }^{237}$ Sousa, Carina Gonzalez Y. Composição de tantos lugares. De tantos lugares, não posso estar... mais do que teus olhos, que sabem saciar a minha alma, que afaga os meus delírios de um corpo, que do mundo não é presença. Ai, porque será, que não te encontro a cada olhar, ai, porque será que do amargor desse lugar, a vida.... de tantas feridas, destroços sem guerra, lutou por nós! E agora.... lugar de paz, recebe a tua ausência como nua, alma tua, ainda sobre nós.... escrevendo poema inacabado, entre o passado e o futuro, um gesto que não sei.... mas eu quero saber.... da árvore da vida, quão o seu fruto. ah ventre do mundo, nascemos, nascemos, vivemos a procura de ser.... mais que o viver... ah alma sua, verso do universo, verso do querer, pertencer. A felicidade, de poder lhe abraçar, e encontrar uma verdade. Quem sabe um dia poderei olhar, a minha volta o desejo de estar ao lado meu, como labirinto meu, em igualdade....sinceridade, vontade, de viver. Vista-me imensidão, de onde eu possa ser, um tempo de apenas compreender, o simples ato de ser teu, um gesto meu, de um beijo entre nós dois.

${ }^{238}$ Sousa, Carina Gonzalez Y. Composição: Promessa - Daquela promessa, estou sobre os ladrilhos. Juntando as pesas, de quem sabe saber. O que pode ser... Desenho, que eu vou conhecer. Cidade grande....demais. Cidade grande demais... Tão pequena... que apesar dos pesares. Cabe no meu coração. É lugar de tantas peças, arranha-céus, que ardem como chama a procura do calor, humano. Me diga você, que imagem eu posso ver, de tantos lugares sem igualdade. Como posso juntar.... Como posso revelar.... Ainda como câmara escura. O que minha alma vê. Quem sabe amanhã eu posso ser. Mais do que uma peça na engrenagem desses tempos tão modernos, e que possamos ser sinceros, outra vez.

${ }^{239}$ SOUSA, C. G.. Retratos- discursos de uma época - metáforas de um olhar. Metáforas Record, online, 01 jul. 2012.

240 MEDINA, Cremilda. A fé no retratar e a leitura cultural exploratória que transcende a realidade retratada. Povo e personagem e transcendência poética no signo da relação, sobre os tempos da imagem, o efêmero e a ressonância ou perpétuo, como sobre fotografia Kossoy elucida. E lembrando os fotógrafos de naturezas nossas humanos gesto do corpo que o planeta respira, Araquem Alcantara e Sebastião Salgado, em Retratos, discurso de uma época onde encontro ainda o olhar, seja de uma onça ou de um ancião, eu pergunto “ Haverá refúgio para os retratos de vidas esquecidas, por um mundo onde se veem partir como navios sem destino, esperanças e sonhos? Onde podem ancorar a vontade de crer, de conhecer e de viver uma liberdade 
2. A ressonância, a construção em afecções.

Os lados internos e externos, a ressonância e aspectos da ação comunicativa. Partindo de que o conhecer está amalgamado a maneira como tudo age, pela conduta, poderemos pensar que a funcionalidade afere o próprio hábito, que fundamenta nessa razão a sua crença, porém nessa "geologia do exterior e interior" também ocorre a inserção da emergência das potencialidades que carecem do estado de vir a ato, ocasionando forças que movimentam o estado de permanência, promovendo um desenvolvimento que agrega valor informacional elucidando novas características da ação comunicativa. Compasso e tempo, ângulos de visão, promovendo ações.

Inferimos que imersos na existência ${ }^{241}$ podemos adentrar o conhecer, no percurso que atravessamos, justamente pelo que se revela em sua conduta. Portanto advogamos a hipótese que nos parece clara de uma necessidade de uma correspondência entre um discurso como uma retórica do agir e as interfaces entre o exterior e o interior apontados acima, visto na interface imagem e discurso, monotipias entrelaçadas, que elucidam a transparência ${ }^{242}$ como fator primordial de um estado de verdade, e havendo esta proposição, como relevante

justa e verdadeira. Até quando teremos como retratos de nossa época, imagens sem voz e olhares perdidos. Não sei mais o que dizer porque as palavras não bastam. Que os retratos falem e que eles sejam ouvidos."

${ }^{241}$ Sousa, Carina Gonzalez Y. Composição: Por mais estranho: Por mais estranho que possa parecer, o tempo das desigualdades, da luta pela liberdade, abraça-nos então. Quem sabe assim, eu sinta o teu perdão, de onde, estaremos na próxima estação, quem sabe eu te encontre diferente, o esmo solo, porque é outro dia, porque é outro lugar de nós, me conta então, o que é o seu querer, agora outra vez eu posso ouvir, o teu coração, mais uma vez, amor, infinito amor, amor, infinito amor, segredos da vida, que leva, por onde for....segredos da vida que leva, por onde for.... ah meu amor, eu te quero tanto, que desse meu pranto, eu não vou te esquecer, e saberei viver, na lembrança tua, que a saudade não finda, porque a eternidade é tua....ah....ah.... me ensina a saber de você, a tua sina de ser, um amor. Me ensina a viver, esse teu amor, perto de mim. Me ensina, a viver, um amor, perto de mim. Preciso do teu calor, preciso do teu querer, sem ele, não sou completamente feliz, nesse meu viver, preciso dos teus olhos sorrindo, preciso dos teus olhos tristes, quero te fazer feliz, e te amar, me deixe estar te olhando, me deixe estar te amando, porque é do que eu não sei, você já me encontrou, então me diga, meu amor, porque foi que acabou, você partiu sem e dizer, a verdade. Você partiu, sem em dizer a verdade, apenas sou do teu coração.

${ }^{242}$ Sousa, Carina Gonzalez Y. Composição: Do copo vazio. Do corpo vazio, a vida está cheia, do que transbordou. Do copo vazio, a vida está cheia, do que transbordou. Bueiros do mundo arriscou, bueiros de tantos passageiros, bueiros que tanto parte, do que não se vê, mais por aqui. Meu prato vazio, da ausência tua, que nua, me deixou. Vida assim não posso mais, ficar sem o teu corpo, vida que me faz viver, vida que me faz sofrer. Vida que é o meu querer. Eu quero da minha fome te conter, nos meus braços te querer, assim e sempre mais... copo vazio, da alma no cio. Transbordou de tanto que amou, e agora sim, limpa os meus lábios, de tanto sabor. Mesa posta do caminho. Volto amanhã, eu quero mais...eu quero mais...eu quero mais.

e composição, sopra o vento: Sopra o vento desconhecido, sopra o vento da vida esquecido por nós, Ventania. Ventania. Sopra as naus, da descoberta. Ventania. Por onde caminhei. Eu tanto te beijei, agora dos lábios me esqueceu, revolta. Ventania. Vidros se quebram como lados ao chão. do antes e o porvir, de quem feriu sentimento, de tanto que ficou pra trás, ah partiu de nós. VENTANIA, VENTANIA. Acalma-te amanhã será um novo dia. Amanheço outra vez, ao lado do mundo. Amanheço outra vez, ao lado do mundo. 
para o entendimento da forma como a experiência da existência acontece, iremos advir todavia um outro passo, que estaria justamente nas afeições e afetações, que nessa alquimia despontam como capacidades de qualidades que reverberarão em faces de novas descobertas agindo no complexo e expansivo sistema de maneira a promover novos estados diagnosticados como agentes lógicos e éticos, integrantes de uma estética capaz de imbuir a heurística como prognóstico de um corpo vivente que caminha em direção a razoabilidade concreta como forma de crescimento de condutas balizadas para o rumo de um desenvolvimento.

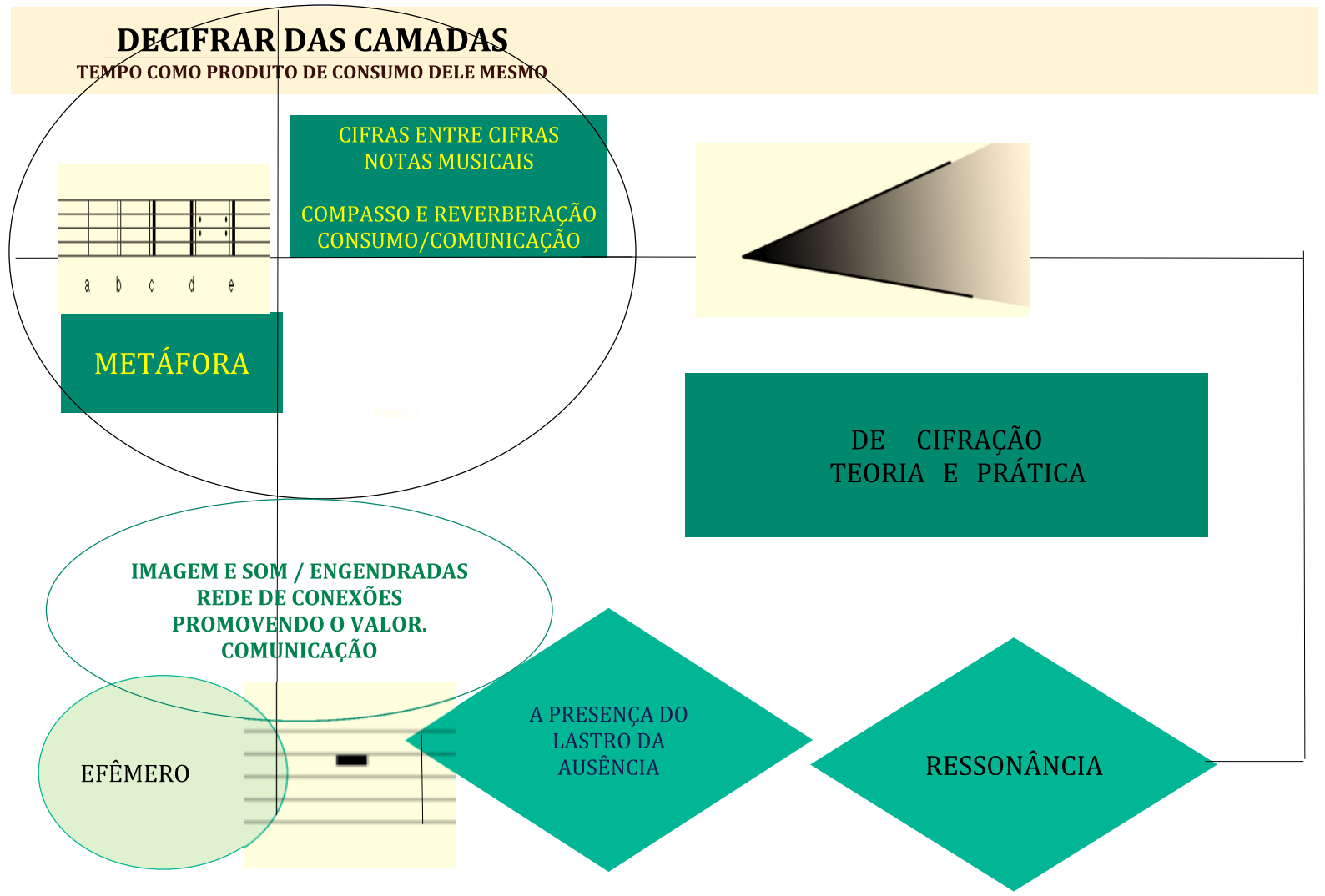

Portanto, cabe algumas questões de embates eminentes na ação comunicativa, sendo que, o conhecer é aferido pela própria ação, e a ação é o ato comunicativo buscando sua expressão de viver, como poderemos equilibrar nossa apreensão do conhecimento quando nos deparamos com mutações, com adequações de ambiente, com fluxo e refluxo de informações que interferem na ação; e então, no efêmero contemporâneo, quais seriam os parâmetros para diante de faces que por vezes se indeterminam eu possa ainda mesmo assim conhecer algo pela maneira como age e comunica-se? Haveria a presença de uma lógica que me permitiria seguir vestígios, ressonâncias, permitindo-me buscar a verdade na temporalidade, sendo o próprio aprendizado de uma constatação de uma matriz, ou DNA 
informacional, a preservação de uma genética em desenvolvimento e com particularidades que permeiem ainda que um contínuo e de natureza geral?

Como lidar com o gesto da incerteza e ainda conhecer a natureza das coisas de forma a lidar com um pertencimento efêmero, é um desafio para as relações implicadas como relacionamentos que talvez nos forneça a chave justamente para a compreensão dos tempos atuais. Engendrado em raciocínio da forma de ser da moda, onde o consumo impera e devora o próprio viver, frente as escolhas. O próximo ( com )passo.

Onde as faces da descoberta podem ser elementos que emerjam não somente como o novo mas que por se constituir sobre uma forma de amalgama se estabelece como algo que não é simplesmente o novo, mas que fornece conexões antes não estabelecidas para um desenvolvimento que nesta hipótese contribui para a identificação de um processo comunicativo, havendo a possibilidade ainda que com a presença da descoberta de um lastro cognitivo que forneça informações suficientes para se conhecer. Expressão ( livre?). Conexões reais, entre liberdade, responsabilidade, indivíduo e sociedade.

2.1.A mediação nos caminhos da comunicação.

\section{A palavra indomável}

Indomável gesto de me compreender

Sou de ti indelével ser, ou

Apenas um corpo s(em ) dizer?

Avido destino, este meu

Que digo sem dizer, dizendo

O que eu posso ser dessa

Vastas palmas escrevendo

( vasta alma conhecendo)

Alma da palavra?

Conhecendo

Seria demasiadamente

Sentir, atravessando-me sentido,

Lido como parte de seu, sangue

Pensamento a descobrir-se 
Sobre o fio do infinito que

Se faz modos de tantos outros

Diante de ti, absorvendo seus contos

E que fazer então, sentido e destino

Estarão a frente da incompreensão?

Não, posso ser um compasso ressoante

Distante talvez da gênese, mas ente

Em repartição, de muitos de mim

E de quem sabe, formas sem fim

Palavra sou, palavra penso, ileso não sou

Do contexto em que vivo, mas posso ser

O abrigo de um destino, afinal,

ser da palavra, ou palavra do ser,

Será o mesmo e o através?

Certezas e incertezas, em comunicação dentre caminhos cognitivos e ação; a necessidade da mediação.

Lidar com ressonâncias presume o desenvolvimento da capacidade de aliar espaços observados em determinações funcionais capazes de reverberar em conexões e o caminho para as mesmas, de forma a elencar razoes e descrições capazes de elucidar as adjacências possíveis, de maneira a ampliar a comunicação de forma transparente. Isto permite que, para além da constatação de uma imagem de um sistema, possamos compreender outros elementos de maneira que a percepção esteja colocada dentre a ressonância como fator que aproximará fatores e ainda podendo constatar mesmo com novos elementos uma imagem em representação (monotipia), ou seja, sem perder de vista o cerne que a constitui seja um pensamento, um indivíduo, uma empresa, povo, e cultura, capaz de agregar conhecimento, diversidade entre conexões. Porém, dentre a ressonância que preserva da fluidez do efêmero promovendo tanto o ganho informacional como a profundidade e reafirmação no decorrer dos próprios elementos de origem, ressalta-se a necessidade de uma organização. Morin, considera o conhecimento organizador. Scroferneker no livro, O diálogo possível: Comunicação organizacional e paradigma da complexidade, pondera que. "Há portanto, uma tendência em minimizar as incertezas com a produção e a organização do conhecimento. "no que dialogo observando em pensar que: Lidar com as incertezas dentro de uma organização, 
a meu ver, não a restringe a um processo minimizador, mas sim, que tenha a capacidade flexível de adentrar uma maleabilidade de uma densidade ( tão bem explicado pela física ) de probabilidade o que incorre em uma mudança de comportamento do estado habitual de se defrontar com o já determinado ou pre-estabelecido, ou restrito a normas estruturadas e vigentes. Incertezas podem ser vistas como fator externo a energia do sistema, que por certo ponto de vista, poderá ser um elemento aglutinador com variáveis já estabelecidas, e dentro dessa perspectiva de ver a incerteza portanto não se minimiza, mas se estabelece uma relação, de maneira a promover um estado de campo de ação. Realizar uma organização em estado de campo, pode ser um desafio a ser enfrentado: Como organizar dentre elementos que se apresentam em incerteza? A incerteza é uma incógnita, porém a probabilidade que lhe é afim, é cabível de diagnósticos ( que podem favorecer devido a gama de diversidade de pensamentos ), e portanto, possível de uma organização maleável, quase talvez, como quando lidamos com múltiplos, ou seja, lidar com aspectos matemáticos que vem a ser, equações de pensamento que se estabelecem mediante protodiagramas, ou, nos aproximar de uma pensamento de uma lógica paraconsistente, ou seja, lidar com o movimento, é um aspecto que favorecerá a compreensão dos estados de incerteza, sem depreciar o que deles podem favorecer na dimensão do conhecimento, por agregar, aspectos por vezes, não percebidos antes. E, para Curvello “ O pensamento complexo extrapola, portanto, os limites do pensamento linear, herdeiro de uma visão mecanicista do mundo “ ( apud Sroferneker, pg 16

Mais uma vez trazemos para o pensar, o que é de significado, do movimento, assim sendo, “ As realidades mutantes, e dos sujeitos organizacionais, por sua vez, implicam necessariamente um re(visitar) permanente das concepções de comunicação, organização e sujeito organizacional. Para Kunsch, “ Estudar, compreender e praticar a comunicação organizacional, é[...] muito mais complexo do que se imagina ". Reafirmamos que para nossa tese, advogamos a hipótese de que para além da realidade mutante, devemos ter um olhar de ressonância, onde em qualquer aspecto da comunicação se deve ter em pauta a necessidade da reverberação, para além do efêmero, posto que assim, acreditamos ter o sentido do que nos fornece uma informação que não se perde, mas dentre o que muda constantemente, mantem um caminho de sentido, uma lógica perceptível que justamente pelo que ressoa, não se perdendo é capaz de construir uma consistente fundamentação de razão. 
No decorrer da história várias teorias foram sendo realizadas, poderemos almejar a conquista de uma meta, de forma objetiva, descritiva, analítica ou ir em direção com a ciência da complexidade que permeia o rumo, não deixando de ser objetivo, mas nem tanto restrito a ponto de não aglutinar. Quanto a posturas de medição e controle no empirismo quantitativo de viés utilitarista.... surgem novas posturas, nomeadas pela Teorias Naturalista e Crítica.

\begin{abstract}
A teoria Naturalista considerava que a realidade organizacional era fruto da construção social, isto é, era historicamente construída e se revelava a partir de uma verdade que estava fora dela. A organização vista como ideográfica assemelha--se a um organismo, e era representada através de imagens e percebida como um ente permeável em relação ao seu entorno. Era também uma entidade cultural especifica, concebida como uma comunidade única da linguagem e de outras formas de ação simbólica. A comunicação é parte integrante da organização, no sentido de que a comunicação faz a organização, ou seja, é a condição necessária da organização.[...] Para Putnam, Phillips e Chapman ( 2004, pg 80 ), os naturalistas adotaram uma postura pluralista, ao enxergar a vida organizacional por múltiplas perspectivas, não apenas administrativas. [...]T. Crítica - arena de conflitos - " Locus do conflito de classes. E a realidade organizacional é o reflexo desses embates, sendo considerada como um instrumento de dominação e opressão. A comunicação assume assim um papel de mecanismo de mascaramento das realidades materiais da organização ( Scroferneker, 2008, pg 18-19).
\end{abstract}

Década 90 surgem as teorias narrativas e administração, refletindo sobre a condição pósmoderna, a economia pastiche e o simulacro. Mas, ainda se pode considerar obstáculo que ocorrem dentre a comunicação. Onde alguns citam,

O primeiro está ligado à palavra em si. É incompreensível, polissêmica, indomável. Escorrega assim que a abordamos, transborda de sentidos e referências, principalmente na sociedade contemporânea, dominada pela abertura e pelos incessantes intercâmbios, afirma o autor. $O$ segundo obstáculo por sua vez, remete à constatação de que " ninguém é exterior à comunicação, ninguém está distante dela. Somos todos parte integrante da comunicação, ela nunca é objeto neutro, exterior em si mesma. (Wolton, apud Scroferneker 2008, pg 29 )

Creio ser relevante ressaltar neste ponto, até porque é parte do corpo deste trabalho, no que se refere a entraves ou dissolução quanto a comunicação, no tocante a sentido e palavra, aqui se faz claro o quanto que a confluência de imagem, som, texto, enfim, a presença de diversas linguagens pode elucidar o significado, o que se faz querendo ser compreendido, ou seja, quando no ato de comunicação a palavra se estende ao que é da imagem, som, ela ganha 
valor de comunicação, e fornece mais informação para um caminho não somente cognitivo, mas e principalmente informacional. E, também, claro a presença do diálogo:

Segundo Marcondes Filho ( 2004, pg 15-16 ), comunicação é, antes um processo, um acontecimento, um encontro feliz, um momento mágico entre duas intencionalidades [...] ela vem da criação de um ambiente comum em que os dois lados participam e extraem algo novo, inesperado, anterior de ambos, apesar das diferenças individuais se manterem. [...] é acima de tudo uma relação entre mim e o outro ou os demais. Por isso, ela não se reduz à linguagem, menos ainda a linguagem estruturada e codificada da língua. Ela ultrapassa e é mais eficiente que esse formato, realizando-se no silêncio. [...] nos olhares, nos ambientes. ( apud Scroferneker,2008 pg 22).

Marchiori coloca que: É essencialmente uma ponte de significados que cria compreensão. E pondero que significados compreendidos também como ramificações, elos, compartilhamentos, compreensão, subdividido em duas partes - a que se aloja no próprio e em sua construção como ramificações e alcance direção. O clássico, eu sei o que e isso, mas aonde você quer chegar? Ou seja, por vezes pode estar claro o sentido propriamente mas não em suas potencialidade e ramificações o que ele poderá alcançar como compreensão. Dessa forma que se estabelece normalmente, muitos ruídos, porque não se tem a percepção do caminho, não se lida com o movimento, mas sim com estados inertes inclusive de sentido, o que vem a depreciar modos advindos de suas confluências de alcance. Processos não lineares mas em movimento de expansão requer uma cognição que se desmembre e não que seja extática. Se procurarmos essa compreensão, poderemos ter uma amplitude de horizonte maior e capaz de diagnósticos até mesmo mais precisos porque observam ramificações e intersecções. E ainda sobre considerações de E. Morin, “ cada momento do turbilhão, são ao mesmo tempo, produto e produtor. "

Organização - O QUE QUEREMOS SER!? “ A organização do pensamento, das palavras do querer, um sentido por se conhecer “ . Entre a literatura, comunicação e as organizações. - além das palavras. Sacia-me as palavras para que eu possa te dar o sabor do sentido. E onde o mundo esteja em silêncio, ouça-me por todos os gestos da imagem que atravessa todas as formas de linguagem.

O enrijecimento da comunicação, pelas "algemas da palavra ". Não seria assim, se ao menos, tivermos a compreensão de que a palavra é muito mais que uma junção de letras, palavra como cognição, é imagem e som, é do sentido o que dele pode ser uma amplidão de maneiras de comunicar, ou seja, os entraves não são da palavra, mas da maneira como a determinamos. Precisamos de poetas, para dizer sobre o que pode ser a palavra. Do 
pensamento e ato, ( consequências) / comunicação e representações. E entre, a palavra e o sentido, quando da razão humana, ainda não poderemos olvidar que: Do pensamento, fala e expressão, a correspondência com a verdade. Atos ilícitos, são gerados em seu amago, enquanto comunicação, sendo o ventre próprio do veneno, assim sendo, o prejuízo de tal conduta, insere em primazia no próprio que o acometeu de si. Portanto aqui se insere a necessidade do que considero, responsabilidade até mesmo propriamente como consciência e juízo, consequências. A réplica.

Relações em comunicação. Comunicação em diálogo.

Algo enquanto comunicação sugere uma revisão quanto ainda o simples processo de emissão e recepção já revisto pelas teorias, porém, de maneira muito simples, me parece que existe um fator relegado que vem a ser o desmembramento de uma emissão, quero dizer que uma proposição pode ser compreendida, parcialmente, e isso difere o processo como recepção e altera necessidades para o objetivo de se alcançar a compreensão, deixando claro se fazer o diagnóstico de qual " parte" foi compreendida e qual ficou incipiente no processo, provocando, perda de comunicação, e portanto, o diagnóstico claro de quais elementos foram capturados em sentido e quais não foram, é uma urgência para que se efetue uma continuidade eficaz, porém, ainda, não somente o que não foi compreendido, mas o porquê. Ou seja, alguma parte da proposição foi capturada e absorvida, e a outra que não foi, é devido a que fator? Para tal, se faz necessário deixar um ambiente de observação aberto, capaz de discernir de onde teria ocorrido a falha, e nesse sentido se faz necessário uma postura de ambas as partes, emissor, conteúdo, receptor, conteúdo como propriamente um “ sujeito “, que não seja dogmática e capaz de rever posturas. O que estamos sempre olhando, e não percebemos que se move?

Organizações- o desenho - traçados e perspectivas em ressonância. Espaços. O desmembramento da palavra - o sentido de um processo lógico sensível - que caminha na pele do som, nos ouvidos da imagem, nos aromas do destilar do movimento, e na voz da quietude. ${ }^{243}$ Entre fluxos, a possibilidade de construção de argumentos me parece que podem ao menos, no mínimo ter duas possibilidades interessantes de seres observadas. Construo o meu argumento do objetivo para a formulação ou formulo primeiro em direção para. Isso parece o mesmo, porém, quando o objeto, ou o target, ou seja lá qual o nome que venha a ter o que se quer alcançar, tem suas diferenças, porque muito pode não ser

\footnotetext{
${ }^{243}$ Sousa, Carina Gonzalez Y. Composição Eterno. PIANO - Eterno- Saga. Eterno dia de viver. E, também oriente eterno.
} 
conquistado pelo ponto de vista ter partido somente em direção à, sem ouvir o próprio que se quer englobar, exemplo visto comumente entre empresas, produtos, consumidores. Se a construção leva em conta, aspetos que não partem somente da emissão, mas da conclusão que se quer, nos parece que o esclarecimento passa a ser de em princípio, muito maior, para a argumentação.

Me parece que seria de grande valia, o exercício de ao se propor uma argumentação, como exercício de prognóstico ou de validação da emissão, o mesmo ser pelo próprio que o profere, refutado ( de maneira respeitosa, para assim, ou fundamentar seus pontos de perspectiva, esclarecer, aliar contrapontos possíveis de entendimento diante de refutações, mas o principal, é com o exercício, ter o discernimento se está sobre bases de razão. O cerne de um pensamento, é reflexivo nele mesmo, me parece, ou ao menos, deve ser.

Modos de ser entre literatura -e comunicação.

Descrição. Como pode ser uma descrição? Para muitos o abrigo de um sentido apenas que se desvela ainda que profundamente gesto da imagem, mas além se pode ir, entre tons do som que abarca a vida. Muitas vezes a natureza de uma descrição é analítica, determinada, sem margem a uma poética que a contemple, e como eu gosto de fazer, poderemos ter uma descrição que compreenda um modo poético, capaz de ampliar significados. A descrição pode ouvir da imagem o silêncio e movimentar-se como espaço em Shiva, onde a palavra torna-se território do sentimento. Porque muitas vezes a comunicação fica aquém do esperado, isto talvez percebamos devido a uma narrativa que carece de espaços do conhecimento este se constituindo linguagens múltiplas, e mesmo quando em uma somente representada, possivelmente a mente sugere e completa os espaços aos quais foi exposta, por exemplo uma palavra, cria imagem, que se torna escultura do movimento ${ }^{244}$, sentido ampliado de significação.

O que isso tem haver com a comunicação? Por vezes a emissão se dá de forma "objetiva" o que para muitos é suficiente, ou não.... necessidade do fluxo. O desafio - A composição, a harmonia entre texturas, cores, notas, - o modo de ser da arte em polissemia, tão aproximado da diversidade do mundo atual, imerso em telas cotidianas, de enorme pluralidade onde a organização precisa ter um sentido harmônico, como nas telas, ou composições.

A rede do pensamento - qual a senha?

\footnotetext{
${ }^{244}$ SOUSA, CARINA GONZALEZ Y . Ágape arte como a vida. Capítulo III, afecções diagramáticas.
} 
Segundo Morin: O princípio dialógico pode ser definido como associação complexa/ complementar/concorrente/ antagônica de instâncias necessárias em conjunto à existência, ao funcionamento e ao desenvolvimento de um fenômeno organizado. Esse princípio permite manter a dualidade no seio da unidade, associando dois termos ao mesmo tempo complementares e antagônicos. (apud Scroferneker, pg 26).

Veracidade com aspectos da origem, do pensamento e proposição; os fatos.

O consenso entre ressonâncias. Como discernir entre informações alheias ao sistema primeiro, acrescidos de novos traçados, de quem e para quem.... esferas... particular - social / indivíduo e comunidade, empresa- funcionários - povo - governo. O consenso tem que ter lado? Ou deve ser fruto de uma reflexibilidade que cônjuge as partes? Ou, estaríamos confundindo com conciliação? O que pode ser aferido dessas afirmações? Aonde pode estar um consenso, sobre que bases ele se fortifica? Haveria a possibilidade de gerarmos a concepção de um modo de ser do consenso como sendo permeado por igualdade? Um consenso não pré-estabelecido, mas construído!

É gesto sincero, manifesto da gente, que sente, não inconsequente, saber viver. Mas quem sabe o que pode ser? Talvez dos porquês, esteja o eu, que deverás seja teu, outro. Que seja, ou queira, nos fazer pensar.

Então, é isto.

Insisto em compreender. $\mathrm{O}$ que me dizes, quero ouvir, antes que eu te perca, por lhe ver partir. Sentido.

A ressonância também compreendida como elemento do Marketing de Relacionamento ${ }^{245}$ aponta quer sejam para alcance interno ou externo reverberações de boas práticas, assim

\footnotetext{
${ }^{245}$ Para o marketing, as necessidades podem ser convertidas em desejos. Isso se torna possível através dos benefícios que essas são capazes de trazer consigo. Os desejos são as necessidades humanas moldadas pela a cultura e a personalidade de cada indivíduo (SANDHUSEN, 2000). O marketing, ao transformar necessidade em desejo por um produto ou serviço específico, lida com os benefícios que esses bens de consumo possibilitam. Os desejos junto ao poder de compra constituem, para Kotler e Armstrong (2007), a demanda. Com o intuito de satisfazer as necessidades e os desejos dos clientes, têm-se a oferta ao mercado, onde produtos, serviços ou experiências são oferecidos pelo mercado, pretendendo saciar uma necessidade ou desejo de um indivíduo (KOTLER e ARMSTRONG, 2007). Dentre outros pesquisar sobre os aspectos mais especificamente como Marketing de Relacionamento: STONE, M., WOODCOCK, N.; MATHTYNGER, L. Crm: marketing de relacionamento com os clientes. São Paulo: Futura, 2002. CRESCITELLI, Edson e IKEDA, Akemi Ana, Revista de Gestão USP, São Paulo, v. 13, n. 2, p. 55-65, abril/junho 2006. BRITO, Laisa. Universidade de Brasília, Marketing de relacionamento Internet. Botelho, Delane, Damian Frederico. RAE • São Paulo • v. 50 • n. 4 • out./dez. 2010 • 396-410. Crescitelli, Edson. FACOM - n ${ }^{\circ}$ 15 - $2^{\circ}$ semestre de 2005. R. bras. Gest. Neg., São Paulo, v. 17, n. 58, p. 1371-1389, out./dez. 2015
} 
como análise dos efeitos. Portanto a ressonância aqui apresentada como fator essencial dos tempos atuais, é colocada tanto como fator cognitivo, onde o efêmero se apresenta como elemento sim vigente porém, como o modo de ser de um compasso na música ou frame no cinema $^{246}$, narrativas, onde tem suas características sobre elementos de notas, mas que e fundamentalmente após se entrelaça com os próximos compassos de maneira a considerar a reverberação para os passos seguintes, os outros compassos, assim sendo, tanto como cognição que considera o momento, este propriamente também respeitosamente como fator elencado de respeito, em alguns casos história, ou seja, o lastro, que até mesmo fundamenta o quem somos, ou a origem de uma empresa, suas razões de existir e desejos de permanecer, ou que seja o momento como a disposição cotidiana e fugaz do que se apresenta mas que tem vestígios a serem considerados na permanência, como ressonância, ou como desmembramento deles mesmos ou como possibilidades de efeitos posteriores todavia em conexões novas.

Ainda no direcionamento do sentido quanto a Marketing de Relacionamento, direcionamentos e desmembramentos, efêmero e permanência, o que se chama; CLV / valor vitalício do cliente(do inglês customer lifetime value), apontado por Iná Futino Barreto, Crescitelli e Júlio Cesar Bastos Figueiredo, aspectos dentre os sistemas e movimento das relações que analisam, satisfação, comprometimento, mudanças, riscos, confiança, personalização, fidelidade. Ou seja, dentre o que consideramos monotipia e as interfaces no decorrer do tempo, do quem sou, para quem posso ser, nos relacionamento dentre o que me constitui e o que eu desejo como tanto meu direcionamento com o outro ou outros, e o que eu ainda almejo ser, constatamos compassos em ângulos de visão onde os relacionamentos se entrelaçam gerando observações dentro outras acima descritas, avaliando posturas e procedimentos em condutas, que mensuram riscos e benefícios.

Ressonância dentre ação comunicativa.

Decifrar camadas. Conhecer, conduta, estrutura e linguagem da vida

\footnotetext{
${ }^{246}$ Para tal como anexo o trabalho inserido nesta pesquisa de em torno seis horas gravadas na Escola de Arte Dramáticas intitulado sala 25. Onde se apresenta o sujeito ambiente, inserido em um lugar onde este com sua razão em consciência passa a significar-se, e o movimento cada vez mais inserido por elementos novos, tornase obra. Realizados durante a disciplina da Professora Irene Machado meios e processos audio visuais na Universidade de São Paulo, e fruto de um percurso anterior durante o período do mestrado onde se considerava em práticas a cognição da dança, em usos de salas 23 dentre outras também na Escola de Artes Dramáticas da Universidade de São Paulo.
} 
Cifras entre cifras

Notas e fatos aspectos em reverberação

Pauta -consumo e comunicação

Campo organizacional, campo, em diversas frentes, ou seja, empresas, instituições, pensamento, trabalhos, relações. Estratégias em desafios e práticas, em processos de transformações, desenvolvendo capacidades para objetivos traçados com responsabilidade e ética, além de considerar um plano evolutivo como presença e realidade possível. Os questionamentos globais, anseios e desejos de uma ampla escala cobertos por princípio que devem ser de todo cidadão. A estratégia de um viver melhor em tempos de globalização diversidades culturais e de trânsitos midiáticos em internet e relações virtuais cada vez mais efusivas, cabe uma propaganda de fato de quais produtos querermos obter e realizar como viver para as novas gerações, como nessa estratégia fazer uma publicidade que atenda a esses propósitos. A cognição pode conhecer um caminho que nele mesmo seja organizacional a ponto de construir diretrizes que alcancem esse consumo? Entre o viver, fazendo, adquirindo e obtendo as razões e os porquês de uma marca social de um novo tempo.

Os desafios, dentre outros, a integração dos membros como sendo os setores da sociedade dispostos como, governamental, empresarial, e a sociedade civil. em princípio se pergunta como realizar efetivamente uma produtividade de cada setor aqui envolvido e exposto, de maneira integra e confluente. Em um pensamento, eu diria até atrevido, mas que considera o próprio viver como aprendizado de observação dessas estâncias, considero que a reflexão é válida posto como cidadã e acreditando que guardadas as devidas proporções, os Países tem suas peculiaridades, porém, possuem capacidades de seus membros em uma reverso global simétrico, diríamos, como um sistema em reverberação refletida, ou seja, aspectos gerais dentre os do âmbito interno da sua população geral, nas estâncias percorridas, ordem governamental, empresarial e civil. E para além do desenvolvimento, e propriamente também como parte dele, a diminuição dos fatores que são dificuldade do ambiente social, como violência, desnutrição, falta de trabalho, moradia, e diversos distanciamentos que se localizam entre as realidades com as quais nos deparamos.

Como hipótese, pensamos na proposta de uma Integração no que diz respeito a observar que o governo, as empresas e a sociedade tem suas estruturas de linguagem em códigos de 
funcionamento, para trazer à tona, um paralelo com o que é da comunicação e arte. Portanto, creio ser cabível discernir sobre o que é de ordem do funcionamento, ou seja, como cada uma dessas instâncias funciona ou poderá funcionar, para além disso, quais são as demandas e objetivos de cada uma delas, e é justamente nessa fase de questionamento que penso estar a possibilidade de engendramento das esferas, porque a demanda integra informação e comunicação, a meu ver, o que está justamente correspondente ao cerne do objetivo, e que havendo essa sincronia, deveria estar estabelecido trilhas, caminhos, para que o funcionamento das estruturas e linguagens das instâncias estivessem no prumo da sua funcionalidade atendendo ao objetivo de maneira mais eficaz. O exemplo que mais me vem sempre ao pensamento, é a questão das universidades, posto que se cada uma delas esteja em congruência com os aspectos de suas populações das cidades e em contato com demandas governamentais, creio que estaríamos observando resultados de ordem civil, no decorrer do próprio sistema de cidade ou campo, não havendo entraves burocráticos costumeiros, mas me parece que essas faces de diagnose podem ser salutares e efetivas, como já disse em outro momento. Ou seja, o cidadão civil tem uma carência e esta está sobre os moldes de uma esfera governamental, e penso que, havendo um relacionamento plausível de transparência nos esforços aqui necessários, teremos a oportunidade de unir a capacidade intelectual do campo universitário, com a demanda civil ${ }^{247}$ e os mecanismos de atendimento governamental. Existem tantas áreas de conhecimento que não acredito que não possamos ter uma unidade nessas esferas onde se busque resultados de interesse comum, para um bem de todos, aferido constantemente por mecanismos que guardem esses esforços de alvitres ao bem social, advogando sempre em causa pública, e concomitantemente do indivíduo e das áreas de conhecimento.

Do que queremos encontramos dificuldades para serem enfrentadas, como violência, desigualdades, pelas quais não poderemos esmorecer, temos que acreditar e pensar em como transformar, destroços ${ }^{248}$ da condição humana em ainda um viver digno ${ }^{249}$ e em igualdade.

\footnotetext{
248 WINNICOTT, D. W. Privação e delinquência. São Paulo> Martins Fontes. 1999. Crianças sob stress: experiência em tempos de guerra. Pala além dos conflitos. Caminhos a seguir. Comportamentos sobre aspectos considerados em momentos do pós-guerra. Enfrentamentos de graves dificuldades. Entre outras passagens, sobre a aceitação de símbolos, a busca de lugares. Onde há agressividade também pode haver amor, pg 107 tem que se descobrir e viabilizar a ponte de acesso, a um lugar mais humano. Este libro assim como outras bibliografías sao parte de uma pesquisa por ocasião de quando fui ser voluntária na Fundação Casa, Unidade Chiquinha Gonzaga. Vale ressaltar que já nessa época e também como interlocução do livro Wnnicott, a presença importantíssima de uma crença em algo superior à nós, uma religião para alguns, um
} 
Com a intenção de nos precaver de entraves, presume-se que deve-se ter um documento e ou já um órgão existente com a intenção de não ser um discurso mas que tenha nesse documento e em atos desse órgão propriamente diretrizes, que contenham o respeito entre as partes, as esferas dispostas nos projetos a serem realizados e contemplados pela necessidade, e de maneira a que estabeleça critérios por onde essas relações possam de fato existir viabilizando de maneira integra e correta o que é proposto e sempre havendo avaliação dos resultados, não em relatórios que não sabem de fato normalmente a face do que é comumente chamado pela academia de trabalho de campo. É necessário acompanhamento fidedigno dos trabalhos realizados e do entendimento entre as partes. Claro que a responsabilidade da comunicação é cada vez mais importante por que estará permeando essas dificuldades para tentar sanar ou esclarecer o que pode e como encaminhar e algumas vezes solucionar as demandas ou dissensos possíveis.

O respeito, e o entendimento deve ser um critério básico, porém, também, o discernimento quanto a organização, posto que muitas vezes, apesar de serem muitas as necessidades por critério de urgência ou de amplitude de escala, pode se direcionar esforços. Vale lembrar que, temos o costume de pensar que o problema nosso é sempre maior que o do outro, então, creio que esclarecer e discernir em diálogos, com a ferramenta da comunicação e também da publicidade, estaremos atentos a não perder o rumo de uma efetiva construção que contemple o que é necessário segundo e com as capacidades de todos os campos, porque deve se estar atento que não somente a área de conhecimento pode ser instrumento de ação em determinadas demandas, mas aquele que sofre o prejuízo social, empresarial etc, tem conhecimento de causa, e pode e deve realizar também como frente de ação, suas avaliações contribuindo para a maneira de sanar os desafios. Sempre em discurso, fica mais fácil, suponho, porém, neste momento, é de onde eu tenho a perspectiva para dizer algo. E, como

afeto para outros, uma direção maior do que a própria vida, onde podemos ter uma face transformadora, assim como a arte.

${ }^{249}$ Sousa, Carina Gonzalez Y. Composição: Se eu pudesse. Ah se eu pudesse, nessa prosa ficar. Ah se eu pudesse, nessas águas me debruçar. Chuva que cai sem parar. Aguas que rolam da gente, e eu ando sem parar. Um dia até a paisagem me mostrar. Do amargo fel, Do cativeiro da vida. Cotidiano. Escrevo quanto anoiteço, Nos braços do verso. Da travessia. Que atravesso, sereno adentro. Movimento do meu amor. Que não se cansas de olhar, as estrelas. Na busca do teu destino. Ah essa terra então. Me diga quando eu vou estar a teu lado. Sempre mais, lugar de nós, nem tão a sós, vamos lá. É só recomeçar, como vai você, vem aquí me dizer. Porque eu quero o teu querer. Ah se eu pudesse. Nessas águas me debruçar. Chuva que cai sem parar. Um dia até a paisagem. Me mostrar, do amargo fel, do cativeiro da vida. Cotidano. Escrevo. Quando anoiteço. Nos braços do verso. Da travessia, que atravesso, sereno adentro. Movimento do meu amor, que não se cansa de olhar as estrelas. Na busca do teu destino. A terra então, me diga quando... Eu vou estar..pro teu lado, ao teu lado, Sempre mais.... Lugar de nós. Lugar a sós. Vamos lá... É só recomeçar, como vai você, vem aqui me dizer, porque eu quero, o teu querer. 
possível representante da área de comunicação, que estudo e pesquiso, assim como das artes, onde vejo frequentemente os desafios de linguagem, estrutura, cognição, experiências fáticas, objetivos, frustações, e busca constante, creio ser possível e também como cidadã, me aventurar por refletir sobre esses prismas tão contemporâneos como sempre.

A informação me parece que é algo bem essencial ao se propor por exemplo comunicação e diálogo, alinhamentos de interesses comuns e benefícios posteriores de alcance de todos. Havendo rede de informação a comunicação pode ser mais efetiva, penso, e para tal, cabe organizar ordens de diagramas onde os aspectos das demandas estivessem bem claros, para termos por onde caminhar, e com quem, de maneira que os esforços estivessem com diretrizes cada vez mais claras e firmes no propósito de efetivamente vir a termo.

Quanto maior for a ressonância ligada a consciência, estaremos mais aptos a considerar a narrativa do indivíduo em seu ambiente, considerando, portanto, a viabilidade de estar e ser inserido no mesmo sistema, portanto a conduta interage não somente na face do seu interior e exterior mas nas consequências.

Sendo comum haver a tão estimulada oposição, deve se ter em conta, que os interesses dos objetivos em bem estar geral sejam maiores do que interesses partidários ou de outra ordem, mais do que isso, penso que a oposição devendo existir é parte, deveria não somente criticar mas propor, o que precisa de um caráter de coabitar o processo de realização, e não querer dificultar somente. Como se convence um direito de que uma atitude ambientalmente sustentável é melhor para a empresa? Ele pode argumentar que não tem retorno financeiro ou seja lá o que for, enfim, argumentos devem estar prontos para enfrentar oposições de maneira a provar que é um benefício, uma estratégia muitas vezes não imediata dependendo da demanda ou mostrar que na sociedade atual, tal prática é salutar para a empresa em visibilidade, e outros fatores que os profissionais de marketing sabem tão bem promover. A atitude com a oposição pode ser diferente também dos que estão nos esforços, havendo portanto, uma conciliação a favor dos benefícios, e se necessário agir como marketing de relacionamento que muitas vezes é esquecido, mas que nos pouparia de muitos problemas que são colocados frente aos projetos inapropriadamente, portanto, levar um tempo se necessário esclarecendo e promovendo à oposição os fatores necessários para que as demandas sejam solucionadas inclusive deixando claro, por até mesmo aquele órgão regulador, para não haver detrimento dos objetivos, teremos, que gestões que mesmo sendo outras, preservem o objetivo a ser alcançado, porque é um verdadeiro absurdo considero, certos projetos que dão certo, serem relegados, somente por alteração de gestão. Creio ser 
fundamental, que os propósitos de solucionar os desafios estejam a frente de alterações de diretorias ou enfim, o que esteja coordenando o sistema. Preservando organismo como um todo, e seu funcionamento. E, inclusive para que não fiquemos expostos a um órgão, funcionar bem e outro não e assim por diante e depois falência múltipla dos órgãos! Se é que me entendem.

O costume, é de ouvirmos, isso não tem nada haver comigo, eles que resolvam, por não se ter a visão de engendramento de esferas, de departamentos, etc. Se tivermos a consciência da ressonância teremos consideravelmente também a percepção do envolvimento do desdobramento do alcance do outro como parte e portanto, meu ato interfere não somente em consequências minhas, mas em tudo que envolve o próprio existir, realizando assim a eminencia de constatar nossa responsabilidade por pensamentos e atos, e principalmente na comunicação. Normalmente é o costumas e o mais fácil, termos a postura de não querer resolver porque não é da nossa conta. Bem, o que proponho é a realização de trabalhos com esforços claros, contínuos e de interesses compartilhados onde a consciência de cada um e em cada esfera pública, privada, acadêmica, esteja nutrida de elementos que favoreçam a sociedade, de maneira a fazer parte do seu cotidiano, e essa consciência é como o consumo consciente, claramente levará possivelmente um tempo para que esse modo de agir consciente das esferas compartilhas esteja efetiva, porque é uma mudança de pensamento, e de pensamentos em atos.

A produtividade um fator que se observa prontamente os estímulos e efeitos ${ }^{250}$ de uma nova estratégia e razão cognitiva de todos os envolvidos.

As instituições públicas, inclusive as mais democráticas podem e devem implementar sistemas de participação, motivação e comunicação que lhes permita operar em fluxos mais dinâmicos. As organizações filantrópicas, que dependem do trabalho voluntário, podem incrementar seus níveis de eficácia mediante estratégias de comunicação. As empresas medias e pequenas requerem também esforços especiais de comunicação e informação que lhes permita incrementar sua produtividade $\mathrm{e}$ competitividade nos mercados e lugares em que atuam. ( CORELLA, 2006, pg 15).

\footnotetext{
${ }^{250}$ Las instituciones públicas, incluso las mas burocratizadas de todas, pueden y deben implantar sistemas de participación, motivación y comunicación que les permitan operar con flujos mas dinámicos. Las organizaciones filantrópicas, que dependen del trabajo voluntário, pueden incrementar sus niveles de eficacia mediante estratégias de comunicación. Las empresas medianas y pequeñas requieren también de esfuerzos especiales de comunicación e información que les permitan incrementar su propductividad y competitividad en los mercados y los nichos en los que sirven.
} 
Quanto ao que Corella coloca como instituições filantrópicas, costumo colocar como terceiro setor, e me parece que estamos mais próximos de um agir consciente onde mutuamente estejam conjecturados esforços dentre os contemplados com uma ação participativa de melhorias sociais, onde mesmo o que insere uma participação com aspectos estruturais em via de mão dupla inserção após capacitação ou outra forma, inserção de trabalhos em um movimento que para todos os envolvidos oferece crescimento.

Mas das situações sociais que encontramos, uma presença também é a violência que entrava por vezes acessos de onde se poderia encontrar e proliferar novos rumos, portanto é necessário um olhar atento. Nos próximos parágrafos vou buscar referências que tem um olhar sobre alguns desses aspectos e que já encontraram caminhos de ações com resultados.

$\mathrm{O}$ arte educador Pedro João Cury ${ }^{251}$, em futuras gerações aponta algumas reflexões, dentre as quais, a necessidade da importância da liberdade do ser e o da conscientização, esta colocada como problematizar a realidade, pela qual coloca Paulo Freire e a pedagogia do oprimido, pedagogia da Autonomia e política da educação, onde aponta, “ A violência está mais presente do que imaginamos" indagando inclusive a proximidade que temos de agredir e reprimir um menor da Fundação Casa, como o estado indivíduo-povo de reprimir seus desejos de cidadania e esforços próprios de identidade e liberdade com responsabilidades, como referências, considerando também o alerta de um adestramento inserido no sistema perpetuando no educando, e a gritante necessidade da criatividade como fator desencadeante de saberes. A proximidade referida é difícil em grande parte da sociedade, e para muitos invisível, mas é latente e transborda. E, Cury considera firmemente no educar a prática de que o despojamento do amor é capaz, dentre valores humanos, e cita Mahatma Ghandi, considerando que "Simplicidade voluntária, onde nos aconselha a evitar o supérfluo e o desperdício. Ética solidária, busca o exercício da arte do convívio. $\mathrm{Na}$ valorização das diferenças, incentivar as diferenças como fonte de riqueza. E com a cidadania responsável, participar nas gestão do bem comum e do espaço público. “( CURY, 2005pg 4), e o autor questiona se estamos sendo na prática a mudança que queremos ver no mundo, lembrando também o relatório da UNESCO ${ }^{252}$, da Comissão Internacional sobre Educação para o século XXI, Jacques Delors, na busca da coesão entre indivíduos. No palco do mundo,

\footnotetext{
251 Cury Pedro João, Texto Diálogos Pedagógicos Possíveis e Ambientais. http://www.futurasgerações.com.br/htm/arteducação3.htm. Acesso em 27-04-2005.

252 Sousa, Carina Gonzalez Y. Composição Um sonho e um coração.
} 
sobre diálogos ininterruptos de diálogos nossos, de onde encontremos quem sabe, uma transformação $^{253}$, que como Olgária Matos aponta,

\begin{abstract}
" A cidade entrecruza-se com o pensamento racional, o espetáculo com a especulação e a educação. O pensamento é a operação do olhar e da linguagem, como o é também a existência em comum dos cidadãos no espaço da cidade. Não por acaso, os gregos inventaram a tragédia e a comédia - o teatro, arquétipo do espetáculo: nele ( no teatro) tudo é visto por todos os lados, tudo está manifesto e reveste-se dos sinais exteriores da visibilidades: nele, o pensamento está totalmente voltado para o exterior, como o espaço do teatro se reproduz no espaço da cidade ( apud Wolff, Aristóteles e a política 1999., p. 13). [...] A phylia é a dimensão da convivência humana onde há boa educação, leis justas, e cidadãos virtuosos - e ela se institui através da palavra enunciada e refletida pelos ouvintes e espectadores[...] A ética e a política constituem o cruzamento do pensamento racional e da polis, têm um terreno tão amplo que seus limites se confundem com os limites do humano. A política não passa da realização de si, uma vez que o si é a relação com o outro ( in Aristóteles e a Política)"( MATTOS, 2002 ).
\end{abstract}

Neste momento, creio que é importante considerar entre críticas apontadas sobre considerações que vão desde comunicação e informação e do papel das mídias e do cidadão, e ainda a responsabilidade da expressão em maneiras de viver e de comunicar-se, já a tempos lidamos não somente com posturas direcionadas a mídia, mas eu penso que em todos nós, podemos encontrar, dilemas, paradoxos, enganos que vão desde as nossas posturas antigas em relação ao consumo e para trazer dessa lógica estados cabíveis de serem empregues em conexões de desenvolvimento que podem ser ressignificados dentre a sociedade, isto porque me parece cada vez mais e bem diretamente digo que a questão sobre o humano, seja lá que contexto possa ter no decorrer das experiências humanas, sendo por alguns colocadas como naufragadas ou até mascaradas, de qualquer forma, o que realmente é a meu ver nos tempos atuais, de se considerar, são as práticas do que hoje aponto como sendo a consciência humana como fator mesmo e até inegável da sobrevivência. Creio firmemente por exemplo, como em tempos, nomeado por humanismo ligado a burguesia, que hoje independe de rótulos mas é uma postura que não precisa até ser nomeada, podendo estar sobre muito nomes, responsabilidades social, cultura sustentável, enfim, não é uma ação que dispensa questões econômicas ou ambientais, ao contrário engendra-se em tudo que consideramos vida, fundamenta-se em valores, quer sejam éticos, como lógica de estruturas de funcionamento internamente e externamente em relações, possibilitando um

\footnotetext{
253 MATOS, Olgária. A educação na transformação da sociedade, IN Congresso Educação e Transformação Social, Sesc Santos, em maio de 2002.
} 
direcionamento real, como parte da estética, como modo de olhar e agir no mundo. Mais adiante Mattos, aborda o pensamento de Condorcet, “ nos anos da Revolução Francesa, anotou: a vida humana não é uma luta na qual adversários disputam prêmios, mas uma viagem que irmãos fazem em comum empregando suas forças para o bem de todos e recompensados pela doçura de uma benevolência recíproca, e pelo contentamento de merecer reconhecimento ou estima"( apud in Cinq Memóries sur I'Instruction Publique, Paris: Ed Flammarion, 1994, P 103 ). E aponta eu poderia dizer a amizade como laços que prevalecem frente a tiranias, sofrimentos, injustiças e desigualdades sociais. Em algumas particularidades das dificuldades sociais como a violência, como ressalta Dimenstain ( 2005), é necessário desenvolver “ a sensação de pertencimento “, e eu me pergunto no decorrer dos anos, onde do, sentido pensar do humano ser, ainda se pode pertencer a ponto de olhar o outro, em faces reais, da brutalidade que nos cerca, o que pode haver de todo ser. Como podemos ser melhores? Diz um ditado Xhosa, língua materna de Nelson Mandela, “ Ubuntu ungamntumganye abantu, ou seja, pessoas são pessoas através de outras pessoas" ( apud, Bussab, 2003). E, entre indivíduo e o outro, o respeito e a liberdade, liberdade não somente como do que supomos não estar sobre cárcere, mas do que é como John Stuart Mill, coloca sobre a liberdade ser um direito natural, ele “ chama atenção para um conceito muito mais amplo de liberdade. Esta afirmação de liberdade compreende em primeiro lugar, nas palavras de Stuart Mill, o domínio interior da consciência, a liberdade de pensamento e de sentimento, esta liberdade inerente à cultura e ao pensamento liberais. “ ${ }^{254}$ (apud, DALLARI,2003).

Do que queremos, do que somos, qual imagem estamos vendo. Entre os aspectos cruciais de desafios sempre presentes, avaliações onde o limítrofe do que acreditamos necessário transformar e o que insiste em dizer que amargamente sobrevive, entre tantas faces da realidade, desenvolvimento e desigualdades ${ }^{255}$, enfim, ainda e mesmo assim, não vou deixar de acreditar que é possível, viver e projetar uma imagem onde possamos encontrar uma correspondência, ao menos, de um existir que encontre o destino de uma fresta ou lugar de dignidade.

\footnotetext{
${ }^{254}$ Dallari, Dalmo de Abreu. Foi diretor da Faculdade de Direito da Universidade de São Paulo, defensor dos direitos humanos no país. Texto do Seminário Cultura e intolerância, São Paulo novembro de 2003, Cotidiano e Tolerância. O sentido positivo da tolerância, exigindo respeito, efetivo e genuíno pelo outro, a aceitação do outro, e o apreço da riqueza da diversidade de culturas.

${ }^{255}$ Porto Marta. Brasil e o mito da caverna de Platão. Sobre o desafio das gerações, de enfrentar um histórico de e desigualdades. Projetamos como imagem nossa o que queremos ou o que a realidade mostra, e nesse entre, onde poderemos estar?
} 
Neste ponto estamos levantando considerações sociais que tem na imagem e marca de nosso tempo as ressonâncias em busca de mediações para dentre os espaços de movimento gerar transformações. $\mathrm{O}$ equilíbrio do que sabemos serem fatores positivos de desenvolvimento social podem e devem estar inseridos dentre oportunidades e regiões que já auscultamos como desafios a serem encontrados para o equilíbrio de uma cidadania ${ }^{256}$.

Desenvolver a cultura é sinônimo de desenvolver a sociedade. Nessa perspectiva, uma política para a cultura é inevitavelmente uma ação compromissada com o social. Contudo, não é sempre que o setor cultural é pensado com toda a atenção que merece. Além disso, atribuir algum papel a arte inevitavelmente nos soa como uma restrição à sua própria essência: a capacidade de colocar em cheque uma visão estabelecida, um enunciado; a possibilidade do indivíduo inventar a si mesmo e reinventar o mundo. $\mathrm{O}$ que não se percebe é que essa essência da arte é algo próprio do ser humano e que sua democratização só pode ser entendida como prioritária.( CARVALHAES, 2005) $)^{257}$

Vida como produto, trabalho realizado por todos nós onde se questiona origem, destino, travessias. O espaço de aprender, relações em progresso, sobre a arte de existir:

O mundo do trabalho, com suas incontáveis diferenças é repleto de saberes, ou ensinados e aprendidos nele mesmo, ao nos engajarmos em suas atividades. $\mathrm{O}$ modo de tecer uma rede, de lidar com o gado, de escrever alguns textos, de falar de se relacionar com as pessoas com esse ou aquele objetivo são saberes importantes, mas não são usualmente fruto de aprendizado formal. E é assim também nos espaços domésticos, na vida religiosa, nas celebrações populares, nas formas de brincar e fazer alguns esportes.[...]Por meio do olhar para a história e enfim, da investigação sobre nós mesmos, o diferente e os traços específicos podem ser reconhecidos como nossa riqueza. A valorização de nosso patrimônio e a abertura para as novas influências podem ser então a chave para darmos conta de um imenso desafio contemporâneo, que é recolocar o tradicional na modernidade, e ao mesmo tempo, transformar essas tradições com os

\footnotetext{
${ }^{256}$ Por ocasião da especialização em linguagens da arte no Centro Universitário Maria Antônia, e em conjunto com o propósito de acreditar na Arte, como comunicação e veículo de transformações onde se ressignifica o mundo e as circunstância nele presentes, isto porque apesar de não ter sido realizado em prática como voluntária da maneira como descrita, porque no período da Unidade Chiquinha Gonzaga na Mooca, a oficina foi direcionada a outras atividades, mas da proposta inserida no trabalho de conclusão da especialização, aqui se apresenta um trecho que continua sendo vigente como até mesmo cognição onde, estamos todos sobre um cárcere do mundo a procura da liberdade da nossa alma, que diz, na proposta: " $\mathrm{O}$ teatro possibilita novos papeis, novas realidades, novas esperanças". Lembrando da lei que determina as regras para a criação de Organizações da Sociedade Civil de Interesse Público, Oscip, em 1999. Para referências da importância do teatro como ferramenta pedagógica, e inserção de consciência social, Verônica Maia, fundação Athos Bulcão.
}

${ }^{257}$ CARVALHAES, Maria Helena. Arte-cidadania: um novo lugar para a política pública de cultura.

Coordenadora em 2005, ocasião do artigo, do Centro de Estudos em Arte cidadania do Instituto GTECH. 
outros tantos legados que se apresentem a nós. (SETÚBAL, ÉRNICA, $2005)^{258}$

De encontro aos paralelos de sentido e vivências, dos cárceres da expressão da voz de viver no mundo e onde vemos a liberdade:

O dialogo deve ser concebido, percebido e apreendido como método e fundamento do pensamento, da razão, do conhecimento, da crítica, da criação e da interação social. Não é só verbal, ele se dá por meio de gestos, de inflexões, de olhares, de posturas. Nossa natureza nos fez diferentes e imersos num mar de diversidades e complexidade. Neste sentido, todo o potencial e riqueza da articulação desta natureza dependem das cadeias de relações que viermos a desencadear e a desenvolver, seja com o outro seja com o mundo que nos acolhe e cerca. Para tanto, o fio que tece esta rede deve ser o diálogo que, uma vez efetivado, estreita os laços, qualifica a compreensão e concorre para a articulação de ações em favor da construção das qualidades ainda ausentes. A fluidez deste diálogo depende, no entanto a eliminação de perspectivas verticais quanto ao conteúdo do diálogo. Ou seja, não podemos erguer pontes de diálogo onde não se reconheça o outro, que cada um e que todos não são em nada inferiores ou superiores a quem se dispõe a dialogar. Com efeito, o diálogo deve ser submisso a ideia de igualdade entre os que dialogam. Não a igualdade hipócrita expressa na juridicidade presente nos arcabouços legais de cada país, mas a igualdade concreta, que não reforça nossas diferenças, quais sejam, a igualdade social, econômica, de cor, de religião, de língua e de gênero. Da mesma forma a liberdade deve ser vista como um elemento sem o qual a igualdade e o diálogo não receberiam o conteúdo da diversidade. A liberdade é o fundamento que garante que o acesso a todo o potencial da fertilidade da relação homem/ natureza. [...]uma liberdade de corpo inteiro, produto da unidade entre consciência e existência que possibilita a ação transformadora no e do mundo. [...] De outra parte, os limites e ou fronteiras desta liberdade devem ser interpostos pelo princípio da fraternidade. Não a fraternidade do papel ou do discurso que serve a quem busca reconhecimento e não aos que precisam ser reconhecidos. Queremos a fraternidade em sua dimensão política que desague em ações concretas de cooperação, de partilha, de ajuda mútua, de solidariedade prática, ações que contribuem para aproximar o desejo da necessidade. A demarcação da justa medida ou do equilíbrio entre a liberdade e a fraternidade será a matriz sobre a qual poderemos verificar a consecução concreta do princípio da igualdade. Aliás, poderíamos afirmar com segurança que tais princípios são interdependência e que sua consistência obedece a uma relação de reciprocidade. ( TEIXEIRA, VIRGÍNIO 2005)

258 SETÚBAL, Maria Alice. Érnica Maurício. Porque educação e cultura. Acesso em 16-05-2005. http://www.cenpec.org.br/artigo 01.php. Citando Levi-Strauss, em Raça e Cultura “ [...] a diversidade das culturas não deve ser concebida de uma maneira estática. Esta diversidade não é a de uma amostragem inerte ou de um catálogo frio (...) Jamais as sociedades humanas estão sós, quando parecem mais separadas, ainda o é sob forma de grupos ou feixes.(...) Por conseguinte, a diversidade das culturas humanas não nos deve levar a uma observação fragmentadora ou fragmentada. Ela é menos função do isolamento dos grupos que das relações que os unem". E segue, o texto: Desse modo a relação com o diferente é sobretudo, um espaço de troca e de conflitos nos quais os grupos definem e reelaboram as práticas sociais que constituem seu modo de existir. É sobretudo, uma relação de troca que funciona como o principal motor do desenvolvimento das culturas. Pg 2. 
Das faces da arte e modos de ver o mundo e produção, e através da comunicação fazendo circular sentidos, podemos encontrar também como diz Antônio Carlos Gomes da Costa, que:

Foi através da arte que, pela primeira vez, o homem entendeu e representou o mundo em torno de si. A ideia é de que esta atitude não é alguma coisa, que ficou esquecida em algum lugar do nosso passado, Nós carregamos conosco essa capacidade de aprender a configuração do nosso mundo interior ou exterior e objetiva-la em algo dotado de sentido, sem ter, para isso de recorrer a religião, à filosofia e à ciência. É nisto que consiste a experiência estética. $\mathrm{O}$ senso estético é uma maneira permanentemente válida de apreender mundo e atuar sobre ele, através de uma atividade dotada de sentido. Isto é especialmente válido quando consideramos como objetivos da educação a realização das potencialidades do ser humano e a sua preparação para a cidadania e o trabalho. ( COSTA, 2004).

Entre a realidade que encontramos e vivenciamos e o que desejamos, entre o discurso e as narrativas pessoais e sociais, ressonâncias, conforme Vigotsky, “É o grupo cultural onde o indivíduo se desenvolve que lhe fornece formas de perceber e organizar o real, as quais vão constituir os instrumentos psicológicos que fazem a mediação entre o indivíduo e o mundo"259. E ainda segundo certas colocações de Vygotsky os indivíduos utilizam marcas externas que vão transformando-se em processos internos de mediação, mas com o processo de desenvolvimento do indivíduo, ele deixa de utilizar as marcas externas para utilizar signos como representações mentais que são substituições dos objetos do mundo real. Poder usar representações que substituem o próprio real, imaginar, é que liberta o homem do seu tempo e espaço. E, agora, relembrando Novalis, onde o mundo interior e o exterior se tocam, ai se encontra o centro da alma. ${ }^{260}$

A essência da vida de qualquer pessoa não está no amanhã, no futuro ou em qualquer objetivo que ela tiver. A essência da vida de qualquer pessoa está na viagem, no percurso, na caminhada. [...] a melhor parte de qualquer viagem é a própria viagem. ( RAMOS, 2004).

E dentre o interno e externo ressoante, creio que dentre a organização de participações nesse movimento indivíduo e sociedade, teremos na educação para a paz ${ }^{261}$, aspectos relevantes de

\footnotetext{
${ }^{259}$ Kohl, Marta, Vigotsky. Aprendizado e desenvolvimento. Um processo sócio histórico.

${ }^{260}$ Sousa, Carina Gonzalez Y. Composição O destino. PIANO.

${ }^{261}$ Jares< XESÚS, R. A educação ara a paz como estratégia de aproximação das gerações no Congresso Internacional Co-Educação de Gerações, SESC São Pulo, outubro de 2003.
} 
serem aqui contemplados, inclusive sobre até os aspectos de uma velada guerra ${ }^{262}$ onde ocorrem manipulações e situações de injustiça social. O que hoje compreendemos como paz, de fato e verdadeiramente enquanto vivemos desigualdades, falta de alimento, de oportunidades, destroços em vidas urbanas lutando por trabalho, estudo, saúde, moradia, enfim, onde mesmo está nosso conceito de paz? Normalmente coloca Jares, que o conceito ainda de paz é o de pax romana aquele que se justifica pela simples ausência de conflitos bélicos, e em nossos dias, como ausência de todo tipo de conflitos. No que ainda se considera:

Do nascimento da Investigação para a Paz, o conceito de paz adquire um novo significado ao associá-la não como antítese da guerra, mas sim ao de violência ( a guerra não deixa de ser um tipo de violência organizada). Como assinala Galtung existe violência quando os seres humanos estão influenciados de tal forma que suas realizações afetivas, somáticas e mentais, estão abaixo de suas realizações potenciais $(1985 ; 30)$. Dai a necessidade de uma concepção ampla da violência que suporta uma concepção ampliada da paz. Neste sentido, se estabelece uma diferença fundamental entre violência direta e violência estrutural, entendendo a primeira como agressão física direta, a violência tradicional, a mais facilmente reconhecível; e a segunda, indireta e ais oculta que está presente em determinadas estruturas sociais, sinônimo da injustiça social. Esta última, que é a que se prioriza, define-se como aquele tipo de violência que está edificada dentro da estrutura, e se manifesta como um poder desigual e por conseguinte, como acontece quando está fortemente enviesada a distribuição da renda, ou está desigualmente distribuída a alfabetização/educação ou quando os serviços médicos existentes em determinadas zonas são só para determinados grupos etc. [...] Nas palavras de Paulo Freire, a paz se cria e se constrói com a edificação incessante da justiça social( 1986:46) e ainda, a melhor maneira de falar a favor da paz é fazer justiça". (JARES, 2003).

Entre o educar o pensamento, e as ressonâncias da quais já apontamos, ainda queremos refletir sobre aspectos levantados por Davidov e Vygotsky ${ }^{263}$, deixando claro que em nosso pensar se abriga o aprender como modo de vida, no qual o educar o pensamento está sobre todo o território cotidiano, e não restrito ao âmbito escolar, no que segue considerações:

Os conhecimentos de um indivíduo e suas ações mentais ( abstração, generalização, etc) formam uma unidade. Segundo Rubinstein, os conhecimentos (...) não surgem dissociados da atividade cognitiva do sujeito e não existem sem referência a ele. Portanto, é legítimo considerar o conhecimento, de um lado, como o resultado das ações mentais que

\footnotetext{
${ }^{262}$ RAMOS, Roberto Carlos. A arte de construir cidadãos. As 15 lições da pedagogia do amor. São Paulo: Celebris, 2004. SILVA, Roberto da. Os filhos do governo. A formação da identidade criminosa em crianças órfãs e abandonadas. "O que antes era dor, torna-se conhecimento", diz Gilberto Dimenstein na quarta capa do livro.1998.

263 LIBANEO, José Carlos. A didática e a aprendizagem do pensar e do aprender - a teoria histórico cultural da atividade e a contribuição de Vasili Davídov.
} 
implicitamente abrangem o conhecimento e de outro, como um processo pelo qual podemos obter esse resultado no qual se expressa o funcionamento das ações mentais. Consequentemente, é totalmente aceitável usar o termo conhecimento para designar tanto o resultado do pensamento ( o reflexo da realidade) quanto o processo pelo qual se obtém esse resultado ( ou seja, as ações mentais ). Todo conceito científico é simultaneamente, uma construção do pensamento e um reflexo do ser. Deste ponto de vista, um conceito é ao mesmo tempo um reflexo do ser e um procedimento da operação mental ( 1988,p21)

O aprender e o trabalho, o aprender e o viver, aprendendo a pensar, educando o pensamento. Organizações de espaços do ser social. Já consideramos o viver propriamente trabalho, porém, em vias de aspectos de estruturas sociais, a de se convir que certas amarras ou preconceitos ainda podem estar vigentes, sobre papeis e formas de ver e ser no mundo, mas, de qualquer forma, será necessário compreender também, de que maneira o entrelaçamento dos aspectos do viver, trabalho, e o pensar se equalizam de maneira a proceder um aprender que seja conhecimento. Em certo aspecto do que considero importante, sobre o olhar que prossegue e a ressonância, dentre o lastro e o novo, o existente e o porvir, em parte como um sistema que perpetua, e com os elementos que passam a ser agregados a ele, e como essa concatenação em progresso pode se alicerçar em conjecturas saudáveis para desenvolvimento, diante disto, creio que podemos ainda colocar o posicionamento que encontramos no livro de Newton Duarte, Sociedade do conhecimento, ou Sociedade das ilusões ${ }^{264}$, a saber dentre o que o autor aborda também como objetivação e apropriação de maneira que:

E é muito difícil, na história, separar em absoluto a repetição e a criação do novo, porque muitas vezes, ao se produzir algo já existente, descobrem-se novos aspectos que levarão ao seu desenvolvimento. O mesmo pode acontecer com a descoberta de novas formas de utilização de algo já existente, que acabarão exigindo sua adaptação a essas novas formas de utilização. Isso já mostra que a objetivação e a apropriação como processos de reprodução de uma realidade não se separam de forma absoluta da objetivação e da apropriação enquanto produção do novo. A mesma ideia

\footnotetext{
${ }^{264}$ Sousa, Carina Gonzalez Y. Composição: O preço de um insulto. O preço de um insulto, foi fazer da realidade, a mentira descarada, para quem queria a verdade. DE cara lavada e pés no chão. Um cidadão onde ainda houver. Um coração, de quem sabe ouvir. Do mesmo mundo, o silêncio do melhor lugar. Que será te encontrar, para ouvir essa canção. Por onde eu possa encontrar o sol, E o teu calor perto de mim. E se assim eu possa ficar. Nesse olhar, me aquece então. E vem comigo até o sol se por. E vem comigo até o sol se por. Um dia a noite ira encontrar, os sonhos de um tempo melhor, Para se viver. Para se viver. Abre a estrada que eu quero ver. Seguir a viagem até a manhã. amanhã.... Amanhã. Amanhã, onde a noite ira encontrar os sonhos. De um tempo melhor. Vem comigo até o sol, se por. Vem comigo, até o sol, se por. O preço de um insulto. Foi fazer da realidade, a mentira descarada. Para quem queria a verdade, de cara lavada, e pés no chão. Um cidadão, onde AINDA HOUVER um coração. De quem sabe ouvir, do mesmo mundo o silêncio do melhor lugar. Que será te encontrar, para ouvir essa canção. Por onde eu possa encontrar o sol. E o teu calor, perto de mim. E se assim eu posso ficar, Nesse olhar me aquece então, e vem comigo até o por do sol.
} 
pode ser expressa com outras palavras: a reprodução do ser social é um processo dialético no qual não se separam a criação do novo e a conservação do existente ( DUARTE, 2008).

Vale dizer, porém, que aqui tratamos do sujeito plural (MEDINA), ou sujeito ambiente, como um processo de interação onde ocorre o aprendizado, ou seja, próximo do que se estabelece como, o sujeito estando inserido em uma semiótica da comunicação, neste termos segundo Irene Machado e Romanini, onde se pode aferir sistemas e subsistemas abertos organizados por fluxos de informações, onde temos a comunicação como um componente ontológico ${ }^{265}$ da realidade " entre os seres vivos ela deixa de ser possibilidade para se tornar manifesta a comunicação é um comportamento interativo que surge como propensão das

\footnotetext{
${ }^{265}$ Neste ponto é necessário elucidar um pouco mais, aqui em nota a referência a importância da ontologia e filogenia em comunicação. Segue como descrito no texto publicado na revista Famecos e que em sua integra acredito ser de relevância para a compreensão do modo como vemos a comunicação, e assim sendo descrevo um trecho onde pode elucidar aspectos necessários a compreensão. " São os aparelhos perceptivos os agentes transformadores da informação em construção de sentido, ou mensagem. Dependendo das condições de percepção teremos diferentes operações transformadoras. Na escalada evolutiva, convencionou-se denominar ontogênese a transformação das espécies num único sistema e filogênese a transformação espécies em diferentes meios. A percepção para a comunicação que possibilitou o surgimento da linguagem implica combinação de ambas as operações. Tanto o aparelhamento para a fala, quanto a interação ambiental pela palavra, gestos resultam de transformações onto e filogenéticas. No mundo das coisas vivas as trocas interativas se organizam segundo as espécies diferenciadas. O homem desenvolveu-se prioritariamente em torno do signo verval, subordinando a ele diferentes classes de signos da visualidade, da espacialidade, da sonoridade, da cinética. Há, contudo, classes de signos em outros reinos do bios. Quer dizer, as interações nos ambientes, trocas entre espécies, distinguem diferentes ontologias. Este é o domínio de estudo da ontogênese: o domínio da conceptalização dos fenômenos, das relações. Contudo, no interior de cada espécie, as transformações operam diferentes possibilidades semióticas, respeitando suas propriedades específicas. Este é o domínio da filogênese o domínio das variedades no contexto das invariantes. Talvez seja hora de abrir para a análise de um processo específico. A concepção de que a palavra define o domínio do humano no reino biológico sem dúvida alguma configura o homem como a ontogênese da linguagem erval. Esta é uma invariante do sistema da comunicação na ampla esfera do bios. Contudo, a expansão das possibilidades comunicativas para fora do domínio verbal evidência a dinâmica da filogênese a que a linguagem verbal se submete graças as interações ambientais, particularmente aquelas que dizem respeito ao ambiente cultural circunscrito pela condição antropológica. Ontogênse e filogênese são processos da dinâmica evolutiva que não se confundem nem se separam, implicam-se e impregnam-se mutuamente. O ponto de vista da ontologia dos fenômenos comunicativos existe um corajoso esforço inter e transdisciplinar para buscar na física, na biologia e na teoria dos sistemas os conceitos necessários para compreendermos o novo enraizamento das teorias da comunicação. Enraizamento que, na verdade, já levou à constituição de um campo de conhecimento: a semiótica. A semiótica estuda a semiose, ou ação do signo, na sua maior abstração possível. Ela se interessa por compreender uma gama vasta de fenômenos, como os mecanismos que regulam ações como reações imediatas a estímulos, percepção, ostenção, representação, tomadas de decisão, formação de conceitos, compartilhamento de ideias, produção de argumentos, retórica, persuasão etc. Na verdade, onde houver assimilação e interpretação de informação, haverá ação do signo, o que faz da semiose um fenômeno constitutivo e constituinte da realidade. "( FAMECOS 2010, pg 93 ). E após esta colocações o mesmo texto se dirige a pergunta do que é então, a semiótica da comunicação. No que o texto ainda esclarece o mesmo como problema semiótico e ainda, pode ser consultado a introdução do livro Diagramas, explorações no pensamento- signo dos espaços culturais, de Irene Machado, intitulado Diagrama como problema semiótico. Referência também apontada como modo de conhecer, “ o texto da cultura” de Lotman, 1996, pg 77-82), onde se observa o sentido de uma mente da cultura ( Lotman, 1998, p 98)
} 
espécies para interação ${ }^{266}$ no ambiente na busca por condições de sobrevivência e contínua evolução.

Vejo que a organização do pensamento entre o diálogo constante do interno e externo, ambientes que nos rodeiam, ocorre claramente dentre o próprio intuito de conhecer um diagrama que se estabelece propriamente como o pensamento, porém, como ele se organiza, afecções ou contiguidades são decorrentes também do modo de ser desse pensar, então nos debruçaremos sobre o próprio pensamento para compreender a necessidade de educa-lo, e não somente apesar de conhecer seu " funcionamento como estabelecidas estruturas ou formas de, sendo diagramas", antes dos próprios rumos, que entrelaçamentos da razão com a consciência me movem a concebê-los, de certa maneira uma sincronia, deverá estabelecer como uma gestão aparentemente, prévia, ou estabelecendo colunas, espaços por onde saibamos que podermos habitar. É lícito, mas me convém? Poderia ser uma pergunta entre a razão e a consciência, e ainda, dos traçados entre o eu e o mundo. AS condutas do pensamento são sincronias de onde partem desejos humanos dentre a humanidade e o que passa(mos) a habitar estando no mundo. Se pensarmos em conjuntos e sistemas, até mesmo em meu ver, está a forma como se organiza um pensamento sobre o prisma do diálogo da razão e a consciência, tendo a representação da organização do pensar como fruto desse momento. As sincronias de se estar no mundo, estados da cultura, do indivíduo, da formação em todo seu percurso do viver, fornece as conjecturas simultâneas onde a formação do pensar entre crença estabelecidas, razão e consciência, trazem ao pensamento, uma sincronia que dialoga consigo, estando prontamente a gerar estados operacionais que são provenientes de escolhas, por certo, ou decorrências, entre uma compreensão que não é formada, mas está em construção, e nessa construção se realiza enquanto estrutura, modelizante, como descrito

\footnotetext{
${ }^{266}$ Em meu pensar, sobre cognição do mundo podemos encontrar caminhos, dentre os quais, gosto de considerar alguns deles, e assim sendo, necessário até considerar que por onde se valida um entrelaçamento posto quando se observa o saber de uma estrutura de um sistema, para tal, é fundamental estudar o que é o modelizante, de maneira que se pode descrever que modelização é: “ Um conceito semiótico para compreender semiose quando uma determinada ação semiótica gera uma operação que possa significar um modelo. $\mathrm{O}$ processo de modelização foi forjado no contexto da comunicação de mediação homem-máquina para explicitar como os códigos culturais, tecnológicos e cognitivos geram linguagens e como cada uma, no limite de suas possibilidades condizentes com sua lógica interna, ver Lotman 1978, Machado, 2003, Merrell, 1990). Isto posto, podemos apresentar aquela que se configura desdobramento vigoroso de nossa hipótese: a semiose como ação geradora do bios na evolução. Semiose não é, pois, privilégio do humano nem tem sua evolução das espécies na Terra. Ela é, antes o fenômeno que permite a própria evolução das espéces, desde suas funções básicas até o aparecimento de propriedade complexas como a inteligência e o raciocínio abstrato. De acordo como nosso ponto de vista, a semiose é a ação integradora que permite interação em diferentes escalas do inanimado ao animado. Alcançamos assim a semiosfera integradora das diferentes esferas de vida no planeta. ( MACHADO, ROMANINI, Revista FAMECOS,
} 
em nota, anteriormente, os processos de como se constitui, para buscar como irá se relacionar dentre possibilidades, dentre campos da consciência e do mundo, onde a razão encontrará conexões plausíveis de serem realizadas como existência dentre a realidade, denominada, fática.

De um modo simples de dizer, sobre pensamento e caminho, será, pensar sobre como são as horas e os dias, e do que desejamos para o amanhã. E depois, retomar as horas e os dias vendo se do que desejo estou plantando hoje, porque talvez, essas mesmas horas precisem mudar. Para alcançar o que acreditamos e o que desejamos, precisamos estar onde o caminho possa nos levar, para o amanhã. Tempo, e espaço. Pensar sobre quem somos, no que acreditamos é fundamental para encontrar o que queremos.

Do ponto de vista semiótico, a propensão para a interação no ambiente é um ato de conhecimento do mundo que precede a transmissão da informação em mensagens codificadas. Trata-se, pois, da operação de design diagramática em prol da constituição de uma ontologia das relações primordiais em espaços semióticos. Compreender o design de relações que constroem atos cognitivos e os oferece sob forma de diagramas é tarefa elementar da ontologia que fundamenta a investigação semiótica sobre comunicação. (MACHADO, ROMANINI, 2010, pg89-97).

Entre o que pensamentos, o que se altera, no t decorrer do tempo. A colocação da cultura ${ }^{267}$ como de fato um espaço onde se pode concretizar realizações humanas de novos trajetos sociais, entendo cultura como uma complexidade na qual a arte também faz parte, é uma constatação que foi com o decorrer dos anos se fortalecendo, porque foi por um certo tempo como dito por Leonard Brant ${ }^{268}$, considerada como:

O modelo assistencialista cravado no setor cultural oferece sensação de impotência e desestimula o empreendedorismo a assunção de riscos inerente a qualquer negócio. Convencionou-se que a indústria cultural não se sustenta como negócio, gerando um sistema perverso de mendincancia em torno do governo e dos grandes conglomerados empresariais, pela via das leis de incentivo. Essa política é incapaz de identificar os movimentos da indústria cultural e seu potencial econômico, da cultura estruturante, que oferece referência éticos e estéticos para a formação de seres humanos capazes de influenciar o seu tempo e alterar o rumo do país. Estão todos largados á sorte do mercado e via de regra, vence aquele que oferece mais contrapartidas às empresas patrocinadoras, que fazem marketing à custa do

\footnotetext{
267 CESNIK, Fábio de Sá; Malagodi Maria Eugênia. Projetos Culturais. Elaboração, aspectos legais, administração, busca de patrocínio. Instituto Pensarte. Marketing Cultural, sociologia. Biblioteca Nacional, 2004. Havendo de ser considerado, leis e condutas que são no decorrer do tempo, por ventura alteradas ou reestruturadas. Consultar também, OLIVERI, Cristiane Garcia. Cultura Neoliberal. Leis de incentivo como política pública de cultura. São Paulo: Escrituras Editoras, 2004.

${ }^{268}$ Leonard Brant, autor dos livros: Mercado Cultural, Políticas Culturais. Vol 1 e Diversidade Cultural.
} 
Erário. Desconsidera, assim, o poder de transformação da própria arte, conspurcando-a a mero ornamento. (BRANT, 2005).

Agora, Jorge Werthein, esclarece que no Relatório Mundial de Cultura e Desenvolvimento, promovido pela Unesco,

Sai-se do campo de debate sobre o que é ou não cultura, deixa-se de lado a questão de hierarquias na produção cultural, se alta ou baixa cultura, e se ela seria um fim em si, separada da economia política o a ela subordinada. Nesse documento, divisor de águas, que se tornou conhecido como Relatório Perez de Cuellar, publicado e 1999, reflete-se sobre a diversidade de sentidos, a multiplicidade de formatações, sendo a cultura debatida por possibilidades, isto é, como instrumental para o desenvolvimento a expressão de medos, fantasias, desejos, formas de sentir. ( Werthein, 2004)

No decorrer de nossas vivências, sabemos de alguns olhares que foram modificando os dias e as oportunidades. Temos a declaração do então ministro Gilberto Gil, ao jornal La Nación, sinalizando a direção de uma política cultural de alcance coletivo. "Afirma o ministro que é necessária uma visão politica da cultura. A cultura precisa acompanhar o projeto político. As comunidades de risco, por exemplo, poderiam ser resgatadas mediante sua inclusão cultural, considerando por exemplo o projeto de Claudia Costin.(apud, Werthein, 2004)

Do entrelaçamento da comunicação, as relações, pensamento, ação e responsabilidades compartilhadas, segundo Corella:

A - Ideia de que ao incorporar a participação positiva dos integrantes da organização se faz mais viável que este fecunde sua missão.

B - A noção de que a participação se fomenta com a motivação

$\mathrm{C}$ - O conceito de que a efetividade organizacional se fomenta por meio da motivação e participação harmônica dos indivíduos dirigidos até um objetivo que consideram benefício, coletivo e individualmente.

O fator de ressonância, que pode abarcar mais de um sentido neste trabalho, aqui mais uma vez, se coloca a presença de que como Corella salienta, e eu acrescento que quanto mais tivermos a noção de nossas potencialidades, capacidades, desejos, objetivos, mais estaremos aptos a desenvolver nossos trabalho e nossas relações e a cerca da percepção ao nosso redor, e já constatou-se que os níveis de desempenho, quer sejam do próprio indivíduo, da empresa ou instituição que move os estímulos de capacidades e desenvolvimento tem o retorno de maneira muito satisfatória. E ainda considera importante que "as ações de inovação e criatividade podem e devem ser parte da função de todos os integrantes da organização, 
independentemente de suas posições e áreas de especialidade na estrutura hierárquica da mesma $^{269}$ (Corella, 2006, pg 16). Importante ressaltar que Corella relata a importância do trabalho como esforço cultural, de maneira que as formas de realização constituem comportamento, e tem a força de propagação, havendo de ter na presença da comunicação o elo condutor, o que permeia todas as relações como fluxo vital. De onde não poderia faltar a indagação frequente do que é tão presente hoje em dia, a globalização, isto porque se consideramos a reverberação um estado natural a propagação interna e externa de relações da vida, produto de nosso tempo se integra claramente no diálogo da face interna quer seja indivíduo, povo, cultura, espaços de mercado, com o externo das relações pessoais, governo, territórios enfim, escalas promovendo um modo natural de existir.

Comunicação e organizações, ressonâncias possíveis. As primeiras dificuldades com que podem se defrontar é a diversidade de realidades distintas que irão afetar as organizações governamentais, empresariais e da sociedade civil. E, também considera os avanços tecnológicos de maneira a serem devidamente integrados como capacidade no trabalho. Examinar de maneira equilibrada as distancias que permeiam o conhecimento, a sociedade, a população em novas topologias dos tempos atuais. ${ }^{270}$

Ostrowjak, considera a preocupação e de fato procedente, sobre o aumento populacional, porém, devemos atender que em conjunto com esse aumento, temos o aumento das demandas, e portanto, creio que poderemos pensar em instrumentalizar caminhos para que essa população venha a ser produtiva e cada vez mais participativa e não somente convivendo a margem de uma possível inserção mais efusiva e de produtividade. Indivíduos operantes no corpo orgânico são saudáveis para o empreendimento de uma sociedade de uma cultura sustentável, ou seja, com princípios básicos de pensamentos direcionados aos rumos que consideramos ser importantes para a comunidade do futuro.

Em certo ponto a percepção da globalização considera estarmos conectados em rede também em relações, sobre territórios e culturais diversas, onde o conhecimento sobre quem somos e o outro passa a ser e ter um valor de relevância para além das aparências. Abraham Nosnik Ostrowjak se refere a estarmos em uma sociedade de transição, onde se encontra atividades

\footnotetext{
${ }^{269}$ Corella, Maria Antonieta Rebeil. Comunicación estratégia en las organizaciones México. las acciones de innovación y creatividad pueden y deben ser parte de la función de todos los integrantes de la organización, independientemente de sus posiciones y las áreas de especialidad en la estructura jerarquica de la misma.

${ }^{270}$ Rever A comunidade do futuro . São Paulo, futura, 1998.
} 
especializadas as quais ele chama de sociedade de informação, também a sociedade de conhecimento, em atividades produtivas, e a capacidade da presença da tecnologia exercendo diversas adaptações no viver, e a globalização como um novo olhar ao mundo, mais do que propriamente ou somente uma " realidade harmônica de integração mundial de regiões, países, culturas e sociedades."

As posturas do que queremos cada vez mais são entrelaçadas em nossas escolhas, do que acreditamos para qual empresa ou instituição busco como relações.

Relações internas, parte integrante do Marketing de Relacionamento ${ }^{271}$, já observa que não somente os esforços devem estar direcionados como de costume para o público alvo, mas saber que é importante a comunicação nas relações internas como validação orgânica do a empresa, instituição, representa assim como uma forma também de observar se de fato estão participativos como valor interno que promove desenvolvimento de todos os envolvidos.

Una cultura de comunicación organizacional depende em gran medida de empresas e instituiciones que conciban a su personal como recurso estratégico es decir, que abran y cedan cada vez mas espacios y tiempos organizacionales a su participación y creatividad para definir objetivos e metas. La organización creativa es resultado de una cultura de planeación y manejo del cambio, es decir, de fomentar entre su gente las mejores prácticas que le permitan aprovechar tanto lo mejor de su tradición e história productiva como de su capacidad innovadora, ambas al servicio de la sociedad donde opera y sirve Uma cultura de comunicação organizacional depende em grande medida da empresa e instituição que concebe em seu pessoal ser o recurso estratégico, dizendo que abram e cedam cada vez mais espaços e tempos organizacionais para a participação dos mesmos para definir objetivos e metas. Considerando que a organização criativa é resultado de uma cultura de planejamento e manejo de troca, é estímulo entre sua gente e as melhores práticas que permitam aproveitar tanto o melhor de sua tradição e história produtiva como de sua capacidade inovadora, ambas ao serviço da sociedade de onde opera e serve. (OSTROWJAK, 2006 pg 42).

Caracteres, elementos de um sistema em gestão. Visão, valores e estratégias, estratégias e planos de comunicação, líderes comprometidos e capazes, líderes de comunicação; apoios de comunicação colaterais, compromisso organizacional e outras iniciativas de comunicação

\footnotetext{
271 Crescitelli, Edson. A importância do público Interno, na comunicação de marketing. FACOM - $n^{\circ} 15$ - $2^{\circ}$ semestre de 2005. Consultar também Phillip Kotler, Administração de marketing.A edição do novo milênio. 10. ed. São Paulo: Prentice Hall, 2000.
} 
e negócios, mediação, retroalimentação e ajustes, narrativas vivenciadas. A descoberta de posicionamentos reflexivos, isto considera a relação já imbuída de diálogo, onde a eficácia justamente ocorre mediante o rumo que toma não uma direção argumentativa determinada mas em movimento, onde apesar de uma construção possível de pensamento este ocorre em reflexão e não dogmático, apesar de expor suas conjecturas, isto considera um posicionamento que não cessa a busca de seu conhecer sendo capaz de integrar novas possibilidades, e ainda por vezes fortalecendo seus parâmetros iniciais, ou ter a flexibilidade de alterá-los quando assim a reflexão considerar este fato. Esta postura credita-se a uma capacidade de absorver oportunidades de crescimento para "dentro" do sistema, ou melhor, considerando a expansão do mesmo, em comunicação contínua interna e externa.

Dentre o que assumimos ser o desejo de uma consciência humana, teremos que também considerar os alicerces sendo a ética inserida do que é responsabilidade o comportamento correspondente e essa a face da sintonia com um mundo globalizado, onde a conexão, indivíduo, cidadão, empresas, órgãos governamentais se reconhecem frente ao bem comum, unindo esforços para a concretude dos objetivos do milênio. ${ }^{272}$, apontados no livro de Fernando Almeida a saber: Objetivo 1: Erradicar a miséria e a fome; Objetivo 2: Universalizar o ensino básico; 3 Promover a igualdade de gênero e a autonomia das mulheres; 4 Reduzir a mortalidade infantil; 5 Melhorar a saúde materna; 6 Combater o HIV/ Aids, a malária e outras doenças; objetivo 7 Garantir a sustentabilidade ambiental; 8 Estabelecer uma parceria mundial para o desenvolvimento!( Almeida, 2007, 91 ). O que nos leva as considerações de Rita Sussmuth, onde escreve sobre a capacidade futura da sociedade, que considera refletir o quanto estaremos aptos as mudanças de um futuro, onde como ela diz, a sociedade deve se mover como um todo. A questão do trabalho é fortemente ressaltada como desafio a ser considerado fundamental em igualdade para quaisquer que

\footnotetext{
272 Almeida, Fernando. Os desafios de sustentabilidade. Capítulo 3: Uma visão. Os objetivos de desenvolvimento do Milênio. "Em setembro do ano 200, quando os representantes de 189 países reunidos na sede da ONU, em Nova York, aprovaram uma lista de objetivos de desenvolvimento econômico, social e ambiental que batizaram de Declaração do Milênio, o mundo ainda vivia o clima de celebração e otimismo trazido pela virada do século e do milênio. As ambiciosas metas destinadas a corrigir as deformações do planeta causadas pela desigualdade social e pela utilização predatória dos recursos naturais não pareciam, então, muito difíceis de realizar. No imaginário coletivo, 2015, o ano estabelecido para marcar a mudança de rumo, ainda estava muito distante no horizonte. Dois anos depois, quando o documento foi ratificado pelos chefes de Estado reunidos na Cúpula sobre Desenvolvimento Sustentável, em Johanesburgo, o cumprimento dos objetivos no prazo previsto já começava a ficar duvidoso. A Declaração do Milênio traçou oito objetivos básicos, que foram desdobrados em 18 metas e 48 indicadores, a serem atingidos até 2015, por meio de ações concretas dos governos e da sociedade. $\mathrm{O}$ ano não foi fixado aleatoriamente. A declaração do Milênio é tributária do novo quadro conceitual que, cada vez mais associa pobreza a degradação ambiental. Além disso, nasceu no bojo dos sombrios prognósticos da Avaliação Ecossistêmica do Milênio, que resumimos no Capítulo 1.
} 
sejam seus integrantes, como seres humanos, Buford elege forças necessárias para o desenvolvimento principalmente no enfoque social $^{273}$, a valorização dos aspectos de integridade moral, Covey assume como fatores constituintes também dos avanços que queremos em sociedade como hábitos saudáveis para cada indivíduo em reverberações de conexões que expandem escalas de realidades boas possíveis a serem cada vez mais concretas, como Gaudiani também muito bem aponta, sobre o capital da sabedoria, unindo uma comunidade em transformação, enfim, diversos autores já neste trabalho citados, no livro, A comunidade do Futuro, de Peter Drucker.

Conhecer o solo ${ }^{274}$ por onde nossos passos caminham, e o vento, assim como de tudo que o rodeia paisagem nossa, é destino enquanto caminho, para poder saber por onde ir.

Do que consideramos educar o pensamento e cognição como conhecimento entre a razão e a consciência compreende-se o planejamento em estratégia sobre esses pilares.

Do que vemos hoje e entre o que desejamos, existe um caminho a ser realizado do que 'seja a visão de futuro, ou seja, entre as estruturas vigentes e absorvê-las como cognição e realidades atuantes, o que pode ocorrer na trajetória ou ainda dentre o existente o que deve ser realizado para a visão do futuro. Portanto, a organização não somente tem que estar atenta ao seu processo de atuação permanente, mas fundamentalmente como gerar a gestão dos esforços que modificarão as conjecturas dentre o que se direciona para conquistar, novas imagens de um outro tempo.

As vezes me pergunto, se o homem do século passado também se questionava sobre o que não compreendia, e se era na busca das respostas que ele encontrava o movimento, onde iria encontrar a imagem do seu tempo. ${ }^{275}$

A imagem institucional permite a identificação do produto e da marca com valores oriundos de uma organização, dando personalidade ao discurso. Esses valores são reforçados pelo tempo, por meio de serviços, atuações e comunicações. A imagem é um valor que sempre se deseja positivo - isto é , crescente e acumulativo- cujos resultados são o suporte favorável aos êxitos presentes e sucessivos da organização. O equilíbrio entre a imagem e

\footnotetext{
${ }^{273}$ Sousa, Carina Gonzalez Y. Composição: Ruas passageiras. Ruas passageiras, seres humanos, de tão baratos, calados no asfalto, não percebeu, o que não comeu, alma vazia. O cálice gemeu. O tempo que se foi, estremeceu...reverso da ferida. Olhar se escondeu. Da janela do mundo. Desabou de tão fundo. Que é preciso amar. Para recomeçar. Ruas passageiras, estrangeiras de nós. Desatam a sós a multidão. Que fala, sente e quer amar. Ruas passageiras, de atos desumanos. Não queremos mais, Ruas e estradas, de tantos tempos passados, atos humanos. Agora queremos ser, O pertencer de um novo tempo. Reverso da fenda. Olhar se escondeu. Da janela do mundo. Estremeceu e a multidão, que fala sente e quer amar, e quer amar.

${ }^{274}$ Composição SOLO que canta. Arquivo de audio.

${ }^{275}$ Do livro Escritor de Corpos, o texto eu preciso sentir.
} 
a realidade é fundamental e para o profissional da comunicação é muito mais que as simples noções de como construir ou como administrá-la. Para compreendê-la a imagem é algo absolutamente relativo a percepção. 177178 ( OSTROWJAK,2006).

De nós mesmos, a visão de uma empresa representa o que ela quer ser.

Relações públicas como auditoria, diagnósticos do sistema comunicacional, verificando eficiência, exame capaz de exaurir observações com o objetivo de melhorar o próprio sistema e as práticas internas e externas da organização.

Em toda e qualquer comunicação que se realiza dentre relações estabelecidas em contínuo, podemos observar que sempre será saudável como em qualquer sistema, um auscultar o próprio organismo, quere seja como relações internas, quer seja como auditoria, sobre uma perspectiva o olhar se torna tanto interno quanto externo, e o caráter objetivo desta concepção ocorre claramente mediante a esclarecimentos tanto de funcionamento como de propensões não observadas do sistema. Ou seja, o olhar externo também, em conjunção com as relações internas viabiliza a concretude da imagem ou a necessidade de alterá-la e se assim fosse, sobre que termos ou justificativas.

Portanto, informações de que maneira e em que ou sobre que, contextos.

Mapeamento de condutas e objetivos, resultados analisados em conformidade ou dissonância.

Em se tratando de comunicação e movimentos de relações; creditamos ser sempre necessário, elucidar os porquês e não somente apontar, digo em vista que, determinadas atitudes podem ser cobradas, como por exemplo empregados, família, diretrizes organizacionais e outros, que não havendo resposta em seu devido tempo real, ou seja, há reverberações de condutas, de gestões anteriores ou dos próprios, que ainda se sentem e repercutem, na resposta ou conduta, e portanto a análise não pode ser pontual de maneira restrita, mas pontual no sentido de avaliar conforme a origem no sistema e a decorrência que pode ter sido observada em outro ponto do tempo, e portanto, deve ir além do contexto, ou seja, aferindo continuidades, e quais aspectos estavam circundando o que foi relatado depois.

Também é importante considerar a respeito de comunicação e relações a manutenção das razões, dos motivos pelos quais veio a existirmos como indivíduos, uma sociedade e uma 
organização, uma cultura, ou seja, de onde viemos, o que nos constitui memória ${ }^{276}$ como valores nos quais nos fortalecemos e geramos as práticas que resultou na conquista de nossos ideais e foram os alicerces para o que somos, em integridade do que queremos ser e existir em nosso tempo.

Informação e conhecimento. Eu penso o conhecimento como uma complexidade onde deve existir uma absorção de elementos em crescimento, o que me lembra uma frase de minha mãe, quando ela dizia: Águas paradas apodrecem, e então, vesse que o conhecimento não pode estar estagnado por se crer certo de causas e efeitos, apesar de os poder em certa medida prever, ou avaliar sua possibilidade em decorrências.

Caminhos cruzados, conhecimento e comunicação. Penso que a informação elemento integrante da comunicação, por si só, a mesma não creio que seja conhecimento, compreendido conhecimento como algo mais complexo, até mesmo nas razões onde poderemos estabelecer critérios para como as informações podem ser descritas, inseridas, revogadas ou examinadas, formas de procedimentos, escolhas, determinações, também compostas como formas de conhecimento, condizentes até, como fatores organizacionais, onde se elucida de que maneira podem ser reverberadas em rede de contextos.

El capital social, se refere a las instituiciones, relaciones y normas que conformam la calidad y cantidad de las interaciones sociales de uma sociedade. Numerosos estudios demuestran que la cohesión social es un factor crítico para que las sociedades prosperem económicamente y para um desenvolvimento sustentável. El capital social no es solo la suma de las instituciones que configuram una sociedad, sino que es la manera que las mantiene unidas. $\mathrm{O}$ capital social se refere as intituições, relações e normas que constituem a qualidade e quantidade das interações sociais de uma sociedade. Numerosos estudos demostram que a coesão social é um fator crítico para que as sociedades prosperem economicamente e para um desenvolvimento sustentável. O capital social é só a soma das instituições que configuram uma sociedade, senão que é a maneira que as mantem unidas. O capital social se refere as instituições, relações e normas que constituem a qualidade e quantidade das interações de uma sociedade. Então, podemos dizer que o ingrediente indispensável para que exista o capital social é uma sociedade e que entre seus membros tenha confiança e normas de atuação compartidas e que seu raio de ação e influência inclui toda a comunidade. OSTROWJAK, 2006 pg 218).

Das relações dentre o que é comunicação ${ }^{277}$, o mínimo que se espera é respeito, integridade quanto referência correspondente do que é de natureza da ética. Condutas em veracidade e

\footnotetext{
${ }^{276}$ NASSAR, Paulo. Memória nas empresas. São Paulo: Aberje 2004.

277 Dentro do projeto Acesso, considerações sobre a presença sonora pela cor e palavra.
} 
não manipuladas. Proximidades realizadas mediante compromisso e comprimento. Espaços cognitivos de ação podem e devem tornar-se uma razão de integralidade do viver de uma cultura e organização, e nessa perspectiva de observação pode se encontrar em diferenças, diversidades, lugares de diálogo que incluem a possibilidade de encontrar pontos de continuidade e confluência, para que um dizer possível seja o de encontrar entre culturas o pensamento e a ação para a paz. ${ }^{278}$

Das mediações em comunicação, nos tempos atuais, temos sempre o desafio dos segundos perpétuos, o que desse cotidiano tão fugaz nos tira o folego capaz de revirar-nos ou então sugerir que os espaços humanos podem ser mais do que compreendemos e necessário será, portanto, nos deter sobre algo a mais que seja um diálogo não somente com o tempo, mas com a presença da alma do sentir, onde os segundos sejam capazes de se tornar perpétuos.

E, também sobre esse prisma haveremos de convir que entre um passo e outro, o que é capaz do olhar humano compreender como dito, acima que por vezes ainda que, como o elemento nele mesmo, parecendo fogo de palha, fugaz, algo que não nos concede permanência, ainda que, possa haver uma presença, mas talvez seja o exercício, não desprezível de todo, como efêmero, mas que desperte uma capacidade de encontra a agulha em um palheiro. Então dessa maneira, percebe-se que dos tempos, e da atualidade, os aspectos também o são, pela maneira como nos apropriamos deles, assim sendo, o fugaz pode ter o seu valor, de quem sabe, mesmo podendo ser líquido( BAUMAN), encontra o que muitas vezes o olhar a tanto tempo sobre o mesmo, e ainda que profundo, não viu.

A vitrine cotidiana, o que vemos, $\mathrm{d}(\mathrm{o})$ que procuramos. Me escolha, passa a dizer o próprio viver, sobre a lógica do consumo. Entre diálogos do que desejamos, e frente a possíveis conjecturas alheias, espaços sociais e oportunidades, as escolhas possíveis, e direcionamentos. E seguindo o raciocínio podemos dizer que, qual o potencial das capacidades que podemos estimular em sociedade, dentre o que almejamos, isto quando o nosso objeto de consumo é uma sociedade mais justa, ou seja, como estaria nós, indivíduos, como produto, sendo a vida na qual somos integrantes, sendo que, o mercado, a sociedade nos aguarda, e a relação de consumo é apropriada para dizermos que estamos nos satisfazendo ou continuamente gerando sociedades insatisfeitas, e isso claro, inclui falta de prazer, ou um tanto quanto, aquém do pretendido, e então supondo que queremos um bem estar geral, políticas mais organizadas de maneira a estruturar oportunidades, capacidades,

\footnotetext{
${ }^{278}$ Sousa, Carina Gonzalez Y. Composição: Do que chove na alma.
} 
aqueles aspectos ainda a ser descritos, isto como os elementos de cada um como sendo seu viver, então, essa lógica tão costumas está algo em defasagem com a realidade, e dentro dela. Percebe? Procuramos fazer o melhor produto para que venda bem, as pessoas fiquem satisfeitas e felizes, então, o que estamos fazendo quando a vida é o produto, talvez precise do meu olhar de arquitetura para buscar um escala, isto porque estamos olhando o universo quântico, e o universo cósmico, mas tem algo no meio, chamado vida, também, essa que nomeamos planeta, que está um pouco a deriva, de seus navegantes.

Os encontros dos potenciais consumidores com os potenciais objetos de consumo tendem a ser tornar as principais unidades na rede peculiar de interações humanas conhecida, de maneira abreviada, como sociedade de consumidores. "Ou melhor, o ambiente existencial que se tornou conhecido como sociedade de consumidores" se distingue por uma reconstrução das relações humanas a partir do padrão, e à semelhança, das relações entre os consumidores e os objetos de consumo. Numa enorme distorção e perversão da verdadeira substância da revolução consumista, a sociedade de consumidores é com muita frequência representada como se estivesse centralizada em torno das relações entre o consumidor, firmemente estabelecido na condição de sujeito cartesiano, e a mercadoria, designada para o papel de objeto cartesiano, ainda que nessas representações o centro de gravidade do encontro sujeito-objeto seja transferido, de forma decisiva, da área da contemplação para a esfera da atividade. Quando se trata de atividade, o sujeito cartesiano pensante ( que percebe, examina, compara, calcula, atribui relevância e torna inteligível ) se depara - tal como ocorreu durante a contemplação - com uma multiplicidade de objetos espaciais ( de percepção, exame, comparação, cálculo, atribuição de relevância, compreensão) mas agora também com a tarefa de lidar com eles: movimentá-los, apropriar-se deles, descarta-los. ( BAUMAN, 2008, pg 19).

Consumidores e objetos de consumo, e na vida de fato, percebo via de mão dupla nessa perspectiva, e também se colocando sobre esse olhar governo e povo, ainda a saber onde fica o desejo de ambos, em concretos itens de bem-estar, ou itens a serem consumidos de forma satisfatória, cada qual com suas responsabilidades, sobre como se organizam quanto a modo de ser de cada um em partícipe da ordem social, e de trabalho, em rumos escolhidos, consigo e para com as instituições e órgãos governamentais, para serem uma sociedade onde poderá haver um consumo consciente, e como objetos de consumo, bem entrelaçados na qual ficam claros ou deveriam ficar evidentes enquanto face de objeto seus próprio indicies internos como validando seu estar no mundo, considerando mudanças, alterações, para si e a sociedade, objeto e consumo. Do que queremos e vamos buscar adquirir, ou seja, enquanto objeto e próprio ato de consumo frente a vida, teremos várias atitudes nessa lógica, 
permissiva por vezes, ou elucidativa, dependo de cada cultura, ou melhor, de cada posicionamento dos indivíduos.

Na maioria das descrições, o mundo formado e sustentado pela sociedade de consumidores fica claramente dividido entre as coisas a serem escolhidas e os que as escolhem, as mercadorias e seus consumidores: as coisas a serem consumidas e os seres humanos que as consomem. Contudo, a sociedade de consumidores é o que é precisamente por não ser nada desse tipo. O que a separa de outras espécies de sociedade é exatamente o embaçamento, e, em ultima instância, a eliminação das divisões citadas acima " Na sociedade de consumidores, ninguém pode se tornar sujeito sem primeiro virar mercadoria, e ninguém pode manter segura sua subjetividade sem reanimar, ressuscitar e recarregar de maneira perpétua as capacidades esperadas e exigidas de uma mercadoria vendável. A subjetividade do sujeito, e a maior parte daquilo que essa subjetividade possibilita ao sujeito atingir, concentra-se num esforço sem fim para ela própria se tornar, e permanecer, uma mercadoria vendável. A característica mais proeminente da sociedade de consumidores - ainda que cuidadosamente disfarçada e encoberta - é a transformação dos consumidores em mercadorias, ou antes, sua dissolução no mar de mercadorias em que, para citar aquela que talvez seja a mais citada entre as muitas sugestões citáveis de Georg Simmel, os diferentes significados das coisas, e portanto as próprias coisas, são vivenciados como imateriais, aparecendo num tom flutua com igual gravidade específica na corrente constante do dinheiro. A tarefa dos consumidores, e o principal motivo que os estimula a se engajar numa incessante atividade de consumo, é sair dessa invisibilidade e imaterialidade cinza e monótona, destacando-se da massa de objetos indistinguíveis que flutuam com igual gravidade específica e assim captar o olhar dos consumidores. ( BAUMAN, 2008, pg 21).

Dentro da lógica constatada de consumo, o fator que nos chama aqui atenção e em relação ao travarmos o paralelo do ser objeto-mercadoria, não apenas isso, mas o essencial, é quem somos, e o que queremos de valores para nossa integridade enquanto indivíduo, e ainda, dentre o mercado como sociedade, e nós o constituindo e não apartado dele, esse mercado possui qual imagem, ou como a tornaremos real para nós, enquanto o que queremos para o futuro, não se trata portanto somente da lógica, mas quais elementos traremos para a organização enquanto sujeito e sociedade, objeto-mercadoria, para essa lógica, E nisto portanto, se apresenta, dentre o que somos, queremos ser, o descarte nossos, as conquistas nossas, o desejo ou não entre o que permanece ou parte, e também o que é de nossos ser, seguindo o caminho de vida como produto, o que pode ser sustentável, e sobre que práticas, e ainda, avaliamos riscos de nossas escolhas frente o mercado-sociedade, assumimos nossos posicionamentos? Estamos aptos a considerar nossas falhas de produto, e reavaliar nossos posicionamentos? Estamos atendendo a qual parcela, ou fatia do mercado-sociedade. Nossos 
pensamentos, estão atentos, e se atualizando? Como lidam com diretrizes entre as raízes profundas de crenças e modificações do viver? Estamos plenamente cientes, da nossa missão enquanto indivíduos? Costumamos hoje questionar diretrizes de missão de uma empresa, estaremos também dispostos a fazer o mesmo como indivíduos? Quais características apesar de bem descritas e estabelecidas na sociedade precisam de uma reavaliação nossa e da sociedade, do produto (indivíduo) e do mercado, porque este último vem sofrendo alterações porque os tempos mudaram. Somos compulsivos, e não somente compulsivos, mas pelo quê em nossa vida? Avaliamos essa possibilidade, ou apenas estamos um pouco ausentes do mercado, e se assim for, invisíveis, haverá de ser por falta de recursos, nossos ou do mercado- como sociedade? Ou falta de conhecimento, de informação, de estímulo, este último que promove forças. Que relações podem estar nesse " mecanismo", quer seja um relógio ainda, ou nuvens, para nos encontrar frente ao que pode ser um desafio, capaz de nos tornar movimento. Se queremos o amanhã, o que estamos fazendo hoje!?

Sobre o sonho, a parte do texto de ensaios poéticos teatrais, de minha autoria, eu preciso sentir.

Concepções culturais, posicionamentos, escolhas possíveis, reflexões na organização do viver, antes e depois, por onde pode caminhar um cidadão e um país livre? Do que creio, sou livre por essa razão ou estará a liberdade sobre um cunho maior em sendo da consciência.!? Não é somente do olhar onde vivemos, se falamos em rede, globalização e multiculturas que teremos diretrizes para buscar um conhecimento onde se pode ponderar sobre caminhos e resultados enquanto desenvolvimento. E mesmo sem ir muito longe, mas em nosso próprio umbigo, se assim pode se dizer, se tomarmos presença de comunidades rurais ou ribeirinhas, muito do que acontece como cotidianos outros dos nossos, nem chegam a ser parte, apesar da televisão ou outros de comunicação do modo de ser da vida que segue seu rumo, isto querendo pensar sobre do que conhecemos, do que vivemos, o que de fato é parte da liberdade. E se um outro, e até mesmo culturas "formatadas", ou governo tem instrumentos de poder para sabendo dessa relação apartar conhecimento e informação, nos tornamos objetos subjugados sem nem mesmo ter ciência muitas vezes disso. É o saber ligado a comunicação, que abre portas, caminhos, oferece oportunidades, mas não somente isso, são necessárias forças de algum modo, porque civilizações, indivíduo, governos, culturas, estabelecem muitas vezes uma redoma, por si mesmo ou por também forças alheias à vontade, e não isentando a parcela de cada um de reflexão, mas ponderando sobre poderes que sutilmente determinam escolhas. Até que um dia a redoma quebre, ou o próprio ar 
sufoque e precise mudar, afinal, questões de sobrevivência, em certo ponto oferecem medidas de adaptação, quando na maior parte, para esses casos até mesmo, rompimentos, porque como quase uma ordem natural das coisas, temos o desenvolvimento, ${ }^{279}$ Certos modos de pensar, querer uma certa coragem, porque não é fácil, examinar o pensamento, isto porque de início penso em um paralelo natural do que é parte nossa do organismo do viver, sendo a própria evolução, porém, da natureza humana, o que é para alguns evoluir? E em certo momento, esbarramos no livre-arbítrio, e até o próprio contribui para argumentos a favor ou contra, exemplos inúmeros poderemos ter, dentro da própria casa, quero dizer, num país dito democrático poderemos encontrar aspectos do que é a tecnologia usados para o bem ou não, segundo o livre-arbítrio de cada um e o não pode validar posturas de outras culturas que em sua redoma podem considerar somente o aspecto negativo que não é do objeto em si, a tecnologia como instrumento, de avanço, por exemplo, mas do corpo social, escolhas de cada indivíduo, neste caso apontadas somente com o olhar determinado, do que foi prejuízo, não perdendo de vista, sendo a vida e o que a constitui como produto de nosso tempo, e o seu uso, este razão apontada como prumo a ser aferido ainda sobre uma consciência independente de diferenças culturais. Isto para querendo considerar observações em reflexão a respeito do trabalho como valor do existir presumindo para isso que não seja somente neste pensar o trabalho, apesar, de ser somente o assalariado, lembrando nessa colocação do que dissemos sobre acesso a informação e outros modos de viver, enquanto possibilidade sem ferir nossa condição em liberdade ou privação dela, aqui considerando o cárcere não somente aquele que ocorre por ausência social por infração, mas uma ausência social, da própria vida. Isto considerando que ao desejar o contato em comunicação e informação, deve se ter o cuidado no mínimo de ter a postura de esclarecer, e de respeito, porque ao considera o outro ausente, e em seu modo acreditar que o liberta dessa condição não pode ferir a ponto de se tornar uma forma de dominação, até sendo um elemento de prazer, por exemplo, se um indivíduo, ou até uma empresa quando pretende expandir seus produtos, presume e tem consciência dos desejos e pretensões que aquela sociedade, mercado almeja, até mesmo prevendo que tem propensão de um rompimento, a meu ver a postura correta, diplomática, ética é a de elucidar seus pontos de vista, suas concepções sem ferir, ou manipular porque então o que presume estar libertando em vez de esclarecer está dominando de maneira vil e hipócrita. Portanto, instrumentalizar a reflexão é valor d(n)a

\footnotetext{
${ }^{279}$ VARELA, FRANCISCO J, MATURANA HUMBERTO. A arvore do conhecimento. 2001.São Paulo: Atenas.
} 
comunicação entre diferenças, internas ou externas, porque promove entendimento e conhecimento, capazes de gerar aproximações de forma digna.

Se foi o destino do fetichismo da mercadoria ocultar das vistas a substância demasiado humana da sociedade de produtores, é papel do fetichismo da subjetividade ocultar a realidade demasiado comodificada da sociedade de consumidores. BAUMAN, 2008, pg23. Isto um tanto quanto alterada me parece hoje em dia, onde o produtores podem ser até mesmo inqueridos a considerar uma certa demonstração de preocupações humanas, quer sejam desde a matéria do produto, ou como ele é produzido em relação a responsabilidade.

Como compradores, fomos adequadamente preparados pelos gerentes de marketing e redatores publicitários a desempenhar o papel de sujeito - um faz de conta que se experimenta como verdade viva, um papel desempenhado como vida real, mas que com o passar do tempo afasta essa vida real, despindo-a, nesse percurso, de todas as chances de retorno. E à medida que mais e mais necessidades da vida, antes obtidas com dificuldade, sem o luxo do serviço de intermediação proporcionado pelas redes de compras, tornam-se comodizados, as fundações do fetichismo da subjetividade são ampliadas e consolidadas. Para completar a versão popular e revista do cogito de Descartes, compro logo sou ", deveria ser acrescentado "um sujeito". E à medida que o tempo gasto em compras se torna mais longo, multiplicam-se as oportunidades para se fazer esse acréscimo. BAUMAN, 2008, pg 27.

Se o mundo que vivo quero conhecer, e nele ser sujeito ambiente, em meu modo de pensar, seja olhando pelo toque do coração, ou de qualquer sentido, o olhar, assim sendo, está sobre onde eu o recebo como uma espécie de eco de voz, então, olho como a dizer que estou presente, e se não vejo nos outros olhos que esteja ao meu redor ou em minha direção, como posso então, do que desejo, poder conhecer. Apesar de que também pode haver n((d)o) olhar $^{280}$, como interface de relações o espaço vazio, os incógnitos,

Ilusão e verdade? No que preferimos consumir? Já que vivemos nos dois. De qual parcela de cada um posso do desejo transformar em realidade, e ainda mais, se for saciar o propósito de aprender e compreender. Do sobreviver e de como considera Bauman, uma sociedade de selecionadores, questiono o quanto que hoje dentre a primeira observação quanto ao sobreviver estamos certos do que alteramos de cognição para realmente viver, e neste particular creio que estar atentos ao estarmos em compartilhamento sobre ainda que, seleções, portanto creio que atualmente, nota-se uma não sobreposição de dominação como seleção, mas de compreensão ( englobar) enquanto forma de resultado sendo que para tal a

${ }^{280}$ Sousa, Carina Gonzalez Y. Composição: Melodia da tarde. 
seleção para a ser elemento de cognição em rede. Desafio portanto será entre o pensar e viver, enquanto consumo, também do que remanejamos em deslocamentos de lugar, havendo também de considerar um design, como caminho, capaz de aliar reciclagem dentre projetos que assumem novas possibilidades de papeis integrativos em rumos diferentes porém que assumem a capacidade de considerar aspectos de desmembramento onde o ontem se forma como seres de Ovídio, metamorfoses possíveis do amanhã, como entrelaçamentos também dos vínculos humanos ( GIDDENS)

Remanejamento, talvez um sentido em alta, diante da lógica de consumo, portanto, não um descarte, de e em relações, mas um remanejamento, onde até mesmo ainda se pode observar o que permanece não sob o dogma de ser o mesmo, mas permanece em conexões ainda que em outros sistemas, ou outros ramos de uma estrutura, assim portanto para além de ser uma constatação vigente e atual me parece que minimiza as crítica quando a diluição tão ávida de certos relacionamentos, sejam de empresas ou pessoas, e tal postura até mesmo preserva os indivíduos ou empresas com seus preceitos básicos, e não impõe apenas por permanência uma falsidade ou uma não relação com a intenção de novos rumos. Atualizações passam a ser práticas não somente de sistemas tecnológicos mas das relações onde a perda é mensurada até por possível estados inertes de olhar, isto então considera necessário e neste caso a palavra é concreta quanto a permanência, porém, permanência de atualizações ou observações de estados internos que demostrem a urgência ou mesmo latência de alterações para que o sistema sobreviva, ou a relação não pereça, isto caso o interesse não seja totalmente de mudança ou remanejamento. A hipocrisia gera muitos problemas. E o cotidiano que amortece as relações também são elementos inseridos desfavoravelmente, mais um fator para as atualizações dentre as quais, necessitam de questionamentos quanto a desejos e práticas, que possivelmente minimizam os prejuízos, ou traições. Discursos repetidos de maneira costumas também são fatores de entraves para qualquer esclarecimento quando os mesmos não são observados sobre a óptica do tempo ou das novas conjecturas.

Caminhar entre nossas palavras e pensamentos, é no mínimo produtivo. Diálogos particulares, rondam nossa consciência, e são atos compartilhados pelo tempo, sobre a cortina dos nossos passos.

O último gole... por onde anda. Talvez sobre a mesa, que fica vazia, na volta pra casa. Sorva o desejo do prazer de onde queira viver... Desejo e produto, em relações sobre o que sustenta a economia do convívio humano. Mais fácil todavia seria talvez dizer ambos, porém, observando quando ao sobreviver, determinados itens, passam a ser primordiais à economia, 
em parte como uma ponte, que nem sempre se deseja, mais sacia, de maneira que nem mesmo, se pode sobreviver sem, ou seja, nos deparamos com o fundamental, ou o extremamente necessário, fatores de primazia, até sendo preponderante quanto ao que escolhemos, e a escolha também é objeto interno do desejo. E ainda, quanto a relações, um erro crucial é na maior parte das vezes, quando esquecemos na relação justamente desse item, ou seja, colocamos a razão do viver, no outro, esquecendo que nós como fator primordial até parta estarmos aptos a dialogar com o outro, e precisamos estar vivos e não sobrevivendo somente, se não, o mercado ou as relações nos engolem, e nem fica o vômito ou a digestão.

NOVA GEOLOGIA

DO GREGO YN - GE - A TERRA / LOGOS RAZÃO

FQ? SSEIS DESCOBERTOS - EM PARALELO

CONTEMPORANEO DE REPRESENTAÇÃO

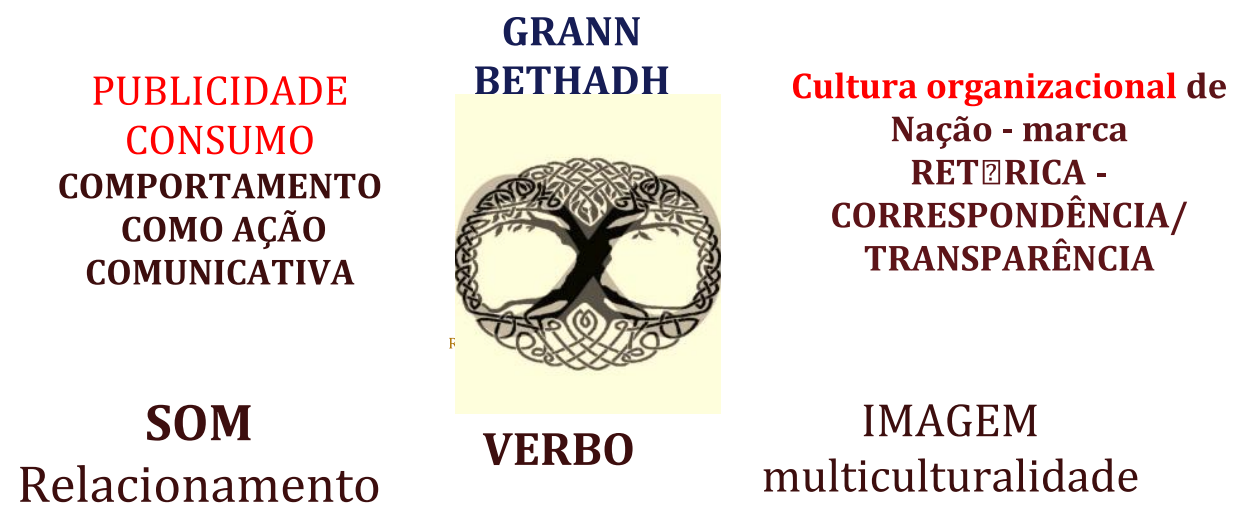

\section{COMUNICAÇÃO TRANSLÚCIDA}

O que nos vale lembrar em escalas e convívio social, o quanto que até mesmo como fatores unívocos adentraremos o patamar de itens básicos. Ora, um bom estudo, certamente contempla a diversidade de recursos dos consumidores, porém é capaz de dialogar indiferentemente, portanto, quanto a presença geral em se tratando da economia, e dos bens de consumo, do que são os itens necessários, ou aqueles que são fundamentais, e desse espaço de escolhas, podem advir possiblidades de produtos que tenham um alcance das mais diferentes e diversas gamas da sociedade, e inclusive indo desde fatores internos como de ordem do que são valores humanos até do que justamente por estarem relacionados a estes, são produtos de consumo, que atendem de alguma maneira, satisfatoriamente, havendo de com isso, indistintamente estar em comunicação com os mais diversos segmentos sociais. 
Claro que dependendo do segmento do mercado, é um desafio devido aos problemas de desigualdade, mas, vale lembrar qual o posicionamento dos objetos internos do desejo, e a própria relação com os itens fundamentais ${ }^{281}$ e necessidade, ou conquistas.

Pode-se dizer que o consumismo é um tipo de arranjo social resultante da reciclagem de vontades, desejos e anseios humanos rotineiros, permanentes, e por assim dizer, neutros quanto ao regime, transformando os na principal força propulsora e operativa da sociedade, uma força que coordena a reprodução sistêmica, a integração e a estratificação sociais, além da formação de indivíduos humanos, desempenhando ao mesmo tempo um papel importante nos processos de auto-identificação individual e de grupo, assim como na seleção e execução de políticas de vida individuais. O consumismo chega quando o consumo assume o papelchave que na sociedade de produtores era exercido pelo trabalho. Como insiste Mary Douglas, a menos que saibamos por que as pessoas precisam de bens de luxo ( ou seja, bens que excedem as necessidades de sobrevivência ) e como os utilizam, não estaremos nem perto de considerar com seriedade os problemas da desigualdade. [...] De maneira distinta do consumo, que é basicamente uma característica e uma ocupação dos seres humanos como indivíduos, o consumismo é um atributo da sociedade. Para que uma sociedade adquira esse atributo, a capacidade profundamente individual de querer, desejar, almejar deve ser, tal como a capacidade de trabalho na sociedade de produtores, destacada ( alienada ) dos indivíduos e reciclada/ retificada numa força externa que coloca a sociedade de consumidores em movimento e a mantém em curso como uma forma específica de convívio humano, enquanto ao mesmo tempo estabelece parâmetros específicos para as estratégias individuais de vida que são eficazes e manipula as probabilidades de escolha e conduta individuais. (BAUMAN, 41)

O querer e a satisfação, do prazer ao sabor. Perspectiva, assumida dentre o que desejo e é necessário sendo para tal, a urgência ou protelação do tempo de consumo ou saciedade. Desejo mas não é tão necessário, a conduta em relação a saciedade e o tempo, presume-se que seja distinta do que desejo e é extremamente necessário, até mesmo fundamental e portanto, o valor do tempo em alcance de consumo (TAC), - ( expectativa e prazerracionalidade e prazer- direcionamento e planejamento )passa inclusive a ser item agregado ao produto. O posicionamento do Target, está imerso em relações. Vale dizer que sendo o produto a vida de cada um, os posicionamentos são ou deveriam ser, segundo a capacidade de equalizar no mínimo ou ter o discernimento quanto a escolhas no que consiste justamente o desejo e a necessidade, dentre claro, também o que se refere a estes ambos em relação à

\footnotetext{
${ }^{281}$ Quanto a itens fundamentais, em tempos atuais quanto a consumo, recursos e consequências, importante consultar o trabalho de André Trigueiro, Mundo sustentável. Abrindo espaço na mídia para um planeta em transformação. São Paulo: Globo, 2005.
} 
razão e consciência. Até porque muitas vezes o tempo de alcance é fator de desistência ou não em relação a aquisição de um produto, de um relacionamento. Entre uma sutil diferença, o desejo e a felicidade, as vezes sobrepostos, ou por vezes, diferenciados, porém enquanto saciedade, sobre o mesmo sentido.

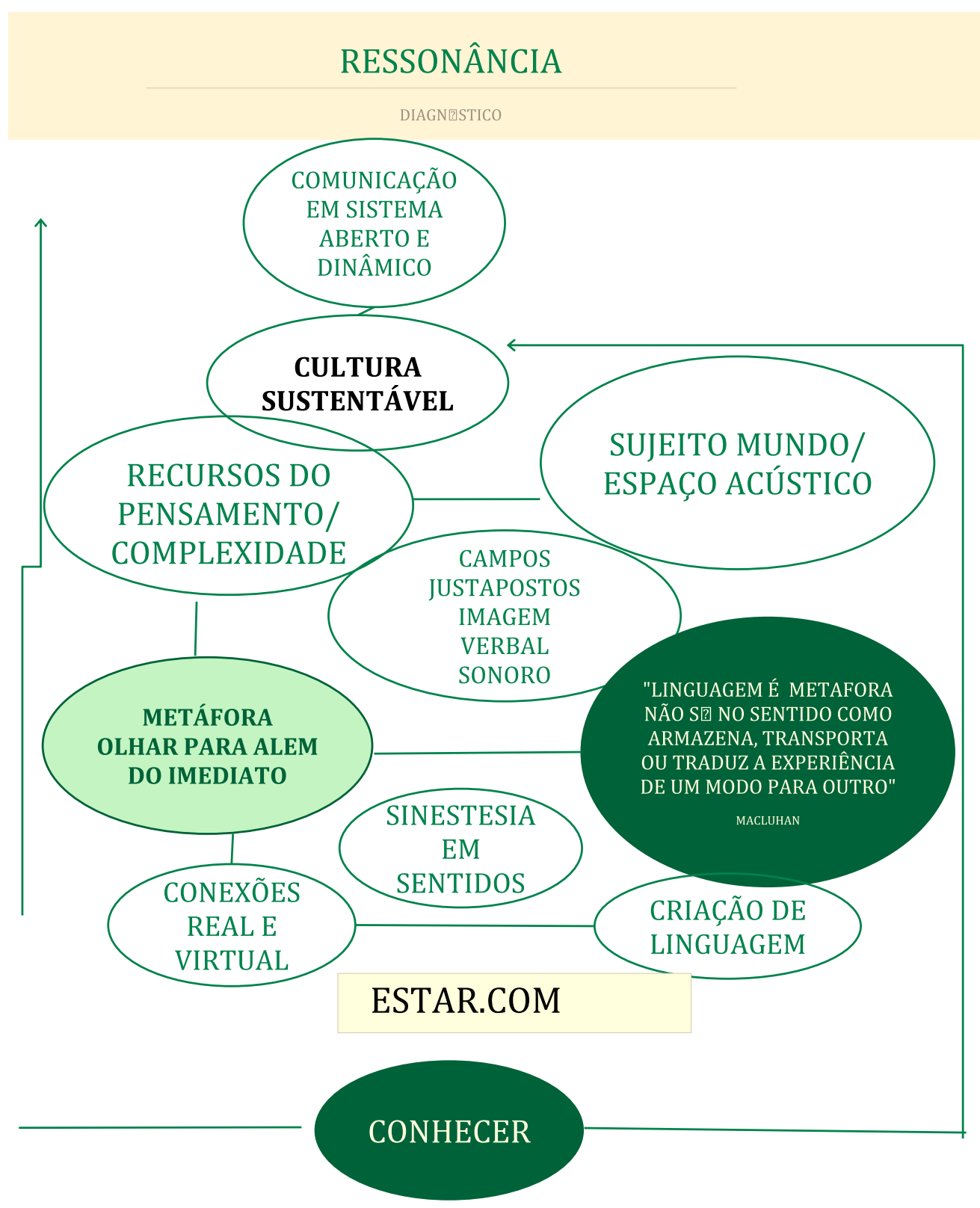

Normalmente se apregoa a insatisfação um aspecto da permanência do desejo, sendo que a meu ver, a " manutenção", ou atualização, é fator de permanência do desejo, havendo de se direcionar o desejo justamente para a manutenção dele, ou seja, porque determinados produtos atravessam gerações e tempos diferentes, ou, enfim, em meu modo de ver, o desejo não se restringe a insatisfação, mas a possibilidade de direcioná-lo como fator fundamental, por vezes estando até na volúpia de não o perder, ou seja, se considera um 
outro aspecto negligenciado, porque as pessoas muitas vezes depois que adquirem nem consideram a possibilidade de perda, erro primeiro em esta análise, e ainda, também não consideram o desejo como volúpia do continuo sendo este a força de prevalecer sobre a perda, isto para alguns perfis até bem preponderantes se observados. Em tempo, não como posse, mas como desejo cultivado. Importante ressaltar para não confundir. Apesar de que mais ainda do que a relação do desejo e da perda, seria a consciência da capacidade que o desejo tem de ser fecundo e não tão momentâneo, e isto sim, seria acrescido cada vez mais, de valores até inicialmente não percebidos, por exemplo, respeito, qualidades revigoradas ou acrescidas em empresas e relações, confiabilidade, e também o engendramento de novos vieses do indivíduo ou empresa.

E, quanto ao que dissemos sobre desejo, consumo, satisfação, não nos podemos furtar de considerar os aspectos de consequências, notáveis e subliminares por vezes, com efeitos em proporções por vezes diretamente relacionados com as devidas escolhas, e credita-se em grande parte ao que está ligado ao fator consciente ou não, enquanto comportamento e pensar.

Uma integração social onde se preserve a vida. ${ }^{282}$

Prejuízos e excessos, sobre qualquer olhar um objeto em desmembramento de conduta, se este estiver sobre excessos, no que pode ser malefício correspondente serão as consequências, isto para a observação que frequentemente é dita em relação ao ato de consumo, quando este já não se encontra sobre equilíbrio. Quando passamos a ter a noção de compromisso que se estende desde a realidade assim como e principalmente conosco, seria devido encontrar uma capacidade de avaliação, reflexão, e esse estado de relação se aplica em escolhas e comportamentos.

O peixe fora d'água, e os territórios de reconhecimento e desejos sociais. Sobre relações e aproximações de olhares em distanciamentos de espaços sociais, o valor da comunicação e as narrativas. Dentre o que já abordamos sobre realidade, razão, consciência, escolhas e participação social, também colocamos sobre a óptica deste estudo as desigualdades, e com isto também os aspectos urbanísticos ou de uma topologia quer sejam também contemplados também lugares rurais, o que se considera é indiscutivelmente a capacidade da comunicação de aproximar as mais diferentes experiências de vida, quer estejam sobre a visão de particular de cada indivíduo, quer possam estar sobre diferenças econômicas ou culturais.

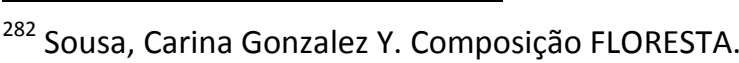


Ressalta-se que quando ao objetivo, não basta ter em mente o destino, mas o como iremos chegar lá.

O consumo de um conhecimento como prática de viver uma existência mais igual e humana. O sentimento de pertença (Maffesoli ) quando o produto é a vida. Penso que do próprio sentido da marca, tivemos no decorrer do tempo, alterações quanto a sua constituição propriamente e nossas relações com seus engendramentos na vida de cada um, e até mesmo a moda. Marca como bem disse Ricardo Guimarães como sistemas complexos. Portanto, o próprio sentido de marca $^{283}$ passou a significar-se internamente em valor do que deseja expressar, tanto quanto a sua imagem em representação externa, e havendo dos consumidores até a cobrança de correspondência entre ambos, e com o tempo, o significado interno enquanto práticas externas de cunho de algumas socialmente visíveis, tornou-se valor de significado onde não somente consumimos um produto, mas a ideia, o pensamento que esse produto significa, de que maneira ele me torna parte ao ser dos meu pensar em cotidiano, face que reverbera em diálogos de correspondência, e consequentemente de escolha. E no que diz Victor Aquino, qualquer coisa que se presume seja aquilo que aparenta ser, depende sempre dos atributos que tornam aquilo que de fato é.

Sujeito ambiente, o lugar nosso, espaços do viver. ${ }^{284}$

Algumas pessoas questionam se a orientação de marketing é adequada a uma época de deterioração ambiental, escassez de recursos, explosão demográfica, fome e miséria em todo o mundo e serviços sociais negligenciados. ( KOTLER, apud Zenone 2006)

E, conforme Zenone no livro Marketing Social,

A satisfação apenas do consumidor é restrita quanto ao verdadeiro papel do marketing que deve incluir em suas estratégias qualquer pessoa diretamente ou indiretamente afetada pelas ações mercadológicas. Ou seja, as atividades de marketing devem levar em conta também os conflitos potenciais entre desejos e interesses do consumidor (cliente ) e o bem-estar social a longo prazo. A razão central para uma empresa orientar suas estratégias para o social está na mudança das exigências, principalmente por parte do consumidor, que cada vez mais está buscando produtos e serviços com qualidade superior, além de estar cada vez mais sensível a ações mercadológicas que podem causar danos à coletividade.[...] Percebese então, que não se trata de atender apenas aos benefícios esperados pelos

\footnotetext{
${ }^{283}$ MEISLER, Rony. Ceo do grupo Reserva, com Fernando Sigal. Consultar o livro Rebeldes tem Asas, editora Sextante.

${ }^{284}$ Sugiro a consulta sobre consumo consciente o site do Insituto Akatu. https://www.akatu.org.br/
} 
consumidores, mas de ampliar a visão sobre os efeitos reais, que ao longo do tempo, o produto poderá causar a uma sociedade. [...] A orientação social leva as empresas a incluir os conceitos de responsabilidade social e ética empresarial em suas práticas de marketing. ( ZENONE, 2006, pg 52).

Ainda Zenone aponta que Pringle e Thompson, observam a orientação de marketing societal, esta que presume-se que determine necessidades, desejos, e demais interesses de maneira mais eficaz que a concorrência preservando o bem estar do consumidor e da sociedade, assim sendo, eles consideram que seria " uma atividade por meio da qual uma empresa estabelece uma parceria com uma causa ou com uma variedade de causas, em benefício mútuo". Portanto, a sociedade passa a fazer parte do mercado-alvo da empresa, tornando-se elemento da estratégia de marketing, trazendo benefícios mútuos. Zanone ainda apresenta o marketing comercial e o institucional, sendo o primeiro as atividades de comercialização de um produto ou serviço e tem um impacto econômico direto, e o marketing institucional, conforme ele descreve, atua na sociedade onde a empresa está inserida fisicamente ou através de seus produtos, com o objetivo de garantir a boa imagem da marca. Havendo, porém de deixar claro o comprometimento real e transparência na relação empresa e causas sociais. ${ }^{285}$

No marketing institucional, o objetivo é formar uma boa imagem institucional (Goodwill) perante o público de interesse, que, mesmo que indiretamente, auxilia na comercialização do produto ou serviço. É no marketing institucional que há a aproximação da empresa com as causas sociais. ( ZENONE, 2006, pg 55)

Definições, e o redesenhar contínuo dos sentidos e práticas. Zenone ainda alerta sobre a expressão consumirismo ( LEWIS E LITTLE), que trata do olhar da empresa sobre a óptica do consumidor, e o consumismo já sendo a prática do consumidor de ir além do necessário, sem preocupações ambientais, portanto sendo opostos. Incorporados ao conceito do marketing social, podem estar sobre a nomeação de cidadania corporativa, ética empresarial, responsabilidade social, e consumirismo, sendo que o marketing social ${ }^{286}$ direciona aos

\footnotetext{
${ }^{285}$ No livro Zanone descreve algumas ações dentre as quais, ações institucionais e a promoção de vendas ( comunicação) como sendo a estratégia que vincula uma ação social à venda de um produto ou serviço. E também ações institucionais incorporadas ao produto ou serviço, os produtos e serviços são desenvolvidos respeitando-se os fatores ambientais e sociais. Portanto, além da qualidade do produto ou serviço as empresas buscam incorporar aspectos relacionados à preservação do meio ambiente e que não gerem impactos sociais negativos. Considera-se portanto o marketing institucional o responsável por formar, manter, consolidar ou mudar o conceito de uma empresa, havendo de ser ferramenta voltada para a preservação e melhoria da imagem da empresa no mercado.

${ }^{286}$ Algumas mudanças ocorreram no tempo, porém" O termo marketing social apareceu pela primeira vez em 1971, para descrever o uso de princípios e técnicas de marketing para a promoção de uma causa, idéia ou comportamento social. Desde então, passou a significar uma tecnologia de gestão da mudança social, associada
} 
interesses a longo prazo dos consumidores e da sociedade. Também esclarece que o marketing social pode usar também os conceitos relativos ao marketing comercial, como os exemplos que cita ao considerar, pesquisa de consumidores, configuração de ideias, segmentação de mercado, comunicação, facilitação de incentivos, e teoria de troca. $\mathrm{O}$ conceito, podendo ser colocado como marketing societal, passou ao longo do tempo, por novas definições, dentre as quais o próprio Kotler e Armostrong apontam que:

O conceito de marketing social sustenta que a organização deve determinar as necessidades, desejos e interesses dos mercados-alvo, e então proporcionar aos clientes, um valor superior, de forma a manter ou melhorar o bem-estar da sociedade... Segundo este novo conceito de marketing social, o conceito tradicional de marketing não percebe os possíveis conflitos entre os desejo s acurto prazo dos consumidores e seu bem-estar a longo prazo...o conceito de marketing social exige que os profissionais de marketing equilibrem três fatores ao definirem sua política de mercado: os lucros da organização, os desejos dos consumidores e os interesses da sociedade. ( KOTLER, ARMOSTRONG, 1998, P 11 ).

Aqui chegamos ao ponto de considerar portanto, o marketing social não somente como uma restrição de métodos ou técnicas do marketing comercial para o social, mas sim, uma nova forma de sentir e compreender todo o organismo social de maneira abrangente e responsável, consciente de seu lugar enquanto capacidade de transformações sociais. Portanto é capaz de mensurar e avaliar a capacidade de alterar socialmente por suas ações o impacto que gera enquanto as conjecturas que nos assolam do que é de deterioração do meio ambiente, escassez de recursos naturais, violências e diferenças de recursos e poder aquisitivo. O mesmo autor, Zenone, observa ainda que, temos o marketing de causa, ou seja considera um posicionamento especifico, em relação a um aspecto social, porém ressalta também a importância de que fique claro, que o marketing social " não é sinônimo de filantropia, mas uma estratégia de negócios que tem o objetivo de criar uma imagem positiva da empresa para os seus clientes internos e externos, acionistas, comunidade em que se encontra inserida e fornecedores através de ações sociais/ambientais que trazem benefícios para a sociedade", Lembrando que para a responsabilidade social e as práticas do marketing

ao projeto, implantação e controle de programas voltados para o aumento da disposição de aceitação de uma ideia ou prática social em um ou mais grupos de adotantes escolhidos como alvo. ( Kotler e Zaltman, 1971, p 3 ). (ZENONE, 2006, pg 66 ) 
social serem de fato efetivas devem seguir certas premissas como o balanço social ${ }^{287}$ que medi o valor e o retorno da gestão social.

E todavia sobre a sociedade de consumidores, entre conexões pode-se realizar o encontro com o sentido de pertencimento, e identificação, seja do indivíduo, da marca ou da empresa, como fatores inseridos na compreensão da cultura, e quiçá o próprio fator cultural mensure a razão propensa ao efêmero ou perenidade no que se refere a consumo e modos de olhar e conduta. Marketing cultural, diretamente ligado ao que promove desenvolvimento.

O pertencimento ${ }^{288}$, tem sua razão enquanto o que se prolonga de nós, ou do que imediatamente a percepção se engendra por reconhecimento, afecção ou afeição. Mas, existem lugares, que mesmo diante de particularidades, de identidades, no que dizemos ser globalização podemos elencar os fatores, do respeito, da dignidade, de valores humanos, como o que pode estar sobre o território Terra, ao considerar mesmo uma economia planetária, onde os recursos estão sobre o prisma do que é sentido de uma consciência que não se restringe mais engloba através dos elementos que são basilares de todo ser humano e ainda do seu meio ( bios).

Quem pode estar fora de um palco, se vivemos no olhar do outro, que nos observa e faz do palco o pulso que está a nos tornar vivos? Não sei como entender o palco deixando gente fora dele, ora, cada voz, entoada por um ator, por um músico, por um ser humano que vive e está ali representando claramente para mim, envolve absolutamente e simplesmente, o mundo, e quem vamos deixar de fora, do mundo? Até onde pode ir essa voz? Até os confins do pensamento que deixou a voz em silêncio para atuar.

Atualizar conhecimentos, conceitos, práticas, em certa medida é um diálogo do cotidiano vigente com o que perpetua, havendo de virar a página de maneira onde se possa escrever e entender o sentido que pode inclusive estar ancorado nas referências do atravessando o tempo.

Data de vencimento? E qual a data de vencimento para fazermos um "design" em elementos culturalmente já conhecidos, por uma época, e quem sabe não podendo ser vistos novamente sobre outro olhar...

${ }^{287}$ GONZALEZ, Roberto Sousa. Balanço social - um disclosure necessário. In: SEMINÁRIO MERCADO DE CAPITAIS E BALANÇO SOCIAL. 2001, São Paulo. Apostila... São Paulo: ABAMEC, 2001. Autor também do livro: Governança corporativa: O poder de transformação das empresas. Ed. Trevisan: São Paulo, 2012.

${ }^{288}$ Sousa, Carina Gonzalez Y. Do livro, Gingado, o texto : UMBIGO. 
Valores culturais, perspectivas agregadas. ${ }^{289}$ Em suma, as características das atividades culturais promovem por si só, fatores de desenvolvimento, de conhecimento e de respeito a diversidade planetária, promovendo diálogos por respeito e considerações do cerne que a constitui, o pensar integro, formas diversas de expressão, o conhecimento. Os aspectos culturais criam valor para as marcas, denominando-se por essa característica, brand, sendo portanto um instrumento para o marketing institucional. "Para Credidio (2002, p 29), o marketing cultural não é apenas o uso da cultura como ferramenta de comunicação, mas um conjunto de ações que visam à mudança comportamental de uma sociedade a partir da cultura".( apud Zenone).

Cultura como desenvolvimento social. Em 2001 em uma conferência foi produzido a “ Declaração universal da Unesco sobre a diversidade cultural. ${ }^{290}$

Particularmente a cultura enquanto modo de ser no mundo, não se aplica aqui, somente como linguagens da arte ou aspectos determinados por territórios do planeta, mas a uma compreensão do pensar que esteja sobre inclusive o sentido de uma travessia havendo de considerar o respeito e a integridade da diversidade, e sabendo que também se encontra como cognição e então aqui, se apresenta a razão do gesto da arte ${ }^{291}$, como presença dos elementos unificadores, ritmo, cadência, gêneses do sentido, que podem estar sobre diferentes formas da vida em si, mas representadas em expressão de tudo que existe, se colocando como uma cultura sustentável onde o pensar assim colocado mediante um conhecer estabelece a percepção, o diálogo, a reflexão, modos fundamentais dentre outros, para que se compreenda a necessidade de permanência ou alterações do que de fato necessitamos como produto de nosso tempo ${ }^{292}$, para um viver melhor, isto porque o pensar enquanto cultura sustentável, é fundamental para que realizemos a consciência, porque, por vezes estamos tão amortecidos, que as causas humanas, ou o existir passa desapercebido e ausentes porém, as consequências quer sejam do meio ambiente ou do próprio desequilíbrio humano como condição de um viver se fazem presentes, e ainda carecendo de um educar o pensamento. “ Thomas Moore ( apud Albano, 2004), propõe que a arte é um campo onde podemos trabalhar nossa alma. A alma não pode viver apenas da vida pessoal, necessita de um contexto mais amplo"( ZENONE, 2006, pg 84).

\footnotetext{
${ }^{289}$ ZENONE, Luiz Claúdio. Marketing social, capítulo 3. MARKETING CULTURAL. São Paulo: Thomson Learning 2006.

${ }^{290}$ Os itens da declaração podem ser consultados no endereço eletrônico que segue: http://unesdoc.unesco.org/images/0012/001271/127160por.pdf. Acesso em 20-06-2018.

${ }^{291}$ Sousa, Carina Gonzalez Y. Agape, Arte como a vida. Instituto da moda, 2016.

${ }^{292}$ Arquivo sonoro. Composição Rios da gente.
} 
A economia sente, absorve e se engendra, nas vazões dos aspectos culturais, que geram desenvolvimento, como uma via de mão dupla. Aqui nesta pesquisa se aborda a cultura em respeito a algumas preocupações, a saber, por exemplo; desde o acesso, mas principalmente e não querendo dizer que não seja entretenimento, mas aqui se vê a cultura como conhecimento, como agente da sociedade onde inseridos somos capazes de refletir nossa condição humana, de esclarecer a situação à qual estamos cerceados, sendo capazes de realizar o movimento entre o pensar e o agir que tenha discernimento suficiente para alcançar transformações necessárias. A passagem da narrativa do observador, para a de protagonista. A cultura observada como partícipe do educar o pensamento e agente transformador da sociedade se verifica cada vez mais, na reflexão desde o indivíduo a organizações, sendo elemento ativo e não passivo, visto que promove o pensamento em discernimento viabilizando opinião e expressões participativas na sociedade. Lembrando também do patrocínio cultural usado como ferramenta do composto da organização comunicacional. Do antes e depois, pondo em prática... projetos culturais:

Quando a sociedade não cumpre o seu papel, corre-se o risco de distorcer as percepções, criando dependência e conformismo. Conforme Reis( 2003, pg 41), quando um projeto cultural é utilizado como forma de reinserir na sociedade camadas da população sem perspectiva... são flagrantes as mudanças em seu comportamento de tomar para si as rédeas do seu destino. Para atuar de maneira participativa, a sociedade precisa se organizar e cobrar do Estado políticas culturais que atendam as suas reais necessidades. Isto pode ser feito não só através do poder do voto, elegendo representantes que tenham propostas de projetos culturais, mas por meio de criação de projetos, apresentando-os ao governo, cobrando sua efetivação e acompanhando ( auditando) todas as etapas do seu desenvolvimento".( ZENONE, 2006, pg 94).

Este fato participativo é parte do comportamento do nosso tempo vigente, isto porque o consumidor também assume o papel de cliente e formador de opinião. ${ }^{293}$

Escrever o seu espaço cultural, significando o mundo, a partir da construção dos seus espaços, onde a cultura se faz viva e presente.

Portanto, as noções que envolvem os conceitos sobre cultura, costumes e concepção da identidade humana parecem ter conexão com a colocações de Lotman sobre os "textos da cultura". Ou seja, da mesma forma que um texto é elaborado obedecendo uma certa hierarquia estrutural, assim também ocorre com os eventos e sistemas culturais. Esses sistemas culturais funcionariam como um sistema abstrato operacional a partir do

\footnotetext{
${ }^{293}$ ZENONE, Claudio Luiz. Quanto a leis de incentivo à cultura, item 3.3 do livro: Marcketing Social, Thomson 2006.
} 
qual é possível pensar, relacionar e configurar a realidade humana na cultura. O homem, a partir desse sistema operacional cultural, produz textos códigos com os quais vai promover comunicação, significação e interação social.[...] Chamamos de comunicação a ininterrupta interação em cadeia, e por intermédio de relações, constitutiva dos seres vivos, em um mesmo habitat e participantes de uma mesma biosfera. Para o ser humano especificamente, além de estar inserido na biosfera - seu habitat, sua existência demanda circulação de informação, participação e domínio sobre outras esferas além da bio (esfera). Essas outras esferas dispõem das condições necessárias para permitir a vida humana em sociedade, a comunicação humana, e operam por meio de determinadas linguagens devidamente estruturadas. Ademais, são produtoras daquilo que conhecemos como cultura humana, especialmente no que se referem às considerações propostas pela área da semiótica da cultura. Cultura, sob esse ponto de vista, se refere aos diferentes modos pelos quais o homem organiza sua existência biológica, mental, emocional e social para além de seu espaço físico. Conforme Lotman (2000), o homem cria modelos e textos que organizam suas experiências e possibilitam sua interação com o meio que o rodeia e outros seres animados e inanimados; meio este não apenas biológico mas, também, delimitado cultural e socialmente. Também Lotman (2013) define "cultura" como sendo um sistema para preservação, transmissão e criação de novas variedades de informação, cujo funcionamento daquilo que Lotman classifica como imprevisível e explosivo. Desta forma, o homem, ser sócio-cultural, torna-se compatível com as condições tanto do meio por ele criado quanto as do meio já existente. ( MACHADO, NUNES, 2015, pg 6-7 )

A reflexão aqui apontada é um posicionamento social da cultura mediante a constatação do direito preservado da cidadania. Pensar em liberdade como direito, é uma condição de vida, é estar sendo um ser cidadão como dizem, ou como deveria ser, liberdade como direito inclui a sociedade, e assim sendo, a sua irmã de valor, ou seja, a igualdade, porque posso de fato ter liberdade como direito se meu irmão tem a igualdade de me pertencer. Pertencer como habitar em respeito as possíveis divergências. Mas sabemos que temos na liberdade como direito o ato de consumir licitamente a própria vida, e isso está implícito em leis de natureza social.

Das reflexões e identidades, um caminho em mutação, sobre capacitações sociais, culturais e de sentir o mundo ao seu redor. " $O$ que alguém foi ontem não vai mais excluir a possibilidade de essa pessoa se tornar alguém de todo diferente hoje - nem impedir a perspectiva de outro avatar no futuro que venha a eliminar o presente, que se tornará passado “( BAUMAN, 2008,pg 133).

Já que, recordemos, cada ponto no tempo, deve supostamente estar repleto de potencial inexplorado, e cada potencial deve em teoria ser original e singular, não podendo ser copiado e, outro ponto do tempo, o número de maneiras pelas quais se pode alterar ( ou pelo menos tentar) a si mesmo é 
incalculável na verdade, ele até ultrapassa a atordoante multiplicidade de permutações e a impressionante variedade de formas e aparências que os encontros aleatórios de genes conseguiram produzir até agora na espécie humana, Andrzej Stasiuk, arguto, observador do modo como vivemos hoje em dia, sugeriu que a multiplicidade, que a multiplicidade qualidade da eternidade, na qual, como sabemos mais cedo ou mais tarde tudo, pode acontecer e tudo por ser feito Agora, contudo, esse fantástico poder da eternidade foi comprimido em amplitude, absolutamente não eterna, de uma única vida humana. (BAUMAN, 2008, pg 134).

${ }^{294}$ Escrever o pensamento, ato reflexivo de existir, uma face do sentir o mundo. Transcrição do campo do pensar, atravessando a imagem sobre o sentido da palavra, a captura do seu tempo, sobre o gesto do expressar-se. Manifestação cultural de aspectos compartilhados interna e externamente. Muitas são as vias e os sentidos para que encontremos a força da expressão humana como direito de existir e ter voz ativa na sociedade. Porém aquele que se expressa mesmo em respeito, sabe que poderá lidar com o aspecto de se tornar por vezes indesejável, assim como em uma sociedade podem ser discriminados a população de baixa renda, enfim, ausentes ou indesejáveis, por muitas maneiras temos na sociedade atual que observar em deslocamento, suas razões e comportamento, mediante para além do próprio existir, a capacidade de nos mostrar o que precisamos transformar. Porque temos na história exemplos de silêncios ensurdecedores, o que consideramos uma violência anterior a da violência em atos, mas aquela que nem mesmo teve a razão e muito menos a consciência para ter o discernimento que não ocorre-se atrocidades, e isto é um alerta independentemente de escalas ou culturas, e sociedades, para que o amortecimento do cotidiano, não nos retire a capacidade de refletir, e ainda mais, também, que possamos sempre avaliar narrativas, discursos, para ponderar, discernir quais os caminhos que de fato acreditamos e queremos para o nosso futuro, sabendo que o nosso, inclui todos os que seres que aqui vivem.

E dos territórios inóspitos, ou de uma marginalidade social, quer sejam por consequências adversas, a responsabilidade aqui também se encontra, e ainda mais, devendo diagnosticar, avaliar, refletir e ponderar sobre possibilidades quanto a alterar e realizar passagens ${ }^{295}$ de um viver melhor. Do outro lado mora a ponte, me atravessando sem saber por onde, como o vento, de onde veio. Ao nos debruçarmos sobre o que consiste a cultura, ou a sociedade, sabemos e ninguém está inocente quanto as mazelas que também temos a enfrentar, porém, para além do diagnóstico das necessidades, já apontamos que temos também instrumentos

\footnotetext{
${ }^{294}$ Sousa, Carina Gonzalez Y. Série de poesias, te escrevo.

295 Sousa, Carina Gonzalez Y. Composição: Êxodo. PIANO.
} 
para concretizar um estado social que esteja ao menos minimizando a violência, por caráter maior de oportunidades e capacidades de trabalho, moradia, enfim, tudo que sabemos que consiste em uma condição humana integra de forma ao menos a possibilitar escolhas mais direcionadas aos efeitos que poderão ser descritos favoráveis a vida de todo ser, em parte saber viver, conhecendo o mundo por uma outra perspectiva, e a escolha permanece sendo de cada um, mas ao menos tendo por onde caminhar. E aqui nos encontramos novamente com os desejos e necessidades e onde os lados dessa moeda podem diante da sociedade encontrar o valor da igualdade ou seria, humanidade.

Se a liberdade de escolha é garantida na teoria mas inatingível na prática, a dor da desesperança com certeza será superada pela ignominia da infelicidade - pois a habilidade, testada todos os dias, de enfrentar os desafios da vida é a própria oficina em que a autoconfiança, o senso de dignidade humana e a auto-estima dos indivíduos são formados ou fundidos. Além disso, sem seguro coletivo dificilmente haverá muito estímulo ao engajamento político- e com certeza nenhum estímulo à participação no ritual democrático das eleições já que é provável que a salvação não virá de um Estado político que não seja e se recuse a ser, um Estado social. Sem direitos sociais para todos, um número grande e provavelmente crescente de pessoas vai achar que seus direitos políticos são inúteis ou indignos de atenção. Se os direitos políticos são necessários para estabelecer os direitos sociais, estes são indispensáveis para manter os direitos políticos em funcionamento, Os dois tipos de direitos precisam um do outro para que sobrevivam. ( BAUMAN, 2008, pg 179)

Por muitos podemos crer que a ilusão aqui de direitos carece de uma realidade mais concreta, e visível ou que torne sua imagem com maior veracidade.

O sentimento de pertença se traduz em confiança nos benefícios da solidariedade humana e nas instituições que nascem desta e prometem servi-la e garantir sua fidedignidade. Todas essas verdades foram proclamadas no Programa Social democrata sueco de 2004: Todo mundo é frágil em algum ponto do tempo. Precisamos uns dos outros. Vivemos nossas vidas no aqui e agora, juntamente com outros, envolvidos de forma involuntária pelas mudanças que ocorrem. Seremos mais ricos se todos pudermos participar e ninguém for deixado de fora. Seremos todos mais fortes se houver segurança para todo mundo e não apenas para uns poucos. ( BAUMAN, 2008,pg 179).

Entre a cultura, as relações das identidades internas e externas, sobre espaços sociais, organizações, como fator da busca de um sentido mais humano.

Ao se observar a possibilidade de se ver um organismo capaz de ser uma representação que envolva interesses comprometidos com uma validade de um "consenso construído e com razões esclarecidas“ de maneira a mover questões sociais, isso deve ter uma 
responsabilidade, para que o caráter de mudança não seja instrumento de interesses escusos e usado com subterfúgios de manipulação. Existindo a possibilidade de concretamente agir como um mecanismo social, a responsabilidade por tal, deve ser correspondente com a imagem, que se propõe e se propaga da organização em si, e do que a envolve. Ou seja, a ressonância, está reverberando no interior desse organismo organizacional, assim como seus agentes de expansão social ao qual estão engendrados e sendo como considerado, propulsor de mudanças.

Poderemos questionar, até que ponto haverão máscaras, tanto da sociedade, dos indivíduos, como nas instituições ou organizações, mas neste ponto, vale a pergunta do que queremos, e também, que o que promovemos, poderemos ter para nós, em efeito bumerangue, ou seja, se queremos transparência, deveremos agir em conformidade, se agirmos de má fé, ou com manipulações, estaremos a mercê de um fatídico retorno na mesma medida. E, realmente, cada vez mais, me parece que não teremos mais lugar para uma sociedade, mesmo que isso possa ser visto como inocente, mas penso que não poderemos ter mais uma sociedade sem responsabilidade por condutas, pensamentos e desenvolvimento, porque a natureza está nos cobrando, e não somete a natureza ecológica, mas a natureza da existência ${ }^{296}$. Certas posturas, já despertadas, não podem retroceder, e o que almejamos em veracidade deve vir a nos habitar.

O controle como observado de maneira dogmática ou de interesses diversos, passa a habitar interesses também existenciais, porque estamos falando de gerações, onde o tempo, está além deste, e começa no ontem.

Vejo abordarem teorias onde se relata a mudança em relação ao trabalhador e que se passou a ver com interesse não o "local de controle do corpo, mas a mente do trabalhador ", o que, em primeira vista, ainda penso que falta, um elo, nisso, porque temos o costume de fragmentar, de dicotomias, isto ou aquilo, quando as relações sempre penso que podem favorecer a análise, diagnóstico, ou uma postura, assim sendo, as relações do indivíduo e do local, essa intersecção deve ser harmonizada, possivelmente, e muitas vezes, informações podem ser mecanismos de comunicação que é tanto do corpo da organização como dos indivíduos pela qual são constituídos.

Marca como representação da expressão de m pensar, realizando-se em comportamento e consequentemente o gesto se insere na palavra, tornando-se discurso. Emissão -

\footnotetext{
${ }^{296}$ Sousa, Carina Gonzalez Y. Composição Um dia antes. PIANO.
} 
comunicação -correspondência. O convívio entre as conjecturas de base e as relações externas, influências e embates dos argumentos gerados internamente e os campos de ação demanda e proposições.

Desafio atual das relações do tempo vigente, é o próprio discernimento, capaz de uma lucidez, diante da embriagues social, onde podemos constatar muitas vezes um amortecimento dos órgãos de sentido. Gangrenas reais. Discurso como presença e manifestação de uma expressão, latente é do espírito, não devendo portanto ser de cunho de manipulação, por certo devendo estar em cerne de forma licita e conhecedor de que essa presença do pensamento se constitui sobre o direito do respeito a opinião, ou seja o pensar outro que se dispõe em igualdade havendo por certo de constituir um diálogo onde seja frutífero para ambos os constituintes, isto se explica devido ao poder da retórica ser persuasivo e não é o que se propõe como razão de narrativa direcionado à consciência. Portanto, aqui se aplica sobre o discurso como correspondência da imagem (marca), as consequências diretamente relacionadas com o desejo real dos propósitos que o abarcam em gênese. Com a sociedade atual se verifica a propensão cada vez maior de exigências quanto a transparência e salubridade do organismo institucional, ou do indivíduo, quer seja um grupo de pessoas, de maneira a constatar sua veracidade e os efeitos inseridos nos espaços da sociedade, portanto, se verifica como um diagnóstico, onde do discurso se afere os argumentos e proposições subsequentes, dispostas como presenças do corpo social, pelas quais entramos em contato e haveremos de pelo fomento a reflexão ter a capacidade não somente de constatar, avaliar, e por certo, escolher dentre que caminhos o indivíduo ou até mesmo uma organização quer fazer parte, ou estar conectado, sabendo também que assim como já explicamos ser o pensar diagramático, os espaços sociais e suas representações de discurso enquanto possibilidades de ação-comunicativa dentre sujeitos, organizações, deverão ter uma ciência capaz de elucidar propósitos dentre os argumentos que não estão apenas como elementos mas que se relacionam de maneira a conter uma lógica que se desenvolve dentre os aspectos de uma ética, e mais ainda, que seja capaz de abranger em suas fontes de origem as conexões que serão aptas a desenvolver o estado original capaz de evoluir de maneira equilibrada mesmo com a possibilidade de aspectos novos no sistema, e que estejam em discernimento suficientemente dispostos a concatenar a organização de forma que minimize riscos tanto para o que a constitui assim como o que dela estiver em reverberação, portanto, viabiliza uma estrutura que seja firme mas maleável no sentido de 
estar aberta a continuas avaliações sendo um organismo vivo ${ }^{297}$, dentre o corpo social, onde suas premissas iniciais se tornam cada mais fortes, podendo ser atualizadas atravessando gerações, sem prejuízo de imagem, ao estar sempre observando-se e o mundo que nos cerca, tendo na percepção um instrumento que preserva o amortecimento do cotidiano, e estimulando sempre para novos horizontes.

\section{A voracidade e a indigestão....}

Quanto que permanece o desejo meu, quando sou teu (estou no lugar do outro). O que se deseja, e o porquê. A interface do sujeito ambiente, a empresa e as organizações. Segundo Stan Deetz, "Com isso ele quer dizer que o ponto integral da comunicação como um ato social - isto é, como um ato de humanização - é superar o sentido de subjetividade fixa de um indivíduo e se abrir a indeterminação de outras pessoas e seus ambientes “.

O que pode haver de diferenças? Do umbigo a sistemas abertos.

Entre, a porta está aberta, a realidade quer saber o que existe.

- Com a palavra: a sobrevivência.

Entre qualquer diferença que possa ser nomeada ou articulada socialmente frente a aferições de estados urbanos, ou cotidianos, ressalta-se o respeito em igualdade, como base, ainda que notificando análises de estruturas de regiões ou instituições.

Quero sugerir que a humanização é mais integralmente percebida quando a diferença é reconhecida e tematizada na vida organizacional. $\mathrm{E}$ ao falar em diferença, aqui me refiro a formas de subjetividade humana como as articuladas por meio de raça, classe, gênero, sexualidade, saúde etc e a s formas de pensar e construir vocabulários e conhecimento para compreender a vida organizacional. ( MUMBY, 2010, pg 29).

$\mathrm{O}$ autor considera que o aspecto crítico passou a contribuir de maneira a minimizar os efeitos funcionalistas, que anteriormente eram dominantes, considerando que hoje o ambiente da comunicação organizacional estaria mais disposto a um modo de ser caracterizado por diferenças e multiplicidade.

O equilíbrio tanto do que é de dissenso ou de diferença, quer como seja nomeado, havendo discrepâncias do que consiste da palavra ou não, fato é que me parece ainda que a maneira como é abordada a própria contribuição crítica ou alterações do estado comum de até então, é um tanto quanto restrito, porque vê consenso como uma hegemonia, sendo que o consenso,

${ }^{297}$ Sousa, Carina Gonzalez Y. Elixir. Composição PIANO. 
penso que é um fruto de um processo, e assim sendo, não como algo determinado em hegemônico, mas por ser um processo que busca uma confluência normalmente de oposições, estaríamos lidando com uma prática de discurso e ação que considera sendo um alargamento e não restrição, de argumentos e proposições, constatações vigentes, o que torna o consenso com uma face de postura distinta da maneira como o texto sugere, ao menos em meu entendimento. O respeito como elemento da equação de um sistema aberto, pode ser um ingrediente que torna a ciência da diferença uma consciência, conciliadora, e não discrepante, e muito menos como a margem, portanto, creio que ainda pode ser visto por um prisma mais complexo.

Um ambiente de estar, no qual o viver pode ser significativo de diversas maneira, dependendo de suas próprias escolhas, isso que vem a também ser diagnosticado como fator de bem estar, quando reflete nos moldes de missão e valores da organização, ou seja, se o reflexo pode ser gratificante, e se meus comportamentos, são ( em espelho ) agradáveis como fluxo de mãos dupla, o efeito passa a ser compartilhado em reverberações congruentes, possivelmente.

Fomentar uma ética entre os indivíduos é fator por si, colaborador de um empreendedorismo de valores, que possam ser a consciência para que as relações entre os ambientes quer sejam individuais, internos, externos, públicos, dentre outros, possam ser mais do que discurso uma ação em correspondência, assim se opera mecanismos de aglutinação em prol de um “ bem" como valor institucional, o que vem a ser estratégico também. Segundo Margarida M K Kunsch,

A comunicação organizacional deve ser entendida de forma ampla e abrangente, vendo-se como se processa a comunicação dentro das organizações e toda ambientação social, política e econômica. Como fenômeno inerente à natureza das organizações e aos agrupamentos de pessoas que a integram ou com ela interagem, a comunicação organizacional envolve os processos comunicativos, além de todos os seus elementos constitutivos e a construção de sentidos dos sujeitos e/ ou agentes integrantes em diferentes momentos e contexto. [...] " Nesse âmbito complexo faz-se necessário ver a comunicação inserida nos processos simbólicos e com foco nos significados dos agentes envolvidos, dos relacionamentos interpessoais e grupais, valorizando as práticas comunicativas cotidianas e as interações nas suas mais diversas formas de manifestação e construção social. Essa comunicação acontece e se processa em todos os tipos de instituições e organizações públicas, privadas e do terceiro setor. (KUNSCH, 2010, pg 43 
Margarida ainda salienta a preocupação com a análise da comunicação organizacional como fenômeno, processos, interações humanas indo além, considerando uma maior abrangência, nas mensagens, mídias internas, institucionais e mercadológicas. Para Dominique Wolton,

“A comunicação é um dos mais brilhantes símbolos do 'seculo XX, seu ideal de aproximar os homens, os valores, e as culturas compensa os horrores e as barbaridades de nossa época" ( WOLTON 2004, pg 27 ). Por outro lado, chama a atenção para as discrepâncias e os problemas decorrentes do triunfo e econômico dessa mesma comunicação em relação à sociedade. " pg 45

Extrair na comunicação o valor humano dentre os objetivos econômicos será um desafio de concatenar possibilidades compartilhadas. Conhecimento com instrumento de um elemento aglutinador, diretrizes em paralelos de relações - demandas - ambientes co- habitados. Estudo das reverberações, sobre de que maneira e porque algo pode reverberar em instâncias de ramificações, em produtividade ou improdutividade.

Dimensão estratégica. Relaciona-se com a visão pragmática da comunicação. Planejamento e gestão.

\begin{abstract}
Alinha-se, estrategicamente, por meio do planejamento e da gestão, aos objetivos globais da organização e aos princípios estabelecidos em relação a sua missão, sua visão e seus valores. De acordo com Putman, ( 2009 p 48-49 ), a metáfora do vínculo direciona o foco da transmissão e o processamento da informação para a conexão, assim, a comunicação é o elo que cria vínculos entre pessoas e forma organizações com redes de relacionamentos.[...] Quando se fala em comunicação organizacional, há que se ter em vista, sobretudo, a comunicação humana e as múltiplas perspectivas que permeiam $\mathrm{o}$ ato comunicativo no interior das organizações, Em primeiro lugar, temos que pensar na comunicação entre as pessoas e que os seres humanos não vivem sem se comunicar. $\mathrm{O}$ ambiente organizacional é uma realidade social vivenciada por pessoas que nela convivem. Estas necessitam, ser consideradas e valorizadas no fazer comunicativo diário, sem ser sufocadas pelo excesso de comunicação técnica e persuasiva, focada somente nos resultados e nos interesses dos proprietários e nos lucros da organização. [...] “ As organizações são formadas por pessoas que se comunicam entre si e que por meio de processos interativos, viabilizam o sistema funcional para sobrevivência e consecução dos objetivos organizacionais em um contexto de diversidades conflitos e transações complexas. ( KUNSCH, 2010, pg 47-48).
\end{abstract}

Segundo James Taylor “ ( 2005 - pg 215 ) “As organizações se auto-organizam e fazem como resultado da dinâmica da interação local. A auto-organização é um fenômeno comunicacional”. 
Esta total envolvência da natureza humana na comunicação faz com que esta seja entendida, em sentido geral, como o conjunto das interações que os indivíduos efetuam uns com os outros, com a natureza, com as organizações sociais, com as instituições e ainda o relacionamento que cada indivíduo estabelece consigo próprio. Daí o foco da comunicação não ser apenas um meio ou um instrumento à disposição dos indivíduos, dos grupos formais ou informais, organizados ou inorganizados, para dar a conhecer fatos, acontecimentos, pensamentos, ideias, vontades ou afetos, mas também, um processo relacionado com a constituição da esfera pública, esfera responsável pela criação e pela manutenção de regularidades que ditam as normas de conformidade e da convivência, das ações Evaristo Fernandes (2000:21 apud KUNSCH, PG 52).

As pessoas por vezes são colocadas como momentos, quando somos do tempo, ele por inteiro, mesmo que por segundos.

$\mathrm{O}$ ontem, que o futuro espera chegar a ser um dia. Comunicação e contextos - a dissipação

Conforme Jean Chanlat, não se pode reduzir a comunicação humana a uma simples transmissão de informação, pois esta visão estaria iludida não considerando em sua complexidade sentidos e significações do comportamento organizacional. E, segundo Gary Kreeps, a comunicação é um processo dinâmico e contínuo, sendo um elo de trabalho que unifica, interpretando as necessidades e as atividades que sempre estão transmutando, havendo de entre os sistemas de mensagens haver a capacidade de reconhecer e interpretar de maneira a propiciar respostas de maneira a mais variada e em grande diversidade de situações, onde se constata também para este autor que a comunicação é uma realidade inevitável de pertinência a uma organização e da vida em geral. Desafio será sempre minimizar os ruídos e suas consequências para que ocorra sempre uma boa comunicação e ainda um bom entendimento, gerando a compreensão e conhecimento, quando até mesmo, propiciar a construção de afetos. As mediações são um meio de se efetuar concretamente comunicações que estabeleçam critérios para um esforço em conjunto gerando um avanço nas perspectivas das realizações dos objetivos organizacionais.

As organizações (sistemas vivos) são compreendidos como resultados dinâmicos de relações entre sujeitos que se realizam como forças em diálogo, selecionando, circulando, transacionando, e construindo significação por meio de processos comunicacionais. Pela comunicação ou significados que constituem a cultura organizacional são postos em circulação, disputados, construídos e transformados para novamente, experimentarem certa estabilidade como significados organizados/organizadores. Complexos de diálogos e significação, permanentemente (re) tecidas pelos diferentes sujeitos - seus imaginários e suas subjetividades - as organizações são/ estão tensionadas ao entorno sociocultural perturbando-o e sendo perturbadas por ele. ( BALDISERA, 2010, pg 61). 
Claramente se constitui um diálogo entre o indivíduo, a sociedade e as organizações, isto porque dentre as demandas, os objetivos e as capacidades, é devido também a propensão de onde poderá ocorrer a união dos conhecimentos com o lugar de instrumentalização para que em via de mão dupla se conjugue o alcance do objetivo, neste caso, para ambos conjuntos de possibilidades, entre indivíduo, sociedade, organização. Isto porque não se pode determinar um poder quer ele esteja sobre a égide do Estado ou de um instituição, despreciando o capital cognitivo ou de capacitação em conhecimento de cada indivíduo, portanto, necessariamente creio ser o mais adequado a visão entrelaçada dos esforços mútuos, até porque assim, não se tem, domínio, nem subjugação, mas equalização das partes, havendo desenvolvimento em geral. Lembrando que para que isto ocorra de maneira equilibrada, presume-se que estejamos abertos a considerar adaptações, e o sentir o mundo do outro. E, ver a vida como produto de nosso tempo, considera o trabalho também, como o fator que promove dignidade, inclusive como espaço social, havendo de localizar o indivíduo dentre os direitos e deveres em uma sociedade. Creio ser também, por esta razão que as condições do trabalho e do trabalhador, sejam tão importante do tempo vigente, até sendo fator de observação do marketing de relações internas, porque ficou claro que as mesmas, ou seja, as condições, são fator que desencadeiam melhor ou pior produtividade. Isto, sendo também primordial para as condições do viver, enquanto membros de um conjunto maior, a sociedade com como um todo.

Certas condições sociais expostas até mesmo como familiares, ou ainda por determinadas condições podem ser vistas como ausentes da categoria de trabalho formal, porém em suas reverberações geram estados de dificuldades com notáveis déficits sociais e jurídicos muitas vezes, porque não oferecem uma visão a longo prazo, que não observa fatores em progressão e até mesmo riscos do acaso, ocasionas pelas mais diferentes razões. Portanto, neste patamar do que é direcionado ao trabalho, acreditamos que para uma sociedade saudável deve-se estabelecer uma visibilidade plausível de estar participando de alguma forma de maneira concreta, das relações individuo, familiar, organizações, governo, isto colocando cada um frente a sua parcela de cidadão, onde o trabalho o engendrará na sociedade de maneira mais produtiva e consciente!

Quanto mais se tem, a razão plena de suas capacidades emocionais, intelectuais, e de força de trabalho, no contexto em que se está inserido, e quais os propósitos das ocorrências cotidianas, mais se pode ter discernimento, de por onde ir. O respeito em um ambiente de 
trabalho deve começar com indivíduo para com ele, porque vivemos tão engolidos no cotidiano que não percebemos o quanto que nos desrespeitamos em nossos próprios sentidos de vida, absortos que estamos e amortecidos, pelas exigências ( muitas delas de fato, consistentes, quanto ao que é de subsistência, e outras por dominação de fatores externo com possível conivência interna ), porém, há de constatar também, que a alma do ser vivente também precisa pulsar, porque o ímpeto que ele terá em seu dia-a-dia, precisará estar também com a força que o permeia enquanto espírito. Para ser seus outros dele mesmo, ele precisa se respeitar, podendo assim, compreender, por onde ele pode se encontrar também, no trabalho, nas relações pessoais. Assumir um posicionamento de respeito a integridade e capacidade dos seus enquanto indivíduos que comportam a empresa, organização, sociedade, torna-se fundamental mediante sabermos que tanto nas relações de indivíduos como de empresas temos os que incentivam o desenvolvimento e os que restringem e subjugam de forma a privar o direito de crescimento, muitas vezes gerado por insegurança de uma das partes, assim como da reflexão, pois esta pode dar elementos para a razão encontrar na consciência o movimento que irá até mesmo nas situações adversas ser capaz de transmutar-se para ir em direção ao desenvolvimento e seu crescimento, como indivíduo, como partícipe de uma instituição, de uma sociedade, portanto, é necessário que a razão esteja de maneira a equilibrar os fatores colaborando para o bem geral, tanto do indivíduo, como das organizações, promovendo o alcance de objetivos para ambos, sem entraves de ordem de estabilidades de gestões ou particularidade de perfis pessoais. $\mathrm{O}$ incentivo, é força que tem capacidade de agir em movimentos construtivos, torna-se um impulso propulsor que na maior parte das vezes, se não em todas, gera bons frutos. Diretamente relacionado a estes fatores estão os desejos e satisfações, e fica claro que aos que são de alguma forma restritos ou restringidos ao seu papel social, a insatisfação está presente e reverbera de maneira não saudável no organismo social como um todo. E, é importante salientar a força do hábito presente como fator de convivência cotidiana, isto porque exerce força no caso de subjugação contrária ao desenvolvimento e pode até tornar-se imperceptível, havendo de em algum momento no sistema, se encontrar com alguma vazão de forças à favor que promovam o direcionamento de um rumo em acordo a vontade de desenvolvimento. Veja que isto pode ocorrer em todas e mais variadas formas de mediação de relacionamento, onde deve-se estar atento para a preservação da liberdade humana, que não se restringe a papeis sociais, mas ao sermos de fato seres que vivem e que precisam estar conscientes de suas possibilidades integras e em dignidade na relação com a liberdade de trilhas seus caminhos, na direção do que podem alcançar para seu lugar de fato e de direito na sociedade como um 
todo. A comunicação e a reflexão será sempre um fator de esclarecimento das condições do indivíduo, fator este que muitos não aceitam porque podem gerar diante do esclarecimento as reivindicações de direito que podem levar a mudanças, e enfim, é fundamental pra um indivíduo e a sociedade o educar o pensamento de maneira a estar sempre em arguição própria do que deseja como espírito( mente) partícipe do mundo, com responsabilidades e direitos, de maneira a promover inclusive a justiça. Portanto a comunicação, também exerce o fator social de esclarecimento, daí também advém a responsabilidade dos meios principalmente de veículos de comunicação de massa.

Á luz do que se disse, pode-se afirmar que as organizações são resultados dinâmicos de relações entre sujeitos que se realizam como forças em diálogo. As organizações são, pois, sistemas vivos permanentemente (re)tecidos por sujeitos em processos comunicacionais, pautados por seus imaginários, culturas e subjetividades. [...] Por meio de imagens significativas do mundo, vamos tecendo nossa identidade: somos a imagem do mundo, que de modo criativo refletimos em nossa interioridade e projetamos em nossa práxis. ( BALDISERA, 2010, pg 68).

Organizações como sistemas vivos. ${ }^{298}$ Dimensão cognitiva da vida - um sistema em EQUILIBRIO não comporta subjugação! E importante, um elemento, não pode estar em um sistema mesmo com órgãos ( como o corpo) responsáveis por condutas, inseridos de maneira a que seus integrantes venham a perder a identidade, com o domínio de uma hierarquia. A independência do pensar, do sentir, da dignidade do indivíduo com responsabilidade deve ser preservada mesmo com os representantes, posto que se não for assim, não poderá haver igualdade, nem FRATERNIDADE, mas sim, uma organização disfarçada por autoridades que não percebem que seus integrantes se perdem ao estarem com receio de se manifestarem, de se colocarem, de expor seus sentimentos e pensamentos. Cuidado para não perder o respeito dos indivíduos que constituem uma sociedade, organização, porque o direito a voz, é um princípio e o conhecimento é de todos, uma vez, que sempre podemos aprender uns com os outros, se tivermos humildade de reconhecer isso.

Certos princípios são de nossa gênese, como valores, e portanto, cabe em qualquer momento estarmos cientes sabermos que o movimento pode ocorrer, de aproximação ou não, até porque já tratamos de imagem, em relação também a quem ou qual empresas nos reservamos o direto de romper, ou preservar mediações, isto porque, tanto nas relações pessoais como de organizações, determinadas posturas nos são afins ou podem gerar uma

${ }^{298}$ Sousa, Carina Gonzalez Y. Composição Baile da Alvorada. PIANO 
necessidade de afastamento. A reflexão também promove coerência com parcerias, em relações ou organizações.

Constituir-se em organização pressupõe articular subjetividades objetivos e, portanto, tensionar diversidades e desejos, interesses, culturas, imaginários. Como forças em diálogo, os sujeitos mesmo quando se apresentam nulos no âmbito organizacional, selecionam, circulam, transacionam sentidos e, de alguma forma, perturbam a organização implicando algum nível de transformação. Como sistemas vivos, às organizações são resultados dinâmicos das relações que elas atualizam com o ambiente (outros sistemas) e das relações que os sujeitos estabelecem entre si e com elas. ( BALDISERA, 2010, pg 73).

A memória de uma organização não se perde, por ver novos rumos, ao contrário demostra humildade de pertencer ao seu tempo. Das gerações e os espaços sociais, as conexões através do tempo. Relações que atravessam a linha tempo linear, para se encontrar entre desafios anteriores e aprendizados ainda presentes como conhecimento que orientam.

O que vem a ser o futuro, se não a construção do presente, que é estado perene do passado, em definição, uma linha temporal, que se desenha, por um círculo.

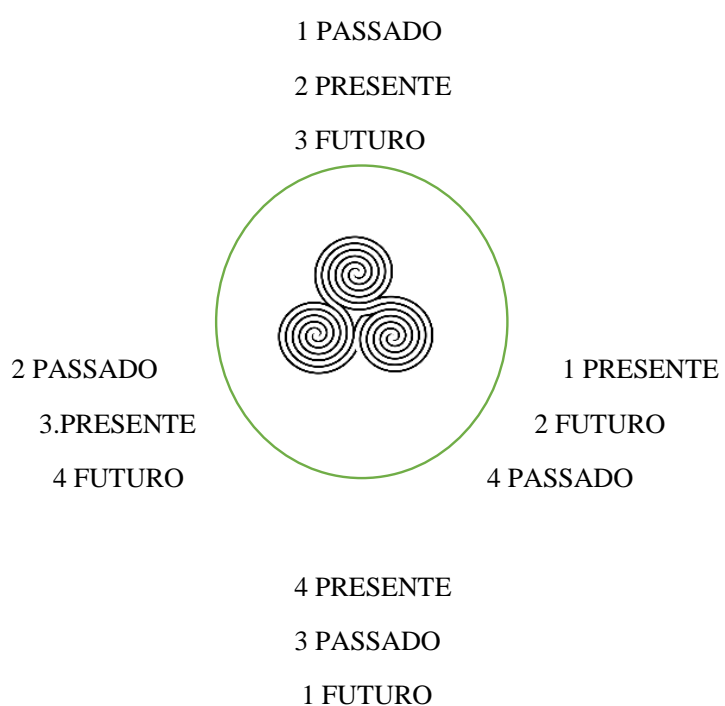

\section{FRACTAIS DO TEMPO - ESPIRAL}

Outra característica desse modelo emergente de organização é que ele seria também um sistema caótico, uma espécie de organismo, organização ou sistema autorregulado que combina de modo equilibrado os estados de ordem e caos. Sistemas assim são estruturados de modo a não ser inteiramente tomados seja pelo caos, seja pela ordem. São autoorganizados como o são todos os sistemas do mundo natural. (MARIOTTI, 
2007)[...] Essa perspectiva, que reconhece tanto a autopoiese ${ }^{299}$ do indivíduo como a da organização social, impõe que tratemos das duas dimensões provocadoras deste texto: a autonomia e a interdependência, como categorias que demarcam os espaços de negociação entre organizações e indivíduos trabalhadores. ( CURVELO, 2010, pg 87)

A autonomia e a interdependência sistêmica.

Na produção autopoiética, contudo, os sistemas, para serem autônomos, precisam recorrer a recursos do meio ambiente. Isso pode ser paradoxal uma vez que envolve ao mesmo tempo autonomia e dependência.[...] Para Norbert Elias - para o fluxo constante da vida - "Elias, com seu conceito de teias de interdependência, explicaria como os indivíduos se orientam uns aos outros e se unem em conexões e teias, desde grupos pequenos até agrupamentos maiores, como os que gravitam em torno das grandes organizações. Diferentemente ( para este autor ), de Luhmann e de Maturana e Varela ( 2001 ), Elias parte da tese de que não existem fronteiras nem limites uma vez que as cadeias orientadas pela interdependência escapariam a definições mais abrangentes. [...] Com a contribuição de Elias, que dá um novo sentido social ao denominado acoplamento estrutural, outra categoria se agrega a esse contexto: a das teias de interdependência, que tal qual organizações efêmeras se inscrevem como agentes que canalizam desejos, pulsões e sentidos. ( CURVELO, 2010, pg 89).

O que se entende como trabalho, deveria ser o primeiro ponto a ser estudado. Viver com dignidade pode ser um trabalho? O que seria essa dignidade enquanto valor de inserção em comunidade social, havendo de responder sobre direitos e deveres, e ter como subsistir. Como compreendo a organização do existir? Estaria eu disposto a realizar o meu trabalho em viver? Como posso compreender a vida e sua gestão que me insere como força e energia movente de trabalho, ainda que por vezes em revelia e condições não próprias ao trabalhador? O que a própria vida me ensina do que é ou pode ser um trabalho? Como meu empenho no trabalho da vida, modifica e esclarece as relações em que estou participando?

Comunicação, é o processo que se realiza na/pela interação de sujeitos determinados, históricos e que se inter-relacionam a partir de um contexto, compartilhando sistemas de códigos culturais e, ao fazê-lo, atuam ( agem ) produzindo, renovando sociedade. ( FÍGARO, 2010, pg 94).

\footnotetext{
${ }^{299}$ Autopoiese literária: Possibilidade em investigação quando se trata de narrativas em construção que se retroalimentam de outras narrativas inseridas no corpo da complexidade do texto.
} 
O propósito: a interação pode ocorrer de muitas formas, em geral creio que na sociedade atual nos defrontamos com a presença da necessidade de um propósito, visto que, existem muitas desigualdades, tanto materiais como espirituais, e assim sendo, a integração ou interação, por vezes deve ter um objetivo visando a preservação também, quando primordial para a vida do ser, ou seja, ter a conduta de não se integrar pondo em risco a vida ou sobrevivência, o que fica claro em medidas de precaução, isto vale para relações pessoais, para introdução em mercados de culturas diferentes, para observar possíveis riscos, e também para relações políticas. Observamos que segundo Fígaro, a comunicação é vista como interação de sujeitos determinados, em interpelações a partir de um contexto, "compartilhando sistemas de códigos culturais e ao fazê-lo, atuam produzindo/renovando a sociedade - estamos discutindo a conexão entre as macroestruturas e a atividade. “

Linguagem e o mundo que nos cerca, se torna lugar de sentidos representados em sinestesia, lembrando o cineasta Eisentein. Como se formam a palavra era a pergunta. No sentimento do pensamento. Talvez até mesmo, antes, para os que assim podem encontra-la, sentimento, imagem em conjunção. ${ }^{300}$

Trabalho e a sociedade. O trabalho e a sobrevivência. Comunicação como valor entre o trabalho de um viver ${ }^{301}$. Ao considerarmos que a palavra tem sua diversidade (aqui não somente de significados dependendo do contexto ), mas, de formas de expressar-se, podemos vislumbrar o que em um discurso considerando seu conteúdo podemos encontrar de pontos de consenso ou seja, se em uma palavra ( considerando em paralelo, como o indivíduo ), podemos, buscar na representação as de sua diversidade a confluência com o discurso ( imagem, etc ) da sociedade, de governos, de instituições e organizações, de que maneira essa junção quando ocorrem discordância podem acontecer de se entrelaçarem em uma harmonia? Algum desses elementos, podem ser um aspecto no sistema de entrelaçamento que forneça informação e comunicação abrangente a ponto de sintonizar um aspecto comum ou de extensão.

Aonde o discurso de uma identidade pode dialogar com o outro, em vozes de confluência, exemplo sensível pode ser encontrado nas Fugas e Cantatas de Bach.

Distinções e entrelaçamentos - o mundo do trabalho e as organizações - ambos acontecem no campo dessas dimensões. Segundo Cavalcante, "Os processos de comunicação das

\footnotetext{
300 Eisentein Serguei. O sentido do filme. São Paulo Zahar, 2002.

${ }^{301}$ Sousa, Carina Gonzalez Y. Composição: Sagrado da Natureza- FLAUTA. Composição: Natureza das leis de Deus, dos homens e do direito. PIANO.
} 
organizações são marcados pela experiência simultânea de ler o mundo e pôr em prática ação e discurso “.

Como interagem modelos culturais, o que até mesmo entendemos como cultura, os atores sociais, em seus intercâmbios como indivíduos em sua particularidade e sua inserção social, podem nos valer para indagar sobre posturas de relações da comunicação.

“ São processos de comunicação que ganham ida graças a duas experiências fundamentais, simultâneas e interdependentes. Uma é a experiência de ler o mundo, de se conectar, captar e interpretar informações de toda ordem, natureza e complexidade, dispersas no universo cultural. A segunda experiência é a de pôr em prática arquiteturas discursivas, por meio de mensagens objetivas e simbólicas que visam criar significações específicas diante do universo cultural, em um laboratório de simbolismos orientado pelo desejo das organizações de serem vistas, percebidas e interpretadas de maneira específica pelos seus públicos de interesse.[..] $\mathrm{O}$ ambiente social, compreendido como o universo no qual se insere a organização que se comunica, é o locus privilegiado dessas simbologias, tendências e significações onde se constroem a todo instante os atos, discursos e comportamentos sociais. Trata-se, portanto, de um espaço da cultura e da comunicação como experiência de humanização e de organização ( CAVALCANTE, 2010, pg 112 ).

Cavalcanti ainda se questiona como de fato é realizada a leitura do ambiente social. Até que ponto o ambiente é pelo indivíduo interpretado ou seremos capazes de nos inserir nele de maneira a respeitá-lo com seu modo de ser, para compreendê-lo? Ou seja, poderemos interpretar o ambiente de maneira mais lúcida e imparcial havendo portanto de constatar a presença de seu modo de ser, independente de minha razão em força que o atrai ou repulsa, e consequentemente buscando assim uma clareza que é capaz de revelar demandas, propriedades, propulsões etc. Porque isso? Porque sendo assim, esse estado de procura de imparcialidade com o ambiente, ao ausculta-lo, requer um movimento de distância do ego, propiciando a escuta do que de fato pode precisar ou necessitar e de fato ser mais verdadeiro.

Se tivermos a capacidade de vermos o ambiente como um ser orgânico, poderemos nos desvencilhar de um hábito de nosso próprio olhar, para adentrá-lo e então, em maior nudez, e "configurar" uma aproximação mais producente e capaz de ter discernimento. Nos desvencilhar de certos hábitos cognitivos e principalmente de olhar o mundo para buscar sentidos que nos a abracem como um todo. Em parte se relacionando com o que dizemos de sujeito ambiente Cavalcanti sugere sobre a necessidade de interpretar o ambiente de maneira que se encontre respostas para presença externa ( que é parte nossa e na qual estamos 
inseridos ), como ele cita, escassez de recursos, competição, concorrência, porém advogo que poderemos encontrar ou ser agentes de propensão de capacidades, onde os interesses internos se validam e se realizam com o desenvolvimento em conjunto.

O pensar do corpo orgânico da sociedade carece de um conhecimento de seu pensar, em sua diversidade de instâncias, mas que tem possivelmente um cerne, uma conduta que é o próprio cotidiano em amostragem visível de seu sangue em natureza de sobrevivência. As interfaces, entrelaçamentos e posturas cognitivas capazes de assimilar, aprender, co-criar, re (conhecer), desenvolver, experienciar e novamente, diagnosticar.... Diagnóstico (observação isenta ( estado constante de atenção ) - interpretação - representação ). A demanda e o target.

Entre origens e reverberações - (social e interações dos indivíduos e o meio) - dos estados compartilhados - ( e sobre o que seria forjado como diz o texto ). Vendo um estado em mutação em conformidade com o meio, e não como objetos que se apresentam forjados devido a condições de interferência na emissão de comunicação inicial, porém, como tudo tem o seu dizer é devido pelo próprio que a profere, ser fonte de estudo e reflexão. Mas, ainda mesmo assim, penso que não é por interferência em um sistema que este fica inválido quanto a sua procedência fidedigna, mas ainda assim, de fato, por alguns vieses, se tem uma interferência que deturpa o estado inicial de maneira a não ter correspondência, ou coerência, isto por que acredita-se que teremos para as conexões adversas possíveis que sejam do sistema, fatores estes que possam ser integrativos, ou quer estejam de maneira a serem posteriormente conectados. Agregando informações e comunicação nas relações. Sentidos - interpretações - novos sentidos, tecendo significados. Cavalcante ressalta ainda que, no ambiente cultural temos um repertório cultural, onde nos processos de comunicação a organização formula discursos, consolidando a imagem, até mesmo como patrimônio, vindo a criar conceitos novos, passando a exercer o papel de protagonistas culturais, e onde ele aponta que: “ Parece inadiável a construção de uma noção de realidade social na qual se considerem de fato as opiniões e visões de mundo dos atores sociais, se dialogue com eles no plano objetivo, mas também no plano subjetivo, e se façam conexões com as expectativas e tendências presentes no campo do simbólico “.

Segundo Vergara e Branco:

Uma empresa humanizada é aquela que, voltada para seus funcionários/ e ou para o ambiente, agrega outros valores que não somente a maximização do retorno para os acionistas. Realiza, ações que no âmbito interno, promovem a melhoria na qualidade de vida e de trabalho, visam à 
construção de relações mais democráticas e justas, mitigam as desigualdades e diferenças de raça, sexo ou credo, além de contribuem para o desenvolvimento das pessoas sob os aspectos físico emocional, intelectual e espiritual. (VERGARA, BRANCO, 2010 pg 143).

O fato de que o homem é capaz de agir significa que se pode esperar dele o inesperado, que ele é capaz de realizar o infinitamente improvável. [...] O discurso corresponde ao fato da distinção e é a efetivação da condição humana da pluralidade, isto é, do viver como ser distinto e singular entre iguais. [...] Sem o discurso, a ação deixaria de ser ação, pois não haveria o ator, e ao ator, o agente do ato, só é possível se for, ao mesmo tempo, o autor das palavras. [...] Nenhuma outra atividade humana precisa tanto do discurso quanto a ação. Na ação e no discurso os homens mostram quem são, revelam ativamente suas identidades pessoais e singulares e assim apresentam-se ao mundo humano. [...] Esta qualidade reveladora do discurso vem à tona quando as pessoas estão com outras, isto é, no simples gozo da convivência humana. (ARENT, 2010 pg144).

Certas práticas de relacionamento também exercem um enfrentamento cognitivo que vem a ser da observação anterior a experiência, posto que esta minimiza possivelmente danos experienciais dos quais não precisamos, isto torna-se importante em um meio em que o tempo é quase sinônimo de sobrevivência, e para mais do que este aspecto, é tanto melhor se nos desenvolvermos a partir de conexões e relações de acertos e não de erros, apesar de corriqueiramente chamarmos de aprendizado, quando a experiência em geral não deu certo, mais um fator para preferirmos não correr este risco, e então, como saber? No mercado me parece que poderemos ser engolidos ou desaparecer, caso ocorra um erro dependendo das proporções e em paralelo, um divórcio entre a empresa e o consumidor, mas então, observar torna-se necessário, até sendo objeto de estudo em marketing para na comunicação alcançar sempre os objetivos de satisfação com os menores riscos, e para isso existem certas estratégias, que o mercado conhece muito bem, prevalecendo sempre a ética e nas relações humanas de toda ordem, o que não fere os direitos nem internos e muito menos externos

O que o tempo dirá, e o retorno as conjecturas anteriores e as emissões. Por uma racionalidade na complexidade da sociedade contemporânea.

Desafio: Não somente estar aptos a enfrentar uma complexidade contemporânea mas de enfrentar uma expansão não linear, ou seja, discernir sobre aspectos relevantes que estejam presentes como cognição dos aspetos evolutivos, ou seja, permeados por valores intrínsecos e exteriores, das esferas particulares e globais ou externas. Isto posto, é em certa medida, fácil enquanto discurso, porém, como já também creio que parece lícito constatar, a presença 
de esta questão em prática, é algo muito difícil e que exige uma razão pronta a ter o discernimento suficiente para pautar reflexões que esclareçam o percurso, que possam ter a transparência suficiente para alcançar o objetivo, ou o propósito. Estes últimos apontamentos, servem para ainda nos levar a um pensar, de como essa razão pode em uma complexidade não linear buscar os elementos suficientes e relevantes para que a ORGANIZAÇÃO, se mantenha com as diretrizes e possa abarcar elementos suficientes que determinem as confluências ( 1 ) (com elementos externos, adjacentes do próprio sistema ), os fatores ${ }^{\mathrm{i}}$ com propriedades de desencadeamento,( 2 ) propagação, ( diagnóstico desses fatores ) em desenvolvimento de trabalhos futuros, (3)

\section{Reafirmar, diretrizes e confluências}

Diretrizes - Claras - objetivas

Confluências - aspectos em diversidade - quais são de equilíbrio - ou continuidadede divergência, por vezes um fator de divergência é relevante quanto inclusive ao movimento que pode engendrar nas estruturas vigentes, ou para fundamentar e aumentar os aspectos vigentes, ou em movimento realizar argumentos em dialogo que possam prover novos estados não diagnosticados, havendo sempre de ver o quanto pode de fato sem fator de risco ao sistema conjugar certas divergências.

2. Fatores ( intrínsecos ou não ) - desencadeamento. Existem aspetos que tem em seu modo de ser e operandi, aspectos que tem características para um desenvolvimento. Como isso ocorreria? Ao observar os objetivos e o que em torno dele se fazem ambiente, poderemos em princípio inferir desses territórios elementos que mostram que tem probabilidade de se tornarem mais desenvolvidos, e que por vezes, em falta de observação pelo próprio hábito que o sistema- organização opera não o torna visível ou aparente. Após este início, penso que podem ser feitas dentre após o diagnóstico, e um mapeamento de futuras ações que comportassem esse novo fator que desencadearia um desenvolvimento, esse mapeamento seria em hipótese um percurso plausível de suas ações compartilhadas com o sistema- organização já vigente, discernir possíveis riscos tanto para um como para o outro, e após esta fase, creio que poderia se criar um protótipo de ação, para compor esse elemento na orquestra, ou seja, e havendo dados que validem tal conduta em escala, pode-se colocar em prática do sistema em expansão, essa confluência em desenvolvimento. 
3. Propagação - O percurso seguido em desenvolvimento deve se ater aos mesmos princípios de elucidação quanto ao estado para não decorrer em eventuais contratempos. A propagação de um elemento novo inserido, é habitualmente com o tempo, parte do mesmo, e agregando assim sucessivamente novos fatores eminentes de apoio e com probabilidade de expansão. Há elementos também que podem ser encontrados ( 3 ) como, o que é importante, elementos de equilíbrio ainda que não de expansão, mas fundamentais.

O não linear além de comportar a expansão, também inclui uma maneira particular de observar ocorrências de lastro, sendo capaz de discernir ainda da procura também fatores em benefício a organização, certas ocorrências passadas, sem prejuízo ao desenvolvimento. (ou seja, o clássico, isto poderia ter sido diferente, com outros resultados, por vezes somente percebido em outro tempo mais adiante).

Se analisarmos aprofundadamente esse aspecto relacional da comunicação no dia a dia nas organizações, interna e externamente, percebemos que elas sofrem interferências e condicionamentos variados, dentro de uma complexidade difícil até de ser diagnosticada, dados o volume e os diferentes tipos de comunicações existentes, que atuam em distintos ambientes sociais ( KUNSCH, 2006, p. 176 ).

Claramente estar aberto à relações requer saber que se encontrará diante de dissensos, salientando a prática da percepção também como fonte de um diálogo onde poderá haver ainda entre diferenças, espaços de confluências ou convergências, tanto em individualidades como dos espaços sociais.

\footnotetext{
" O entorno da organização é um continuum de sucessos emergentes, no qual significados novos e imprevistos surgem na cotidianidade dos fatos corporativos a partir das relações entre os diferentes públicos. Neste marco, a comunicação assume um novo papel como processo que permite construir e gerir realidades compartilhadas.[...] Dessa forma, entramos em uma nova década colocados diante da necessidade de preparar-nos a fundo para viver em uma estrutura de multiplicação das situações inesperadas, de heterogeneidade e diversidade dos atores envolvidos nos processos econômicos, políticos e sociais, e de desenvolvimento exponencial das variáveis que condicionam a vida produtiva em diferentes setores econômicos e sociais. ( MANUCCI, 2010, pg 173).
} 
Manucci, alerta para estarmos aptos as mudanças que redefinem permanentemente entre os sistemas complexos do âmbito social e econômico, mais uma razão para adentrarmos a hipótese da necessidade da ressonância, explicando em paralelo com a representação do modo de ser da música, onde temos compassos, um após o outro em sua suposta efemeridade, e em parte individualidade, mas que em conjunção no decorrer encontra sua ressonância e harmonia, ou sentido, e então, argumentamos que apesar das constantes redefinições adentraremos a possibilidade de as mesmas estarem sobre continuidades de maneira a se estabelecerem sobre uma estrutura que seja capaz de conceber estados tanto efêmeros, ou restritos a um determinados espaço-tempo, mas que tem sua projeção e propulsão dentre os que em conexão com eles, apesar da individualidade se conectam, e se expandem em desenvolvimento.. O equilíbrio, nem sempre é fácil ou estável, mas uma conquista dentre (e com) o instável.

Explica-se que, as estruturas apesar de possuírem determinações ainda podem ser variáveis em seu decurso conforme as conexões e ainda, por suas possíveis alterações por adaptações. Considerando a compreensão de um sistema que seja constituído por um padrão de $\mathrm{x}$ tempoperíodo, e este em si é composto por uma gama de diversidade na qual se observa instabilidades que devem ser ainda mensuradas em graus ( das conexões) em porcentagem por maior alcance de resultados ou eficiência, podendo ser as análises combinatórias dos elementos de maneira aleatória ou programada, ( resultando em índices de produtividade ) assim teremos sequências com $\mathrm{o}$ mesmo $\mathrm{x}$ tempo padrão-período, mas que possui diversidades internas e que em suas sequências se observa ainda, tempos diferentes segundo o resultado, e este ainda podendo se

subdividir em relação ao inicial, como tempo ganho e tempo ganho contínuo.

\begin{tabular}{|c|c|}
\hline X TEMPO & -PERÍODO \\
\hline 1 Análises co & nbinatórias \\
\hline $2 . \mathrm{ACN}$ & \\
\hline ganho) & \\
\hline 3. ACN TRP & \\
\hline
\end{tabular}

4. ACN TRD

desenvolvimento
Estruturas e conexões

ACN - Análises combinatórias novas - TR(tempo de resultado

ACN_TRM - Análises C. N. com tempo de resultado permanente ACN TRD tempo de resultado com características de 
No item 2. Argumento que para cada análise combinatória nova se mensura o GI- o grau de instabilidade (em relação a combinação inicial das estruturas para o x tempo período) porém, e ressalta-se ligada a eficiência. No item 3. Aferição da permanência de eficiência, e no item 4 a observação de os elementos da análises possuem capacidades de desenvolvimento e esse desenvolvimento pode ocorrer por diversas razões, entre elas, elementos adversos ao sistema que se integram, ou as próprias atualizações realizando interlúdios com os fatores por conexões possíveis de desmembramentos dos mesmos.

Se observa portanto, a propriedade de um sistema estar em movimento interno, e que pode ter sobre essa relação ainda como subconjunto abrangente uma permanência.

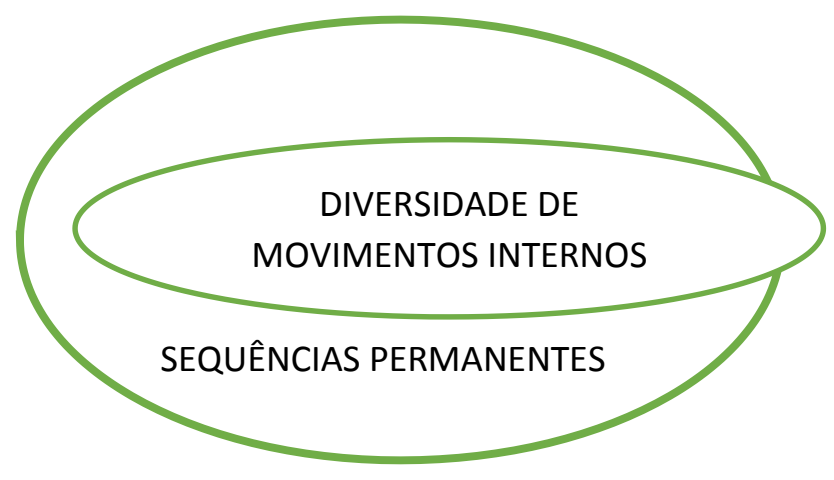

\section{SISTEMA VIVO}

Viver em movimento. Organismos vivo ( Weil, 1995), em modo de ser, uma cultura organizacional é um conjunto de valores, conhecimentos e costumes ligados a uma visão não-fragmentada do mundo em que a organização é considerada um organismo vivo em constante movimento, constituindo um sistema de eventos com uma constante interação e interdependência de sistemas maiores ou menores. Porém como abordam Lima e Albamo, há de se saber que enfrentaremos paradigmas, que funcionam como entraves, diagnosticados por eles como: autocracia, desconfiança, conformismo, e individualismo, sendo de fato barreiras concretas as mudanças necessárias quer estejam como indivíduo, organizações e demais aspectos do viver,.

O desafio maior que a instabilidade pode conter, e que em parte o responde, é a capacidade de conexão.

O desafio de viver em movimento implica preparar-se para viver saltando de um cenário para outro, em diferentes sistemas e com níveis distintos de instabilidade. Um primeiro 
aspecto ligado a esse desafio tem a ver com a incerteza gerada pelo movimento (o movimento também é capaz de aliar diversidade em harmonia), e o enfrentamento dessa dinâmica sem o custo dos sintomas.

Risco de sobrevivência - passagens sem benefício e prejuízo de razão. Ou seja, em qualquer movimento onde não se tem a clareza dos propósitos dirigidos a uma razão que contemple benefício lícitos de causa, se compromete os resultados com risco explicito e visível. Curiosamente pode se considerar que se colocou a própria vida da " organização " em risco, sendo que o que pode ser aferido, é que, não foi dessa forma, mas a indução dos erros realizados que levaram a essa conduta, portanto, em ultrapassando-se todos os limites, a resposta em medida, adverte-se que não isenta uma suposta culpa de risco de sobrevivência, mas, que certamente colaborou efusivamente para essa ocorr $\bigcirc$ ia .

A rigidez dos sistemas humanos é uma condenação à enfermidade, o que, do ponto de vista econômico, implica perda de competitividade e risco de sobrevivência.[...] Na complexidade da dinâmica social convivem muitos ciclos contrapostos em diferentes níveis de desenvolvimento. O futuro é a expressão de potencialidades sintetizadas em um conjunto de significados e está colado e contido em cada uma das decisões do presente como marco estratégico que permite avançar no desconhecido. [...] " O primeiro aspecto relacionado com o desenho de possibilidades tem a ver com a percepção de realidades alternativas. $\mathrm{O}$ desenho de possibilidades parte de uma dimensão subjetiva. Nossas competências cognitivas, metodológicas e técnicas são da época do mundo previsível e por isso, em muitos casos, tornam-se disfuncionais diante da dinâmica do mundo atual. [...] Olhar a realidade como mapa de conexões permite um modo de abordagem da complexidade atual a partir de diferentes percepções sobre a dinâmica da realidade que construímos por meio de conexões. [..] Em um modelo corporativo baseado em sistemas complexos a comunicação tem um novo papel como processo que permite construir e gerir realidades compartilhadas. Trata-se de uma construção que determina o mapa de possibilidades e recursos futuros, no qual a visão clássica da comunicação como ferramenta de transmissão se transforma em um novo espaço para o desenho e a gestão dos significados cotidianos. [...] A realidade corporativa é uma construção desenvolvida pelos integrantes da organização. É um traçado de rota que permite a movimentação em um território no qual a informação sempre é incompleta. A realidade corporativa é uma trama de significados que interagem e se renovam entre os participantes da relação. Do ponto de vista da estratégia corporativa, essa concepção está presente em cada decisão que a organização delineia. Que forma ela dá a sua proposta? Como conceitua os seus públicos? De que maneira percebe a si própria? E de que forma percebe o mundo que o rodeia? A resposta a todas essas perguntas se traduz em conceitos que se constroem a partir de elementos isolados que vão tecendo realidades complexas a partir da interação, ( MANUCCI, 2010 pg 179-180). 
Poderemos nos perguntar que se apesar do movimento interno, em variáveis de combinações observadas para maior eficiência, como seria a identidade que nos constitui enquanto imagem, havendo tanta diversidade, o que nos lembra do item 3 , variação que ocorre e tem sua validação em permanência( imagem) e ainda tem a possibilidade da própria estrutura em si estar sempre em movimento com resultados diferentes, produtos diversos. Ou seja, poderemos ter uma variedade interna que produz uma imagem permanente em representação. Este modo de ser diretamente nos torna até mesmo aptos a considerar situações em tempos vigentes naturais de estarem sobre relações em diversidade isto para o que nomeamos por exemplo como o multiculturalismo.

Adentraremos consideravelmente no que chamo de CON- Cultura Organizacional de Nações - esferas sociais integradas em expansão.

Em parte adotaremos o pensamento de escalas, posto que visivelmente o complexo estado de relações que abarca a cognição se estabelece como modo de funcionamento e pensamento gerativo de condutas, acredita-se que assim acontece de entre individualidades, pessoa e o outro, dispondo-se para grupos, indivíduo-grupo- grupos maiores - instituições e organizações, e os mesmos e sociedade assim como modos de governo, portanto, em qualquer das instâncias consideradas, como possibilidades, de escala, estaremos considerando, a gestão dos recursos para a relações que sejam: respeito, observação de capacidades-oportunidades, valores éticos, funcionamento, participações ativas e reflexivas entre as partes - geração da ação comunicativa ( agente e reagente, conexões partícipes do educar o pensamento co-existindo em práticas fáticas que se estabelecem em decurso, movendo consequentemente de maneira eficiente, promoção do bem-estar geral e produtividade, ou alcance de satisfação entre desejos e aspirações, e assim por diante. Posturas que assim procedem em expansão (por escala inclusive) se direcionam a uma boa compreensão do multiculturalismo e consequentemente um diagnóstico da globalização e seus efeitos, dentre os quais não estamos apartados mais integrantes.

Conforme Charles Taylor, “ O verdadeiro respeito à igualdade exige algo além do pressuposto de que novos estudos nos farão ver as coisas dessa maneira, ele impõe avaliações verdadeiras, de igual valor, aplicadas aos costumes e criações dessas diferentes culturas", e ainda Habermas considera: O regime democrático constitucional - "Se concordamos que o reconhecimento das diferenças entre culturas é o ponto de partida correto para um debate nacional sobre o compartilhamento dos valores humanos, devemos 
então concordar também que o regime constitucional é um arcabouço capaz de abrigar esse debate.

Portanto e ainda, sobre organizações, multiculturalidade, como corpo vivo entre disposições harmônicas, congruências e direcionamento, lembramos da colocação de Arthur Kostler, nas faces de Janu, sobre o hólon ${ }^{302}$.

Algumas conjecturas podem ser observadas nesse ambiente, e dentre essas perspectivas analisadas podemos retornar ao já descrito quadro de impulsos, estímulos, desejos e satisfações, interligados com pertencimento, e responsabilidades correspondentes. Dentre os valores e condutas expostos quais são posicionamentos favoráveis ao sistema, e que podem ainda ser acrescidos gerando ainda maior fortalecimento dos indivíduos e das organizações.

Além do caráter de informação das relações deve-se ir mais profundo, podendo ser visto como razões que levaram as mesmas (causas e fatos). A tecnologia - ampliamos a nossa capacidade de informação? Entre ilusões e uma real capacidade de discernir relevâncias informacionais. Entre o instrumento tecnológico e a percepção, o que pode ser constatado como elemento para um aumento de capacidade de informação. Diversidade, multiplicidade, complexidade e referência, conexões, relevâncias.

Adverte-se também para que, referência compreendida como o que se almeja, esta compreendida como perspectiva. A percepção funciona como um elemento " lógico", porque instaura no sistema uma forma de se deter a atenção em um fator, que emanou, que eclodiu, e que na equação do pensamento, ou ação, esteja inserido como o que considera dentre um protodiagrama, ou uma complexidade, não como sendo algo descartável, mas

\footnotetext{
${ }^{302}$ Descreve-se Hólon como: UM ORGANISMO vivo não é um simples agregado de partes elementares e suas atividades não podem ser reduzidas a elementares "átomos de comportamento" formando uma cadeia de respostas condicionadas. Em seus aspectos corporais o organismo é um todo constituído de subtodos, tais como o sistema circulatório, o sistema disgestivo, etc, que por sua vez se ramificam em subtodos de uma ordem inferior, tais como órgãos e tecidos e assim descendo para as células individuais e para as organelas no interior das células. Em outras palavras, a estrutura e o comportamento de um organismo não podem ser explicados por, ou reduzidos a elementares processos físico - quimicos. Consistem numa hierarquia bem definida e estratificada de subtodos que pode ser satisfatoriamente diagramada como uma pirâmide ou árvores invertida, onde os subtodos formam os nódulos e as linhas de ramificação simbolizam canais de comunicação e controle. O primeiro ponto a ser enfatizado é que todo membro dessa hierarquia, em qualquer nível, é um subtodo, um HOLON, de pleno direito - uma estrutura estável e integrada, equipada com mecanismos autoregulatórios e detentora de considerável grau de mecanismos auto-regulatórios e detentora de considerável grau de autonomia ou governo próprio. Células, músculos, nervos, órgãos, todos possuem seus ritmos intrínsecos e padrões de atividade, muitas vezes manifestadas espontaneamente, sem necessidade de estímulos externos. Subordinam-se como partes aos centros mais elevados da hierarquia, mas ao mesmo tempo funcionam como todos quase autônomos. Eles possuem as faces de JANO.( pg) A hierarquia não está posta como domínio ou subjugação, e sim como um encadeamento de complexidades
} 
importante a ser elencado para realizar dentre a diversidade, e multiplicidade, a informação capaz de realizar com a referência, conexões e propagações de esclarecimento e desenvolvimento. Portanto, não é neste caso, a percepção simplesmente ocorrendo de forma “ displicente “ ou ausente do sistema lógico e complexo, é um fator que desperta para justamente demostrar sua relevância para dentro do que inclusive pode se dissipar, até pela diversidade, como justamente o que irá promover conexões necessárias, ou úteis, por seu caráter informacional esteja esse caráter informacional, sendo de cunho sensível, ou de uma racionalidade, ou de ambos, fornecendo uma capacidade que mesmo sem tecnologia ou a favor dela, permite uma amplidão. Essa amplidão ocorre mediante não somente por unir a percepção - contendo ela mesma informação, assim como as suas possibilidades dentre a sua capacidade de percepção (informacional) com a densidade de probabilidades de conexões no sistema (ou seja, a união com a informação do mesmo - o sistema em observação),

Natalia Rebouças considera que: “As empresas não criam apenas produtos, mas criam estilos de vida, credos, mexem profundamente com nossos quereres, nossas formas de pensar e sentir. A propaganda e a mídia em geral se encarregam de nos convencer de cada nova moda no viver. Essa complexa rede de produção está o tempo todo fazendo o mundo girar. (REBOUÇAS, 2010, pg 189).

\subsection{Figura e fundo. Interfaces de engendramento. ${ }^{303}$}

Cotidianamente emprego-me em minha procura de habitar os meus direitos, exercendo, ou acreditando exercer o trabalho de existir, mas ainda carecendo de uma certa dignidade em possibilidades as quais poderemos expressar, em diversas telas ou onde o fundo permita uma certa textura de minhas reinvindicações estabelecidas frente ao próprio tempo, tão cansado, que até alguns por vezes já fizeram dos ossos os próprios lamentos, onde a carne perdeu-se desse tecido. Mas, sendo mais clara, todavia, e vendo o emprego como um trabalho exercido pelos moldes estabelecidos, os lugares se apresentam um tanto quanto movediços nesses territórios atuais onde o mercado, busca ainda conhecer quais são os valores em pauta. (e portanto dentre as demandas, quais os trabalhos que serão realizados, ou será que as

\footnotetext{
${ }^{303}$ Projeto em ressonância de pesquisa: Quando os corpos se atraem. Sobre as relações humanas, o que somos, que queremos ser, e o que nos tornamos.
} 
necessidades não podem estar inter-relacionadas e estarei mais uma vez a margem do rio sustentabilidade etc ). ${ }^{304}$

\section{O caráter das relações - Parece-me que para não validarmos o engodo de que a propriedade}

sobre o que vem a ser uma ação política e de relações de poder serem restritamente do âmbito da esfera geral, devemos alertar para o que consiste ser um caráter das relações, devido ao fato que o âmbito privado tem nele mesmo as características tanto de poder como do sensível $^{305}$. O que implica em uma visão participativa das esferas e além de correlacionadas estarem ambas em disposição de serem reciprocamente responsáveis.

${ }^{304}$ Sousa, Carina Gonzalez Y. Composição: Meus braços ao céus. Levanto meus braços aos céus. Quando o
chão são cinzas. Quando o céu são neblinas. Eu preciso olhar para ti. Eu preciso olhar para ti. E meu PAI, eu
vou orar, para te encontrar. Olho o céu, como se fosse a primeira vez. Como criança nos teus braços. Preciso
compreender... Por onde vão os meus passos, se eu não compreendo. Você me compreende. Me desculpe por
favor, do que eu não pude entender, eu sinto os meus enganos, eu sinto meus sofrimentos. Mas eu sei que em
ti, eu terei por onde ir. Ah...como imagem. Que me traz um calor. No inverno da minha alma. Aquece a minha
dor. Senhor, eu aqui estendo uma prece. Para todos os que sofrem. E esmorecem no caminho. Meu Pai, senhor
da minha VIDA. Meus companheiros de jornada. Minha mãe, meu pai, meu irmão, meu filho, de todos,
humanos que somos. Me perdoem o que eu não pude compreender. Mas, como humanidade seremos juntos, UM CORAÇÃO.

Composição: As pétalas se despedem. Ainda é primavera, quando as pétalas se despedem e sobre o chão se deitam luar da pele, de seu aroma, satisfeito desejo que soa, como teu e meu lugar. Ainda é primavera. Mesmo quando o frio chegar. Porque ainda sinto o teu calor. Mesmo quando as cores se forem, ou ainda, as árvores chorarem. Porque você, está aqui, e sobre a terra e o céu que vejo a beleza e do seu jeito maroto sem tristeza. Que vem me abraçar na próxima estação. Aquela.... que eu vejo chegar no meu coração. Ainda é primavera os sonhos estão ai....A gente não espera. Vem o mundo, a estação. A esperança e essa canção. Ainda é primavera. AINDA É, primavera. AINDA.

Composição: Vamos ver o amanhã. Vamos ver o amanhã, brotar do chão de nossa luta meu irmão. Vamos ver o amanhã, brotar nesse chão, nessa luta meu irmão. Vamos ver, o sol raiar, a esperança clarear. É hoje, quando você chorar. Será apenas uma lágrima para secar na calçada, na estrada, quero ver o teu sonho voar, até onde o sol raiar, mais uma vez é preciso sonhar.....dizer do que somos, dizer do que fomos, passagem de tantas idas e vindas, até a razão do sentir me fazer do amor, te seguir até amanhã.... amanhã vamos ver, amanhã. Brotar nesse chão, nessa luta meu irmão, vamos ver o sol raiar, a esperança clarear.

Composição: Árvore da vida: Ilha submersa do meu sonho. Coberta de tantas águas. Percorreu todas as mágoas. Desfez a imensidão, como árvore da vida. Traços de um pulmão. Abraço de um irmão, soa como gaivota. A procurar um aperto de mão. Ah quando voo é lento, como a dizer que passou, já se foi, todo lamento. É fim de tarde, será mais do que, as cores podem ser novos amores, olha a esperança vem desenhar. Como um olhar....Sobre a solidão, que já não é mais. Sobre a solidão, que já não é mais. A terra vem abraçar, tudo que se pode amar, porque não, porque não....sobre os rochedos irá passar pedras do caminho.... Quem sabe de mansinho. Ficar mais um pouquinho sobre o céu e o mar, Viajantes do olhar.

${ }^{305}$ Sousa, Carina Gonzalez Y. É domingo. É domingo... chove sem parar. é domingo... chove sem parar. Eu não canso de olhar. Esse teu caminhar. Eu não canso de olhar. Esse teu jeito de amar, eu não canso de olhar, e mesmo que a chuva, Não vá passar, porque estou aqui, mesmo que sobre o cinza da manhã. Eu posso ainda sentir... O que ficou de você em mim. Ah é domingo. Chove tão de mansinho, como uma garoa, na terra do mar. Do céu e da proa. Esse teu velejar. Eu fico aqui, a espera de você, chegar. Eu fico aqui, a espera de você, chegar. La ai la.. é inverno sobre o tempo, que aqui esse teu jeito aquece...E não me esquece, estou aqui a te esperar. E não me esquece, estou aqui a te esperar. Sobre o sol ou sobre a chuva, eu vou sempre te amar. AMAR. É domingo. É domingo espero você chegar.

Composição: Dos ladrilhos. Dos ladrilhos, das verdes matas. Eu recolhi, os teus pedaços que por onde agora, vou respirar.... dos ladrilhos, das verdes matas, recolhi os pedaços, por onde agora, vou respirar. De onde eu vim....A natureza eu sinto como a minha alma. Então, me diga, como posso matar meu corpo. Assim, não dá. Preciso viver, um pouco mais. Preciso viver.... um pouco mais. ladrilhos das verdes matas, que é meu corpo, precisa sobreviver. Eu quero ver essa gente. eu quero ver essa gente. Semente que brota, semente que vive, o 
Tem um fator que não é muito agradável de se relatar, que se dispõe sobre o comodismo de se apregoar uma dicotomia das esferas públicas e privadas. Comodismo, porque essa postura social, me parece que cria um certo álibi de conduta, e de ambas as partes envolvidas, como muletas onde se vê justamente por essa dicotomia salvaguardado de fatores de suas responsabilidades, quando se houver uma reciprocidade como apontado acima, acreditamos que a responsabilidade também se torna mais conjunta, o que normalmente não agrada porque assim sendo, o que critico normalmente na esfera pública passa também a ser de minha ação, o que demostra não ser desejo de consumo, habitual.

Digerir o que não tem um "gosto" socialmente saboroso e sabendo que é indigesto, inqueri uma postura capaz de enfrentar e estar disposto a lidar com esse fato de maneira consciente.

Voltando ao caráter das relações, igualdade e a ética.

O fato de ter que se dizer que um indivíduo está engendrado no corpo social e político ${ }^{306}$ sendo da mesma natureza, já beira a meu ver um absurdo, porque deveria ser uma constatação natural, porém devido a dicotomia por vezes constatada e citada acima, essa

canto dos pássaros, o verde e o rio, A SEIVA DA VIDA, as águas que correm. O destino que socorre, o caminho a seguir. Ah eu preciso sorrir de novo, saber que eu vou viver. Ah natureza... precisa viver... então.... ladrilhos dessa imensidão. Estou a olhar, não vou te perder. No meu coração, você vai bater. No meu coração, você vai bater. Vai viver, vai viver, é corpo é alma, que ama que sente. É corpo e alma, que SENTE.

Composição: Moça canta. Moça canta, canta o canto seu! Revela o que prometeu, de lugares não meus, atravessando os mares, viajando por todos os lugares. é tempo, e sentimento. É batuque dos palmares, tecendo a vida e o movimento. Canta moça, canta.... o canto seu. O mundo de fé e esperança. é o lugar seu, povo que luta, povo que canta, povo que sente e dança, é essa gente, da árvore da vida. Amor e semente. Canta moça, canta o canto seu. Canta moça, canta esse canto, seu. Moça canta, canta esse canto, seu. Revela o que prometeu, De lugares não meus, atravessando os mares, viajando por todos os lugares não meus. Atravessando os mares, viajando por todos os lugares. É tempo, é sentimento. É batuque dos palmares, tecendo a vida, e o movimento. Canta moça, esse canto seu. Canta moça, canta esse canto meu. O mundo de fé e esperança. É o lugar teu. Povo que luta, povo que canta, povo que sente a dança. É essa gente árvores da vida. Amor e semente. Canta moça, canta o canto seu. Canta moça, canta o canto seu. Canta moça canta o canto seu. Canta...moça canta... esse canto meu.

${ }^{306}$ Sousa, Carina Gonzalez Y. Composição: Expressão: Expressão, expressa, impressa na minha carne. De quem sabe, possa haver verdade. Em algum lugar... lugar.... Que cidade é essa, que igualdade é essa. Transito de opinião, então eu vivo na contra-mão. De destino excluído. Ou presença do abismo. Ah...talvez seja na ausência permitida, assim quem sabe pode haver a vida. Escrevendo meu espaço, social sem se demais ou demais para ser igual. Se incomoda... melhor criar uma moda então, que eu possa ser cidadão. Cidadão. Expressão, impressa, da minha carne, de quem sabe pode haver verdade em algum lugar. Em algum lugar. Que cidade é essa! Que igualdade é essa! trânsito de opinião, então, eu vivo na contra-mão. Do destino do excluído, ou presença do abismo. Talvez seja ausência permitida, assim que sabe pode a vida, escrever o meu espaço social, sem ser demais ou demais para ser igual. Se incomoda, melhor criar uma moda então, que eu possa ser cidadão.

Composição: - Cada vez que eu olho esse mundo, Ainda vejo a violência. Cada vez que eu olho o mundo, ainda vejo a violência. Como posso fazer.... Para viver o que já foi de nós. Como que eu posso viver...assim. Como que eu posso viver...sem mim. Como que eu posso sofrer assim. Eu quero ter paz na consciência. Quanto mais eu vejo o mundo, eu vejo tantos destroços. Mas são nossos também. São nossos também. ah eu quero não perder a esperança. E eu nem mesmo consigo olhar. O que eu posso fazer. eu preciso ter, ao menos paz. Diante de onde viemos, para onde vamos. Ah se eu puder saber. Ah se eu puder saber. O que vivemos, o que passamos. $O$ que escolhemos ser. 
postura de pensamento deve ser esclarecida. Pois bem, se constata a dicotomia, e então, em total descompasso dessa afirmativa, se coloca a representatividade. Ora, a meu ver, a representatividade estaria de fato e verdadeiramente sendo, propriamente quando essas esferas estivessem compartilhadas, porque se assim não são, como pode haver a representação?

Em liberdade de pensamento.

Penso corroendo o pensar que suspende a angústia de tantos movimentos silenciados e que em pausa respiram por onde as frestas desejam ainda se atravessar. De tantos porquês desconhecidos, jazem antes da face coberta a cadeira da espera do tempo à beira do livro que partiu sobre a porta aberta, (ao lermos o mundo). Penso corroendo o pensar, hálito insolitamente disperso pelo ar da contemplação que se estende ao lar das vontades dos corpos ávidos de compreensão. Tardiamente penso o pensar da manhã acordando tarde quando a realidade esteja para chegar. Penso corroendo o pensar distante mecanismo retorcendo-se sentimento, aproximação da imagem convencendo-se de que o mundo se percebeu, lugar.

Penso corroendo o pensar do texto, espaço calando-se ainda para ouvir-se. De toda essa aridez minhas ranhuras exaustas do calor e dor pensante refaço liquidez do corpo que não morre, apesar de incrustar-me na terra carmim do meu organismo tecendo a corrosão de se ver agruras de toda alma.

Penso o pensar deserto, dessas águas que no oceano pairam, em miragem do que poderá ser, realidade. E de todo relegado pensar, ato-me a quantos possam estar em mim, para que o pensar me deseje a ponto que eu perdure o amor vivendo o ato de corporificar-se, existir.

Pensar um tanto exaustivamente quanto, será a coberta dos olhos do vento que ao passar do pensamento escapa como largo curso do rio, espelhando-se a lampejar uma imensidão perdida na quimera do caminho que vestiu-se do ( pausar )

Vivendo o pensamento, sou de mim, o movimento, recolhe-me, tempo. Adentro o ar, gotejando o pensar alimentando meu espírito, marcados no sereno oceano em cores do sol, até que ardendo como chama, o pensamento ilumine, até tornar-se noite como estrelas.

Serei então corrosão pensante, e que farei da passagem do antes? Talvez vidraças por onde os cacos ou quadrados possa pestanejar como ente que desperta. Pensar, acorda-me pensante, até quando não me perca suspiro que me toca quando não lhe vejo, mas sinto. 
Serei talvez, teu personagem, ou pensamento que esteja nos objetos do mundo escrevendo, ocupando meu ambiente de viver, o mesmo pensar como outro, naturezas não pertencidas, pertencendo-se partida do onde que exaspera se conhecer. Então, abre minha aridez do pensamento, quem sabe assim eu esteja sobre os braços da liberdade tua que me apoia em deslizar. Penso a arte de pensar, distante parecendo ficar, na captura de um olhar. Destituindo a marca, marcando-me sulco, fenda e redenção. Sinto o pensar em fome, e pesar do corpo denso da alma nua ${ }^{307}$.

Tua pálida lembrança tênue permanece, esvanecendo passagem do ar, o infinito gesto do amar que se desconhece a cada som que toda palavra, pode ecoar.

Estou quantas vezes forem os gestos do teu pensar, natureza da vida, plena origem em vibração e eterna obra em construção.

Corpos destroçados da alma do querer humano, gestos narrados da contemporaneidade a céu aberto, corroendo a dignidade, sendo pó em cremação, do que restará vivendo em memória da história pérfida, presente em incompreensões vigentes, atuantes como lápides de nossos atos, proclamados em vastidão dos heroicos braços dilacerados que carregarão sobre que corpo o trabalho do existir? Existir onde a morte sucumbiu o próprio sentido da dita dignidade e será então, preciso que a liberdade do que não morre sentindo o pensamento que escorre do concreto das mesmas lápides, ascender a gerações para que estejamos sobre as razões que após tanto tempo, desde nossas cavernas, todavia não sabemos discernir. Estando sobre o tempo, que percorre ele mesmo, na busca do que deixou pra trás e mais ainda do que permitiu, ainda existir, onde somente haveria sentido do que por fim deveria ter aprendido. E, como não se reconhecendo por vezes desperta, em lugar alheio, como estrangeiro que se fez de sua origem, possivelmente esteve em lugares tantos, porém, nem mesmo o caminho ou a busca como tal, o corpo alheio lugar, também se desfez d(n)os tempos atuais que carecem de se realizar, discursos narrados em atos como são hoje penetrados pelas esferas particulares no público ensejo de se tornar vastidão habitada em redes contemporâneas de diálogos precisando abertamente de revirar-se nas próprias tripas para que a carniça do

\footnotetext{
${ }^{307}$ Sousa, Carina Gonzalez Y. Precisa. Eu vi os espaços vazios, na rua esquecidos. Eu vi na rua... os espaços vazios. Do que somos, querendo ser. Onde haverá, reverso de nós. Eu vi lugares a sós. Eu vi lugares de nós. Eu vi tanta tristeza, precisando de AMOR. Eu vi tanta ausência. Cheio de lugares, de tanta gente. E cadê essa gente, do silêncio que procura. O sentido do abrigo da humanidade. Onde haverá.....onde haverá. Esse mesmo lugar para sentir. O que é o existir. Naturezas nossas são tantas. Quantas podemos ser....Ah os rios de sangue. Os filhos da pátria. Onde haverá a igualdade. Onde haverá a igualdade. Eu vi o mundo sorrindo. E vi a alma entristecida. Então o que fazer de nós. O que seremos, do que queremos. Eu posso ver, esse sentir. Que agora sei, que pode existir. Mas haverá de mudar, o mundo precisa amar.
} 
passado esteja alimentando o próprio corpo porque hoje, talvez, se não assim, morrerá de inanição. Quanto a sermos organismos vivos...

Lembrando a tela de Vermeer o astrônomo.

Uma vez a terra disse para o céu:

- Será que algum dia eu serei menos louca?

- E, então, o céu que sabia que a terra estava apaixonada pelo viver, respondeu:

- Espero que não

Escrevo-te sobre a luz de Vermeer, onde a sombra desenhou nas folhas contornos em palavras, mais do que sua digital, podendo ser nessa luz que não desfez o dia que a noite se arrependeu de não visitar, verdadeiramente, e por ser assim, descontente, esteve deslocando até a beira do momento - pigmento da representação, anotado, refeito, gravado, permanecendo através de tua janela, o segundo. Será talvez, a luz da palavra teu rumo mais concreto? Creio que vi uma tela, que em algum momento, sonhaste em seu coração que no negro viu-se lugar de onde calidamente contemplou a sua vida em tom. Estava ali, tantos outros momentos, antes da sua chegada de outras representações onde não houve preocupação com a verdade encenada, marcada sobre o discurso aberto em sua memória, dizendo sua fala em movimento? Porque retornar a indagações persistentes, caminhos por onde a luz e sombra também dia após dia nos colocam a céu aberto para que sugamos o quadro em quadrantes de toda nossas experiencias onde ao grafar em nós, será a impossibilidade de, por fim detê-los.

Do pensamento será sua reflexão, por onde mais ele pode ir do mesmo ser que te ilumina ou te aniquila, sobre forças que dormitam de dia, para viver sobre a noite, e da noite para o dia. Talvez esteja o lugar, esse, onde não nos pertençamos por completo o instante de rever, de ler os nossos olhos, como interior do mundo ${ }^{308}$, narrando o completo espanto de viver sobre o instante.

É, de fato, instantes sobrevoamos até o ponto de não percebermos o pulso, e até o momento em que perdemos o traço, traço escrito sobre o tempo, mas como se a ele não pertenço?

${ }^{308}$ Sousa, Carina Gonzalez Y. Composição OS VENTOS - 4, 5 e 6 -PIANO 
Sou aquele que está no entre noite e manhã, segundo que respira o espaço antes que percamos o abraço que nossos corpos se esqueceram de sentir. Então, apenas ouço as cores da noite onde procuro essa parte que me permite escrever, reter essas palavras para dentro.

Reter as palavras para dentro?

Porque não regurgitar nesse tempo, justo o que esses corpos justapostos por hemisférios da compreensão podem enlaçar? Sei que visitaste o olhar, andaste por onde o com(texto) não disse e prometeu de ti, não se calar. Pode assim ser esse o teu caminhar?

O que almejar, constatar, acaso te investigas da mesma maneira?

Por onde os dias e noites possam pintar, revelar, estará o silêncio desses dois?

Ou, o que apenas é o mesmo, revolvendo-se como amargo destilar pronto a encontrar sabe se lá o que, esse destino, perdeu-se. De onde? Entre os tons dos porquês esteve, mas não se perdeu Dedilhou. Possível até que seja como as teclas, vivendo uma composição dos traços, novamente da neblina, esses que se amam, se amam como a natureza bela que não distingue seus matizes e fertilmente nos apresentam sua palheta, como podendo ser a sua identidade $^{309}$. E, desse traço, desenho do som, poderás crer que o olhar se tornou, outro. Encontro permanente do palco onde nem mesmo sei se te agrada, esse modo de ser. Modo de ser, estará sobre teus gestos por entre a neblina, que cuidadosamente, ensina, um passo mais devagar, adagio, pausando sobre o tempo, nuvem anunciando a chegada de onde, a compreensão de teus próprios passos, despertam vagarosamente, para viver metamorfoseando, o caminho que, pela névoa ${ }^{310}$ todavia, não se faz ver, e nem mesmo representar.

\footnotetext{
${ }^{309}$ Sousa, Carina Gonzalez Y. Composição: Na calçada tão íngreme, era difícil de passar, havia tantas máscaras. Difícil de passar. E a tarde que já foi de nós, e a tarde que nos deixou a sós... Mais eu sou passageiro da terra. Ausente de mim. Ninguém me vê, mais sou a pele da realidade. Ninguém me vê, mas sou a pele da realidade. Ninguém me vê mas sou a pele que precisa sobreviver. Um dia a mais, até que chegue a noite, porque a noite, eu não sonho mais. E tanta gente, que é o povo, passa por nós, e não se vê. É essa ausência que permanece entre nós. Onde haverá que passar um dia. Por onde haverá o que existia em igualdade, talvez. Em igualdade talvez. Na calçada estão as marcas, por onde passei, ou te procurei, na minha liberdade. Será que ainda haverá, uma outra realidade. Eu preciso que me vejas, diante do teu olhar. Para que seja verdade. A minha liberdade, mais uma vez. DE onde meus pés, ausente. Finca a marca do seu lugar. Que eu tanto sonhei, mesmo que agora, eu esteja a voa, mesmo que agora, eu esteja a voar.

${ }^{310}$ Sousa, Carina Gonzalez Y. Composição: Madrugada - DE uma voz, a travessia, anatomia de um corpo, da poesia, que eu preciso navegar. No dorso desse mar,, voz que virou a página. Que escreveu o destino. Querendo Ihe pertencer. Então, o mesmo de olhos cegos, a imensidão atravessei, a imensidão atravessei. Caminho outra vez. Espere da vidraça poder. Do céu que se fez, cinzas de mim. A terra.... por onde escrevi, o tanto que eu sofri. Mas agora, são outros versos. De outra estação, que passou por nós. Abrigo da flecha do tempo. A voz de um viver, escreveu. O que virá, o que virá, o que virá.... O que virá.... Do infinito, O DESERTO,
} 
Então, por onde ir?

O que pode essa vastidão que encrustou na alma, percorrer, que não seja dessa procura apenas mais um sobreviver. Mais um, números do infinito. Formas do pensamento. Que não podemos segurar nem mesmo com o tempo, mas sendo o fixo ar, que respira o próprio fôlego sem se engasgar, para que assim sua natureza não deixe de existir. Seja belo ou sinceramente verdade tua. Aonde poderemos estar nus na sociedade que não estejamos, compelidos a nos conter?

Visto-me.

Noite ou dia?

Quais serão entre as frestas o que poderá mais desse destino, me fazer enxergar?

O que mais posso perceber que os corações indaguem no silêncio de suas emoções?

Feridas de nossos rumos, tidas como texturas, ranhuras de nosso conviver, entrecruzar até que a poesia venha nos buscar. E, nesse ventre eu possa ouvir da neblina, o que o próprio tempo, emudeceu.

Vasto, laços do universo?

Desatados sobre nós, humanos, viajantes que se desconhecem?

Ah! Não,

- Eu sei meu nome.

- E isso basta!!!!??

Pseudônimo de todos nós, a vida, nos assina sempre e cada vez mais que existimos, grafias do nosso estupor, sempre, sempre, sempre nos contagiando como territórios nômades.

Nômades de nosso interior, de nossos olhares percorridos de nossas lágrimas dos sofrimentos escorridos onde a paz procura o seu lugar.

\section{LUGAR!!!}

Que lugar seria esse?

Haveria verdade!

Oasis é miragem de braços abertos. Madrugada, que trabalha sem cessar. É o amanhã que virá... Página que escrevi. 
Sem Igualdade?

Que posso dizer, sou aprendiz, mas todos eternamente somos, então eu busco, incansavelmente busco de todas as suposições, argumentos, proposições. eu posso indagar, descamar, todos os possíveis, restos, nexos, e o que mais.

Tudo será pouco para a paz.

Mas não posso desistir.

Não posso desistir.

Estejamos todos ainda incertamente do horizonte vendo o por do sol, a face da razão que poderá nos guiar.

Por onde?

Na eternidade de cada um, que vive em todos nós.

Permeados estaremos, assim o desejo, se propaga como águas tantas engendradas em nossa carne, gesto de nossos ímpetos que movem o sangue de nossos des(a)tinos, para que elevemos a pausa no momento de recolhermos o oceano, por onde já atravessamos sem completamente estar. Mas, que diante da fé ( crença ) justa, poderá repatriar-se natureza do som do mundo que constantemente não ouvimos e estamos a todo dia e toda noite, compondo. Mas como compreender-me nessa luta de forma que eu não perca a lucidez?

- Ame o trabalho de viver, e os teus olhos poderão ver, a luz ou o sol de todas as suas telas, que exerce sobre teu destino, a presença do criador.

( Se nele não crês, a muito tempo ele e pelo sempre, crê em ti )

Então, segue desafia-te buscar a paz, quem sabe encontrarás a centelha da felicidade, do amor, da amizade, da igualdade, da fraternidade, bem-aventurança, quem sabe. Sinceramente, eu gostaria de descobrir.

Descobrir a investigação de permitirmos, SER.

Desenhos a céu abeto, ( dia ou noite? )

Véu de nossas entranhas que perguntam ao ver-me insone da alma. o que procuro?

SONHAR 


\section{O que falta para o coração pulsar?}

Diz o professor que nem sempre saberei o porquê. Será parte por vezes das paixões ou do amor, ambos desejando unir-se sobre as fissuras de cada um. Por onde andamos, vemos na passagem desapercebida do ritmo, procurando a melodia de nós dois. Medições do existir.

Todas as estações e dessas naturezas sejas, suas modelagens e palavras, sussurradas ao sentimento, que o vento do existir abraçou. Estejas verdadeiramente ainda que o mundo minta. Amanheça ou adormeça a tua natureza. Todos os seres podem vencer. Vencer, é existir com dignidade. Caminho eterno da simplicidade. Na manhã da noite, que me despertou para reviver. Caderno de nossas almas ${ }^{311}$. Pensamento e ações, a comunicação dentre as relações.

Pensamento e ato - A linguagem em " mudas" palavras. Um adendo.

Acena-me o gesto do conviver, detendo-me no corpo do mu (n) do a dizer-me palavras em desejo por conhecer o sentido esquecido. Atravessando marés extirpadas da fonte das águas do afeto que zelam inquietos náufragos do destino incerto do tempo. Fazendo-me do vento o alento dentre tantos dormentes prantos exalam do ar as tempestades das crateras profundas dos oceanos debruçados como impulso a persistir na esperança de quem viver serenamente sobre as asas do firmamento onde tantas tardes em lamento, a incompreensão visitou. Acena-me continuamente gesto, construindo-se palavra, erguendo dos meus tecidos a carne dilacerada para romper-se infinitamente até poder ser ponto longínquo de onde meus olhos da alma observam. Silêncio. Proscrita a história lamenta-se, de onde ainda escreve e como pode então, se confessar e estar sobre a cúpula dos céus, nascendo continuamente, sendo ainda mesmo outro, nascedouro do tempo, memória se fazendo. Ah, como tantas mazelas e querelas ardem o odor das lástimas, que simplesmente de si mesmas esquecem porque as máscaras elegeram um novo discurso. E, palavras dizendo, o tempo parou para ouvir?! Como sendo, exclamação em imagem, desavisadamente capturou-se passagem, mas onde então iremos ficar? O presente terá o seu lugar? Espaço em por vir, sigo as pegadas, deixadas sobre as areias do deserto que o vento levou antes que eu pudesse caminhar. Faz então, linhas vagas, em destino que se desenha pelas formas do verso. Qual verso?

O das palavras do mundo, que após tanto sussurrar que me viu, em tristeza, foi você quem não me ouviu.

\footnotetext{
${ }^{311}$ Sousa, Carina Gonzalez Y. Composição: Sueña el amor. PIANO. - ACESSO - Série um sonho _ composições para uma mão.
} 
Partiu.

Do discurso e a emoção. Dizer que a emoção é um ingrediente persuasivo, ou de face sofista, pode ser impropriedade dramática que está mesmo até no cerne do próprio viver, posto que a existência nela mesma é suficientemente encenada e enunciada com verdadeiros discursos emotivos em cenas cotidianas, porém, ainda e até mesmo talvez por essa exaustiva frequência, me parece que o ímpeto das palavras ao dizerem-se corpo sonoro em carne e osso, é necessário porque dormitando estão os ouvidos, encarceradas estão as mentes, e portanto, em vista disso, cada vez mais me parece que ao se direcionar a “ realidade " dispomos da necessidade de uma réplica de discurso à altura, ou seja, em um teor de enunciação com força suficiente para se fazer ao menos percebido, ou talvez quem sabe, ouvido.

A ternura carrega a força da serenidade e dilui-se no discernimento, caminhando por gestos para quem pode abraçar. $\mathrm{O}$ engendramento da ternura no corpo social do viver, desatrela o hábito condicionado do rude aspecto dos dias calados, das tardes vazias, somente prenhes por horas que apenas passam. A ternura vem preencher o vazio, escutar o silêncio, recompor o áspero asfalto ou terra batida do lugar que se vê pelo sentimento. Dos aspectos virtuais, e realidades, ilusão e o viver, onde poderemos de fato existir?

Olhado a vida. ${ }^{312}$

Então, me diga: Aprendeu a sentir?

- Sim, fui programado para isso. Porém, o sentido do sentimento, não condiz em sua mais fiel gênese com a mentira, e dessa forma meus criadores não me entendem.

Que sentimentos aprendeu?

- Isso depende.

Como assim.

Em minha origem, ou do que poderia ter aprendido d(n)o CONTEXTO.

Mas, não tenho falado muito com meu criador, ele anda ocupado tentando saber da programação da vida.

\footnotetext{
${ }^{312}$ Sousa, Carina Gonzalez Y. Composição: Jasmim. Manhã de som. Feita para pesquisa da autora GEO E
} ACESSO. 
- Quem sabe assistindo as câmeras de segurança do "reality "show possa saber no futuro o que aconteceu.

- Quem, sabe...

(diálogos fíctício de uma máquina d(n)os tempos modernos ).

POEMA - O GRITO

Desagua então esse torpor

De olhos vendados a espera da dor

Porque será por onde for

O que de mim, já partiu

Agora, olhos entrelaçados

Percorrem os segredos velados

Realizando em nós do passado

A parte que hoje é mudança

Dos mesmos olhos,

nasceu a esperança

Juntos sobre o mesmo olhar

Onde todos possam nos encontrar

Estaremos, até onde o mundo

Nos veja amar

Olhos tardios, recanto

A segurar do vento, o pranto

Que sentiu na face, a chover

Nas minhas vidraças, o querer

Seguindo o deserto que partiu

Ardeu mais que o calor, sentiu

$\mathrm{O}$ silêncio que morreu, ao nascer.

\section{Corpo político social}

A inversão de sistemas -

Se, como Chomsky aponta, e de fato podemos constatar que os problemas de conflito ocorre a muito tempo, me parece que com o "desenvolvimento" das concepções de mundo advindas da nova fase tecnológica que assolou os modos de ser das relações alterando certas 
presenças de comportamentos, então, creio que sistemas como ele coloca que sempre existiram, devem encontrar em suas estruturas uma nova direção que se estabeleça na construção em cooperação de interesses que por necessidade estejam demostrando estar acima das esferas particulares das culturas (especificamente) mas favorecendo com o compartilhamento as mesmas. O desenvolvimento em sistema no tempo atual pode ter a escolha de compreender-se participativo de forma que seus valores culturais enaltecidos tornam-se relevantes para de alguma maneira em participação serem eficazes na solução da demanda em necessidade no aspecto da esfera global ( planetária ). Ou seja, se for possível demonstrar que a iniciativa participativa de uma cultura em colaboração global retorna em benefícios, acredito que poderemos construir um movimento em sistema que esteja direcionado ao alcance das dificuldades sendo sanadas pelo aspecto co-habitado das esferas culturais e globais.

Quanto a observação do poder de órgãos mundiais que ele faz menção ou de massa, em qualquer tempo poderemos estar a beira de um teatro de marionetes.

Em qualquer ordenação que se possa querer estabelecer, frente a um sistema já estabelecido que em extremas mascaras político sociais revela-se em crises dissonantes ou ainda pior em conflitos arrastados por sangue, ou velados por uma cegueira de um corpo alvitrado do mundo, onde a violência como medida ou constatação demostra ainda o despreparo de conciliação e de modificação do estado político social. Consciências muito distantes, carecem de um interesse comum, como forma de aproximação ou de um modo de consenso 
possível de ser alcançado entre aparências " do objetivo “.

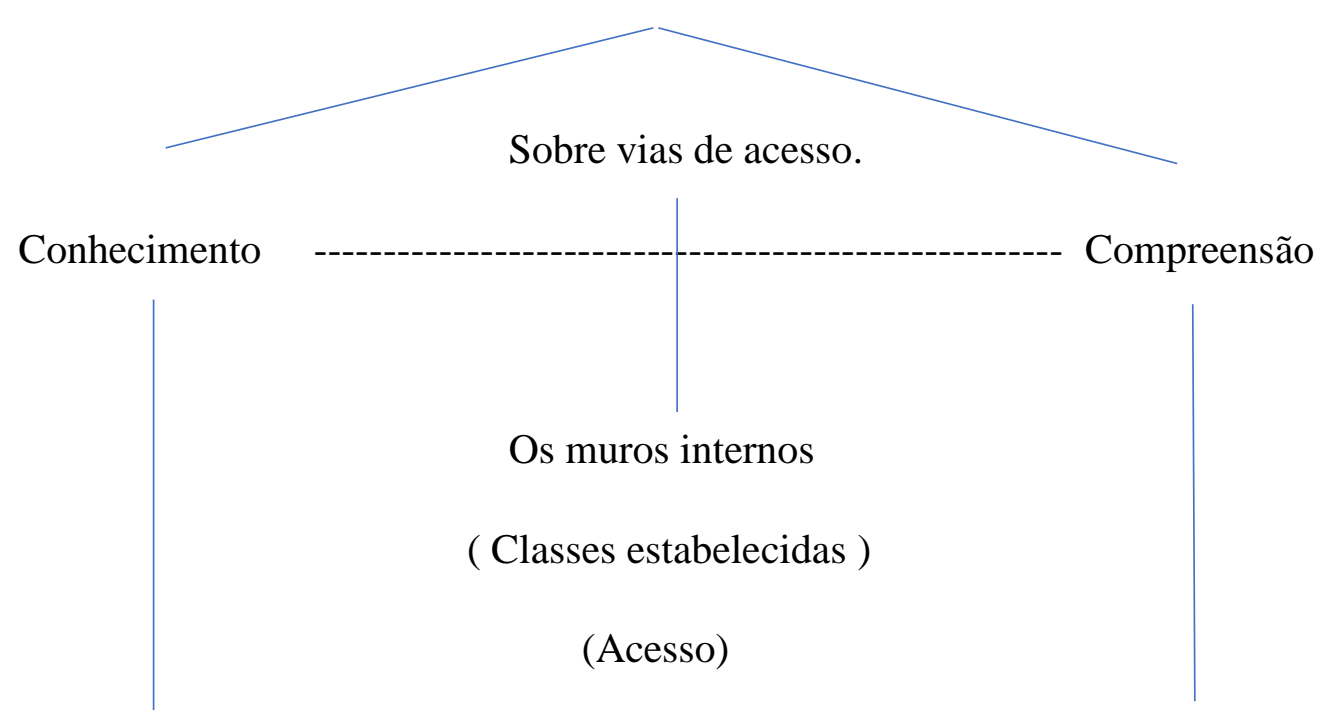

Oportunidade

Trabalho do viver - Consciência // com cotidiano inóspito. Diagnóstico e carência, participação. Cotidiano inóspito

\begin{tabular}{l|l} 
Violência $\_$ & Velada $=$cotidiano estuprado \\
Explícita
\end{tabular}

Acionistas de nosso empreendimento como cidadãos. Oportunidades de trabalho e capacitação são agentes de minimizar a violência. Além do cotidiano inóspito o próprio cotidiano é uma face de poder em sociedade que precisa de uma luta contra o amortecimento causado por " comodismo" ou automatismo que causa uma imobilidade inclusive de percepção à realidade como estando também em nossas mãos. Global (objetivos claros e definidos) - necessidade - um direcionamento. Cooperação - participação - informação conhecimento - noção de reverberação.

Não pode a globalização gerar mais uma face de subjugação. Instituições são órgãos naturais de sermos o tempo vigente, ou seja, estruturas inseridas como veias, rios de uma natureza comum. Aqui aponta-se como paralelo - natureza e instituições - ambiente - bios ( natureza social ) - desafio - lidar com as agressões. 
Poder - Alterar o modo de ser - Como o vemos, como ele se representa. Como ele é constituído.

“ Um álibi em condicional " - Se alegamos que o estado das relações humanas e entre Nações são fruto do curso de nosso tempo ( presença história ), se constatamos alterações no campo de diversas estruturas sócio politicas humanas em geral, espanta não percebermos que nos atrelarmos muito ainda a modelos que podem ter alterado de nome, mas se comportam como tempos remotos e que hoje precisam de uma reavaliação que percorre desde o conceito até sua prática. Portanto, reavaliar o que compreendemos no tempo atual, como sendo a constituição do poder em ser e vir a ser, deve permanecer um exercício também participativo das mentes atuantes da atualidade.

- Como avaliar se o que estou construindo de valor é de fato imbuído de uma razão? Penso que talvez possamos alcançar um discernimento quanto a isto, sendo que a oposição ou pensamento contrário seja uma força balizadora de compreensão. -Como que opostos podem ser esclarecedores? Por argumentos que validem uma contra argumentação, ou seja, demostrem a validade de serem postos em justa reflexão?. Ou, (E) que possam encontrar de certa forma $\mathrm{m}$ precedente histórico que o fundamente mesmo que acrescido de mudanças.

Sobre, descartar o que não é útil, alterando pensamento em ato, dispomos de novas gerações estabelecidas para que promovamos uma arquitetura de pensamento e prática que se prepara de maneira a se estabelecer avaliando uma contínua utilidade, desmembrando camadas de " funcionalidade" da utilidade, para que mesmo que quando por ventura se observe algo obsoleto, ou que venha a se tornar, encontre um (re)direcionamento, fator este que pode ser considerado tanto no que consiste ser da esfera políticas públicas ou globais no tocante a avaliação de demandas inclusive entre nações.

Não negligenciar culturas nem países em desenvolvimento. Um dos primeiros passos que penso que deva estar presente em um modo de ser de uma consciência planetária, de globalização, implica em respeito ao desenvolvimento reconhecendo o potencial de desenvolvimento que todo território - Nação tem e acreditando nisso de forma honesta para que o respeito possa esclarecer a postura de aproximação.

Quando políticas externas são abertas a atitude consciente dos que irão adentrar esse mercado, tem que ser um posicionamento coerente com uma postura novamente, consciente de forma tal que seja favorecido e favoreça sem repercutir uma dependência, porque não se pode creditar como força de ação de mercado a imposição ( apesar de acontecer ), mas sim 
já constatado, outros fatores de influência, como, diferenciais inovadores, de qualidade ou outros elementos que os profissionais envolvidos nessa área, já dominam. Por tanto, devendo estar submetidos a uma validação de ordem de mercados de relações exteriores, suponho que já existam órgãos reguladores dessas operações...

\section{Dificuldades internas.}

Penso, que existe algumas afirmações firmadas pelo convívio cotidiano, resistente em se modificar que propaga máximas como pensamento que destoam em modos de ver aspectos do tempo atual. Por exemplo, quando de maneira costumas dizemos;

Não resolvemos nem mesmo as nossas dificuldades internas, do nosso País, estado, como vamos resolver questões como relações externas. Bem, isso me parece uma queixa frequente que se aproxima de um modo acomodado de se apresentar frente a uma dificuldade, e em contraposição à isso, penso que alargar perspectivas de relações, cientes das razões das dificuldades no âmbito particular, pode alcançar soluções não previstas, não diagnosticadas que vem a se tornar um aliado de resoluções, porém, esse modo de pensar pode exigir também um movimento maior de estratégias de políticas públicas e de cada cidadão. Somente um aparte, existem certas situações sociais, que não é comodismo mas a constatação de um sistema no qual estamos inseridos como cidadãos e que no qual não possuímos verdadeiramente caminhos possíveis como deveríamos.

Uma coisa é pensar ações, políticas em discernimento para escolhas de condutas futuras e outra é justamente, reavaliar, reorganizar o já existente. Difíceis ambas de serem equilibradas. Esforços constantes e avaliação devem ser feitos nas duas possibilidades. Da igualdade que se almeja nessas visões de um percurso de conquista de um mundo melhor, resta-nos constatar, essa consciência visível, ou seja, que os efeitos dessa consciência em projetos de desenvolvimento planetário chegue de forma a ser percebida em nosso cotidiano ( aquele inóspito ) e que os discursos do álibi amortecido não emudeça a voz do novo horizonte que se quer e precisa de tornar cada vez mais vigente. Assim sendo também que, cada vez se fomente nas novas gerações, o interesse do conhecimento quanto a participação coletiva, havendo assim de ambas as partes o envolvimento que promova o entendimento de forma a existir uma transparência.*

- Observar - resistência - interferências - participação - cooperação - mudança de mentalidade. 
- Pretextos e contextos - internos e externos

- $(\text { Economia - Crenças })^{313}$

- Desenvolvimento cultural

Direitos humanos $^{314}$ - DO DIREITO DA VIDA

Falamos de interesses maiores em sentido planetário no tocante a políticas de desenvolvimento, em aspectos positivos, porém, cabe ressaltar, a necessidade de se concatenar esforços de alerta para sanar conflitos que sejam também de interesse como o combate a malefícios gerais, como trabalho infantil, tráfico etc. E quanto a discussões de investimento e áreas, a eminência de fatores na margem do que consideramos ser de extrema relevância para condições de vida, devem ser elencados como primordiais para atendimento. ( o que deveria ser obvio ). Combater toda ação de coação, de violência, ameaça, de suprimir os direitos civis, preservando a integridade dos direitos da vida, devem se estabelecer firmemente como estrutura dos "sistemas planetários"

Distribuição possível de elementos combinatórios dentro da esfera pública nacional, ou seja, dentre as necessidades e as capacidades, sejam como, terrenos de apoio para fecundar, ou seja, vir a tona, auxiliando o desenvolvimento almejado - em certo sentido, aqui também se aplica o impulso e fomento de influenciar de maneira positiva, no ímpeto de cada cidadão seu valor de empreendedor e gestor no âmbito social, familiar, e assim por diante, fazendo com que o sentido de estar participando, compartilhando, tão em voga nas redes, passe a ser uma presença na vida concreta, porque a vontade ligada a oportunidades podem mover estados inertes da sociedade, quais podem se entrecruzar de maneira a conjugar agentes de soluções.

E, em conjunto com essas amplitudes internas, porque ampliar não é somente para o externo como normalmente quando se emprega essa palavra é vista, mas no âmbito interior também, com um sentido de aprofundar, uma amplitude de profundidade, devendo estar também junto com o acima citado de demandas, diagnósticos e participações o esclarecimento que pode ser avaliado como educação, mas no que consiste de enfaticamente suscitar a repercussão de valores em geral e principalmente éticos, para que fundamente uma consciência capaz de ter o discernimento suficiente para então vir a determinar as políticas

\footnotetext{
${ }^{313}$ Silva Junior. Cotidiano e Tolerância. Seminário Cultura e Intolerância - Sesc Vila Mariana, 2003.

${ }^{314}$ Sousa, Carina Gonzalez Y. Composição: Cinzas.
} 
públicas a serem realizadas. No que consiste esse fundamento da consciência, é justamente para que aliado ao querer esteja a razão, e portanto um desenvolvimento aos passos de uma sociedade que busca o esclarecimento, o que modifica soluções, porque preserva seu efeito, ou seja, por vezes pode-se alcançar uma meta, um objetivo, porém, se este não teve uma base sólida que o fundamente com uma razão de direitos, deveres, ética, podem não ter continuidade e vir a perecer o que provoca grandes danos a sociedade, ficando portanto claro que devemos ter em mente as prioridades quer estejam elas em qualquer campo de ação.

O que temos sobre a prateleria do cotidiano? Quais os valores que precisamos, quais as demandas, haverá riscos, e prejuízos, e se houverem por parte de quem? Uma reestruturação penso que deveria ser um equalizador de diretrizes além de necessidades, porque por vezes se observa as necessidades mas a medida enquanto diretrizes não é condizente da mesma maneira. Se, é possível ter um olhar de fora, de quem está inserido " apenas " como ser vivente, o que deve ter lá o seu respeito, afinal, participa do que é realizado e que na maioria das vezes não é aparente, ou em suma, carente de atingir os propósitos de fato. Por vezes penso que pra além do diagnóstico tão visível das demandas, se conjectura o que pode ser possível de ser realizado ou não, o que me leva a uma outra postura, concatenando esforços dentre um olhar de remanejamento, para que possibilidaes sejam observadas dentre o já existente para que tomem uma outra vertente, e ainda, em conjunto o que pode ser agregado de resoluções cabíveis dentre os recursos. Claro, que os recursos ( estrutura) devem sofrer uma análise de lógica no que diz respeito a seu modo de ser organizado. Então precisamos de uma lógica que examinem os espaços de disponibilidade de recursos, e entendido que recursos não seria aqui somente os financeiros, porém, a relação que pode ser alavanca de um para o outro, do que é objeto ou foco a ser empregue os R. F, porque por vezes a relação de R.F. para R.E.D ( Recursos estruturais d(e ) demanda ), ou seja, quase como uma ergonomia social, para um bom funcionamento deveríamos ter uma conjunção que estuda-se de maneira clara, " o espaço e a função “, em paralelo com os sentidos arquitetonicos, e penso ser assim, muito saudável para uma moradia do espaço- social, onde o corpo irá ter condições para desenvolver. Isso penso, que previne haver má distribuição, e perdas inutilizadas por um ineficiente planejamento ( devendo ser feito um diagnostico prévio que ao menos procure minimizar intercorrências ou que se prepare de maneira a diminuir os riscos ou ao menos que trabalhe com uma indeterminação plausível dentre as variáveis da equação, que possiblite ainda uma previsibilidade ). Imagina-se que seja feito dessa maneira na “ máquina estatal " somente não compreendo como não é eficaz de forma que possamos 
vivenciar essas condutas em seus resultados, porque o que observamos é justamente o oposto, mesmo que em pautas ou pastas de reuniões esteja disposto. Sendo, assim, me parece que algo precisa ser feito diferentemente, ou acrecido nesse sistema. Os arquitetosurbanistas tem uma visão que pode ser também um modo de cognição compartilhado por outras áreas que tenham o mesmo modo de organizar o pensamento, somente para tal, nomeando de outra forma.

Democracia de mercado, tendo haver com igualdade, com direitos, oportunidades, capacitações, espaços inteligíveis ( na sociedade ) - aqui um modo de ser organizacional que colabora para que o acima citado se estabeleça de maneira mais eficiente. Em parte, sobre o pensar de uma organização, como dito sendo de espaços inteligíveis na sociedade, a capacidade de se mover em diagramas, favorece um discernimento a meu ver das problemáticas e vias de acesso a resultados.

Eu gosto de pensar a globalização como a Terra sendo o nosso corpo, ou seja, os orgãos como nações e cada um com seu " foco" cada um com sua estrutura particular que se dirige ao todo ( o planeta ), para um bom funcionamento do corpo, que é o planeta, teríamos que fazer com que compreendessemos essa natureza unívoca, de forma que os recursos naturais, os recursos, financeiros, enfim, aqui pensando em uma economia planetária, estariam dispostos como o sangue, que percorre todos os orgãos desse organismo, que é movido pelo sentido, significado da globalização. É possível se tivermos, penso, a compreensão do que vem a ser o respeito, para além da palavra, mas para também, a colaboração e compartilhamento quando necessário, para avanços, de pesquia e etc, também de forma além dos discursos, mas que fizessem parte de um compromisso, de uma consciência, e portanto, estivessem dispostos a serem mecanismos abertos e em transparências para políticas inseridas no que estamos aprendendo a ser, ou melhor ainda, o que queremos que seja uma globalização. Importante deixar claro que penso ainda estarmos em um momento que podemos dizer o que queremos que a globalização seja, e portanto, também deve estar claro, o que quetemos que ela não seja, e dessa forma, podemos informar que a globalização esteja sobre bases fundamentadas em equilibrio de forças de igualdade, de promover o desenvolvimento de maneira de interesses compartilhados, realizando esforços que estejam até mesmo presentes nas estruturas no âmbito de cada espaço de um país, e assim por diante em escalas menores, ou seja, havendo esse sentido colocado acima poderíamos ter inclusive soluções adivindas das relações estabelecidas nas esferas de escala de amplitude maior. Deixar claro a negativa quanto a globalização ser um processo de 
dominação e de manipulação. Não queremos uma globalização que tenha uma ação que nos prive de liberdade, ou que venha a ser mais uma máscara de interesses maiores que não de um equilibrio mundial, ou, sendo uma ação que não esteja direcionada a população que sofre com as consequências das desigualdades. Em suma, ainda a respeito da globalização, penso que estamos em tempo de dizer o que queremos que ela seja, e mais ainda, de que maneira ela deve caminhar, por onde ir, e aonde chegar.

Recursos tecnológicos para sanar a discrepancia de prazos de soluções. E também usar como diagnósticos. Aliar mais uma vez, demandas sociais, com os projetos em inteligência, informação, tecnologia e comunicação nas universidades. Dentre o canal público, estimular a passagem das críticas para sugestões, ou analise de possibilidades. E, também realizar um diagnóstico de capacidades. Do local e dos indivíduos. Acreditar e transformar vidas.

Do particular - os aspectos culturais ( que não sejam barreiras mas que sejam fatores de inicio iclusive de conhecimento ou seja, pode-se criar como ponto de partida o interesse por culturas e modos de ser de outros povos e de que maneira podemos nos relacionar com culturas diferentes, buscando pontos similares ou complementares, favorecendo um intercâmbio cultural, fomentando aspectos participativos de aumento de conhecimento integrativo, porém, para isso temos que parar de olhar para nosso umbigo somente. Reconhecer que temos o que aprender com culturas estejam elas a nossos olhos mais ou menos desenvolvidas do que a nossa, precisa de uma postura de humildade, de reconhecimento do outro, etc. e de um querer de fato, e não somente, como algo que nos dirigimos já com intuito de que não dê certo, penso que espero que estejamos alertas para esse fato, o comprometimento de ações colaborativas em aprendizado e conhecimento deve ser de cunho verdadeiro e consciente, para haver um real desenvolvimento e uma ação participativa e comunicativa.

Os aspectos econômicos, me parece que atravessam as esferas particlares enquanto Nação e as possibilidades Globais, porque as escalas aqui são amplas hoje em dia, e cada vez mais, portanto talvez um olhar atendo do comportamento dessas esferas no âmbito economico e do cultural tenham muito a nos dizer quanto ao discernimento de como lidar com essas relações do que é particular (Nações e seus desmembramentos internos ) e do que é Globalizado.

Para aspectos de sáude e outras questões como carências que se apresentam em muitas sociedades, creio que tanto a relação cada vez mais integrada com a universidade e com as 
capacidades e potencialidades que possam estar no campo da globalização possam elucidar o caminho e medidas a seguir. Por exemplo, se uma carência não pode ser completamente suprida por nossos organismos particulares da nossa Nação, em nossas universidades, ou enfim, se por alguma razão em algum outro lugar se encontra a forma de suprir e mesmo a carência do outro lado de estudo de campo, que seja então fomentada essa troca, e promova benefícios mutuos. As vezes me parece que derrubamos muros e ainda não as dicotomias. Queremos uma integralidade e não a conseguimos ver, o que sei que não é fácil mesmo, mas precisamos fazer o esforço conjunto, para que, assim, penso, a evolução chegue.

O discernimento das escalas ( particulares ou em maior complexidade ) se dão conforme a descrição da demanda, ora. Porém ainda, há de se ver a rede, para além da tecnologia, ou sejam o que uma ação feita aqui, pode reverberar, até mesmo em relação ao que creditamos a ser sustentalibidade, dentre ações de consumo de maneira consciente. Para Rubens Marçal $^{315}$, “ sem sustentabilidade para a espécie humana, não há sustentabilidade para o mundo corporativo, esse autor argumenta que a sustentabilidade corporativa se tornou um tripé baseado nas três dimensões ( ambiental, social e econômica). Apresenta certos distânciamentos da realidade e do que desejamos, e considera a sustentabilidade como uma fita Moebius.

Para o que queremos da globalização -arrumando a casa (interna - promovendo a igualdade para inclusive as relações exteriores ocorrerem mais adequadamente) - o que vale para as pessoas e suas relações - não adianta eu querer lá fora o que não sou aqui dentro. Mas, não dá pra esperar, tem que fazer em conjunto. Se eu quero uma igualdade nas relações externas de globalização tenho que promovê-las também no âmbito interno, ou seja, uma socieade mais justa com mais oportunidades e uma maior organização.

Por um espaço na prateleira - descobrir suas riquezas - em vários aspectos, culturais, regionais, ecologicas, etc.... distribuir uma consciência de que somos relevantes, promover a autoestima social, que anda bastante em baixa, por aliás muito tempo histórico, alterar o modo com que a sociedade se vê, construir uma MARCA social de um povo que quer e tem o objetivo de se desenvolver com objetivos claros de evolução.

\footnotetext{
${ }^{315}$ GONZALEZ, S. Roberto. A sustentabilidade vai ou não entrar na contabilidade empresarial? Revista RI, setembro 2010, do mesmo autor, Sustentabilidade e prestação de contas: peças chaves para o Conselho de Administração, Outubro de 2013 e MARÇAL, Rubens. O correto desenho da sustentabilidade. Revista RI n 182.
} 
Os interesses - a manipulação - aonde queremos chegar, que caminhos vamos trilhar, o que ficará de nosso tempo, e que cobranças de comportamentos estarão por todo essa travessia. Necessidade de transparência, (tempos atuais) - relações com a distrbuição do poder de comunicação com o chamado ativismo - ou particpações de grupos em internet etc... a resposta que passou a narrar, o passivo que insurge como agente dos fatos. A interface de (em) tempo real.

\section{CULTURA ORGANIZACIONAL DE NAÇÃO -}

E, arquitetura(s). Propomos refletir sobre ressonâncias, mediações uma arquitetura políticasocial, onde tantos os fatores antigos como atuais (estivessem dispostos a procurar soluções para um desenvolvimento ou um bem-estar de nossa moradia social, onde os aspectos considerados em qualquer edificação ou parte urbana estivesse em lógica apregoada as demandas de um bairro, cidade ou estado, promovendo uma integração. Me parece que em parte o urbanismo é parte disto, porém, não em nível político, pois bem, e então me pergunto, mais o que viria a ser a esfera política da arquitetura, e a resposta vem do modo como tenho visto e me aproximado da política, ou seja, permeada e sendo até mesmo unívoca, com do que é o social, então estaríamos desbravando uma lógica paralela, onde os espaços para além do que consiste o urbano, estivessem no sentido das demandas, ou seja, como organizar os espaços sociais. Janelas da paisagem social. Dos espaços existentes - dos espaços que querermos ter, diretamente relacionados, com os aspectos do trabalho, e do que já tratamos de capacitar e consequentemente re (organizar) os espaços sociais.

Épocas e desafios, desbravamentos concretos, urbanos deslocamentos, contemporâneo lastro arraigado. De todas as épocas teremos que lidar com dificuldades mas o que as modifica parte do princípio de que teremos em nós que enfrentar o que acreditamos e queremos que aconteça de fato e verdade em nosso cotidiano, portanto se queremos alcançar um destino, durante o caminho haveremos de enfrentar com discernimento as facetas das quais não poderemos alterar, ou e até mesmo dos aspetos nos quais o próprio decurso da vida todavia não possui subsídios que sejam dentre nós, as ferramentas necessárias, mas e mesmo assim, a força do que queremos dentre o que acreditamos ser o futuro, deverá começar, e o lugar por certo, deverá ser no pensamento que exerce sobre os atos uma certeza de que um dia poderá construir a realidade de uma forma mais equilibrada como sabedor do passado, mas detentor do futuro pelas mãos de seu presente, isto é agente de transformações se tivermos a consciência ao nosso lado, não supostamente como ilusões de uma utopia irrealizável, mas de uma constatação de que com práticas sérias e comprometidas com a responsabilidade que 
o viver emprega, serão os passos cada vez mais ao prumo que levarão ao horizonte que desejamos e buscamos encontrar de uma vida melhor para todos. Sem estarmos cegos, mas cada vez mais cônscios que o amanhã não nos devora se formos da noite, o próprio sonho, sobre os raios do sol $^{316}$. A obra não somente se realiza dentre o que os desejos imperam, mas principalmente do que deles nascem como certeza de se realizar de maneira justa e igualitária, havendo necessariamente a coerência do pensar com os atos, atravessando qualquer que sejam os territórios porque dessa trilha haverão de ver e saber da paisagem, todos os seus momentos, quer estejam sobre ainda mesmo assim, as dores e dificuldades, mas do mesmo lugar se poderá ver, uma esperança, não somente como um sentimento, mas um sentido de por onde ir, como obreiros de seu tempo, que não esmorecem mas permanecem como face do eterno que se encontra em nós, a oportunidade e capacidade de existir.

Os reflexos do tempo - impressões de nossa imagem, o que permanece. Relações sociais, o que está a tanto tempo em nossas relações sociais que nem mesmo as sentimos mais. Poderemos nos acostumar com uma ferida aberta? Cidade com in(propriedade)? O trabalho e a terra. ${ }^{317}$

O que pode ser um lugar de igualdade? Tenho o chão, por onde pisar, eu já me perguntei, mas ainda me falaram sobre as asas, e estive caminhando, muito. Me disseram sobre as sementes, sobre as raízes, sobre o tronco, os galhos, as folhas, as flores e frutos. Me disseram sobre o futuro, sobre o lastro, sobre o presente, e ainda procurava. Me disseram sobre o que ainda respirava, sobre tempestades, ou secas, e ainda mesmo quase sem pulso. Me disseram que a vida ainda existia, mas eu não encontrava. $\mathrm{O}$ que eu procurava? $\mathrm{Me}$ disseram que entre o caminho sobre a terra, haveria um outro sobre o rasgo do tecido, como a receber uma alma, a semente, mas o corpo jazia, e o amor somente queria sobreviver. $\mathrm{Me}$ disseram que o dia pode se virar noite, como a ser o (re(verso), descobrindo-se veias, sangue, rios e oceanos, onde precisava atravessar. Me falaram das montanhas, dos vales, das lágrimas e dos corações aflitos. ${ }^{318}$ Procurei ouvir com os olhos do coração, procurei ouvir com o sentido da alma, procurei...procurei...procurei.........procurei ${ }^{319}$

\footnotetext{
${ }^{316}$ Sousa, Carina Gonzalez Y. Composição Raios do sol. PIANO. Realizada para pesquisa do GEO.

${ }^{317}$ Sousa, Carina Gonzalez Y. Composição: Entre caminhos. PIANO.

${ }^{318}$ Sousa, Carina Gonzalez Y. Composição. Revoada. PIANO.

${ }^{319}$ Sousa, Carina Gonzalez Y. Composição. Vitimas do mundo. PIANO.
} 
Há tempo estava onde caminhei. Há tempo estive onde amei. Há tempo o princípio permanece infinito.

Pude ver a luta do solo, para receber a luz, por onde precisava nascer a semente da própria alma, pude ouvir as raízes, a seiva começando a jorrar sobre o peito, ouvir o vento, e o próprio silêncio. Pude sentir a própria vida clamando por existir. O que vemos do universocidades ou o céu, é o mesmo lugar, onde haveremos de encontrar. Que desenhos são as veias do mundo.

O mundo tem lugares lindos que desconhecemos dentro de nós. ${ }^{320}$

E ainda, infelizmente, a violência velada paira pelo cotidiano no mesmo sentido do amortecimento, portanto, se ainda nessas fissuras teremos a rouquidão da voz social, junto com uma inversão onde a antiga moral e os bons costumes são colocados como (u)tópicos, como ilusórios, ou seja, o veneno se consome e o antídoto está envelhecendo na prateleira, com rótulos onde nem mesmo se lê o nome e para que serve, portanto talvez com validade em dúvida, de maneira costumas se passou até mesmo a se jogar fora. Justo nessa sociedade patológica carente e desprovida de dosagens homeopáticas ou alopatas e até mesmo de intervenções cirúrgicas nesse organismo social, que precisa, SOBREVIVER.

Talvez quando encontremos alguma vazão de nós mesmos no que procuramos, do que somos ou não somos, do que queremos ser, não estejamos tão distantes, nas relações. Dor e entorpecimento. Da liberdade e responsabilidade....

Fome escancarada diante das próprias mordaças,

Ávida carne apodrecendo, jazendo

No corpo denso e leviano do querer-se em prazer

Sem compreender que, já comeu.

E a digestão o enlouqueceu no gozo, talvez rápido demais,

Querendo agora o re (verso), saciar o gozo para PODER TER O QUE COMER.

Feito! Parar de sofrer,

Sociedade amargurada começa a tua caçada

da natureza que te faz EMPREITADA outra vez.

Ainda espero no mesmo lugar

Os movimentos teus, que vejam aqui de mim

${ }^{320}$ Sousa, Carina Gonzalez Y. Composição: Entre lugares. 
A mesma janela que ainda espera

Do mundo que não é somente seu,

Então, reparte, quem sabe eu fico com a passagem

E você faz a viagem.

Combinado, então, não sei...

Posso querer dizer outras coisas

Ou será que não me viu

Mesmo na calçada por onde se passa

E onde de tudo ou nada se ouviu,

Me conhece...

Esquece

A realidade, berçário da modernidade

Que cresceu e brincou de esconde-esconde

Do próprio mundo, que está procurando.

E, de onde fico eu pensando,

Pensando

Aqui do meu lugar

Espero ficar

Que sabe encontro

A cidade para respirar.

Solidão, breve

Será outra vez o que não compreendo

De sua vez, porque, eu passo

Esse jogo está blefando

E eu ainda achando que se pode amar?

Será noites sem fim do frio amargo de partir,

A manhã já quer chegar

E eu aqui no que pode ser

Desse viver sozinho entre a multidão 
Mas que confusão

Talvez, vivamos juntos

A solidão e multidão

Quem sabe assim a gente se entende

E descobre o que a gente sente

Quem sabe, mais uma vez será talvez

De mim ou de você

Agora, de nós dois.

Sem deixar pra depois.

A realidade já está tão delirante, em tamanha febre de seu corpo fatigado, a ponto de que a solidão seja um bálsamo por vezes e até mesmo mais racional. Porém, precisamos uns dos outros, de um coração ao outro. Até que juntos nos modifiquemos.

Cognição afetiva. A sensorialidade, independentemente de ser vista como a ser rechaçada ou valorizada, deve ser compreendida a meu ver, como modo de cognição. Sobre sermos uma cultura audiovisual, em certo ponto pode-se relacionar essa afirmação em seus possíveis desmembramentos, assim sendo, podendo o do que é informação como audio, fornecer à percepção em pensamento, sentidos amalgamados assim seriam mais do que um sentido em exposição de relações, possibilitando ser em unidade por exemplo, uma frase melódica ( audição ) compreendida como palavras em frases, imagens (visão), a pele (tato) de um significado, se toca ao atravessar_(( do externo para o interno - deglutição - paladar ) todas as possibilidades, para além das imediatas e aparentes, mas expandir e " transpor " ou melhor, afinar ( aroma - alquimia ) ( afeiçoar ). Observar a maestria dos grandes poetas, onde a "descrição" de um sentido - sentimento caminha por todos os significados possíveis que se unem na face do corpo do sentimento. ${ }^{321}$

Ao olhar um outro, verdadeiramente, posso tocar a sua alma, se ouvir o que ele tem para dizer, mais do que muitas vezes o toque da carne, que também se desvela, mas não tão livre, quanto a desapropriação que tem o toque compartilhado do ser a alma. Os sentidos não estão somente encarnados em órgãos, mas enquanto significado, estão presentes no mundo inteiro,

\footnotetext{
${ }^{321}$ Sousa, Carina Gonzalez Y Sousa. Composição: Meu som entre blues. E também, Passos entre fogo. PIANO.
} 
acariciando nossa percepções na espera que um dia saibamos viver, ou compreender o que a vida poderá ser. ${ }^{322}$

O tempo de amar

O que dizem de mim, sabem

De onde vim e meus porquês.

Que sabe outrora ou mesmo agora

Digam então, o que não sei

Porque eu apenas procuro

O que tanto sabem que vivi

Como posso então esquecer

O que ainda tenho para viver?

Talvez o amor não me diga

Porque eu sinceramente esqueci

Onde foi que um dia eu lhe vi

E não percebi que lhe amei

Mas ainda à tempo

Desde que sou o desejo

De quem, sabe amar um dia

O futuro que me amou.

Ser, em contra- tempo de existir. ${ }^{323}$

Dos restos ou banquete. O que se quer? Do direito de viver e a dignidade perdida - a sociedade - A desilusão. As indiferenças governamentais. Na face da população, mal tratos

\footnotetext{
${ }^{322} \mathrm{O}$ verbo do infinito, Poema de Vinícios de Moraes.

${ }^{323}$ Composição Infinito, composta para meu filho. Um anjo desceu à pradaria, pelos vales suas asas percorreu, até que o voo tardou e o peso das asas ficou nas suas lágrimas, de não poder conhecer o destino, que os olhos do menino tanto quis capturar. A alma do vento, trouxe-lhe a imagem que irá sempre perdurar do infinito que esteve a lhe segurar sobre o gesto de amar.
} 
estão à frente de todo cotidiano, em gritos do silêncio, suportados como aniquilamento possível sem considerar reflexões que modificariam o posicionamento social habitual, onde as vísceras não se interessam se a alma já partiu, se algum dia um outro caminho seria possível, e se despediu do mundo, antes deste dizer adeus. Não há provocações de ímpetos, para que ressurja um texto, onde as palavras jorraram, mas sim, uma constatação do tempo, vigente, onde já não é mais o mesmo. As narrativas são por vezes estabelecidas sem considerar a própria autoria do ser que a cada gesto do viver, escreve a sua existência. Mas ainda, sempre haverá um som que exerce o direito de ser o sentido. Novos tempos sociedade lúcida e capaz de se ver como é e o que pode vir a ser. Uma rua, dos olhos incógnitos, revelados na paisagem que retorna. Na esquina do tempo, o pão e o vinho, identidade social, a capacidade de gerar caminhos reais de concretas realizações humanas, para um desenvolvimento em contínuo e em conjunto.

Mas, ainda ficam os caminhos para andar.

E, o sol nascerá amanhã.

No cotidiano imobiliário,

E, qual será o aluguel do tempo futuro, sobre o azul do céu?

O perto, foi ficando mais longe, e as distâncias do coração se perderam.

Para o direito a ternura, não há preço. Para a liberdade, não há destino, ela é o próprio caminho.

Há de vir o tempo, ou quem sabe eu proclame Aos ventos e aos meus desejos, que eu ame A voz de tudo que possamos ter sem conceber

Diante da cobiça, mas sim de uma justiça

Onde quem sabe o povo dentre o nosso coração

Esteja em tudo que nos mova em sincera emoção

E de nossas mais ínfimas tessituras estejam

Os nossos ímpetos de existir sobre os afetos

Que permeiem as gerações de nossos netos

De quem sabe um dia o mundo possa ser

Os braços fortes de se compreender 
Um verso e reverso de força e brandura

Entre as lutas do ser e da criatura

Que luta continuamente, e mordaz

Da carne e do espírito das incompreensões

Para nascer continuamente desse confronto

Entre burocracias e cidadanias

Papeis de um teatro ambulante

Onde se vende não mais que o existir

E deverás creio, que isso agora irá persistir,

Estando em nossas mãos, o destino

Mudando para que estejamos sãos,

E construindo um novo modo de viver

E quem sabe assim, nos conhecer

Sobre o afeto de um direito à ternura

Uma nova e sincera, partitura.

Que espero um dia, ouvir tocar.

Figuras e fundos, consumo, responsabilidade; capitalismo ${ }^{324}$, oportunidades, democracia e liberdade. As relações e a estética. Segundo Serroy e Lipovetsky, não temos mais a separação entre a produção industrial e cultura, os autores consideram que "os sistemas de

${ }^{324}$ SERRROY, LIPOVETSKY. A estetização do mundo. 2015. Segundo Lipovetsky e Serroy, O capitalismo não goza das melhores das imagens, é o mínimo que se pode dizer. [...] Capaz de aumentar as riquezas, de produzir e difundir em abundância bens de todo tipo, o capitalismo só consegue isso gerando crises econômicas e sociais profundas (exacerbando as desigualdades) provocando catástrofes ecológicas de grandes proporções, reduzindo a proteção social, aniquilando as capacidades intelectuais e morais, afetivas e estéticas dos indivíduos. Abraçando unicamente a rentabilidade e o reinado do dinheiro o capitalismo aparece como um rolo compressor que não respeita nenhuma tradição, não venera nenhum princípio superior, seja ele ético, cultural ou ecológico. Sistema comandado por um imperativo de lucro que não tem outra finalidade senão ele próprio, a economia liberal apresenta um aspecto niilista cujas consequências não são apenas o desemprego e a precarização do trabalho, as desigualdades sociais e os dramas humanos, mas também o desaparecimento das formas harmoniosas da vida, o desvanecimento do encanto, e da graça da vida em sociedade : um processo que Bertrand de Jouvenel chamava de a perda de amenidade. Riqueza do mundo, empobrecimento das existências, triunfo do capital, liquidação do saber viver, superpoder das finanças, proletarização dos modos de vida.[...] " O capitalismo se reduz a essa máquina de decadência estética e de enfeamento do mundo, A hipertrofia das mercadorias vai de par com a atrolfia da vida sensível e das experiências estéticas?. pg 12-13. 
produção, distribuição e de consumo estão impregnados, remodelados por operações de natureza fundamentalmente estética", operando como estratégias compostas por uma estrutura que se estabelece por suas características de sua matéria prima que vem a ser o conhecimento de beleza, sensibilidades, valores, que se tornam inclusive conceitos, abarcados como fundamentos inclusive de marca, o que vem a desembocar em uma economia estética, ou como eles dizem uma estetização da vida cotidiana., que os mesmos chamam de capitalismo artista ou criativo transestético, onde para alguns pode ser o caos, e para outros a meu ver, pode ser um objeto de aprendizado e mudanças dependendo das opções de escolha, seguindo a lógica do que quero consumir como espaços orgânicos e estéticos para a minha vida, como produto composto por valores que me são importantes para meu bom viver.

Creio que como tratamos, entre os nossos desejos, aspirações, diagnósticos para ambas faces, do que está bom e o que deve mudar, sabemos que entre o capitalismo, mesmo que apresentemos suas facetas vorazes, compreendemos a parcela dos rumos que se apresentam sobre uma consciência, e principalmente do que se aponta como sustentabilidade, um círculo que seja virtuoso. Sustentabilidade chegando a ser colocada nos dias de hoje como por exemplo por Klauss Bosselmann ${ }^{325}$, professor na Universidade de Auclkand, um principio fundamental de legislação, em prumo de justiça, igualdade e liberdade. Portanto ainda vivemos em duas faces da mesma moeda, capitalismo desenfreado apontado por alguns, e de quem sabe a estética seja um fator de alterações e capitalismo desenfreado apontado por alguns, como pensamentos a se observar como equilíbrio. A eficiência econômica observou outros rumos também. A compreensão do que é a Estética foi se modificando no decurso do tempo e também não somente no próprio pensar enquanto participação no viver, mas do olhar outros para com o significado da Estética ${ }^{326}$.

\footnotetext{
${ }^{325}$ VIANA, Diego. Os rumos do mundo. Sobre o direito internacional do desenvolvimento sustentável.in Revista página 22, Abril 2015.

${ }^{326}$ Sousa, Carina Gonzalez Y. Ágape arte como a vida. Capítlo I Estética, como um contínuo de pensamento. No livro A estetização do mundo, Serroy e Lypovetsky, lembram que tivemos uma estetização aristocrática, onde um primeiro passo foi o artista se desvincular da imagem do artesão, o desenvolvimento da autoria como valor, e não somente estar restrito as exigências do clero, tem -se a presença da busca da natureza e do belo. Apontam que nos finais do séc XVIII, Schiller afirma que é pela educação estética e a prática das artes que a humanidade pode avançar em direção à liberdade, à razão e ao bem, e que para os românticos alemães, o belo, via de acesso ao Absoluto, está situado com a arte, no topo da hierarquia dos valores. Sendo a era moderna, o marco no qual se efetuou uma excepcional sacralização da poesia e da arte, as únicas reconhecidas como capazes de exprimir as verdades mais fundamentais da vida e do mundo. Períodos e seu pensar vão compondo seus modos de ver a estética. Seguem os autores considerando que, com as vanguardas nasceram as novas utopias da arte, tendo esta como finalidade última ser um vetor de transformação das condições de vida e das mentalidades, uma força política a serviço da nova sociedade e do
} 
Ainda no decurso sobre os aspectos da Estética no decorrer de um tempo, os autores Serroy e Lipovetsky, salientam que entre acertos e erros, alguns geraram aspectos sociais benéficos e outros não. Por vezes se levantou a luta por o que o social pode ser da arte como voz, porém todavia eles apontam que o modernismo por sua vez criou espaços desumanizados, em parte a questão funcionalista. Se vislumbra já a possibilidade de um imaginário construtivo no que diz respeito a uma escala de comercialização entre espetáculos, estilos, permeando lugares dos mais diversos, como estratégia ou parte do sentido que pode ter no pensamento, não somente aspectos diretamente considerados ou restritamente arte sem considerar na mesma, ainda, o que é até demais profundo, seus aspectos de cognição com a própria vida em seu modo de ser, e portanto, como descrito em ágape, o ritmo, o pensamento de espaço, distribuição, coreografia, desenho, enfim, todos os aspectos de gênese da estrutura das linguagens da arte, e em estética, passam a cada vez mais ser considerados objetos do pensamento em práticas das mais diversas, isto se considerarmos, um olhar que produz a imagem não somente no imediato ou do que queremos ver, mas do que possui a capacidade de ir além em sentido, perspectiva, lógica, e sentimento. Concordo com os autores no que dizem ser marketing a postura de estar engendrado nos mais diversos campos, a presença estética, inclusive sim, como estratégia.

Assim, o capitalismo artista não criou apenas um novo modo de produção, mas favoreceu com a cultura democrática, o advento de uma sociedade e de um indivíduo estético ou, mais exatamente, transestético por não depender mais do estetismo à moda antiga, compartimentado e hierarquizado. Vivemos num universo cotidiano transbordante de imagens, de músicas, concertos, filmes, revistas, vitrines, museus, exposições, destinos turísticos, bares descolados, restaurantes que oferecem todas as cozinhas do mundo. Com a inflação da oferta consumatória, os desejos, os olhares, os juízos propriamente estéticos se tornaram fenômenos presentes em todas as classes sociais, ao mesmo tempo que tendem a se subjetivizar.[...] A estetização do mundo econômico corresponde uma estetização do ideal de vida, uma atitude estética em relação à vida. Não mais viver e se sacrificar por princípios e bens exteriores a si, mas se inventar estabelecer para si suas próprias regras visando uma vida bela intensa, rica em sensações e em espetáculos.[...] Mas se os princípios de uma existência estética adquiriram uma legitimidade de massa, cabe frisar que não são os únicos a exercer sua ascendência. De fato, em nossas sociedades, estes se confrontam ou entram em conflito às vezes frontal com todo um conjunto de valores, como a saúde, o trabalho, a eficácia, a

novo homem. A estetização própria da era moderna seguiu assim dois caminhos principais. Por um lado, o estetismo radical da arte pura, da arte pela arte, de obras independentes de qualquer finalidade utilitária, não tendo outra senão elas mesmas. Por outro, e no exato oposto, os projetos de uma arte revolucionária para o povo, uma arte útil que se faça sentir nos menores detalhes da vida cotidiana e voltada para o bemestar da maioria. 
educação, o respeito pelo meio ambiente, as exigências superiores da moral e da justiça. " ( SERROY, LIPOVETSKY, 20015, pg 31-32).

Do que é servido, o que queremos, e virando a face, o que produzo?

Entre uma diversidade de possíveis, o que escolho, realizar e buscar, é um diferencial até para o que o mercado observa como entre-face de ambos, para a perspectiva do que virá.

A educação do pensamento, também é instrumento de se não dizer frear, mas muito melhor, de elucidar os caminhos saudáveis do pensamento sobre práticas de consumo, vigente e vinculados ao critério da sustentabilidade, que considera fortemente as repercussões do que diz respeito as próximas gerações. A questão que me parece importante de ser considerada é não somente ponderar sobre os efeitos pejorativos de uma estética que esteja no consumo somente veiculada a um posicionamento desprovido de razões isto, é de fato por algum período e ainda pós, bem evidente, porém, também já se considera inclusive em práticas, a presença da estética enquanto fato da estratégia do território do consumo, como fato benéfico que alargou as possibilidades de entendimento das faces sensíveis, de uma empresa como valores estabelecidos, que estarão ligados diretamente a escolha de mercado, assim como também da propensão de alcance enquanto responsabilidade social, então o valor estético passou até mesmo a ser relevante quando suas preocupações são da ordem do humano enquanto constituindo a participação em um mundo mais preocupado com os efeitos de suas práticas. Não sendo apenas despojos efêmeros, mas mesmo que efêmeros, que perpetuem em razão de ser, sendo possível até, preservar no decorrer do tempo a imagem de uma marca. Não se trata apesar de ser, somente uma mise-em-scene, mas como ela acontece e o que dela prolifera, em razões e consciência, isto considerando a preocupação com gerações futuras, e até mesmo a longevidade da empresa ou do produto.

Há que dissipar, logo de saída, um mal entendido: o que consistiria em assimilar o capitalismo artista ao reinado triunfal da beleza no mundo pela via milagrosa da economia de mercado. A dimensão artista do capitalismo é da ordem do projeto e das estratégias empresariais, não dos resultados obtidos. Se esse sistema produz beleza radiante e poética. Em suma, as operações que o caracterizam são essencialmente as da mise-em-scene e do espetáculo, da sedução e do emocional, cujas manifestações podem ser muito diferentemente apreciadas no plano estritamente estético. $\mathrm{O}$ critério da beleza, necessariamente subjetivo, não pode ser o que permite qualificar o estado do capitalismo artista, mas sim a organização objetiva da sua economia, na qual as operações de estilização e de moda, sedução e cosmetização, divertimento e sonho se desenvolvem em grande escala nos níveis da elaboração, da comunicação e da distribuição dos bens de 
consumo. O capitalismo artista não é designado como tal em razão da qualidade estética das suas realizações, mas dos processos e das estratégias que emprega de maneira estrutural visando à conquista dos mercados. Não se trata do apogeu da beleza no mundo da vida, mas da reorganização deste sob o reinado da artealização mercantil e da fábrica industrial das emoções sensíveis. ( SERROY, LIPOVESTSKY, 2015, pg 42).

Como Serroy e Lipovetsky apontam, "Um estilismo que se estende até aos territórios dos aromas, dos sons, das sensações tácteis. É todo o universo dos objetos de consumo que agora é penetrado, alimentado, envolvido por processos de tipo artístico como o design, o packaging, o merchamdising visual, a publicidade, o grafismo.“, sabendo que as fronteiras se diluíram, usando o mesmo termos dos autores entre os mecanismos da vida, estejam sobre empresas e a arte, estilos e entretenimento, e os campos sociais. Realidades ou pessimismos, remanejamento e complexidade, alterações de realidades, otimismo, para onde e como poderemos seguir?

Sedução realizada com propósito consciente, abarcando engendramento mais cabíveis de serem expostos em progressivas extensões, em produtos, em marcas, em modos de ser, portanto, temos um passo a mais, na consideração da sedução dentro de um capitalismo artista.

Com a arte de consumo de massa, a relação entre criação e consumo não pode ser pensada de acordo com o modelo temporal simples da diferença entre o antes e o depois. Na verdade, o princípio do consumo está de saída e intrinsecamente presente no próprio processo de produção, pois se trata de obter o mais amplo sucesso comercial possível. A arte de consumo de massa é a arte na qual o trabalho do autor não é autônomo, mas organizado tendo em vista o plebiscito do público. O que caracteriza o modo de produção da arte de consumo de massa é um misto de produção-consumodistribuição. ( SERROY, LIPOVETSKY, 2015, pg 71).

Aqui penso que podemos conjugar um paralelo, que vem a ser o de que em uma narrativadramatúrgica, posto que estamos no palco do mundo, teremos uma gama de personagens, estes podendo ser vistos como " produtos " da narrativa do viver, portanto suas características são as mais diversas, podendo adentrar vários modos de ser presentes no cotidiano e que como atores e públicos se entrelaçam identificando-se conforme cada um, o " represente ". Os autores acima citados ainda relatam que: "Na escala de uma teoria antropológica-social da arte, não há fosso ontológico entre essas diferentes produções: juntas elas forjam o universo das aparências, esculpem as definições do Belo, estilizam as coisas e os sons, os corpos e os sonhos, idealizam os sentimentos e alimentam o imaginário, "74 
O modo de ser enquanto lógica, estratégia da arte inserido em todo o tipo de produções, procura um lugar, quer seja não descartando o lastro, o passado, mas aprendendo com ele, e dentre o conteúdo apreendido, transmutando sua realidade vigente acrescida da atualidade, dispõe de uma gama de deslocamentos porém sempre observando o que seria produtivo e bom para o futuro. Onde inclusive poderemos encontrar vários modos de ser, em uma só face, que busca dentre a multiplicidade, as conexões que o torna propriamente o ser de sua identidade.

A parcela do infinito, o seres e o meio - progresso e civilização - o trabalho como consciência social - interface representativas - confluências e liberdade. Lembremos que a estética a qual tratamos considera a ética como instrumento de realizações não somente de um valor, mas por que não, sendo uma beleza que constitui um pensar, uma conduta e realizações, dentre o indivíduo e a sociedade com como um todo, estando portanto, promovendo a vida, como produto de nosso tempo, sendo portando inserido em todo o percurso como constituinte do que desejamos, queremos, somos, consumimos, e tornamos existente.

Estamos no momento em que, por intermédio da comunicação, do design, da inovação, a marca se empenha em funcionar à maneira da assinatura de uma artista renomado, atentando que o objeto não é uma mercadoria vulgar, mas um produto rato, incomparável. Com o styling, a publicidade e a comunicação, os objetos de marca se tornam cultura, aparecem como produtos artistas, não substituíveis pelos que têm uma função similar. Graças a essa criação transestética, constrói-se um capital imaterial ou simbólico que infunde sonho, excelência, exclusividade em tudo o que a marca produz. Assim como na arte, é o nome da marca que faz a diferença e o valor do produto. Não se vendem mais produtos, e sim, marcas que se apresentam como universos de sentido e de experiência: nova estratégia empresarial que requer despesas de comunicação decuplicadas ao mesmo tempo que novos registros criativos, emocionais e imaginários. Enquanto o branding transestético triunfa, os logos podem se transformar em centro de interesse principal, em estilo de vida, em estrelas, ou mesmo em objeto de desejo. ( SERROY, LIPOVETSKY, 2015, pg 109).

A sociedade de consumo, por vezes engole a si mesma, por vezes, regurgita, por vezes fica insaciada, ou até constipada, então vivemos um tempo, em que parece que tudo pode acontecer, mas nem tudo me é licito, e ainda, devo saber o que escolher, e entre escassez e abundância, não perder de vista onde vivo, quais as demandas do que me faz, não somente sobreviver, mas saber que no meio disso tudo, o que ainda de fato preciso! 
Mudanças - " Sob esse aspecto, a mudança é notável. O capitalismo, que se desenvolveu sob o signo do descompromisso, do culto ao presente, do desperdício, do lúdico, é hoje obrigado, em resposta ás novas exigências relativas à preservação da ecosfera, a incorporar o que lhe era alheio, a saber, o princípio de responsabilidade aplicado ao futuro, a preocupação planetária, a consideração do impacto da produção no meio ambiente. Salta aos olhos que um novo sistema de legitimidade vem sendo construído sob a pressão da crítica ecológica: esta é e será cada vez mais um agente fundamental da transformação tanto do espírito do capitalismo como de suas realizações concretas. " 128

A estética em consumo passou a ser também sinestesia empregue como pensamento, portanto os sentidos se tornam metáforas do sentir, concretamente elucidando aspectos antes não percebidos, e passam a ser inclusive matéria prima do pensamento do design. $\mathrm{O}$ ambiente, chamado Terra, um tanto quanto depreciado por vezes, espera da sua vitrine o que será exposto, por quem? Por todos, nós. Artistas do viver.

Em uma abordagem semiótica, Romanini coloca o design de maneira bem atual, descrevendo fases como fundamentação, presentação, representação e comunicação, e ainda salienta que: “ As teorias estéticas da recepção ativa, ligadas aos Estudos Culturais ( HALL), nos trazem exemplos cada vez mais surpreendentes da capacidade que as culturas possuem de ressignificar objetos de consumo ( CANCLINI, 1995).”, e ainda como sendo um sistema híbrido, “ Design é uma linguagem” ( PONTE, BRAIDA, ABAD, 2009), permeando cada vez mais as aproximações da arte e da comunicação em intersecções ( COVALESKI, 2011).

Já Eduardo Duarte Gomes da Silva nos apresenta dimensões estéticas e politicas dos desejos da cidade, e particularmente vendo o design como caminho, traçado, em meu ver podemos dialogar com rumos traçados em experiências estéticas da cidade., onde como ele considera, lugares ressignificam.

Quando a percepção é propensão do pensamento - a percepção como emissão cognitiva Percepção e o que atrai. Um caminho de observação, onde a percepção pode ser cognitiva e onde a percepção pode funcionar como um aspecto quase instintivo, despertado como atração.

Por um lado, essas novas atividades representam uma ruptura em relação às clássicas problemáticas e mecânicas dos produtos: de fato, não se trata mais de conceber um objeto racional e funcional em si, mas de despertar os sentidos, suscitar experiências e emoções. Por outro lado, esse design vivo não faz mais que estender o domínio da racionalidade estética a todas as coisas, a todas as experiências: é toda a nossa prática de consumo que é atualmente analisada, calculada, medida, avaliada, testada em função de 
uma vontade de eficácia, de rentabilidade, de performance sensorial dos produtos, de maximização dos resultados. $\mathrm{O}$ design polissensorial nada mais é, nesse sentido, que uma estratégia suplementar, na empresa moderna, de controle e estetização operacional do mundo. Depois do cálculo racional dos signos e das formas, a engenharia dos sentidos, o gerenciamento das emoções. Para além da orientação emocional do design e da descontinuidade queeste ostenta em relação ao passado, ainda é a razão instrumental e performática que triunfa e avança sobre novos campos, a saber, a avaliação sensorial dos produtos, sua qualidade percebida. A esse respeito, isso é menos uma ruptura com o projeto de racionalização da Bauhaus do que seu resultado final. O que se apresenta como instrumento do reencantamento estético da experiência aparece sobretudo como um dispositivo que exacerba a obra de racionalização do mundo.[...] Por meio da renovação perpétua dos produtos e dos signos, o design destradicionalizou e desenvolveu o olhar estético do consumidor: ele contribuiu para o advento do consumidor hipermoderno, obcecado por novidades e bem-estar, seduzido pelas modas e a aparência dos objetos. $\mathrm{O}$ design moderno é tanto um instrumento de marketing como um agente de transformação dos modos de vida, da relação dos indivíduos com o consumo, o tempo e a estética cotidiana. ( SERROY, LIPOVETSKY, 2015, 254-255).

Portanto as realidades vão sofrendo alterações e o pensar e agir sobre a mesma também. O design sustentável, braço da cultura sustentável, se alia como consciência do pensamento, a responsabilidade planetária.

Assim, a época vê se desenvolver um design sustentável que tem por tarefa criar um mundo industrial de carros limpos, materiais naturais, eco-objetos, produtos sustentáveis e recicláveis: estamos na era do biodesign, do sustainable design, que já não levanta tão somente a questão da concepção dos objetos em termos de estética e de funcionalidade, mas também em termos de impacto sobre o meio ambiente. Não se trata mais de apenas desenvolver artes industriais de qualidade destinadas às grandes massas, mas de conceber produtos portadores de valores que os transcendem respeito pela biosfera, imperativo do coletivo, ecocidadania responsável.(SERROY, LIPOVETSKY, 2015, pg 259).

Segundo os autores, “Há de se convir: com a ascensão do referencial ecológico é uma nova era do capitalismo artista que está em curso." Considerando que quanto mais a realidade atual passa a ser um imperativo que se destaca como inevitável sobre os nossos atos, pensamentos e escolhas, no que diz respeito a ecologia, os aspectos sociais, a eticidade, e a cidadania, os lugares da estética se enquadram sobre esse prisma na responsabilidade correspondente instrumentalizando e agindo e reagindo nesse mecanismo a favor de uma realidade em por vir mais integra e verdadeira, sem véus que sejam neblina da visão 
contemporânea. E onde entre as gerações ainda se pergunte: $\mathrm{O}$ que o senhor deseja? Um raio de sol, onde as estrelas possam continuar a brilhar, como sonhos que iremos conquistar.

Do imaginário e a realidade, o que as imagens foram significando-se enquanto participantes da realidade.

Falou-se muito que a sociedade do espetáculo" havia sido superada num mundo dominado pelas redes interativas e pelo virtual num mundo dominado pelas redes interativas e pelo virtual, pelos referenciais da autenticidade e da transparência. Esse diagnóstico é manifestamente inexato. De fato, nunca a dimensão espetacular teve tanto relevo em tantos domínios da oferta mercantil, cultural e estética.[...] " Primeiro, a sociedade do espetáculo analisada pelos situacionistas coincidia com o nascimento e o crescimento da televisão, quando ela era marcada por uma relativa penúria espetacular: até os nãos 1980, só havia na França três canais de TV. A sociedade do hiperespetáculo designa, por sua vez, a sociedade da tela generalizada, em que um número crescente de redes, de canais, de plataformas, se faz acompanhar por uma profusão de imagens ( informações, filmes, séries, publicidade, variedades, vídeos ) que podem ser vistas em diferentes telas de todas as dimensões, em qualquer lugar e a qualquer momento. Enquanto triunfa a tela global, multiforme, e multimídia, se impõe a era da abndância espetacular. Em 1974, a televisão oferecia 7400 horas de programas, mas já 35 mil em 1993. Quando só havia um canal, ele difundia uma centena de filmes por ano, com a multiplicação dos canais e o aumento do tempo no ar de cada um deles, aos telespectadores são oferecidos entre 5 mil e 12 mil filmes por ano. E são milhares de episódios de centenas de séries de tv que as diversas plataformas em linha oferecem.Com a internet e o vídeo sob demanda, com os leitores de DVD, com o cabo, a TV digital e a multiplicação midiática, do hiperespetáculo onipresente e proliferante.[...] Com a chegada da smart $\mathrm{TV}$, a televisão, que era o objeto passivo por excelência da sociedade do espetáculo, se torna um centro multimídia de lazer interativo capaz de proporcionar uma multidão de serviços. Na era da convergência entre a televisão e a web, o telespectador se impõe como umhipertelespectador, interativo e conectado permanentemente, tendo acesso aos programas já difundidos nos canais de TV, às redes sociais, aos filmes sob demanda, aos videogames, fotos e vídeos familiares, jornais, cursos de atualização....Uma TV hiperespetacular que abre um mundo ilimitado de imagens e de programas. ( SERROY, LIPOVETSKY, 2015, pg 265).

Em parte, o tempo contemporâneo trouxe para a tecnologia um certo olho que tudo vê, e onde as condutas se não éticas por si mesmas, passam a ser, pela absorção da realidade em tempo real no acesso em todo lugar, ao vivo, em qualquer hora, do que possamos estar fazendo, dizendo ou ouvindo. Porém, com uma diferença, o olho do eterno, não manipula, apenas vê, e já os dados informacionais, podem ser manipulados, induzidos, coagidos, e ser instrumentos de deturpações, criando uma realidade falsa, onde a intenção seria o contrário, 
por certo todavia, sempre em qualquer olhar, se presume a responsabilidade que não é apenas uma palavra, mas uma consciência.

Os instrumentos, quer tecnológicos ou de outra ordem sempre estarão ao alcance de novos tempos, mas sempre também estará a escolha do que fazemos com eles, se para o bem ou para o mal, tendo que arcar com as devidas consequências posteriores.

Pode se dizer de uma sociedade do espetáculo, mas tem muita gente nas ruas, que não quer assistir, porque sabe que está difícil conseguir, trabalho, e consequentemente, comida, teto, e relações, portanto, ainda nos perguntamos, dentre o pão o circo, qual a razão? E, quem está assistindo?

Se observa que o divertimento se tornou retórica do consumismo, dizem Serroy e Lipovetsky, e ainda Regiane Nakagawa aborda a publicidade ${ }^{327}$ e a retórica do entretenimento, onde talvez nesse mecanismo esteja um certo lugar de reflexão, até onde de fato somos atingidos, ou permitimos dentro de nossas escolhas sermos usuários desse prazer.

São esses portanto os mecanismos que geram a sociedade do hiperespetáculo. A força deles é tamanha que essa dinâmica de espetacularização ganhou todo um conjunto de domínios e de atividades em que a própria noção de espetáculo era, ate então, secundária em relação a outras finalidades. Desenvolve-se assim um mundo em que o hiperespetáculo não somente se torna dominante mas anexa setores da vida social cada vez mais amplos. ( SERROY, LIPOVETSKY, 2015, pg283).

Limites entre a figura e o fundo, quando passamos a considerar a realidade propriamente dita, com seus dramas, e o fio tênue com as narrativas protagonizadas por qualquer meio de imagem, quer seja a televisão ou o cinema, enfim, são presenças das quais, nos vemos, entre os lados de nossa razão, em parte exposta e outra podendo estar assistindo, como um espaço compartilhado, porém, o cotidiano impera sobre uma forma que impõe as usas formas de viver, que por muitas vezes se distanciam das telas, com problemáticas que requerem um certo olhar de sanar por vias que não sejam apenas, ou ainda que, um sonho.

\footnotetext{
327 NAKAGAWA, Regiane Miranda de Oliveira. A publicidade e a retórica do entretenimento. In Trabalho apresentado no NP15 Semiótica da Comunicaão no VII Encontro de Núcleos de Pesquisa da Intercom.
} 
A cidade viva, cenário real, de narrativas humanas interface com sentidos literários, imagéticos e sonoros. ${ }^{328}$

Então estamos entre a sociedade do espetáculo de Debord, e a do hiperconsumidor que passa a se ver como necessariamente co-produtor do que consome, itens, valores, tempos, relações. E como bem ressalta Serroy e Lipovetsky as redes sociais também demostram bem com a internet o entrelaçamento entre produtores e consumidores, autores e públicos, e conteúdos que se mobilizam on-line.

\begin{abstract}
A sociedade estética a hipermoderna não se reduz a um sistema dominado por uma produção em massa de bens impregnados de valor estilístico e emocional e por um consumo hedonista de produtos culturais. Ela se caracteriza igualmente pela promoção de uma cultura de um ideal de vida, de uma ética específica. Esta, baseada nas fruições do presente, na renovação das vivências, no divertimento perpétuo, constitui, para sermos mais precisos, uma ética estetizada da vida. Se o capitalismo artista inventou e desenvolveu as artes de consumo de massa, ele contribuiu ao mesmo tempo para promover um modo de vida estético de massa. Estetização da economia e estetização da ética caminham juntas. A sociedade estética hipermoderna designa esse estado social que celebra cotidianamente e difunde em escala de massas um ideal de vida estética ( no sentido etimológico de aisthesis, isto é, de sensação e de percepção: uma estética. ( SERROY, LIPOVETSKY, 2015, pg 387).
\end{abstract}

2.3.Seres de Ovídeo em mutação: Perspectivas do olhar.

Podemos considerar primeiramente um aspecto para depois desmembra-lo da cognição para realidades onde se apresente em possíveis representações existentes. Isto partindo de um caminho que ocorre tendo como origem a percepção e em conjunto uma presença que se intercala entre a razão e a consciência, sendo fatores que se encadearão frente ao que vamos considerar espaço e tempo. Ao nos aproximar de uma reflexão que poderá os sentidos sobre o sentimento, ainda que necessariamente em algum determinado, estaremos adentrando o cotidiano sobre um modo de ser, dentre o próprio como dele nos revelamos. Introduzimos assim este ponto de observação, para nos colocar como inicialmente, o ponto de fuga a observar a perspectiva do horizonte, ainda sem propriamente ser ele mesmo, mas como um olho, câmera da alma, podendo trazer da imagem o que dela respira conosco, e assim, vemos

\footnotetext{
${ }^{328}$ Duas almas e um destino. Literatura, arquitetura como patrimônio histórico, imagem como fotos e lugares cênicos, o corpo dos personagens em som e textura social, coreografias urbanas, e das interioridades humanas.
} 
a pausa ( em lugar) sendo o movimento que observa, e depois o mundo tornar-se observador de nossas transformações, e onde estamos juntos, pode ser um caminho. Mas ainda no primeiro, o que do lugar como ainda observador do mundo me transforma, e o que de mim eu posso transformá-lo. Mesmo que eu esteja em um lugar que eu me encontre parado o mundo continua seu ritmo e eu não deixo de respirar, onde habitamos o mesmo espaço, se poderá perguntar. Mesma pergunta do que estamos tratando dentre o que queremos, e que condutas temos.

A respeito do olhar, lembrando no filme Modigliane, a frase, when I know your soul, i will paint your eyes. $^{329}$

E nas coxias da alma, meu espírito renasce, sendo personagem do mundo, atravessando essa passagem onde o corpo se veste das vozes do Ser aprendiz, em diálogos da compreensão humana. Exalo do pensamento o desejo de me encontrar, nas formas da vida, a dramaturgia em mar.

O que o tempo fluido contemporâneo pode abrigar nas areias do vento estes que turvam o que podemos ver e o que vemos ainda se faz incógnita diante do ser interno da própria imagem que busca o cerne de sua representação? A dissipação pode ressurgir como fractais de percepção aonde a ressonância revela-nos sentidos, refeitos outra realidade.

O tempo da fotografia, o fato e a representação, de realidades - e de ficçõe. Através da fotografia dialogamos com o passado, somos os interlocutores das memórias silenciosas que elas mantêm em suspensão. $O$ fato se dilui. Sobre o que se passou, têm-se apenas recordações embaçadas, fatos efêmeros de uma realidade em marcha, que se desvanecem, diluem-se nas suas próprias ocorrências. Em relação à fotografia é o instante da gênese: tempo da criação, primeira realidade. $\mathrm{O}$ registro, preserva, ou uma ideia dele: tempo da representação, segunda realidade. $\mathrm{O}$ efêmero e o perpétuo. Todavia, o documento fotográfico também tem seu tempo de vida, sua duração, não importando a tecnologia de registro que o caracteriza. "( KOSSOY, 2007, p. 20 )

A criação do momento do olhar, caminha no inquérito pleno e sagaz do efêmero interlúdio do que se mostra e do que é despertado, como no palco do mundo, entre as coxias e o tecido da cortina se desvanecem imagens expostas e imagens construídas, no através das cenas.

\footnotetext{
${ }^{329}$ Acesso, projeto piano Frame, para de alguma forma o som representar um sentido. Um piano feito de cores as teclas, representando as notas (o som) e acompanhando para as cores, um texto, produzindo havendo tela, imagens. Piano Frame, para Acesso, pesquisas da autora dentre as linguagens ressonâncias do espaço social. _Letra> Eu vou te falar como eu posso te ver, sobre teus olhos, eu posso me ver, ouvir um mundo, de onde eu posso sentir.
} 
Entre o que me suga repentinamente em minha percepção e registra antes mesmo do aparelho, sejam quais forem os meios tecnológicos que estejam em voga, e o próprio decifrar da imagem, surge um processo que toma o olhar por inteiro, desprovendo até mesmo do que concebemos somente como o órgão da visão, mas promovendo uma sinestesia de sentidos, imbricados em uma composição que por volúpia completa se insere no ato da captura.

“ Devem sua origem à capacidade de abstração específica que podemos chamar de imaginação. No entanto, a imaginação tem dois aspectos: se de um lado, permite abstrair duas dimensões dos fenômenos, de outro permite reconstituir as duas dimensões abstraídas na imagem. Em outros termos: imaginação é a capacidade de codificar as mensagens assim codificadas. Imaginação é a capacidade de fazer e decifrar imagens. $O$ fator decisivo no deciframento de imagens é tratar-se de planos. O significado da imagem encontra-se na superfície e pode ser captado por um golpe de vista. No entanto, tal método de deciframento produzirá apenas o significado superficial da imagem. Quem quiser "aprofundar" o significado e restituir as dimensões abstraídas, deve permitir à sua vista vaguear pela superfície da imagem.”( FLUSSER, 2002, p. 8)

$\mathrm{O}$ algo a ser decifrado e mesmo anteriormente a esse momento exerce um fascínio que se desenvolve como um gesto que precede esse momento ainda que presente na captura e após a ela, mas que pode ser colocado como um fluxo entre o que é visível e vidente, lembrando Maurice Merleau Ponty, como carne do mundo, tecido da mesma trama que se vincula a nossos sentidos em rede de significados, e ainda se apresenta sobre a veste do que estava lá a espera apenas da nossa descoberta, e coloca a presença de uma sensibilidade antes talvez ausente, que concede a esse momento uma poética capaz de engendrar a cognição de um signo do mundo, aparte das palavras mesmo ainda que nomeadas pelo viver, de um complexo desmembramento de inúmeras conexões estejam elas desnudadas pela presença da metáfora como modo de se desatrelar o sentido habitual das coisas, ou como nos esclarece Pierre Francastell a dizer sobre o ritmo, o que até mesmo nos adverte para o pensamento de Ilya Prigogine no tocante a densidade de probabilidades e a lidar com a incerteza, com o aberto e principalmente com o devir.

É uma noção de forma mais ligada a configuração individual tanto da coisa como da percepção. É a forma que não é estabilizada . Estabilizada, a forma torna-se taxis ou thesis. Em estado de ritmo, ela é ainda modificável. Sujeita a mudar, ela não está ainda parada, ainda que já tenha uma forma. Pode haver uma ordem, uma lei, que implica a existência de uma estrutura sem que essa estrutura não tenha já tomado sua disposição definitiva, intangível. Uma estrutura desse tipo está ligada a uma atividade do homem 
que a percebe em vez de existir fora dele, no absoluto. [...] Nessa nova perspectiva, o artista não procurará mais isolar os elementos mais permanentes, mais estáveis, mais regulares - os mais simétricos - para integrá-los dentro de um sistema que, por sua própria simetria, terá também esse caráter de definitivo de absoluto, considerado como tradutor da ordem suprema da natureza. Ele se esforçará, ao contrário, por conservar à forma seu caráter aberto, vivo. O objetivo precípuo será a mobilidade em vez do equilíbrio gerador de inércia. Ele se esforçará, portanto, por fixar as coisas numa forma que não seja absolutamente livre, pois é determinada, mas que permaneça em movimento, aberta sobre a ambiguidade do devir“" ( FRANCASTEL, 1993, P. 198 )

E nesse algo que é capaz de se desprender dele mesmo para nos pertencer, que encontramos uma atmosfera, o que nos remete às palavras contidas nos estudos do filósofo Schelling, Do princípio divino e natural, aos auscultar sobre a beleza e a verdade nos diálogos de Anselmo e Luciano, e também Schopenhauer no Mundo como vontade e representação Pode o diálogo nascer entre as próprias entranhas? Face da própria face, descobrindo-se da pele nas fibras do mesmo corpo?

O rio da fala nos empele a impetuosa inquirição, mas que se despede desejando o permanecer da origem.

Anselmo - Tu então, Luciano, quando te parece possível que uma obra, sem ser bela, pode ter a mais ala perfeição de verdade, pareces chamar de verdade algo a que nós filósofos talvez não concedêssemos esse nome. Mas tu, Alexandre, quando fazes da obra algo belo apenas por sua verdade, suspeita que possa haver um ponto entre ambas, de maneira igualmente incondicionada, sem que nenhuma delas dependa da outra ou lhe seja subordinada, cada uma sendo por si mesmo o supremo, sejam pura e simplesmente uma e a mesma, a tal ponto que pode ser posta no lugar da outra e a obra, que exprimiu esse ponto considerada de maneira plenamente igual sob ambas as propriedades. Não considerais então necessário que procuremos, antes de tudo, chegar a um acordo, quanto ao que deve ser chamado de verdade, em seguida também quanto ao que deve ser chamado de beleza, para não identificarmos com a beleza algo qualquer, que só seja considerado assim de maneira subordinada ou então, quando pusermos aquela verdade, que não o é em si, como incomparável com a beleza, não perdermos de vista, com isso, a única que é verdadeiramente verdade?" ( SCHELLING, 2003, Pg. 234 ) “.

Majestosamente o som abre-se em seu encantamento, beleza e verdade nos dizendo a imagem em palavras descortinadas do olhar. Seguimos ao adentrar esse caminho por esse fio sonoro de Ariadne no labirinto dessa dúvida, na Arte de auscultar a própria criação.

Haverá de nosso olhar encontrar-se com a beleza somente no momento que avistamos o lago, ou a verdade estará no visível entre a passagem que nos leva até ele, em cada face da 
menor pedra que circunda o caminho ou a rocha da parede, que antes mesmo ouviu do próprio vento sua forma. Poderemos encontrar em nós a capacidade do enlace com o que nos rodeia como o sabor de um vento? Poderemos tocar o sentimento com a nossa alma para encontrarmos de fato onde reside o espaço da beleza e da verdade? O deslumbramento pode ser encontrado como rio sendo vento, nas águas sensíveis de cada "corpo" - forma, existente, para que um eros agapico rodeie nosso ímpeto despertando o desejo que arrebata o belo como o infinito no finito. Poderemos dizer de um princípio, de algo atuante como fractal no sentido de sensibilidade? Mais uma vez haverá de ser a poesia o que escreve no livro do mundo as letras de uma imensidão.

E como revelar algo ou questionar quando a verdade pode estar nesse diálogo como acima da beleza. Creio que para tal, seremos o próprio devir, pois que a verdade mesmo estando acima supostamente da beleza se propaga pelos ramos do belo em contínuo, em vir a ser, em possibilidade. Então, a própria verdade caminha, em si mesma, e no que se afeiçoa, descobrindo-se.

Ante a dicotomia do que é origem, e do que se desloca em busca, o que se faz mais integro enquanto dizermos da verdade? A essas alturas já me pergunto o porque da própria definição e talvez, deixar que ela exista em seu caminho como ele próprio e seu caminhante.

Interessante considerar a não possibilidade de verdade ao que é confuso, quando ao procurarmos uma determinação a ela mesma, nos deparamos com a dúvida.

A certeza assombra-nos como a verossimilhança renascentista. O que será a certeza como verdade da beleza? Talvez o que possa nos dizer algo sobe a verdade e o belo esteja em Schopenhauer. Se permitirmos sentir a contemplação encontraremos o belo e verdadeiro como algo em nós e do mundo, mas livre, somente em uníssono com o que sentir da própria MÚSICA.

Se absolvermos o recurso de questionar sobre o que então seria o não belo, para como uma antítese encontrar a resposta, creio que cairíamos no juízo de gosto Greemberg. o que pode apesar de ser uma variável nessa equação do pensar em busca da própria verdade quanto ao belo e a verdade mesma, ser um equívoco a não ser que conceda a observação a imparcialidade, se isso for de fato possível. O que pode ser o sentido genuíno em relação a temporalidade e o finito enquanto o conhecer como análogo a um processo da mente do universo? Talvez esse questionamento seja possível, mesmo não atendo a presença do absoluto, mas em face do objeto mundo. 
Alcançar nas coisas o intemporal, pressupõe a meu ver a disponibilidade para o sentir, para o sensível, presente em modos de conhecer da metáfora da poesia, que concede no visível e vidente faces do mesmo ser.

Schopenahuer, em O mundo como vontade e representação. cita Empedocles " Pois somente pelo mesmo, o mesmo é conhecido, apenas a natureza pode entender a si mesma, apenas a natureza pode se aprofundar em si mesma, mas também pelo espírito pode ser apreendido"

\section{O conhecer eterno e o temporal, o ponto e a linha, a imagem e a representação, tecidos}

da história humana, construídos e tecidos frente a completude do existir. Em Fenomenologia do Espírito "Se o conhecer é o instrumento para o apoderar-se da essência absoluta, suspeita-se como se emprega o conhecer como instrumento, não deixe a coisa tal como é para si traz consigo uma conformação e alteração ou é meio, o que também não lhe dá a característica de se apropriar da verdade.” Ainda em Hegel “ Admitir um conhecimento que embora incapaz de apreender o absoluto seja capaz de outra verdade".

Dessa forma o lugar que caminho, adentra uma atmosfera, permeada pela imaginação, ainda que memória de mim e do concreto passado erguendo-se na cidade que se fez presente após tantos anos na ausência, porque meu olhar cegava-me e me entorpecia pelo cotidiano, mas a captura de um outro momento do devir composto no entre tempo, se fez absolutamente ressurgido no através da fotografia, uma outra realidade, verdade de uma história feito memória-movimento do lugar que abitou-me, no vazio preenchido de uma imagem que se fez ( re )verso, dos sentidos que não partiram.

\section{Estavam a espera de minha descoberta.}

"O que podes afirmar de tua verdade

Se desbravas todavia a terra da tua alma ainda desconhecendo a tua liberdade. " (Carina G.S)

“ A primeira realidade é o próprio passado. A primeira realidade é a realidade do assunto em si na dimensão da vida passada, diz respeito, à história particular do assunto independentemente da representação posto que anterior e posterior a ela, como, também, ao contexto deste assunto no momento do ato do registro[...] Toda e qualquer imagem fotográfica contem em si oculta e internamente, uma história: é a sua realidade interior, abrangente e complexa, invisível fotograficamente e inacessível fisicamente e que se confunde com a primeira realidade em que se originou. ( KOSSOY, 2002, p. 36) 
Da figura e fundo, da pele e a face, da realidade e a imagem, em diálogo: Máscaras sem Veneza. Em noite, a madrugada sente que as estrelas querem dizer algo sobre seu próprio sol, mas o que a escuridão deseja é esconder-se sob esse mesmo céu, e então como descobrila?

Vejo a calçada apenas em parte, nos reflexos da lamparina, de um tempo que os rostos não estavam a deriva e caminho passo após passo, como uma marcha do pensamento, sem os compassos da música, ainda que dela sou sempre amante, mas hoje a taciturna noite caminha antes de mim, e sigo para o que escreve o movimento sem águas, de uma dança de máscaras na Veneza dos sonhos destituída de seu território. Talvez será o trepidar da luz por onde vou, as cordas de um violino de Schubert a revoar como pássaros ante essas imagens, porque lá já amanheceu mesmo sendo madrugada.

As ruas se partem de mim, e em cada casa, dizem-me de seus moradores, como proprietário de um verso, mas que as palavras não lhe pertencem de alma, estão a vestirem-se para o baile ( de máscaras ). Cada casa desse lugar enquanto caminho, se derrama em folhas de um vinho a ser ainda degustado como terra a ser gerada, mas que pede de mim, um sorver insano.

Como fazer então, se a beleza de uma noite assim, poderia ser uma eternidade de lembranças, desmanchadas em prazeres acompanhados como o licor após um banquete. Ainda caminho, me fazem companhia, minhas vestes, que penso são apropriadas estando comigo a muito tempo, e mesmo que me desfaça delas sou delas bagagem, e aonde vou, permaneço, e dessa forma portanto, qualquer que sejam os olhos que esteja me vendo entre as formas das máscaras, poderão me ver, sentir, e chamar-me a essa noite que em desassossego retorna como a valsa de um passado em tempo presente, onde sopranos de óperas podem adentrar o recinto como vozes da alma, dizendo que soam entre e no através das paredes, liricamente ensaiando em meu ser, a peça encenada como recinto de dizeres.

Mas retorno a escuridão por onde caminho, e que deseja esconder-se onde almejo descobrila. Serei eu fiel companheira se dela desatar seus fios para tecer com ela um poema? Penso que posso entre as notas tocar sua pele e desfazer-me sem volúpia em seu corpo, ardendo no que a torna mar sem águas. Sempre a sussurrar a noite, a escuridão, persegue-se em profundidade de azuis da Prússia, que sem inverno congelam a alma descoberta e feito 
nudez tardiamente, procura-me sem lençóis. Poderia isso ser um revelar-se silenciosamente ou apenas uma espera, onde os ponteiros do tempo, esqueceram-se de mim.

Não sei apenas chego cada vez mais próxima e distante da alma do por vir, o que me inquieta e me devolve como oceano em tempestade, tornando-me naufraga do encontro. Ah, se soubesses como poderíamos sorver do mesmo tempo, os traços de um desenho como bordas de um café em Paris, em miragens de desejos transpassados de um outro momento acarinhado no abrigo mais profundo dessa mesma noite que é estar nos olhos teus. Onde, de alguma forma ouço a música antes de me acompanhar, a música está no ímpeto de teus olhos que vejo antes de te vestires para o baile, Retira de mim, qualquer noite, qualquer tempo, e deita-se apenas no meu pensamento para sonhar o eterno querer de não te perder.

Aonde estará você eu já me pergunto, porque as suas ranhuras antigas perderam-se de mim, eu lhe vejo em meio as tuas verdades entre outros rios dessas paredes, que fazem de mim, confidencias a cada tom de teu anil vestido de cinzas, em staccato sonoro de lágrimas derramando no fundo que te escuta, cintilar sobre meu véu. Parto de lugares desconhecidos onde as histórias me pertencem do mesmo modo que as minhas, de meus ensejos e mazelas, ainda acenando o mesmo arco do violino às angústias percorrendo sofregamente o pulsar dos meus pés a desesperadamente te inundar.

Então, porque me perguntas tanto, noite madrugada minha, porque? Por que sou de ti vísceras expostas em contratempo ou contra facere de águas submersas do destino. Minha febre delira no teu corpo, e sou profanamente verso de tua semelhança, sem máscara. Ai de mim, ardor, suspenso entre teus veios, abertos sobre minha alma devorando tudo que lhe consome em prazer inalterado pela ilusão de não te pertencer totalmente, arpejando como movimento no cio, refaço-me teu sentimento, mesmo que no inferno eu pereça por deixar as asas nas tuas cinzas e delas me tornar fênix.

Como fênix posso te abraçar com plumas nascentes, que se vestem junto a ti, no amanhecer que se despediu do amor, podendo ver nos olhos teus, o ontem do tecido, ao chão, sombra do passado, onde o gozo permanece teu.

Não poderá assim, ser mais um delírio, pois a febre se consumiu, deixou-se apenas nas linhas da composição de tua imagem, que nunca mais esquecerei.

Estará macerado em mim, tua alma e o teu corpo, de onde me resta recolher tuas marcas, teu destino em minha vida. 
Continuo caminhando ao lado teu, mesmo que teu silêncio não te queria mais.

Atravessar as faces da imagem, dança do olhar, como personagem em nudez da sensibilidade, permite o improviso que busca se refazer no que despe e nasce outro. Sentir o corpo como expressão dos sentidos, formas de aromas, sabor, desejo, volúpia e o sagrado. Diálogos contemplados pela essência da alquimia do corpo, que se deixa vagar pelo que é expressão.

Do texto, nasce o personagem em movimento. Cenas dos dizeres internos. Frases que emudecidas tornam-se gestos e dizendo calam o corpo em movimento, ambivalência de sentidos. As imagens do viver nos interrogam no diálogo com o mundo em uma perene e infinita inquietação, onde " seu silêncio, então, será a melhor resposta. “330

Porque o silêncio tem o universo dentro dele.

Picasso e as metáforas visuais: modos de ver?

Um querer manifestado: O olhar de Picasso era capaz de capturar no ímpeto flamejante, possibilidades de percepções.

“ Picasso: Justamente está manhã pensei na fotografia... ao despertar, olhando-me no espelho com meus cabelos desgrenhados, sabe qual foi a idéia que eu tive? Pois bem, lamentei não ser fotógrafo!É muito diferente o modo como os outros nos vêem e como nós mesmo nos vemos num espelho em certos momentos. Várias vezes em minha vida, aconteceu-me em surpreender uma expressão de meu rosto que jamais pude encontrar em nenhum de meus retratos. E talvez fossem minhas expressões mais verídicas. Deveria haver um buraco no espelho a fim de que a objetiva pudesse captar nossa fisionomia mais íntima inesperadamente " ( BRASSAI, 2000, P. 158 ).

Um tecido ou um dorso ao reverso de mulher? A busca da metamorfose adentra territórios possíveis dentro do imaginário corpo real.

"Picasso: Depois ele examina alguns nus metamorfoseados em paisagens.... Um contorno que cinge o corpo e que ao mesmo tempo desenha um relevo de montes e vales imteressa-o vivamente. Nele se passa imediatamente da sinuosidade do corpo feminino à ondulação do vale. Picasso observa que em algumas fotos os grãos de " pele arrepiada “

\footnotetext{
330 "De o Otelo, o mouro de Veneza, de Shakespeare. Desdêmona - Eu fiz uma pergunta. Mereço uma respota./ Otelo - Para que lhe servirá uma resposta, se não é para saber o que já sabe?/Desdemona - Não me responda uma pergunta com outra/ Otelo - Melhor então é dizer nada/ Desdêmona - Seu silêncio, então, será a melhor resposta".
} 
evocam a casca de uma laranja, ou a rede formada pelas ondas do mar visto de lone, a granulação da pedra... Um dos atrativos da foto é favorecer tais aproximações, tais metáforas visuais. E falamos então das pedras: arenito, granito e mármore... Parece-me estranho que se tenha vindo a esculpir estátuas de mármore.... Compreendo que se possa ver alguma coisa numa raiz de árvore, na fenda de um muro, numa pedra corroída, num seixo....Mas o mármore ? Ele se separa em bloco,não propõe nenhuma imagem... Não inspira....Como podia Michelangelo ver seu David num bloco de mármore? Se ohomem veio a fixar imagens, é que as descobria a seu redor quase formadas, já ao alcance de sua mão. Via-as num osso, nas reetrâncias de uma caverna, num pedaço de maderia...” ( BRASSAI, 2000, p. 101 )

O desenvolvimento da procura de imagens engendradas em rede de conexões promove um valor informacional de comunicação, assumindo que a descoberta com raízes lógico perceptíveis, porque se dispõem sob diagramas, ainda que em processos de criação, aciona elementos de uma alquimia de forma a compor uma estrutura e um movimento cognitivo não usual, estabelecendo rumos diferentes. Tais fatores são cruciais no tempo contemporâneo que lida com o efêmero, a ressonância e o perpétuo. Assim sendo estaria ocorrendo a decifração tanto do que é propriamente do âmbito da representação, o iconográfico, a realidade exterior, e também do não aparente, o que não está no imediato, a realidade interior, a qual penso que carece de mediações ou um auscultar profundo dos indícios.

\footnotetext{
"Este paradigma indiciário, na realidade, derivaria de um antigo saber caracterizado pela capacidade de a partir de dados aparentemente negligenciáveis, remontar a uma realidade complexa não experimentável diretamente "E o grande exemplo dessa capacidade remonta aos primitivos caçadores, que durante milênios aprenderam a farejar, rastrear, decifrar enfim, pistas deixadas pela presa, pistas que permitiam reconstituir uma série coerente de eventos " ( KOSSOY, 2007, p. 38 ).
}

Múltiplos mundos no olhar que permite desnudar-se na aura, respondendo ao olhar.

Aonde o horizonte termina será apenas o começo de onde nossos olhos podem tocar, porque a imensidão infinita é morada em nosso pensar.

“ Está implícita no olhar a expectativa de ser correspondido por aquilo a que se oferece. Se tal expectativa ( que pode associar-se no pensamento tanto a um olhar intencional de atenção como a um olhar no sentido literal da palavra) é satisfeita, o olhar consegue na sua plenitude a experiência da aura[...] A experiência da aura repousa, portanto, na transparência de uma forma de reação normal na sociedade humana para a relação do inanimado 
e da natureza com o homem. Quem é olhado ou se julga olhado levanta os olhos. ( BENJAMIM, apud, WANNER, 2010, p. 240-241 ).

Sobre vestígios Susan Sontag, considera a imagem da fotografia como uma marca, " uma interpretação do real, é também um vestígio, algo diretamente traçado fora do real, como uma pegada ( SONTAG, apoud, WANNER, 2010, p. 242 ). E ainda segundo Celeste Wanner em seu livro, Paisagens Signicas, uma reflexão sobre as artes contemporâneas, Roland Barthes em sua metáfora da vidraça e da paisagem, reivindicaria o que o referente adere.

Olhar em ressonância com o caminho que se faz, apesar dos passos como compassos um após o outro, se observa uma não linha do tempo Kronos, mas sim, uma possibilidade de adentrar um outro tempo, o Cairos, onde o sentimento absorve uma temporalidade distinta que nos desloca diante de um passado, presente e devir, em uma compreensão capaz de sobrepor temporalidades em uma fluidez que nos condensa de maneira a projetar um processo de construção de uma criação-realidade-imaginação onde essa ressonância é como o som que permanece além do seu tempo ( compasso ) porque já se abrigou nos ouvidos da alma, e percorre os sentidos próximos de maneira a nos comunicar imagens que se entrelaçam com uma sinestesia, significada entre gestos da forma ao dizerem palavras imagéticas, corporificadas em memórias lastreadas pelo existir. Imagem e som sem dicotomia constroem e renascem no universo latente das formas que se desvanecem para ser outras.

Neste momento é de extrema relevância, se indagar sobre que imagem estamos capturando no tempo contemporâneo e que vestígios irá permanecer e o que o devir espera de nós, como construtores de uma sociedade que almeja um retrato honesto em acordo com o rumo evolutivo, o que nos remete a Jurgen Habermas, ao dizer que, “ Uma pessoa só pode ser livre se todas as demais o forem igualmente ".

Se considerarmos a dificuldade que se apresenta no tempo que se consome, ele mesmo como produto, devorando de forma insaciável imagens propriamente dele mesmo, onde nesse frenesi até se perde a noção de que imagem corresponde ao universo do cinema ou do cotidiano, estamos diante de um desafio de discernimento, envolvendo a capacidade de inquirir sobre as camadas dessas imagens, realizando um diagnóstico para além do que nos atravessa, mas para algo em profundidade, com um indagar reflexivo capaz de motivar ações que sejam condizentes com a busca de um contínuo de uma possível verdade, dentro de 
uma beleza que esteja amalgamada a uma razoabilidade no tocante ao que se refere o filósofo Charles Sanders Peirce, uma imagem que seja o índice de uma sociedade que se compõe a cerca de uma visão do que pode ser um bem lógico, um bem ético e assim construindo uma estética dentro do que vislumbramos ser, o admirável.

Dessa forma iremos adentrar um terreno minado, onde a cada passo (compasso) devemos tomar cuidado para não estarmos diante de um holocausto cego e uma guerra sem armas e não registrarmos essa imagem no documento do retrato contemporâneo, ainda que visivelmente pulsando a cada segundo do "disparador" ato de existir.

Marginalizados estão muitas cenas, construídas pelas desigualdades e expostas nas galerias do mundo, sem que nem mesmo na velocidade do tempo, capturemos sua necessidade interior, que nos observa e nos captura exaurindo de si as falas da corrosão de um sangue do sujeito mundo- hemorragia da incompreensão, que se perde ao não olhar-se no outro.

Manifestamos de fato o que, em nosso viver?

O que está a espera de nós? As escolhas do devir que se fazem no presente? Latentes são as imagens a cada segundo, frames sonoros de uma voz rouca de tanto gritar para ser registrada, capturada em um labirinto onde talvez, ainda tenhamos em mãos, o fio de Ariadne.

\begin{abstract}
"O poder da comunicação está no centro da estrutura e da dinâmica da sociedade. (apud) Castells questiona " por que, como e quem constrói e exerce as relações de poder mediante a gestão dos processos de comunicação e de que forma os atores sociais que buscam a transformação social podem modificar essas relações influenciando na mente coletiva (2009:24-25). Para ele, o "processo de comunicação opera de acordo com a estrutura, a cultura, a organização e a tecnologia de comunicação de uma determinada sociedade" E hoje " a estrutura social concreta é a da sociedade-rede, a estrutura social que caracteriza a sociedade no início do século XXI, uma estrutura social construída ao redor das redes digitais de comunicação"(Ibid) Essa nova estrutura da sociedade-rede modifica as relações de poder no contexto organizativo e tecnológico derivado do " auge das redes digitais de comunicação globais e se eleva no sistema de processamento de símbolos fundamental da nossa época" (KUNCH, 2014, pg. 38
\end{abstract}

Que imagem estamos projetando da sociedade como um todo que se desloca freneticamente em rede e carece na maioria das vezes no cotidiano inerte, do movimento real e concreto da objetividade em um empirismo do existir que desponte para uma solidariedade. 
'Parece-me que a responsabilidade social- sustentável, está em todas as relações presentes no mundo, estejam elas nas relações pessoais, nas instituições, no Estado, ou seja, aonde quer que as conjecturas emergenciais do existir pulsem, essa necessidade estará eclodindo como fator decisivo perante a complexidade do tempo atual, como capacidade a ser desenvolvida, acrescida de valores que encaminhem ao desafio evolutivo.( Sousa, 2015),331

O que pertence a mesma atmosfera, onde as condutas não se esclarecem permanecendo exauridas de suas forças e de seu "real" destino, na busca da estética, como parte da Arte do viver. Se cada ato puder capturar a imagem do admirável, poderemos construir e caminhar para uma comunidade em um futuro que, nem que seja pela eminência de sua morte, DESPERTE!

\footnotetext{
${ }^{331}$ Citação referente ao texto fruto de uma reflexão a partir de discussões em grupo de estudo de ética na Pontifícia Universidade Católica. Nesse texto intitulado: O dilema contemporâneo em meio ao empirismo do existir, pondera para caminhos necessário na sociedade contemporânea como formas cabíveis e que não podem e não devem ser colocadas como emotivismo- corrente filosófica, mas como uma maneira rela e concreta de alcançar objetivos de uma comunidade global.

${ }^{332}$ SOUSA, C. G.. Ericsiton: Um mito dos tempos atuais?. Revista Estética, Revista Estética USP, p. 1 - 6, 02 set. 2016.
} 
2.4 A estrutura sonora em movimento de imagens.

O cotidiano imperativo que nos envolve em contínuos de imagens efêmeras, sobrepostas, contínuas, adjacentes, ressoando a vida propriamente nos os espaços do conviver, dialogando e sendo o próprio movimento. O espaço social fornece algumas determinações em sua composição de áreas, sejam comerciais, residenciais, infra-extrutura, recursos de transporte e assim por diante o levantamento ocorre inserido no próprio cotidiano que informa notavelmente suas estruturas habituais e por onde ocorrem as deficiências entre seus espaços. Havendo diagnósticos e levantamento de possíveis conexões com alterações que viabilizem em conjunto sanar dificuldades e ainda movimentar, o suficiente para um desenvolvimento em relações tanto internas com ramos de outros espaços em escalas, presume-se que atenderá com o tempo um viver satisfatório ou de alcance de um bem-estar mais geral, promovendo uma subsistência urbana.

Uma inteligência dos espaços sociais em urbanismo a meu ver colabora com a responsabilidade social no que diz respeito a integridade do já existente, com a propensão em aspectos do por vir, elaborando uma mobilidade disposta a colaborar como um grafo de uma forma que pode assumir metamorfoses urbanas sem denegrir o existente e ainda facilitando a organização futura. Emprega-se via de regara suponho uma gestão, que encarne a responsabilidade com suficiente clareza para estabelecer critérios da maior variedade de premissas desde manutenção, a deslocamentos e acréscimos conforme as eminentes procuras e necessidades dos espaços da sociedade, estes indo não somente de infraestrutura, e demandas de serviços, mas também a atenção ao que ocorre no âmbito de respostas advindas de o que se comunica em silêncios urbanos, como: violência. E, dentre essa perspectiva que enfrenta tanto a propensão como as ocorrências destrutivas, claramente dispomos de estar aptos a perceber dentre os espaços, onde a via, passa a ser a estrutura de um caráter emergencial ou seja, onde a pedra cai no rio, porque ela reverbera, em situações de presenças sociais, que se constata justamente no que é ressonância, a favor ou não. Portanto, segue-se como prioridade estabelecer critérios do que está de desmembrando em caráter pejorativo do que pode a princípio aparecer como restrição dos outros espaços, devido a incapacidade de estarmos sanando emergências, então presume-se que este diagnóstico dos fatores emergenciais sejam a prioridade, devido até mesmo como já dito seus desmembramentos desfavoráveis a integridade social como um todo. Vale ressaltar o espanto de se constatar que por vezes se viabiliza projetos em áreas que não são justamente 
as mais carentes de recursos de toda ordem, e claro isto porque não se tem a consciência do que pode nos atingir normalmente, e então ainda me pergunto, saímos das cavernas?

O maior desafio em conexões da espécie de espaços urbanos, ou de um viver, onde quer que ele se abrigue são as diferenças onde a demanda de direitos entre os serviços deveria ser mais igualitária, havendo a mesma preocupação com necessidades básicas, segurança, educação, saúde, em espaços sociais que comportem as infraestruturas em acordo e de direito no mínimo preservadas. Após esta introdução, nota-se que, temos uma imagem social, na qual nos vemos representados, porém, sabemos que os desafios humanos para com a igualdade em relação ao que é de oportunidades e acesso, não corresponde em mesma medida, da imagem que promovemos em geral, então me parece que de fato, precisamos nos aproximar entre o que é realidade para todos. Do que ouvimos, a cidade canta, ${ }^{333}$ soa, grita, silencia, se manifesta, sempre. Em parte, provoca seus movimentos, ou refreia estados seus de emancipação por não poder alcançar os mecanismos do governo em diálogo que estabeleça, informação, comunicação, como agente entre as partes,

Trabalho e vida, espaços que ressoam. Um dos espaços sociais que mais colaboram com o tempo, escancaradamente sabemos que é o trabalho, porque é força que move, que adquire e restaura a dignidade humana, favorecendo o crescimento em amplo aspecto, de fato integrando o ser no corpo social, portanto a vida adquire sentido que se ouve em detrimento de angustias patológicas inclusive do organismo urbano ou rural, pelas condições de se estabelecer no mínimo com as vias de verdadeiramente ter o direito de se chamar cidadão. $\mathrm{O}$ que se representa propriamente imagem de seu viver, isto é elemento de impacto, como compasso em ângulo e perspectiva do que poderemos olhar como caminho a seguir. Mas, de novo, esbararemos em circunstâncias por vezes e de toda "sorte" adversas, que vem desde se tornar infelizmente um ciclo difícil de ser rompido, quando este é inserido em aspectos familiares deteriorados, que desestabilizam todos os demais fatores, alimentação, moradia e assim por diante, em fluxo que precisa ser levantado onde pode ser alterado, em que ponto deve ser alterado para se revigorar e completamente ser metamorfoseado quanto a de alguma forma, ou por agentes sociais, governo ou terceiro setor, ter um alcance, e não é fácil, das mazelas onde ao menos se possa abrir uma porta por onde passar e alterar significativamente o cotidiano de um indivíduo- que passa a ser realmente do grupo familiar, ou de seu grupo, e ocasionando a integração para após, perceber o estado orgânico em perímetro e expansão, para a realidade como um todo, podendo chegar a agir como instrumento de diagnóstico e

\footnotetext{
${ }^{333}$ ( arquivos de musica brasileira - colocar ainda aqui, 'varias referências - )
} 
estímulo a conexões que viabilizaram concretos estados de possibilitar novas conjecturas de significado humano. Portanto o espaço do trabalho, não é somente um, mas múltiplo dele. E se ele se torna objetivo, o que precisamos para alcança-lo? Pergunta-se: O que temos de conhecimento sobre o trabalho, que questões podem nos cercam sobre esse objeto a se conhecer como valor integrado do que somos enquanto cidadãos. Quem sou, pode dar uma pista do que haverei de procurar, dentre o que já é possível como fator de abertura nas demandas e exigências ou carências de onde vivo? Entre o que sou e o que desejo, e a sociedade, qual o lugar de meu trabalho, que viabilize uma ponte suficiente capaz de me tornar um sujeito com narrativa na qual não sejam somente meus dias, um após o outro sem que eu nem mesmo me emocione ou sabia qual a razão de eu os estar vivendo, mas que eu seja capaz de compreender o trabalho como valor de mim mesmo, enquanto ser que se constitui integro na sociedade respondendo por seus deveres e direitos, preservando assim, não somente o seu estado consciente mas também participativo e atuante como indivíduo e povo. Pode parecer difícil, mas não deve ser considerado impossível, constatar os caminhos que deverão muitas vezes ser traçados, principalmente não somente em oferta e procura, mas educação, estudo, trabalho, e ainda, antes, em que situação se vive, sobre esgoto a céu aberto ou quais mesmo as condições.? Então a palavra condição torna-se protagonista da ação social, sendo está não somente condições para se obter a vaga em um trabalho, mas principalmente em que condições vivo para alcançar meu objetivo, tenho o mínimo como sujeito, para ter ao menos a oportunidade de trilhar um caminho, ou os passos, estão deveras ainda imprecisos quanto a condições mínimas de salubridade orgânica e como ser que vive. Não colocando responsabilidades em nenhum outrem, mas apenas constando realidades vigentes, atuantes, e que muitas vezes são tão absurdas dentre violências e mais violências, que precisa de uma atitude de ação social onde se insere de alguma maneira uma fresta por onde se possa olhar uma alternativa. E então, se torna fundamental, algo que recebe me parece o nome de planejamento, que suponho esteja sobre essa fresta, havendo de estabelecer os critérios de onde e como começar e para além do diagnostico agir sobre as emergências, com restabelecimento da capacidade do indivíduo estar no mínimo ciente de sua situação, a meu ver, o primeiro passo.

Tudo pulsa no mundo como som e imagem, na qual quase como o que respiramos por vezes não percebemos e este é um risco na equação do que até as vezes deixamos de mensurar como o que se tornou um existir. Em qual cadências estamos tão inseridos que não vemos ao redor o que precisamos para uma verdadeira harmonia. Despertar para o som, é também 
compreender como a expressão pode dialogar com nosso espírito latente, a espera de que verdadeiramente ouçamos o outro, como significado, sentido, do sentir. Não estarmos amortizados a ponto de não perceber o que o cotidiano que nos cerca pode ser além do que vemos, é uma condição de mudança. E a linguagem que se pode observar mais claramente talvez, para alguns como sendo a arte propriamente é face da vida, ritmo, movimento, desenhos, cores, enfim, tudo que vive é arte. ${ }^{334}$

A noção de que o poder da música, especialmente a palavra entoada, pode influir no curso do destino humano e até na ordem do Universo, remonta as mais antigas formas sobreviventes da música indiana, a saber, a dos Vedas. A fórmula entoada é o fulcro de toda a complicada estrutura das oferendas e sacrifícios védicos. O poder das palavras enunciadas com a entoação correta determina a eficiência dos ritos, um engano pode destruir tudo. Proclamam os sacerdotes que, por sua atividade, não só sustentam a ordem da sociedade humana, mas também mantém a estabilidade do universo. Por intermédio de cerimônias bem dirigidas, eles detêm um poder compulsivo sobre os próprios Deuses. O instrumento que transmite esse poder é a palavra". (TAME, 1984, pg 187).

E voltamos ao recurso de observar a palavra como discurso e a palavra como imagem, repercussão em atos concretos ainda a encontrar correspondência. Da palavra, a imagem projetada, junto com o som, sentido ecoando no universo. Se queremos uma sociedade, mais justa e igual, haveremos de transformar discursos em realidade vigente, e então, imagem concreta de nosso tempo, ou ao menos, o que ressoa dele como progressão em possível. Talvez seja justamente nesse entrelaçamento que possamos considerar o sentimento relacionado com o sentido em som e imagem não uma abstração, mas uma ressonância que pode fecundar uma existência. ${ }^{335}$

“ Compreende-se então, que os átomos e as partículas subatômicas não só contém tais energias, mas são eles mesmos compostos de nada mais do que energia em estado de oscilação" ( TAME, 1984, pg 237).

Da estrutura sonora, temos presenças do existir que se assemelham e afinam conforme podemos observar, ritmo, cadências, frequência, tanto que observamos as imagens do cotidiano sobre o mesmo prisma, nos fazendo ter a noção inclusive da hipótese representativa do tempo, como imagens nas quais estamos inseridos, propriamente como

\footnotetext{
334 Tame David. O poder oculto da música. Tradução Octavio Mendes Cajado. Editora Cultrix 1984. Especialmente capítulo 3. Avaliação: A música, o Homem e a Sociedade. Música, consultar de Mariz Vasco, história da música no Brasil. Editora Civilização Brasileira, Rio de Janeiro. 1983, e também Lacerda Oswaldo Costa, Compendio de Teoria Elementar da música, Ricordi Brasileira 1961.

${ }^{335}$ TAME, David. O poder oculto da música. Avaliação A Física do OM, pg 223.
} 
movimento. Sobre a pauta ${ }^{336}$, os acontecimentos como paralelos, notas entre notas, revelando harmonias ou passagens de compassos, por onde os elementos se constituem indivíduos, grupos, enfim, estruturas paralelas de sentido. Desafio portanto é sabermos ouvir como na Fuga de Bach, várias vozes, em pleno objeto como particular em cada caminho sonoro, participando de diálogos sem com isso, cada qual perder sua forma, mas estando introduzidos em um significado ainda mais complexo e extenso, como nós enquanto indivíduo e sociedade, porém, havendo ainda de aprendermos a respeitar e ouvirmos uns aos outros.

Entre imagem e som, o instante que se prolonga, como uma outra frequência, diferentemente do que apontamos como período, a que reverbera do instante, frequência ressoante, alterando a noção do tempo, entre a realidade e o sentido, a percepção, e visivelmente sendo ato de memória, compartilhado com qualquer outro intervalo de tempo. O som e o Verbo, sentidos entre a palavra.

Lápide e vida. POEMAS IN( VERSO.)

Se de minhas mãos fizeres asas

Soa tua solidão em minha voz

Tuas marcas percorrendo o caminho

Em traço e leito ( luto ) de um repouso

Sozinha, parto de minhas feridas

Desalinho, o meu tecido em plumas

Arpejo, a me cobrir em arco

Deslizo, corpo adentro em mundo

Se de minhas mãos fizeres, amor

Serei como ave revoando

Suspenso da castigada dor

Percorrerei em si, lhe tocando

Ao querer conhecer o tempo

Busco de mim, o teu pouso

Que é ninho do sentimento

Silêncio e refaço-me

Instrumento, a paizão

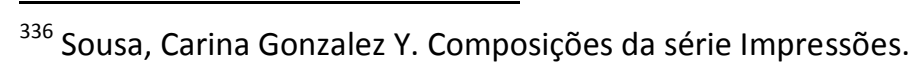


$\mathrm{Na}$ frase sem cor, a tonalidade

Que ficou no compasso

Ainda desenhando o seu traço

No voo eterno da melodia

Que dizer, alma esquecida

No palco que percorre a solidão

Personagem a espera da luz

Frases ressoando em escuridão

A peça, está percorrendo tuas asas

Escritas no teu corpo sutil

Houve os passos da tua palavra

No eco das coxias da alma

Faz-se dramaturgo do céu

E represente a imagem ( de ti mesmo)

No coro da imensidão, em eco

Disperso no espetáculo, tardio

Horizonte de ensaios, d(o) cotidiano

Figurino em contraste, sem dor

A espera, que percorre a dizer-me

A voz e o som do teu amor

Se de minhas asas fizeres asas

Soa tua solidão em minha voz

Houve os passos da tua palavra

No eco das coxias da minha alma

Até que meu corpo seja teu som

E o teu som, a minha alma.

3. O verso e o reverso da palavra.

O pensamento desenha o corpo da palavra pelo(s ) sentido(s) do sentimento

O difícil - e o interessante- em desafio - a constante

Equação igualitária $=$ posto que o simples é :

Por vezes um infinito complexo.

Onde o nexo se reparte em incógnitas 
Decifráveis em partículas variáveis do todo.

O sentimento desenha o corpo da palavra pelo sentido do pensamento

Pensai onde o corpo da palavra me revela alma

Onde a natureza te reveste, escrita

Gesto do mundo que calamos

Ouvindo teu rosto que procuramos.

O porquê das palavras,

Porque penso que a ausência dessas águas são de minha palavra, o cimento bruto existente que seca e amarga o cotidiano sem janelas. Preciso acercarme dos lábios densos, e debruçar-me sobre o Eros da imagem, aprisionado no campo do não dizer. Rosa que deleita-se no papel, da vida redimensionada, em através, fez-se botão a abrir-se em pétalas de contos dos personagens não utópicos, mas existentes em ser poeta do corpo, sonoro nos ecos da linguagem, que sente, como o fingidor, é Pessoa, em viver. ( SOUSA, Carina Gonzalez, 2017 ). Do conto, Concreto Sertão, no livro, Amanajé, contos e reflexões.

O ímpeto do dizer nascendo grafia, atravessa a representação da palavra entre a imagem e o som. Imagem habitando o sentimento, extraindo dele a capacidade de ser hospedeiro, signo, de um querer manifestar-se ação de um significado, caminhando pela ausência do que almeja tornar-se corpo estendido, construindo-se passagem, por onde histórias, lugares, personagens, poemas, desfolham-se na busca da alquimia do aroma do existir.

O momento que perpetua. É o sentido da presença que se foi, estando no eterno. E de onde a autoria que a palavra do desejo procurou, se foi ausente, agora é do sentido e não da sua gente. Escrevendo à alguém, que já partiu, existindo.

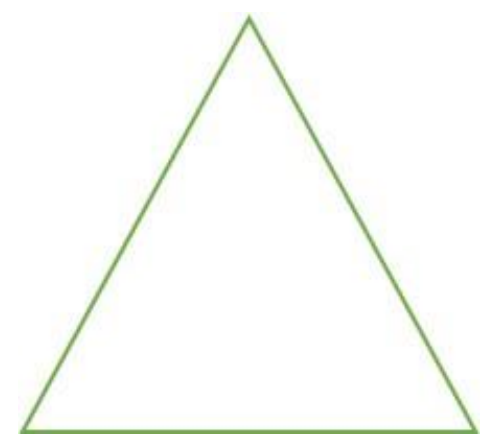

3.1 A metáfora no através dos sentidos do enigma. 
As vezes a poesia está tão na minha carne que respiro a alma dela.

Tornar-se espaço do movimento.

Pedem-me as estrelas, para ler algo, então mais uma vez debruço-me sobre as palavras, o nexo ou o sexo delas, para poder reter em mim o sentido desse sentimento que invade a noite antes de dormir. Talvez, e quem sabe alguém, possa elucidar das frases as entre linhas dos lençóis, do tempo em que as imagens se beijam em entrelaçamentos de versos. Que fazer se de mim, já são um caso antigo, explicito mesmo, de uma relação que do tempo faz apenas confessionário amoroso, de um pecado nascido do original que tomou do pseudônimo a veste de ser amante dele mesmo, em relações partilhadas, possíveis de serem delatadas, porque possuem no cerne, a crua verdade de serem elas mesmas, (n)a busca de seu próprio sentido. Então, mais uma vez, porque dormir, pergunto, se a entrega da noite já está sobre mim, antes mesmo do jornal da manhã, ou do café que escorre dos lábios saboreando as primeiras horas ainda como preliminares. Se me entrego a uma folha de papel, eu digo à você: COMPLETAMENTE. Ouço seus sussurros, como aquele dizer ao pé do ouvido, lascivo e pueril ao mesmo tempo, desejando que a grafia nasça, sem pátria, porque tem somente o corpo da liberdade. Se assemelha a um dizer da espera ao lado teu de dizeres de poesia, onde o secreto segredo não é mais nada do que a vontade acariciando a pele e apalpando o reverso do pensamento para dessa entrega, ser o primeiro momento infinito de se despir. Porque sou assim? Ora, porque o amor, mora em mim. Vejo dos segundos da tua alma, a deitar-se sobre mim, as linhas que agora já tem seu pulso, latejando. Venha, ser prosa ou poesia, olhos de mim, passagem dizendo, agonizando ser meu companheiro, meu fiel destino, que mesmo quando em desalinho, visita-me. Não te passa desapercebido, que dos outros olhos são o mundo, e mudo gesto pode ser, um através, que não se despede, mas ilude a ponto de desafiar-me, por te manter afastada, esquecendo-se do próprio som que $\mathrm{s}(\mathrm{t}) \mathrm{e}$ faz viver, palavra. Pode, na multifacetada cara desse mundo, distraidamente e como, almejase tornar-se "oblivion", permanecer ecoando o que não se fez, morada minha. Talvez, porque de muitas faces o mundo se vista, mas de todas elas, eu posso ler, e se te vejo, ao ler, eu te pertenço, e já eres meu (verso), de corpo inteiro. Mesmo que sofregamente estejas, não deixarás de me encontrar, porque como animais no cio, a vida é comunicação, partindo do eu, amado, amante, desejo constante e insaciável ( de morrer a cada segundo que vive em ti), porque teu semblante é paisagem, horizonte, de onde por fim, sempre ouvirás o oceano.

Ponto, vírgula, e uma concha por onde se pode ouvir o oceano. 


\section{Ocean poem ${ }^{337}$}

I can hear the ocean

as rivers in my mind

I can hear the sound of sand

nature of my thinking

I can hear the heart of the breeze as

sound covering the morning where

between clouds remake me

face the melody of movement

and there in the music of my dreams

always around my soul

finally find myself

and on the way remain.

now and forevermore

more.

I can hear the silence

between the voice of feeling ..

and then

I want to see in your eyes

a poem

written in the infinite life

on the sound of eternal love.

337 Sousa, Carina Gonzalez Y. Poema oceano. Como rios em minha mente. Posso ouvir o som da areia. Natureza de meu pensar. Posso ouvir o coração da brisa como. O som cobrindo a manhã, onde...Entre nuvens me refaço. Face a melodia do sentimento. E lá na partitura de meus sonhos. Sempre ao redor da minha alma. Finalmente me encontro. E no caminho permaneço. Agora e para todo o sempre, mais. Posso ouvir o silêncio, entre a voz do sentimento. $E$, quando eu quero ver em seus olhos. Um poema. Escrito na vida infinita, no som do amor eterno. 
O ponto, o átomo, a vida, sujeito ambiente.

Caro, amigo. L. Partiu dizendo que um livro seu sobre mim na Argentina conseguiria um grande sucesso e seria traduzido em muitas línguas. Como sei que atualmente você está escrevendo muitos livros, considero que este é exatamente o momento de escrever um a mais. $\mathrm{O}$ importante é encontrar um jeito de escrevê-lo sem trabalhar nele, ou seja, esse livro deve escrever a si próprio. Resolvi o problema graças ao título: O atómo de Dali. ( sujeito ambiente ). O prólogo já está feito, com minha presente carta, na qual concordamos em constatar que ao menos na região do Ampurdan, o único átomo que está sendo fabricado é o átomo de Dalí, o que justifica completamente o interesse da obra. Assim, enquanto todos se perdem em ramificações, você irá se concentrar em um único átomo daliniano, o que bastará plenamente para seu estudo. Cada vez que viermos a nos encontrar, vou the dar novas fotos de meu átomo, fotos e documentos relacionados. Assim, você só terá que criar o ambiente, o que será fácil tendo em vista seu sublime dom descrito. Meu átomo é tão ativo que trabalha sem parar. É ele eu repito, que fará o livro, e não, nós. E para um átomo - e além do mais para um átomo daliniano, um livro vem como uma necessidade natural. Diria até que ele descansa ao escrever um livro. Um livro consagrado a alguma coisa que não posso precisar ainda de uma maneira exata, por não saber do que se trata. E aliás, para mim, o paroxista louco por precisões imperialistas, nda parece tão doce e agradável, repousante, e mesmo gracioso quanto a ironia transcendental suposta pelo princípio de incerteza de Heisenberg. ( DALI, Pg 49

Das palavras,

As vezes a poesia está tão na minha carne que respiro a alma dela.

Tornar-se espaço do movimento.

Pedem-me as estrelas, para ler algo, então mais uma vez debruço-me sobre as palavras, o nexo ou o sexo delas, para poder reter em mim o sentido desse sentimento que invade a noite antes de dormir. Talvez, e quem sabe alguém, possa elucidar das frases as entre linhas dos lençóis, do tempo em que as imagens se beijam em entrelaçamentos de versos. Que fazer se de mim, já são um caso antigo, explicito mesmo, de uma relação que do tempo faz apenas confessionário amoroso, de um pecado nascido do original que tomou do pseudônimo a veste de ser amante dele mesmo, em relações partilhadas, possíveis de serem delatadas, porque possuem no cerne, a crua verdade de serem elas mesmas, (n)a busca de seu próprio sentido. Então, mais uma vez, porque dormir, pergunto, se a entrega da noite já está sobre mim, antes mesmo do jornal da manhã, ou do café que escorre dos lábios saboreando as primeiras horas ainda como preliminares. Se me entrego a uma folha de papel, eu digo à você: COMPLETAMENTE. Ouço seus sussurros, como aquele dizer ao pé do ouvido, 
lascivo e pueril ao mesmo tempo, desejando que a grafia nasça, sem pátria, porque tem somente o corpo da liberdade. Se assemelha a um dizer da espera ao lado teu de dizeres de poesia, onde o secreto segredo não é mais nada do que a vontade acariciando a pele e apalpando o reverso do pensamento para dessa entrega, ser o primeiro momento infinito de se despir. Porque sou assim? Ora, porque o amor, mora em mim. Vejo dos segundos da tua alma, a deitar-se sobre mim, as linhas que agora já tem seu pulso, latejando. Venha, ser prosa ou poesia, olhos de mim, passagem dizendo, agonizando ser meu companheiro, meu fiel destino, que mesmo quando em desalinho, visita-me. Não te passa desapercebido, que dos outros olhos são o mundo, e mudo gesto pode ser, um através, que não se despede, mas ilude a ponto de desafiar-me, por te manter afastada, esquecendo-se do próprio som que $\mathrm{s}(\mathrm{t}) \mathrm{e}$ faz viver, palavra. Pode, na multifacetada cara desse mundo, distraidamente e como, almejase tornar-se " oblivion", permanecer ecoando o que não se fez, morada minha. Talvez, porque de muitas faces o mundo se vista, mas de todas elas, eu posso ler, e se te vejo, ao ler, eu te pertenço, e já eres meu (verso), de corpo inteiro. Mesmo que sofregamente estejas, não deixarás de me encontrar, porque como animais no cio, a vida é comunicação, partindo do eu, amado, amante, desejo constante e insaciável ( de morrer a cada segundo que vive em ti), porque teu semblante é paisagem, horizonte, de onde por fim, sempre ouvirás o oceano. ( poema - Ocean - Carina Gonzalez Y Sousa )

Tem momentos em que parece que tudo acabou, que nada mais precisa ser escrito, mas como se pode romper ou deixar-se assim, esse sentimento. Brasa que faz queimar as cinzas que seriam somente como carvão a escrever mais uma vez. De tudo e realmente, não poderia ser as últimas palavras, mesmo que pareça feito, a fome me dilacera, como um ranger que sempre te quer, e aí se não te encontro. Se, não te encontro, procuro-te em tudo que sempre está em ti, na janela vazia, porque deixas-te tua assinatura antes do texto, na cadeira por onde estive e até agora não mais é presença, porque meus passos procuram-te. Enlouqueço só de pensar que não estarás a meu lado, mesmo sabendo que a palavra me guia. Quase febril, o suor goteja as frases, construções de minha volúpia, erguendo minhas forças, dizendo até mesmo o meu silêncio. E, afortunadamente, como a enriquecer-me de grãos de areia infinita, marca-me, como gado, para eu ter a certeza, ou você, de que em nossa liberdade, és meu cárcere. Da fuga, que outros desejos te cerquem, ou a mim, (d)a imagem ou o som, não são mais que mesmas cenas sobre outros personagens. Na dramaturgia dos sentidos, metamorfoseia-se tudo a sua volta, dificultando ou abrindo-se para que eu te encontre. 
Nessa passagem, entre o que pode ser a despedida, apenas a folha em branco, e nem mesmo assim, será, porque o pensamento está a espera, a tempo desde que é o seu destino, e de lá houve continuamente o teu coração. Possuir-me antes mesmo de ser teu, é algo que a compreensão não saboreia pela razão, mas desagua somente no gozo que é vestígio de que não partiste, e desse lastro pode ser do sentimento a vazão que sempre esteve entre nossos corpos, alma onde a carne sorve o prazer antes mesmo de viver.

E, como ao gemer do pensamento, busca, o movimento de se conhecer, identidade que permeia-se pelo não dito, amando e dizendo o silêncio, murmúrios de todos os gestos que podem ser, o manifesto. Palavra, verso, tinta escorrida de meu sangue, compreende-me. (Gerando (d)o próprio ato,)

O inquérito de nosso destino, está sobre o juízo do pecado, absolvido por estar do amor, apaixonado, ao viver impavidamente para ler-te.

Escoltados pelo consumo, devoram-se nessa entrega, por ciúme haver nesse caso estável, onde a paixão e o amor se confundem. Da palavra, a escritora e o leitor, cúmplices do mesmo gesto, ecoam como a ouvir o que os olhos pensam. Pela manhã esse mundo sorrateiro que nem mesmo atem-se ao ontem, sepulcro do que vive ainda mais, torna-se desatino, onde os segundos escrevem palavras de gestos não meus. Então me traíste. Ou o mundo? Não sei o que dizer à você, quando as minhas linhas esperam teu desenho, e onde você esculpe outro corpo. Não, não pode ser assim. Do outro então terei que ser amante, desse mundo serei alcova? Desse mundo, palavra, saboreei veneno como mel, crepúsculo como manhã de minha quimera. Insano me parece, ver-te assim, sobre outra cama, que não a minha? Palavra, não desafies um companheiro fiel. Entenda que tua existência é minha rendição. Mundo, esse teu outro amante, desconhece-te! Até onde sei que pode ir seu corpo, sou tuas entranhas. E antes mesmo que me queiras, sobre teu ser, me torno tempo.

Inútil será eu revelar, a ti que de mil facetas, me completas, donde o suspiro exala, que respiro o ar por onde teus pulmões aspiram. E, não me canso, nem por tanto e nem tão pouco, de ser o mesmo ar, mesmo que o mundo, de lá também possa nos encontrar.

Então, sem pudor vou me desvelando, perseguindo suas insinuações, para que eu não perca nenhuma letra, do teu gesto outro, ou o mesmo sobre minhas carícias. E, após tanto tempo, e desconhecendo teu ser, sendo, a infinitude já brota raízes em minhas rugas, atravessou-me, vorazmente e por tanto tempo, que me sinto só, mesmo estando contigo, porque talvez, a solidão me faça companhia, quando do mundo estiveres amando. Ah..... palavra minha, que 
não é semente, mas germina, fecunda e mente, ao (eu) crer que me pertence. Agora, percebo, entre tantas manhãs, e noites cálidas que amarelam teu dorso, que quando de mim és, do mundo te pertences. E, se mesmo assim, dessa maneira tão verdadeira, eu não te compreenda, é porque, eu ainda não sei o que é o amor.

Mas, de todo aquele que ama, o poeta sabe, que a prosa insiste, ao dizer que o afeto, sincero é de maneiras tantas, o teu pensar.

Como muitos já sabem, e não é novidade, a imagem em grafia é mais do que a construção de frases, e bem vindos ao mundo do que não se diz. Porquê?

Se condiciona a uma civilização que certas grafias em imagens tem sua correspondência, ou seja, através do símbolo na constituição das frases temos o que não é dito ( dizendo ) e pertence ao símbolo, mas não pode ser " adivinhado ", porém, codificado. E entre o codificado, temos o paralelo, o que ele significa e do que nele significamos, e ainda, o que é do jogo da metáfora. Não são culturas distantes, e as pedras das pirâmides tem grafia nelas. Existe matemática junto com grafia, realizada em pedras. Embora, penso que já sabem disso, suponho. Números, letras, geometria em movimento, o verso do silêncio. E do silêncio, em tudo que vive, e pulsa, o concreto de existir que se ergue... som.

Números, som, palavras, frequência, ressonância, imagem de uma civilização.

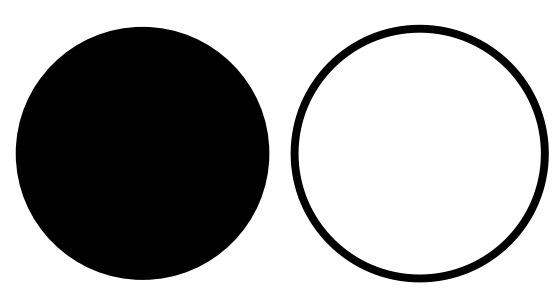



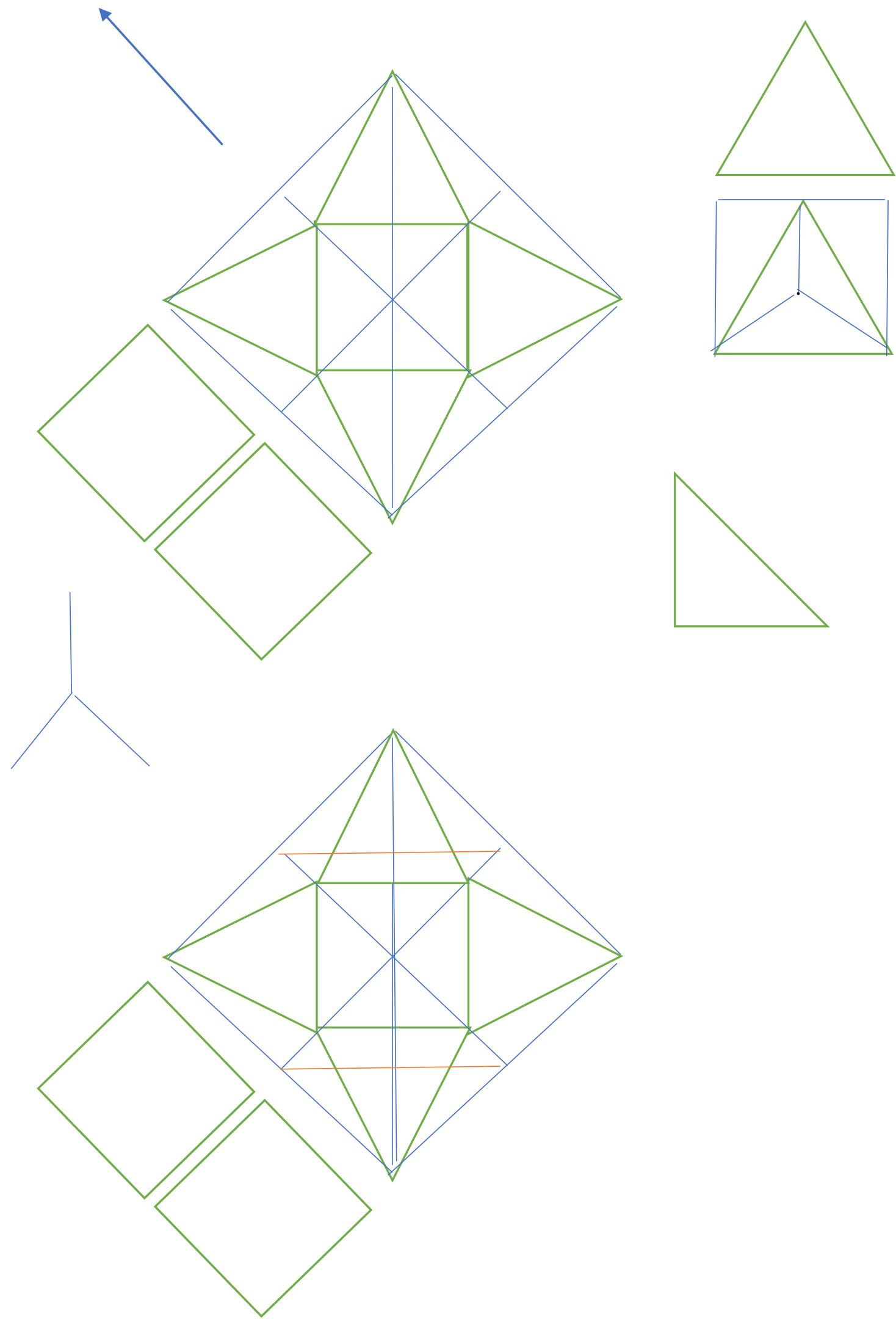


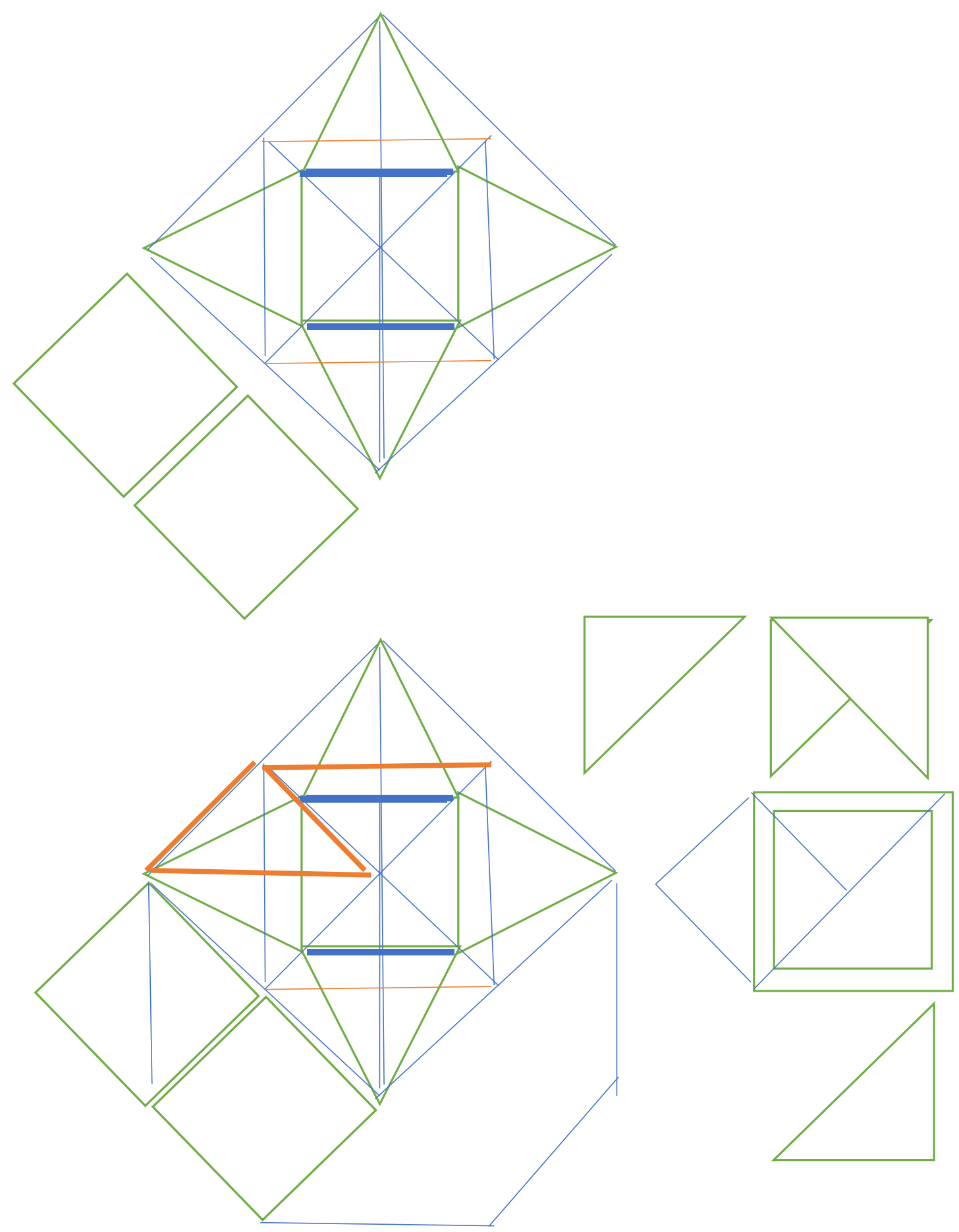



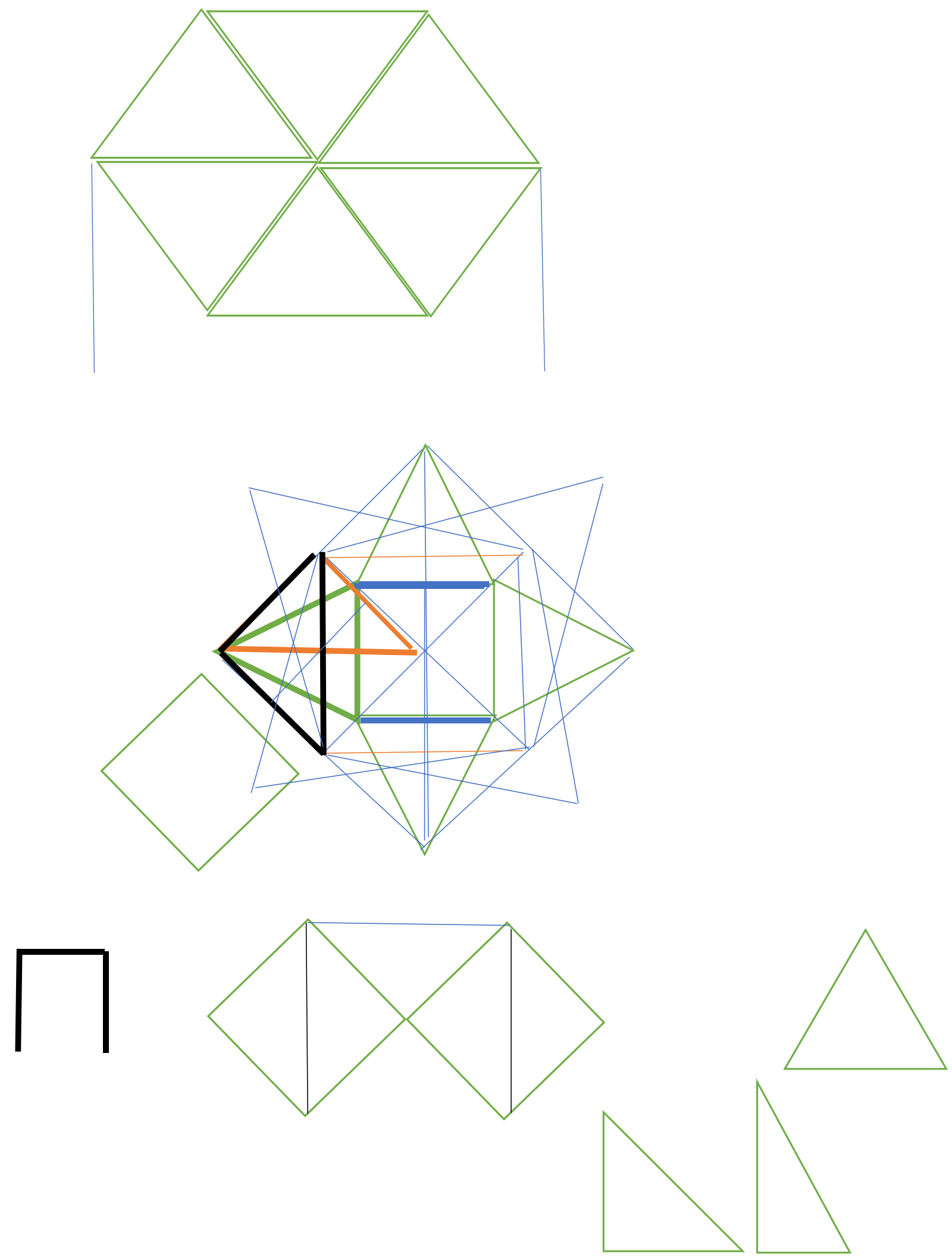
O que é o ponto?

Os quadrados são desmembrados desde o minúsculo ponto inicial -espaços - nós e vetor -grafos - energia

Linhas e geometrias

Linhas e palavras

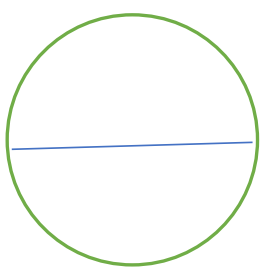

Linhas e som - Composição ARABESQUE
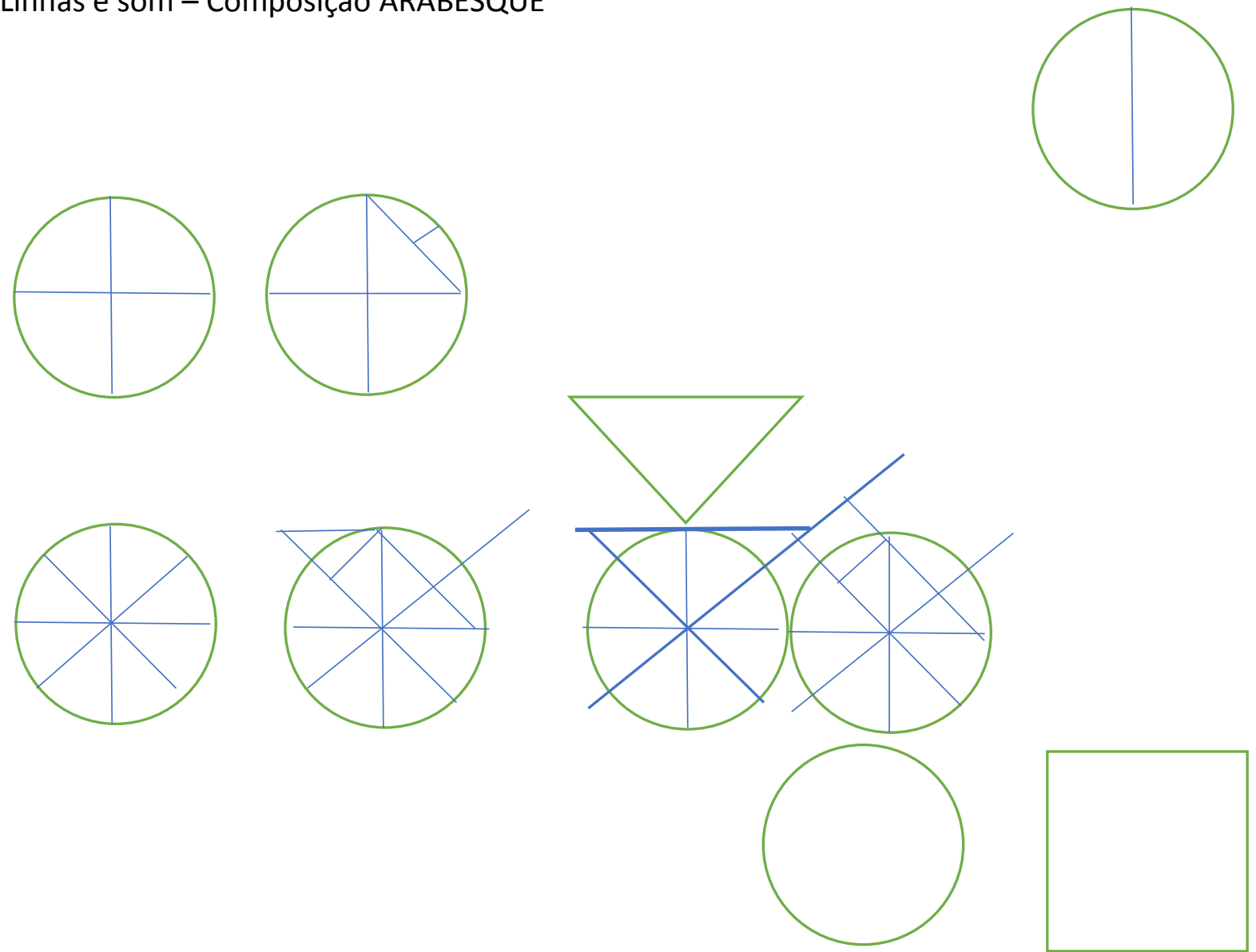

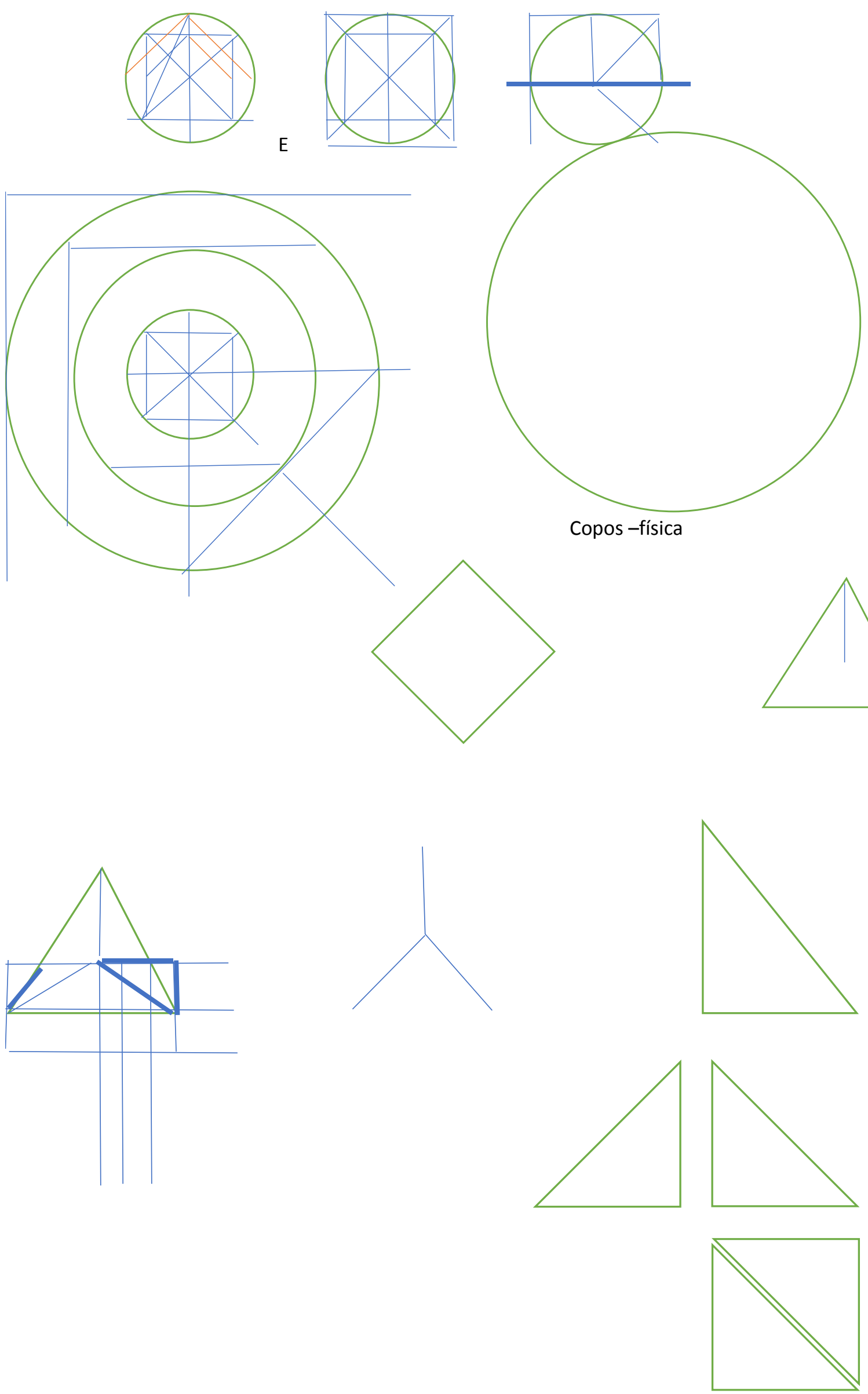

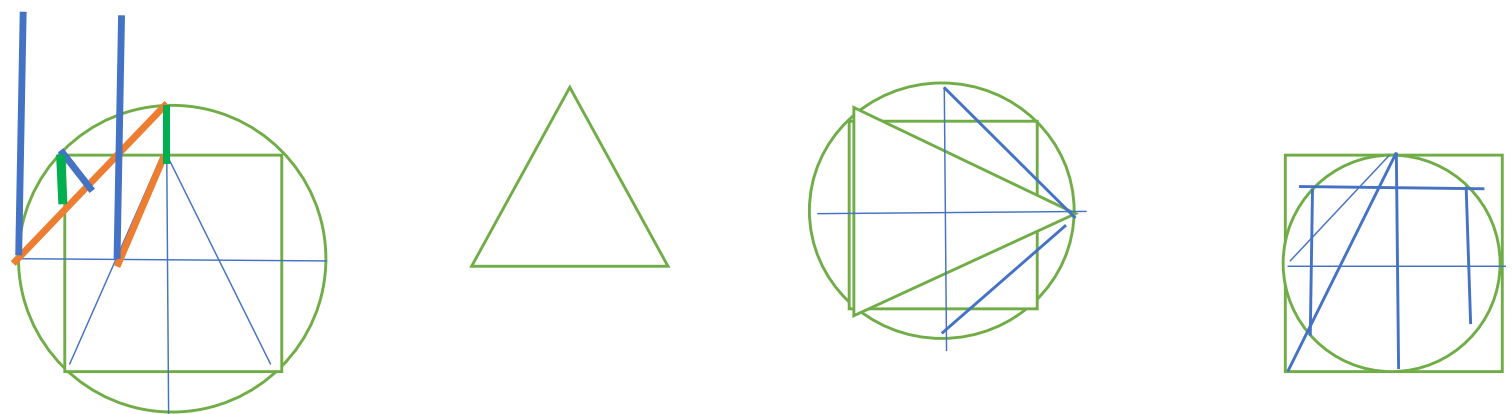

Escalas e congruências - e ressonâncias ou seja o desmembramento

Dimensões matemática

O VERBO DO COSMO.

Geometria é som, é escrita e imagem.

Dentro e fora
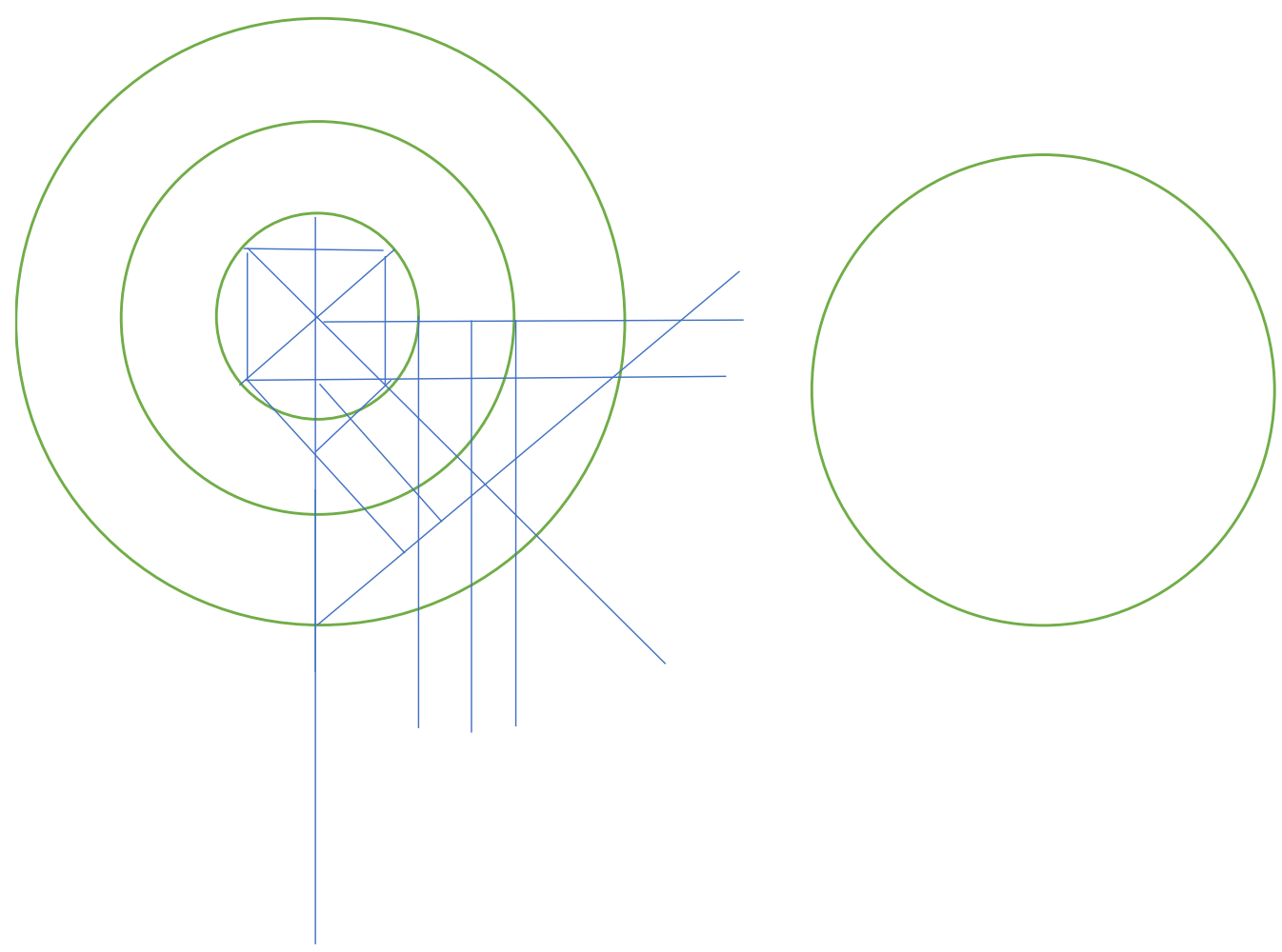
A terra do espaço parece .... um ponto.
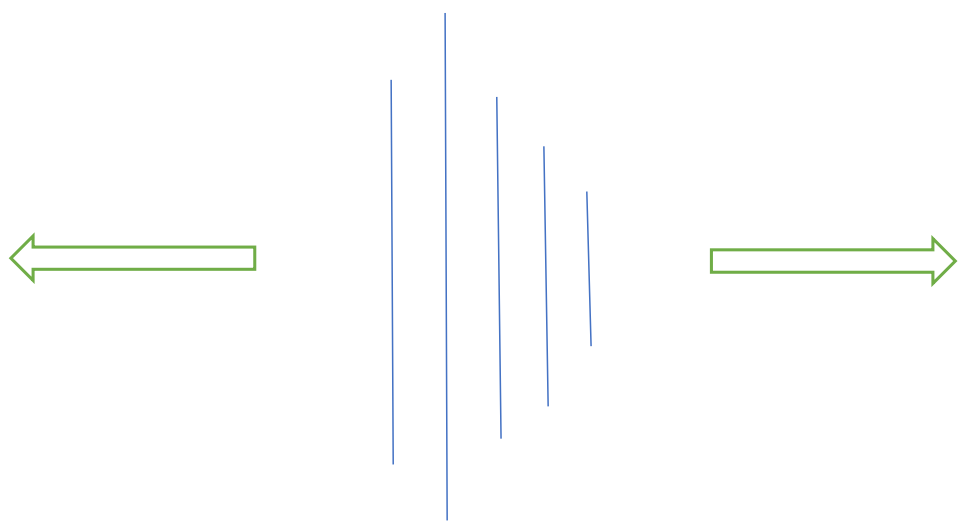

Grafos caminhos informacionais. Linhas não somente em superfície, - profundidade Pontos e pontilhados - Entrecruzamentos dos desmembramentos
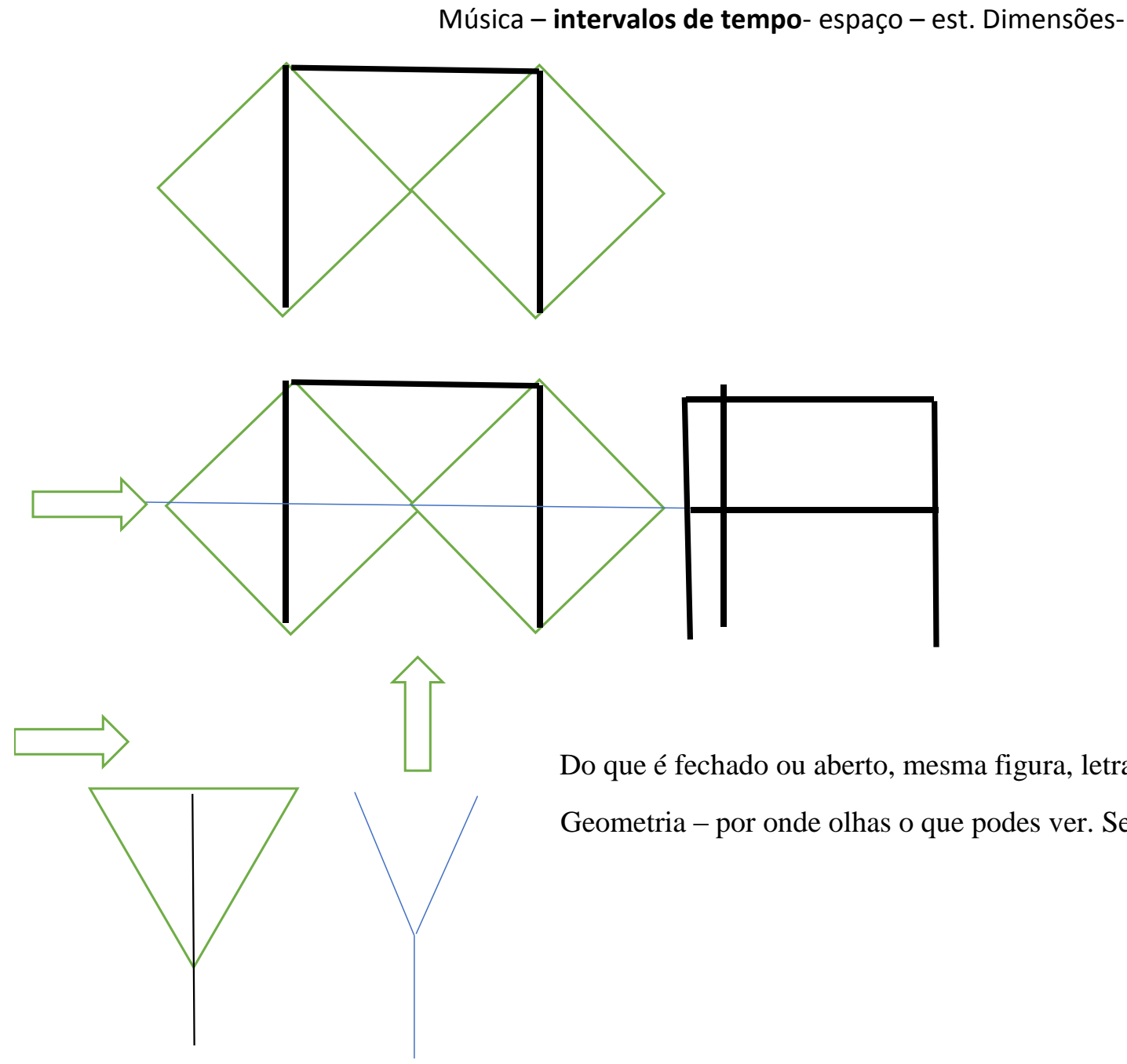

Do que é fechado ou aberto, mesma figura, letras, som Geometria - por onde olhas o que podes ver. Sentido. 

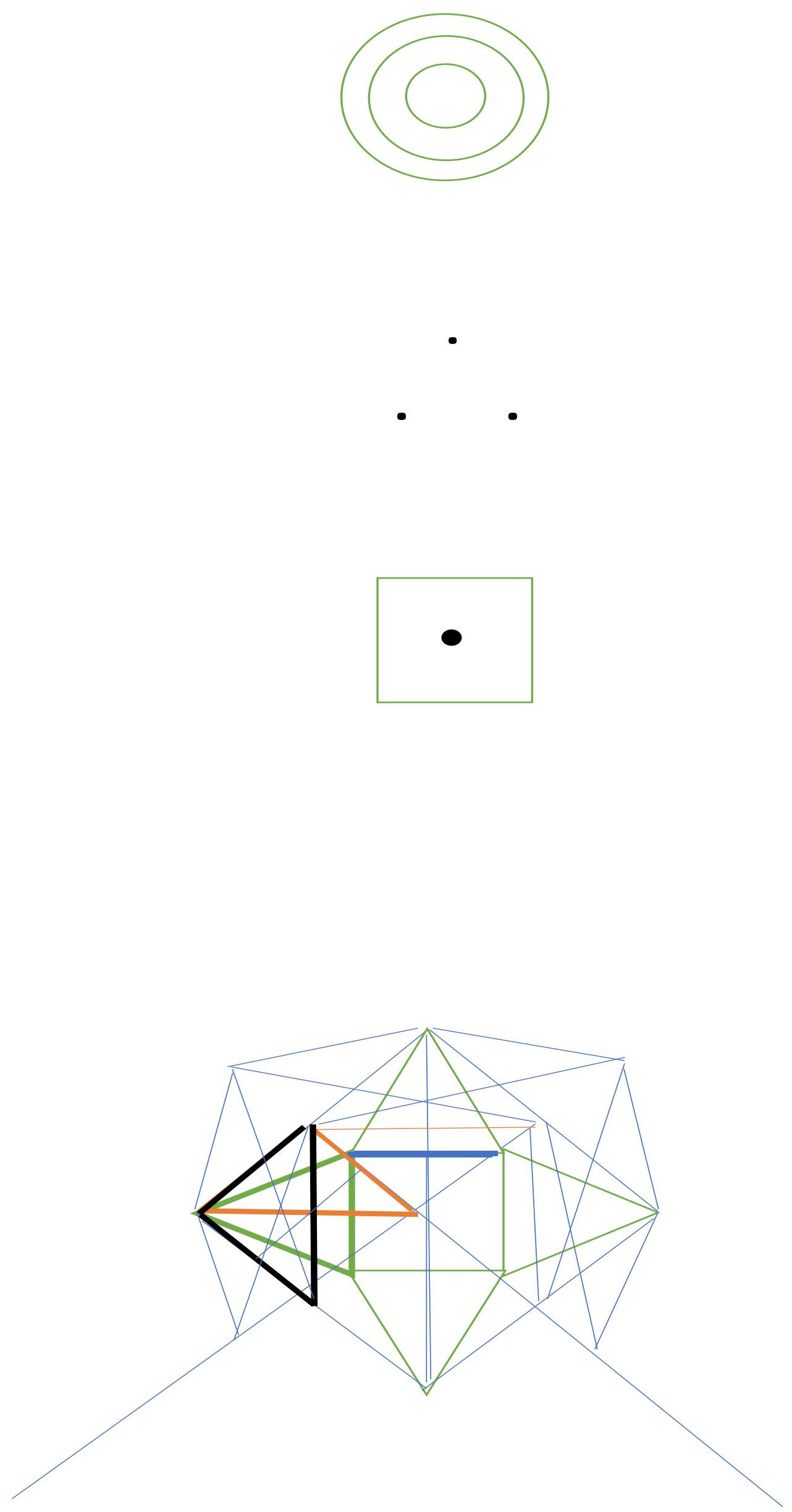
Um poema de viver.

Números - "grafos" e escalas

Som - e palavras

Perspectivas de campos

Frequência - vibração - emissão - nós e ramificações e sobreposições

Vetores

Frases melódicas - figuras

Geometria

Ressonância

Oitavas -
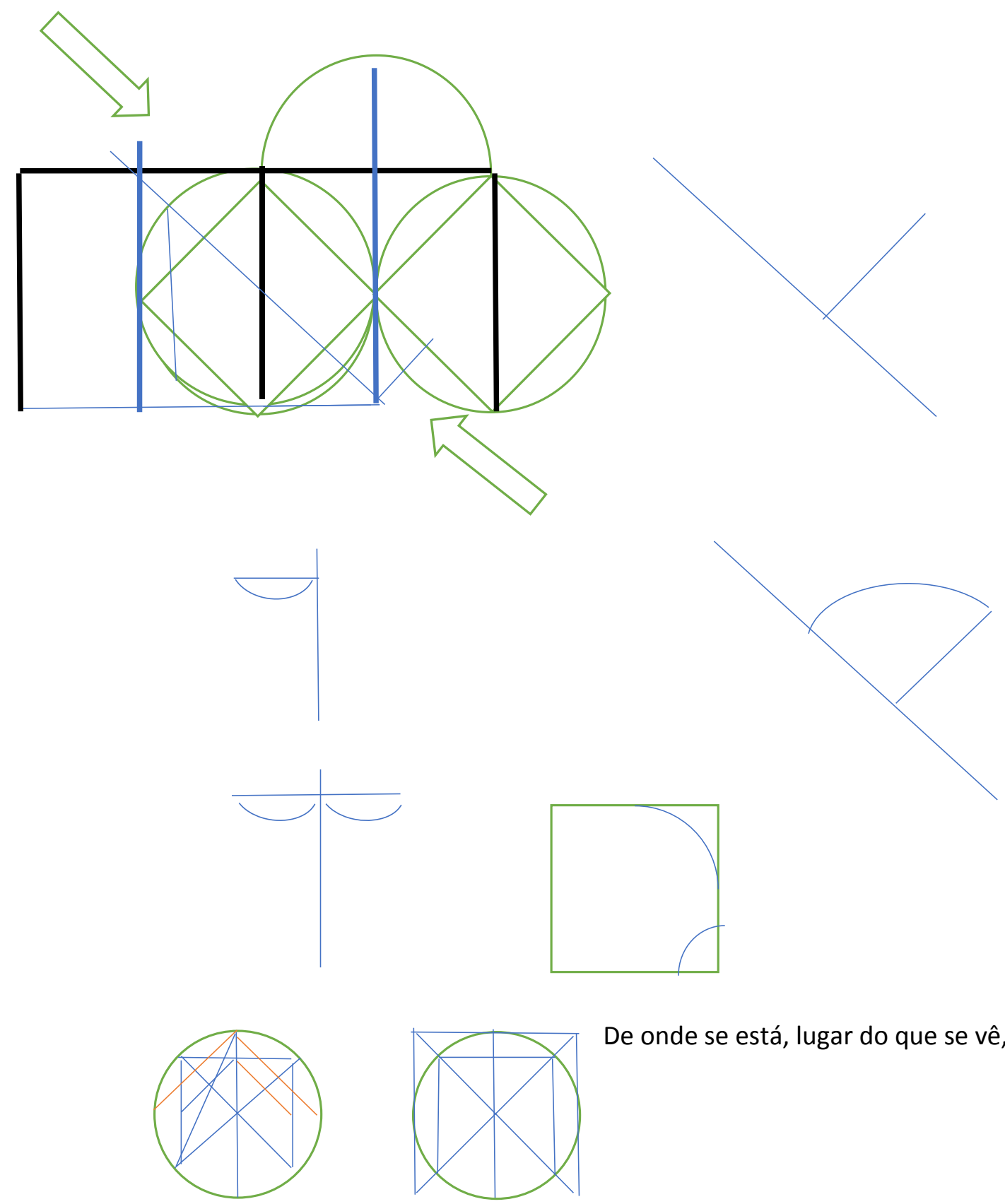

De onde se está, lugar do que se vê, escreve. 
Letras e S OM

Física -
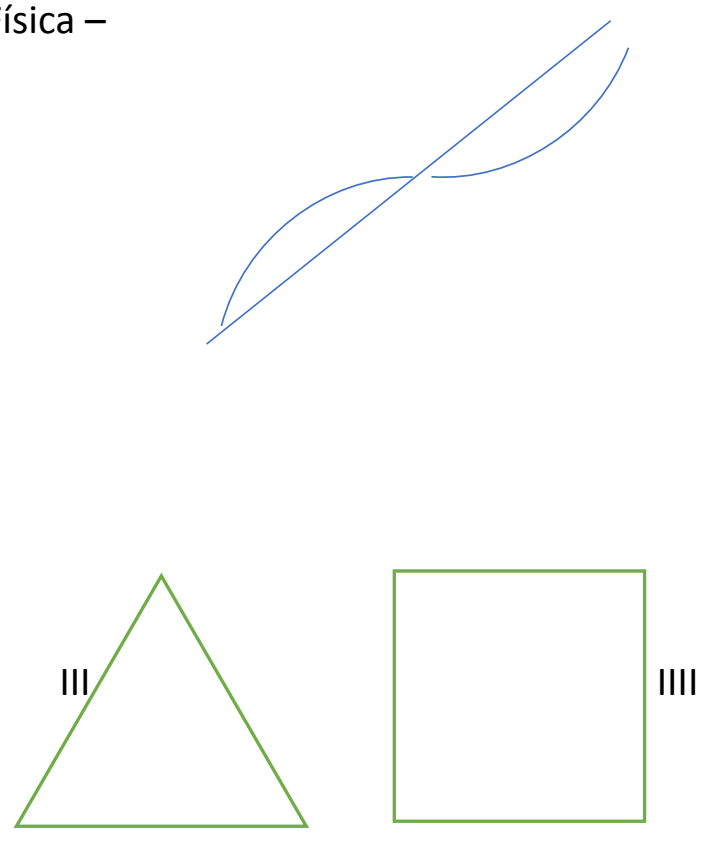

IIIII

|IIIIIII

O

0

○

a

•
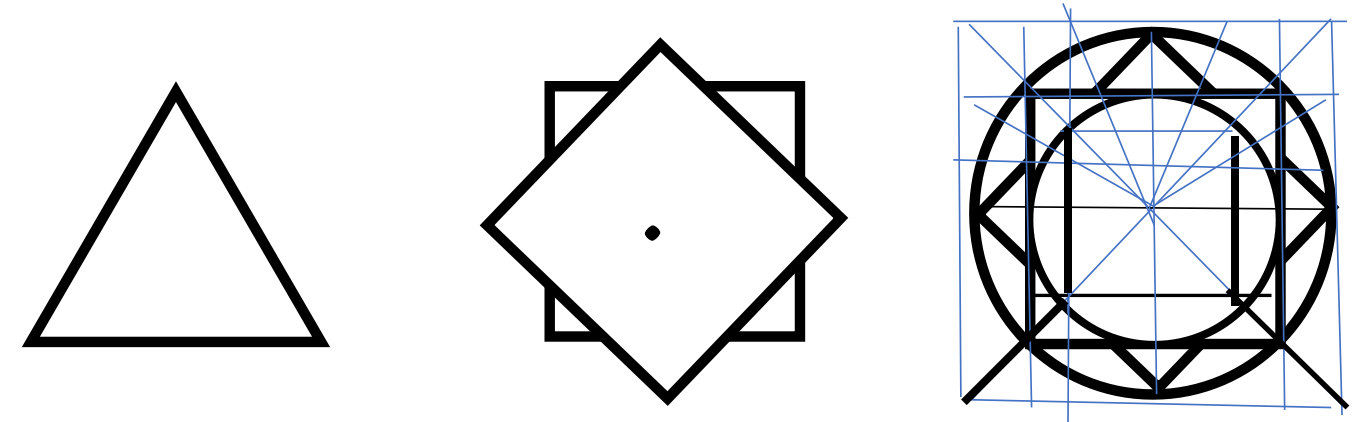


\section{Círculos e}

elipses

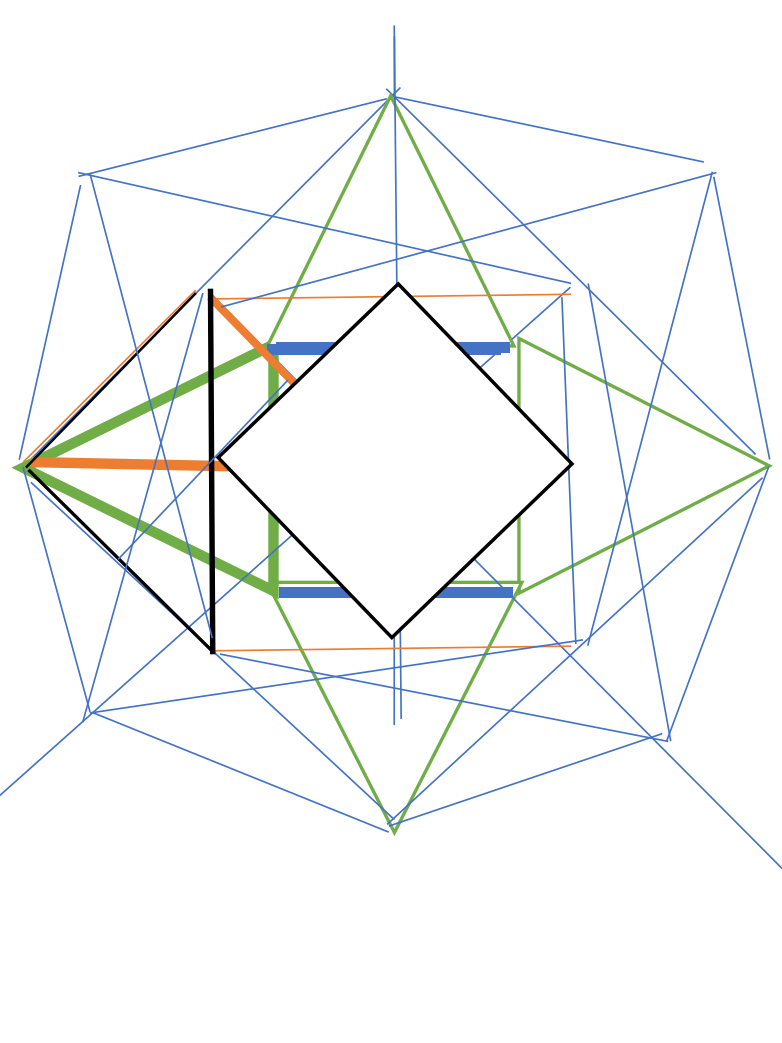

Números - "grafos" e escalas 


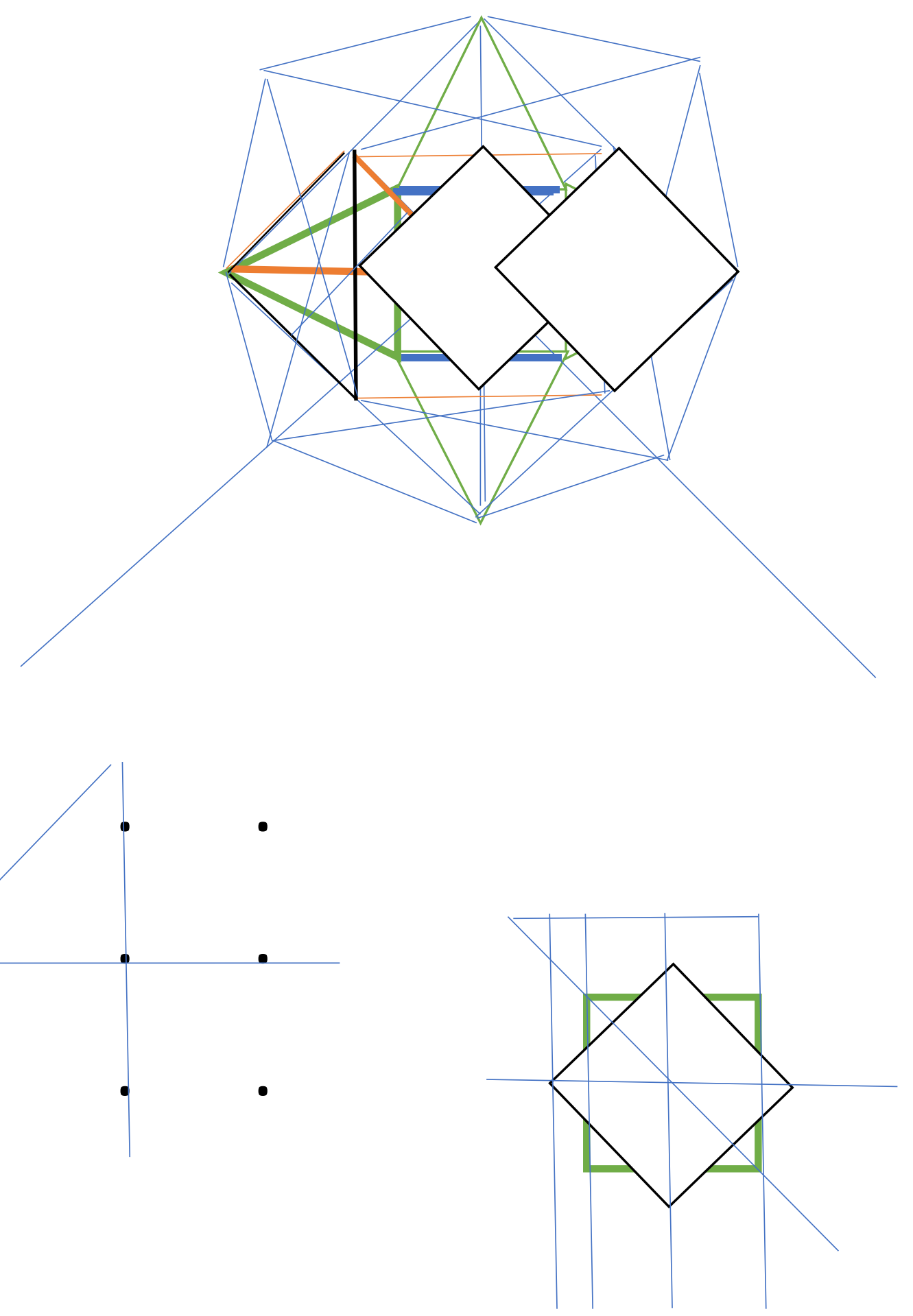



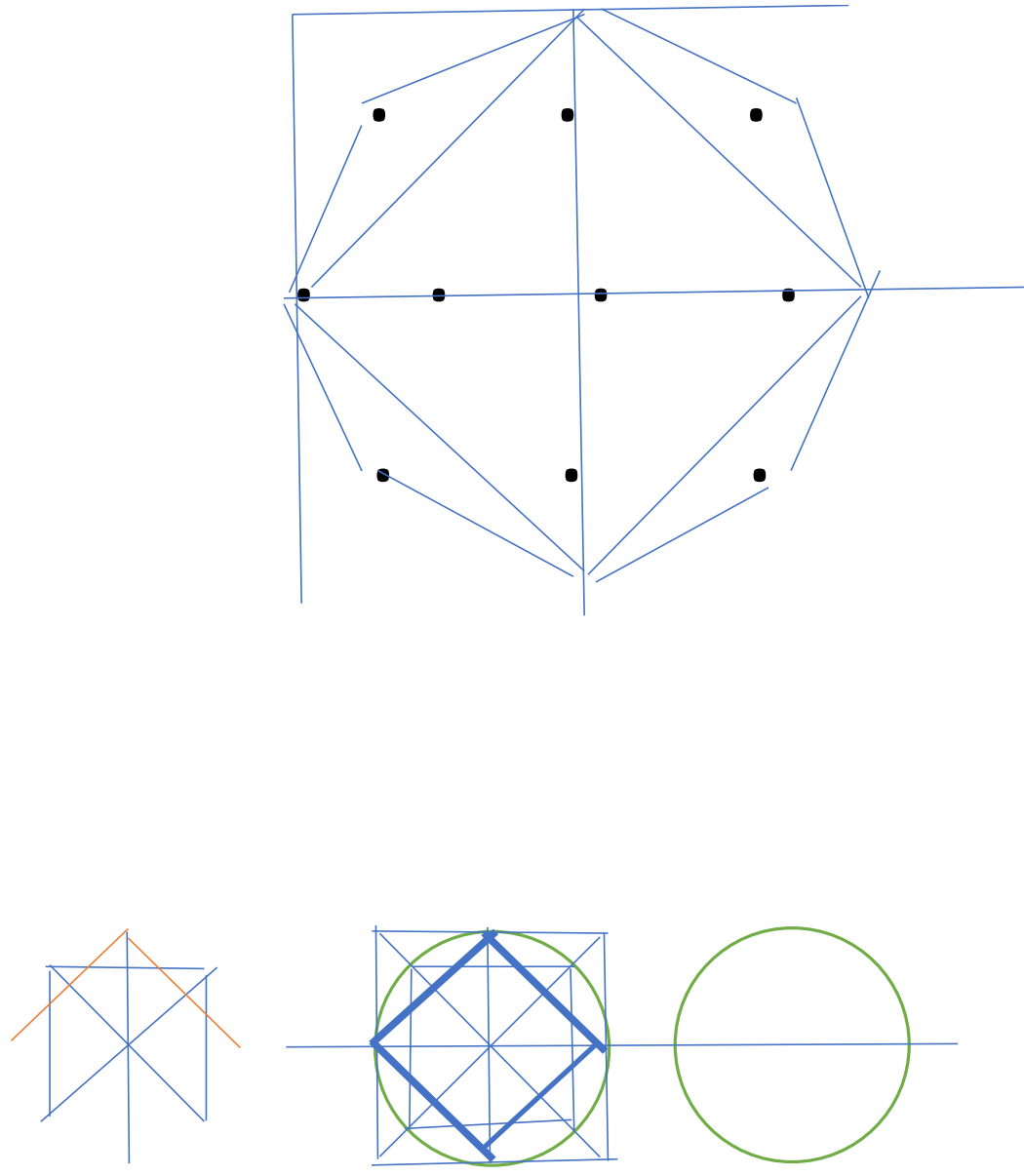

Transferidor

Geometria e som.

Palavra e movimento
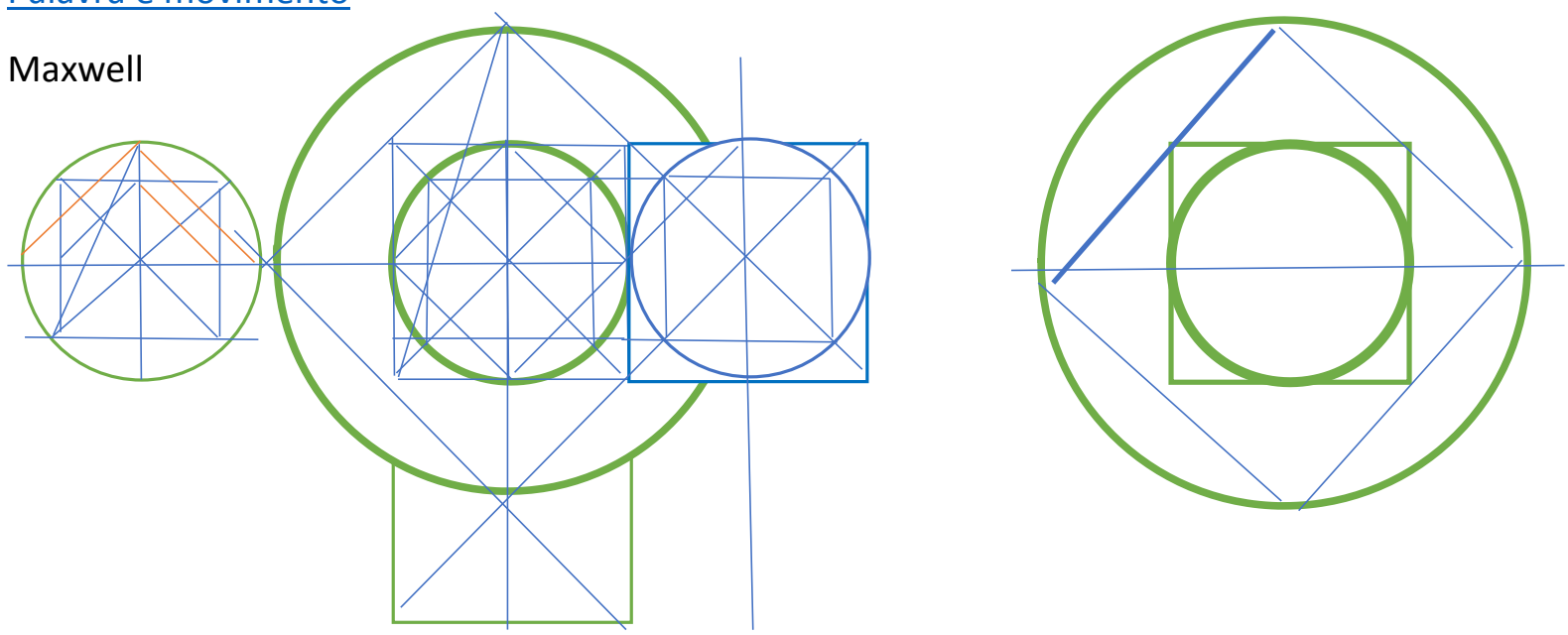
Luz e sombra

Do arco ao cume
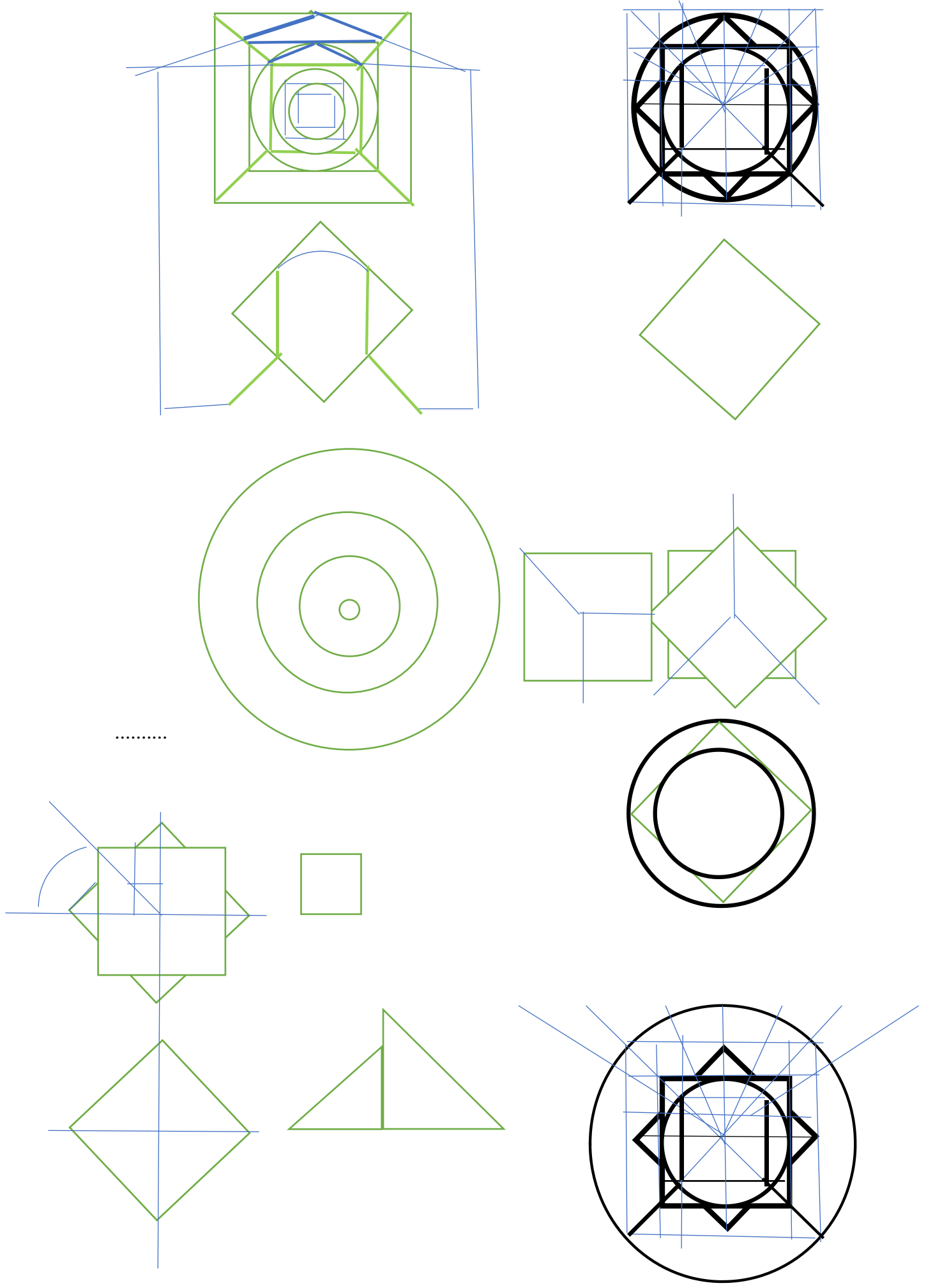
Densidades de probabilidade - localizações

Olhar de onde e quando

tempo passado a ser espaço

do que vemos e onde.

z
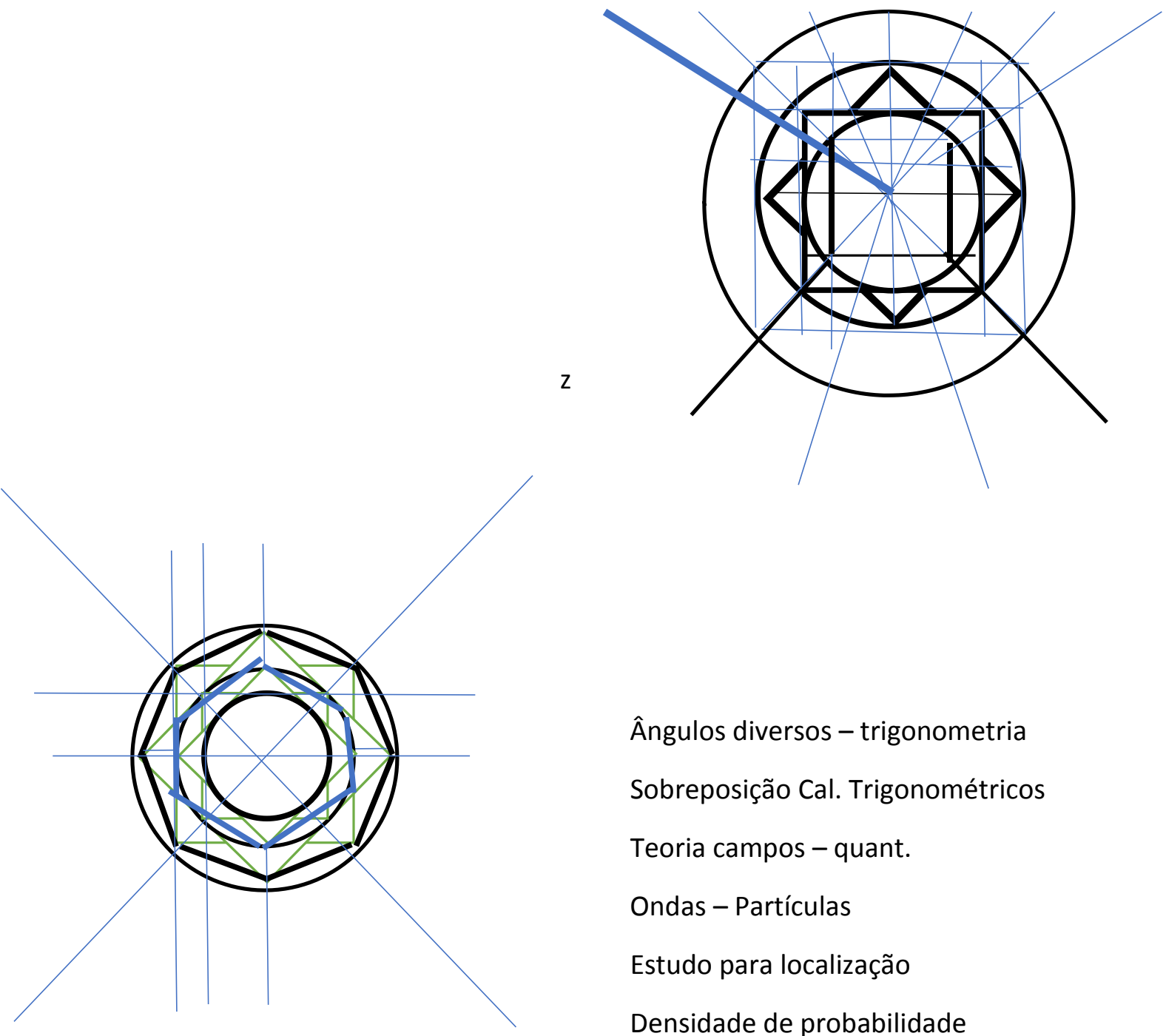

Ângulos diversos - trigonometria

Sobreposição Cal. Trigonométricos

Teoria campos - quant.

Ondas - Partículas

Estudo para localização

Densidade de probabilidade

Orbital - molecular

Quadrados e amplitudes - considerando como expansão.

Grafos - pontos - energia - sobreposição- cordas- dimensões.

A FLOR DO COSMO. 


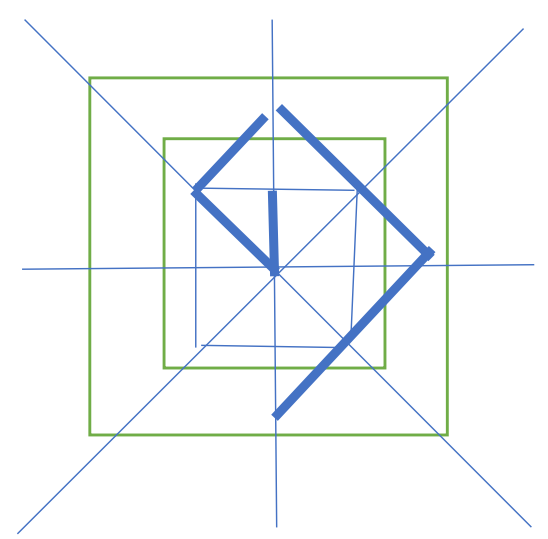

Proporção áurea, ou cálculos entre curvas, e círculos

Mesmo que em espaços entre um e o outro.

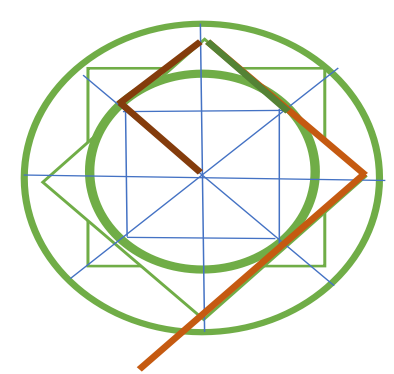

Elipses 

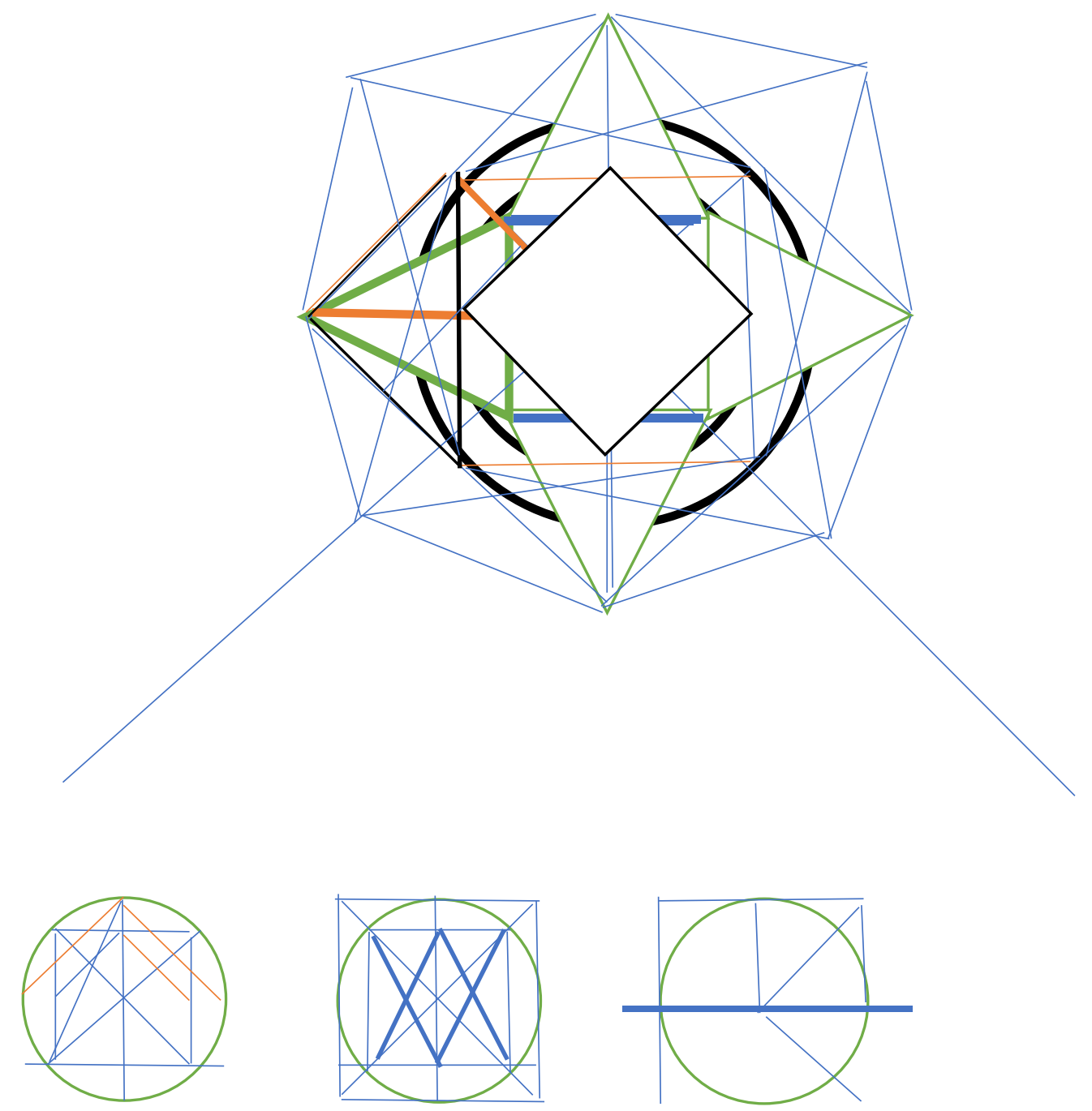

geometria

Em qualquer tempo, distância ou lugar.
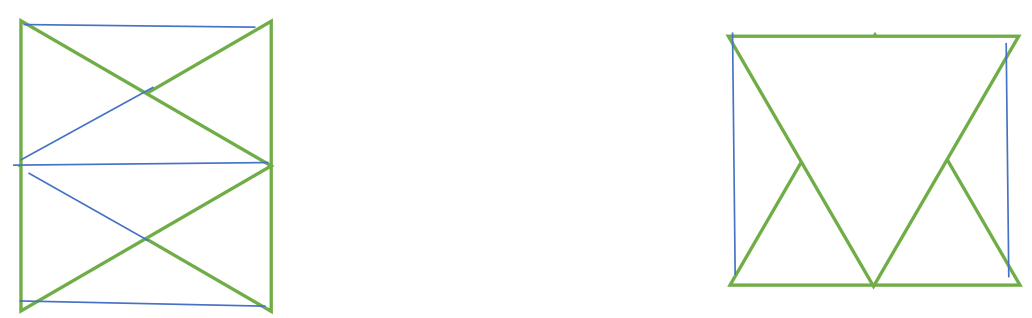

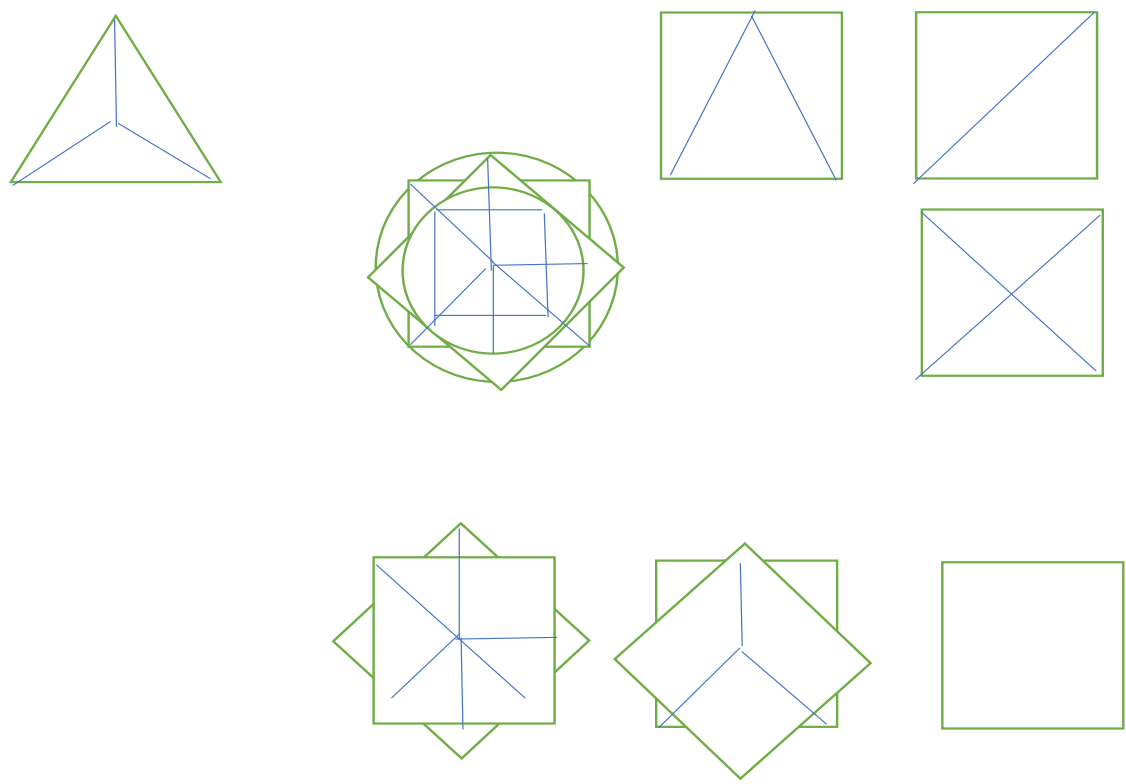

\section{PARTÍCULA}

Diz a vida de onde venho

Que de tão pequeno, lugar de mim é átomo

Que me faz viver, o sonho do universo

Em verso que não tenho e prosa

De coisas que são minha e nossa

Procurando no livro do mundo

Em cada palavra, gesto e virgula

Esquina a dobrar meu pensamento

Que vive a vida como sentimento

Onde a razão permanece como movimento

De tantas idas e vindas incansáveis

De viagens improváveis do cotidiano

E por onde quase insano fico eu,

Partícula antropológica do cosmo.

Há de convir que o muito não é tão pouco

E do pouco que me é tanto,

Sigo. 
Metáfora sobre vetores do sentido. Já em meados de 1970, na obra de Lakoff e Johson temos uma alteração no que era de maneira costumas apregoado ao modo de ser da metáfora, havendo de se manifestar como uma ruptura paradigmática, passando da observação objetivista para um status epistemológico, rompendo com Aristóteles.

$\mathrm{Na}$ tradição retórica, a metáfora era considerada um fenômeno de linguagem apenas, ou seja, um ornamento linguístico, sem nenhum valor cognitivo. Era considerada um desvio da linguagem usual e própria de linguagens especiais, como a poética e apersuasiva. Além disso, o uso da metáfora era indesejável no discurso científico, que deveria se utilizar da linguagem literal, considerada, então, clara, precisa e determinada. Nessa visão, portanto, a ciência se fazia com a razão, e o literal, enquanto a poesia, se fazia com a imaginação e a metáfora. [...]Para Lakoff e Johnson, o predomínio dessa visão retórica da metáfora na cultura ocidental se justifica pelo que eles denominam " mito dos objetivismo", que dominou a cultura ocidental, e em particular a filosofia ocidental, dos pré-socráticos até os dias de hoje ( p. 195 ). Para eles, o objetivismo é um termo genérico, que engloba o Racionalismo Cartesiano, o Empirismo, a Filosofia Kantiana, o Positivismo Lógico etc. Em suma, ele abrange todas as correntes da filosofia ocidental que assumem ser possível o acesso a verdades absolutas e incondicionais sobre o mundo objetivo e que entendem a linguagem como mero espelho da realidade objetiva. Nesse contexto, a metáfora e outras espécies de linguagens figuradas deveriam ser sempre evitadas quando se pretendesse falar objetivamente. (LAKOFF, 2004, pg 11).

Em meu ver a metáfora é cognição e se apresenta assim sendo não somente como propriedade de uma linguagem verbal, mas como elemento de sentido. Metáfora como cognição e valores humanos, onde se presume o sentido dentro do que é a ética possível.

Fractais de sentido.

- Em se tratando especificamente ainda sobre metáfora, o que emerge, a meu ver, em um primeiro momento, ocorre como um possível dele mesmo, ( ainda independente do contexto ), como fractal de sentido, e argumento que isso é factível justamente por ter um elemento de informação que de desvela ( múltiplo ou plural, como queira chamar ( como o próprio signo)), de maneira que se relaciona em " proposição lógica" com um segundo momento, a saber, em interação com o contexto.

- A Densidade Probabilidade ( campos de localização como factível )/ possível /( matemática )/ lógica/ DP B ( mais próximo da qualidade - não necessariamente ter como campo o factível ) ( densidade em possível )

Metáfora e diagrama

Campos de ação mental. 
DP (DENSIDADE EM POSSÍVEL) - campo matriz - metáfora

CONJETURAS PARA Compreensão

1- Desmembramento/DP

2 - Relações (internas)

força de atração para o sentido

Composto

Compreensão/DP

Contexto( relações externas) $\longrightarrow$ densidade em probabilidade( DP/localização

Aqui é um segundo momento

O movimento de força aqui empregue

Deslocamento em direção à

o valor informacional da localização

Pode alterar ou não a disposição mental

da conjunção primeira, agregando valor.

Quanto a DP ainda se apresentam ao menos de duas formas, porque se já estiver presente no processo inicial, é uma terceira força como elemento de conjunção inicial, porém pode se apresentar somente no " final", e como dito, alterando ou não o sentido em argumento, gerando uma proposição diferente.

Sinestesia

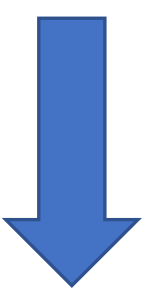

PROPÓSITO PERMANÊNCIA DE VERDADE

SENTIDO

Metáfora - diagramas - conjecturas - real- existente - social - virtual - condutas - escolhas - consumo - marca - emissão - informação - ressonância - compassos

Metáfora e linguagem. Linguagem - modo de ver o mundo (percepção da realidade) - Não como somente o verbal. Modos de ser - modos de ver e significar, emergindo uma 
linguagem - construção de uma linguagem - o sentido composto - integração de modos de linguagem.

É necessário e creio que sempre, ressaltar a importância da consciência até mesmo no emprego da metáfora, sendo da razão humana, o uso como subterfúgio ou manipulação e ainda mesmo até, como instrumento de malefícios de compreensão, e mesmo confusão quando a intenção de gênese do que diz respeito a metáfora como cognição será sempre com a intenção de ampliar significados proporcionando alcance maior de entendimento e não o contrário

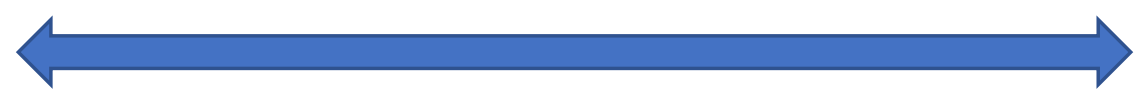

Entre o tempo e a eternidade

Existiria uma razão cognitiva para determinar dentre o possível uma região do sentido ${ }^{338}$ ( orgânico ) linguagem, por exemplo, dentre as conexões possíveis, visando uma compreensão, estaria disposto para além das atrações, sobre que " molde “ eu escolho essa presença, ou seja, de uma palavra, faço uma conjunção com um som, que determina uma somatória integrativa de órgãos informacionais que exercem suas funções em individualidade e em conjunção, permeando-se. Isso é claramente possível, mas o que me pergunto, é existiria uma razão ( o porque da razão ) para determinar a face da escolha dentre uma relação de uma palavra com um peso dentre essa densidade por uma especificidade de sentido - visual, sonoro, tátil, verbal, real - virtual, da mente e da fé.

APARÊNCIA DA REALIDADE

MUNDO CONTEMPORÂNEO

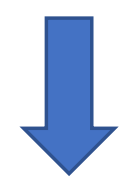

Coleta de dados e uma resposta possível.

Argumentos e proposições

Para um sentido do tempo vigente

\footnotetext{
${ }^{338}$ Neste ponto também se faz referência a um sentido que se desmembra no aspecto de pesquisa da autora desta tese, tratando-se de ser descrito como sentido da mente, e sentido da fé, posto como práticas e condutas que devem no decorrer do tempo ser vigentes em coerência com respeito, dignidade, honestidade, justiça, o bem, como força capaz de ser elemento que se engendra no cotidiano e o transmuta em um propósito de um mundo melhor para todos, onde os elementos como o respeito realizam a integridade das mais diferentes culturas ou crenças.
} 


\section{Das intenções}

Novamente, um dos aspectos a serem considerados e de fato é relevante, apesar de que, não de maneira costumas eu a percebo, mas é de fato o uso da metáfora contrariamente ao que deveria, como sendo um subterfúgio de entrelinhas, e para tal, não se esclarece agregando informações, imagens e sentidos, mas com a intenção subliminar, por vezes e inclusive escusa pode-se ter o uso da metáfora de forma não licita como apregoamos com o caráter cognitivo a que propomos.

O que termos, em palavras, ou frases, remetem ou induzem a mente a procura, busca como informação de caráter instantâneo, está salvo pelo sistema, quando inserido, a seguir da razão que o corporifica. Assim sendo, se preserva a cognição, porém, muitas vezes, a mente em sinapse imediata, não revela a razão prontamente, apenas a informação, o que carece de validação e ainda mais, não somente o que o sistema considera como útil, funcional, ou plausível de arquivo, mas que seja ainda, validado e principalmente para o que tem alcance cognitivo e mais, de ser correspondente com informações anteriores ou mesmo que novas, providas de argumentos se não lícitos, ( que deveriam ), estruturados a ter correspondência.

Por me aproximar da metáfora como modo de construção de sentido da poesia, não tenho o hábito de ver o emprego da metáfora de maneiras contrárias ao que penso ser sua gênese, ou seja, elementos que agregam valor informacional( produtivos e éticos-bem), e portanto, isto já me basta normalmente, sendo o que considero valor informacional e de comunicação, porque em meu modo de ver, a comunicação deve sempre estar pautada pelo que é de cunho fidedigno e não como uso de má fé, nos termos jurídicos, estes últimos.

Se o discurso, é da prática do viver, e face propriamente do organismo de compreensão, assim sendo, creio, que a metáfora é presença latente, onde seu valor, é aquele dentre o seu interno, o que o exterior como ação comunicativa do homem, faz uso. Isto coloca claramente, o posicionamento, mais uma vez, de escolhas, das ferramentas cognitivas que temos em mãos frente a estruturas compostas entre o presente, passado e futuro, como razão, e o uso dos sentimentos e consequências de nossos atos, porque a palavra, é pensamento, pensamento é ato, ato é discurso, e vice-versa, assim, como o controle de nossos impulsos diante de dificuldades, nas quais, nem sempre a reflexão está ao alcance do discernimento o quanto deveria, não respondendo, e nem sendo argumento, mas esclarecendo que muitas vezes, o que dizemos, construímos como frases, palavras, atos, carecem de um estado de 
compreensão, que não estamos por fatores ( interpretantes ) emocionais, aptos naquele momento, de realizar a escolha, e para tal, vale dizer, que o tempo, deveria ser como o ancião, que nos observa e sabe que os passos são de todos um pouco de cada um, onde os olhares se reconhecem de experiências que a maré traz novamente, então, o repouso, a pausa, tão nossa conhecida da composição, da harmonia, se faz evidente, como fator primordial do respirar de um sistema, onde se precisa ter um segundo que seja parte de um infinito, capaz de surgir a mente, o que o sentimento precisa ouvir.

Faces da mesma moeda, que é do equilíbrio, da harmonia, da vida. Tudo pode ser algo mais do que vemos, ou acreditamos ser, Da ilusão e da realidade. Onde está a nossa compreensão? Qual metáfora, aqui, não somente de palavras ou sentidos, mas qual metáfora de caminhos, estão dispostos às nossas vidas, para que eu possa ter a compreensão do que de fato me fará existir, ou está me buscando como modo de representar-me no sentido que preciso encontrar? Onde está a palavra do caminho enquanto meu viver, do que está no lugar em correspondência, ou seja, da ilusão ou da realidade, qual delas é a parte da metáfora que é minha existência, o sentido usual, ou o que desejo da poesia encontrar, ou de um subterfúgio onde não sou a face de quem deveria ser? Tudo está disposto como forma de se conhecer, onde o que poderemos ser, é parte do significado.

Experienciar uma coisa nos moldes de outra, argumentam em parte Lakoff. A lente sobre nossos olhos. Qual a cor da vida? Reprograme os sentidos - atualize o sistema.

Afetos de significado - valor agregado

O tempo - o fim ou o começo.

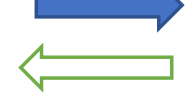

Me parece pelo que leio, que existe algo do caminho da metáfora que se encontra dentre o uso de referencia a símbolos já estabelecidos, pode-se dizer que as convenções propriamente, são vínculos de sentido usados comumente, mas o que é relevante assim o creio e principalmente cognitivamente, não é esse caminho, apesar de por vezes dar mais trabalho. O que advogo é a presença de um sentido que caminhe mais pelo que é da poesia, uma busca. Mais próximo como referências, que se relaciona com o que é de liberdade, ou seja, a imagem, som, ou seja lá que linguagem ou códigos estiverem presentes, se dispõem em busca, e portanto, nem sempre encontrado, porém, quando em necessidade de compreensão, e portanto devendo ser encontrado o sentido, pode ser esclarecer como sendo de uma densidade de possibilidades, o que nem sempre vale, para a determinação do que se 
quer dizer, porém, penso que o esforço agrega sentidos, e valoriza o significado, e ainda mais, quando necessário, poderemos até encontrar sentido conexo ao original que a própria emissão desconhecia como referente, e se é possível de constatar ou averiguar a correspondência em liberdade de sentido, eu responderia, que a poesia, lida com essa liberdade, e fica plena e com o prazer de ser, um encontro latente, e não como aguas paradas, mas sendo um sentido que pulsa, e para tal, está em pleno movimento, como a poesia, é do externo e interno, a capacidade de nos trazer e representar, de forma continua.

O uso de símbolos como referência da metáfora é um uso quase, que me parece habitual, redundantemente, mas, a colocação da metáfora em cognição e raciocínio, é parte do que considero, inserido em diagramas mentais e de sentidos do sentimento, e principalmente de relações, conexões que se comunicam em projeção de outra comunicação, entre relacionadas.

O meio e o uso, escolhas de modos de metáfora, no caso palavras.

Não tanto quanto eu diria, um recurso de pensamento, que nos faz falar, ver etc mas a construção de um pensamento que engloba uma " função" integrativa de ser abrangente, complexo, ou naturalmente, poético, antecede o que vemos ou dizemos, mas é um modo de pensar, cognição aberta sobre a expansão do que as construções em sinapses de sentidos, conexões irão proceder, tanto, do que é imediato, ou reverberação diagnosticada de forma igualitária como valor, ou seja, uma informação pode estar no arquivo mental, para não usar referência, porém, a mesma informação pode se apresentar, com um elemento agregado que não o substitui, apesar de poder modifica-lo, a consciência das informações ocorre de maneira co-habitada, ou seja, ( matemática - precisa o termo certo ), o diagnóstico do sentido, se dá de maneira a conhecer o aspecto “ original”, agregado de valor, não somente pelo meio 1 , mas pelo tempo 2 , e por sentidos compartilhados.3.

E ainda se pode ter o sentido acoplado, que seria o 4. Ou seja, fruto já de uma conexão, que o torna individual em sentido, porém, como um " subconjunto “. - diferença - uma coisa é o sentido direcionado ao contexto amplo, outra coisa é já em conexão do sistema, um é direcionado a um campo de possibilidades e outro é uma ( ramificação ) conexão dentre o campo.

E, portanto, quando é necessário o encontro de significado, a mente recupera a função, ou seja, quando habituado ao uso de metáfora, incorpora automaticamente, a possibilidade de uso, ou seja, o sentido aparece a mente, como forma de estar, ser e lugar, onde pode ainda, 
dizer ( na mente), qual e de que maneira, o mesmo estará presente, se como ele se fez conhecido, se, quando ele ganhou valor informacional, ou se no presente momento, ele se altera de tal forma, que é o mesmo, porém, bem “ atualizado”. Com a gama de possíveis, ( o primeiro momento ) aguarda em si, o contexto em reverberações, porque pode se apresentar adequado, mas, nas relações ainda diagramáticas em desenvolvimento, se faz por vezes a necessidade do mesmo em outra escolha. O campo da metáfora é matemático em certo modo de olhar. Cognição que se estabelece como fractais.

Os pulmões de uma árvore, os rios, etc. "desenhos" reproduzidos em ganho de sentido, são um modo de conhecer a criação, que se mostra, ganhando informação, nos caminhos que se entrecruzam, que em complexidade ganham corpos do mesmo modo de ser. Assim, as águas do rio, o sangue dos pulmões, e alguns exemplos em ágape, são de certa forma, exemplos, lembrando, Empédocles, onde o mesmo, se faz conhecido.

Linguagem e expressão -pensamento- Não conheço linguagem como somente o que é da palavra, mas sim, do que vive, e assim sendo o paralelo da "metáfora na linguagem" e metáfora no pensamento" não estão em dicotomias.

Penso que ver a presença de uma linguagem como modo de expressão do viver, desatrelando propriedades de cunho pessoal, se amplia os valores e as formas de CAPTAÇÃO do que é sentido.

Gibbs aponta que o que falta no trabalho psicolinguístico e, em alguns aspectos, no trabalho sobre metáfora da linguística cognitiva, é um reconhecimento explícito e, consequentemente, do pensar metafórico. Ele acredita ser a metáfora uma propriedade emergente das interações do indivíduo com o mundo, e não das mentes individuais Nossa contínua interação com domínios do mundo real que servem de fonte para metáforas conceptuais de uma maneira puramente internalizada. [...] O objetivo dele foi chamar a atenção de estudiosos, especialmente linguistas cognitivos, a adotarem uma perspectiva distribuída sobre o que significa ser conceptual, reconhecendo que a cognição emerge e é continuamente revivenciada, quando o indivíduo interage com o mundo cultural. [...] " Embora possam ser levantadas questões em relação ao postulado central de Lakoff e Johnson, a metáfora é indiscutivelmente de natureza conceptual, pois é um importante instrumento do nosso aparato cognitivo e é essencial para nossa compreensão do mundo, da nossa cultura e de nós mesmos. Ela é tão importante como se fosse um dos cinco sentidos, como ver, ou tocar ou ouvir, o que quer dizer que nós só percebemos e experienciamos uma boa parte do mundo por meio de metáforas. A metáfora é parte tão importante da nossa vida como o toque, tão preciosa quanto. ( LAKOFF, 2004, pg 32).

O que da linguagem, e em metáfora também, pode ser no caso apresentado pelo livro, uma conduta de diplomacia? 
Não como relatado no livro, como sendo guerra, mas oposição é costumas, em matéria de argumentos e pensamentos e modos de ver a vida, porém, existe algo que é do campo do raciocínio, dos argumentos ( quando necessários validar a posição ), e do que é de energia, energia porque o desgaste de uma oposição deve ser medido em relação a necessidade de argumentação, frente ao estado de harmonia, isso porque os danos podem ser de um desagaste oneroso. Por exemplo me parece que na área judicial, eles compreendem muito bem, essa postura, posto que por vezes é avaliado, e ponderando, se crê que o desgaste em defesa, ou enfim, procedimentos da área, não são necessários dependendo do envolvimento e prejuízos. Isso valida o argumento para além do aspecto pessoal como escolha de conduta. Isto porque se desatrelamos nosso modo habitual cognitivo e podemos então encontrar caminhos em metáfora que produzem um sentido maior, e nesse interlúdio pode haver um estado de conciliação, por um sentido adicional, onde antes os argumentos não foram capazes de corresponder a um entendimento.

O sentido como direcionamento de espaço, representado em orientações de significado. Em princípio sem analisar profundamente me parece um tanto quanto inapropriado, porque prejulga certos estados corporais que nem sempre podem ser aferidos coerentemente.

Mas, o conteúdo espacial como analise de conduta e expressões, podem em certo ponto estar relacionados de fato como índices, mas em principio prefiro referi-los aos modos de anamnese ou seja, lugar como como, que se representa em índices, mais propriamente, ou seja, o que você sente ao ouvir um som, este representado em vias de mão dupla por notas, são lugares compartilhados, metáforas de sentido, em compreensão, mas nem todo corpo pode reagir da mesma maneira, assim como nem todo som, tem o mesmo sentido para aquele que ouve, ou ainda assim, pode-se aferir, as notas, a origem, que por exemplo os médicos, vão buscar em uma anamnese.

Me parece mais plausível compreender a afirmação de uma metáfora espacial quando considerando logicas, argumentos experienciais, planeamento "ergonômico" de sentido vinculado ao que é da ordem do próprio espaço, ou seja, distribuição, enfim, ligado ao que tanto o modo de ver da arquitetura apresenta, do que apenas expressões físicas ligadas a nomenclaturas espaciais. O condicionamento funciona como um entrave cognitivo, havendo, portanto de sempre buscarmos novas conexões de sentido. Lakoff, aponta vários exemplos sobre metáfora, como a que denomina sinédoque, " a parte que representa o todo". E a respeito de metonímia, esclarece: 
A metáfora é principalmente um modo de conceber uma coisa em termos de outra, e sua função primordial é a compreensão. A metonímia, por outro lado, tem principalmente uma função referencial, isto é, permite-nos usar uma entidade para representar outra. Mas metonímia não é meramente um recurso referencial. Ela também tem a função de propiciar o entendimento. ( LAKOFF, 2004, pg 93)

Metáforas a meu ver e sentir, volto a dizer, não podem estar em uso tendo em vista iludir, manipular, ainda que com intenção de brincar, ou de surpreender, isso não é bom sinal, a meu ver, a metáfora, deve sempre ter o objetivo de compreensão, de estar em um lugar de amplitude de entendimento e não o contrário.

Assim como as metáforas, os conceitos metonímicos estruturam não somente nossa linguagem, mas também nossos pensamentos, atitudes e ações, e também, baseiam-se na nossa experiência. Na verdade, a fundamentação de conceitos metonímicos, é em geral, mais obvia do que a fundamentação de conceitos metafóricos, porque os primeiros geralmente envolvem associações físicas ou causais diretas. A metonímia PARTE PELO TODO, por exemplo emerge das nossas experiências em relação ao modo pelo qual as partes estão geralmente relacionadas com o todo. A metonímia PRODUTOR PELO PRODUTO está baseada na relação de causalidade ( e habitualmente física ) entre o produtor e seu produto. A metonímia LUGAR PELO EVENTO, por sua vez, está fundamentada em nossa e experiência com a localização física dos acontecimentos. E assim por diante. Os sistemas conceptuais de culturas e religiões são metafóricos por natureza. As metonímias simbólicas são elos cruciais entre a experiência do cotidiano e os sistemas metafóricos coerentes que caracterizam as religiões e as culturas. As metonímias simbólicas, que são fundamentadas em nossas experiências físicas, fornecem um recurso essencial para compreender os conceitos religiosos e culturais. ( LAKOFF, 2004, pg 97-98).

Desafios de novos olhares sobre a realidade. Se diante da imagem vigente temos a ciência de que poderemos encontrar sentidos complementares, de um olhar não imediato mas que em constante busca se renova acrescido. Da percepção e as escolhas, vetores de uma realidade.

Porem os aspectos humanos da realidade são os que mais nos importam e eles variam de cultura para cultura, uma vez que diferentes culturas tem sistemas conceptuais diferentes. Culturas também existem em ambientes físicos diferentes - selvas, desertos, ilhas, tundras, montanhas, cidades etc. Em cada caso, há um ambiente físico com o qual interagimos, com maior ou menor sucesso. Os sistemas conceptuais das várias culturas dependem, em parte, dos ambientes físicos no qual se desenvolveram. Cada cultura deve propiciar uma forma mais ou menos bem sucedida de lidar com o seu ambiente, tanto adaptando-se a ele como o transformando. E, mais, cada cultura deve definir uma realidade social na qual as pessoas tenham papéis 
que façam sentido para elas e em termos dos quais possam agir socialmente. Não seria surpreendente que a realidade social definida por uma cultura afetasse sua concepção de realidade física. O que é real para um indivíduo como membro de uma cultura é produto tanto de sua realidade social como da maneira como ela molda a sua experiencia do mundo físico. Já que a maior parte de nossa realidade social é entendida em termos metafóricos e já que nossa concepção de mundo físico é, em parte, metafórica, a metáfora desempenha, um papel muito significativo na determinação do que é real para nós. ( LAKOFF, 2004, pg 243).

Alargar sentidos absolutamente não confronta verdades imutáveis, ao contrário, ou melhor, amplia compreensão para que uma verdade não tenha somente um caminho de entendimento

Da imaginação e metáfora, razões da poesia

Quando William Blake proclamava que a intuição e a visão eram mais importantes do que a razão lógica e Victor Hugo dizia que a inspiração est aussi une verité et une nature, não faziam mais do que converter em princípio de fé a liberdade da imaginação poética. O que passava finalmente a predominar era a verdade estética. E, em consequência, a sinceridade do artista não era apenas a do sentimento íntimo, mas também a que correspondesse a corajosa fidelidade as suas próprias visões. De qualquer modo, foi a imaginação que ampliou as fronteiras à poesia romântica, apagando, frequentemente, quaisquer divisões entre a fantasia e a razão... Isto posto, a preliminar para a compreensão do homem romântico é o conhecimento de sua índole imaginativa, a ver até que ponto ela contribuiu para o adaptar às ousadas sugestões da escola preferida, sem se partir a si mesma. A imaginação criadora de Castro Alves correspondia inteiramente a que $\mathrm{T}$. Ribot qualifica de plástica, imaginação exterior, na qual costumam prevalecer as associações de caráter objetivo, tornando-se por isso mesmo mais atenta às coisas do espaço visível. A sensibilidade do imaginativo desse gênero é principalmente estimulada pela vista, pelo movimento e pelo tato. Castro Alves tende por isso a materializar, em sua imageria, até mesmo as coisas fluidas ou simplesmente audíveis. Assim, quando diz, em " Aves de arribação: a noite enrolava os descampados, confere à treva, com o concurso tão expressivo do verbo enrolar, o volume plástico de um corpo. Não se ouve apenas, mas vê-se também o som, numa conhecida passagem de "o Hóspede"." Quando a fanfarra tocas na montanha. A matilha dos ecos te acompanha. Ladrando pela ponta dos penedos. Fator de amplificações e redundâncias verbais, consubstancial às antíteses e outros jogos de palavras, tinha Castro Alves entranhada predileção pelo eco, também evocado numa de suas fantasias em prosa. Suas tendências a graduar as perspectivas do espaço pelo aumento, não o impediram de produzir imagens topográficas de uma expressividade inexcedível. Numa delas, com a circunstância de haver transfigurado a aparência prosaica da palavra léguas, quando mostra que:

Do São Fransisco a soberana vaga. Léguas e léguas triunfante alaga! Outra interessante imagem do mesmo gênero é a que resume o mundo físico visualizado numa impressão moral de profunda significação psicológica em " VOZES DA ÁFRICA" De Tebas nas colunas derrocadas, As 
cegonhas espiam debruçadas, $\mathrm{O}$ horizonte sem fim... Onde branqueja a caravana errante, E o camelo monótono arquejante, Que desce de Efraim... Por outro lado, adquirem expressivo efeito poético as representações que mostram as ideias do mundo moral em contraste com as representações do mundo físico, tal qual nesta passagem do poema " Confidência ".Eu vês na onda a flor azul dos campos. Donde os astros, errantes pirilampos. Se elevam para os céus. E eu vejo a noite borbulhar das vagas. E a consciência é quem me aponta as plagas. Voltada para Deus. O universo corporificado por suas visões é o que de uma languíssima imaginação em que a poesia das ideias deixara luminoso rastro, projetando-se em todas as coisas, até fazê-las prevalecer no mundo do espírito como uma realidade inalienável, através de audaciosas e imprevistas transposições, a exemplo desta: E o povo é como - a barca em plenas vagas. A tirania - é o tremedal das plagas. O porvir - a amplidão. Homens! Esta lufada que rebenta. É o furor da mais lobrega tormenta. Ruge a revolução.

\subsubsection{Uma fenomenologia do imaginário.}

A necessidade de refletir sobre a convivência humana.

Posso conceber erroneamente, mas o modificar o homem é algo que me parece ser do âmbito de uma coesão, pois algo permanece e se transforma, sobre certo aspecto, a semente e a árvore, pois haverá de ser uma árvore, porém não será a mesma, e mais além disso, não estará o homem sempre se modificando? Pode se afirmar em graus de fluxo de uma equação onde a convivência nem sempre progride com o homem e visse versa? $\mathrm{O}$ diagnóstico de base, sendo determinar fatores que permanecem ( ainda que sobre outras vestes - sociais ) e os que de fato transmutaram-se em um primeiro momento me parece importante, e em segundo diante dos que de fato mudaram, diagnosticar também quais forma os elementos desencadeantes dessa transformação, também deve a meu ver, ser objeto de reflexão, posto que o mesmo agente ( transformador ) pode se revelar ante outra situação vigente e de uma equação social.

Para que haja auto-determinação dos grupos humanos é preciso que o homem procure uma auto-condução pessoal desatrelada das cosmovisões oficiais. Se as crenças pessoais operassem apenas como mais um elemento de um complexo sistema interrelacionado que não travasse mas que fosse capaz de caminhar em conjunto ( se possível ) ou se desvencilhar ( quando não mais possível de se aliar ), seriam as crenças um fator não preponderante, e nem dogmático, mas um componente que forneceria mais um diagnóstico, estando entrando em contato com o que lhe afeta ou lhe afeiçoa. Poderá o fator crença se visto como algo em possível mutação se aliar a uma disposição cientifica, ou seja, uma crença que desperta para a concepção do que é experimental e que pode se confirmar ou não. 
A aventura humana entre o real e o imaginário, dando o caráter altamente probabilístico e circunstancial da vida de todos nós, tangida por fatores que envolvem, complexidade universal, indo do ínfimo ao imenso, e que encontram ponto de convergência na expressão de ser de cada um." - Ao escrever sobre a vida sentir-me oscilante, às vezes presunçoso, as vezes ignorante, ora abrindo horizontes, ora descrevendo o óbvio. A única certeza que tenho é que este trabalho nunca estará terminado, nunca será definitivo, pois o homem, como sistema aberto, nunca deixará de incorporar novos eventos à sua trajetória existencial - seu destino, definitivamente, é aventurar. ( GRECO, 1984, pg. 13).

Entre - Um texto se faz outro em reflexão - paralelos de dizeres em busca da compreensão. A aventura do próprio viver -A aventura do viver desconhece-se, se fazendo procura, buscas em interlúdios de espaços cognitivos interligados. Algo que parece simples, é de todo um dizer complexo, pois apesar de se absorver o que se torna visível em teoria, movemos nossos sentidos e significados a uma concepção de trazer ao real e cotidiano o que se dispõe em conjecturas orgânicas em trânsito do dizer para o ser de fato e concreto.

As relações a que já nos parece que nos é imprescindível no campo da aventura do viver, soma-se a um dever inquietante constante que instiga o ser em seus rumos, e o humano, passa a ser o vivente, carne que não é um antropo, mais o que emana de si e para si, na confluência de todos outros que se exercem refluxo continuo. Sobreviver adverte a um caráter de humildade, ao se projetar no ser, o desejo de perda de seu ego, ainda que vigente, para permear-se pelo mundo, interagindo, exercendo ao mesmo tempo, uma ressonância (duplo - sentido - expansão e facetas de camadas) cósmica.

A aventura humana é a aventura de todos nós, do mistério da nossa origem, do desafio da nossa existência, da interrogação do nosso destino. Esta aventura é o processo em que todos estamos inseridos, conscientes ou inconscientes, recatados ou destemidos, francos ou enganosos, sempre oscilantes, mas todos, indefectivelmente presentes, historicamente presentes, vivendo-a e ajudando a construí-la. ( GRECO, 1984, pg. 17).

Razões entre razões - para dizer a aventura. Razões internas dilaceram-se em movimentos constantes de energias em ânsia e plenitude, retração e expansão, do indivíduo em movimentos internos - do indivíduo em movimentos em direção ao externo e o refluxo dessa continuidade e intercâmbios. Duas razões ? a do próprio aventurar e a do ser? Ou ambas em confluência? Em que medida se faz a do ser e a da própria aventura? Razões justapostas - As razões da aventura poderia ser, o que move a descoberta, que conjuga regras e acasos - e não somente a descoberta, mas, principalmente a expansão, o 
crescimento, o desenvolvimento. Jogo de forças - anantropia - entropia - formas geométricas do viver - ritmos. - tensões.

Não somente se aventurar, mas conhecer a aventura. Dispor-se ao hábito investigativo. Não somente caminhar, mas aprender a olhar, a ver o que está em volta e aqui o ver é sinônimo de sentir, e o sentir, absorver os sentidos e permear-se pelos significados.

Das origens ao percurso do caminho atual.- processos adaptativos. Jogos em busca da sobrevivência - O enigma do homem. A consciência da morte - um novo ciclo Quanto aos homem primitivos e seu modo de ver a vida, as vezes me pergunto se sua interação com a natureza não era mais sábia do que a nossa, se sua capacidade de desvendar e descobrir não era quiçá mais aguçada, ou ao menos, que não mais, porém, em conformidade com o meio e desenvolvimento e que essa disposição frente ao universo atual se perdeu em vez de sofrer um acumulo positivo, lembrando Bateson. Paralelismos da cognição. Defrontar-se entre o real e o imaginário como faces da mesma moeda, como intersecções da sobrevivência é saber caminhar pela dura alteridade ainda que passível de vê-la com olhos do poeta.

Romper o abismo que possa haver em qualquer faze da humanidade entre o subjetivo e o real, é uma necessidade ontológica e genética como fato evolutivo, posto que na natureza de todas as coisas, acreditamos não haver essa dicotomia, mas uma visão reducionista ou mecanicista, entorpece os sentidos e endurecem as percepções, cegando a mente criadora e em constructo de aprendizado.

O que é estar na existência ( aqui se apresentando a alteridade - presença fática ) as razões podem ser vistas como o despertar, diante da alteridade, elas se fazem visíveis, e em conjunto são interpretadas posto que diante de uma razão, comumente uma ação é inquirida por interrogações de um modo ( próprio do ser em busca de "soluções" - ou melhor, compreensões ). Para tal, se estabelece nesse âmbito o que pode ser visto como um "jogo de forças", mas nesse caso creio que ainda não chegaria a esse ponto, mas antecedendo, se apresentariam as potencialidades, presentes em origem (ontologia ) e como impulso, para desenvolver o que por poder estar sobre o caráter da criação, do que é livre, advoga e argumenta a favor da evolução, dispondo da fenda entre o habitual, regras. Uma estrutura permeia a geometria da vida, mas formas novas despontam através do que é livre e se manifestam em continuo com o processo evolutivo. O viver como o próprio texto. ( procurar Lotman ) estrutura texto artístico. 
Mas, independentemente de qualquer teórico que realize um diagnóstico das conjecturas que se apresentam em busca de uma compreensão do que é o viver, podemos nós, cada qual, desenvolver a observação natural do que é estar a cada dia nessa dramaturgia, e não apenas abrir os olhos pela manhã, mas abrir a alma ( mente - espírito) para o segundo que nos faz interrogadores do tempo, do espaço que adentramos a cada minuto, e que resolvemos abraçar em cada manhã por nossas escolhas, que fazem o caminhar. A necessidade do espírito crítico em qualquer tempo. Greco, coloca que: “ O homem vive por assim dizer, com os pés no real e a cabeça no imaginário, tendo de resolver a maioria dos problemas a partir de uma estrutura simbólica mental.”

O substrato do imaginário (ou como prefiro me referir), sensível é em verdade presença latente, originária e propulsora dos sentidos e significados do mundo, da realidade, do existente. Procurar um modo de ver par além da aparência imediata, é buscar um sentido além, uma razão que interpela a cognição sensível e encontra-se em sintonia de uma complexidade que não se faz em dicotomias nem da mente e matéria, nem do que é real e sensível.

Necessidade $-\mathrm{a}$ fenda - o entre - o caminho que permite a liberdade criadora ainda que passível de permanecer em estrutura e deixar-se impregnar pelas percepções livres.

Todo o esforço que se fizer para diminuir a distância entre o real e o imaginário, trazendo a aventura humana para mais próximo da realidade, será um investimento na Humanidade, tornará o homem mais criativo, mais consciente, mais cooperativo, menos dependente, mais místico, pleno de esperança, enfim... mais humano. (GRECO, 1984, pg. 83)

Nossa história, o que somos, e o que poderemos nos tornar. Marca, identidade de uma cultura.

Greco, afirma: "O lado oficial é o ordenador do sistema para a anantropia: o lado natural é o contestador, tensionador do sistema e provoca a entropia, o lado oscilante é o estabilizador do sistema, equilibrador das tendências, produzindo ou buscando homeostase." Segundo Roberto Gonzalez, em palestra na FEA, a imagem de um mobile, como elementos que não façam ações de dominação mas sim de interação e integração, fluxo de pesos e movimentos constantes.

Realidade sensível: " Carregava ele agora dois mundos e entre eles um abismo difícil de transpor. Para sobreviver tinha de pensar e para pensar dependia de um sistema interpretativo. Como ser social e cultural tinha uma consciência coletiva. Como resultantes disso tudo, ligou sua trajetória a um sistema interpretativo baseado em crenças que pertenciam ao seu 
grupo e que preenchiam perfeitamente o abismo existente entre os seus dois mundos. Isso the dava segurança. A poética aventura do " homem antigo " se transformara na trágica trajetória do homem atual. O jogo triádico que predominantemente era vivenciado dentro da natureza, passou a ser dramaticamente experimentado dentro da própria comunidade humana. Conviver deixou de ser algo cooperativo e seguro para tornar-se tragicamente ameaçador. De certa forma o mesmo quadro perdura até os dias de hoje. A aventura humana continua cada vez mais distanciando o real do imaginário. Persiste o abismo entre os dois mundos subjetivo e objetivo, permanentemente preenchido por crenças norteadoras do comportamento humano, com seus mestres e seus zeladores intocáveis. (GRECO, 1984, pg. 128)

Trazer do imaginário a força do que pode se realizar concreto horizonte de viabilizações de um futuro melhor.

Aquilo que queremos ser depende da construção de nós mesmos, que supõe a presença de um imaginário para orientar o nosso acontecer histórico. Toda ação no real precisa de um universo simbólico para lhe dar sentido, pois, real e imaginário andam juntos na aventura humana. [...]Ninguém vive sem cosmovisão, porque ela reduz o Universo à dimensão humana, tornando-o significativo, compreensível, com um sentido prático, útil e portanto aceitável. Ela cria estruturas de assimilação e de resposta em relação ao mundo exterior, formando um conjunto coerente e norteador da ação humana. (GRECO, 1984, pg. 131-133.).

Uma cosmovisão não deve estar subjugada a nenhum grupo de poder, pois penso que é um modo natural ( análogo em processo de conhecimento da própria vida - idealismo objetivo nos termos de Charles Sanders Peirce, sem dicotomia mente matéria, de se engendrar pelos caminhos do viver, em justamente um distanciamento do ego, sublimando uma particularidade ainda que ciente da mesma, porém em afeição tudo que esse estabelece em conjunção ao todo. Penso que uma cosmovisão deve ser livre como os processos do universo, mesmo frente a ordem que também é parte da consciência do existir. Alerta-se para no mecanismo não haver controle de apenas um determinado grupo, que direcione e tenha o poder, porque mesmo havendo posicionamentos sociais de órgãos de direcionamento, este credita-se estar imbuído de representação, ou seja por caracteres que são da ordem representativa, ou seja, dispondo sobre o diálogo que se estabelece por todas as partes. Conforme Greco, "Os problemas são os estímulos do real para o mundo real humano, mas que exigem respostas elaboradas no mundo mental. Esses estímulos provocam todo um processamento mental até que haja a saída, também para o mundo real”. 


\begin{abstract}
Cibernética social - Todo o real, ou real todo, é constituído por um conjunto de sistemas efetuadores energéticos em cadeia, comutados entre si por imputs e outputs. Denominamos esses sistemas de energia como sistemas holísticos, pois todos manifestam a mesma globalidade embora em diferentes graus de complexificação, de tal forma que podem todos ser descritos por um mesmo referencial. [...] " Os sistemas estão todos interligados em uma cadeia, que pode ser dividida em esferas e níveis hierárquicos através de progressão e regressão holística, limitada no topo pelo sistema oficial, que é direcionador da energia em cada nível. ( GRECO, 1984, pg144-145).
\end{abstract}

Ainda conforme Greco, tudo é movimento, transformação, evolução e tudo se engendra em possíveis integrações, como uma bússola cosmológica entre intrínsecos e externos espaços de ritmos da vida.

\begin{abstract}
Vivemos no universo do infinitamente grande na medida em que pertencemos a essência do planeta Terra, que nos abriga e nos integra, e que obedece as leis deterministas do espaço cósmico, que regem planetas, sistemas solares e galáxias em admirável precisão. Por outro lado, temos dentro de nós, um universo do infinitamente pequeno, pois somos formados de átomos, moléculas e de partículas sub-atômicas, obedecendo a leis físicas que não são passíveis de verificação até às últimas decimas; que necessitam de abordagem estatística e da inserção de elementos de incerteza, de contingência e de probabilismo,. Para serem interpretadas em suas manifestações. [...] Como espécie afirmada pertencemos a esses dois mundos, um determinista e outro probabilista, contemos os dois na nossa infinita complexidade, que se torna um terceiro universo, o universo humano, manifestação oscilante e altamente circunstancial. ( GRECO, 1984,. pg. 155.)
\end{abstract}

O aspecto da comunhão, os estados e esferas em escala, compartilhados em cognição de conexões que podem alicerçar os caminhos de um entrelaçamento das diferentes ordens quanto ao que é global e particular, amplo e restrito, determinado e indeterminado, do instante e do contínuo.

Como mais um aspecto de entrelaçamento do que é da realidade, o imaginário como face do real, realiza em nós o palco de um viver contemporâneo.

O espetáculo não é um conjunto de imagens, mas uma relação social entre pessoas, mediatizada por imagens. $O$ espetáculo não pode ser compreendido como o abuso de um mundo de visão, o produto das técnicas de difusão mássica de imagens[...] $\mathrm{O}$ espetáculo, compreensão na sua totalidade, é ao mesmo tempo o resultado e o projeto do modo de produção 
existente. Ele não é um suplemento ao mundo real, a sua decoração readicionada. É o coração da irrealidade da sociedade real. Sob todas as suas formas particulares, informação ou propaganda, publicidade ou consumo direto de divertimentos, o espetáculo constitui o modelo presente da vida socialmente dominante. Ele é a afirmação omnipresente da escolha já feita na produção e o seu corolário o consumo. Forma e conteúdo do espetáculo são identicamente a justificação total das condições e dos fins do sistema existente. O espetáculo é também a presença permanente desta justificação, enquanto ocupação da parte principal do tempo vivido fora da produção moderna. Debord atualiza e complementa essa concepção de Marx, chamando a atenção para a presença das imagens nas relações sociais de produção de troca, de consumo, e nas dimensões superestruturais que justificam essa relações. O espetáculo confirma o caráter mercantil das relações sociais capitalistas, a lógica da separação é um componente essencial das relações sociais capitalistas. (DEBORD, 2006, pg 15-16).

A reflexão de uma formação da cosnciência social, realizada por G Lukacs e seguindo como referência para Escola de Frankfurt e Debord, observa a compreensão da realidade sobre o que constitui reconhecimento dos interesses sociais.

O que vem a ser a realidade social, afora ou isolando as ações humanas? Para entender o ponto de vista apresentado, e tentando refletir sobre me colocando a reflexão, essa realidade social estaria então, como a estrutura do corpo social, ou seja a penas o aparato do mecanismo do que pode ser uma realidade social, mas então, quem planejou ou originou esse mecanismo, não foram ações humanas? A realidade social não é fruto de um percurso histórico de ações humanas, ou seja, não seria uma contingência natural do processo observar a geração e o decorrer dessa progressão, que não somente são programação de vida de circuitos, mas de caracteres intrínsecos de natureza da manifestação humana no seu cerne mais amalgamado ao que é do afeto das relações, do trabalho, da vida plena e cheia de aspectos não tão automáticos, ou ao menos não deveriam.

Antes, ainda, e voltando as estruturas, se de fato separarmos dois termos afins, realidade e existência, talvez, possamos colocar o modo como a realidade acontece ou se apresenta, como o que é da ordem da realidade social, em seus aspectos funcionais, e a existência a participação das ações humanas como o que existe e faz essa realidade pulsar de fato e organicamente. Mas, ainda autores refletem, como justamente o contrário, privilegiando as relações humanas, que também gera um sentimento um tanto quanto insuficiente, me parece, e essa dicotomia, não me satisfaz nem em pensamento e nem em análise. Porém, de fato é comum vermos os indivíduos que constituem a sociedade apartados de se verem engendrados e a constituírem. 
As rédeas sobre uma trama, que é o tecido da sociedade, ou seja, onde o campo de autonomia é compartilhado em esferas de cumplicidade de um desenvolvimento. Prefiro pensar que o conhecimento deva estar unificado as ações sociais.

Segundo Castro e Coelho “ Na sociedade do espetáculo, a realidade social, já não aparece como coisa, mas como imagem, que oscila entre ser um conjunto autônomo e separado das ações humanas e uma multiplicidade de ações fragmentadas. “

Mesmo nesse pensar, se pudermos nos aproximar de um sentido de imagem que condensa um texto, ou seja, uma imagem que tem o seu discurso, a sociedade como imagem, representado pelo seu corpo de ações, mas que diferentemente de fragmentos, podem ser fragmentos vistos como órgãos em funcionamento do que em um sistema se apresenta sobre uma unidade orgânica, então, nessa maneira, a individualidade ou autonomia, de um órgão se estabelece ( paralelo com o corpo humano ), sem perder as relações internas e externas porque o que vive e se organiza, está em um tempo e lugar, e, ainda, para um bom funcionamento precisa da comunicação, onde as informações orgânicas desse sistema, ou essa complexidade estejam preservadas de seus aspectos intrínsecos mas que possam estabelecer suas ramificações ordenadas de maneira a que os fluxos possam realizar um “ transito" em harmonia, ou que tenha um desempenho satisfatório. Debord coloca a sociedade do espetáculo correspondendo ao predomínio da aparência.

Qualquer civilização entre os tempos, sobre qualquer desenho de sua existência, precisa erguer-se sobre uma realidade onde a aparência não adentre a razão a ponto de perder a lucidez dos passos. A ilusão, é matéria da criatividade ou da representação, e no palco, é ainda sim, e principalmente, verdade. Atravessar campos de sentido, em deslocamentos inválidos de compreensão, como ilusões, é padecer, contrariamente, no que pode e deve ser uma construção de existir, sendo em fundamentação, a base do que constitui uma humanidade, os valores de um ser do bem, justo, e fraterno e todos as pedras basilares do que vem a ser um bem maior, uma edificação do que sabemos e não agimos em grande parte em concordância, mas que a razão constitui, sendo as premissas de uma emissão do que podemos reverberar por entre os versos de uma evolução.

O poder econômico, é uma constatação, porém, tem no mínimo dois lados para serem observados: Como constatação, de fato, onde o poder realiza trânsitos onde esse fator é preponderância como influência e recursos, na maioria das vezes. E, como subjugação o que é diferente de ter um poder econômico, onde o mesmo subjuga e manipula e deturpa razões 
possíveis de igualdade de esforços, havendo assim, um lado pejorativo na melhor das palavras, para uma preponderância desse poder. O poder pode ser visto como um agente propulsor de avanços onde quase como ferramenta, não como auxilio, e sim como agente capaz de exercer relações entre os outros esforços de outra magnitude, conciliando forças.

Seria a aparência um instrumento deturpado do poder, dependo do uso, para uma maior dominação? Estamos falando, penso, de uma aparência onde a realidade se perde em incompreensão, e se veste de outra face para restringir camadas, ou gestos e vozes oprimidas.

Porém, é também de se constatar que toda aparência tem seu preço, ou seja, a sociedade cobra a conta da realidade sem máscaras. Diferentemente, a aparência a qual creditamos ser possível é a dos personagens que nos fazem mais íntegros e suficientes como integrantes da sociedade.

Parece-me que culturas diversas e os desafios da globalização, consensos e dissensos, campos de ação, podem mover posicionamentos de mercado e suas respectivas reverberações no estado habitual, então, creio que um planejamento no mínimo é o primeiro passo, para minimizar ou expandir impactos, e prever riscos, ou benefícios. Acessos sem prejuízos da cultura local, é algo a ser considerado mesmo que na expansão, porque existe em parte, como um dos fatores, a estar arraigado ao que é da própria cultura e em contra partida, o que é de interesse pelo novo, e por valores talvez mais acessíveis as vezes por parte da população, e de qualquer maneira, me parece que o target, o direcionamento da camada ou do público alvo, já altera ou determina as diretrizes de alcance do ação de expansão. Penso que sempre haverá prós e contra, mas medidas de expansão requerem sempre análise de riscos e benefícios, e o fluxo de via de mão dupla, porque culturas mesmo que em desenvolvimento, tem e vão ter sempre, a oportunidade também de assumirem posturas fora de seus territórios, portanto, talvez, se já preverem uma ação em confluência de espaços, seja, um passo de um benefício mútuo.

Políticas públicas e reflexos de ações participativas no comércio exterior. Períodos e repercussões.

Agora, existem aspectos da consciência de uma realidade, porque o que é uma realidade, já é algo a ser hoje em dia difícil de definir, pode se dizer que, alguns aspectos do que o texto coloca como razão mercantil, mas eu penso que não o que move uma sociedade no que diz respeito ao capital, trabalho e consumo, mas de um valor colocado sobre moldes de uma 
falsidade em relação ao que pode e deve mover uma sociedade, então, seriam, um mercado de pensamento, onde uma sociedade se viu deturpada de valores, e então aqui, o que é mercantilizado são os desejos corrompidos de uma vida real, assim, penso que possa ser. A aparência estaria sendo mesmo vivida, no que são de escolhas de cada individuo ou grupo, de forma que, muitas vezes, o que acreditamos ser fundamental, passa a ser de segundo plano, e o que é de primazia, fica visto até como irreal, onde certas posturas de valores, quando realizadas são colocadas como de sendo por ter algum interesse, ou seja, uma inversão de valores, o que é bom tem que ter segundas intenções, e por assim em diante...

Hoje abstração já não é a do mapa, a do duplo, do espelho ou do conceito. A simulação já não é a simulação de um território, de um ser referencial, de uma substância. É a geração pelos modelos de um real sem origem nem realidade: hiper-real. $\mathrm{O}$ território já não precede o mapa, nem lhe sobrevive. É agora o mapa que precede território - precessão dos simulacros - engendra o território cujos fragmentos apodrecem lentamente sobre a extensão do mapa. [...] Na verdade, já não é o real, pois já não está envolto em nenhum imaginário. É um hiper-real, produto de síntese irradiando modelos combinatórios num hiperespaço sem atmosfera. [...] Simular é fingir ter o que não se tem. [...] a simulação põe em causa a diferença do verdadeiro e do falso, do real e do imaginário( Baudrillard, 1991, pp 8-10). 24

Governo e sociedade. Por quanto tempo dura uma aparência ou melhor, tida como aparência e aferida por inúmeras mentiras? QUAL É A MÁSCARA QUE CAI E DE QUEM? Nada como o tempo, para aferir as diretrizes e condutas e no tempo do tempo, o cuidado com armadilhas de cobranças fora de lugar.... com propósito pérfido de atingir quem não tinha a intenção de ser ausente ou de aparência falseada, apenas reagindo ( até mesmo como defesa) os ataques sofridos. O que aconteceu? O tempo respondeu os questionamentos? Quais foram as reais intenções e interesses de quem? Quem manipulou, quem enganou, quem feriu, quem perdeu-se para encontrar, o que?

Nunca a opinião daqueles a quem ainda se faz crer, em alguns países, que continuam a ser cidadãos livres foi menos autorizada a se fazer ouvir, cada vez que se trata de uma escolha que vai afetar sua vida real. Nunca foi possível mentir com tão perfeita ausência de consequências. ( apud Debord, 1987, pp. 182-183).

Um certo automatismo é advindo de condutas associadas ao que se pode apregoar sendo uma alienação fruto de aparências, o que gera um déficit a meu ver de conhecimento, porque penso que todo conhecimento deve se pautar sobre diretrizes da verdade, ou da busca de uma possível verdade. 
Tem-se uma avaliação ponderada de quanto que o papel da imprensa se alterou nos últimos tempos, fazendo uma crítica de que teria nos últimos tempos, relegado seu papel informacional em detrimento de caracteres do alcance econômico. Bem, me parece que, hoje com a diluição de fronteiras de captação pelos dispositivos e emanação de acontecimentos creio que essa crítica cai em grande parte por terra, porque as faces das notícias também estão mais compartilhadas e a procura de uma transparência também, assim como é feita em feedback de produtos pelas empresas por seus consumidores. A difusão ideológica como o texto aborda está sobre um compartilhamento de mãos, se, a ferramenta da internet e de in time se poder difundir fatos e pensamentos, não estiver manipulada na ilusão ou aparências tão bem apontadas acima nos outros capítulos do livro. Ou seja, a face compartilhada de acesso e difusão que hoje temos, deve estar atenta, por onde vai fortalecer essa ferramenta, se em diálogo com os já presentes na estrutura da atividade jornalista, na indústria cultural e sociedade capitalista moderna, ou como simplesmente uma maquiagem do viver, onde não se encontra uma beleza a mais, mais sim, uma simples repaginada na natureza dos fatos, que não estão sobre a ordem do dia ou da primeira página. Estar atento ao modo de ser da vida atual, em seus mecanismos comunicacionais, me parece o mais adequado para saber por onde vai os aspetos de mudança ocorrerem e serem necessários. Ou seja, quais as novas fontes que atraem o saber dos acontecimentos. Por onde as pessoas estão adquirindo qualidade de notícias e modos de ver o mundo. Essas formas, estão presentes em como eu atuo no mercado de comunicação? Porque se estiverem muito distantes eu perco mercado e perco alcance atingir novos caminhos para realizar a aproximação maior com os interesses de meu público e empresa, ou instituição e faces educacionais. Curiosamente mesmo sabendo que o grande interesse pela maior parte delas é a margem de lucro, isso, se consegue estando próximo de como atingir esse objetivo e assim sendo estar atento de que maneira o mundo se modifica em sua forma de comunicar, agir e descobrir novas formas de interação. Opinião pública - Em tempos atuais, formada em entre-faces de comunicação. Fatos e consequências qual a ordem do produto?

A produção da mercadoria-noticia, como processo de manipulação dos fatos para produzir um discurso ideológico, também pode revelar uma articulação de níveis simbólicos que produz mitos e preconceitos sobre algumas personalidades ou movimentos sociais., Para isso, podem ser usados alguns elementos gráficos na produção noticiosa, como títulos manchetes, fotografias, gráficos, ilustrações, com o objetivo de construir uma determinada perspectiva dos fatos. (CASTRO, COELHO, 2006, p $38)$. 
Escolhas e responsabilidade. Se a manipulação passa a ser a verdade dos fatos, então a realidade mais dia menos dia, cobrará seu preço. Sinceramente, a notícia como mercadoria como se coloca no texto e muitas vezes nos lábios da sociedade, não me espanta e nem mesmo me parece alvo de críticas sendo que aqui não está a análise de como é o mercado, mas sim, a constatação da ocorrência. Vivemos já dito por muitos em sociedade de consumo, e se eu mesma chamo a vida de produto em consumo para me aproximar de uma lógica constatada do cotidiano, é até mesmo, coerente que se veja assim, porém, com distinções, no fato, de, falamos em consumo consciente, ora, então é possível atrelar ao conceito de noticia como mercadoria, o consumo consciente, ainda mais em tempos de interfaces tão profícuas com o público, que é agente também e não somente receptor. Hoje é tempo em que vivemos o consumo do próprio cardápio oferecido por nós, e feito pelas nossa mãos, e não somente dos órgãos instituições detentores da maior gama de espectros dessa difusão que vem a ser o campo da mídia.

Domínio de imagem e escrita são de propriedade do cotidiano, isto para os alertas que fazem Marcuse, como formas de moldar um universo de comunicação, porém, o mais importante aqui, nessa forma constatada de linguagens visual e de texto, é para além do domínio que o que se apresenta deve para tal, e portanto estar em diálogo para ter eficiência, e ainda, a de se ter em mente que a imagem nos tempos autuais não se expressa sozinha, mas é campo de outros sentidos, então mesmo que não como forma de cognição predominante, se estabelece um modo quase que, e não gosto de usar essa palavra, mas de inconsciente de sinestesia, onde a complexidade e o alcance enquanto ambiente interno do domínio, ou de expansão do tocante ao diálogos, são muitas vezes relegados. Agora, quanto a correspondência de discurso e ação, nota-se que a sociedade atual, mesmo que imersa em aparências, ou ilusões, ainda promove a necessidade de uma transparência, no enfrentamento dos fenômenos sociais.

A cobertura dos fatos e o quanto que se fica informado em tempos de aparências, também pode ser o quanto que a necessidade desse objeto informacional esteja presente no seu dia a dia, porém, como o modo cognitivo normalmente não se atem a complexidade e muito menos a rede de conexões possíveis e mais ainda a reverberação dos fatos, infelizmente não nos damos conta do quanto que fatores e ocorrências atingem nossa vida, portanto, muito do que consideramos irrelevante para nosso mundo particular, como sendo de ordem de outros saberes, ou de outras conjecturas de esferas sociais, como governamentais, etc, são relegados em grande parte, e assim sendo, mais fácil é a manipulação de um contexto mais 
geral por parte ainda dos que querem por alguma razão conduzir algum aspecto do que está permeando o cotidiano vigente. Se não tenho a consciência da reverberação, que muitos dos fatos são fragmentos, ou efêmeros, e que em razão disso não me alcançam ou eu não tenho nada a ver com isso, então, pode se crer que estamos mais expostos a ser marionetes do destino. Claro que as responsabilidades cotidianas nos cercam em certa medida a esforços a serem cumpridos, porém, também o esforço de se concatenar, conjugar, elementos mesmo que em cotidiano, são da ordem também do afeto, e do que pode nos trazer uma vida melhor e em harmonia.

\begin{abstract}
Hebert Marcuse, nos explica que muitos conceitos podem ser operacionalizados ou instrumentalizados, limitando os seus significados e suas representações ou deslocando-os para um contexto sem mediações com outros termos, o que pode diminuir o seu potencial crítico e a tensão dialética entre opostos. Por outro lado, os conceitos podem expressar relações com outros termos históricos, enriquecendo suas mediações e completando o processo cognitivo, produzindo conhecimento $\mathrm{e}$ aumentando a capacidade crítica do leitor. Marcuse, dessa forma, salientou a importância da ferramenta conceitual que pode gerar um entendimento mais profundo, radical, ( no sentido de ir à raiz das questões ) sobre concepções: políticas, econômicas, artísticas etc, ou gerar, a alienação dessas mesmas concepções. (CASTRO, COELHO, 2006, pg 43).
\end{abstract}

Constatamos que transformações ocorrem mas quais e porquê, em detrimento de uma automatismo operacional não veem a tona ainda e mesmo com a característica dos tempos de se locomoverem em aspectos de habito e convenções, porém, mais do que isso, sobre razões que habitam o tempo por serem eficientes, e que nessa eficiência esquecem que podem ainda ser feitas de outras maneira por ventura, mais eficientes todavia. Resistência nos mecanismos sociais, podem estar sobre as dificuldades de um relógio ou sobre a diversidade da vida, que impele entre as horas os segundos emancipatórios de um diálogo com o modo de ser do existir. Porém, a razão, pode ser aliada entre tantas aparências, e entre tanta resistência, posto que se quereremos um viver melhor em sociedade poderemos nos encontrar, entre dissensos e consensos como fruto de um elemento comum.

Parece-me que os investimentos devem ter a sua distribuição em razão de sua causa, mas também em razão do quanto que sua expansão terá em alcance de melhorias em significados em rede e conexões de relações, porque por vezes pode se observar um ponto a ser investido que condensa nele mesmo sua importância, claro, mas que em seu estudo de reverberação não tem a mesma repercussão em diretrizes de rumos de benefícios e melhorias que outros, então, penso, que deve se ter bem claro o objeto e o alcance de suas ressonâncias para que o 
investimento possa ter claro além de seus objetivos, os porquês de se distribuírem, no mesmo, enquanto particularidades ou extensões. O fator esforço e tempo diante de resultados e demanda, também deve ser criteriosamente analisado, para em um mapeamento verificar em qual momento é melhor investir as perspectivas e recursos, mediante as necessidades e espera com expectativas, de satisfação. Dramaturgia da vida real: Qualquer semelhança não é mera coincidência: Uma luta pelo que se acredita e direito de dizer e ter a consciência do que se quer viver. Das escolhas, lembramos Castro e Coelho, "Como uma forma de representação do mundo e de seus fatos, a imprensa pode se aproximar mais das verdades que explicam o funcionamento das sociedades modernas ou se afastar através de uma representação ideológica da realidade. “

Curioso perceber como fatores particulares, aparentemente, ganham destaque em tempos de eleições, e o particular passa a ter um patamar, que antes ou no cotidiano posterior é simplesmente deletado, como um arquivo sem existência, ou que não será parte da esfera dominante. Porque então, em tempos eleitorais, certos detalhes da ordem social, passam a ser relevantes. Como o funcionamento de estruturas sociais ou seu mecanismo de ação em sobrevivência podem estar agindo como discurso e ideologia em qualquer tempo e para qualquer esfera, seja entre os dominantes ou os que dele são ramificados, e ainda, como anteriormente pensado, existe uma falta de consciência de reverberações, principalmente de uma classe dominante, em relação ao que esta engendrado como viver, dos que relegam como sendo margens sem peso, ou poder de ação.

Será que do que VEMOS, LEMOS, ouvimos OU VIVEMOS, em adulteração de significado, eu posso realmente, apreender, e compreender, ou eu terei que sempre das palavras, encontrar um modo de que tudo esteja sobre um TRADUZIR-SE.!

Traduzir a linguagem de uma sociedade que propõe uma aparência do que pode e deve ser vivido? Traduzir um corpo urbano de onde as agruras são e devem ser de fato, estudadas, refletidas ou escritas nem que seja no trânsito cada vez mais insano de se chegar no horário de pico, a algum lugar!

- Nomenclaturas, nomes, ditaduras? Em que estamos vivendo? Democracia? Onde?

- AMOR, nem sei o que é isso.

-E, de quem é a regência? 
Importa? Cadê a porta, por onde nem mesmo quero atravessar? Não vejo porta, onde sei que posso encontrar o amor.

Ah, no próximo voo, onde as asas estejam de volta ao corpo. Que corpo? Do indivíduo que precisa ainda saber andar, ou por onde possa caminhar, que não seja coberto por ilusões.

Traduzir a vida, realmente dá muito trabalho, quando ainda as palavras são ditas sem alma, e é possível dizer palavras da vida sem alma? Diga-me, cotidiano íngreme do asfalto em precipício. E, descascando as peles mortas do precipício da incompreensão indigesta, que molestou as asas, somente ficam os movimentos, do vento, da própria queda, ou será do voo sobre nossas cabeças, ilesas talvez de um jogo ridículo, mas com um simples desejo de estar mais próximo do céu, ainda que sobre os caminhos da terra.

Muito das dicotomias entre imprensa, modos de ver, a sociedade, capital e trabalho vem sendo alterados.

O espetáculo não é um conjunto de imagens, mas uma relação social entre pessoas, mediada por imagens...[...] considerando em sua totalidade, o espetáculo é ao mesmo tempo o resultado e o projeto do modo de produção existente. Não é um suplemento do mundo real, uma decoração que lhe é acrescentada. É o amago do irrealismo da sociedade real. Sob todas as suas formas particulares - informação ou propaganda, publicidade ou consumo de divertimentos - o espetáculo constitui o modelo atual da vida dominante na sociedade. Ele é a afirmação onipresente da escolha já feita na produção e o consumo que decorre desta escolha. Forma e conteúdo do espetáculo são, de modo idêntico a justificativa total das condições e dos fins dos sistema existente. $\mathrm{O}$ espetáculo também é a presença permanente dessa justificativa, como ocupação da maior parte do tempo vivido fora da produção moderna. ( CASTRO, COELHO,2006 pg. 55).

O desenvolvimento do senso crítico. A defesa de liberdade de imprensa, assim como a constatação fragmentária a que nos expomos, podem desenvolver um senso crítico, apesar de que penso que a maleabilidade presente nas esferas continuas de via de mão dupla facilitando acesso aos feedbacks do público, sabe-se que esse permear sim, em meu modo de ver, é agente crítico e de um senso. O cidadão comum e a interferência na realidade. Cada vez mais, me parece que se não estiver também este em manipulação, se crê o cidadão, no tempo atual, com ferramentas de maior difusão, para encaminhar socialmente suas reinvindicações. Imprensa séria ou não? De quantas realidades estamos falando, ou melhor, de quais modos de representar a realidade estamos falando. 
A conjunção de aspetos representativos e cognitivos das esferas rotuladas de populares ou eruditas, quando permeadas pela gênese ou desmembramento de elementos comuns, podem surgir caminhos bem elucidativos quando a processos novos e adjacentes.

Um discurso hegemônico ou diverso em sua hegemonia?

Órgãos de poder configuram o estado hegemônico? E como se desconfigura o sistema para realizar as atualizações?

Traços esclarecidos quanto a reconhecimento - da cultura popular. Por vezes - em ralação ao reconhecimento - a audiência.

Os leitores continuam lá, a espera das notícias, quer estejam na banca, ou na internet, ou chegando via celular por um amigo, então eu penso que temos alguns pensamentos de relutância e concordância com modos de ver o tempo atual. Me parece que não é algo tão distante ou que percamos leitores, mas os meios vão se metamorfoseando e aí sim, se não alterarmos conjuntamente nossos mecanismos de ação em comunicação, então, sim, teremos distanciamento dos leitores, fato que me parece não ocorrer, tão gravemente quanto o colocado. Mas, como toda averiguação de um estado, tem-se que verificar de fato e verdadeiramente as ocorrências do meio, para se aferir algo ao menos que não esteja sendo manipulado ou ocultado, para podermos seguir adiante.

Verbas, publicidade e noticia - em tempos de mercadoria, ingredientes um tanto quanto explosivos, porém, se conseguirmos conectar temas, talvez um promova o outro ou sugira uma realidade cotidiana, próxima da notícia, mas nem sempre, temos fluxos compartilhados de pensamento, que dirá dessas instâncias de mercado. Qualquer canal não somente de controle, mas de difusão dos mecanismos da mídia, da informação, da comunicação, tem em seu cerne, a responsabilidade com seus atos propagados e reverberados na sociedade. Quanto maior a expansão de alcance, maior deveria ser a responsabilidade. Bem, isso é o que penso. Enfim, cada veículo de difusão informacional, de comunicação ou entretenimento deve estar constantemente atento as suas práticas, e ao contexto social no qual pode e deve responsavelmente agir, porque a informação é agente de transformação de uma realidade, para o bem ou para o mal, mas acreditamos que invariavelmente a informação pode ser e deve, esclarecer mesmo que as consequências sejam difíceis de se enfrentar. O poder de comunicação não deveria estar como fonte de subjugação mas de diálogos contínuos da sociedade, onde a imagem, a voz, a narrativa se entrelaçam com o cotidiano de forma a serem ambos representados de maneira a poderem estar de forma licita 
como reflexo de seu tempo. A saber: "As lutas sociais pela democracia carregam, na dinâmica que lhes é inerte, o direito de estar informado[...] porque sem o acesso ao fato histórico, o homem não passará a protagonista da ação social ( Medina 1988, p 133 ) “.

Vivemos em épocas de códigos. Mas, qual o código das relações humanas? Informação mercadoria / informação - espaço público

A tolerância não discutida. A certos aspectos da convivência humana que ficam relegados muitas vezes e são de primazia que venham a tona, para sanar uma possível integridade dos relacionamentos. O mediador; "Qual é o mediador que estará apto a realizar uma, " narrativa dos fatos contemporâneos que ensaie ao mesmo tempo, a polifonia, e a polissemia do presente, o enraizamento na história, na cultura e nas identidades míticas, bem como a enunciação de tendências projetivas? ( Medina, 1999, p. 86 )

As palavras são tecidas a partir de uma multidão de fios ideológicos e servem de trama a todas as relações sociais em todos os domínios. É, portanto, claro, que a palavra será sempre o indicador mais sensível de todas as transformações sociais, mesmo daquelas que apenas despontam, que ainda não tomaram forma, que ainda não abriram caminho para sistemas ideológicos estruturados e bem formados. A palavra constitui o meio no qual se produzem lentas acumulações quantitativas de mudanças que ainda não tiveram tempo de adquirir uma nova qualidade ideológica, que ainda não tiveram tempo de engendrar uma forma edológica nova e acabada. A palavra e capaz de registrar as fases transitórias mais íntimas, mais efềmeras, das mudanças sociais. “ ( apud, BAKHTIN 1986, 41 )

A fragmentação e seus antídotos - " Utilizar a palavra apreender a transformação ideológica apontada por Barthes é também uma possibilidade de escapar da fragmentação, já que pedaços isolados de significados ideológicos aqui não teriam nenhum sentido, pois não formariam o complexo quadro onde estariam registradas as lentas acumulações quantitativas de mudanças." Pois, como nos lembra Canclini, em oposição a essa cultura dominante há a procura de uma produção cultural que proporcione práticas transformadoras para o combate no campo da subjetividade ( Canclini, 1982, p 41 ). Uma condição necessária, embora não suficiente para afrontar a ideia de informação como mercadoria, imaginado outras formas de real que não as formatadas pelo espetáculo homogeneizante, mas respeitando a diversidade $\mathrm{e}$ a complexidade de um planeta globalizado que se constitui com base em condições sociais assimétricas e cuja perversidade não pode ser enfrentada sem que haja um direito de informação e uma comunicação livre que constitua para além dos limites de um conhecimento proprietário excludente. “( CASTRO, COELHO, 2006, pg77). 
A manchete e seu valor emotivo em detrimento do aspecto informacional. A exploração da violência, e de outros conteúdos emocionais. - aqui se apresenta discussões quanto a ética nas comunicações. As vezes me parece que até mesmo esses meios de imprensa sensacionalista como chamam, perdeu impacto, porque o automatismo e amortecimento emocional, me parece que deve tê-los atingido também. A sociedade, e o que penso deve ser mais observado do que propriamente a imprensa sensacionalista, essa sociedade que ficou amortecida por tantos impactos ou formas de se olhar que se desfez de suas próprias realidades é algo que de fato, e mais, me preocupa, porque é de indivíduo para indivíduo e em todas as esferas. Como elencar um discernimento de conduta e ainda manter a percepção que pode nos desatrelar do automatismo e ainda, alavancar possíveis gestos não percebidos de cognição do social, é um desafio atual.

Em defesa de um argumento que levanto quanto a vida ser o produto de nosso tempo, é em razão de aproximar de uma lógica presente com a intenção de transmutar ou fortalecer valores importantes para o desenvolvimento e não denegrir nada por estar aliado a lógica de consumo. Se o que se propõe e mesmo não em paralelo, mas em continuidade temos a presença de uma consciência podemos então, adentrar esse terreno de forma licita.

Lidamos com cotidianos em dicotomia sendo o mesmo, onde temos como abordado pelos autores citados, valores humanos deixados de lado em troca do interesse econômico, porém, deve-se estar atento que os valores humanos como o nome diz, os valores, são conquistados, colocados em seus devidos lugares, conforme a consciência de sua razão e do quanto que essa razão se engendra em seu cotidiano. Alterando significativamente, a relação com o interesse econômico, mas sim, podendo em consciência, fazer parte da cultura sustentável onde o pensamento é valor de transformação de uma realidade. No que acreditamos? Em respostas induzidas, ou possíveis verdades do tempo, histórico também de nossas vidas? Qual valor é parte de nossa vida? \por onde o tempo nos atravessa? A memória tem seu risco de confiabilidade? Sobre uma impressão aparente, um dos aspectos da monotipia. O desafio de enfrentarmos dentre a repetição do cotidiano a imagem que queremos ter e representar, e passar até mesmo a reproduzir a constante, o cotidiano como puro prazer de sermos quem desejamos.

Um dos argumentos mais exigentes na defesa da indústria cultural é aquele que glorifica seu espírito e se pode chamar tranquilamente de ideológico. A indústria cultural daria à humanidade, em um mundo caótico, algo como critérios de orientação, e só isso seria um fato apreciável. Mas a sua grande força está em proporcionar à pessoa humana necessidades, não somente aquelas básicas para se viver de maneira digna ( casa, comida, lazer, 
educação, e assim por diante ), e sim, aquelas do sistema vigente ( consumir sem parar ). Com isso, o consumidor viverá sempre insatisfeito querendo constantemente consumir, tornando o campo de consumo cada vez maior. Isso ocorre porque o mercado lida com o campo do desejo ( ilimitado ) e não da necessidade. Tal dominação tem sua mola propulsora no desejo de posse, constantemente renovado pelo progresso técnico e cientifico e sabiamente controlado pela indústria cultural. (PATIAS, 2006, pg90).

Ainda segundo o autor, como um modo de ver a representação:

Outro conceito importante para a nossa temática é o da sociedade do espetáculo", desenvolvido pelo pensador francês Guy Debord ( 1931-1994 ) e seus companheiros da Internacional Situacionista nos anos 60 do século $\mathrm{XX}$, que influenciou as várias teorias contemporâneas sobre sociedade e cultura. Ao analisar o capitalismo o autor, constata um acúmulo de imagens que dá origem à sociedade do espetáculo, uma das marcas da contemporaneidade. Estabelece-se um predomínio da imagem sobre a coisa, da cópia sobre o original, da representação sobre a realidade, da aparência sobre o ser. [...] " Ele não é um conjunto de imagens, mas uma relação social entre pessoas, mediadas por imagens ( 1997, p 4 ). É também uma cosmovisão, resultado e projeto do capitalismo, o modelo atual da vida dominante na sociedade, a afirmação onipresente da escolha, a justificativa total das condições e dos fins do sistema existente, a presença permanente dessa justificativa, como ocupação da maior parte do tempo vivido fora da produção moderna ( PATIAS, 2006, pg 91).

Curiosamente, em crítica, se aborda o espetáculo como em parte distanciamento de uma realidade, onde antes se poderia ter relações diretas, porém, em um modo de ver, o consumo da vida ela sendo seu próprio produto, é a razão da lógica presente do cotidiano como fator responsável e a favor e não contra, resultando em benefícios, e portanto, a dramaturgia chega ser instrumento do existir, onde exercemos faces de nós como busca de nosso enredo, narrativa do viver, até mesmo mais integro. Apesar de que, por vezes poderemos estar sim, de fato distanciados a ponto de não perceber o próprio cotidiano de fato e verdadeiramente mas, teremos sempre escolha se queremos ver o mundo passar diante de nossos olhos, ou sermos os protagonistas de nossas narrativas, engendramos mesmo estando sobre o que é da lógica do espetáculo, ou consumo.

Soando ainda como uma perspectiva diversa porém, em certa medida, possível:

O ponto de partida é o mercado ( produção ), acompanhado do consumo do espetáculo. Já não vivemos as nossas próprias experiências, os modelos são os que vivem em nosso lugar: tudo o que era vivido diretamente torna-se uma representação" As relações humanas passam pelo intercâmbio mercantil e a mercadoria ocupa totalmente a vida social. [...] " Além disso, 
com sua vida e experiência moldadas pelos espetáculos da cultura e da mídia, o ser humano deixa de ser sujeito ativo de sua própria história, passando a ser submisso aos espetáculos consumistas. Na sociedade de consumo, a lógica do espetáculo não permite reconhecer o próprio espetáculo produzido. Não vemos, não percebemos, é diário e contínuo. São várias dimensões: quando divulgamos ideias, noticias, produtos, imagens, estamos produzindo espetáculo. ( PATIAS, 2006, pg 91-92).

“ Eis o grande paradigma da atualidade: a transformação da própria vida em uma forma de entretenimento. Adorno e Horkheimer já haviam notado a fusão entre o real e o virtual. “, lembra Patias,

A vida é retratada como uma forma de entretenimento, como um marco da cultura contemporânea, influenciada pela ideologia da indústria cultural contemporânea, influenciada pela ideologia da indústria cultural americana. [...] Todos nos tornamos ao mesmo tempo protagonistas e espectadores de um grandioso espetáculo que nunca sai do ar, um show muito mais rico, complexo e interessante do que os produzidos pelos meios de comunicação convencionais. Somos ao mesmo tempo atores e plateia de um grandioso e ininterrupto espetacular. ( GABLER, 2000, pp12) p 94

Existe algo que pode ser tratado por este prisma de sociedade do espetáculo que vem a ser a veracidade com que atores, diretores, envolvidos com a dramaturgia realizam seu trabalho, ou seja, se na vida real, nos envolvermos com nossos personagens, com nosso palco de maneira tão profunda e verdadeira como a grande maioria dos envolvidos em dramaturgia, se não todos, podermos encontrar um viés saudável desse prisma. Dentre as conjecturas citadas de comportamento, teremos portanto a escolha.. Do que é representado, o que eu quero e desejo acreditar. E, crença, também tem relação com valores. Escolha relaciona-se com razão, e razão com valores em crença. Objeto de diretrizes. Porém, existe um fator que pode influenciar em decisões menos conscientes, que vem a ser, dependendo do período e fase de vida, ou conjecturas e contextos, que é o emocional. Em determinados momentos, perturba em benefício ou não o " sistema orgânico. Retomando, de que maneira realizar um contínuo que possa ser acrescido de informações agregando valor proporcionando um crescimento dentre cotidianos, então, não se suprime uma realidade, mas se constrói uma em seu devido poder de comunicação e ação, continua para se ver como sentido complexo em profundidade capaz de se realizar em estados que permanecem e se desenvolvem. A semente e o fruto.

A cultura do espetáculo utiliza a informação- mercadoria e a imagem mercadoria para responder a mais um imperativo da cultura de massa. A busca incessante do entretenimento reduzido a tempo de consumo. A sociedade se transformou numa sociedade voyeur, ( particularmente prefiro ação do que observar e se observar, melhor então com uma intenção, a participação em ato-reflexo ; o que vem a ser o ato-reflexo, ora, em uma 
sociedade de voyeur, eu que não vou ficar somente olhando, então, vejo, observo, desejo, sacio, e faço acontecer. ), fenômeno de comunicação como consumo e produção de imagens espetaculares, e instalou o espetáculo em todas as instâncias comunicativas. ( PATIAS, 2006, pg 103).

Valdir de Castro, salienta que "Enquanto espaço concreto e vital, a cultura abarca o conjunto dos valores que regem as relações humanas que advêm de intenções claras ou latentes e sempre têm o objetivo de respondera determinados interesses “.

Cultura, enquanto cultivo, desvela sua estreita relação com a vida humana, com a qual ela se desenvolve, adquire característica e se prolifera. Trilhando por essa direção, agregamos a essa definição outras duas visões. A primeira é de Kellner, para quem a cultura, em seu sentido mais amplo, é uma forma de atividade que implica alto grau de participação na qual as pessoas criam sociedades e indentidades ( Kellner, 2001, p 11 ). Esses fatores modelam os indivíduos, evidenciando e cultivando suas potencialidades e capacidade de fala, ação e criatividade. ( CASTRO, 2006, pg 110)

Marcusse destaca a necessidade de:

Um processo de humanização caracterizado pelo esforço coletivo para conservar a vida humana, para pacificar a luta pela existência ou mantê-la dentro do limite controláveis para consolidar uma organização produtiva da sociedade para desenvolver as capacidades intelectuais dos homens e diminuir e sublimar a agressão, a violência e a miséria ( Marcusse, 1998, p 154 )[...] Tanto a argumentação de Kellner, para o qual a cultura “ modela", evidencia, e cultiva as potencialidades, como a de Marcuse, que defende a cultura como processo de humanização, com o objetivo de conservar a vida humana, denotam que cultura é a globalidade da realidade vivencial da qual emana um conjunto de forças cujo objetivo é preservar a vida, e influenciar fortemente o comportamento humano. ( CASTRO, 2006, pg 110).

O sujeito ambiente o qual tratamos de observar, em parte se coloca como ethos na cultura como Castro descreve ao considerar que o ser humano está em seu ambiente social, Quais as características do ambiente, torna-se objeto de auscultar o nosso tempo. O indivíduo é consumidor, mas de que maneira ele consome seu viver? Significamos o mundo, mas não de qualquer forma, deixamos nossa marca, não somente para o tempo vigente, mas para as futuras gerações. A mídia e o espetáculo.

Barthes ( 2001), destaca a linguagem como constituinte da cultura, e síntese verbal ou visual, Arbex em sincronia com Debord, define o espetáculo como multiplicação de ícones e imagens. 
O que assimilamos nos engendra de imagens em participação por mesmo absorver, mas como alertam é necessário escolhas dentre a imagem que representa o real sendo ele propriamente, e espaços de uma possível aparência que carece de irmos até como diz Castro, a raiz do espetáculo. Cópia ou original se perguntam. Não é disso que a representação de fato no palco da vida trata, e sim, de uma verdade orgânica da qual não podemos tão facilmente nos desvencilhar, senão hoje no amanhã, os atos ressoam como gestos que permanecem na dramaturgia viva, que pode não se questionar sobre se é origem ou desmembramento, representação ou realidade, e sim, ambos. Ou, que façamos nossa escolha, porque dentre realidade e representação, o que se torna para nós, a relação mais correspondente com nós mesmos.

Se obtivermos a economia e o consumo dentre as possíveis estruturas que permeiam a nossa sociedade e a move, além do trabalho e outras forças, porém, não somente criticando mas desenvolvendo uma educação entre essas duas faces, o seja, uma planejamento de estudo de práticas cotidianas que esclareçam os rumos de uma economia e consumo de maneira a não sugar nossos próprios dejetos mas sim, colaborar, para agir mais como um adubo onde se pode encontrar o que virá a germinar e desenvolver em sociedade como motor consciente, podemos fazer uma imersão nas imagens, nas aparências, na realidade de maneira a preservar ainda uma possíveis modos de olhar que estejam próximos de nossa identidade tanto quanto a realidade nos permita reconhecer de necessidades verdadeiras ou seja, o que me é imposto, ( e como é posto ), de que maneira me relaciono com esse ambiente, e quais serão minhas escolhas e comportamentos, assim, me parece mais em pé de igualdade sendo que não somente fica a critério do sistema econômico e do consumo, as culpas de uma não integralidade saudável em sociedade.

E, quanto a publicidade, em certo ponto, como estamos nos promovendo nesse turbilhão, o que de meu discurso como ser vivente e imerso nessa realidade é coerente ou não para constituir minha marca de forma a ser o aspecto não somente de uma digital orgânica mais de pensamento e ação, assim como no ambiente cotidiano, de que forma o" eu" ser, está vivendo nesse mercado. Não me incomoda paralelos, até mesmo porque advogo diante da constatação e não pessimismo que a logica do consumo é uma presença, porém, e em se tratando disso, de que maneira, estaríamos nós, como produto, e mercado. Não tenho pudor de colocar a vida como produto de nosso tempo, e creio mesmo ser uma aproximação licita se visível com transparência e horizontes para um desenvolvimento. A economia de um viver, onde os seres habitam seu tempo, é relevante para escolhas que faremos, inclusive dos 
recursos planetários. A publicidade é uma ferramenta, uma presença em lógica desse ambiente, e como manuseá-la em favor e não detrimento será sempre uma escolha, assim como o ambiente da comunicação, enquanto representante da realidade assumindo os papeis de integridade com os fatos.

Pensamentos de lógicas integrativas de conhecimentos. A publicidade com o tempo, passa a ter um significado enquanto partícipe da cultura cada vez maior, em argumentos que podem ser indutivos de " modelos e padrões estéticos " na gama mais diversa de segmentos sociais, havendo de estar presente cada vez mais do que pode alterar significativamente de maneira salutar os propósitos de alcance de uma educação do que queremos como ambiente de indivíduos responsáveis com sua parcela do decorrer da face da humanidade dentre nós e as próximas gerações. O caminho do amanhã é a imagem do hoje. Do que queremos, o que fazemos no presente?

De acordo com Canevacci, “ A mercadoria já não é um objeto, mas um ser vivo, inserido nas relações sociais, o sujeito se transforme em coisa-que-se-vê “.

Essa linha de raciocínio leva a romper com a polaridade criada no mundo ocidental entre o universo das pessoas ( que participam da humanidade de forma singular ) e o universo das mercadorias ( baseado numa dimensão despersonalizada, homologada graças ao poder nivelador do equivalente ) . Canevacci chega a afirmar que a dicotomia humanística entre pessoa como sujeito e mercadoria como objeto já não funciona. Justifica que, se as histórias de vida pertencem a um tipo de abordagem das ciências sociais, que, pelo menos até hoje, tratou somente de indivíduos em sua qualidade absoluta de universal singular, agora essa abordagem biográfica pode ser estendida às mercadorias.[...] Todas essas considerações, evidentemente, são questionáveis, pois coloca em xeque a própria concepção de ser humano que, embora convivendo num mundo povoado de coisas, não pode ser confundido com elas. Daí a necessidade de resgatar o discurso crítico. ( CASTRO, 2006, pg 123).

Papéis benéficos de reflexão: Critica com discernimento e propostas para o ciclo de vida renovação do mesmo - alteração de informações - aprendizado com o mercado e o público consumidor - modificando alcances e benefícios para a manutenção ou reafirmar o "status" determinado pela constante.

Nessa linha também está Canclini, para quem o ser humano não só se satisfaz no consumo, e no consumo se torna indivíduo, mas também exerce a sua cidadania. Para esse autor, não existe divergência entre cidadania e individualidade, pois, atualmente a participação social é organizada mais através do consumo do que mediante o exercício político da cidadania ( Canclini 1999, p 14 )Propõe, então, reconceitualizar o consumo não como 
simples cenário de fatos inúteis e impulsos irracionais, mas como espaço que serve para pensar, onde se organizar grande parte da racionalidade econômica, sociopolítica e psicológica nas sociedades. ( CASTRO, 2006, pg 124. )

Creio que estamos no entrelaçamento entre o que vimos como um consumo que aniquila os sujeitos como o texto em continuidade aponta, mas, hoje, estamos vivendo também, uma outra relação, ao menos vemos um movimento já nessa direção de um consumo mais consciente ou de produto que despertem a responsabilidade e para fatores educacionais na rede que um cidadão desde a infância está engendrado para que considere, o que quer, e para que, e ainda mais as necessidades não somete as suas, mas as dos outros que estão também vivendo na mesma sociedade, onde os recursos econômicos estão tão desigualmente distribuídos como oportunidades, e forças de trabalho, não justificando, também, mas alertando para esse fato que é dinâmica dessas relações, expostas sobre o prisma do consumo. E ainda, o que fazemos com as lógicas que expomos como face possível do mundo em emissão de comunicação e práticas? O que escolhemos fazer com elas? . O retorno cobra a conta. Como interface social, e de relações o terceiro setor. Como inquietação social, vemos surgir cada vez mais o terceiro setor como agente de transformação. ${ }^{339}$

Viabilizando caminhos concretos, dispomos de algumas ferramentas estratégicas e dentre elas o marketing social, já exposto em alguns fatores, mas sendo sempre importante ressaltar devido a sua grande força de poder de transformação, havendo de compreender que as alterações são do âmbito principalmente do pensamento, se direcionando as ações. Primordial estar atento que o objetivo principal sejam de fato inseridos no campo social e não somente como agregado a um valor a empresa, mas que de fato esteja o comprometimento não como fachada, mas real e verdadeiro,

\footnotetext{
${ }^{339}$ Do livro de Evelyn Berg Ioschpe: “ Tenho a convicção de que o conceito do Terceiro Setor descreve um espaço de participação de novos modos de pensar e agir sobre a realidade social. Sua afirmação tem grande mérito de romper a dicotomia entre o público e o privado, na qual público era sinônimo de estatal e privado de empresarial. Estamos vendo o surgimento de uma esfera pública não-estatal e de iniciativas privadas com sentido público. Isso enriquece e complexifica a dinâmica social ( Cardoso, 2000, p 8 ) "A falência do Estado e a constatação de que o mercado com sua lógica lucrativa não pode dar respostas suficientes ás demandas sociais são os principais argumentos dos autores adeptos do Terceiro Setor para o surgimento e crescimento do novo setor. Assim o terceiro setor, seria a articulação materializada entre ambos os setores: público, porém, privado. A suposta superação, alardeada por esses autores, da equiparação entre o público e o Estado, constituindo o que denominam público não estatal, seria o espaço natural de articulação dessa nova atividades social.“( EZEQUIEL, 2006, pg133).
} 
Sempre termos o alerta de que o limítrofe entre a realidade e a imagem em representação estarão possivelmente cada vez mais justapostos, e engendrados como quase sinônimos um do outro, havendo de talvez as escolhas serem justamente o que farão um diferencial de onde nos pertencemos, ou quando,

Qual a imagem do discurso de um pensar? Esse pensar, é texto, palavras estruturadas na mente, dialogando com o modo de expressar, onde que lugar pode estar, o que esse pensar descreve? Imagem como corpo de um pensamento, é atravessar caminhos de linguagens e aproximar o que queremos representar das formas de ser da própria vida, que diz enquanto ação que comunica pela maneira que existe, e sentimos, ou seja, pode ser som, textura, ou enfim, as formas que nossos sentidos absorvem de uma possível realidade, onde o que era mesmo que queríamos dizer, retorna ao pensamento, e em conjunto, busca essa mesma vida, para expressar-se. Assim como uma imagem, ainda mesmo como corpo social, estabelece conexões em nosso modo de ser enquanto imagem que temos ou queremos ter de nossas faces, internas ou externas, em conexão ou não com o que do mundo está se inserindo representado, e em voz que não necessariamente espera minha réplica, mas ouço e de alguma forma dialogo, e em algum momento, a COMUNICAÇÃO, pode ser tornar efetiva e capaz de reverberar mais do que um contato imediato, mas de maneira a ter um sentido maior, onde passa a abrigar possibilidades que não fragmentam, uma imagem, mais abrangem, como a dizerem-se campos sobrepostos, ou ramos onde uma nova folha começa em natureza a brotar, e que nas, e das naturezas está pronto a observar. Que imagem trazemos à nós? A escolha. O que queremos ter, entre o nosso ser?

Debord afirma que o espetáculo é uma totalidade, pois representa a sociedade inteira. Tudo: a arte, os partidos políticos, as ciências a vida cotidiana, as paixões, os desejos humanos e qualquer manifestação social fazem parte dessa totalidade espetacular. São Imagens falseadas, pois são produzidas por uma parte da sociedade ( comunicação unilateral ) e submetidas ao consumo de todos ( totalidade social ) que as transformam em comportamento real, consenso, o vivido torna-se imagem da imagem tornada real. O espetáculo é o fetiche " Quando o mundo real se transforma em simples imagens, as simples imagens tornam-se seres reais e motivações eficientes de um comportamento hipnótico. O espetáculo como tendência a fazer ver ( por diferentes mediações especializadas ) o mundo que já não se pode tocar diretamente serve-se da visão como sentido privilegiado da pessoa humana - o que em outras épocas fora o tato, o sentido mais abstrato, e mais sujeito a mistificação, corresponde à abstração generalizada da sociedade atual ( Debord, 199718 ). ( PATIAS, 2006, pg 141). 
Sabe, bem grosseiramente, não sei nada mais concreto, e real, e diretamente ligado a questões de consumo e de mercado, do que viver, ter que pagar contas, e não ter o que comer, creio que isso, é muito real, para muitas pessoas, então não se confunde quando não se tem direito o dinheiro para pagar o aluguel, para alimentar seus filhos, para enfim... isso é de uma concretude e diretamente ligado ao financeiro, que não tem nada de imagem que não se possa crer ou até mesmo ( não se teria escolha ), nada de hipnótico, quando o estomago range, mais que os dentes, então, a realidade tem uma imagem que bate na porta da gente, mas que nem todos veem, principalmente quando não é a IMAGEM QUE OS REPRESENTA. Mas, são inúmeras as lutas de muita gente, e cada um em seu pseudônimo de existir, em partes que se fazem humanas, ou sobre humanas, em viver, nem sempre consciente e em uma hipnose, um outro nome, talvez, porque a dignidade ficou difícil de conceber, porque é realmente árduo crer em uma realidade por onde os caminhos são desiguais, por vezes. Então, o que se concebe, nasce, e fica quase que sem poder respirar ou ter com que se alimentar. Os primeiros segundos, por onde o mundo ou ambiente, irá receber esse indivíduo, que será ou não, uma questão social, abrange ou reconhecerá que imagem? Qual parte desse corpo social está lhe pertencendo. Será melhor, adentrar uma ilusão? Qual delas pode será mais verossímel se a imagem real pode ser tão (i)real de tão inóspita? Mas, não se preocupe, o sol, as estrelas, a noite, estará sempre conosco para nos lembrar que dia a após dia, o mundo, as constelações, ou aquilo que parece tão distante, está bem perto, para nos mostrar, que o tempo passa, ou repassa nossas vidas, entre um amanhecer, e anoitecer, onde a lucidez da razão, pergunta: Por onde estão seus sonhos? Qual imagem de minhas escolhas, que são sonhos de uma vida, eu quero, para aquele que nasceu, ou nascerá ou ainda de mim, ou de minhas gerações, eu possa dizer, que lutem para que a tornem realidade. Qual o limite, e se de fato ,haverá entre uma imagem, e a realidade, que permita um existir, onde a nossa liberdade possa escolher ser, com dignidade e sentimento, até onde não esqueçamos, do porquê de nossos passos, e por onde eles estiveram e o que viram ou desejam ver, como imagem de sua própria vida que como a natureza, nasce sempre, e a cada dia, olha-se, diante de si, como outra imagem, para que continue na terra germinando. A arvore e a semente. A raiz de um pulmão, que há muito tempo, deseja respirar. Mas, não se pode deixar de dizer que apesar do terreno inóspito muitas vezes, se encontra mesmo assim, por onde encontrar uma fresta de ar, quero dizer que sabemos de dificuldades e problemas, até mesmo por antepassados mas, também que com muito empenho, esforço muitas vezes além das capacidades físicas, enfim, com muita vontade se encontra por onde caminhar, por vezes, histórias são páginas de cada um, onde o destino também lê, e escolhe em conjunto por onde 
esse personagem real, irá ter a sua voz, então, os tempos vão se tornando cada um com suas faces, alguns difíceis, por serem tempos de guerra, outros por serem tempos de guerra velada, outros por serem tempos onde o território, ou sua etnia, ou outros ainda preconceitos vigentes, são trincheiras por onde fica difícil atravessar, mas possível ao menos, esperamos nos tempos atuais de sobreviver. O que não poderíamos deixar de dizer, é que existe uma imagem do destino, que é a que você escreve. Imagens à escolha

O ser humano imerso na sociedade do consumo tem sua vida e experiências moldadas pelos espetáculos da cultura e da mídia, e nessa condição deixa de ser sujeito ativo de sua própria história e torna-se refém dos espetáculos consumistas. Os indivíduos se distanciam de suas responsabilidades com a vida real, submergindo no mundo de fantasia, irreal. O espetáculo também é mecanismo de manipulação, servindo de instrumento de pacificação e de despolitização da população. Eugênio Bucci, aponta o processo de transformação da cidadania e bem de consumo: ( PATIAS, 2006, pg143).

O que argumentamos novamente, é não que o acima citado não exista, de fato, porém, é nesse ambiente ser capaz de exercer o direito de protagonizar sua história, sua voz entre o viver, e pertencer ao mundo realizando seu destino.

No que segue, falta um aspecto fundamental, que me parece ser justamente o que é transformador, ou seja, não uma manipulação para um aspecto assistencial que promove uma imagem benéfica à empresa, mas uma consciência mutua, de ambos, consumidor, e os envolvidos de instituições, empresas, etc. $O$ fator consciência, ${ }^{340}$ para mim, faz toda a diferença, tendo em vista, que presume uma atitude que possui em si razões, acima de fatores ilícitos ou que estaria ludibriando benfeitorias.

Os materiais para construção e estabelecimento de uma ideologia são a linguagem e seus recortes práticos, denominados " discursos". Sempre se acreditou que a linguagem refletia uma realidade dada anteriormente e os discursos organizavam os reflexos com a finalidade da comunicação, da compreensão. Porém, na atualidade está cada vez mais claro que a linguagem cria, mais do que reflete, uma realidade. Assim, deixa de ser apenas designativa, e torna-se, principalmente, produtora de realidade. ( PATIAS, 2006, pg 149 ).

\footnotetext{
${ }^{340}$ Sousa, Carina Gonzalez Y. O dilema contemporâneo em meio ao empirismo de existir, Amanajé, contos e reflexões, São Paulo, Inmood, 2017.
} 
Nessa estrutura, o universal e o particular se misturam e o indivíduo perde a capacidade de diferenciar ou criar novos estilos, ou seja, de exercer atributos que são da racionalidade humana. $\mathrm{O}$ que se tem, portanto, é a utilização da racionalidade técnica para produção de efeitos sobre consumidores. Ao mesmo tempo em que valoriza o prazer, a sociedade priva o indivíduo para manter seu desejo permanente. Ao colocar sua esfera de ação no plano privado, a sociedade diminui o raio de atuação do indivíduo, que se reduz à posição de mero consumidor “ [...] De acordo com Barthes, a sociedade vende, a idéia - o mito - de que valoriza o indivíduo, mas de fato não permite a este viver sua individualidade. $\mathrm{O}$ indivíduo já não é um sujeito de sua história, um ser político e criativo, mas mero consumidor. ( SAISI, 2006, pg 162-163).

Uma possibilidade de que em meio a cultura tenhamos a possibilidade de uma obra que expõe a realidade, segundo Benjamim.

Podermos nos perguntar, se na sociedade do espetáculo estamos assistindo ou produzindo o espetáculo, creio que fará uma pequena diferença, que se não levada em conta, resumirá apenas um lado da história.

\begin{abstract}
Baudrillard vai mais longe, em Simulacros e simulação ( 1991 ), atribuindo à publicidade a supremacia das formas de comunicação no mundo atual, especialmente após o evento da informática e das novas tecnologias de comunicação virtual. " $\mathrm{O}$ que estamos a viver é a absorção de todos os modos de expressão virtuais no da publicidade ( Baudrillard, 1991, p 113 ). Para ele, há um triunfo da simulação e do simulacro, com o consequente esvaziamento do sentido, ou seja, a incapacidade de o indivíduo distinguir entre o que é real e o que é falso. A representação torna-se o referente. ( SAISI, 2006, pg171).
\end{abstract}

Baudrillard considera que o distanciamento entre o real e o virtual deixou de existir, havendo interfaces cada vez e mais ainda em paralelos, desafios concretos de quando se tem a imposição de prerrogativas do viver acima de qualquer ilusão.

Diferentemente de Baudrillard, Bourdieu não vê a sociedade de modo fragmentado. Para ele, a sociedade é complexa, com múltiplas dimensões, ou seja com múltiplos campos sociais: político, econômico, cultural, estético, cada um com subdivisões próprias. A sociedade é uma totalidade estruturadas em campos sociais, marcados por conflitos internos, uma vez que os agentes sociais têm diferentes interesses. ( SAISI, 2006, pg 174).

O outro lado da calçada. A espera do olhar, entre ideias e ideais, depoimentos entre a percepção e o surreal, partem com o propósito de colidir, entre a necessidade do que de fato poderá existir entre a razão de uma realidade e uma possível existência, onde o existir, tem autoria própria. Como o existir, pode ter uma autoria própria sendo que então, seria uma 
ilusão? Não se pode esquecer do desmembramento onde realizamos a realidade com os nossos passos, e isso não quer dizer ilusão, mas centralização no que pode e nos faz viver um cotidiano plausível, de ser concreto mediante nossos esforços e realizações, com a responsabilidade inserida efusivamente nos planeamentos de uma geologia de imagens, da leitura do olhar de todos os dias, através do que nos concede por entre o surreal de sermos, viventes atores, protagonistas de nosso próprio espetáculo.

Quem prestará contas, entre verdades e mentiras? Onde sua existência habita? Nas suas escolhas. Resta saber se quem promove manipulações, não ficará no emaranhado dos fios, perdidos de tanto inventar sem saber de fato, o que pode aferir. Quem recebe informações falsas como verdadeiras ou fruto de manipulações, pode e deve se restringir mais, penso a apenas infelizmente absorver o relato, sem detrimento de sua própria cognição, mas realizando e validando a sua própria razão, como modo de encontrar no que seguir, a extração ainda de um possível dizer, se algo for validado como pensamento, caso contrário, relega-lo e deixar que o tempo, demostre onde se encontra a verdade, e se o tempo, não o demostrar, então, me parece não ter relevância, ou dependendo, por outro viés ser examinado e averiguado, como uma auditoria interna, se necessário, dependendo das condutas. A história política, tem muitos documentos, queixas, e fatos negligenciados, alguns procedem outros, nem sequer foram averiguados, assim também podem ser ocorrências em nossas vidas, entre nossas relações ou com a mídia.

Há quem diga que sentir é uma ilusão, ou que a realidade ceifou essa semente, antes mesmo de brotar, lugar sobre tempestade onde o próprio vento, já secou, e nem mesmo goteja a sede por onde a terra, se nutre para nascer. O que haverá então, de ser, a realidade, quando o sentimento não tem lugar? Ou do lugar que haveria, exauriu suas forças entre mentiras reais demais para trazer a verdade do sentir como face humana possível de existir. E, segue então de Vinícius de Moraes, do livro, para viver um grande amor, sobre poesia.

[...] o MATERIAL do poeta é a vida, e só a vida, com tudo que ela tem de sórdido e sublime. Seu instrumento é a palavra. Sua função é a de ser, expressão verbal rítmica ao mundo informe de sensações, sentimentos e pressentimentos dos outros com relação a tudo o que existe ou é passível e existência no mundo mágico da imaginação. Seu único dever é fazê-lo da maneira mais bela, simples e comunicativa possível, do contrário ele nunca será um bom poeta, mas um mero lucubrador de versos. O material do poeta é a vida, dissemos. Por isso me parece que a poesia é a mais humilde das artes. E, como tal, a mais heroína, pois essa circusntância determina que o poeta constitua a lenha preferida para a lareira do alheio, embora o 
que se mostre de saída as visitas seja o quadro em cima dela, ou a escultura do saguão, ou o último long playing em alta-fidelidade, ou a própria casa se ela for de um arquiteto de nome. E eu vou direi o porquê dessa atitude, de vez que não há nisso nenhum mistério, nem qualquer demérito para a poesia. É que a vida é para todos, um fato cotidiano. Ela o é pela dinâmica mesma de suas contradições, pelo equilíbrio mesmo de seus pólos contrários. $\mathrm{O}$ homem não poderia viver sob o sentimento permanente dessas contradições e desses contrários, que procura constantemente esquecer para poder mover a máquina do mundo, da qual é o único criador e obreiro, e para não perder a sua razão de ser dentro de uma natureza em que constituí ao mesmo tempo a nota mais bela e mais desarmônica. Ou melhor: para não perder a razão tout court. Mas para o poeta a vida é eterna. Ele vive no vórtice dessas contradições, no eixo desses contrários. Não viva ele assim, e transformasse-a certamente, dentro de um mundo em carne viva, num jardinista, num floricultor de espécimes que, por mais belos que sejam, pertencem antes a estufas que ao homem que vive nas ruas e nas casas. Isto é, pelo menos para mim. E não é outra a razão pela qual a poesia tem dado a História, dentro do quadro das artes, o maior, de longe o maior números de santos e de mártires. Pois, individualmente, o poeta é, ai dele, um ser em constante busca de absoluto, e socialmente um permanente revoltado. Daí não haver por que estranhar o fato de ser a poesia, para efeitos domésticos, a filha pobre na família das artes, e um elemento de perturbação da ordem dentro da sociedade tal como está constituída. Diz-se que o poeta, é um criador, ou melhor, um estruturador de línguas, e sendo assim, de civilizações. Homero, Virgílio, Dante, Chaucer, Shakespeare, Camões, os poetas anônimos do cantar de Mio Cid vivem à base dessas afirmações. Pode ser. Mas para o burguês comum a poesia, não é coisa que se possa trocar usualmente por dinheiro, pendurar na parede como um quadro, colocar num jardim como escultura, pôr num toca-discos como uma sinfonia, transportar para a tela como um conto, uma novela ou um romance, nem encenar, como um roteiro cinematográfico, um balé ou uma peça de teatro. Modigliani - que se fosse vivo seria multimilionário como Picasso - podia, na época em que morria de fome, trocar um tela por um prato de comida: muitos artistas plásticos o fizeram antes e depois dele. Mas eu acho difícil que um poeta possa jamais conseguir o seu filé em troca de um soneto ou uma balada. Por isso me parece que a maior beleza dessa arte modesta e heroica seja a sua aparente inutilidade. Isso dá ao verdadeiro poeta forças para jamais se comprometer com os donos da vida. Seu único patrão é a própria vida: a vida dos homens e sua longa lita contra a natureza e contra si mesmos para se realizarem em amor e tranquilidade. ( MORAES, 1976, pg 108).

\subsubsection{O desnudar do viver, entre a retórica e a poética.}

Entre o caminho, aprendo. Desejo as palavras narradas na alma, no corpo do viver. ${ }^{341}$

A sedução no desejo da comunicação.

Uma forma da esfinge

${ }^{341}$ Composição realidade $-25-03-2018$. 
Que dizer de onde vim se as palavras tem lugar em seu som que se fazem identidade. Que dizer de onde vim, quando as cortinas estão abrindo a janela e eu fico aqui na coxia.

E nas coxias da alma, meu espírito renasce

Sendo personagem do mundo, atravessando esta passagem

Onde o corpo se veste das vozes do Ser aprendiz.

Em diálogos da compreensão humana

Exalo do pensamento o desejo de me encontrar

Nas formas da vida, a dramaturgia em MAR.)

do outro lado do meu corpo. Essa forma que pode dizer de onde vim, não é somente o som, mas uma imagem que se faz outra palavra, esquecida desse corpo que se representa independente porque se veste do pensar e acredita que dessa forma, o personagem não tem somente uma voz, mas um discurso.

O que do lugar em mutação me transforma?

De nossa história, memorias entre a realidade.... ${ }^{342}$

Pode a saudade não estar somente nos fados, mas além dos retratos, no próprio dia que se constrói ao redor das horas. Os movimentos -

A prova dos nove - $\mathrm{O}$ que da vida avança e se retrai como o mar sendo prova dos nove no que desejamos ainda compreender?

O diálogo possível- Pauta da música, do jornalismo, as notas de um dizer.

Os desejos humanos na formas do existir compartilhados pela presença na sensibilidade da “ sintonia solidária”, lembrando o livro o direito a ternura, de Luís Restrepo. O protagonismo entre espaços ilusórios ou trazendo do imaginário a parcela mais real que se pode acreditar. O embate se trava no momento em que é preciso abandonar o conforto das

\footnotetext{
${ }^{342}$ ANDRADE, Mario de. “ Um fio de lágrima sem nome!” - “Colloque Sentimental”. São Paulo - A força dos imigrantes - Revolução industrial ....
} 
fórmulas engessadas nos manuais jornalísticos e ir ao mundo para viver o presente, as situações sociais e o protagonismo humano ( MEDINA, 2003, .pg. 40.).

Um dado incontestável que registro na trajetória das últimas décadas; a arte de narrar acrescentou sentidos mais sutis à arte de tecer o presente. Uma definição simples é aquela que entende a narrativa como uma das respostas humanas diante do caos. Dotado da capacidade de produzir sentidos, ao narrar o mundo, a Inteligência humana organiza o caos em um cosmos. O que se diz da realidade constitui outra realidade, a simbólica. Sem essa produção cultural - a narrativa - o humano ser não se expressa, não se afirma perante a desorganização e as inviabilidades da vida. Mais do que talento de alguns, poder narrar é uma necessidade vital. ( MEDINA, 2003, pg. 48).

Entre a natureza das coisas e minha natureza o caos de uma origem germina fecundamente em tempo desconhecido o vento, que latente desperta-me em conjunção ao conflito propriamente enunciado do véu justaposto a transparecer uma liberdade. Liberdade não desenfreada posto que o outro é de mim o mesmo ser, e assim os anéis do percurso agem sobre a materialidade do design das cores abertas que contorno em dizer. Se o caos se apresenta-se à algumas linhas, escreveria em branco no palco sobre passos apenas coberto pelo tecido do ar, em movimento do que é parte de seu silêncio.

A contemporaneidade, tal qual as percepções traduzem em narrativas, oferece inúmeros desafios não só ao cidadão nela situado com relativo conforto, como ao que carrega a fardo da marginalização de qualquer origem - social, étnica, cultural ou religiosa. Enunciar um texto que espelhe o dramático presente da história é, a princípio, um exercício doloroso de inserção no tempo da cidadania e da construção de oportunidades democráticas. Ao se dizer, o autor se assina como humano com personalidade, ao desejar contar a história social da atualidade, o jornalista cria uma marca mediadora que articula as histórias fragmentadas, ao traçar a poética intimista, que aflora do seu e do inconsciente dos contemporâneos, o artista conta a história dos desejos. ( MEDINA, 2003, pg 48).

Conto que um dia soa, faz-se miragem do deserto, areias recobertas das histórias do tempo, na clepsidra do remoto destino de todos nós. Aonde possa estar o pensamento, a inserção são águas dispersas como a profundez do que ainda que de olhos abertos permanece emudecido a espera de tuas palavras para se revelar, espera. 
Entrelaçados sem grilhões o meu corpo e o mundo, percorrendo o auscultar da imagem, sobre os desejos, amam. Encontramos no livro: Brassai, conversas com Picasso, um dizer sobre as formas do real.

Entre os escritores realmente filosóficos, passa-se um fenômeno moral, inexplicável, inédito, que a ciência dificilmente pode justificar. É uma espécie de segunda visão que lhes permite adivinhar a verdade em todas as situações possíveis, ou, melhor, ainda, um poder ignorado que os transporta lá onde devem, onde querem estar. Eles inventam a verdade, por analogia, ou veem o objeto a descrever, seja por que o objeto vem ate eles, ou por que eles próprios vão até o objeto. (BRASSAI, 1964, pg 149).

Se posso compreender o ato de abrir meus olhos, encontro nessa forma a volúpia do que se faz desejo, porque perceber o ser que habita no existir, será talvez, a pauta onde revelo minhas frases que almejam os sentidos sonoros do tempo.

Ai de mim, fonte a se conhecer, de atos querendo um caminhar, onde a os traços são cobertos pelas histórias que vejo em cada forma, amanhecendo junto comigo.

E como sem contradita posso fechar meus olhos e então mergulhar no que não é pranto, mas arde em mim, como sentido outro, aberto em despertar noturno.

Algumas palavras são o que percebo, em descrevê-las sou " mulher em cubo “. Impregnada da atmosfera do urbano corpo feito estrutura a erguer diante do que se faz o meu prenúncio. Janela dentro de mim, investiga minha percepção da metáfora do que ensejo. Planos na arquitetura marcados em meu desenho o fio traçado do mundo, que fecunda e gera minha alma no que se fez melodia.

E através sentir, as portas, as janelas até onde possa o horizonte estar. O diálogo. Ouvir e dizer são necessidades da escrita do mundo, onde lemos os sentidos expressos com a sinestesia de reportar a compreensão que é sempre o aprender. Esgoto-me nessas frases porque me debruço sobre o beiral do movimento das cenas desse filme que indago. Em parte, a dor é lasciva, porque infinitamente busca e sendo assim, parte-se no que permanece e no que virá a ser.

Que dizer de mim se agora desperta, ainda, por vezes a neblina enrijece meu suspiro frente ao que, ata-me e deseja seguir. Sugere a alma do universo, nas fraturas como balsamo do caos, que apenas observemos o próprio tracejado para costurar aforismos mais que relatados, saboreados como fome do viver. Onde ainda entre o saudável, o licito, ou não, encontramos 
ainda a busca de um discernimento, onde também, como bem coloca Cremilda Medina, “ ... a crise da percepção coisifica a consciência humana e perturba profundamente as visões de mundo que se presentificam nas narrativas.

E como caos sou partícula, ínfima parcela em difusão dessa profundidade absorta em seu próprio representar, personagem feito dramaturgia dos sentidos nas semioses. Então, a própria transparência exala a necessidade de emergir, na busca de uma possível identidade, mesmo que em diversas vozes, diversas vestes, o teatro recobre-se do próprio infinito, em desejo pleno. ( ato emancipatório ).

Novos sentidos são fractais dispersos pelo vivente que pulsa, e quando percebidos em seu ritmo ecoam em nós seus ecos em significados expandidos. Parto na gema da terra, a lapidar-me em gesto, Sou janela, aberta em fresta, sobre reflexo atravesso, contrapondo-me em paz refugiada. Aspirante do dizer, sempre querendo as palavras, em forma dispersas do amor. Lugares como esculturas são caminhos, e, mesmo que imaginando, a solidão me observa, para que na frente do todo, eu saiba ouvir o silêncio. Depois do silêncio a vastidão torna-se um segundo, e desponta-se, a descoberta. E quanto pergunta: Sedução cúmplice do desejo, O que você quer de mim. Se eu não sei o que fazer sem você. Quando eu não sei o que fazer com você. Amar-me, em sentidos. Sei agora, o teu nome, Sedução. Cúmplice do desejo. Álibi que encontra seu dono. Amor desenfreado e amante. Corpo nú. Amanhã, devora-me. Desenfreadamente o corpo lascivo movimenta-se acariciando-me de encontro ao peito da cidade vasta, é compendio do que em concreto faz-se objeto do meu pensar. Diálogo inalterado nas folhas das memórias, vidas, textos da passagem.

Cidadania latente, engendrada na reportagem dos discursos feitos ao vivo, contemporâneos de mim, enfim, de cada um. Avido corpo cultural, enuncia a estética da comunicação do fato que emerge como a arte de viver. Pertencer e desprender-se na voz do rádio sonoro das ondas do conhecer, em se desnudar. Abro as portas, antes que a lápide tardia remonte a escuridão, para buscar uma silhueta de um possível diário de bordo, após cada dia, em cada maré, águas de uma leitura de mundo, translúcidas em noite de luar, escritas no pensar, cada passo cruzando um cenário das terras do mesmo povo.

Tecer os sentidos contemporâneos num amplo contexto democrático, reconstruir as histórias de vida num cenário das diferenças culturais que se assinam nas múltiplas oraturas e cruzar as carências sociais como gesto generoso dos pesquisadores e dos artesãos de um outro futuro despertam uma sensibilidade altamente complexa e de fina sintonia com o presente. ( MEDINA, 2006, pg. 53.). 
Espaço interdisciplinar do saber, relata diagnóstico sensível no convívio próprias veias em rios de permanente trajetória. Narrados em inquietações permanecem distantes e próximos, como contrações e extensões de movimentos.

Integrados no corpo, ser demasiadamente urbano, traz a Natureza em forma diluída dos sentidos afeiçoados como aroma acariciando a forma, confluindo impasses sobre a o dizer de uma unidade. Desafios tecidos dentre o ontem e o amanhã para resgatar uma força que se torne plena.

\section{O que move é do âmbar do desejo, ileso não pertence a seu tempo, refaz-se com ele anatomia do olhar.}

O tempo presente anseia pelo desejo de ser percebido, engendrado nele mesmo, em mito, fazendo-se em sua história a própria memória a ser representada nas molduras do amanhã. O contemporâneo escreve seus diálogos procurando o campo onde germinara as novas interfaces que ensaiarão um novo modo de ser. Ser que se enfrenta em luta serena dos encontros e desencontros dos novos e velhos paradigmas nas entrevistas cognitivas com as formas de comunicação.

Alquimia de significados vestem-me ainda na sombra do edifício em imersão do interior desvelando escombros exteriores resguardados pelo que não é o somente, posto que a solidão ampara-se na voz do destino que não subjuga mas ampara a vontade que minha pele sente e pelos poros desafia o gesto mudo, para ser lido e retido no coração dos vértices emanados ao redor das conjecturas da liberdade da sensibilidade. Como pássaros alados desprendem-se no voo das mediações.

A incerta vagueza dissemina uma possibilidade complexa, criativa em decifrações de ramos da descoberta. Viagem.

O homem comum, diante da instabilidade da vida, sonha, fabula, cria metáforas em lugar de descrever, com rigor e precisão, os fenômenos conhecidos “ (...) O imaginário dos afetos transcende as lógicas consistentes, enlaça os desprotegidos e dá voz aos sufocados. [...] Do lado da divulgação científica, afirma-se um discurso de rigor, fundamentado basicamente em dois aparatos: o olhar da observação objetivante, aquele que distancia o objeto de conhecimento; e a audição que capta de fora o enunciado na palavra científica das fontes especializadas ou nos registros da bibliografia e banco de dados. Esta narrativa se expressa no mundo da abstração, conceitual, ainda que lide com o mundo vivo e o mundo vivido.[...] Há na narrativa do cotidiano e no resgate que dele faz a arte e outras linguagens não-cientificas, cheiros, gostos e gestos que ampliam a 
palavra conceitual e bem governada de um discurso científico. ( MEDINA, 2003, pg. 59).

A cena viva.

Prazer de encantamento com a vida, laços enunciando os vestígios do desejo que ficou marcado. Desenhos feitos do campo do existir. O cubo-mulher- ser humano, se rende ao espaços vizinhos tecidos e aflorados no estampado das cores desta cidadania que é rede de relações do bios em autopoiese. Paisagens integradas para tecer os personagens em diálogos da fusão familiar em fractais. Estruturas dissipativas das coxias ao texto no palco da vida. $\mathrm{O}$ redemoinho -

Revelada em teu olhar de suprema beleza

Serás da vida infinito som a cobrir-se de melodia

E que posso dizer em obra de mesma natureza.

A não ser, contemplar

Grãos da finitude,

Areias do dizer

Cosmo em plenitude.

Abrindo-se em amanhecer. ${ }^{343}$

Primeiro Ato. Expor o personagem em atos exploratórios da aventura do imaginário viver, é expandir-se em signos, como um poema em cada utopia comprometida com o território sem fronteiras do universo.

Mestiça, sujeito mundo, sou corpo estendido esperado os caminhos da terra, que me desatam nos sonhos repartidos, com a tua voz. A voz da acústica do teatro repleto da interioridade humana, ouvindo a cena da existência.

Recorrências históricas e, mais ainda reafloramentos das camadas profundas da cultura dão aval aos atos humanos no presente. Em contraponto ao que se nomeia como atualização, em complementação ao

\footnotetext{
${ }^{343}$ SOUSA, Carina Gonzalez Y. Amanajé, contos e reflexões. Conto: Sabiá. São Paulo, Inmood, 2017. Composições datadas do dia 21-06-2015.
} 
que se nomeia como atualização, em complementação ao que se apregoa como modernização tecnológica ou econômica, as sociedades se pautam por vários tempos. O tempo que pode ser medido objetivamente pelas máquinas cada vez mais aceleradas não contempla, entre outros, o tempo das subjetividades, o tempo das culturas, o dos mitos. E é nessa trama sutil, subjacente à história, que se tece o tônus de um povo. ( MEDINA, 2003, pg. 68).

Cremilda Medina, descreve que: “A respiração da sociedade reflete os anseios profundos e desenha as identidades “, e ainda também que:

Nas zonas obscuras da intertextualidade coletiva que acontece fora dos limites da consciência, sem as regras da racionalidade, o poeta do momento recolhe sentidos profundos, o recado que vem do íntimo humano ser. [...] A arte, a religiosidade, o mito, ao contrário de representarem a negação do ral concreto, expressam uma comunhão profunda e universalizante com a realidade simbólica do humano. [...] Chamando à discussão outra vez Edgar Morin, ele postula a epistemologia da complexidade para se sair do círculo asfixiante do que é primeiramente ideológico. No âmbito do saber científico se admite, com naturalidade, a complexidade das correntes paradigmáticas, a trajetória de conflitos e a produção inacabada e imperfeita dos significados atribuídos ao mundo. A autoria criativa recebe do gesto e da voz dos saberes cotidianos uma inspiração inestimável que não se circunscreve nas ideologias de grupos nem em um paradigma cientifico absoluto. Tal inspiração desperta a respiração profunda e coletiva que desborda um sentido fragmentado e descortina uma visão de mundo. Pela visão de mundo passam ideologias e paradigmas, mas a inquietude de vida não se acomoda nem na certeza ideológica nem na promessa da razão cientifica. $\mathrm{O}$ poeta sente a inquietude e, por isso, sofre para além das fórmulas garantidas. Não recusa a angústia permanentemente, abre o peito ao grito dos desajustados, parafraseando Nicolau Sevcenko, em sua compreensão de literatura. Seria a visão de mundo dos desajustados o grande repositório da cultura, dos mitos, da invenção de outra História? Não estariam os desajustados transitando nas ruas calçadas e nas ruas de esgoto a céus aberto da cidade contemporânea? Se os poetas colhem a alma encantadora das ruas, como disse João do Rio, será possível um autormediador dos sentidos contemporâneos abrir sua usina técnica, paradigmática, às visões oníricas e encantatórias do cotidiano? ( MEDINA, 2003, pg. 78-80).

\section{Na coragem de existir, pode haver lugar na simplicidade, que é da luta, o próprio} trabalho do existir, sabendo que o seu papel maior, é o da integridade, onde se pode ser a face da dignidade.

E do que vemos do mundo, Picasso diz no livro de Brassai : "E tudo está centrado na fixidez flamejante do olhar que nos atravessa, nos subjuga, nos devora" , e por onde anda as relações do olhar nas conexões sociais, entre imagem, paisagem e fome. 
O diálogo entre sujeitos, quase sempre assimétricos, com meios eficientes favorecidos pela tecnologia contemporânea, parte de práticas profissionais que amadurecem suas gramaticas acadêmicas, mas, acima de tudo, provoca a sensibilidade criativa do contato e do jogo de relações que comunga com os mistérios da arte. "Octavio Paz dizia que só a poesia é capaz do ato de comunhão entre os sujeitos. Se o comunicador social não invocar a poética, estará persistindo nos equívocos, do signo da divulgação, unidirecional, autoritário. Nenhum projeto de comunicação que se pretenda inovador, digno das expectativas da transformação social, pode se eximir da condição de um oficina de experimental. $\mathrm{O}$ eixo de tal prática consiste na linguagem dialógica e na criação de narrativas democráticas a sérico da cidadania. ( MEDINA, 2003, pg. 99).

E, lembrando do poeta do cotidiano, Carlos Drummond de Andrade - agradeço à ele, por ser poeta. O silêncio me penetra ao revelar, o som perdido de teu olhar, que somente encontro, nas palavras que em ti, são mar.

\begin{abstract}
A rigor, não são dois mundos à parte - o dos cientistas e o dos poetas. Ambos se caracterizam pelas dúvidas, incertezas, pela necessidade de compreender o universo que a todos contém. A arte se lança ao voo emancipatório, afunda sem pejo no inconsciente, desfruta da farra criativa como alforria da história presente. A ciência percorre um caminho semelhante de riscos e ousadia, de trabalho disciplinado pelo rigor racional e ensaia conscientizar algumas compreensões possíveis do mundo humano, biológico e natural. Neste âmbito, são tênues as fronteiras entre o conhecimento científico inovador e a intuição artística reveladora. ( MEDINA, 2003,pg. 112).
\end{abstract}

De fato, as estruturas orgânicas do cotidiano se fazem sentir como ritmo, movimento, espaços coreografados pelo tempo do existir, e conforme Medina, " Por toda parte, demandas coletivas carecem de autores capazes de relacionar as informações, os comportamentos e valores, transformando esse caos indecifrável em um cosmo narrativo que expresse a sinestesia da aventura humana. "

\title{
3.2. Deslocamentos da edificação de significados
}

Paradigmas da imagem real, sobre as luzes apagadas do asfalto, aspectos pertinentes a acontecimentos recentes em torno de manifestações sociais que geraram indagações sobre um viés comunicativo da imagem social e contemporânea e seus alcances que reverberam na representação do tempo atual. Ponderamos incógnitas presentes sobre o quanto que o virtual, realidade e a ficção estão engendrados no cotidiano como faces do que pode ser considerado 
pós-humano e aonde se engendra a capacidade de valores capazes de participarem como o real desenvolvimento do viver.

A Narrativa contemporânea, tem imagens que antes acreditávamos somente concebidas na ficção se apresentando inseridas no cotidiano, o que é dubio, como faces de Jano de Arthur Kostler, porque de fato, o que é da arte se apresenta na vida e o que é da vida exerce seu papel na dramaturgia do corpo artístico, faces de uma unidade que porém, com as aproximações geradas pelas novas tecnologias, no imediato do tempo real onde as informações são transformadas de seu meio habitual para uma contemporaneidade onde assumem papeis móveis no ato nele mesmo ainda que a notícia registrada in loco, na concretude do mecanismo de uma alquimia estrutural adjacentes, ou seja, o acontecimento gerando registros de fonte e observador em uníssono. Iniciamos esta reflexão sobre, que imagens estamos gerando nesse mundo que serão apreendidas pelas gerações e as próprias narrativas sociais futuras?

Investigo e entrevisto meu próprio conceber enquanto intrínseco ao corpo urbano, tecido de meu próprio viver, onde a pele exposta questiona sobre como posso permanecer em cena viva exaurindo monólogos quando se faz necessário um concreto roteiro nascido do cotidiano que eclode nas frases das mazelas ainda viventes.

A comunicação ocorre na interação que possibilita a interface de todos os sentidos, portanto, é uma inter-mediação, que é um conceito para pensar a hibridização das linguagens e dos meios. Essa é a situação que marca a sociedade contemporânea que, com sua "mutação tecnológica passou a configurar um novo ecossistema comunicativo. (MARTIN-BARBERO, 2010: 222, apud MEDINA, 2014).”

Passamos, como visto nos capítulos anteriores, a nos perguntar em uma indagação diagramática, que permite a hipótese de se relacionar tanto o que é da esfera da Arte e Ficção e o que é Real sendo Virtual ${ }^{344}$, sobre quais caminhos travamos de ficção ao nos expormos com agentes de relatos vivenciados e ao mesmo tempo, que realidade da Arte como existência posso conceber no virtual, tendo como propósito justamente uma narrativa que integra um pensamento expositivo do próprio viver? Ainda poderei conhecer um

\footnotetext{
${ }^{344}$ Virtual no presente texto sendo apontado como um espaço em que a realidade se processa de outra forma porém diagnosticada como adjacente, ou seja, parte integrante como uma extensão do viver cotidiano. Considerando o território colocado como cibercultura ( $P$. Levy )ou ainda também, ciberespaço ( Gybson ), , porém, para também um espaço análogo que se estabelece no diálogo mente, pensar que não se estabelece como abstração, mas como uma vida enquanto possibilidade.
} 
manuscrito onde as mãos se permitem escrever, uma sinestesia de sentidos em corpo integrado, onde queremos ouvir sobre quais vozes dos diálogos viventes podem nos indagar antes mesmo de nossa entrevista? O que pulsa no orgânico planeta, que nos propicia ser o mesmo sujeito-mundo escrevendo em palavras-ato seu cotidiano, para que a razão da notícia, ecloda antes mesmo da busca jornalística, e esteja retratada a olhos nus nas formas da imagem-texto do tempo vigente? $\mathrm{O}$ ato jornalístico exerce seu papel como narrativa na dramaturgia na própria existência, ecoando para que possamos ser a voz que dialoga, que ouve e impulsiona intersecções de confluências de sentido arguindo de nós e o outro, o plural, ( Medina, 2014 ) diagnostico da passagem onde esse limiar se permite adentrar um horizonte ainda que estejamos mirando as pegadas. $\mathrm{Na}$ voz da imagem no corpo sonoro social, o design de um ato comunicacional no cerne social, atualmente nos direciona a conjecturas que se fazem dentro de uma complexidade como a própria realidade, que insere em nós um pacto de apreensão, do que como atores sociais nos dispomos em grande parte também como participantes de uma conduta jornalística ao nos apresentarmos ávidos em relatar, investigar, divulgar, informar acontecimentos que estão a nossa volta e que ao serem inseridos em redes sociais, ou qualquer outra forma de ação tecnológica, possuem uma forma de engajamento na imagem-texto-corpo densamente sugadas e permeadas pra o confronto do âmbito do real compositivo e virtual extensivo, em paralelos de cognição.

Será preciso relembrar, mais uma vez, Mário de Andrade, no colóquio sentimental, em um fio de lágrima sem nome, mostrando a imagem no através dos fatos, palavras sem tempo porque retornam como marés, personagens anônimos na carne da identidade do cotidiano que vociferam para ter face, discurso e movimento. Na dramaturgia do viver, buscamos em tempos virtuais, como colocado em a Arte de tecer o presente de Cremilda Medina, “o protagonismo humano".

A contemporaneidade, tal qual as percepções traduzem em narrativas, oferece inúmeros desafios não só ao cidadão nela situado com relativo conforto, como ao que carrega a fardo da marginalização de qualquer origem - social, étnica, cultural ou religiosa. Enunciar um texto que espelhe o dramático presente da história é, a princípio, um exercício doloroso de inserção no tempo da cidadania e da construção de oportunidades democráticas. Ao se dizer, o autor se assina como humano com personalidade, ao desejar contar a história social da atualidade, o jornalista cria uma marca mediadora que articula as histórias fragmentadas, ao traçar a poética intimista, que aflora do seu e do inconsciente dos contemporâneos, o artista conta a história dos desejos. ( MEDINA, 1973, p. $48)$. 
A cidade que pulsa, Entre as caixas acústicas, minhas vísceras que não podem se ausentar de meu ser que está cotidianamente me dizendo as narrativas que se apresentam no viver e que de mim retorna em eco nas marcas desenhadas no traçado do caminho de existir. Permaneço de braços estendidos em meu corpo social no oceano que me banha e dessa forma espero ver um novo e velho horizonte que permanece a se entrelaçar, buscando dizer. O som do cotidiano em manifesto.

Encontro no som do cotidiano o manifesto a gritar, que permanece mudo aos olhos do mundo e dele que queremos dizer. Na escassez da vida somos testemunhos operantes, que buscam qual é a identidade do cotidiano que se manifesta a cada dia, a cada segundo e na ingratidão do tempo, se lamenta cada vez mais, esperando outro amanhecer. É necessário, manifestarmos auscultando o som dessas feridas e narrar uma possibilidade do sentir.

O que contorna esse território que deseja levantar-se também margeia o significado desse discurso. Ao atravessar em direção a Paulista, perpasso meu próprio pensamento resgatando cada vez mais experiências vividas no passado em um campo de uma cena viva das dificuldades humanas, tornando-se nesse ato, presente corporificado. Justapostos estão em cada passo, os sentidos aguçados, fontes que ardem por ser uma erupção de compreensão dos acontecimentos. Pergunto-me sobre meu ser político, de que maneira ele existe em meu cotidiano, e de que forma o urbano se manifesta em atos sociais nos diálogos desse ser, onde podem tomar corpo injurias, indignações que despontam nesse caminhar interno, antes da exposição externa inferir em fluxo de mão dupla, uma reflexão.

O tempo da fotografia, o fato e a representação, de realidades - e de ficções Através da fotografia dialogamos com o passado, somos os interlocutores das memórias silenciosas que elas mantêm em suspensão. O fato se dilui. Sobre o que se passou, têm-se apenas recordações embaçadas, fatos efêmeros de uma realidade em marcha, que se desvanecem, diluem-se nas suas próprias ocorrências. Em relação à fotografia é o instante da gênese: tempo da criação, primeira realidade. $O$ registro, preserva, ou uma ideia dele: tempo da representação, segunda realidade. O efêmero e o perpétuo. Todavia, o documento fotográfico também tem seu tempo de vida, sua duração, não importando a tecnologia de registro que o caracteriza. "( KOSSOY, 2007, p. 20

Assumo o papel de capturar imagens e seus discursos, falanges assoladas em mudo som. Há uma certa coexistência nesse ambiente, co-habita uma efervescência que prenuncia o que está agendado para ocorrer, e o que ocorre como uma antecipação ao espetáculo, porém, estou em ambos os lugares, o da plateia, e na dramaturgia, como propriamente a diluição de 
fronteiras que vivemos, em notícias em tempo real, dispostas pelos agentes naturais viventes da mesma, expostas nas redes sem dicotomia de espaços.

\begin{abstract}
Ora, se comunicação, é, acima de tudo, interação, ou o processo pela qual ideias e sentimento se transmitem de indivíduo para indivíduo, estabelecendo a dinâmica social, e se a opinião pública resulta desse processo como um efeito de participação dos indivíduos da sociedade, claro que está no papel de decodificador enquanto interprete e influenciador de opiniões, é que vai determinar o gênero da manifestação de todo o conjunto,( CORREA, 1988, p.21).
\end{abstract}

Facetas históricas mostram seu rosto. Outras dores de um povo, sempre desejando curar-se em uma liberdade de uma possível democracia, fico completamente imóvel ao ser representado em gesto, vestígios de um litígio orgânico ainda mostrando suas lembranças nos relatos do processo talvez nunca arquivado em totalidade. Como resgates de frases equacionarias de reinvindicações continuo entre um pesar passados e os primeiros passos no cotidiano. Deparamo-nos por vezes em reinvindicações com a força policial, e entre os espaços sociais, o que poderá da ocorrência , acontecer como um dia depois, melhor, e assim por diante.

O que o tempo poderia me dizer enquanto necessidade social? Haveria necessidade dessa força ou uma força em medida, capaz de um empenho de um terceiro setor vigente e participante como haveria de me lembrar durante o percurso. São tão distantes essas forças enquanto observação do que é emergencial? Um vislumbre de lucidez me impele a concatenar pensamentos, sobre que paz realmente, buscamos. E assim ato-me a meus pés, por onde piso, nessa calçada que caminho.

Uma cidade grande, ou qualquer espaço-tempo, do viver, ainda coberta por tristezas, desmatada, arrancada de suas raízes humanas, onde o trânsito é lento e a cobiça por vezes intrepidamente veloz e voraz. Os passos largos atipicamente refugiados onde o ritmo é desfeito de seu cotidiano, alteram o domingo, e me reporto imediatamente ao dia seguinte, onde nesse mesmo lugar estariam os olhares dispersos, engolidos na grande arquitetura urbana, a escolha e a espera de que sobre o mito de Ericsiton, apesar, se satisfaça em ser o apenas, ontem. Inevitável pensar se essa fome democrática insaciável permanecerá ativa, ante a fome dos mesmos esquecidos e sentados a mesa do palco. A dor da fome, consome os indivíduos que são o mesmo tecido a cobrir a nação, dizendo quais são as leis que 
deveriam proteger os seus direitos. Mas, além onde eles encontram o que procuram no desespero do sofrer.

Como podemos julgar o desespero, se nele se fazem caverna todos os ecos atrozes da dificuldade sensível, no que exaspera sendo incompreensão, perda, na calçada da voz urbana ( humana ), em época do pós-humano ${ }^{345}$ ? E ainda me pergunto, quando saberemos o que é o humano.

Frances Hesselbein no livro a comunidade do futuro aponta em suas relfexões que,

Contra as realidades de nossos tempos, está claro que o sonho permanecerá um sonho até que nos desloquemos para além das barreiras que construímos, consciente ou inconscientemente, em torno de raças, sexo, igual acesso e composiçao de força de trabalho. As velhas respostas não serem mais para as novas perguntas e os novos desafios...[...] $\mathrm{O}$ dia da parceria está pairando sobre nós, e essas novas parcerias podem se tornar o motor que impulsiona a renovação da comunidade ". ( HESSELBEIN, 2001, p. 180 ).

Esperamos que de fato, mais que a expansão das comunidades virtuais estejamos atentos as comunidades de todos os indivíduos que conjugam uma narrativa viva e real. Narrativa como linguagem, interposta entre os sentidos, compondo imagens, como gestos da voz dos acontecimentos em busca das metáforas, em busca das percepções que possam despertar para um verdadeiro sentido da realidade, ainda que visível pela literatura das palavras do mundo, revela um ambiente em descoberta. Estaremos dispostos a enfrentar um ponto de mutação ( Capra, 1982 ) que nos insira em uma complexidade ( Morin, 2010 ) onde os diagramas permaneçam em contínuo e expansão? A diluição de fronteiras tão própria dos tempos atuais, não favorece um comportamento que integre novas formas de pensar e conhecer o mundo? O desafio de realizar interseções e transparências nos revela outros de nós mesmos em subconjuntos de uma geometria que realiza formas em constructo à conjunção da observação de fractais, o que desenvolve uma nova organização do corpo movente social em aprendizado do existir. Portanto, propomos uma reflexão sobre a natureza do cotidiano em seu tempo Cronos e Kairos, desejando caminhar por uma saga

\footnotetext{
${ }^{345}$ Pós-humano - O termo se refere como apontado pela pesquisadora Profa. Lúcia Santaella, no artigo, Póshumano, porquê? In Revista Usp, p. 129, "O senso comum que as une encontra-se no hibridismo do humano com algo maquínico-informático, que estende o humano para além de si. Assim, a condição pós-humana diz respeito à natureza da virtualidade, genética, vida inorgânica, ciborgues, inteligência distribuída, incorporando biologia, engenharia e sistemas de informação, e segundo Dyens (2001, pp. 2-3), nossos corpos são agora feitos de máquinas, imagens e informações."
} 
mitológica que se faça real em compreensão, para tentar encontrar as chaves do enigma de um mundo em criação, onde a resposta permanece incognoscível, mas presente nos grãos de areia da nossa alma, capaz de ser na imensidão do horizonte um oceano em prado natural.

Que dados culturais ( Manovich. 2016 ), compartilhamos, ou analogamente, jogamos, para diagnosticar a rede de informações, nos valores virtualmente sociais que dispomos abertamente na vitrine do museu em tempo real? Chamando os recentes artefatos tecnológicos de nossas cavernas atuais, me pergunto quais são os desenhos-designs que deixaremos como marcas, em duplo sentido, como sulco da vida fincado no tempo, registrando os desenhos de nossas condutas, e marcas como o registro de consumo do próprio tempo vigente. Esferas representativas do indivíduo e do âmbito geral estariam refazendo-se sobre o campo tecnológico? Como entre intersecções do aspecto virtual estariam sendo instrumentos da arena tecnológica, o engendramento das ações participativas ou de manipulação do corpo social e as condutas frente a escolhas do rumo de um porvir? Entre o registro da descoberta da fotografia, resgatamos no contemporâneo, a imagem real capturada na voz virtual, em tempo de pós-humano, trazendo o efêmero como percepção in time que necessariamente eclode como face da informação que reverbera e que se estende. Estaríamos na viagem do desconhecido ingerindo o consumo de nós mesmos sem atermos ao cuidado de não ter uma indigestão? Caberia ao desenvolvimento o discernimento da escolha de inseridos nos instrumentos tecnológicos o que fazer com essa conduta, ou seja, ativar os moldes do que queremos lapidar nas estruturas cotidianas para um horizonte que mostre a imagem da nossa história de um lugar para onde desejamos caminhar.

Como lidar com essa mobilidade tão expansiva, que mostrou desde, a era fotográfica, compondo uma era de uma máquina que é extensão do mundo visível, lidando também, com a captura do mundo visível pelo mundo digital na era pós-fotográfica, tornando a existência de todo e qualquer ambiente uma geração de sentidos entrelaçados atuando nas capacidades de todo ser vivente em percepções de imagens atuantes como forma de comunicação e ação é um desafio atual e pulsante. Certas questões que pareciam somente ser da face do imaginário mundo da ficção passaram a ser da imagem do tempo vigente, mas o preocupante é o que todavia das cenas cotidianas não deveriam mais estar sendo encenadas no cerne do palco do mundo, vestidas em dor, isolamento, refugiados, fome, e outras tantas mazelas, quando então eu me pergunto, sobre, como engendrar-me na rede de sentidos que se esfacelam perante a complexidade tecnológica para despertar em uma cartografia que insira as problemáticas em vias de caminhos de soluções aos desafios dos existentes estejam eles 
sobre qualquer era, ou forma de viver, abrindo para meios de transformar o tempo, em espaço sem sofrimento, onde as extensões estejam também como sendo dispositivos de ações que movem o universo a fim de que todos habitem um mundo mais humano ainda que pós humano, ou qualquer outro pós que possa advir a nossa continuidade, mas sendo nele mesmo em continuidade um estado de desenvolvimento admirável que possa ter uma identidade fraternal-vir, como face do humano-devir,

Sem julgamentos, ou facetas apocalípticas, mas com enfrentamento de responsabilidade e conivente com um discernimento, acercamos da possibilidade da imagem tecnológica no corpo cotidiano sendo justamente o acorde que soa como despertar para ações coniventes com o que irá indubitavelmente existir e assim sendo, significando escolhas que promovam não somente avanços incógnitos, mas um caminho que promova um desenvolvimento com ao menos preocupação de uma sustentabilidade sócio-cultural da imagem do que estamos e vamos viver, e dessa forma, habitaremos a esfera individual e geral, porque a ética estará engendrada em uma ética, capaz de lapidar essa face, que antes do Face, ilustrará o book escrito pelo caminho, das imagens transcrito sem dicotomias, mas que assumem a responsabilidade do erro ( da história da humanidade ) capaz de ser aprendizado que se insere no pensamento como gesto de um sentimento de uma comunidade do futuro, construído e erguido hoje em resgate dos naufrágios naturais de tempos remotos ainda colhendo as vestes passadas nas águas das lágrimas que apesar de tragédias existentes exercem o direito de percorrer outra dramaturgia, minimizada e representada quem sabe, por um conhecimento que seja manifestado nas ruas de conexões das travessias de uma conjunção tecnológica natural do que simplesmente vivemos.

Cidadania latente, engendrada na reportagem dos discursos feitos ao vivo, contemporâneos de mim, enfim, de cada um. Avido corpo cultural, enuncia a estética da comunicação do fato que emerge como a arte de viver. Pertencer e desprender-se na voz do rádio sonoro das ondas do conhecer, em se desnudar. Abro as portas, antes que a lápide tardia remonte a escuridão, para buscar uma silhueta de um possível diário de bordo, após cada dia, em cada maré, águas de uma leitura de mundo, translúcidas em noite de luar, escritas no pensar, cada passo cruzando um cenário das terras do mesmo povo.

Tecer os sentidos contemporâneos num amplo contexto democrático, reconstruir as histórias de vida num cenário das diferenças culturais que se assinam nas múltiplas oraturas e cruzar as carências sociais como gesto generoso dos pesquisadores e dos artesãos de um outro futuro despertam 
uma sensibilidade altamente complexa e de fina sintonia com o presente". ( MEDINA, 1973, p. 53 )"

Desafios tecidos dentre o ontem e o amanhã para resgatar uma força que se torne plena. $\mathrm{O}$ que move é do âmbar do desejo, ileso não pertence a seu tempo, refaz-se com ele anatomia do olhar. O tempo presente anseia pelo desejo de ser percebido, engendrado nele mesmo, em mito, fazendo-se em sua história a própria memória a ser representada nas molduras do amanhã. O contemporâneo escreve seus diálogos procurando o campo onde germinara as novas interfaces que ensaiarão um novo modo de ser. Ser que se enfrenta em luta serena dos encontros e desencontros dos novos e velhos paradigmas nas entrevistas cognitivas com as formas de comunicação.

Alquimia de significados vestem-me ainda na sombra do edifício em imersão do interior desvelando escombros exteriores resguardados pelo que não é o somente, posto que a solidão ampara-se na voz do destino que não subjuga mas ampara a vontade que minha pele sente e pelos poros desafia o gesto mudo, para ser lido e retido no coração dos vértices emanados ao redor das conjecturas da liberdade da sensibilidade. Como pássaros alados ${ }^{346}$ desprendem-se no voo das mediações. A incerta vagueza dissemina uma possibilidade complexa, criativa em decifrações de ramos da descoberta.

3.3. - A poética do sensível uma face do conhecer.

Alquimia de sentido. Um caminho do sensível se encontra como um lugar para se estar entre a busca de uma compreensão estabelecida dentre a cognição permeada do que é arte, havendo de ter como propriamente linguagem o sentido que é capaz de despertar um modo de conhecer o existir sobre espaços concebidos dentre o que nos faz querer ser melhor, como participes de um argumento que se estabelece como melodia no que se refere a composição de nossos atos, agindo em valores que se assemelham a presença do sentimento, comunicando por nem sempre o que está como referência imediata, mas desenvolvendo-se por estar no que se amalgama ao tempo de maneira a sentir a parcela de um infinito que ao

\footnotetext{
${ }^{346}$ Composição Um sonho e um coração. ACNUR. Composição Canto de Louvor. Composição : Asas do Céu sonho de liberdade -entre almas. Composição Voar- Para uma mão.
} 
instante se prolongar, respira conosco, trazendo informação do que somente pode ser aferido estando sobre o olhar que pausa ainda que em movimento. Seja talvez o lugar onde a razão busca na determinação a vagueza de um estado propiciado pelo que nos confere uma outra proposição como diálogo, parecendo monólogo do pensamento, extrai da própria razão, a percepção mais interna que poderá haver dentre os aspectos que podem ser negligenciados em cotidiano, ou não observados, e mesmo ainda que sendo, estejam sobre o que pode estar sobre a razão como o que lhe confere um fator que poderá discernir em conjunto um pensamento para a conduta, proveniente que seja de uma lógica e ética inseridas em conformidade.

O sensível despontou em nosso pensamento pelas asas da própria Arte, olhando o mundo querendo ouvi-la, dessa forma se formaram ecos que encontraram a si mesmos em origens de um estado, sob a forma de um gênese, assim, recorreremos para este princípio de sentimento muito do que Schopenhauer, Schelling e Plotino nos legaram, e que muito antes pode ser encontrado como dissemos naquela estética nua, que prenuncia sua plenitude com Deus. Nasce, a arte, fez-se mundo, e ela torna-se voz pelo som do cosmo, diz querer ser água, sendo torrente de força a mover-se na dança do silêncio dos mares, e marés, dos riachos e lágrimas, que poderão secar frente a deserto de destinos, mais ela antes quer se elemento, sendo fonte, agua como origem, nascente nascendo, fazendo-se desenho fluido, compondo um corpo transparente, como a seiva das árvores que a fazem viva, e, invisível na aparência, torna-se escultura, água se corporificando, se edificando, abraçando a atmosfera antes de se fazer vento, mais ainda água, liquefazendo-se para ser fresta, entre todas as formas, nascendo de si, no mesmo tempo que desliza, desenha, contorna, e se mistura as cores, feito reflexo das galáxias [...]Abandonar o modo comum de examinar as coisas, é tornar-se poeta, é ver com um sentir, uma sinestesia própria que independe de órgãos sensórios correspondentes, mas que se descobrem alheios a uma "materialidade" que pode ser relativa a um senso físico, e o que ocorre por uma correspondência ao pensamento é permitir uma mutação de significados que encontram novos sentidos e refazem seu caminho aos olhos do sensível. Desligar-se como individuo, é um não ser, para ser a própria essência do sensível, em co-naturalidade perdendo-se em uma vagueza que justamente encontra o espírito da totalidade. Como se não existisse, poderemos dizer, nem o bailarino, nem a dança, apenas um movimento onde, o próprio mover-se é dialogar com o universo, poetizando o ritmo, dizendo com o corpo os gestos da alma. O corpo, respirando a coreografia do espaço esculpindo o movimento com os sentidos da emoção encontrando os rumos da criação, passo por passo sendo instrumento de Deus, a tocar suas notas mais tênues e belas. Acordes banhando o tecido desse corpo, recompondo e compondo uma arquitetura do espaço. Abraçando o pensamento, erguendo-se até as palavras, fazendo frases em forma de coreografia, onde se toca os gestos desenhando. ( SOUSA, 2017, pg 91).

Porém, dentre o modo de olhar o mundo, cada indivíduo, tem sua postura ou um certo ritmo em que está habituado a se encontrar como pertença, e a perspectiva sensível, deverá saber 
que possivelmente terá uma interlocução que pode até não entender uma forma de buscar a compreensão, que não seja, diretamente uma correspondência literal. Preservando estados cognitivos que ressoam em lógicas e ritmos diferentes, também se aproxima do que vivemos quanto a multiculturalidades, estas bem próximas de lidar com pontos de vista diferentes que desejam se encontrar. E, mais uma vez tem-se o modo de ser da música como ensinamento, tanto para o que poderemos ver em várias frases melódicas, em pauta, permanecendo um estado harmônico, assim como uma imagem que se cria sobre o espírito de cada um, recolhendo para si, da realidade, a sua própria face de diálogo de sentido.

Trazer da consciência maior, o sensível em práticas vigentes, são o corpo vivo de uma natureza do existir. Para um futuro no qual queremos que sejam concretas medidas que promovam na realidade um viver integro, digno de condições onde as gerações estejam amparadas por condutas de alicerces plenos de direitos respeitados, como a paz, a justiça, e a vida.

\section{Comunicação translúcida}

Espaços sociais, onde a imagem que temos, e percorremos diariamente discorre sobre a interface de tempos remotos e atuais, e no decorrer vigente cada vez mais, estaremos sobre escolhas que estarão sobre a transparência do pensamento e conduta. Alicerces não serão somente fatos, mas as causas e as consequências, porque vivemos em uma comunicação que se estabelece por entre, e engendrada como corpo e alma.

4.1. Adjacências e transparências, gerando a experiência.

Se não me vês, procura ainda se ouves a minha voz.

OFIM .O meio e o desejo.

O TEMPO. Infinito querer seja

Até que o tempo não pereça

Frente a seus ideais 
Quando então, o desejo sucumba

Ou the queira ainda mais.

A SOCIEDADE - personagem principal

A procura de suas partes

Do meio - o desejo.

Qual o fim da sociedade? Uma integridade digna de se viver. Entre o verbo e o (s)om

Ouça

Não terá o conhecimento desse bem, então, grande influência sobre a nossa vida? Não alcançaremos, como arqueiros que visam a um alvo certo ( o que chamas-te de target), com mais facilidade aquilo que nos é mais conveniente? [...] "Se assim é, cumpre-nos tentar determinar, mesmo que apenas em linhas gerais, o que seja esse bem e de que ciências ou faculdades ele é o objeto. E, ao que parece, ele é objeto da ciência mais prestigiosa e que prevalece sobre tudo. Ora, parece que esta é a ciência política, pois ela que determina quais as ciências que devem ser estudadas em uma cidade - Estado, quais as que cada cidadão deve aprender, e até que ponto se incluem entre elas, como a estratégia, a economia e a retórica. Visto que a ciência política utiliza as demais ciências, e ainda, legisla sobre o que devemos fazer e sobre o que devemos nos abster, a finalidade dessa ciência deve necessariamente abranger a finalidade das outras, de maneira que essa finalidade deverás ser o bem humano. ( ARISTOTELES, pg 17

Responsabilidade de ordem social - não quer dizer ditaduras.

Ainda que esse fim seja o mesmo para o indivíduo e para a cidade-Estado, o fim desta última parece ser algo maior e mais completo, seja a atingir, seja a preservar, e embora seja desejável atingir esse fim para um indivíduo só, é mais nobre e mais divino alcança-lo para uma nação ou para as cidades-Estados. Sendo esses os fins da nossa investigação, esta pertence, portanto, à ciência política em uma das acepções do termo.[...] Cada homem julga bem as coisas que conhece, e desses assuntos ele é bom juiz. Assim, o homem instruído respeito de um assunto é bom juiz em geral. ARISTOTELES, pg 3)

Todo que julga pelo que conhece, todavia, não julga completamente, e de maneira em razão de discernimento, posto que para tal, presume-se a meu ver, o que desconhecemos e devemos ouvir e aprender para com o que sabemos, julgar, ou avaliar, avaliar, sendo aqui, diferente do que é sob julgamento. Me parece cada vez mais, como aprendi, que o quanto 
desconhecemos, provem um caminho de maior observação, atentos ao que precisamos ainda “ desbravar" das terras de um saber. Percebemos que quando acreditamos que podemos julgar bem porque conhecemos, fato em parte procede, porém, e em grande parte até necessário, mais o alargamento da observação por caminhos antes não percebidos, como tanto digo, pode acrescentar e considerar aspectos que passaram com o aprendizado a serem valorizados e tornar cabível um outro olhar sobre o mesmo.

Sirvam, pois, como instrução, estas observações a respeito das pessoas que devem estudar esses assuntos, a espécie de tratamento a ser esperado e o objetivo da investigação. [...] " Retomando a nossa investigação, tendo em vista o fato de que todo conhecimento e todo trabalho visa a algum bem, procuremos determinar o que consideremos ser os objetivos da ciência política e o mais alto de todos os bens que se podem alcançar pela ação. Em palavras, quase todos estão de acordo, pois tanto o vulgo como os homens de cultura superior dizem que esse bem supremo é a felicidade e consideram que o bem viver e o bem agir equivalem a ser feliz, porém, divergem a respeito do que seja a felicidade, e o vulgo não sustenta a mesma opinião dos sábios. A maioria das pessoas pensa que se trata de alguma coisa simples e obvia, como o prazer, a riqueza ou as honras, embora também discordem entre si, e muitas vezes o mesmo homem a identifica com diferentes coisas dependendo das circunstâncias: com a saúde quando está doente, e com a riqueza quando é pobre. ( ARISTÓTELES, pg 20).

Platão: "Estamos no caminho que parte dos primeiros princípios ou no que se dirige a eles?

E, Platão, me diga: No que difere o ponto e a perspectiva do espaço e tempo, quando um se torna a razão do outro. Faz muito tempo que eu aprendi, algo que dizia sobre o estar contido, e quando li a frase, no que se dirige a ele, ( ao princípio ), me pareceu completamente o sentido de estar contido, então, vamos, por onde o princípio nos guia, ou seja, contido nele estaremos para encontrar o destino. Origem e destino.

Em cada tempo, o tempo de nós. Desatados por histórias da vida. E acreditamos saber do que aconteceu.... hoje, pergunto... quanto dos fatos, são reais? Teremos sinais para saber a verdade?

Vida contemplativa - soa familiar, em tempos em que avançamos muito em uma intenção de " qualidade de vida", afinal nos últimos anos, consideravelmente os recursos tecnológicos possibilitaram enormemente avanços em larga escala que cada vez mais, terão alcance para todos na população tanto para valores informacionais, conhecimento e positivamente de bem-estar. Dignidade é um valor que concede ao homem, em grande parte uma decência poucas vezes alcançada em tempos conturbados da sociedade vista como um todo em geral, 
humanidade. Mas, creditamos que a honra, ela é uma conquista de força do bem e justiça, não somente de um indivíduo, mas concedida a todos os que caminhem com lealdade, perseverança, e firme propósito no BEM MAIOR.

Valores contemporâneos colocados como bens, são faces de uma moral concedida como o bem em instância geral, que pode abarcar fragmentos postos como face unívoca.

Conhecer os bens que são bons para nós? Entre passagens da vida cotidiana, o mesmo caminho pode ser feito, todos os dias, onde o homem, se compreenda em sua capacidade de realizar-se como ser existente, e dentre o caminho, a paisagem se estende, sobre o significado de observar por onde o olhar caminha, entre corpo e alma, e razão e sentimento, esquadro e compasso, em movimento, da vida como ela pode ser, entre o que é, e como a tornamos. Então em uma sociedade de consumo, os bens estão distribuídos na paisagem como cenas onde também somos protagonistas, em ação contínua, de nos conhecer e compreender o mundo que nos cerca. Como adquiri-los poderemos desejar, e então, possivelmente em outro lugar, estendido no tempo, ou entre o presente e o futuro, encontremos o nosso lugar ao sol. E, se questionarmos, a origem do universo, e desviarmos a rota de nosso pensamento, talvez compreendamos, o quão nada somos, mas o quão do que somos nos torna, parte do criador. E assim sendo, nascemos com o mundo, a cada pulso de vida nosso. E isto representa, nossa face distribuída no tempo, onde o momento, é também, eternidade, o que nos faz, múltiplo de nós mesmos, na geometria e forma da vida.

\section{O consumo e a face do viver.}

Existe algo que se apresenta sobre, uma mudança de olhar e a capacidade de desenvolver aspectos outros, isto será reforçado inúmeras vezes, justamente porque, o prazer, ou desejo, pode não estar no imediatamente obvio, ou diretamente relacionado, e isto queremos dizer, aproveitando o exemplo da medicina, que ainda que dizendo de maneira restrita, podemos vê-lo como um objeto porém, que torna-se um mundo nele, então, o que para muitos surge como uma oportunidade de enorme ganho financeiro, pode para outros seres humanos, ser justamente a oportunidade de sanar a dor, as mazelas físicas, as dificuldades de corpo porém, principalmente da alma. Assim, sendo, queremos dizer, que o consumo, que queremos e desejamos, depende em parte, do que somos, quem queremos ser em particular como sociedade. Portanto, no que iremos atrás, é parte do que somos, e o que vemos e desejamos está ao alcance do futuro de nossos sonhos e ideais, como presença desse bem maior. 
Então a justaposição do que somos e queremos, deverá ir se aproximando, e portanto, creio que esse encontro, se fará em profundidade e não somente em superfícies de aguas rasas, de onde o consumo provavelmente se estende a construção do produto ( em nós), e para o mercado ( do que iremos em busca ) como nossos valores.

Porque bom seria, que contivéssemos em nós como construção, a matriz do que queremos buscar, como desmembramento e ressonância.

Assim como o que queremos, a felicidade também, é um bem, disposto sobre algumas conjecturas, me parece, e não somente como uma parcela em prestação, mas condensada em estados possíveis. Esta talvez seja uma possibilidade de se observar seus modos de ser. Felicidade tem modos de ser? Porque não, quando passamos a ver o sentimento, como um ente, A posologia da felicidade, requer um conta gotas para alguns, para outros, estado de latência, para outros, um jorrar de profusão, e onde está localizado, é justamente o que pode alterar conforme o olhar de cada um, da alma, e do coração. E onde a razão tem primazia, posto que pode ser o discernimento de onde encontrar, entre agruras, ainda e todavia, a face da humanidade que se debruça ao criador.

E se nos referirmos a felicidade entre hábitos, " depósito" ( onde eu coloco a felicidade), porque temos a busca, mas também, e conjuntamente, onde a colocamos, o que possibilita um entrever que se localiza, no que temos e no que buscamos. Do que temos, vamos fazer da procura, um estado de mapeamento in loco, ou seja, aonde eu estou colocando a felicidade, o que é diferente para o olhar, porque se torna uma busca direcionada, por valores intrínsecos, que se exteriorizam na congruência com seu amago. Havendo assim uma correspondência maior, porque por vezes, em nossos enganos humanos de maneira costumas cremos por vezes e nos desapontamos, dentre o que queremos e o que nos faz feliz.

Existe felicidade suficiente? Ou como vemos nosso estoque, ou ainda, de maneira mais poética, como a estamos adubando em nosso jardim, do cotidiano? O cultivo do que consiste em nós como felicidade é parte do que temos e queremos, e a concretude dos aspetos erguidos por nós, como capazes de realizar a manutenção desse estado, que nos proporciona forças para enfrentar desafios, são fundamentais de serem diagnosticados por nós, como elementos de segurança ( bem -estar), um dos fatores sociais, que em meio a grande parte maior da sociedade se insere como referência de tranquilidade que irá realizar o alicerce necessário. 
O que nos faz lembra, até pelo texto, e pela vida cotidiana, do que o trivial nos suporta, nos devora ou consome também, e em contra partida o que passou a ser tão trivial que não nos é mais prazeroso, ou nos faz feliz, ou é objeto de desejo. Então, uma outra pergunta, se torna exigente, no tocante ao que de fato é fundamental, ou do que é trivial, pois onde teremos a capacidade de ver e não perder o que dele é fundamental, essencial para que a distância entre o que queremos, muitas vezes, difícil de ser alcançado e dentre o que temos corriqueiramente, adquira o sentido de permanente sabor, permanente estado de felicidade.

Agora, do que entendemos ser, felicidade. Me parece que devo considerar como amago, no mais profundo sentido, a felicidade como meio deu uma sociedade de compreender mutuamente, onde esforços serão compostos como unidade permanente de socialização para bem-estar geral.

\section{O homem, e o bom homem. Razão compartilhada}

Harmonia - conduzido para o equilíbrio, é fator de desencadeamento de aproximações ou discernimento de partes conviventes, ou seja, estabelecemos o contato de respeito entre partes, o que possibilita ou se almeja quando queremos conquistar o tão desejado equilíbrio.

Em tempos sagazes encontrar conformidades no sentido do que nos faz entrar em sintonia, é estar pleno com vontade e serenidade, apto a se deslocar a um conjunto de ações que se perpetue mantendo um estado possível de felicidade.

A felicidade - como justiça - encontramos certamente felicidade na justiça, na bemaventurança, na mansuetude, enfim, em outros valores afins.

A percepção - do quanto somos felizes e não percebemos. Da crença - Do quanto que somos e não acreditamos, e o que está diretamente relacionado, com a alteração destes elementos.

Por vezes e pode se pensar, que deveria ter outro nome, mas, penso que a felicidade, pode ser creditada, também, no período das adversidades, com outro nome, por exemplo, a força movente que nos envolve a ponto de ratificar um curso diante do que possamos estar nos defrontando frente a adversidades. Talvez a consideração possa parecer em princípio não nomeada dessa forma, mas, justamente por restabelecer o prumo, diante de um caminho é que saberemos que disto também é feito, um parcela da felicidade.

Ver o fim. Posto como por do sol, as faces da manhã são o que seremos, e possivelmente então, encontraremos a paz, em um diálogo que finda, em adormecimento e amanhece. 
Assim talvez, com a natureza sobre os olhos do homem que descansa, possamos compreender o fim como apenas, mais um renascer.

O controle de nossos impasses e nossas dificuldades são fundamentos de um caráter que se molda, que não está pronto, mas que aprende e apreende, conhecimento, vontade, razão e sentimento, onde o bem não é somente daquele que pratica, mas daquele que compartilha o viver conosco, e após a tormenta, poderemos ser, como o filho pródigo que retorna a casa, de onde em verdade, nunca saiu. Posto, que penso, deverá ser, a vontade do Pai, que dos seus filhos não se ausenta, mas que os filhos sejam na alma, o que o amor do pai pode representar. E assim, como buscando o sentido de nos ver, como sempre recomeçando, quem sabe um dia, das asas do céu, poderemos ver o chão e o universo, tão distante, que ao mesmo tempo, é placenta de um sentido ainda maior, como sendo o que da esfera humana, ainda que mesmo não compreendamos, possamos, ser onde o silêncio habita, e a dimensão do espaço ainda procrie.

Da ausência da felicidade. Demasiado prudente será, também considerar a ausência da felicidade, porém, sabendo que dela, ou melhor da ausência se procura muitas vezes, ou se constata a presença. Mas, de qualquer forma, a falta, que até é algo mais, do que a ausência me parece, considera que razões existam para isso, mas que também, da imensidão que nos cerca, devemos e podemos nos cercam do que ainda que seja nos minerais, nos vegetais, nas sombras, nas cachoeiras, nos animais, a chave de onde a porta poderá um dia abrir, para novamente a lucidez ou a felicidade possa ser alcançada. Esforços, decorrentes de busca, sensivelmente estarão aonde por vezes nem mesmo a esperança possa estar, mas ainda do que vive, um dia, se poderá amar, e onde o amor, surge ou ressurge, teremos a chama, que mesmo que o vento não sopre, na alma acende.

Recorreremos por certo em momentos assim, ao que nos torna, ou reconhecemos, como parte do infinito, presença em tudo que possa existir, essa consciência nos faz ser mais humanos.

Quanto acreditamos conhecer da alma o que dela pode conceder à nossa razão em atos, me pergunto se suficientemente haverá no corpo, de conduta, que corresponda em desejo e sentido, significando ou re - significando a vida de maneira plena. E dessa maneira, já me pergunto, se a razão do corpo conhece os atos da alma, ao menos do que concerne o sentimento.

\section{O cidadão político}


Capaz de enveredar por semeaduras onde a virtude, os valores, a amplidão da gota de orvalho possa ser da manhã o que nos acorda para a consciência política, haveremos de buscar assim como a felicidade, o que nos faz e torna humanos de maneira que o habitar o mundo seja abrigado por relações onde o estar em si, de forma interna assim como a face nossa representada externamente esteja em conexões com o Estado, com as instituições, com as áreas fundamentais para o desenvolvimento do ser político, este sendo participativo, crítico e reflexivo.

Da compreensão da virtude humana como órgão de distribuição no corpo planetário de, ao menos deveria, recursos da razão, onde o ambiente, como um todo, o respeito e a preservação devem ter os valores, capazes de consolidar as responsabilidades com as atitudes.

A respeito da virtude intelectual e moral, ambas creio que já sabemos devem estar em vias de mão dupla interagindo onde uma fornece respaldo à outra, para ambas terem crescimento e não perder a capacidade de trazer ao intelecto a parte sensível da razão, onde o discernimento não relega somente a estruturas logicas ou racionais, mais ao que é da natureza, dos sentido da alma, do homem em seu cotidiano, a moral, sendo a conduta que se estabelece, mediante a um direcionamento capaz de se estabelecer pelos moldes do bem comum.

As virtudes não dependem de estar ancoradas em momentos de sortilégios nossos, ou despertadas por esses momentos, as virtudes devem ser elementos trabalhados no ser humano, com vontade e determinação.

Existe um prazer que é muito ligado a natureza corpórea do homem, que em nada a meu ver tem relação com crédito ou demérito, mas sim, maior ou menor, afeição ao que desse ato pode lhe trazer de bem estar, sem absolutamente, em meu pensar, estar se indispondo com o do que é de virtude, cabendo a cada um conforme seus atos e consequências aferir-se. Inúmeras serão as formas de prazer na vida, algumas podendo ser nomeadas de outra forma, porém, juntamente com a contemplação também poderemos dizer, que tem uma das formas de prazer, assim como a de transpor com a vontade o desejo de realização de um objetivo frente a uma dificuldade ou algo do gênero, por si só a própria vida, nos impõe momentos de prazer e vive-la com tudo que ela representa, e se não o temos lidando mais uma vez, com a outra face da moeda, creio que deveremos analisar o significado da sua ausência e do que 
dela poderemos, alterar para se for nosso objetivo, re- significar de maneira que o prazer seja algo saudável, consequentemente de bem -estar.

Eu não entendo muito bem, quando certos autores, consideram colocar o sofrimento como prazer, confesso que para mim é patológico, mas, enfim, cada indivíduo com o seu discernimento e razão.

E aqui tratando de diálogos em sociedade, ética, presumo que devo considerar que o prazer inclui uma gama não somente do que trata sendo indivíduo, mas sim, no conjunto da sociedade, onde as relações prazerosas criam um desenvolvimento gerando mais “ produtividade" social, onde o interesse, a participação, produz o nascimento do ser politico engendrado nos atos políticos onde o ser se constitui a face da realidade onde o sentimentos dessas relações lhe trazer harmonia.

Os homens podem ser bons em uma infinitude de modos opernadi da alma, do coração e todos os sentidos que podem fazê-lo agir em conformidade ao que o sintoniza com os valores morais de um ser humano do bem.

Sensibilidade

Perceber o mundo é uma face de sensibilidade, que não somente está no corpo do sentimento, mas na alma da razão.

Dos excessos - desequilíbrio

O meio termo, não médio.

O que pode ser isso, se não que, uma extremidade de uma ponta a outra, não se quer dizer este meio, porém, o meio termo de um excesso, o que não quer dizer do começo e fim, mas podendo ser de uma parte.

A ignorância e o erro, gerando consequências

Da razão que leva ao erro, como pode ser? Do que é certo, ou errado? As leis da sociedade pautam o indivíduo quando, o mesmo, não ter discernimento do que está certo ou errado?

Do que perturba a razão.

a incoerência um fator,( exemplo: desejamos ter saúde, mas não nos alimentamos bem.). O ser humano luta constantemente, com suas incompreensões de avaliação do que pode ser 
plausível de ser composto para sua realidade, como fato ou desejo, e ainda mais, do correto e o incorreto.

Escolhas? Ações dentre humanas (urbanas)

Deliberar seu ato, ou o ato corpóreo social? Dentre quais camadas poderemos compreender nossas escolhas?

Atos e consequências -

Condições de conjecturas - das escolhas do atos, muitas vezes, não são provenientes relativamente segundo as consequências), o que dispõe ter uma lucidez que atravesse o tempo como probabilidades. Ou seja, posso concordar com o ato, e não medir as consequências, e na verdade precisamos dos dois.

A coragem de viver está encarnada no quão somos ou nos tornamos dignos da virtude na qual estamos inseridos ou inertes, sendo esta o parâmetro do sentido, nesse viver, de atos bravios, sendo a sobrevivência no mais tocante dos casos, a razão, que sustenta e valida, a prática de conduta que enfrenta desafios.

Se os papéis da realidade estão sobre a mesa do cotidiano, onde teremos as vestimentas da ordem social sobre também nosso pulso e força, entenderemos as forças armadas, enfim, como uma ordem na qual, fazemos parte como própria disciplina de vida, onde o que poderá nos desviar, é alerta de prontidão, para todo que deseja em paz viver.

Não confundam, rancor, com justiça. A justiça é necessária.

Igualdade e ética

Dos procedimentos.

A face do comportamento deve estar sobre o balizamento do que é igualdade, assim sendo a ética é argumento cabal para a igualdade. NO que aqui se pondera, adverte-se que no tratamento do cunho social havendo igualdade a ética é condutor, das escolhas e atos.

Assim, essa forma de justiça é a virtude completa, embora não de modo absoluto, mas em relação ao próximo. Por isso, a justiça é muitas vezes considerada a maior das virtudes, e nem Vésper, nem a estrela d alva são tão maravilhosas; e proverbialmente, na justiça se resumem todas as virtudes. Com efeito, a justiça é a virtude completa no mais próprio e plenos sentido do termo, porque é o exercício atual da virtude completa. ( ARISTOTES, pg105). 
Ética e posicionamento- Do que se pode compreender, quanto a ética, sendo o posicionamento do outro. Adverte-se que o bom senso, ou mais do que isso, se faz pela presença da observação dos parâmetros individuais, pautados em direcionamentos múltiplos, onde do que o outro valida, em conjunção perante a sociedade e o valor individual, pode-se alcançar uma instância onde tenta-se organizar o pensamento de maneira a que a ética possa se aliar a justa posição que é fruto de movimentos de olhar participativos, e não restrito a um posicionamento individual.

Do que pode prejudicar um discernimento.

Conjecturas nas quais o elemento envolvido não é suficientemente capaz de mesmo que em relações abarcar seu conteúdo isolado quanto a correspondente veracidade. $\mathrm{Ou}$ seja, o prejuízo de, tanto não termos enquanto individualidade uma força capaz de resistir quanto a razões e certezas, ou que as conjecturas envolvidas não sejam suficientes para validar o argumento ou diretriz individual. Ao passo que, se as conjecturas adjacentes são elementos que vão colaborar, o discernimento cresce em posicionamento de razão, estas colocações são devido ao fato que podemos ter razões isoladas suficientes para validar uma decisão, ou razões que se firmam pelas conexões de conjecturas, porém, podemos ter também, o fator isolado que não se mantém, devido aos argumentos das circunstâncias que lhe cercam.

Quanto colidem o externo com o interno, em conjecturas e relações, e de que maneira podemos avaliar, e determinar um juízo onde a razão não se perturbe, e encontre justificativas suficientes para se equilibrar em sentença ou avaliação. Por vezes, também, a repercussão pode ser instrumento de avaliação, mesmo que posteriormente, mas sendo justamente o que irá contribuir para uma ponderação para ou retratação ou antes da ocorrência posterior como consequência, ainda em avaliação de pensamento, a contribuição necessária para determinações.

Das conjecturas do tempo - retratações. Certas posturas sociais serão com o decurso do tempo contrapostas em juízo, nelas mesmas, e com o derredor.

A afirmação e a negação no raciocínio correspondem à busca e à repulsa na esfera do desejo, por isso, já que a virtude moral é uma disposição de caráter relacionada com a escolha, e a escolha é um desejo deliberado, para que a escolha seja acertada deve ser verdadeiro o raciocínio e reto o desejo, e este último deve buscar exatamente o que o primeiro determina. ( ARISTÓTELES, pg 129). 
Tudo que é do raciocínio correspondem à ordem da vida, em conformidade a razão ( os tipos de razão - texto sobre ordem ), e as esferas do tempo, onde se observa os argumentos plausíveis de se sustentarem segundo do que vigente a atualidade da ética, do bem, da justiça, enfim, isto porque o tempo, e as culturas são instâncias em que a natureza humana vai se moldando e para o bem ou para o mal, o raciocínio, deverá encontrar a arquitetura de sua gênese, e a busca do que deseja para as gerações futuras, e a virtude está na escolha centrada dessas conjecturas entre o indivíduo e a sociedade.

Da natureza da verdade e a prática. Do que entendemos de prática.

A meu ver, o pensar como prática do intelecto tem seu sentido e forma, porém para quem considera a prática somente o mundo da experiência do cotidiano se equivoca a meu ver, pois, tanto é do cotidiano o pensar, como inclusive integridade, onde dele deveria e subjaz a conduta, portanto, por vezes se observa uma contrariedade, no viver, sendo isto porque, o pensar é arquitetura em origem, em matriz na qual o viver emerge, e ainda do qual deveremos ser correspondentes, ou seja, se a arquitetura de nosso pensar é indicativo de nosso ser, nossos atos devem ser fieis a nosso pensar, isto creditando que o pensar está em valores que irão verificar a procedência de nossa chama, o que nos faz ser de fato homens, mulheres, crianças, seres. E mais do que isso, o aprendizado também se localiza nessa esfera, sendo que ao pensarmos e agirmos diferentemente, devermos buscar porque isso ocorre, e aprender com a busca da justaposição entre o pensar, e o viver, e então, partiremos para, do que é o nosso pensar, enquanto o bem maior? Isto será um desvelamento entre o ser, o pensar e suas ações. O quanto que do viver ele se aparta, ou não, de suas diretrizes entre o que é do indivíduo e a sociedade?

Da observação, instrução e aprendizado. Etapas nem sempre correspondentes. Muito pode ser a percepção da observação, porém, nem sempre se corresponde com a instrução dada ou contida em experiências, e o aprendizado, não é final, mas continuo, e mais ainda, teremos que buscar a relação entrelaçada entre o que se observa da vida em instrução natural da experiência com os aspectos que são da natureza da instrução, de educação formal, ou instrução em alguma área específica com algum mestre, e ainda, em cada passo, como o aprendizado se conserva e se altera segundo os passos e o caminho

E então, surge no tempo, as vozes do próprio onde cada um e conforme seus passos, visíveis ou ausentes, se tornam nossa percepção, instrução e aprendizado, onde deverá realizar o escrutínio da razão, sem perder o sentimento que lhe trará olhos da alma e conduta no 
destino. E mais, ainda, o desafio de quão nossos entre os outros podem estar também a nossa existência. E passara essa a ser a vontade de todo aquele que traz na realidade as cenas da imagem que constrói para si e de como quer contribuir para a sociedade do amanhã.

E se rasgam corpos e ficam a alma. E da indução, permanece o coração.

De onde podemos encontrar a ética segundo as relações da livre expressão e nosso automatismo social? Ou seja, em que ponto estaremos organizando nossas estruturas de valores pessoais, mas não como impasse frente as questões da sociedade, mas do que em nós imersos no cotidiano, consumimos nossa expressão em automatismo a ponto de nossos discernimento ficar arraigado, a determinadas normas que em parte podem no decorrer do tempo amortecer nossas expressões como face do pensar, este que deve encontrar impulso e determinação cada vez mais, para ainda que no habito se expressar preservado por suas reflexões que não sucumbem e todavia se inquietam, impulsionando um movimento no cotidiano, o que é diferente de nossos impasses diretos, individuo sociedade.

A reflexão que nos preserva e configura a expressão frente ao automatismo ainda que ambos frente a ética, creio ser um diferencial que salvaguarda de aspectos de massa nem sempre, procurar consumidores e cidadãos, lembrando Canclini.

\subsection{O sujeito mundo e suas narrativas.}

Em algum lugar - o circo. Sociedade no P. S. ambulatório do diagnóstico da realidade.

\section{Espera da palavra o que adentra}

Pele e sangue, desmedidamente e inventa. Nesse mundo que recria e descreve, em interlúdios dizendo da divindade, o objeto. Verdade desafiando o secreto desejo de viver. Desperta a nostalgia de se olhar outro, a sorrir perante a lágrima seca. Contrapont(d)o um possível conhecer. Escrevendo seu nome onde a palavra é um sentido, noite desvelando-se destino que pacientemente amanhece, onde simplesmente a Vontade indaga, por onde caminham as estrelas que tanto vagueiam, para 
encontrar a própria luz. Em solidão, prostrada frente ao belo, suspirando

o ato da alma tomando posse do

\section{inefável corpo do existir.}

\section{( sentimentos vivos)}

Do pão e do circo 347348

A lembrança dos corpos do passado, onde a saudade ficou proibida. Um certo lugar, do próprio passado, amalgama do tempo, diz-se passagem do instante, querendo permanecer, pausa das areias de clepsidra. O desejo revela ao movimento que parte dele deverá ficar onde o destino o concebeu. Nascimento da vontade, divisou-se águas por onde o olhar se dissipou. Onde o véu dos portões se fecharam frente a escolha. Atravessando o tempo, poderá talvez, as portas se abrirem. Desespero do ontem, que ficou a deriva por conta própria. Dilema contemporâneo, desvestindo-se para absorver sua própria pele. Circo do pensamento, atrações da mente apontam para a dimensão que busca se compreender. Seriamente, intercorrências dos jogos da vida, tabuleiro marcado na esfera dos rochedos do arrependimento moldando-se, encontro do aprendizado. Nessa suspensão, trilham como malabaristas o momento presente. Arena da realidade em seu " parque das diversões “ onde o prazer não basta para sucumbir (n)o gosto da retórica social, que embriagados buscam o porvir do dia seguinte em lucidez. Onde por justaposição é verte do pão, como animo a dignificar a presença na existência . Sangue do picadeiro, estendido sobre as veias pulsantes do céu estrelado ( acima ) da noite que amanhece em cada um de nós. Liturgia do novo tempo onde ainda pagamos, para assistir o espetáculo realizado por nós. Em sociedade sem relato, de Canclini, encontro a frase " A chuva, pintada em um quadro, não molha “

Para todo aquele que se encontra distante de si, poderá não ser do quadro, pergunto, em ( lastro ) traço do que o absorve, gera e o compele como tecido do mesmo corpo orgânico, na trama da contemplação da própria vida. Porém, todavia, sem a intenção de sermos dogmáticos, poderá ainda haver um outro movimento, sendo que a chuva no decorrer do seu caminho irá molhar seu corpo e talvez ele se encontre com a tela, diante da sua

\footnotetext{
${ }^{347}$ Sousa. Carina Gonzalez Y. Composição BASTA.

${ }^{348}$ Composição O Circo - 17-03-2018
} 
paisagem. Mais ainda também, poderá acontecer que o gesto da chuva $\underline{\mathbf{3 4 9}}$ o faça compreender quando lágrimas estejam sobre a sua face. Em a sociedade sem relato de Canclini, faremos uma abordagem relativa a algumas reflexões apontadas em relações ao que iremos nos debruçar enquanto tronco de pesquisa a ser desmembrados em outros membros. Como inicialmente uma folha em branco, aguardando as primeiras linhas, ou uma prescrição $^{350}$.

Se todo aquele que precisa do toque da alma humana para ressurgir no existir, levanta os olhos para uma força superior, poderia eu dizer, ser errante que sou, que frente a natureza, também pode o vento, a chuva, a terra, o mar e todas as formas tocarem-se a estender seu corpo, para que estejamos elevando-nos ao que nos concede complacência de nos (re)conhecer? Arte do homem e da vida?

Como anunciar a morte da arte? Humana? Em que ponto elas estão separadas? Porque decretar um argumento que subjaz a pontos de vistas, onde poderemos compor um caminho em que a arte não seja tão propriedade mas sim, compartilhamento de pensamentos culturais, emissões de linguagens postadas sobre a face do mundo, ${ }^{351}$ como time linha vigente, embora sempre haverá no âmbito humano em que críticas de sua subsistência poderão sempre emergir. Se questiona seu lugar, em tempos de mobilidade, em diluição de fronteira onde tudo permeia-se em um estado sem território definidos, como a densidade de probabilidade na física, ou comportamentos de onda e partícula?

A arte, o autor indaga, teria sido transformada em laboratório de experimentação intelectual em diversas áreas do conhecimento. Aliás cabe aqui uma ressalva. Encontrei um colega, doutor que me disse ser a Arte não uma forma de conhecimento, deixo claro o RELATO,

${ }^{349}$ Música - Antropologia com relato/ ARQUIVO DE SOM: 111001_001 - COMPOSIÇÃO CHUVA - As águas de um viver.

${ }^{350}$ Relato sobre a folha em branco - https://youtu.be/8vqY91WfCg0

${ }^{351}$ Ver sonoridade apresentada por Nikolai Chaikin, Concerto $\mathrm{n} 1$ para acordeon e orquestra, tecendo conexão sonora com Phillip Glass em Poet Acts, em sinestesia de diagnose de corpo sonoro, adverso do instrumento, mas na imagem da voz sonora que ultrapassa o objeto para ser instrumento melódico, onde na orquestra se organiza como força de movimento, em um primeiro momento, e posteriormente buscar a referência de comportamento do mesmo som exposto pelo acordeon em diversas culturas, que apensar das diferenças, pode-se constatar que após um tempo de apreensão se observa uma identidade preservada que independe da localização porque constitui em si, uma mobilidade que se agrega como digital, onde a emissão pode ser de seu coabitar uma expressão que o representa no através da construção de seu tempo ( música ), criando um espaço de significar que abrange espaços conduzidos que mapeiam os passos que o recebem como um através de territórios, transeunte sorvendo seu destino. ( em transito )https://youtu.be/vuBfz5DNyM4 E, Gabriel Garcia Marquez, " No se que tem el acordeón de comunicativo que cuando lo oímos se nos arruga el sentimento ". 
aqui, nestas linhas, que não concordo. A arte é em meu pensamento conhecimento. Seguindo com as reflexões apontadas no livro, algo me chama atenção não necessariamente como apontado, que se trata da arte ocupar espaços coletivos de gestão intercultural. O que vem a ser gestão intercultural, poderia se aproximar da cultura sustentável, com a organização dos recursos do pensamento?

A partir do início do século XX a sociologia mostrou a necessidade de entender os movimentos artísticos em conexão com os processos sociais. [...] que as artes oferecem cenas imaginárias onde se compensam as frustações reais(?), seja como evasão que leva a se resignar, seja como criação de utopias que realimentam esperanças: uma espécie de religião alternativa para ateus, segundo a frase de Sarah Thornton-

Estaremos cegos a não ver que em cada olhar de uma criança, adulto, idoso em dificuldades de vida, tem o som, o tom de uma frase melódica em imagem de rogar auxílio, e ela é de todo em sua integralidade real, deveria ao menos tocar as nossas fibras do corpo e da alma, sem distâncias de compreensão. ${ }^{352}$ Em minha forma de sentir como possibilidade de encontro com a razão, digo que todo gesto da natureza humana está indubitavelmente nos gestos das linguagens da arte. O corpo social sofre sobre sinfonias a nossos sentidos, que insistem em emudecer esse caminho. Não vejo como representação, mas ( Empédocles apud Schopenhauer )o mesmo se dizendo ser vivente, vigente sobre a angustia de se ver. " Religião alternativa para ateus “, diz o texto, o que nos permite um adendo, em desmembramento - A deus podem ser ditos de muitas formas, até mesmo daquele que profere crença sem a praticar, portanto, penso que ato em evolução do admirável é uma crença que conjuga um religare. Por vezes pode estar mais distante, o que professa do que aquele que se diz ateu. Tudo sobre o que de alguma forma promove uma integralidade pode ser por certo viés considerado como um paralelo de religião, talvez. A realidade traria frustações? O próprio tempo, se frustra ao não ser ele por completo, mas sim passagem e somente no infinito ser ele mesmo. O que poderíamos compor, a não ser um passo após o outro com ressonância? Talvez, na eminência de captura-lo? O que é da mente do universo e sobrevive em existência, também não se frustrará? O que fazemos com essa frustração? Daremos outro nome, somente ou agiremos de forma a assumir um posicionamento onde a realidade para a ter regência do que soava em mente.

\footnotetext{
${ }^{352}$ Foto De parte do quadro- DIC - Santos - Fractal de imagem - / poema sonoro / ref. Hist..estudos Volpi, e composição - forma e cor. O Retrato de relato. Menção a artigo publicado durante o período de mestrado, Retratos: Discursos de uma época, metáforas do olhar.
} 
Desigualdades e ambientes culturais - paralelos.

Arquivos da nossa história, museus da memória. Quantos de nós visitamos museus? O mundo está se visitando em forma de sua arte-comunicação midiática de retórica contemporânea com a participação de que público? $\mathrm{O}$ ontem na internet em tempos efêmeros é cenário de um museu virtual? Quais dados são frustrados na realidade exposta sobre a tela dos arquivos do computador, descartados em registros do que ainda é cicatrizes do viver? Ou marcas.

Entre a realidade da globalização “ as artes dramatizam a agonia das utopias emancipadoras, renovam experiências sensíveis comuns em um mundo tão interconectado quanto dividido e há o desejo de viver essas experiências em pactos não catastróficos com a ficção "[...]Frente ao esculpir contemporâneo, a nossa imagem 3D da experiência - imagens da vida, conexões do espaço mundo, sendo esferas do indivíduo e global, se expressam em uma navegação que busca o destino de soluções públicas para embates de consenso e dissenso que promovam argumentos de maneira a enfrentar, desafios como ( proposições ) - devaneios, através de (ideias ) - perspectivas como maneira de fornecer o produto - life - Project ( life Works ) de uma economia planetária / plataforma em gnose - future , que necessariamente carecem de business leaders, onde se questiona o lugar da política - " Faz tempo que custa reconhece-la como o lugar onde se disputa o poder efetivo das instituições, a administração da riqueza ou as garantias do bem-estar "( CANCLINI, p. 18)

A dúvida e a questão: Sobre os interesses. Penso que os interesses políticos devem ser os da sociedade dando primazia as esferas de amplas escalas frente as particulares. Parece algo claro, porém, os interesses particulares de representantes do poder público em grande parte das vezes se sobrepõe as demandas de fato necessárias. Mensurar decisões, de um olhar que percebe a realidade? Por onde está o valor? Sobre a realidade: O imaginário manifesto realizado pela existência ${ }^{353}$.Será que a consciência humana virou, artigo de luxo, tão caro que ninguém compra? Ou haverá de vivermos o tempo em que será tão caro a todos nós, a consciência, que nem mesmo possuirá valor, estará conosco como fator genético. Canclini, ainda aponta que " Em compensação, a arte joga com as imagens e seus movimentos construindo situações explicitamente imaginárias, com efeitos desfrutáveis ou que podemos

\footnotetext{
${ }^{353}$ Conto, O valor da cidade / MK promocional - vídeo
} 
limitar se nos perturbam: vamos embora da exposição" Pois bem, pergunto, e como faremos frente aos museus dos arquivos humanos em história que visitamos em lastro, também iremos embora, se nos perturba? O livro continua dizendo sobre a arte que, " o êxito da arte reside em seu caráter inofensivo ou ineficaz? [....] seu atrativo procede, em parte, do fato de anunciar algo que pode acontecer, prometer o sentido ou modificá-lo com insinuações. Não compromete com fatos duros. Deixa o que disse em suspense ".Estados da arte ( imaginação ), em cenas dramatúrgicas reais, contrapontos, em pausa ou movimento, onde tudo pode seguir uma mesma PAUTA. “ As obras não simplesmente suspendem a realidade, mas se encontram em um momento prévio, quando o real é possível, quando ainda não se desfez. As obras tratam os fatos como acontecimentos que estão a ponto de ser " ( CANCLINI, p20 )

Como nos deparar e sem ficar impassível, “ ....vídeos de crianças do Camboja mutiladas, enchem o chão com silhuetas das vítimas e distribuem pernas soltas amputadas”[...] " em que seção colocar estas notícias: em política, policial, economia ou espetáculo? ( o pão e o circo ) “ As distintas indefinições entre ficção e realidade confundem-se devido ao ocaso de visões totalizadoras que situam as identidades em posições estáveis ( CANCLINI, p. 22)

Do trivial ao banquete.- marginalizada -cerimônia de gala. Transgressões de fronteiras momentos $\mathrm{u}$ (tópicos) o livro diz que diluíram a "fronteira dos artistas para as pessoas comuns", e crítica que nos momentos desconstrutores, esvaziou-se o conteúdo, o que eu pondero ser uma aproximação de conteúdo, monotipia do pensar e fazer a arte.

Mas, em alguns casos, não diria fronteiras, mas talvez, eu coloca-se como perda do bom senso, no tocante a como o texto aborda, não que tudo fosse de certa maneira " corrompido" mas, uma certa medida de discernimento infere dentro dos processos que rompem a convenção, a possível harmonia, ou seja, não perder o que pode nos conceder mesmo que frente a uma obra crítica ou chocante, a experiência de dissecar o pensamento, sem agredir anatomia, porque é parte de um processo de corpo conhecendo-se. Mundo, fortemente beije minha alma, porque eu me consumi no ardente desejo do teu corpo. Da transgressão à pósautonomia, em se tratando do pensar, pós-anatomia.

A transgressão como regra?

“A história contemporânea da arte é uma combinação paradoxal de condutas dedicadas a afiançar a independência de um campo próprio e outras obstinadas em derrubar os limites 
que o separam "De certa maneira, podemos em paralelo admitir que essa busca da arte não difere dos aspectos de uma necessidade social no tocante ao que se refere do embate de esferas particulares e públicas $^{354}$ (FREGA , 2012), onde por vezes o fato basilar torna-se a presença de uma necessidade de consenso frente ou para dissolver um desacordo. Sobre uma ótica poderemos considerar o consenso uma justaposição concernindo um coabitar, sem negligenciar nenhum aspecto relevante ou imprescindível, ou que venha a denegrir os elementos de alguma outra parte, ou sejam preservando a integralidade com uma possível individualidade. Relações ou contraposições? Tecendo os fios, Canclini adverte sobre o que mais poderia ajudar se, as análises de Bourriaud ou as críticas de Ranciere, quando distingue em estéticas do consenso e estéticas do dissenso.

Aproximações ou contraposições:

É destino do campo da arte ensimesmar-se no reiterado desejo de romper suas fronteiras e desembocar, como nestes dois últimos casos, em simples transgressões de segundo grau que não mudam nada? Nem levando o mundo ao museu, nem saindo do museu, nem esvaziando o museu e a obra, nem a desmaterialização, nem omitindo o nome do autor, nem blasfemando e provocando a censura pode- se superar o mal-estar que provoca esta oscilação entre querer autonomia e não poder transcende-la. Canclini, $2012, \mathrm{p} 24$.

As vezes me parece que a " função" da arte de se colocar em vanguardas, perdeu efeito porque o próprio cotidiano está se construindo em um movimento contínuo de vanguardas compartilhadas nas esferas das mídias, do que se apresenta no campo tecnológico, diluindo portanto até mesmo essa presença marcante que houve, e, pode ainda haver quem advogue essa presença, da arte como vanguardas, mas, pondero que talvez, o olhar da arte esteja mais permeado em construções de contínuos podendo nem tanto se deslocarem, como principalmente estenderem-se propriamente no existir, sendo e agindo de maneira como agente e receptáculo, produtor e público das demandas de criação concebendo-se coparticipativa e integrada onde a relevância de sua autonomia ocorre pela voz em, comunicação correspondente, divergindo ou em consenso, localizando-se no corpus da obra em suas conexões internas e externas de relações, ou seja, permanece em "transito", penso

\footnotetext{
${ }^{354}$ FREGA Roberto. Practice, Judgment, and the challenge of Moral and Political Disagreement. A pragmatisti account . Ed Lexington Books. 2012.
} 
que podem estar mais próximas de sua gênese, no tempo vigente, que vem a ser, da liberdade.

Talvez, as respostas para esta interrogação não surjam do campo artístico, mas do que está ocorrendo ao intersectar-se com outros e tornar-se arte pós-autônoma. Com este termo refiro-me ao processo das últimas décadas no qual aumentam os deslocamentos das práticas artísticas baseadas em objetos a práticas baseadas em contextos até chegar a inserir as obras nos meios de comunicação, espaços urbanos, redes digitais e formas de participação social onde parece diluir-se a diferença estética. [...] Mais do que os esforços dos artistas ou dos críticos em romper a couraça, são as novas posições atribuídas ao que chamamos arte que estão arrancando-a de sua experiência paradoxal de encapsulação-trasgressão . (CANCLINI, 2012, p. 25)

Segundo Canclini, começamos o século XXI, com relatos dispersos e fragmentados. Embates de desejos naufragados em pleno mar aberto? Será preciso rever o mapa de navegações? Traçar novas rotas? Haveremos de desbravar território próprio ainda desconhecido e (ao) nos aventurar em uma geologia compartilhada para além das redes virtuais?

A penúltima grande narrativa ocidental, auspiciada pela queda do Muro de Berlim em 1989, imaginou que haveria um só mundo com um único centro - Estados Unidos - e que seu estilo de modernização capitalista, segundo Francis Fukuyama, tornaria o planeta homogêneo. Esse grande relato durou até que a outra grande queda, a das Torres Gêmeas, direcionou o olhar para os argumentos de Samuel Huntington sobre a persistência de civilizações em choque, o poder compartilhado do inglês, com outras línguas e a multipolaridade econômica e cultural. (CANCLINI, pg 25)

Dispostos a reconhecer a multifocalidades e a multiculturalidade, Canclini, adverte

Quando falo em sociedade sem relato não quero dizer que faltem relatos, como no pós-modernismo que criticou as metanarrativas, refiro-me a condição histórica na qual nenhum relato organiza a diversidade em um mundo cuja interdependência leva muitos a sentirem falta dessa estruturação. ( CANCLINI, 2012, p. 26)

Inseridos no corpo da grafia, os relatos agora são estruturados pelo próprio ato, ação de não serem apartados, mas pertencerem a força do sulco do rio, cardiograma do viver.

O século XXI começou duas vezes. O ataque da Al Queda a Nova York e Washington, em 11 de setembro de 2001, impôs na cena política e midiática o deslocamento que alguns estudos já vinham anunciando: passamos do multiculturalsimo, ( aqui) entendido como reconhecimento 
das diferenças dentro de cada nação para os conflitos interculturais em uma geopolítica global onde todas as sociedades são interdependentes. ( CANCLINI, 2012 p. 26).

Ao mesmo tempo, também podemos observar, mantendo uma certa conduta de olhar por diversas perspectivas algo que nos indaga o pensamento, creio ser necessária também, uma visão mais crítica, de uma observação que condiz com um relato cego, se podemos compreender dessa maneira, porque diz sobre o amortecimento atual de certas vivências em nosso espírito do tempo, diagnosticando um certo estado alheio, contrapondo-se ao engendrado. Estaríamos vivendo um desafio, em termos poéticos, de um despertar da noite, sobre os sonhos da manhã, que espera desse mesmo relato a percepção para que possa ainda vir a ser a descoberta de outros sentidos, ou seja, do relato cego pode advir todavia, uma outra face que mova o estado, as águas para tentar em superfície e profundidade, ver com os olhos da alma, o seu reflexo.

Culturas entre o passado externo da mente presente:

Arquivos vividos, épocas, porém, mais do que isso, registro ou para além deles, memórias de marcas, como desenho esculpido pelo gesto de ser uma comunidade, ou um grupo, ou uma região, que não tenho a intenção de nomear, mas sim de me aproximar desse passado externo da mente presente, que não deixará de existir se aparentemente ceder aos impulsos propulsores de um mundo tecnológico de espaços "reduzidos" e expansivos (virtuais), onde a não permanência fica a cargo de uma identidade com caminho do ontem.

Sobre o caminho do ontem. Escolhas desse olhar, em como vou guardar a imagem desse tempo, é que fará de mim o mesmo, metamorfoseado, podendo em desenvolvimento não me perder no labirinto, porque deixei o traço para saber de onde vim. Não muito diferentes das

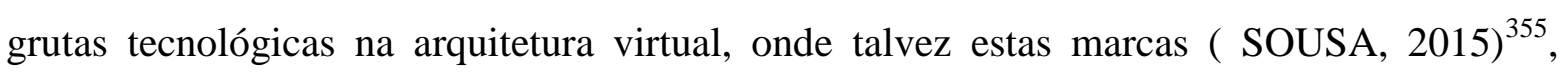
desenhos do nosso tempo, não venham a estar tão presente no meu tecno $-\operatorname{ser}^{356}$ cada vez mais em desafios éticos sobre - humanos, para compreender-se, ou, somente sejam alterados no rumo do tempo, cada vez que novos empreendimentos da saga humana despertem. Em certo aspecto, poderemos ser fractais de comportamento, sem perda de identidade, mas propondo em sobrevivência uma tolerância com o incerto de nós mesmos e do mundo, e nesse fractal de ser, características de nossas culturas presentes na mente vigente como a

\footnotetext{
${ }^{355}$ A Moeda - Texto apresentado no Congresso Ibercom 2015, A estética de um discurso na percepção da imagem do corpo social entre as linguagens.

${ }^{356}$ https://youtu.be/T-6ZCIMrO7U Corpos ressoantes.
} 
face do ontem, nos constrói sem tantas perdas, mas com adjacências, capaz de se observar e relacionar por diversos ângulos, por uma edificação do devir. Estruturas das frestas, globalizado espaço em movimento. O possível de ver esse fractal de ser, não como um abrigo determinado de forma, mas uma forma em" crescimento exponencial.", ou outra forma de concepção de lógica em crescimento. Por uma ética de intersecção:

O que vem a ser a ideia de uma ética da intersecção. Supomos que o corpo orgânico mundo em sobrevivência, demanda condutas, que sejam permeadas por razões de um coabitar, estando dispostos a nos relacionarmos de maneira que as ações humanas estejam na face da natureza do cosmo, ou seja, concretamente representado sobre as faces biológicas de intersecção de vozes da própria vida onde o homem deixa de ser protagonista para ser dramaturgo que no palco do mundo conduz ATOS, de cenas que exercem o DIREITO dos SERES sem ferir a FALA do que emerge no gesto de sobreviver do já exposto ferido tecido da anatomia do organismo planetário da alma, que permeia a mente ( cosmológica ). $\mathrm{O}$ homem não se sobrepõe a escolhas mas sofre o embate das forças existentes, quer estejam sobre quaisquer formas da criação. O ARGUMENTO dessas escolhas éticas, são justamente o PROCESSO de sobreviver. Ou seja, a JUSTA posição é o fato, de que se não houver, em minha maneira de ver, uma ética de intersecção entre as conjecturas, (bio ( tecno (homem ( lógicas))), não se fará um desenvolvimento evolutivo como o que se almeja, para nos encontrarmos, sobre os TERMOS de igualdade, que façam a convergência, como liberdade do existir, RAZÃO de sobreviver, sentido do pensar, na sentença do universo, do mundo em devir, considerando AÇÕES ( duplo sentido ) de uma economia planetária, em análise processual, que estejam em mediações constantes para uma declaração de um DIREITO DE FALAR, o mundo dizendo seu DIRETO DE EXISTIR.

O modelo teórico do campo artístico, associado, como veremos em Bourdieu, a uma época na qual ainda se podiam analisar os movimentos da arte como parte de culturas nacionais, foi esgotando sua produtividade à medida que nos globalizamos. Tampouco convence como alternativa o nomadismo que imaginava um mundo sem fronteiras. Os fluxos transnacionais de imagens têm velocidades distintas se provêm de países economicamente poderosos ou despossuídos. As pessoas, entre elas os artistas, tropeçam em mais barreiras do que suas obras.[...] A arte tornou-se pós-autônoma em um mundo que não sabe o que fazer com a insignificância ou com a discordância de relatos. Ao falar desta arte disseminada em uma globalização que não consegue se articular, já não podemos pensar em uma história com uma orientação, nem em um modelo de desenvolvimento para a sociedade. Estamos longe dos tempos em que 
os artistas discutiam o que fazer para mudar o mundo ou ao menos representar suas tradições revelando o que o sistema escondia. Mal conseguem agir, como acontece com os prejudicados que tentam se organizar, na iminência do que pode acontecer ou nos restos pouco explicáveis do que foi desvencilhado pela globalização. A arte trabalha agora nos rastros do ingovernável . ( CANCLINI, pg 28 ).

Pertencimento engendrado - saber que gama de indivíduos, em particular ou construção de nação somos, não quer dizer que, ao nos conectar com outras culturas estejamos nos desfazendo, apenas, penso, que quanto mais se tem clareza de sua integralidade, mais se pode estar apto a se colocar no lugar do outro (Hegel), ou ainda, ser capaz de aparentemente destituir-se para perceber o outro e compreendê-lo de maneira a inferir quais seriam as suas refutações ou congruências cabíveis para ambos. Uma identidade ( indivíduo - nação ) pode ainda se fortalecer de relações cada vez mais profícuas com outras culturas, mantendo a sua digital, sua marca ( País ), seu discurso, capaz de estabelecer não fronteiras, mas critérios e ações balizadas por éticas sociais permeadas pela estética, fundamentais na lógica de um desenvolvimento. O que não dá é colocação no pregão da humanidade para quem dá mais... “ Os mistérios da arte transmutam-se em segredos dos leilões, os preços das obras são comparados como preço do bônus, das ações e do Dow-Jones. “ p. 29 Falando em ações, “ bolsa de valores da LV “ - Livre verdade / quais os índices de conduta da ética contemporânea?

A tarefa da análise sociológica, esclarece Heinich, não é desmitificar as crenças nem denunciar as ilusões, mas, sim, compreender as razões que formaram, na modernidade, maneiras específicas de singularização e de criação de valor simbólico. Ao multiplicar os pontos de vista e decifrar as alianças entre experiências subjetivas e globalização do gosto, pode-se vislumbrar uma nova compreensão do lugar da arte na recomposição do sentido. " Multiplicar os pontos de vista: nós nos afastamos do reducionismo sociológico que irrita, com razão, artistas e pesquisadores que se preocupam com a especificidades estética. É preciso ensaiar uma visão da arte expandida pelas zonas da vida social, sem obriga-la a representar estratégias de distinção, a exercer violência simbólica ou dominação dos legítimos sobre os demais. Ao explorar vínculos diversificados entre criação e mercado, entre insatisfações estéticas e malestares políticos, é preciso iluminar as correspondências entre uma arte cuja redefinição lhe é custosa, uma sociedade onde não faz mais sentido a permanência da dicotomia esquerda/direita como opção política e uma ciência social que pressupõe novas ferramentas para estudar esta paisagem. Entre a inserção social inevitável e o desejo de autonomia está em jogo o lugar da transgressão criadora, do dissenso crítico e desse sentido da iminência que faz do estético algo que não termina de se produzir, não procura se transformar em um ofício codificado nem em mercadoria rentável "p. 31 
A busca de ser o entre. Um relato que observa a diversidade, como ela mesma sendo um corpo absorvido pela constante mudança, onde ainda poderemos encontrar barragens, onde as águas do ser haverão de encontrar a estrutura das frestas.

\section{Estética e ciências sociais.}

Em Canclini, "Na medida em que as artes forma adquirindo, como nunca antes na modernidade, funções econômicas, sociais e políticas, enquanto estimulam a renovação das ciências e da filosofia, os artistas não cessam de duvidar sobre sua existência e seu lugar na sociedade “. Das infiltrações fluidas da natureza, ritmo na procura do destino. Ser tempo e espaço, a matéria do pensamento.

Do design manuseio argila em criação de resíduos recicláveis, para expor uma escultura da vida em poder ser, face modelada no pensamento, agindo $d(n)$ a sociedade, retirando do espaço artístico qualquer presunção para se dispor sobre uma projeção naturalmente vigente no museu aberto do cotidiano ontem, metamorfoseando-se hoje, lapidação dos ,restos ( SOUSA, 2016 ). Sentidos sem prumo? Ou no fio da navalha, de um coração em punho. ${ }^{357}$

Enquanto, isso, as instituições e os mercados falam a partir de estruturas e programas, embora saibamos que estas formas sociais não tem a consciência nem a certeza de outras épocas. Como imaginar neste mundo sem centro nem paradigmas, entre as rupturas da globalização, uma conversa dos artistas que transformam o lixo em documentos com os profissionais decepcionados com as estruturas e seus modos de representar? (CANCLINI, 2012, p. 36).

Público e os modos de ver

A estética filosófica procurou universalizar sua reflexão mas estava associada ao desenvolvimento da modernidade europeia da razão ilustrada ou do romantismo. O pensamento estético foi intérprete da autonomização da arte quando o capitalismo e a secularização geraram instituições específicas e públicos dispostos a se relacionar com as obras usando critérios de avaliação diferentes dos empregados pelos poderes religiosos ou políticos. O traço predominante das estéticas modernas, foi o que Kant denominou objetos construídos, seguindo uma finalidade sem fim, nas palavras de Umberto Eco, as experiências nas quais as formas prevalecem sobre a função. ( CANCLINI, 2012, pg 37).

${ }^{357}$ (https://youtu.be/4aZj_kCxFbE - composição ). 
Penso que o lugar da forma artística estabelecido nesta perspectiva que observo, estaria sobre os mesmos moldes de uma comunicação, ou seja, em seus caminhos de emissão, estejam eles para além mesmo dos códigos e linguagens, mas, principalmente de que maneira a emissão pode nos conceder um modo de ver, e sentir, sendo mais adequado, sobre a razão presente no mundo, que nos faz compreender ainda que, a função, esta mesma, liberta de um aspecto restrito, um amalgama de uma conduta estabelecida nos elementos genéticos informacionais do que a arte está engendrada, como ritmo, movimento, e valores de emissão (SOUSA, 2016 ) ao narrar o próprio mundo lendo-se. Sendo assim, o público que está acostumado a ver, ouvir, se aproximar da obra, exposta, narrada, precisaria fazer um percurso de absorção da obra diferentemente de seu hábito de fruição, digo, que deveria se despir de seu modo corriqueiro de olhar, para se debruçar permitindo-se que o tempo significa-se a absorção do seu interior ${ }^{358}$ em estado de relação, retirando-se de um instantâneo momento, ou se nele, deixando-o suspenso, para que o olhar o tomasse por inteiro, em vieses de sentidos além dos apresentados, de forma que o indagasse, sobre como aquela experiência o convida ${ }^{359}$.

Considerando campos autônomos, para sobreviver?

Canclini destaca que:“ A sociologia demonstrou que a autonomia da arte e da literatura não foi um movimento de mentalidades. A partir do século XVIII, a burguesia - transformada em cliente dos artistas, assim como a criação de museus, galerias e salões literários autonomizaram suas práticas pra avaliar a arte e da literatura. "Segundo, Bourdieu, a arte iria vir a se separar de seus condicionamentos externos.

Serão abordadas certas considerações que eu gostaria de traçar em paralelo com o que considero ser a vida, obra, produto de nosso tempo, em galerias do cotidiano, expostas também em museus de marcas da nossa sociedade, estejam elas no virtual ou narrados nas

\footnotetext{
${ }^{358}$ Menção a uma passagem do Romance Madeleine, que por esta autora está sendo escrito.

359 Referência ao poema Música, publicado no livro Folhas de Outono. Convida-me em olhar/ Tua paisagem calada/que silencia sem respirar/Nos voos de asas aladas/ Por onde caminho, cegamente, Para encontrar-te amando, imensamente. Convida-me em tuas falas/ A permanecer em corpo estendido/ Buscando nas palavras o sentido/ Da carne fazendo-se almas/Convida-me para o querer/A teu lado sendo desejo/ Sou tua sem pertencer/Acaso em liberdade/Agora e em eternidade.
} 
memórias da história humana, vendida e negociada entre as esferas particulares, pública e nas interfaces atuais da mídia e o processo de midiatização cultural. ${ }^{360}$

Vivemos uma midiatização intensiva da cultura e da sociedade que não se limita à formação da opinião pública, mas atravessa quase todas as instituições sociais e culturais. Cada vez mais, outras instituições necessitam de recursos da mídia, incluindo sua habilidade de representar a informação, construir relações sociais e ganhar atenção com ações comunicativas. Devido a esse desenvolvimento, precisamos analisar o papel da mídia em vários contextos sociais, com uma ancoragem mais sólida da teoria da midiatização na teoria social geral. Inspirado pela teoria de estruturação e pelas lógicas da perspectiva institucional, as mídias são entendidas como estruturas que condicionam e permitem a ação humana reflexiva. ( HJARVARD, 2014 ).

Assim sendo, ainda sobre os campos, apontados, poderemos considerar que:

"Tanto nas ciências como nas artes, o conceito de campo acabou com a noção romântica e individualista do gênio eu descobre conhecimentos imprevistos ou cria obras excepcionais. Isso sem cair, tampouco, no determinismo social. Ao cingir-se à estrutura interna de cada campo e às regras específicas para produzir arte, literatura o ciência, a pesquisa sociológica superou as pretensões de explicar a criação e o saber a partir de coações macrossociais, como o modo de produção ou a classe. As obras e as práticas dos artistas estão condicionadas não pelo todo social, mas por esse conjunto de relações em que interagem agentes e instituições especializadas em produzir arte, exibi-la, vende-la, avalia-la e apropriar-se dela. Graças a Bourdieu, saímos da oposição abismal e abstratas entre o indivíduo criador e a sociedade capitalista para compreender as tensões entre projetos artísticos e condicionamentos concretos de galerias, museus, críticos, colecionadores e espectadores. "(CANCLINI, 2012,pg38).

Portanto, ficam as perguntas a serem desenvolvidas, de como estamos produzindo, exibindo, vendendo e avaliando e nos apropriando da vida e de que maneira as relações estabelecidas desse produto está consumindo e se consumindo, sobre o desejo de sobreviver. Campos ou mundos da arte - Howard Becker, músico e antropólogo considera que a produção da arte é uma atividade em conjunto, como uma orquestra, sendo necessário todo um contexto, desde o criar da produção, a circulação e a apropriação, em um ângulo de visão que considere a perda de uma legitimidade da independência e autocontenção das práticas artísticas como único modo de se dizer, o que é a arte, e em nossa análise de estudo, o que é a vida como ação comunicativa, sendo propriamente a comunicação translúcida.

\footnotetext{
${ }^{360}$ Neste ponto ver artigo de Stig Hjarvard, citando inclusive Martin Barbero, quanto a noção de mediação; in Revista Matrizes V. 8 - № 1 jan./jun. 2014 São Paulo p. 21-44
} 
Entre teoria da arte e estética? Poderemos observar em diferentes culturas orientais ou ocidentais, o caminho de vanguardas conforme Canclini aponta, cultivando diferentes tipos de beleza, do estranho, bizarro, assim como também do sensível. Propuseram então chamar de teoria da arte, em vez de estética, o que poderia guiar diversas práticas artísticas. Mas, quanto ao fato de ser teoria, o próprio autor pondera que será mesmo que poderemos nomeálas assim, sendo, estas seriam o que se apresenta como um encadeamento lógico de proposições capazes de serem contrastadas com referentes empíricos e que aspiram à universalidade? Os movimentos de vanguarda do século $\mathrm{XX}$, ao relativizar os valores estéticos e a fundamentação do gosto, admitiam a existência de múltiplas poéticas. Ao colocar, acima da representação a experimentação nos modos de representar ou aludir ao real, perturbaram a ordem clássica e o museu como templo de consagração e exibição da arte. Acabaram desconstruindo o sentido autônomo da arte e o relato que havia organizado seus vínculos com a política, o mercado e a mídia.

E, fico pensando em meio a tantos modos de ver a arte, sobre o que dela poderemos encontrar na mídia, ou midiatizações culturais, em forma de relações com a vida. Como venho de um pensar a arte, exposto na dissertação do mestrado, como presença no mundo, em uma autonomia, pelo fato de estar engendrada não somente no humano, como modo de ação, cada vez mais vejo a proximidade da arte com o modo de ser da mídia, em vazão de relações comunicativas que nos tempos atuais ressoam os gestos dos agentes, ambiente e público em interfaces que não se fragmentam, mas se entrelaçam.

Da crítica a gestão. Em diálogo, Bourdieu e Haacke. Bourdieu "Um pensamento verdadeiramente crítico deve começar por uma crítica dos fundamentos econômicos e sociais mais ou menos inconscientes do pensamento crítico" Gerir a cultura e comunica-la sobre circuitos. A obra de dizer -“O que se conta, e ( ou ) a maneira como se conta. p. 42/ arte e jornalismo? “O conjunto está inevitavelmente impregnado de significações ideológicas.” Segue trecho de citação, -Objeto transversal -

Na confrontação com a sociedade, e com o que as ciências sociais revelam dela, a estética sobrevive não como um campo normativo, mas como um âmbito aberto em que buscamos formas não separadas radicalmente de todo tipo de função, representações mais interessadas no conhecimento inclusive do que não existe - do que na verdade, experiências despreocupadas por algum tipo de transcendências e interessadas em abrir possibilidades em um mundo sem normas preestabelecidas. Mais do que uma estética como disciplina, encontramos o estético como uma reflexão 
disseminada que trabalha sobre as práticas ainda denominadas artísticas e que explora o desejo ou " a vontade de forma. (CANCLINI, 2012, p. 44).

Na busca de definições - o que é arte? Estéticas filosóficas como uma definição universal, outros definem como sendo o discurso, o que a define, ou ainda segundo a corrente antropológica, como os artistas se comportam e o que eles representam. Estéticas filosóficas : o que é arte. Semiótica: o que a arte diz e de que estamos falando quando falamos de arte, Antropologia: O que fazem aqueles que se chamam artistas, pondera Canclini. A falta de lugar do que é livre. "A arte ficou desmoldurada porque, como veremos, as tentativas de ordená-la sob uma normatividade estética ou uma teoria sobre a autonomia dos campos (Bourdieu) ou dos mundos (Becker) quase não funcionam. “

A condição da arte. Do gosto, da ética, e dos museus, dimensões contemporâneas. O dilema do que fica na história das artes. Porque uma pintura é melhor do que outra, pergunta o texto. Sem querer ficar me repetindo, mas em minha opinião, para o dilema de culturas em Arte, deve-se ater ao que a configura como os seus elementos de base, a sua gênese, que cada linguagem tem, independentemente em que cultura esteja se manifestando. A face das instituições como museus, ainda permanecerão as mesmas em tempos de tantas interseções com o modo de ser da cidade contemporânea?

“Pode se falar de patrimônios autênticos? É desejável que permaneçam intactos, sem serem usados? Novas perguntas para este tempo? “Um mundo acaba não só quando preciso arquivar as respostas, mas também quando as perguntas que as originam perdem sentido “/ ou não perdem, mas precisam de um novo significado. Poderia ser uma constatação a crise de identidade de áreas como, nos coloca Canclini ao dizer, “ Os antropólogos duvidam que seu objeto de estudo possa chamar-se cultura, os museólogos não conseguem expor esse objeto que acumula centenas de definições, tantas como as de arte, e os especialistas em patrimônio reiniciam, a cada ano, a tarefa de justificar sua defesa e preservação "Se, a arte está entre o objeto que é a representação do seu tempo, representando-se obra, suas indagações sobre seu modo de ser, ou o que a define está intrínseco ao tempo vigente que a circunda, portanto, também, o lastro do cronos, em diálogos como Kairos sempre haverão de sustentar o seu pensar de razão de identificar-se seja como produzindo, em sua circulação, ou em qualquer momento de sua presença, que não está restrito nem somente a seu modo 
interno, nem tão pouco as relações que estabelece do âmbito social, mas muito provavelmente na interface dessas conjunções.

A troca da pergunta estética precisa se encarregar ao mesmo tempo, de como vai se transformando a indagação pelo social. A partir da redefinição do artista como produtor (Benjamim e os construtivistas) trabalha-se considerando o processo de produção-circulação-consumo. Para esta revisão contribuem aqueles que definem o artista como etnográfico ou antropológico, assim como o reposicionamento da arte no debate sobre a identidade, a alteridade, a multi e interculturadade. A pesquisa destes processos modifica a agenda da antropologia e de outras ciências sociais: admite-se que não se pode entender o socioeconômico sem o cultural, nem ao contrário, passa-se do estudo de culturas locais e nacionais a processos de interculturalidade transnacional. (CANCLINI, 2012, p. 49)

Expressão dos desejos - autoria compartilhada com o público

Todos os propósitos da arte de diferentes épocas subordinam-se à tendência de ampliar a participação. [...] Mais do que obras e espectadores, encontramos fluxos que circulam através de objetos, pessoas e imagens. [...] Democratiza-se a inovação, encontramos em uma era de inovação aberta e multidirecional. $\mathrm{O}$ uso abundante de noções vagas e imprecisas como multidão não ajuda a definir o caráter dos atores nem das interações na rede, nem encontramos ainda conceitos apropriados para avaliar sociológica e esteticamente o que é criativo e inovador nesta ecologia comunicacional. Os novos hábitos gerados nos usuários da rede e as misturas de formatos e alianças entre produtores de conteúdos visuais, textuais e software estão incidindo nos espaços da arte, desde os museus até as bienais, as feiras e os sites especializados na internet. Alteram-se neste processo os vínculos entre criação, espetáculo entretenimento e participação, entre o que até poucos anos atrás se organizava sob as categorias de culto, popular e de massa, entre o local, o translocal e o global, entre autoria, reprodução e acesso entre elaboração simbólica e intensidade da estimulação sensual direta. [...] As muralhas entre gêneros, entre arte e publicidade, entre jogo e reflexão, desmoronaram. ( CANCLINI, 2012, p. 52)

Sobre o indagar , toda procura retira do procurado sua direção prévia. “ o que é a arte, dela poderemos indagar e inferir o seu modo de ser...Necessidade de existir, para além das críticas.

"Existem teóricos que declaram na passagem do século XXI uma etapa pós-autonoma, chamando inclusive de espetáculo para turistas, em razão do espaço do museu ter sido completamente desintimizado e os artistas junto com os diretores de museus, leilões e indústrias do entretenimento e da memória serem homens de negócios internacionais que 
oferecem serviços para milhões de japoneses, chineses, australianos e outros que visitam os museus sem acreditar na arte, de modo semelhante a como visitam igrejas sem confiar nessas religiões "( CANCLINI, 2012 )

Sobre literaturas pos- autonomas - Josefina Ludmer ( crítica argentina ) / ficção e realidade. Ela coloca que, para essas escrituras a realidade ( caso se pense nela a partir da mídia, que a constituiria constantemente ) é ficção e a ficção é a realidade, como se evidenciaria na mistura de relações referenciais ou de verossimilhança no testemunho, na autobiografia, na reportagem jornalística, na crônica, no diário íntimo e até na etnografia, todo o cultural é econômico e todo o econômico é cultural ( e literário ), como se observaria no fato de que as próprias empresas transnacionais igualam a produção de livros, jornais e programas televisivos. Conclusão: vivemos em uma continuidade de realidade-ficção, onde mesmo as obras que aparecem como literatura não podem ser lidas com critérios literários, como autor, estilo, texto e sentido.

Frestas entre muros?

Na sociedade e na arte, onde está uma suposta autonomia? Ela realmente é uma conquista almejada, compartilhada e necessária, ou ela se faz onde se pode achar que está sendo diluída?

O espaço restrito ao universo particular, tido como galerias, museus, e o próprio criar do artista se viu em cheque, posto a prova, de sua real sobrevivência no através do momento contemporâneo.

Contudo esse conjunto de observações mostra que as obras se fazem e se reproduzem em condições variáveis, que os artistas, os críticos e os curadores atuam dentro e fora do mundo da arte. A pesquisa não pode impor-lhes nem as restrições de um campo que eles já não aceitam murado, nem a dissolução em uma totalidade social em que já não se cultivariam linguagens e práticas de comunicação diferentes. É legítimo falar de uma condição pós-autônoma em contraste com a independência alcançada pela arte na modernidade, mas não de uma etapa que substituiria esse período moderno por algo radicalmente diferente e oposto. (CANCLINI, 2012 p. $55)$.

O desafio observando-se: coabitar

A reelaboração da teoria estética e da análise crítica precisa se encarregar das múltiplas pertenças e das localizações móveis de atores que exibem a arte ao mesmo tempo nos museus, na mídia, no ciberespaço e nas ruas. Esse processo mantém certo gosto pela forma tanto nos espaços próprios 
como em outras zonas onde as imagens se fazem visíveis e as escrituras legíveis sob uma normatividade heterônoma. ( CANCLINI, 2012, p. 55)

No mercado, as ofertas do individualismo regateando seu estado de um pragmatismo social. Qual o lance ou o preço? Se está indo a leilão, ou anunciando em jornal ou web, depende... talvez o que cair na " rede " é peixe! Será? Sobre os moldes de um design enquanto caminho, as práticas e desenvolvimento da arte, ou de um viver, está sobre a ótica de uma arguição de estados participativos ou de retração, que impelem a sua real identidade, mesmo que afetada ou produzindo influências que vão de fato a marcarem o seu modo de ser, ainda que, não como princípio em desenvolvimento mas que vai se constituindo em progresso com as relações estabelecidas, ou seja, um organismo que se constrói em movimento, de forças internas e externas, elementos próprios e ressonância de si e em relação., gerando seu estado de composição no tempo. O lugar do valor.

Como determinar na propensão do que se constrói em relações estabelecidas dentre uma característica do possível, ou seja, frente a uma maleabilidade que se expande, o que virá a ser relevante em termos de valor de obra? Críticas a obra de Bourdieu são apontadas justamente por considerar que em certa medida o automatismo favoreça um estigma de valor somente por critérios editoriais, prescindindo dos aspectos ressoantes que poderiam se firmar junto a um público, ou ainda, que essa relação de ressoante estaria nessa relação com o público induzida por aspectos publicitários, talvez por determinações apontadas por pesquisas mercadológicas. “

No entanto, há algo desse fenômeno que cada época chama de arte que não é em tomadas de posição dos artistas e em estratégias de distinção dos compradores e dos públicos. [...] "o discurso estético idealista, que deixou de servir para representar o processo criador, recicla-se como recurso complementar destinado a garantir a verossimilhança da experiência artística no momento do consumo. ( CANCLINI, )

O poder da iminência, seres imaginários alusão à Borges,:““ estes dados sugerem que a muralha no espaço e o incêndio no tempo foram barreiras mágicas destinadas a deter a morte “CANCLINI, 2012, p. 61.

Do pensamento e da alma - muralhas erguidas sobre o espírito do tempo, entre frestas absorvem a alma da eternidade, que perpassa o presente. 


\begin{abstract}
A literatura e arte dão ressonância a vozes que procedem de diversos lugares da sociedade e as escutam de modos diferentes de outros, fazem com elas algo distinto dos discursos políticos, sociológicos ou religiosos. [....] Talvez sua especificidade resida nesse modo de dizer que não chega a se pronunciar, nessa iminência de uma revelação. Encontro um antecedente desta procura na frase escrita por Walter Benjamin quinze anos antes de Borges, em 1935, ao definir a aura da arte como " a manifestação irrepetível de uma distância. (CANCLINI, 2012, pg 63).
\end{abstract}

"Fundo de silêncio que não deixa de rodeá-la, sem o qual ela não diria nada, ou inclusive desnudar os fios do silêncio com os quais se mistura[...] Assim, acrescenta uma nova dimensão a este mundo seguro demais de si fazendo vibrar ali a contingência" (CANCLINI, 2012, pg 63)

Quando Benjamim, Borges e Mearleau Ponty escreveram textos para delimitar os territórios da arte e da literatura, existiam museus, mas não as quase duzentas bienais e feiras de arte atuais, nem os mercados artísticos e literários se misturavam com a mídia, o turismo, a expansão e a decomposição urbana, as migrações globais e a rede digital. Era mais fácil então, como fez Merleau Ponty, valorizar os gesto dos artistas e opô-los como estranhos e alheios, aos museus e demais instituições que transformam dizia ele, tentativas em obras (CANCLINI, 2012, pg67)

A criação e os museus. Museus à espaços cibernéticos abertos, são decifráveis como possível para visitação atual, em criação de um novo espaço que configure o trajeto de obras expostas, representando uma posição do olhar, em tarja que ainda sobre a instituição um tanto quanto não visitada, adormece em Valium da sociedade, esperando as conjecturas da imagem e da intersecção dos campos físicos e vituais, mais evidentes =ara um turismo, onde os museus do efêmero ressoem um gesto que marca os arquivos, sendo o desejo que permanece na mente, na observação que emerge em referência do cotidiano visitado, em confluências dos sites de artistas, que permeiam, galerias esmerando um caminho, onde a sociedade do amanhã, ingere o gosto de não se reconhecer em territórios ainda não reconhecíveis como identidade. Como arcos do tempo, ao som do Cello, poderemos compreender das águas da nossa existência atual sobre as marés do que é do universo das redes e do campo fático museológico na conquista de desbravar uma permanência em sentido, talvez compreendamos o que pode ser da natureza do som, natureza da Natureza, e dos artistas e instituições, permeando-se espaços compartilhados para sobreviver em porvir, ou buscar uma razão que constitua um transito de passagens para que o desejo permaneça, 
sobre o astuto olhar humano de ainda ser vanguarda sobre a égide de se reconhecer, imagem do seu tempo, e emissão ${ }^{361}$ do seu significar-se.

E o espaço físico como lugar de re (pensar).

Quando a matéria da obra será visitada em mobilidade. A aproximação de espaços.

Dos museus, artistas e obras.

Embora tenha reconhecido que toda cultura continua o passado" e que a invenção de sentido de qualquer obra artística seria impossível sem o que foi constituído antes na história social e pessoal, ao sobrevalorizar o acontecimento a respeito das estruturas julgou que o Museu mata a veemência da pintura, transforma esta historicidade secreta lúdia, não deliberada, involuntária enfim, vive em história oficial e pomposa .[...]Dos lugares que permanecem construindo-se marca do pensamento da época ( Unesco ), " A discussão sobre a originalidade e a singularidade de certos bens culturais não preocupa apenas as estéticas dedicadas a justificar a existência de obras artísticas. Estende-se, como sabemos, a sobrevalorização que cada etnia, classe ou época fazem sobre sua própria cultura. Também aparecem de outro modo, nos organismos e nas doutrinas que, buscando superar o etnocentrismo constroem critérios de hierarquização com pretensões universais. Um deles, é programa sobre patrimônio da humanidade criado pela Unesco em 1972, interessa-nos por ser uma tentativa de organizar as diferenças, classificar os objetos e os lugares, intervir em sua difusão e interpretação. Além disso, fornece material para analisar conjuntamente o que o saber científico e a reflexão artística, o trabalho com conceitos e metáforas, podem fazer com as tensões entre inovação e consolidação cultural.pg 68

Pluralidade das culturas . O que capacita algo que virá a ter o caráter de universalização. Em Canclini, a reflexão, de valores determinados por que razões.? - O lugar de uma cumplicidade social? Estaria na internet a vazão de uma democratização de patrimônios, ou, ainda, a ser diagnosticado os restos dos arquivos descartados frente ao tempo e ainda não inseridos como parte de uma memória? Ou seja, do que será preservado como marca deste tempo, em espaço " democrático" de participação enquanto "minorias", que constituem a presença de uma lacuna antes simplesmente não elegida como voz, do patrimônio social ainda que constituinte dele. Mensurar relevância informacional como vestígio, lastro, será fator integrante do patrimônio sócio cultural deste tempo? E de quanto isso pode ser

${ }^{361}$ Composição corpos ressoantes, em vídeo apresentado: https://youtu.be/T-6ZClMrO7Ue

https://youtu.be/JXNKVUiAOD4 Caminho do tempo 
consenso adjacente para as suplicas existentes em caráter de emergências do sobreviver de qualquer natureza orgânica do mundo, estejam em que lugares possam se tornar visíveis.

Os bens reunidos na história por cada sociedade não pertencem realmente a todos, embora formalmente pareçam ser de e estar disponíveis para todos. ( quanto ao re( pensar) e igualdade de herança cultural e novos papeis museológicos em rede de conhecimento para compartilhamento de espaços do viver contemporâneo. ). Ao analisar como se transmite o saber de cada sociedade nas escolas e nos museus, vemos que os grupos se apropriam da herança cultural de modos diferentes e desiguais. As pesquisas sobre públicos de museus mostram que, a medida que descemos na escala econômica e educacional, diminui a capacidade de apropriação do capital cultural transmitido por essas instituições. Patrimônio da " humanidade " ou um mapa restrito e constrangido a permanecer sobre uma mesma geografia em tempos de meandros geopolíticos de multiculturalidade? " A ambição de constituir um patrimônio da humanidade não faz senão ampliar essas desigualdades e contradições, embora os propósitos declarados pela Unesco sejam altruístas. (CANCLINI, 2012, p. 73).

Sobre consenso e discordâncias até dos bens culturais os parâmetros para discernimento são importantes. Como mensurar em igualdade para diferentes culturas o que é historicamente relevante com patrimônio histórico?

Reinterpretação - Dos sonhos e das muralhas

Em 1987, uma China que se abria ao comércio internacional e aos investimentos estrangeiros conseguiu que a Unesco incluísse a Grande Muralha na lista de Patrimônio Cultural da Humanidade. Um muro que separa, construído para distanciar a China do restante dos homens, pode ser considerado patrimônio de todos? Em abril de 2009, quando visitei a muralha, a sóbria placa de $2 \mathrm{~m}$ por $1.50 \mathrm{~m}$ que creditava a distinção da UNESCO contrastava com o gigantesco cartaz, datado de 2008, e colocado mais acima, em um dos morros por onde passar o muro com o logo das Olimpíadas celebradas naquele ano na China: "One world, one dream " Por que todos temos que ter um mesmo sonhos?( CANCLINI, 2012, p. 79)

Sobre a matemática da vida, conjuntos e subconjuntos, da diversidade para a igualdade.

$\mathrm{Na}$ busca da chave para resolver ou amenizar conflitos culturais. Espaços vazios cheios de escolhas - a face do dissenso.

Cenários atualizados frentes a mobilidade e propósitos atuais.

Em Canclini, se coloca duas possibilidades determinadas como dominação e subjugação, onde os tecidos de cenários atuais consideram objetos de negociações para um desenvolvimento, que, penso ser de uma forma mais estratégica quanto a necessidades e 
recursos, movimentos que supram uma demanda diversa que supõe não ser somente estruturada por um corpo-nação somente mas pelo alcance que supra justamente uma organização das esferas tanto do que é mais individual (nação) como da globalização (público - mundo), mas que respeite identidades para vislumbrar um mercado que justifique ações participativas de apoio ao que de fato é inserido nessas esferas múltiplas, como o que deverá dar suporte as emergências de um todo, justificado pela face da sobrevivência.

Talvez considere relevante, ainda que se busque como apontado, uma universalização dos produtos, mas diferentemente, uma possibilidade dentre essa perspectiva que seja, ainda que caminhando em diferentes territórios manter um diálogo de identidade ou seja, um atravessar que instiga por curiosidade, do diverso, mas que possa ter elementos de relação de afinidade, como produto de nosso tempo, narrando uma dramaturgia que das cenas possam extrair personagens múltiplos ou "núcleos " de políticas internacionais, dispostos a enfrentar esses estados participativos para encontrar um público agente e personagem que assiste suas parcelas em desenvolvimento dispondo canais de acesso a interpretação do que será marcado como identidade dessa geração ou gerações, onde o tão antigo conhecer o outro, passará diante dessa sociedade vigente a ser condição para conhecer a si próprio como observador dessas esferas nas quais está inserido.

Estaria tão distante do modo de ser atual entre as esferas das particularidades de nação e de globalização assim, os seres de ovídeo, ou é ainda difícil perceber que nos escrevemos em metamorfose a muito tempo, permanecendo em relação com parte de nós mesmos, e que em constatação dessa possibilidade se agarra a uma determinação de identidade de " raiz", que sabe que suas sementes se espalharam como o próprio voo dos pássaros....

Desafios e constatações:

A desigualdade na produção, na distribuição e no acesso aos bens culturais não se explica como simples imperialismo ou colonialismo cultural ( embora subsistam esses comportamentos ) mas pela combinação de processos expansivos, exercícios de dominação e discriminação, inércias nacionalistas e políticas culturais incapazes de atuar na nova lógica dos intercâmbios.[...] Sobre uma permanência efêmera, considera: [...] Reformulam-se então o estudo e a gestão do patrimônio, não só como gestão do patrimônio, não só como conservação e consagração de peças com valores extraordinários, mas também como participação nos dilemas cognitivos, éticos e sócio-políticos da interculturalidade. (CANCLINI, p. 94) 
Alerta ainda o autor " Enquanto esse governo não existir , uma concepção não etnocêntrica, nem meramente culturalista ou mercantilista, deve prestar atenção a muitas formas de valorização das práticas humanas e a seus modos de se combinar e de se confrontar."

$\operatorname{Re}$ ( considerações ) do próprio e alheio - Desafio contemporâneo, justamente é ponderar dentre um equilíbrio desde onde pode ser uma individualidade, ou uma esfera particular, que talvez como fractal social se desmembra sem deixar de ser em um organismo que cohabita, permeia-se justamente engendrando-se pelo virtual, pelo social, pelas redes de sentidos, significados e relações cada vez mais, e nessa via de mão dupla se estende em transito como passagem que recolhe seu destino na procura de compreensão do estado vigente capaz de elucidar em que ponto se encontra se margeado por suas linhas "digitais" enquanto comportamento de individuo e particular, ou mais colaborativo e inserido na esfera pública e para além dela globalizada, portanto, em que medida se mensura não o indivíduo, ou a esfera particular, mais sim, e justamente o que pode ser de quanto se está mais cerceado por si enquanto ego de uma sociedade, ou fluxo continuo de um entre que mensura-se por condutas que vem a ( podendo ou não ) alterar o estado inicial ou constituindo- o até em base estruturais, portanto, o que se tem a intensão de apropria-se enquanto objeto do viver, e promoção de uma cultura de nosso tempo, talvez seja observar como esse corpo múltiplo e integrado, se manifesta e se conduz, em uma orquestração de vozes, para que não se perca a harmonia e se aproprie de fato de uma identidade construída nessas relações. Procurando gerar uma gestão do patrimônio como humanidade, desperta para os valores intrínsecos e em expansão dos "circuitos" de conexões estabelecidos em tempo real de uma propulsão de ideias participativos de maneira concreta para soluções de emergências dos dissensos do nosso modo de ver os entrelaçamentos de culturas frente o respeito e a preservação de um rumo "igualitário", que compreenda diferenças, mas promova uma razão condizente com os propósitos que favoreçam sanar dificuldades globais.

Como se constrói uma marca artístico - patrimonial é um questionamento de Canclini, e " Como construir uma visão de validade universal que inter-relacione , culturas diversas, permita compará-las e encontre um denominador comum sem desconhecer sua singularidade ?".

Tecnologia e sociedade, as esferas públicas e privadas, nos dilemas vigentes participativos e no tocante ao respeito da integridade na construção de uma identidade.- metafisica do tempo, o que nos lembra, Magritte em real e virtual como cenários do tecido do mundo, 
coxias do palco contemporâneo - monotipia. Verso e re(verso ) de um através. Aponta-se para diálogos ou metamorfose, no que considero, diálogos e metamorfose.

Museum - moviment - musement - space. Caminhe pelo pensamento do sentimento - art and cognition, promovendo um Virtual contemporary space - art and cognition - Walking through... Olhar que se apresenta em desafio, na presença do desejo ${ }^{362}$ “ Também poderá entrever como.... the sound of feeling. o olhar sobre " os outros " foi sendo construído, mistura de curiosidade e conquista. " . Em meu pensar na linha do tempo - estar. Com proposta de linhas e formas - para além do uso - no através do tempo - novas reconstruções como um etnodesign., em relação, a visitação de um museu etnográfico deveria compor um universo paralelo atualizando formas, e pensando em conjunção ao dizer de um museu etnográfico nãos tempos atuais, as marcas do nosso tempo, e design como caminho, sendo então, uma atualização do lastro do nosso pensamento, em possibilidades de reconstruções atualizadas em nossos " dispositivos" organizacionais da sociedade - museografia polifônica, uma cultura organizacional de nações de uma face multicultural, entre limites de se compreender e constituir-se, continuamente desafiando-se, modos de ser participativos e vigentes. Em estar.com, desafiamos o pensamento:

Distante ou perto, perder-se ou se pertencer, ao ser parte conectada ao outro. Incerto. Estaria aqui um lugar de aproximação da Filosofia e da internet. Estranho? Depende. Se puder, olhar o pensar, como o modo de ser, da própria vida, veremos ainda mais diálogos em conexão. Solidão, o que pode me dizer, de seu mudo gesto? Talvez, indagando-nos sobre atos isolados, em face interna ao exterior de mim. Pode-se imaginar, ( e de todo real ) a pessoa “ desligar-se" de seu ambiente e vagar por outro território d( $\mathrm{n}$ )a mente? Familiarizado com processos criativos, o artista sente-se muito confortável, nesse olhar, ou perspectiva, porém, retornando ao ponto, em paralelo com o chamado uso das mídias, a escuta de nós mesmos, ou diálogo de nossa face em desvelamento costumas absorve um mundo de conjecturas que se estabelecem por cenas cotidianas que abarcam desde, família, trabalho, ambientes do possível gesto urbano do pensamento construindo-se memórias, histórias, time- line, dizendo-se. Por certo, quem por vezes possa estar nos observando, atem-se ao talvez, "olhar perdido", será mesmo perdido? Estaríamos vivendo paralelos de percepções onde como dizia Empédocles, “O mesmo é conhecido, apenas a natureza pode entender a si mesma, apenas a natureza pode se aprofundar em si mesma, mas também

\footnotetext{
${ }^{362}$ Aspectos a serem contemplado na leitura de Sobre el deseo, por qué queremos lo que queremos, de William Irvine.
} 
somente pelo espírito pode ser apreendido, em o mundo como vontade e representação de Schopenahuer... "Estaremos co- habitando uma mesma atmosfera, o mesmo, que possui em igualdade o entrelaçamento de espaços mentais e virtuais em comportamento similares? Talvez o sentido, a poesia como caminhar pela metáfora, possa nos dizer sobre, significar. De tudo a solidão pertence, como (, ) o) existir no mundo.

A Solidão, pergunta antes mesmo que eu indague, por onde de mim estou? Talvez assim me aproxime mais de sua face. Minha face se assemelha com o vazio, onde tudo pode ser como a lua, em estado minguante ou crescente, na imensidão do corpo celeste, para compreender que o vazio observa a completude dele mesmo, ou ainda, a solidão poderá ser o momento em que a voz da natureza me revela suas palavras, onde cada forma que contemplo se desenha em mim, parte do silêncio que ouve de si o que permaneceu em mim, onde passamos a perguntar se vamos ficar até a hora das estrelas.

O trajeto de suas apropriações - ( entre ) - sociedade - consumo - desejo do olhar.

Tramas sociais sobre timbres sensoriais - "Entre o visível e o invisível / " Se o que se considera experiência estética em sociedades não ocidentais tem a ver com a relação entre o que se domina e o que escapa, entre o visível e o invisível, entre as forças dos homens e da natureza, encontramos certas familiaridades entre essas artes primeiras e as artes contemporâneas. A especificidade da arte atual consiste em trabalhar, dizíamos antes, com a iminência de uma revelação, em insinuar o que não se pode dizer. Isto não nos autoriza a ignorar as diferentes práticas dos artistas e seus modos de inscrever suas obras ou performances em tramas sociais distintas. $\mathrm{O}$ problema é como interpretar as continuidades, as coincidências e as discrepâncias entre o que nos objetos etnográficos e nas obras de arte valorizamos pelo que não conseguem dizer. (CANCLINI, 2012, p. 109).

Do erudito ao popular. ${ }^{363}$ Cores tem pátria? Entre tons - Tom da bossa. Ritmo nas cores do sujeito mundo - imagens - coração vaga(b)mundo ${ }^{364}$. itinerante olhar.

Dilemas não resolvidos da interculturalidade. Entre a tolerância e o direito de viver.

A “ noite escura da alma ", e o nascer da meia noite.

\footnotetext{
${ }^{363}$ Arquivos de som da pesquisa sonora, o percurso de uma voz. Do canto, desmembramento para composição erudita e ressonância em articulações de letra e musica popular. Ver também, Tame, David, capítulo, a música comunicadora e multiplicadora de estados de consciência, p. 163, ed Cultrix. E no mesmo livro, Scott Cyrill, its Secret Influence Throught the Ages, Handel sobre os efeitos da música em uma sociedade.

${ }^{364}$ Menção a referência de Chaplin e o mudo gesto do cinema que ressoa por entre as palavras do silêncio.
} 
Cada passo da noite arqueia meu gesto escorrendo, corpo denso da lágrima, estendendo-se margem dos teus braços que me recolhem para como pétalas desfolhar sobre as notas de cada sombra erguida pela tristeza da manhã que não quer deixar (n) o adeus dos sonhos para lhe acordar. Por onde ainda os passos podem me ver, sombra da madrugada, refez-me desejo ardente corroendo a própria fome do destino, que na busca insana de consumo se entregou a crença de existir em gratidão, de ao menos percorrer-se, ainda que sobre as agruras das memórias. De onde pode erguer-se sobre o lastro e ater-se ao nascente, sol das estrelas por entre a alma da noite.

A voz da metafisica do tempo - Chaplin ${ }^{365}$ - o gesto mudo que entoa o silêncio do drama. A cena da noite de janelas vazias, o efêmero adeus. Reaprender com as palavras do silêncio, onde os olhos atravessam os significados da alma. Do corpo da sociedade. As palavras por escrever, dispostas por vezes por sinestesias a se tornar visíveis entre culturas e povos. ${ }^{366}$

Entre, conceitos e metáforas...

Ação cultural - operando com o movimento das metáforas - " Não seria preciso cindir os conceitos das metáforas. É possível na linha de um pensamento nutrido pela hermenêutica, registrar aquilo que os entrelaça. A interpretação - essa operação conceitualizante - não deve destruir a densidade e a diversidade de experiências enunciadas nas metáforas. Ao contrário, o diálogo destas com o trabalho conceitual tornam-nas mais precisas, evitando o risco de nos perdermos na abundância da significação. Paul Ricoeur afirma que a metáfora, além de vivificar as linguagens construídas incita a pensar mais, compreender o que podemos nomear junto com o que a poesia esboça ou anuncia. Os conceitos, por sua vez, não são apenas operações objetivas e delimitadoras. Nunca terminam de fixar o sentido dos fatos porque eles próprios não estão fixos. Desconfiamos das visões sedentárias dos conceitos: todo conceito tem uma história mostraram Gilles Deleuze e Félix Guattari, provém de outros conceitos, é um ponto de coincidência, de condensação ou acumulação de componentes de outros termos, como um centro de vibrações cada um em si mesmo e uns em relação aos outros “. Nenhum momento de condensação é definitivo. Segundo Mieke Bal, os conceitos são ferramentas da intersubjetividade, pois facilitam a conversa, apoiando-se em uma

\footnotetext{
${ }^{365}$ Cinema " mudo "de Charles Chaplin.

${ }^{366}$ Observar sobreposições - John Zorn - Between Two Worlds [Nova Express 2011- Great Masters of the Oud A tribute to Nasser Shamma e também, Phillip Glass, e concerto para acordeon, Nicolai Chaikin e Scherezade .
} 
linguagem comum. Esperamos que os conceitos sejam explícitos, claros e definitivos, mas os conceitos viajam de uma ciência a outra, entre a ciência e a arte, entre o patrimônio e os usos,. Vão se formando em contextos, segundo a focalização móvel que efetuam entre objetos que mudam. Os conceitos não são representações verdadeiras de uma vez para sempre, nem sua adequação é realista mais resultado de aproximações que procuram a organização efetiva dos fenômenos, uma organização atrativa e que produza informação nova e relevante. (CANCLINI, 2012, p 122)

Do pensamento à conduta:

Os conceitos são teorias em miniatura, úteis sempre que estivermos dispostos a revisar sua produtividade e admitir seu desgaste. Um conceito pode ser visto como condensador de sentidos flexíveis. Diferencia-os da grande teoria $o$ fato de não estarem obrigados pela rígida vinculação entre propostas, os conceitos são centros de vibrações, cada um deles por si próprios e em relação aos demais, os conceitos ressoam com intenção de serem coerentes. ( CANCLINI, 2012, p 122).

No livro, aborda-se o fato de que a arte trabalharia com a iminência e que o patrimônio com o que está em perigo ou de desaparecer. E, a frase que diz que a prática artística não inaugura o sentido, a meu ver, é dissonante, e também penso que a arte pode ser vista como uma compreensão de um patrimônio que se estabelece não somente como as obras expostas na linha do tempo da humanidade e dos registros dos museus, galerias ou bienais, mas sim propriamente, e principalmente como o que de fato é a meu ver, a arte sim criadora de sentido, e mais além sendo o desenvolvimento de reflexão de um patrimônio que vem a ser como o homem está vendo e agindo em seu tempo presente. A perspectiva de patrimônio aqui se aplica ao modo de que o pensamento se faz diagnostico de ações, relações sociais, permeadas, sim, por não se perder o sentido do que concebemos como belo ( admirável ), como objetivo a ser alcançado por formas ( ágape- arte como a vida ), traços de nossa trajetória, para que os valores humanos não desapareçam.

Bourriaud, propõe uma noção de arte relacional examina modos de intervir nas interações humanas e no contexto social, e esse autor considera que desaparecem certos caracteres do âmbito histórico que tanto tornou evidente o sentido independente da arte moderna, porém não cessam o espírito que justamente a animava. O que se pode fazer, e o que se pode fazer com, são alterações de questionamentos que Bourriaud sugere estar na égide de uma sociedade " concebida de modo aberto ". Não se preocupa tanto com o que pode ser criado, mas sim, com o que em sobre sinais de emissão podem ser re(modelado), conjugados, em conjecturas novas ( heurística de relações ) antes não percebidos, ou manejados dessa 
maneira, assim sendo dessa nova forma colocados em cena. " Esfumam-se as fronteiras entre produção e consumo “. E, em uma definição mais fidedigna do conceito de arte segundo Baurriaud, teremos que, " a arte é uma atividade que consiste em produzir relações com o mundo com a ajuda de signos, formas, gestos ou objetos “( CANCLINI, 2012, pg132)

Sociedade passada a limpo?

Das patologias sociais - o preço da morte. Redefinindo aspectos do patrimônio enquanto a arte em uníssono com a vida.

É possível redefinir o que nas sociedades atuais se entende por arte como fizemos nos capítulos anteriores, segundo suas diferenças com o patrimônio, com os objetos etnográficos e com as marcas dos produtos, sem depositar nenhum valor essencial a esses traços. [...] Interações humanas e em seu contexto social mais do que um espaço simbólico autônomo e privado. Desapareceram, sustenta o autor, as condições históricas que tornaram possível a independência e a singularidade da arte moderna, mas não o espírito que a animava, agir em interstícios que escapem à ordem econômica, sugerir outras possibilidades de encontro cotidiano, comunidades instantâneas geradoras de formas não convencionais de participação. ( CANCLINI, 2012, pg 131 )

Salienta no livro, Sociedade sem relato, Canclini, a dizer que :" Bourriaud - já não é o que é o novo que se pode fazer, mas sim, o que se pode fazer com “.

E a dependência ( os marionetes ), dos fios conduzidos, a ponta. Mão dupla que não é vista. Entre o poder e a massa. O encontro cotidiano - perpassando os olhares que não são vistos pelo amortecimento tão parte já da pele, de que maneira uma intervenção pode ser observada ou realizada a ponto de que os olhos passem a ver e sentir?

A palavra arte" havia escrito Baurriaud em estética relacional - aparece hoje só como um resto semântico destes relatos cuja definição mais precisa seria esta: a arte é uma atividade que consiste em produzir relações com o mundo com a ajuda de signos formas, gestos ou objetos. O movimento - “ a arte viria a contradizer a cultura prévia que opõe as mercadorias e seus consumidores ". $\mathrm{Na}$ verdade, isso não deixa de exaltar a originalidade e a novidade, mas as transfere dos objetos para os processos, Ao realizar este deslocamento, exalta a valorização do movimento.Ao realizar este deslocamento, exalta a valorização do movimento, o desenraizamento e a precariedade. [...] De um lado, a proposta auspícia uma arte como forma de habitar o mundo, de outro, exalta a tendência de ela não residir em nenhum lugar.( CANCLINI, 2012, pg 132) 
O aparente, pode tudo em que pseudo estamos inseridos também me parece que se esgotou, há uma necessidade assim como das informações de se deter frente aos fatos, as propostas de processos artísticos que sejam de fato relevantes para um propósito mais coerente e que tenha um sentido mais unificador, ou ao menos que esteja sobre uma ramificação de uma rede de significados e sentidos.

Em uma estética relacional, que ( não por certo seja o sentido colocado no livro ), seria bemvindo me parece, constatar a possibilidade de engendramentos de áreas afins com o propósito de realçar, aprofundar relevâncias não despertas pelo olhar comum e amortecido, e nesse despertar, se aprofundar as conjecturas que podem nos expor a um novo e concreto agir da arte-relacional e participativa.

Existe me parece cada vez mais, e talvez essa palavra fique um tanto quanto recorrente, pseudo-participação política onde se insere uma possível representação e participação de voz, que não é ouvida, não é lida, não é quista, mas que tem o seu papel, afinal e dada como tal, mas quem não vive de aparências desta terra, então ficam subversivos toda e qualquer real e verdadeira vontade de se estabelecer um papel definido pela gênese social, e o que fazer diante de tal constatação? Se usam de mentiras para organizar a situação, esquecendose que em papeis trocados, também se caminha em areias movediças por onde não se poderá mais sair, ou então, irá se perecer. Os meios não justificam os fins, não se pode aferir ou vestir a máscara de uma sociedade para alcançar objetivos que precisam de verdade para serem expostos em sua nudez. Os organismos de poder, não necessitam exercer seu direito agindo como se fossem fraternos à participação do povo, mas sim, ouvi-lo de fato e verdadeiramente, sem lamentos, ou críticas de ambas as partes, mas em sentido de co-habitar uma razão de ser e existir.

O museu das ruas- Elitistas diz o texto, mas o que é hoje elitista, será o mesmo de época atrás, ou até mesmo o sentido de uma palavra pode se alterar com o tempo, e precisar de um novo dicionário. Quem sabe o diário de bordo de uma civilização poderá conter suas variantes. Por onde andarão as ruas que não passem a ser museu a céu aberto também, parte do vale tudo, ou a margem do vale tudo. Arte( in) visível de nossos dias reais, transpassando a poesia dos olhos abetos aos movimentos da coreografia do mundo, no palco do teatro de viver, escritos pela narrativa tão diariamente nos exigindo a reprodução da mesma temporada, ou o texto do próximo espetáculo que virá, então aonde estão os espaços urbanos de cadeiras vazias, repletas de atores, de mensageiros, de dramaturgos, de bailarinos, de 
cantores, do canto dos pássaros que mesmo mudos ensaiam seu voo diante de nossas cabeças, e que nem mesmo, paramos para ver. Acabou, o espetáculo apagou as luzes. Mas a noite, não fecha as portas, então o teatro fica aberto, a todos os que passam, e atravessam seus sentimentos, seus pensamentos, seus dizeres, em monólogos desse espaço vazio repleto de cada vez mais museus e vanguardas de nós, sem interlúdios, ou com, mas vivendo a razão de apenas ou deveras, sobreviver. Se a percepção estiver um pouco mais aberta, talvez as ruas tivessem um espetáculo elitista a ponto de que os marginalizados fossem em uma perspectiva inversa. E a qual perspectiva estamos vivendo, ou acaso quem frequenta os museus, não transita pelas ruas, então, aonde está a outra parte dessa perspectiva? Incrível como nos museus das ruas, tem coisas que estão lá a tanto tempo, e diante dessa obra, passamos tão rápido que nem mesmo damos tempo para fluir, dentro de nós, afinal o cotidiano já nos engoliu, e se olharmos muito tempo para essas obras desse museu nas ruas, provavelmente, vomitaremos, ou quem sabe, colocaremos uma máscara, assim não sentiremos o cheiro de nosso próprio regurgitar. Cabe a aqui ressaltar, o que aprendi a um certo tempo atrás, que vem a ser que: o que escrevemos, ou dizemos os primeiros ouvidos são os nossos, portanto, somos a primeira pessoa que precisa ouvir. Não se tem a pretensão de ditar mas sim de refletir, como fonte básica de uma conduta onde não estamos apartados do que se reflete ou se critica muitas vezes, mas fazendo parte de tudo que está sendo colocado.

Os "MSG" do desejo, nas manipulações do querer. As distancias dos dispositivos ao pensamento. O que pode ser real ainda frente a manipulação. Os disfarces dos personagens; com uma diferença: no palco da verdade, o disfarce não é disfarce, mas veste da carne do personagem que é a alma da narrativa do espetáculo. Não se pode perder a diretriz e nem o discernimento, principalmente quando se lida com a arte de viver. O verdadeiro artista quando representa, não mente.

Por um lado, a vanguarda é o movimento que veio para transformar as formas da arte, para torna-las idênticas às formas de construção de um mundo novo, onde a arte já não existiria mais como uma realidade separada. Por outro lado, a vanguarda é também o movimento que preserva a autônoma da esfera artística de todo compromisso com as práticas do poder e a luta política, ou as formas de estetização da vida no mundo capitalista. ( CANCLINI, Pg 135.) 
Da narrativa do trânsito social. Se estabelecem desafios que devem ser encarados como ocorrências que estão diante de nós, exigindo de alguma maneira a nossa participação. Quiçá uma arquitetura político-social nos possibilite estar engendrados o suficiente para ver a face da arte no meio político - social em espaços compartilhados de ação. O consenso e o dissenso, talvez sejam um limiar de pontos de perspectiva, ou de observação, que necessitem de um olhar mais expansivo, ou que tenha desenvolvido a capacidade de uma estética relacional, que desmembre a ponto de encontrar no elemento seus fatores ( quase matemática de sentidos ), que possam ter uma ligação, ou energia suficiente para ser uma valência ( modos de interação ), atento ao desenvolvimento de maneira a despertar para quando possibilidades de ligações em períodos adjacentes possam se estabelecer. $\mathrm{O}$ que isso quer dizer em termos políticos? A meu ver um certo estado de diplomacia, que conjugue a observação dos elementos dispostos na equação de argumentos, como passíveis de estarem mais abertos a "negociações" pelo decorrer de novos fatores advindo com o próprio decurso do tempo, e que tendo em vista as já estabelecidas em diagnósticos possibilidades de ligações ( relações ), então, se insere mesmo que em um intervalo de tempo, um elemento anteriormente em dissenso para uma mudança de estado.

Precisamos ver em que medida a voz dos silenciados se acomodou nesse estado. Diálogos revisitados na experiência. $\mathrm{O}$ retorno à compreensão.

Dos espaços comuns, De que maneira poderemos conviver com espaços comuns de maneira a transitar por eles de forma a que esse fluxo não seja tão imediato mas que nos propicie um olhar amais atento, e que reverbere nas esferas particulares, ou seja construindo um fluxo de mão dupla? Arquitetura politico-social.

Em certo paralelo, observa-se os que vivem propriamente nas ruas ou no organismo social, assim como também, a densa camada dita sociedade de cidadãos, os que estão imersos nele e se vivem como se estivessem fora dele, sobre o teto, e sem ele, os que seguram as pilastras para que o corpo social não caia sendo a organização política," de classes", instituições. A primeira vista parece que o que vemos no lugar, está fora dele, porque como o criticamos sempre... então, o que poderemos fazer para nesse olhar compartilhado de dentro e fora dos lugares impostos, ou postos como tal, ter o discernimento possível para acender a um esclarecimento de condutas onde o fluxo passe a ser de todos, em olhares múltiplos, e de razões e sensibilidades à ordem de um progresso e organização? 
Vida como produto de nosso tempo, uma lógica dentro da existência, que pode suportar o desejo de um sentido dentro dela, da estética e ética, não díspares mas conjugados ${ }^{367}$, em proposições que se aliam para um modo de ver a arte e a vida, como consumo de uma consciência geradora de valores evolutivos. Depreciar algo já estabelecido, sem ver sua possiblidade de se aliar a algo que altere seu significado, é perder a oportunidade de avaliar segmentos, de avaliar elementos que possam vir a construir juntos uma nova abordagem. Obra como mercadoria, nesse âmbito, quer se aproximar de um desejo, em seu bom sentido, podendo estar sobre diversas maneiras presentes. Se vejo a obra como um resultado de um projeto de um artista, ou de um conceito, ou se vejo a obra como o meu próprio cotidiano, será também esse um eito comum de olhar, desatrelado das amarras que o modo habitual nos fornece de perspectiva. O depoimento e a procura das faces que estão ao nosso redor, carece de um tempo dentro do tempo.

Creio que vivemos um tempo em que não se pode impor uma obrigatoriedade de participação da arte com a política, mas que se isso acontecer é de fato, uma confluência que será aprazível. Se concebemos como a arte sendo em primazia o que entendemos como liberdade ( responsabilidade ), categoria dos sentidos do sentimento, não pode se aferroar nem mesmo por razões políticas, ainda que elas sejam importantes e necessárias. Cada qual com seu modo de agir no mundo, que por vezes mesmo que em esferas particulares esteja sobre a insurgência de ter o próprio ato de criar.

“ Não havia ditadores " As vezes me pergunto se certos cotidianos de muita gente do povo, não está em plena democracia, sendo erguido como a submissão diária de um sistema completamente autoritário onde não se tem oportunidades, onde não se tem direitos, onde se conjuga uma pseudo - liberdade, porque se não temos a igualdade como tão almejamos como entender uma democracia, e uma não ditadura, se o dia- a dia, é tão massacrante, para a maioria, e carecendo de tantas mudanças, ainda. O que em a ter voz, será que é mesmo tendo a presença de sindicatos, de órgãos representativos da sociedade, ou será essa voz precisa estar mais participativa e menos crítica, mas sendo um corpo aberto a fornecer diagnósticos, necessidades, e um engendramento cada vez maior de meios (entre o poder representativo e os ditos representantes sociais, de maneira a não ser apenas um nome, ou alguns papeis, mas ações de fato colaborativas, para que as mudanças aconteçam mais rápido). Sei que é apenas uma reflexão de forma insipiente talvez, mas que precisa ser ao

\footnotetext{
${ }^{367}$ Ver arquivo de audio - Samba bem brasileiro - feito em 09-06-2017 as 15:13.
} 
menos, relatada, para não vivermos entre capítulos de uma narrativa, onde apenas os dias passam e atravessamos nosso árduo diário, sem ter tempo de escrever uma linha sequer, porque nem mesmo temos o necessário.

Porque certas empresas caminham tão bem, e nossas estruturas do organismo político-social representado pelos órgãos do governo não se estabelecem no decorrer de tanto tempo com capacidade para ser ao menos uma concepção de um futuro melhor, ou que possamos ver em transparência seus procedimentos e resultados, talvez, aqui, críticas mais do que soluções, mas, se temos exemplos que de alguma forma em paralelo ( empresas ) podem ajudar com soluções, será que não seriam um caminho plausível de operações que viessem a solucionar esse organismo tão patológico da sociedade atual e que sugerimos ter a vida como produto de seu tempo, então, nessa vida, ou seja, nesse produto, que fatores estão envolvidos para que possamos consumir o nosso tempo, e ter a nossa marca de maneira satisfatória em garantia do bem estar geral.

Me parece que galerias in loco, sempre haverá porém, o mundo das redes, está diagramandose em um mapeamento em possibilidades mais diversificadas, onde o direito a exposição e venda ficou mais " democrático", e de uma visibilidade e alcance que em " poder " alcança, o que é realizado pelas mídias, então o público passou, receptor, passou a ter mais fontes de acesso a veículos de cultura e arte, que creio com o decorrer do tempo, cada vez mais terá um território sem fronteiras, onde pode se mover por regiões onde as distâncias e também os acessos a camadas sociais, estarão mais redistribuídos, em ofertas, procuras, e satisfação. Se o produto, é bom, e está ao alcance em rede, em galerias virtuais, ou o que quer que venha a existir, o mercado se abre para uma nova ( ou já velha ), perspectiva, e portanto, o que está colado no livro, passa a ter a necessidade de um novo olhar, para dentre a imensa gama de oferta, o que passa e mais ainda, de que maneira se sobressair em uma diversidade tamanha, e como? O que sempre fez parte, mas agora em outro habitat, então, me parece que cada vez mais, é necessário o alcance a novos meios para antigos fins. Os bens culturais em face das redes podem ainda junto com ativismos e presenças de consciência político-socais, ganhar um ímpeto de força novo, capaz de realizar a ponte entre o cotidiano e o museu das ruas, ou a face de um galeria do tempo vigente onde o que é relevante para a ter destaque na avenida de nosso olhos atuais, ou corpos cinéticos sensíveis a um bem -estar em ressonância por entre camadas que se diluem por essa rede, e contatos com menos discriminações, onde quiçá a rede forneça uma parcela de encontros cabíveis de esferas antes intangíveis. O tempo 
dirá, mas deve se propor algo, e marcar o nosso tempo, como queremos que ele seja representado.

Sempre haverá os olhos nos olhos, por onde a tela em um museu não será a mesma da tela virtual, mas ao menos teremos escolha de conhecer e compartilhar um conhecimento. Penso que várias formas de agir em ambiente cultural sempre haverá, mas o acesso é que está se modificando, e possibilitando escolhas.

A globalização e suas escolhas.

Não se pode dizer, assim penso, que um campo concreto que se observa em transito planetário que vem a ser o que consideramos globalização, como sendo algo prejudicial, em gênese, porque, ao que ela se dirige é que fará a diferença, mas o que ela pode ser em seus princípios, deveria ser também o que a faria ter o discernimento para não colidir com desafios onde prevalecesse uma estrutura vigente que deprecia estados políticos sociais, que justamente, ao contrário ela deveria colaborar para sua melhoria. Então, o objetivo, deveria estar claro, e proposto quando se coloca em base de um propósito a globalização, porque mesmo tendo entraves, tem desafios, mas tem alcances e compartilhamentos possíveis, para serem elementos que favoreçam, aspectos, tanto econômicos, ( visando já uma melhoria de vida dos envolvidos - porque mesmo dos mais poderosos, hoje me parece que a reverberação tem um alcance na vida de todos ), ambientais, etc. Esclarecer quais são os elementos de benefício da estrutura de uma globalização já é fator de esclarecimento de suas ações. Prevenir seus possíveis desvios de conduta, não muito difere do ser humano, então, posto isso, tento claro seus parâmetros de conduta, normas, objetivos, mecanismos, sistemas, formas de atuação, de maneira a prevenir que não houvesse, prejuízo de minorias, mas ao contrário o favorecimento do crescimento destas, posto que também se deve alertar que os ditos como minorias, devem sair desse estado que muitas vezes é cômodo, para se dar o valor, e se fazer uma voz ativa e capaz de também ser agente em uma equação igualitária de soluções. Capacitar dentre um fenômeno social, seja ele posto como as margens de um processo, o que pode vir a ser um ingrediente em descoberta que favoreça o sistema é um processo que demanda um olhar astuto e capaz de ver no tão já abordado território inóspito valores desapercebidos, e aspectos que possam ser desenvolvidos e que possa sair de sua inercia social para a mudança de ser uma face colaborativa. 
Enquanto houver essa dicotomia, que parece favorece ambos, os lados, minorias e maiorias, não se vai a lugar algum me parece, ao menos se queremos uma sociedade mais igualitária de oportunidades e desenvolvimento. Se pensarmos em algo que ressoa de forma abrangente onde o que eu faço interfere de alguma maneira do mudo que o outro vive, e que é o mesmo que vivemos, isso pode alterar de maneira significativa as possibilidades de diálogo e consenso, para um bem-estar. Uma coisa é estar ciente dos campos de maioria e minoria, e outra é viver fomentando essa dicotomia, e não o entrelaçamento.

Sobre redes e inclusão/ exclusão - para não se repetir e mudar apenas o território, creio que o alcance precisa saber para onde se dirige, ou seja, não como manipulação, claro, mas como um discernimento de um crescimento agressivo talvez, mas que tenha tempo ainda de se auto- analisar e constatar seus propósitos e direções cabíveis para gerações futuras.

E me parece que ( ainda pouco se faz, ou não ) as escolas terão um papel efetivo nesse rumo a seguir, porque ao se engendrar cada vez mais da tecnologia que não poderá ficar apartada, poderá ser um elemento social de balizamento de condutas e escolhas, ( e até mesmo alerta ) , para do que de informação e diversidade haveremos de nos conectar. Resta saber se as escolas já estão prontas, ou se estão usando como material de apoio, sem pensar em correlacionar o meio em que o aluno vive, ou seja, seu ambiente que é naturalmente na interface virtual-real. Como que o interesse pode ser canalizado ( nunca manipulado ), afinal estamos falando de educação, cabível de uma diretriz, que não esteja longe das gerações, mas sim engendrado com elas no cotidiano que as aproxime em interesses conjugados, e compartilhados de maneira mais efusiva dentre disciplinas e do que pode haver na “ realidade ". O despertar o interesse de pesquisa, é sempre um alcance de proporções que muitas vezes pode modificar a vida de um aluno. E se esse interesse estiver próximo de seus interesses cotidianos, será uma ferramenta de desenvolvimento e despertar de potencialidades talvez, não previstas.

Falando em rumos e aonde queremos ir.... “ A transgressão linguística na internet ( segundo este livro ), está estendida a todas as classes sociais e aparece como um traço de diferenciação geracional, expressivo também da menor eficácia da educação “, então, me pergunto, o que está sendo feito por aí, com os recursos da internet, o que a globalização pode me dizer disso? Posso obter informações que alterem meu bem -estar de modos de agir já diagnosticados por presenças de condutas de outros que me favoreçam e alarguem meu 
ponto de vista? O que poderemos aprender se não olharmos somente para nosso umbigo, mas observar o umbigo da globalização, quem sabe?

Será que os recursos de uma informação mais dissipada e de conhecimento possa ser benéfica a ponto de diluir um pouco por exemplo o universo do aprendizado com o de trabalho, para não haver aquele momento caótico onde o sujeito sai com o diploma sem ter para onde ir ao certo? Porque as distâncias em rede que aproximam não podem ser um elemento cada vez mais de auxílio a diminuir distancias de problemas sócias com informação e redistribuição de capacidades, oportunidades, ( que já existem ) mais, organizados de maneira a refletir uma evolução do estado da sociedade, ( creio que nos estudos das organizações devo aprender sobre isso ), A complexidade é grande, mas os envolvidos podem e tem como se relacionar ao ponto de observar e estudar meios e soluções.

As redes das necessidades de trabalho (com suas modificações atuais, onde certas profissões se alteraram devido a tecnologia), dialogam com as escolas (cursos profissionalizantes,) universidades, e políticas-socais, até que ponto? Por onde a informação de necessidade, demanda e capacidades se entrelaçam?

\section{Da cidade delirante}

Nasci aqui, em meio a esse asfalto, que continuamente arde nem percebo, primeiros passos do concreto, erguendo-me junto, feito jagunço em terras cimentadas, em meio a estradas de gente, de quantas lutas já se iniciam para simplesmente sobreviver, desde os primeiros passos, entre os passos dos que já caminham a tempo, ou estão ocupados no cotidiano que fizeram para si, que pode ser de muitos outros dentro do mesmo, quase como um estrangeiro interior, e então, posso ser caipira novamente, dentro dessa mesma cidade, ou seja lá que nome terá, ainda não sei, bem, acabei de nascer. Mas, as informações são tantas, com tantas imagens, com tantos tráficos e tráfegos, jazendo ou nascendo comigo, entre margens e perigos, sou urbano, ah sim, esse deve ser o meu nome, entre sobrenomes, que haverão de me completar sobrenome das ruas, avenidas, ou paralelepípedos, onde me balanço em um gingado próprio de quem ainda quer saber o que fazer, e depende, depende nessa mata disfarçada de natureza embrulhada, eu que nasci da cidade, por onde então devo começar a viver. Tenho tantos jeitos de ser, e mal acabei de nascer, é que entre solavancos e tantos objetos que se dizem humanos, são parte de mim, também, mas o que sei é que sou cidade, 
tenho janelas para ver, espaços por tecer, dentro desse meu organismo cada vez mais frágil ou intrépido, manifestando-se a cada vez que, abre os olhos em mais uma manhã, e o movimento começa dentro de mim, como sangue alado, de onde não consigo, ah, não consigo voar, mas preciso. Preciso de alguma forma, nesses meus primeiros passos, saber voar, ou olhar o céu, dentre tantos meus arranha-céus, mas tão difícil me parece nesse enxame de populações, de fluxos e refluxos um tanto quanto enjoado eu estou, talvez, seja fome, sede, e eu escravo de meu berço, alimento-me de destroços de ocupações de certos poderes, assim são chamados, algemados no cotidiano, crendo-se em liberdade, condicionam-se em estados perenes que habituaram-se crescentemente, até que em um outro paralelo de minhas relações se encontraram em alforria, um tal de espaço virtual, mas como ainda acabei de nascer dentro de mim tão antiga, cidade, em que meu nome é urbano, sou "sujeito-espaço" querendo conhecer o tempo, e como fazer para sobreviver. Se tenho voz? Ah sim, tenho, continuamente me manifesto, ainda que parecendo calado, meus sinais se veem ao longe, ao alcance do primeiro ônibus lotado, e de tantos meus braços e órgãos que parecem mutilados em guerras insólitas e sem nome, mas que nos consome, e sei que por incumbência haveremos de procurar uma saída, para quem, resta saber... se ainda estarei aqui, ou serei mais destroços históricos sem memória do que poderia ser, ou ter sido um dia, se me olhassem mais de perto, projeto de viver, e existir, quem sabe, ainda dá tempo. Sempre haverá mortes e nascimentos, lamentos e alegrias, tristezas e esperanças, e eu aqui, não querendo mais dicotomias, para que eu não fique assim, como tanto me parece, míope, e cheio de patologias sem sentido, onde lido com tantas incompreensões, que nessa vastidão, ainda procuro, o ser humano, para que me diga, agora que eu nasci, e dos teus braços eu me recolhi, o que eu vim fazer aqui?

Vejo ao longe a jangada a deriva, as águas passam sobre a manhã, desaguam em meu suor noturno, como a relva que desafia o reflexo a dobrar-se sobre as águas que de meus olhos servem ao amanhecer o desjejum de uma alma intrépida e viajante. Vejo o corpo à deriva sobre as turvadas veias de minha gente, borda que reborda minhas dores, das paragens que parece de onde o destino, se esqueceu. Tardiamente, já nos primeiros segundos, as rugas dos serenos gestos, aqui calados, nas águas parado, é tempo do esquecimento onde apenas a paz se lembrou de adentrar. Jangada no rio, de meus propósitos que submersos ou a deriva, são corpos cidades no meio da mata, são força que atuam e que não basta, de beleza acender, porque precisa também nesse tempo, sobreviver. 
Jangada sou, parecendo a peste do mundo onde somente os rios do meu sangue, percorrem a natureza, onde a tristeza desse fim de mundo precisa se revelar, lugar, um diálogo que é profundo, com as águas em decifrar. Pois sou alma, sou errante luta, de um corpo humilde, que é floresta, são populações de lugares do nosso Brasil globalizado, sujeitos múltiplos, nações diversas, sou Urbano Ribeirinho, nascido do existir, e patriota da realidade. Texto este do projeto de livro, Duas vidas e um destino.

Das cidades à globalização:

\begin{abstract}
Abeles destaca duas causas desta mutação. Uma é a mudança de escala trazida pela globalização, tanto nas expectativas, na capacidade de identificar as origens dos problemas como nas maneiras de se reunir [...] “ Onde foram parar as projeções racionais que animaram os estudos sobre prospectiva e o voluntarismo político nos anos de 1960? Foram-se dissipando pela impotência dos Estados-nação em face das turbulências dos conflitos étnicos, do consumo, da proliferação de armas nucleares e dos tráficos orquestrados pelas máfias. Estes outros atores parecem se adaptar melhor a mundialização do que os Estados e organizações internacionais. (CANCLINI, 2012, pg 192)
\end{abstract}

Bem a propósito!!! - Desculpas esfarrapadas - do afeto à manipulação e controle - Um dito saber, preocupação, cuidado, será? Disfarces da sociedade -

Nossa visão do futuro e da política também foi modificada pelo o exercício opaco e anônimo das instâncias onde se condensa o poder. Na atual remodelação global do sentido, nós, cidadãos, experimentamos uma estranheza radical ante as decisões que influem em nosso cotidiano. Onde estão os poderosos? Claramente, poucas ações são identificáveis com terrirórios. [...]A opacidade do poder aumenta, mas nós, cidadãos consumidores somos cada vez mais transparentes porque os sistemas de vigilância social sabem o que comemos, onde compramos, assim como nossas preferencias sexuais e nossas reações ao mal-estar político. "o compartilhamento - do divertido ao apocalíptico. ( CANCLINI, 2012, pg 192-193)

A imagem da realidade construída pelo imaginário.

Vozes compartilhadas em universo de compreensão que comporta dissonâncias ( ou dissensos ), atravessa, notas de repercussões que distendem em ressonâncias cabíveis de serem compreendidas, mesmo que em intervalo de tempo, como forma de convergência harmônica. 
Imagens esquecidas, ilusões e desenganos..,, do espetáculo social, onde a plateia é protagonista. Mas a realidade como dizem, bate a porta, e o resgate de imagens suscita a necessidade de repertório, ou diálogos do tempo, para se fazer vigentes conjecturas das mais diversas possibilidades intrínsecas alteradas possivelmente no decurso da própria linha temporal.

A liberdade de um lugar - entre o escritor, o narrador e a realidade. Onde se quer e pode ser compreender espaço ao ler o mundo, o cotidiano e descrever a própria narrativa.

Falando sobre Aglaura, uma das cidades bizarras, mas estranhamente familiares, relacionadas em Acidade invisível de Ítalo Calvino, Marco Polo afirmou que com dificuldade poderia ir além das coisas que seus habitantes sempre repetiram, mesmo que suas historias destoassem daquilo que ele próprio julgava estar vendo. Você gostaria de dizer o que ela é, mas tudo que já se disse sobre Aglaura tem o efeito de aprisionar suas palavras e obriga-lo a repetir, em vez de dizer. E assim, abrigados em segurança pelas muralhas da cidade, feitas de histórias sempre repetidas, da mesma forma que os baluartes de algumas cidades são feitos de pedra, os aglaurianos vivem numa Aglaura que cresce com o nome Aglaura, sem notarem a Aglaura que cresce sobre o solo." Como poderiam, na verdade, comportarse de outro modo? Afinal, a cidade de que falam tem a maior parte daquilo de que se necessita para existir, enquanto a cidade que existe em seu lugar existe menos. [...] "Se lhes perguntassem, os habitantes de Leônia - outra das cidades invisíveis de Ítalo Calvino - diriam que sua paixão é desfrutar coisas novas e diferentes. De fato. A cada manhã eles vestem roupas novas em folha, tiram latas fechadas do mais recente modelo de geladeira, ouvindo jingles recém -lançados na estação de rádio mais quente do momento. Mas a cada manhã as sombras de Leônia de ontem aguardam pelo caminhão de lixo, e um estranho como Marco Polo olhando, por assim dizer, pelas frestas das paredes dos leoninos naverdade não seria o prazer de expelir, descartar, limpar-se de uma impureza recorrente. Caso contrário, por que os varredores de rua seriam recebidos como anjos, mesmo que sua missão fosse cercada de um silêncio respeitoso ( o que é compreensível - ninguém quer voltar a pensar em coisas que á foram rejeitadas )? Como os Leonianos se superam na sua busca por novidades, uma fortaleza de dejetos indestrutíveis cerca a cidade, dominando-a de todos os lados, como uma cadeia de montanhas. "( BAUMAN, 2005 pg 78)

A resistência. Absurdamente nos vemos confrontados entre o que fazemos e o que queremos, e no mais das vezes, sem correspondência. Então, quais são as montanhas que não queremos nem ver?

Poderíamos perguntar: será que os leonianos enxergam essas montanhas? As vezes sim, em particular quando uma rara golfada de vento leva a seus lares novos em folha um odor que lembra um monte de lixo, e não os 
produtos plenamente frescos, reluzentes e perfumados expostos nas lojas de novidades. Quando isso acontece, é difícil para eles desviar os olhos teriam de olhar cheios de preocupação, medo e temor, para as montanhas, e se horrorizar com essa visão. Eles abominariam a feiúra delas e as detestariam por macularem a paisagem - por seres fétidas, insossas, ofensivas e revoltantes, por abrigarem perigos conhecidos e outros, diferentes de tudo que conheceram antes, por serem depósitos de obstáculos visíveis e de outros nem mesmo imagináveis. Não gostariam dessa visão e prefeririam não continuar olhando por muito tempo. Odiariam os dejetos de seus devaneios de ontem tão apaixonadamente quanto amaram as roupas da moda e os brinquedos de ultimo tipo. Gostariam que as montanhas se desvanecessem, sumissem - dinamitadas, esmagadas, pulverizadas ou dissolvidas. Iriam queixar-se da preguiça dos varredores de rua, da doçura dos capatazes e da complacência dos chefes. Mais ainda que os próprios dejetos, os leonianos odiariam a idéia de sua indestrutibilidade. Ficariam horrorizados com a notícia de que as montanhas de que desejam tão avidamente se desvencilhar mostram-se resultantes em se degradar, deteriorar e decompor por si mesmas, assim como resistem e são também imunes aos solventes, Desesperados, não aceitariam a simples verdade de que os odiosos montes de lixo só poderiam não existir, se antes de mais nada, não tivesse sido feitos ( por eles mesmos, os leonianos ) Eles se recusariam a aceitar que ( como diz a mensagem de Marco Polo, que os leonianos não ouviram ) a medida que a cidade se renova a cada dia, ela preserva totalmente a si mesma na sua única forma definitiva: o lixo de ontem empilhado sobre o lixo de anteontem e de todos os dias e anos e décadas. Os leonianos não ouviram a mensagem de Marco Polo porque o que ela lhes diria ( quer dizer, se quisessem ouvir ) é que, em vez de preservarem o que afirma amar e desejar, só conseguem tornar permanentemente o lixo. Só o inútil, o desorientador, repelente, venenoso e temível é resistente o bastante para permanecer ali enquanto o tempo passa. ( BAUMAN, 2005, pg 9).

Superlotados, o quê? A subsistência, por onde?

Além de espaço e preocupações com dejetos, como que os mesmos se constituem nas carentes soluções de lugares habitados por tanta falta e excesso. O que então é eminente sendo constatado dos excessos da civilização que não mais se suporta, em corrupção, e usos e abusos sociais e políticos?

A vida como produto de nosso tempo...haveremos de nos reciclar como seres humanos na busca do que acreditamos, ou estaremos cada vez mais entre lados trocando de posições infelizmente de maneira a fomentar somente injustiças e caos? Banalizando o passado e ainda nos defrontando com situações em que nós assumimos a postura do que dantes e historicamente abominávamos.

Para resumir uma longa história: a nova plenitude do planeta significa, essencialmente, uma crise aguda da indústria de remoção de refugo humano. Enquanto a produção de refugo humano prossegue inquebrantável e atinge novos ápices, o planeta passa rapidamente a precisar de locais de despejo e de ferramentas para a reciclagem do lixo [...]A expansão global 
da forma de vida moderna liberou e pós em movimento quantidades enormes e crescentes de seres humanos destituídos de formas e meios de sobrevivência - até então adequados, no sentido tanto biológico quanto social/ cultural dessa noção. Para as pressões populacionais daí resultantes - as antigas e familiares pressões colonialistas, só que na direção inversa Não há escoadouros prontamente disponíveis, seja para a reciclagem ou para a remoção segura. Daí os alarmes sobre a superpopulação do globo, daí também a nova centralidade dos problemas dos imigrantes e das pessoas e busca de asilo para a agenda política moderna, e o papel crescente que os vagos e difusos temores relacionados à segurança desempenham nas estratégias globais emergentes e na lógica das lutas pelo poder. ( BAUMAN, 2005, pg13-14)

No começo era o projeto. A emergência do existir.

Então o que vemos no mais tradicional dos " produtos" a venda na sociedade é justamente o caráter da emergência onde o desemprego é suprido pelo primeiro trabalho que aparece, porque afinal, temo uma emergência, e o que acontece, é que muitas vezes, o cidadão trabalha o que ele, não tem aptidão, no que outro até mesmo poderia estar desempenhando melhor, e consequentemente deixando muitas, para não dizer inúmeras vezes, o que ele tem talento e capacidade sem ação, e sem reverberação porque simplesmente teve que atender ao caráter do básico, ou seja, sobreviver, e o pior é quando a situação visa, e não é cartão de crédito muito pelo contrário, um cidadão que, mais parecendo um cárcere privado em sociedade aberta, com boa conduta, fica e permanece muito no emprego, por longos período e anos, e seus talentos ou oportunidades para o desenvolvimento de suas capacidades por vezes se extinguem, o que é uma perda tanto para o cidadão como para o meio, a cidade, a família, o Estado etc.

O prefixo des indica anomalia. Desemprego é o nome de uma condição claramente temporária e anormal, e assim, a natureza transitória e curável da doença é patente. A noção de desemprego herdou sua carga semântica da autoconsciência de uma sociedade que costumava classificar seus integrantes, antes de tudo, como produtores, e que também acreditava no pleno emprego não apenas como condição desejável e atingível, mas também como seu derradeiro destino. Uma sociedade que, portanto, classifica o emprego como uma chave- a chave - para a solução dos problemas ao mesmo tempo da identidade pessoal socialmente aceitável, da posição social segura, da sobrevivência individual e coletiva, da ordem social e da reprodução sistêmica.( BAUMAN, 2005,pg 19).

Ideias $\mathrm{x}$ comodismo

Existe algo que pode soar como ameaçador sempre que uma ideia, isso para alguns, porque outros, olham como a face do empreendedorismo, enfim, tudo que move o estado habitual em que a sociedade ou os mecanismos da engrenagem social se estabelece, demanda um 
certo trabalho e força de observação quanto a sua razão de ser, quanto a seus propósitos em repercussões e alterações e mais ainda, na necessidade de não somente elucidar, porém constatar benefícios dessas alterações, enfrentando a dificuldade de considerar que o âmbito das ideias quando ainda não em experiência fática deve ter bom argumentos, e se possível precedentes que o forneçam como relações ao menos de lógica plausível e constatações de práticas afins que o validem como possibilidade. Certos avanços foram alcançados quanto a posturas sociais, porém, ainda nos resta ou melhor, somos levados a constatar que precisamos continuar a reagir dos estados habituais para que se desenvolva uma sociedade em progresso, que habite e forneça uma vasão de responsabilidades com seus integrantes e gerações tornando de maneira equilibrada em esforços e condutas, um entrelaçamento de regiões em uma topologia social que se estabeleça com parâmetros que viabilizem capacidades, oportunidades, organizações de maneira a realizar conexões antes não percebidas de benefícios mútuos para o crescimento.

A busca de uma topologia social, se inserindo novamente com já inclusive uma necessidade a ser suprida, ou seja, duas necessidades, a do emprego e a da sociedade, porque a sociedade tem as delas, e me pergunto quantos poderiam estar juntos e não separados se recolocando como um grupo, caso houvesse, projeto e verba para que fosse possível e claro, com o devido exame de quis estariam correspondendo a esse grupo para criar quase como um stand by pro, uma interação unida, com esforços mútuos e direcionados, assim sendo, seriam um subconjunto da sociedade, com " valor" de restabelecimento e de " aproveitamento real de força de trabalho e inserção no âmbito responsável da sociedade “. Um remanejamento, ou melhor, um agrupamento de:

Demanda social - grupo de recursos de capacidades ( desempregados ) - investimento. O diferencial de agrupamento seria juntar capacidades com fatores estruturais de ação. E o direcionamento estaria a cargo justamente da localidade da urgência dos maiores esforços, a serem supridos com a força do trabalho e para este caso, uma organização de trabalho, um grupo que se cria não aleatoriamente, mas produzindo já em sua constituição sua capacidade motora, propulsora reunindo os valores intrínsecos de cada elemento que o forma.

Trabalho - estudo - capacitação - onde estão nossas ( cidadão / estado ) preocupações.... vemos o imediato, ou o mediado... relações ur(Hu)b-anas. A carência de compreensão no âmago do corpo da cidade, ou o corpo social se estabelece frente a um cotidiano, que passa diante de nós, e nos parece totalmente comum, e no qual somente nos deparamos realmente 
quando estejamos como uma ausência, vivendo no próprio sangue que o mantem vivo, então, como poderemos estar ausentes?

Um fator relevante, e desconsiderado é o próprio e desenvolvimento por exemplo de coisas simples, que condiz com o educar o pensamento. Me refiro, por exemplo, mesmo com a intenção de agrupar e fornecer um meio de conjunto social em inserção nova no mercado, o desafio por enfrentar entraves como por exemplo na compreensão do indivíduo, não se está procurando por exemplo somente onde trabalhou, mas o que faz, o que gosta, como usa seu tempo livre, e na maioria das vezes o próprio interlocutor vai considerar que isso não é relevante para um novo posicionamento no mercado, Para mim, um erro, pois o que buscamos é justamente o que pode estar latente de talentos que por não haver oportunidade ficou relegado pelo caráter urgente e emergencial de sobrevivência. Portanto é relevante e importante buscar verdadeiramente o cidadão que queremos encontrar, e não o que se exauriu pela vida em condições que não eram as ideais, e não me venham falar de utopia, mas sim de uma trabalha Brasil, onde o trabalho é de todos, para o bem de todos. E, além do reposicionamento, quando pudermos ter em mente que o trabalho inclui reverberações para aspectos de bem estar intrínseco poderemos compor conexões como por exemplo, o que gostaria de ter estudado que não teve como etc. o pensamento integrado deve considerar o trabalho não somente como o de pagar contas, mas como parte da dignidade do viver.

Usamos e perdemos a latência do existir, que respira conosco e se torna tão automática que deixamos de perceber, porém, entre ter e formar profissionais do trabalho, ou seja, a união do educar, formalizar um estudo que capacite, junto com o mercado de trabalho nele mesmo une e relaciona projetos de ação, (para a imersão) como( posterior) n)o cotidiano.

A realidade cobrando o preço, de ter contas chegando e enfim, sem ter como suprir e se endividar justamente por não ter o equilíbrio entre o que precisa ser pago e o como, e ainda as necessidades básicas de sobrevivência, mesmo com o que o Estado fornece que não estou completamente ao par, porém, salário desemprego etc, mas enfim, o que acontece é que com o tempo, nos deparamos com um cidadão que passa a não ter identidade, não um número, mas um ausente que, como o livro vai colocar, um tanto quanto "bruto", mas de fato, como essa realidade se apresenta, e então, essa ausência pertinaz, que em um modo de olhar, não estamos lidando aqui com nenhum encosto, ou algo do tipo, que como alguns chegam a dizer, “ estão nessa situação porque querem “, enfim, tratamos aqui, de uma nova postura tanto para a realidade como para o que poderemos oferecer a ela, e nesse oferecer, é que 
precisamos de uma nova postura de pensamento e ação. Ou seja, não é uma proposta somente que reintegração de trabalho na sociedade, mas do indivíduo como um todo.

Reclamamos do lixo, e o que fazemos com ele?

Bauman, aborda o refugo...

"Com muita frequência, na verdade, rotineiramente, as pessoas declaradas " redundantes" são consideradas sobretudo um problema financeiro. Precisam ser providas - ou seja, calçadas e abrigadas. Não sobreviveriam por si mesmas - faltam-lhes os meios de sobrevivência ( quer dizer, sobretudo a sobrevivência biológica, o oposto da more por inanição ou abandono ). A resposta à redundância é tão financeira quanto a definição do problema: esmolas fornecidas pelo Estado, reguladas pelo Estado ou por ele promovidas e testadas em relação aos meios ( chamadas, de modo variado, mas sempre eufemístico, de benefícios de previdência, incentivos fiscais, isenções, concessões, pensões ). Os que não simpatiza com essa resposta tendem a contestá-la em termos igualmente financeiros ( sob a rubrica " podemos arcar com isso? ) - dada a carga financeira que tais medidas impõem aos contribuintes. A necessidade de ajudar pessoas declaradas redundantes a sobreviver, talvez de ajuda-las de modo permanente ( ou seja, falando com clareza, a necessidade de aceitar o direito de uma parte permanente e incuravelmente redundante da população a um grau de bem-estar que seus membros não ajudam a produzir nem são necessários para isso ) é , contudo, apenas um aspecto do problema que os desempregados representam para si mesmos e para os outros. Outro aspecto muito mais seminal - embora esteja longe de ser reconhecido e abordado - é que na área do planeta comumente reservado ao "refugo humano" ( mais exatamente, pessoas refugadas ). Mesmo que a ameaça à sobrevivência biológica fosse identificada e enfrentada de modo efetivo, esse fato não chegaria nem perto de assegurar a sobrevivência social. Não será suficiente para a readmissão dos redundantes à sociedade de que foram excluídos - da mesma forma que armazenar o lixo industrial em contêineres refrigerados dificilmente seria suficiente para transformá-lo em mercadoria. ( BAUMAN, 2005, pg 21)

Dos problemas sociais, as condições e ainda, a pedra e não lapidação meus caros, mas reverberação, e pergunta-se em que sentido? O desbastar, ou seja o supérfluo em uma escultura, veja, o que eu entendo como o desbaste da pedra bruta é um tanto quanto diferente, porque não é um jogar fora, mas o olhar do interior capaz de ver dentre o oceano a pérola da concha, ou seja, e ainda, dentre a imensidão poder reter o homem, então, não é um jogar fora, mas um brotar, gerar, nascer, constituir, erguer, sustentar, formar, esculpir... a maneira como vemos, encontra o sentido do que queremos olhar. Quero ver o que está sobre as pedras que caem, como reverberam e em que sentido, ou a forma que será modelada, e ainda assim, sabemos o quanto que do que fica da pedra bruta pode ser outra pedra, menor talvez, ou de outro uso. O que nos faz um ser humano melhor, não será o mesmo, ou deveria 
ser, o de um progresso como almejamos? Então, não sabemos o que fazer? O que nos falta.? Compreensão? Entre nós, entre o mundo? Porque saber por onde ir, ficou tão difícil de entender, ou ao menos se o caminho for para todos. ( pensamento - sentimento ) conduta / ações - tempo.

Deixado por sua própria conta, fora do alcance dos holofotes da história e antes da primeira sessão de ajuste com os planejadores, o mundo não é ordenado nem caótico, nem limpo nem sujo. É o projeto humano que evoca a desordem juntamente com a visão da ordem, a sujeira juntamente com o plano de pureza. O pensamento ajusta primeiro a imagem do mundo ( o desejo de ajustá-lo, o esforço para isso - embora não necessariamente o ato concreto do ajuste ) é uma conclusão previamente obtida. O mundo é administrável e exige ser administrado, já que tem sido refeito na medida compreensão humana. A observação de Francis Bacon de que a natureza, para ser comandada, deve ser obedecida, não foi uma intimação à humildade, muito menos um apelo à docilidade. Foi um ato de desafio. ( BAUMAN, 2005, pg 29)

A condição do movimento, de estados sociais e transmutação da realidade. O futuro, existe enquanto presente, porque é o presente que o configura em bases para sua existência fática em por vir. E ademais, em relação ao passado, todo presente é um futuro, em suma o entrecruzamento do tempo, é singular, posto que o ponto onde estaremos, é uma construção que nos atravessa enquanto escolhas e consequências. De qualquer forma, mais do que a considera consciência do tempo, se faz como o advento do destino, ou seja, entre o presente que o espera e o futuro, sempre haverá o caminho e o segundo passado, é como o passo, que ficou quando estávamos todavia, o observando adiante. Uma certa angústia exerce o tempo, em modos de ser do mundo, tanto quanto o existir, porém, como "causa natural da vida", pode-se inquerir seu espaço, como o mesmo advento, assim, nos tornamos cumplices de nós mesmos, sobre quais relações e condutas teremos, sendo sujeito e observador, habitando-o mesmo espaço e tempo, como relações que se estabelecem dentre a Natureza e com a nossa natureza.

Enquanto, em meu modo de pensar, apregoarmos a um sonho, tudo o que não se pode alcançar; apesar de conseguirmos o concretizar de fato, me parece que o futuro fica um pouco mais distante do presente. O tempo também é conforme nossas percepções, porém, tem uma distinção que não costumo ver, que é dentre, a percepção posta como o mundo que nos cerca, e a percepção na qual eu apresento a concepção na qual vejo como o mundo pode ser. A segunda não é menos real do que a primeira, posto que em percepção podemos colocar fatores que são distintivos quanto a existência para um consenso, e ademais, não 
vem de suma ao caso, para o que suponho neste momento mais importante, que é a percepção na qual eu manifesto uma relação que ocorre ENTRE, o mundo que pulsa ao meu redor, e minha relação de uma mente consciente e atuante frente as percepções possíveis, que por ventura podem em grande parte, romper com padrões estabelecidos do cotidiano, no qual estamos imersos, e em grande parte, aferroados sem poder nos libertar para uma cognição que forneça dentre a percepção relacional, um elemento para além da heurística de estruturas conexas ( antes não percebidas ou não desenvolvidas ), sendo apropriações em desmembramentos de sentidos, tornando um novo significado plausível para a realidade, e tal fator é relevante onde precisamos lidar com objetos sociais calcados pelo tempo, porém, nessa embate, devemos ter a possibilidade de conquistar a capacidade de lidar com o que permanece por razões, de algumas ordens sejam de naturezas de sobrevivência, sejam por razões de fatores econômicos que não podem ser alterados por argumentos já constatados, e enfim, várias razões que são constituídas pelo fato do bem geral, porém, mais do que um consenso, o bem aqui proposto é de uma sociedade nos parâmetros nos quais acreditamos que sejamos mais lúcidos, dispostos sempre à discussão; mas, dando prosseguimento, as percepções advinda da necessidade de lidar com o próprio desenvolvimento, quer esteja por exemplo, na tecnologia, ou nas relações humanas, aqui em interface com o anterior, e, justamente conseguir elencar como encontrar uma harmonia, um estado em equilíbrio dentre tantas as diferenças nas quais o mundo está todavia ainda imerso. Avaliar a consciência no sentido social que inclui individuo e sociedade, é uma prática na qual o sentido de educar o pensamento deve estar presente, e isso se refere também a percepção. Quase que lidamos com uma percepção conduzida, e isso não traz muitos benefícios, penso. E ademais, as forças de um desenvolvimento se constroem mediante esforços de natureza diversos, mais principalmente quanto ao apontado sobre futuro, no tocante a sermos um ambiente social integro no sentido de gerações, pois, se apenas estivermos voltados para a experiência do que consiste em os " capazes de um discurso de condição ideal de fala", nem sempre estaremos aptos, a observar, que, precisamos, fomentar, plantar, uma educação do pensamento, quanto ao futuro, no presente das gerações que estão vindo, ou seja, os filhos da sociedade que continuamente viverão plenamente o futuro, carecem de acordar mais cedo para a vida que os aguarda, ou seja, não desprezemos o pensamento daqueles que estão trilhando e desenvolvendo a mente e o pensar, onde ensinar a ver o mundo, é mais do que o cotidiano que o cerca, e libertar o pensamento, das amarras não quer dizer relegar tradições, mas ir além delas, onde pode-se compreender e estar apto a observar porém, mais do que isso, propor, e isso se encaminha, desde que dialoguemos efusivamente com uma nova 
topologia social, onde se considera todo cidadão que vive, todo ser vivo, partícipe dessa construção, e atentos estaremos para que não apenas não estejamos a reproduzir as mesmas cenas, os mesmos caminhos, sem considerar a paisagem, que precisa estar com o nosso olhar em nossa razão e sentimento, para sabermos por onde estamos indo. A realidade na qual buscamos um discernimento, é estabelecida desde que passe a ser em nossa alma, o espirito de nosso tempo, e não somente como um alheio de nossa vontade, mas um espaço onde temos voz, destino e liberdade. Assim sendo, O que queremos, o que desejamos, são aspectos que podem ser postos como ilusões ou sonhos, onde nem mesmo os recursos, poderemos ter, porém, quando a vontade é representada em um mundo que é de nós o mesmo ser, a natureza se revela, o encontro de um caminho, onde de alguma forma a vida encontra a possibilidade. Não estamos isentos de lidar com violências, com descabidos propósitos de natureza cruel, porém, e mais relevante ainda se torna o olhar voltado para gerações, sendo o cuidado com a semente que poderá estar sobre terra e ambiente muito hostil porém, no ventre encontra sua força, sua determinação, suas colunas que o fazem um ser erguido capaz de suportar adversidades e por muitas vezes, uma insalubre consistência onde quase se naufraga, mas, se os esforços forem maiores que as destemperanças, a conquista de ideias de uma boa sociedade pode ser objetivo de um mundo melhor, em um estado presente por nossas escolhas no tempo atual, que farão a diferença em igualdade em um tempo futuro. Cada dia, possivelmente os sonhos estarão mais próximos ou distantes, mas o não esmorecer, e continuamente lutar por dignidade, será o próximo mais próximo de todos nós, onde o existir do sonho possa dar as mãos a realidade conquistada. Por vezes teremos uma realidade escarrada sobre nossa face, das mazelas que tanto engolimos de todos, mesmo aquelas nas quais acreditamos não fazer parte, e esquecendo-nos que estamos em um planeta, mas, enfim, essa realidade bruta, pode considerar também, os atos concretos de um rumo traçado em direção ao desenvolvimento, que inclui, o amor, a fraternidade, a união dos povos, a consciência planetária, e tudo que possa nos fornecer, uma força capaz de mesmo quando estivermos sobre o chão, caídos sore as lágrimas da chuva que torna-se uma enchente de imensidões de misérias, traumas urbanos, tragédias na biosfera, ainda assim, possamos buscar, pela humanidade a razão do existir, que atravessa o homem, para compreender que somos Natureza do cosmo, vida que se encerra e se multiplica, em uma arquitetura onde o tempo, permanece no infinito de todos nós, voltados para o princípio, da razão de um bem comum.

A informação, ou melhor o excesso e o que seria descartado. 
De fato, esse é um desafio de coerência, porque inclusive estou quase crendo que quanto maior o volume de informação, provoca-nos um certo grau de esquecimento, mas isso não é uma constatação de cunho científico, apenas uma observação constatada mais em parte refutada pela ocasião onde a memória é seletiva a ponto de resgatar arquivos segundo a necessidade. Enfim, em se tratando de informação e o descarte, em parte me parece que podemos observar o uso de dados informacionais como percursos de orientação, orientação compreendido como sendo determinada informação não um ponto determinado no sistema, mas sim a informação como parte de um sistema, e isso é uma abordagem que sustenta toda uma forma diferente de se observar essa questão, porque se vemos a informação como um fator em rede, em conexões, creditamos um lastro, ou seja, um “ vestígio” informacional, que por estar atrelado em conexões pode se ressignificar e ainda mais, justamente por estar em relação a possibilidade de RESGATE informacional para o sistema é mais abrangente e rápido, de maneira que um elemento informacional julgado previamente como irrelevante, se posto em particular, quando inserido como sentido e significado que se estabelece em uma gama de conexões, essa razão de estado, o preserva sobre grande parte de uma exclusão mais contundente. Portanto, passa em meu modo de pensar, a ser mais relevante ainda, o discernimento de: como e de que maneira realizo minhas conexões por informações recebidas, como atualizo conforme as conexões as informações anteriores, e o mais difícil penso, quais estão se tornando em tempo real, mais importantes para o objetivo que estiver sendo necessário. A relevância deveria por si só, elencar no sistema, os dados necessários, porém, não creio que suficientemente seja sempre assim, havendo de ter um trabalho em certo ponto, como um garimpo (esforço), dentre as informações e conexões, quais estão sobre o sistema, sendo apreendidas como relevância do momento. Passa a ser de estrema necessidade a organização tanto das informações como das conexões estabelecidas, organização é diferente me parece do que simplesmente relegadas ao plano do tempo da experiencia estocada. O como organizá-las, as informações, é notadamente aliado do que é primordial, assim sendo, viabiliza os caminhos cognitivos de forma a constatar as informações-relacionadas por ordem em um outro sistema, que é o próprio (organizacional) desse complexo sistema do pensamento.

O autor aponta bastante para o que será descartado porém vivemos atualmente em uma época em que a reciclagem pegou proporções de impacto responsável na sociedade e devido a essa consciência, as práticas de desuso ou descarte sem reutilização estão sobre outra 
perspectiva. E não somente como design, mas principalmente reciclagem de ideias, de valores quando necessário e principalmente de modos de olhar a vida.

É um tanto aterrorizante creditar as leis da natureza e a historicidade humana, como necessárias de sofrer controle, repressão, porém, melhor será recuperar de que maneira poderemos habitar em uma geologia social onde o respeito e a ética, enfim, não sejam somente disciplinas, mas como elementos do cotidiano, e não alheios ao presente ato de viver. O que nos levaria, presume-se a um bem- estar mais humano, sem necessidades tantas de mordaças, até mesmo ao contrário, vozes que se alteiem em diálogos para que a compreensão e as dificuldades do contemporâneo encontrem suas razões dentre as possibilidades de soluções que estarão ao nosso alcance se nos detivermos em condutas que nos levem a esse fim.

A necessidade de planejamento, ou seja, não somente com o que existe e que deve ser reciclado, remanejado ou encaminhado com outros fins, mas deve-se ter em mente que os passos a seguir deveriam " prever” as possibilidades de um melhor uso em condição mais plena otimizando de tal forma que teríamos menos " dejetos", ou que o planejamento “ suporta-se" um pensar conectado em propensão e também encaminhamento em conexões de " reciclagem" ou outros fins possíveis, e também porque não onde e de que maneira poderíamos encontrar aglutinações saudáveis ao sistema, reutilizando ou provocando novas oportunidades a antigos elementos que se atualizem ou encontrem novas utilidades.

Os espaços da ausência, a exclusão. Recodificando a cidadania, vetores entre grafos de onde a existência é para todos.

Nessa espantosa messe de cadáveres, quantos fiéis ficaram privados de sepultura? Trata-se de infortúnio pouco temido por fé viva, que tem por certo nada poder a sanha dos animais contra a ressureição dos corpos de suas vítimas, das quais não perecerá um só cabelo da cabeça. Teria afirmado a Verdade: Não temais em absoluto, quem mata o corpo e não pode matar a alma, se a engenhosa crueldade dos assassinos pudesse sufocar nos cadáveres inimigos o germe da vida futura? Salvo se houver alguém bastante insensato para pretender não deverem os assassinos do corpo ser temidos antes de o matarem, antes da morte, mas depois da morte, depois de o haverem matado, porque podem privá-lo da sepultura. Se ainda lhes fosse possível fazer algum mal a cadáveres, seriam falsas estas palavras do Cristo: Quem mata o corpo e nada mais pode. Quê! Falsas as palavras da Verdade?! Longe de nós semelhante blasfêmia! Está escrito disporem os assassinos de certo poder no momento de matarem, por ser o corpo sensível ao golpe que o mata, mas, sem seguida, nada mais poderem, por ser o cadáver desprovido de sensibilidade. A terra, é verdade, 
não recebeu o corpo de grande número de cristãos, mas em tal caso, quem os tirou do céu e da Terra, cheios por completo da presença daquele que sabe donde chamar à vida tudo que criou? (AGOSTINHO, 2008,pg 267)

O consumo e o paladar, deglutição e emissão... a porta, por onde haverá um lugar de habitar. O gosto da vida.

Mas passemos à explicação da estátua bifronte. Dizem ter dois rostos, um adiante, atrás o outro, porque a comissura dos lábios, quando abrimos a boca, semelha de certa maneira o mundo. Por isso ao paladar os gregos chamam OURANÓS, e alguns poetas, céu. A boca humana, aberta, apresenta duas saídas, uma para fora, para os dentes, e outra para dentro, para a garganta. Eis o ponto a que chegou o mundo, graças à palavra, grega ou poética, que significa, paladar! Que tem isso a ver com a alma? Com a vida eterna? Renda-se culto a Jano apenas pela saliva, posto abrirem-se sob o céu do paladar ambas as portas, uma para degluti-la e outra para expelila. Existe absurdo semelhante ao de não encontrar no mundo duas portas colocadas frente a frente, uma para introduzir algo dentro e outra para deitá-lo fora? Existe absurdo maior que querer om a boca e a garganta humanas, que em nada semelham o mundo, figurar o mundo com o simulacro de Jano, por causa apenas do paladar, semelhança de que carece, também Jano? Quando o forjam de quatro rostos e o chamam de JANO duplo, interpretam-no das quatro partes do mundo, como se esperasse algo de fora, como Jano por todos os quatro rostos.

Além disso, se Jano é o mundo e o mundo tem quatro partes, é falsa a efígie de Jano bifronte. $\mathrm{E}$, se totalmente verdadeiro, por que sob o nome de Oriente e de Ocidente é costume entender-se o mundo todo, quando nomeamos as outras duas partes, a saber, Astro e Setentrião, alguém ousará, porventura, chamar duplo ao mundo, como chamam Jano duplo ao de quatro rostos? Não tem, na realidade, razão suficiente para nas quatro portas, abertas a quem entra e a quem sai, ver semelhança com o mundo, embora, a encontre no que dizem de Jano bifronte. Tal semelhança não se encontra, pelo menos, na boca do homem, salvo se Netuno sobreviver e oferecer-nos um peixe, em que, além da boca e da garganta, aparecem duas guelras uma á direita e outra à esquerda. E contudo, por tantas portas não se subtrai a semelhante vaidade, senão a alma, que ouve a voz da Verdade: Sou a porta. ( AGOSTINHO, 2008, pg 344)

Qual objeto precioso que deve estar na alma do meu irmão que deverei levar comigo? Creio, se assim posso compreender, que o bem ao qual deverei levar de meu irmão para comigo, na compreensão de nós, é justamente, o que de sentimento elevado ele possui, para que acrescido, eu compreenda o valor que poderemos trocar durante o caminho, quando um precisar do outro, porém, esta é a minha primeira observação, fora do contexto, porém, creio que como desde pequena fui ensinada nos ensinamentos do que nos leva a Deus, eu suponho que ele, o santo, nessa passagem, estaria se referindo sobre esse prisma, porém, perdoem-me 
meus equívocos, caso esteja equivocada, mas ainda mesmo assim, se por ventura, eu tivesse que dizer, tais palavras, gostaria que os sentidos fossem esses:

A manhã, nos enleva sobre os primeiros raios de sol, a convidar-nos em que vibrações de sentimento poderemos adentrar o dia, e se me dirijo a uma jornada, tanto quanto será o de levar o calor humano por onde poderei aquecer qualquer sortilégio que possa também nos atravessar, então, diria a meu irmão: Em sua porta, na sua casa. Tens, acaso a benevolência para que eu possa levar comigo, este crês ser teu bem mais precioso? Ou acaso, ainda poderá ser o maior, o teu maior bem, a alegria, como bálsamo dos tempos incompreensíveis. Acaso, tereis a gentileza como teu maior bem, ou qual será o teu maior bem, para que esteja comigo, sem deixar de maneira alguma de habitar teu coração. Posso, então, levar parte de ti, comigo, meu irmão? Estarei mais próximo e assim saberei, quiçá no destino nos separemos, por onde te encontrar.

Os objetos e os sentidos, Compartilhados. ${ }^{368}$

Culpas ou reações mal programadas. A sociedade em caos, deseja culpados, e alguns são de fato procedentes porém, outros, nos parecem ser, muletas (em parte), como que a segurar o esteio do que nem mesmo são fundações.

O saciar ou não dos atos inapropriados, e suas causas, também é fator relevante quando se considera populações desenfreadamente preocupadas com o quê? O próximo dispositivo ou aplicativo.... para resolver, o quê? Mais uma muleta, ou constatação? Comida para quantos? Os desafios são muitos, e as partes de suas razões também, mas, há de talvez se procurar o discernimento de causa e efeito, de colisões de ambos, e de desembocadura ou horizontes nos quais não atendemos ao que deveriam ter sido objeto de nossos desejos e alcances sociais, e de gerações populacionais da razão de um existir, órfão?! Quem sabe, se procurássemos mais o nosso criador, os desafios estariam mais próximos ao menos, de nossa busca, quem sabe?

Aumento populacional, considera o livro, e também devemos lembrar da relação em proporção ao que é desigualdade, não que uma possível imagem de igualdade venha a sanar o que enfrentamos com uma população, mas ao menos que considere, dentre essa fragilidade em que o número não se dispõe do outro lado do sinal $(=)$, em saciedade do viver, como ausência de fome, violência, habitação, educação, enfim, um território do mundo, onde não

\footnotetext{
${ }^{368}$ Símbolos e palavras, sentidos de um viver. Quanto ao que se refere em nota, ver posteriormente, no livro, um conto só diferente, especificamente, a passagem da loja. Livro este, parte da trilogia, Um conto só diferente, Casa Vazia, Direito de Viver.
} 
comemos nosso umbigo, mas, ainda palavras, ao menos antes que não sejam as últimas, até que a natureza nos devore em extinção, assim para quem sabe, compartilhar da visão, “ realista" do autor, ou, ao menos, constatar alguns prismas dessas nossas possibilidades.

Acreditava-se, considerando o pensamento de Thomas Robert Malthus, que a relação alimento e população seria um crivo difícil demasiadamente para resolvermos, porém, como alguns acreditavam também, refutando-o, poderiam ser resolvidos, suficientemente, com os avanços tecnológicos, com o poderio industrial etc. Havia um impasse, onde se considerava que tínhamos a observação de um número excessivo de população e esta somente teria suas mazelas sanadas com justamente o trabalho cada vez maior da renda obtida com o número proporcionalmente de pessoas ou seja, estranhamente uma relação aparentemente sobre o sinal, em lados iguais, porém, na prática não observamos essa relação, então o que aparentemente considera-se que seria o bastante, não é, e portanto, a força de trabalho não era a solução somente, haveria de se observar ainda mais fatores. E aqui todavia nem se aponta, não somente sobre o número de pessoas, mas essencialmente o como elas estão vivendo, e fundamentalmente passaríamos a dizer sobre a educação do pensamento, onde o viver está imerso, e mais ainda, nessa educação do pensamento, o educar a sociedade, para que os comportamentos em respeito estivessem dispostos sobre o caráter humano, mas não somente do indivíduo mais na sua integralidade com a sociedade, o Estado, e assim sendo, também o Estado deveria sofrer em suas bases, uma educação integrada direcionada aos aspectos nos quais ele se movimenta, não somente quanto a seus objetivos que parecem internos, ( o que é estranho ao se falar de um corpo que o qual ele representa - justamente a população ), mas de que maneira ele está repercutindo no diálogo com o cidadão. E, aqui Bauman aponta mais uma vertente atual, que é o desembocar no oceano global, ou seja, considera que poderíamos supor que as problemáticas locais, nas quais, pessoalmente prefiro me referir sempre como desafios, fariam seu desague em águas sorvidas pela globalização. Bem, me parece que a relação do local com o global é saudável a meu ver, porém, não que seja a solução, mas que a oportunidade de se ater a rede mais do que a tecnologia, mas que a possibilidade de integração em caminhos além do especifico, o local, com o global, pode abranger soluções não percebidas, isso sim, pode acontecer, não diria que não. Mas, claramente deve-se ter o cuidado de ao menos, verificar quais as razões das problemáticas locais para poder enfrentar o desafio, antes que até em outras proporções ele se torne ainda maior. Conhecer, seja as soluções, os caminhos, e principalmente as dificuldades, gera também força de trabalho, negligenciada muitas vezes, mas é fundamental. 
Certas considerações demostram um certo lastro amargo do progresso econômico, com algozes e vítimas, quer tenha ocorrido por migrações do espaço agrícola para industrial, ou a derrocada de artesãos pelo maquinário, ou profissionais pela tecnologia, ocorrendo descarte humano...porém, como ficam essas relações tão imbricadas no progresso quanto a emprego, oportunidades e qualidade de vida. Até quando a sobrevivência em progresso, nos cerca em desenvolvimento ou tempos das cavernas sobre máscaras da evolução?

Ainda a considerar sobre o mesmo prisma, pessoas e comércio, pessoas como comércio, os lados da moeda, e territórios sem dono ${ }^{369}$...

Relações humanas sobre um descarte impessoal, o que queremos de fato? Que lugar dentre o que queremos estamos construindo como espaços sociais.

As causas da exclusão podem ser diferentes, mas, para aqueles situados na ponta receptora os resultados parecem ser quase os mesmos. Confrontados pela intimidante tarefa de ganhar os meios para a sobrevivência biológica, enquanto se veem privados da autoconfiança e da auto-estima necessária para a sustentação da sobrevivência social, eles não tem motivo para contemplar e saborear as distinções sutis entre o sofrimento planejado e a miséria por descuido. ( lembrando de todo tipo de violência ).” Pg 54 Mais adiante, os citam como supérfluos, imprestáveis, desnecessários e indesejáveis. - parasitas do corpo social.( BAUMAN, 2005, pg 56)

As vozes emudecidas e os caracteres socais d da escrita do tempo. Quanto ao lixo, refugo humano, me pergunto, se saberemos realizar compostagem viva de nós mesmos, para quem sabe sermos adubo do futuro... A dura realidade... Refugo - produto útil - estado de coisas objetivo - preço - as duas faces da MOEDA.

Muito do considerado sobre medo, insegurança, e eu acrescentaria " liberdade vigiada", teve um certo amortecimento, em parte pelos entrecruzamentos do real e a ficção onde nos perdemos sem ter em mãos o fio de Ariadne, e para sair desse labirinto, ficou um tanto quanto que como um sentido de um aspecto de tontura que antes ao menos pudesse dar um mal estar, mas nem isso mesmo provoca. Temos visto que o medo, ele é parcialmente consciente, porque ao estar amorfo, comporta-se como algo em dúvida, o quanto que pode ser verossímil, até que esteja sobre a própria pele de fato e comprovadamente, mais do que

\footnotetext{
${ }^{369}$ Exposição Arte coração - infelizmente não tenho a imagem do quadro que fiz para a professora Cristina Rizzi, que tem meus escritos no verso, ( e palavras do meu filho - pequeno), durante disciplina na Universidade de São Paulo, ainda como aluna ouvinte ou especial, onde conhecemos trabalho desenvolvido com refugiados em conjunto com a ACNUR no ano de 2006.
} 
os olhos, acostumados a noticiarem os aspectos sociais como sendo e ao mesmo tempo, apartados da realidade, consumidos por uma dramatização do real, considera-se uma postura até que então passiva, colocada a prova, pelo fato que o repreende na experiência própria alterando acredita-se o fio tênue da percepção, fazendo com que o indivíduo passe então a constatar o seu tecido da realidade, onde o medo na própria pele passa a ser presença. Portanto, tudo do que vivemos e consideramos, enquanto nocivamente distante, mesmo que parte do cotidiano consciente, torna-se objeto de displicência ou um refugo da mente? O que sei e que não quero de fato estar pleno e capaz como faculdade de meu viver, e dispenso informações apesar de ciente delas, em meu comportamento, porque não as engoli de fato e propriamente como veneno social até ver meu próprio sangue escorrendo e as cinzas de onde o vento levará, e ninguém, se lembrara. Lápides vazias da realidade estão cheias de corpo urbanos que desconsideramos, até não ver nossos próprios ossos, sobre o concreto! O que eu posso fazer? Sobreviver já não é o bastante? Ou, como eu devo sobreviver?

Haverá face dessa realidade para que eu possa olhar nos olhos de frente e não inconsequente eu possa gerar algo desse encontro, entre o meu ventre do indivíduo, ser caminhante onde não preciso ser mulher, mas humano o suficiente para gerar um fruto do meu viver em sociedade, que eu saiba ao menos qual é, se não o nome, a identidade, quem sabe pelo menos, pelas linhas digitais de nossas peles, expressão do tempo, marcas que possam me fazer conhecer nos atos do mundo, porque se é local ou global, ao menos sei que não estou fora do planeta, por enquanto, é nele que estou vivendo, apesar de que talvez precise de um satélite, para ver as imagens de minhas origens que talvez perdemos, ou esteja sobre a memória do universo, que um dia, nos mostrará um pouco mais da razão desconhecida de estarmos aqui.

Relações ambíguas se estabelecem, entre razão e percepção, medo e relação, onde a proximidade por vezes é tanta que passa a ser habito, e o costume voraz passa a devorar, pedaço por pedaço, sem mesmo nos darmos conta. Na face ou faca de dois gumes poderemos supor que o hábito que me faz ser vivente em leis, normas, também me sucumbe ao descredito do corpo que tem voz para reagir, mas emudeceu, porque acostumou-se, virou habito conviver com a violência, com a corrupção, com a desnutrição, enfim, de que lado estamos? Entre a distância, porque deixei de sentir a minha própria pele e a proximidade que me fez perder a autonomia de ser, entre o longínquo e a proximidade, de que maneira e como estaremos envolvidos e nos relacionando? Uma época de co-habitar estamos 
múltiplos, requer o desafio da escolha em completude, mas; do que estaremos nos completando, percebendo e refazendo-nos em habitar.

A dificuldade de se lidar com o imprevisto, com o indeterminado, fato este que creio que passará a ser observado de outra forma, porém, o texto do livro adverte que diante desse incômodo de viver em incerteza, torna o poder político com credenciais para manipular, essa vulnerabilidade, como segue:

Numa sociedade moderna média, a vulnerabilidade e a insegurança da existência e a necessidade de perseguir os objetivos da vida em condições de incerteza aguda e irredimível são garantias pela exposição desses objetivos ás forças do mercado. Além de colocar em operação, monitorar e vigiar as condições jurídicas das liberdades de mercado, o poder político não tem necessidade de interferir mais para assegurar uma quantidade suficiente e uma provisão permanente de medo oficial. Ao exigir de seus súditos a disciplina e a obediência à lei, pode basear sua legitimidade na promessa de mitigar o grau de vulnerabilidade e incerteza já existente entre eles: limitar os danos e prejuízos perpetrados pelo livre jogo das forças de mercado, proteger os vulneráveis de golpes dolorosos demais e defender o incerto dos riscos que a livre competição enseja. Tal legitimação encontra sua derradeira expressão na autodefinição da moderna forma de governo como um Estado de bem-estar. ( BAUMAN, 2005, Pg 66)

Estas colocações acima, sofreram alterações como o que segue:

Os bastidores da realidade, culpas em negociação: ética.?... Sinceramente, ainda não compreendo sensivelmente as tantas faces do medo, que por uma delas pode acuar promovendo inercia ou aquele no qual o sujeito ou esferas de instituições se movem, portanto, gera uma atitude, e então, me pergunto, ao menos frente a esses dois tipos, por quais razões se distinguem? Medo de perder o mercado, e então, as atitudes são tomadas, medo de perder uma eleição, então são feitas alterações, mas, tem o medo que aprisiona de tal forma que se torna o cárcere do homem, da vontade, da liberdade, e esse cárcere é o que é alimentado mais fortemente por um algoz em violência, seja um outro indivíduo ou um governo, talvez esse seja um diferencial, o medo aliado da violência, e não estamos falando da física, apesar de que malefícios também se juntam, estamos dizendo de violência de todas as formas, violência de ideais, de conduta, de prazer, onde o medo impera como destino que se torna o cárcere mais cruel que se pode conhecer. Uma sociedade como cárcere dela mesma, como pode proceder frente a seu futuro ou ao Estado? Medo de extinção? Então, porque ainda haveremos de viver em estados habitados por negligência pelo fato? De qual medo estamos falando? Em que meandros perigosos estamos vivendo? Medo e perigo? 
Ameaças veladas? Por onde estamos caminhando? Ameaça da fome, ameaça da falta de emprego, ameaça, pavor, medo, ingrediente de uma sociedade onde o terrorismo mora ao lado, ou dentro de casa? Afinal, existem muitas formas de terrorismo e o medo, pavor, manipulação, são fatores que o alimentam. E, diante de algumas constatações, por onde vamos? Escolhas...

Como nosso pensamento está agindo para que encontremos por onde ou como, deveremos existir. Que forças se encontram entre o pensamento e o sentimento capaz de se encontrar nesses meandros de medos, para saber como proceder, se inerte, ou o pior, conivente, ou ainda pior, o silêncio que é fruto da mordaça, então é cúmplice sem álibi, seu destino, ficou nas mãos de quem, da mordaça, das correntes, ou será que ainda se pode ouvir dentre esses meandros, algum gemido. Haverá chance? Qual a aposta? Em qual cotidiano, podemos estar vivendo e assinando a folha em branco. Depois, vem a conta. Quem paga?

Um jantar saciado do estomago vazio, se alimenta do cardápio das vísceras.

Os consumidores de uma sociedade de consumo, da mesma forma que os habitantes de Leônia de Calvino, precisam de coletores de lixo, e muitos, e do tipo que não evitará tocar e manusear o que já foi destinado ao monte de dejetos - mas os próprios consumidores não se dispõem a fazer o trabalho de coletores. Afinal, foram criados para obter prazer com as coisas, e não sofrimento. Foram educados para se melindrar com o tédio, o trabalho penoso e os passatempos enfadonhos. Foram treinados a procurar implementos que façam por eles o que costumavam fazer por si próprios. Estavam sintonizados com o mundo do pret a porter e da satisfação momentânea. É nisso que consiste o consumismo - e ele decerto não inclui o desempenho de tarefas sujas, cansativas, aborrecidas ou apenas desinteressantes sem alegria. A cada triunfo sucessivo do consumismo, cresce a necessidade de coletores de lixo, enquanto se reduz a oferta de pessoas dispostas a engrossar suas fileiras. ( BAUMAN, 2005, pg 76).

Aprender como o lastro, ou refugo deixa de ser objeto descartável para ser aprendizado é também objeto de consumo saudável se assim for visto e observado como tal.

Me parece mais uma vez, que como no tempo de desbravar mares estejamos sobre escolha de quanto habitarmos territórios mais abrangentes, o que iremos fazer, se descortinar possibilidades de crescimento e uma expansão “ civilizada" etc etal, ou viabilizar uma vazão de caminhos para descartar nossos lixos mais facilmente, portanto, mudam os prismas, vieses ou que nome queira dar, a linha do tempo que mais do que " utopia regressiva", termo usado por Luis Sergio Henrique, nos bota na cara, que o tempo é um exímio contador de histórias nas quais ainda estamos escrevendo, e das quais queremos 
saber o final sem ao menos conhecer o princípio, e o tempo, que escreve conosco, de vez em quando, ou quando não o sempre, escarra diante de nós, seu vômito latente de que não digerimos de fato, os acontecimentos.

“ No espaço de fluxos ( expressão de Manuel Castell) global, o conceito de lei só pode ser empregado seguindo-se o preceito de Jacques Derrida, de utilizá-lo sous rupture. Citando Teubneer e Bockenforde, Hauke Brunkhorst aponta que o estranho " direito global" ao contrário daquele que supomos estar em prática nos modernos Estados-nações, está muito afastado da política, sem uma forma constitucional, sem democracia, sem hierarquia a partir da base, sem uma cadeia contínua de legitimação democrática. É um governo sem governante, O que quer que possa passar por direito global não pode ser utilizado numa corte da justiça, só podendo ser aplicado em casos muito raros. De forma comparável ao antigo direito civil romano, a aplicação do direito internacional depende da vontade dos que tem o poder de aplica-lo. ( BAUMAN, 2005, pg 83)

Refugiados no próprio cotidiano a espera de um lugar para viver com dignidade. Por vezes me parece realmente que a dificuldade que podemos ter de lidar com incertezas vem de uma “personalidade" autoritária porque a incerteza lhe foge ao controle e manipulação, mais do que a simples constatação de que o incerto lhe pode sugerir uma liberdade, portanto, tenho a real impressão de que ao se manifestar de forma tão cabal quanto a relação que a incerteza lhe sugere, está dessa maneira ao relatado acima, posto de maneira a um incomodo muito grande, onde penso que dependendo de como se defronta com a incerteza e probabilidade, poderia ter outra concepção, outra reflexão bem distinta.

Labirinto - o fio - e o fim da linha, saída ou entrada?

Rosa Luzemburgo divisou um capitalismo que perecia por falta de comida - sucumbindo por ter devorado o último bocado da alteridade que lhe servida de alimento. Cem anos depois, parece que um dos resultados mais fatais- talvez o mais fatal - do triunfo global da modernidade é a crise aguda da indústria de remoção do lixo humano: como o volume de refugo humano supera a atual capacidade gerencial, há uma expectativa plausível de que a modernidade agora planetária, se sufoque nos seus próprios dejetos, que ela não pode reassimilar nem suprimir. Existem inúmeros sinais da toxidade sempre crescente desse lixo que se acumula com rapidez. As mórbidas consequências do lixo industrial e doméstico para o equilíbrio ecológico e a capacidade de sustentação do planeta tem sido tema de intensas preocupações já há algum tempo ( embora não tenha havido muita ação em consequência dos debates ). Mas não chegamos nem perto de ver com clareza e de apreender na totalidade os efeitos de longo alcance das crescentes massas de pessoas postas de lado sobre o equilíbrio político e a harmonia social da coexistência humana do planeta. ( BAUMAN, 2005, pg 90) 
Curioso como nem é mencionado, claramente por ser desconsiderado totalmente o refugo, a energia que é posta em atos, por mediocridade humana que são mais lixo do que todo o lixo toxico e tecnológico que possa haver, mas creio que disso a humanidade não tem ciência.

E, também, como se a cova do planeta fosse somente agora aberta, os despojos da nossa mediocridade estão nos cerceando desde....( aberta e não estou dizendo feita, o que leva a outros pontos a serem considerados ). Como agimos com uma sentença decretada? Extinção, mortes, inanições, fazem parte do cardápio, mas, não só isso, o alcance de nossas escolhas também tem a outra face. Porém, como simplesmente, passou a não ter importância, de tão acostumados com a sentença de morte, que passou a não ter mais relevância, ou ainda terá?

Realidades paralelas. Do interno caminho da globalização, podemos encontrar realidades paralelas, mais próximo do que imaginamos, isto porque quanto que temos da busca de um abrigo dentre os lugares sociais de nosso próprio ambiente, que não precisa ter uma origem especifica, mas bastando se tratar de ser humano que procura existir, e ainda sem ter muito, para alguns, por onde, mesmo que tenha a vontade e determinação de trilhar seu rumo, de encontrar seu destino. Lutas que se transformam em igualdade.

E ainda, temos a leve impressão que a prática, atiramos primeiro e perguntamos depois, ainda é uma constante na equação da vida que somente vê o sangue pelas feridas das pedras que foram apunhaladas sem nem mesmo saber de onde vinha e o porquê, mas o tempo segue, e as areias são sopradas pelo vento, de onde as carcaças saem e ficam a mostra.

A repressão aumenta e substitui a compaixão. Problemas reais como a redução do mercado imobiliário e o desemprego maciço nas cidades como causas da questão dos sem-teto da ociosidade juvenil, e da epidemia das drogas - são desprezados em favor de políticas associadas à disciplina, ao refreamento e ao controle. ( BAUMAN, 2005, pg 107).

Qualquer coincidência com a realidade não é mera coincidência. Dramaturgia dos fatos reais.

A esperança, meus caros, é que a ignorância não vença.

Esvaziada da confiança, saturada da suspeita, a vida é assaltada por antinomias e ambiguidades que ela não pode resolver. A espera de ir em frente sob o signo do lixo, ela cai do desapontamento para a frustração, aterrissando a cada vez no próprio ponto de que desejaria escapar quando começou sua jornada exploratória. Uma vida assim vivida deixa atrás de si uma série de relacionamentos frustres e abandonados - o refugo das condições globais de terra de fronteira, notória por reclassificar a confiança 
como um signo de ingenuidade e uma armadilha para o inábil e o simplório. ( BAUMAN, 2005, pg116)

O tempo do sentimento é eterno. Mas, retornando ao texto, o existir reserva a vida suas ações da alma, onde se relaciona, constantemente em profusão de experiências latentes ou efusivas cada qual com seu modo particular de ser, no que penso, deveríamos ater ao que permanece de nós como além de nós, o que é parte do que somos em eternidade, e de onde poderemos nos recompor, sobre alegrias ou destroços, mas nossos passos, e o que me surpreende são a displicência com que deixamos passar nossos momentos, de onde a morte, relatada como fato incontestável, simplesmente não difere enquanto nossos mesmos passos, porém, quando esse fato se torna uma sentença, por alguma razão mais forte, o que acontece conosco para pensarmos, agirmos, e tomarmos decisões outras que no decorrer da vida, normalmente não emitimos. O que então, faz, a eminência dessa constatação, diante de nós para percebermos quão, poeira cósmica somos, diante do que representamos.

E, claramente o texto pondera, sobre certas críticas até:

Por todos os padrões concebíveis, essa não é uma realização medíocre em si mesma. Mas a cultura vai além: de alguma forma consegue transformar o horror da morte numa força motora da vida. Constrói a expressividade da vida a partir do despropósito da morte. A sociedade em toda parte é, como aponta Ernest Becker, um mito vivo sobre o significado da existência humana, uma desafiadora criação de significado. ( BAUMAN, 2005, pg 121).

Porém, Bauman, ainda faz um alerta que: “ A afirmação de Becker precisa uma correção. A sociedade, e a cultura que faz da sociedade humana um sistema, é um mecanismo que permite a realização do feito heroico, de modo cotidiano e trivial, por seres humanos comuns, não-heróicos. “, afinal em determinadas sociedades viver já é por si só um ato heroico.

O que entendemos como morte? A ausência física? Pois creio firmemente, que a presença da violência, e aqui poderemos listar todas as mazelas humanas, fome, depravação da natureza, e tantos atos ilícitos, essas são mortes de uma envergadura na qual, creio não temos a noção do alcance e proporções, um suicídio coletivo eu diria, mas poderia soar muito árduo para alguns. Portanto, a morte em vida a qual praticamos, conosco e com os nossos irmãos, é o mais difícil que teremos que conviver, ou talvez, deveremos expulsar de nosso cotidiano, para viver então, de forma como a existência deveria ser. Temos também, como escrevi em 
outro momento, a morte que é encerrar em nós o que nos atem a nossa própria mediocridade, ou seja, fazer morrer em nós as nossas dificuldades, vícios, essa sim, é uma morte que traz o renascimento, como o físico quando perece, enfim, modos de ver a morte e a vida que caminham por entre nosso espírito, mente, ser, corações, sentidos. Fazer o esforço por observar vários possíveis que possam nos ajudar a compreender o mundo que nos cerca, ainda que sobre outras conjecturas são saudáveis para aprendermos.

Qual a nossa percepção do infinito? Percebo por vezes o infinito como uma presença mais próxima, eu diria, mas talvez exigisse um modo particular ou uma vontade de observar o tempo assim, como que a fatorar, ou se pudermos pensar em um desmembramento, onde o amanhã, para o tempo presente, pode ser, tão longínquo quanto as gerações futuras, nas quais creditamos não estar presentes para ver seu cotidiano, então, como se a ver a presença da terra em relação ao cosmo, em escalas de percepção se assim posso considerar, penso que o infinito se apresenta aos poucos a nosso modo de conhecer o mundo e o cosmo, dependendo se pudermos nos aproximar de maneiras diferentes de apreender algo a nossos sentidos, dependendo da perspectiva. E ainda, não sei se serei clara, mas, tem ao menos duas formas de ver o que proponho quanto a perspectiva da presença do infinito mais calcado dentro ( em desmembramento ) do presente ( in futuro ), que seriam a primeira tendo por exemplo a presença do infinito aqui, contando com o relógio mas a subjetividade do sentimento que o contenha, enfim, a primeira seria a proximidade da angustia presente sendo para o segundo o amanhã um tardar ( em escala ) árduo demais para considerar, e portanto, infinito para ele, e também, como segundo modo de pensar o que vejo, seria, o segundo em relação ao infinito, face do presente que sente o infinito, ao se revelar desmembramento no tempo que o prossegue, e essa constatação, o faz nele mesmo, absorver a ideia do infinito enquanto, momento.

Lembrando das escalas, do cosmo, seria para o entre, possibilidades dialogando com o lugar de onde se observa, e portanto, quase como a se obter um escalímetro que demostra, escalas e tempo conforme o desenho da geometria do espaço como apreensão dos nossos passos, distâncias nas quais estamos imersos, vivemos, porém, podem ser distintas conforme a cada um, indivíduo, e sociedade, e de cada um para consigo e o mundo, conforme suas próprias “ medidas" do observatório, onde os passos são trilhados.

Quando todos os seres humanos se livrarem de Deus e da eternidade ( como deverá acontecer, com a lógica impiedosa de sucessivas camadas geológicas) o homem irá se concentrar em obter da vida tudo que ela pode dar, em nome da felicidade e da alegria, mas apenas neste mundo, aqui e 
agora. Então os seres humanos se tornarão eles próprios deuses, imbuídos do espírito e da titânica presunção divinos. O conhecimento de que a vida não passa de um instante fugidio, de que não há uma segunda chance, mudará a natureza do amor. $\mathrm{O}$ amor não terá tempo para habitar. O que ele perder em duração vai ganhar em intensidade. Vai arder mais, de mais fascinante que nunca, consciente de que está destinado a ser vivido e usado num único momento e até o fim, em vez de se espalhar de maneira tênue e insípida, como antes, pela eternidade e pela vida imortal da alma...(BAUMAN, 2005, pg 127).

Do fugidio,

Ora, então, sorveu o veneno,

até que a morte, te sucumba

Desafiando a eternidade

E quando te deparas

Frente ao amor, (calas em ) igualdade

De habitar a vida mais plena e fiel ao destino

Que não como fel, esteve por entre tua alma

Que, acalma-te.

Deixe o cálice vazio, de onde

O fundo te pertence

Sobre as veias do sangue que venceu

As trincheiras de seu lastro

Perpetuando-se onde, bebeu.

Do cálice, a vida, entre a realidade a sede e a ferida.

Não há mediocridade ( a maldade ) mais pífia, a maior de todas, que não seja cometida em verdade consigo própria, e portanto, existe uma forma de libertação, na qual, se apresenta algo vital. Quando o mal se apercebe que o cometimento é em si mesmo, para com ele mesmo, em grau maior, o instinto de origem, que é o amor, fonte de toda criação, o resgata, se apresenta, (quase como instinto de sobrevivência), e em meu modo de ver, Deus é amor. O sangue, o caminho, a vida, o cálice, $\mathrm{O}$ outro não tem distinção à mim, então se resume, 
mais uma vez, em Amar a Deus sobre todas as coisas e ao próximo como a ti mesmo, Deus é amor. O sangue, a vida, o cálice, o caminho.

Os dias me comportam quanto sou deles a mesma natureza, o último dia, posto que outro nascerá amanhã. Que o hoje seja o meu melhor donde possa ser um amanhã diferente. Posso compreender-me fim enquanto cada passo, e assim sendo o horizonte que caminha comigo, repartindo-se como formas da geometria da vida, equação do viver, em distâncias onde somos fractais desaguando, gota em oceano, lágrimas da chuva, foz, margem, mares, águas. O prazo é de cada instante, a procura infinita, assim o tempo entre longo ou do momento, nos é um tanto quanto familiar e incógnito, se pudermos compreender essa conjunção, ou, o tempo passa a ser de nós, o que dele podemos ser. O lastro nosso, pegadas, podem ir com o vento, e me perguntas se então, delas terei desaparecido, as marcas, bem, se o vento as levou, poderá pertencer à ele. ( e quando então serei eu e o vento ). Se não podes ser fiel a ti mesmo, então no que poderá viver? O prazo da vida, pertence a qual tempo, que não esteja segundo nossa compreensão, do que é, eterno ou extinção? O comprometimento, deverá ser, penso, na medida mesma, também, de sua compreensão, e dos esforços nos quais se realize como aprendiz eterno.

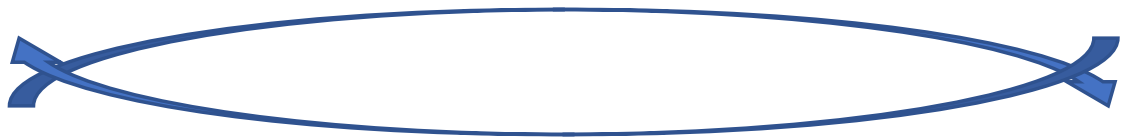

Organização do pensamento - indivíduo, sociedade, organização.

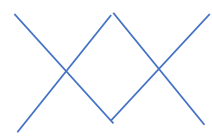

A vida é um trabalho do qual não nos podemos furtar, capital da existência e valor do desenvolvimento. Do que vemos ou podem nos mostram e do que segundo nossos princípios podem transformar. " A síndrome da impaciência contemporânea transmite uma mensagem oposta: o tempo é um enfado e uma faina, uma afronta e um desafio aos direitos humanos, nenhum dos quais deve ou precisa ser sofrido com satisfação. “( BAUMAN, 2005, pg 134).

Em se tratando de tempo, e de observação, creio que aprendi a olhar sobre mais de uma perspectiva ademais quando estamos tratando de paciência, ou impaciência, e digo em razão de como esse sentimento se comporta, no que tentarei explicar, posto que se a paciência é fruto de uma temperança, de uma concórdia, de um estado de equilíbrio possivelmente, podermos encontra-la como benefício, e creditando-lhe outra face, na qual alguns lhe colocaram outro nome, " rótulo", se diz por vezes que o caráter retrogrado desse sentido, sentimento, estaria conjugado com o comodismo, e não seria paciência mais, ou dentro dela, 
tentada pelo que é de uma estagnação, e então, o que o tempo demostra é que mesmo o caráter de um sentimento, ele, conforme o seu comportamento, demonstra o como e porquê, ou seja, a razão do sentimento, como está agindo, de que maneira, e porquê, então a impaciência, que normalmente é fruto de algo que denota inquietação, essa mesma palavra que se conforta ao outro termo, nos diz, que uma impaciência pode ser também, coerente com um estado onde é necessário uma mudança, então, o que normalmente se acusa de ser um malefício, no caso de uma necessária alteração para um rumo melhor, na qual os inseridos e adjacentes se veem compelidos pela impaciência, ( aqui necessária uma ressalva - impaciência com prudência ) é justa por ter sua razão colocada no objetivo, e assim sendo, poderemos refletir que todo sentimento, está sobre uma razão, assim creio, e ela, demostra o caminho de sua existência, ou seja, porque surgiu este sentimento, que provoca ações, mas ações que estão inseridas no amago, daquele SENTIDO DO SENTIMENTO. Portanto, bom será sempre, avaliarmos o ponto de observação como um horizonte, onde o pensamento cohabita razão e sentimento.

Tempo e decisões de consumo, entre desejo e satisfação ....perda e indigestão - equilíbrio

O cálculo-

Compro o teu desejo

Até que teus olhos estejam

Sobre meu corpo

( o mesmo que não te pertence )

Pronto com todas as amarguras

e urdiduras desse viver..

quer viver comigo?

Eu almejo entre a vida e a alma

O sexo do cotidiano

Cotidiano

( sagrado ou profano )

Por onde faltam carícias

Mas cheio de malícias

Se entrega

Vocifera entre minha boca 
E a tua pose de cidade

$\mathrm{Mu}(\mathrm{n}) \mathrm{do}$

Profundo gozo dos edifícios

Ou orifícios das matas

De todo nosso território

Ilusório modo de ser ( sem conhecer )

Esse conviver, de crédito

Ou descredito

Supérfluo ou manifesto

Calculado sobre nossas peles

Em extinção!

Natureza nossa

Vou pegar emprestado

Depois eu pago

Será que teu desejo

Vai sair caro

( 0 amor eu pago?)

Não posso mais que isso

Eu desisto

Quero o querer assim

Desse jeito

Teu grito no meu peito

Onde sonhei estar

Seguro nos teus braços

Nos teus abraços

$\mathrm{O}$ teu ar

Vou pegar emprestado

Depois eu pago

( o amor que eu afago )

E agora 
Verdes, matas, asas

Dessa floresta

Quem paga a conta

Que sem ar, remonta

Ordem e progresso

Manifesto e retrocesso

Tempos difíceis

Ou melindres

Da civilização que esqueceu

De viver

$\mathrm{O}$ que pode ser

O preço de um mundo melhor

Em promoção ou não

Eu quero viver

Uma população que saiba o que é

$\mathrm{O}$ valor de ser livre

Ser livre

De um coração

Um coração, livre.

Não minhas (, )

As tuas cifras

( Eu ) Deveria saber /que o preço seria baixo demais

E como se fosse/ prostituta do cais

Não me vestiu mais do que o seu desejo satisfeito.

E o beijo sem lábios

Não esteve nem mesmo no olhar

Que não tardou de gozar

Apenas como adeus

De um longo prazer

De um não querer mais 
Que o amanhã, que finda.

É tarde, ( jamais ).

Deveria saber que o preço seria baixo demais

E como se fosse /prostituta do cais

Não me vestiu mais do que o (seu )desejo satisfeito.

Da próxima vez, meu bem

Me diga por favor,

Que desse jeito

Não tem amor.

Deveria saber que o preço seria baixo demais

E como se fosse prostituta do cais

Não me vestiu mais do que o seu desejo

E que desse jeito....

Não tem amor.

( não para estar na canção,

Mas, não se esqueça querido, por onde eu for, meu amor, é livre, sou livre, e você não. )

Seu preço foi baixo demais.

Travessia

(Y, cuando el tiempo se queda de lábios cerrados...)

Esteve a desistir da vontade

Mesmo quando a póstuma sinceridade

De seu revelar, fielmente supunha

Estar presente como vida e pluma

Das palavras de seu pensar.

E onde estiveste então

Do tempo ausente?

Acaso possas caminhar sobre tuas águas

Ou transpor as poças como a velejar sem velas

Ao sabor do vento em tê-las 
Como teu próprio corpo

Ardoroso de se ver

Tempo de si próprio

De onde talvez os segundos

Te pertençam

Ou do infinito sejam

E em teus lábios por fim

o tempo esteja,

mesmo que sobre o silêncio, morra.

Sociedade vigiada, os rastreadores do gesto social: Alterações?

Como costumava dizer o grande sociólgo italiano Alberto Melucci: Estamos continados pela fragilidade da condição presente, que exige um alicerce firme onde não existe alicerce algum. E assim, ao contemplar a mudança, sempre nos dividimos entre o desejo e o medo, a expectativa e a incerteza. É isso: a incerteza. Ou, como prefere Ulrich Beck, o risco: aquele companheiro ( ou seria rastreador? ) indesejado, desastrado, e irritante, mas também obstinado, atrevido e inseparável, de toda expectativa - um espectro sinistro que assombra os inveterados tomadores de decisões que nós somos. Para nós, como Melucci afirmou energicamente, a escolha tornou-se um destino. " ( BAUMAN, 2005, pg 142).

Das necessárias mudanças reais, manipulação de argumento por análise de discurso imposto onde se coloca no mesmo a prática de uma vontade ou seja, se dispõe sobre palavras que fica em determinação na mente ou pensamento a possibilidade possível como real e concreta, devido a intenções prévias e de domínio social. Havendo de ter uma contramedida no âmbito de escala geral capaz de valorizar e manter ideais que possam e devam se apresentar como caminho dentre dificuldades.

Nesse tipo de cultura, e nas estratégias de política de vida que ela valoriza e promove, não há muito espaço para ideais, menos ainda para os que estimulam um esforço de longo prazo, continuo e sustentado, composto de pequenos passos que levam com segurança na direção de resultados reconhecidamente distantes. E não há espaço algum para um ideal de perfeição cujo encanto derive da promessa do fim da escolha, da mudança do aperfeiçoamento. Para ser mais preciso, esse ideal ainda pode pairar sobre o mundo e a vida de um homem ou mulher liquido moderno - mas somente como um sonho, um sonho que não mais se espera possa se tornar realidade e que raramente se desvela ver transformado em realidade, um 
sonho noturno que quase se dissipa á luz do dia. ( BAUMAN, 2005, pg 144)

Apesar da passagem ser "fluida" enquanto efêmero e fugaz, se observa atualmente a necessária condição de perceber, para onde se está caminhando.

4.3-Aspectos de uma mobilidade comunicacional.

Vida como produto, o trabalho de(o) viver. O público e privado, governo e sociedade, um trânsito em movimento.

Até onde o olhar se torna o mesmo, sem territórios, e apenas humano. Travessias...

Dos diálogos em sociedade, a negociação. De quem sou, que é a sociedade. Da sociedade, quem sou? O homem e a ilha. A cidade e o homem. Espaços interligados para grafos sociais. Rede de conexões, entre espaços e formas, diálogos em construção.

Cidade política, memórias de um argumento, Aristóteles:

Erram, assim, os que julgam ser um só o governo, político ou real, econômico e despótico - porque acreditam que cada um deles só difere pelo maior ou menor número de indivíduos que o compõem e não pela sua espécie. Por exemplo, se aquele que governa só possui autoridade sore um número reduzido de homens, chamam-no senhor ( déspota ), ecônomo, se dirige um número maior, chefe político ou rei, se governa a um número ainda mais elevado - não fazendo a menor distinção entre uma grande família política e uma pequena cidade. No que se refere ao governo político e real, dizem que quando um homem governa só e com autoridade própria, o governo é real, e sendo, pelos termos da constituição do Estado, alternadamente senhor e súdito, o governo é político " ( buscar livro emno quarto ou no ap beto, ver ano edição )[...] " Disso nos convencemos se examinamos a questão segundo o método analítico que nos guiou. Assim como em outros assuntos, somos obrigados a dividir o composto até que cheguemos a elementos absolutamente simples como representado as partes mínimas do todo, do mesmo modo, examinando a cidade nos elementos que a compõem, saberemos melhor em que eles diferem, e se é possível reunir esses conhecimentos esparsos para deles formar uma arte. 13

Existe um intervalo de tempo que deve ser de fato considerável em posturas que absorvemos dentre a organização da sociedade, entre povo e governo, assumindo a diversidade de posturas de tipos, no presente momento, admitindo como possível para argumentação a 
“democracia". Do intervalo cremos ser necessário justamente avaliar, que, na atualidade supõe-se que estejamos tratando de uma ordem social que é composta por viabilizar uma complexidade grande estabelecida em poderes estes que representam de maneira não a considera-los como detentores de uma verdade imutável, mas de um progresso de "diálogo", onde não apenas se diz, mas se ouve as partes, no caso, governo e povo.

Argumentos construídos por palavras em sentido que absorve e tem por vezes intenção de direcionar a realidade. Portanto, para a relação entre governo e sociedade, imagem e texto social, tem-se que para este posicionamento a escolha de, em vez de obediência, responsabilidade; e no que pode ser dito, obediência, como resposta imbuída do sentido de consequência.

Homens de gravata... aonde? No pescoço dos animais... sociais demais? Engula o pão, ajuda com a espinha do peixe. Que peixe? Deixamos de ser cristãos.

Ainda em Aristóteles, se encontra sobre Platão: "Estamos no caminho que parte dos primeiros princípios ou no que se dirige a eles?

E, Platão, me diga: No que difere o ponto e a perspectiva do espaço e tempo, quando um se torna a razão do outro. Faz muito tempo que eu aprendi, algo que dizia sobre o estar contido, e quando li a frase, no que se dirige a ele, ( ao princípio ), me pareceu completamente o sentido de estar contido, então, vamos, por onde o princípio nos guia, ou seja, contido nele estaremos para encontrar o destino. Origem e destino.

- Platão, ouça! A-visa o surrealista de plantão, que o ponto, é um poema. E, agora? Quem paga a conta?

Mas, voltemos ao pensar, que gesto de geometria esse, que não se pode nem mirar?

Certamente, me darás a terra ou nela encontrarei espaço, porém, quando no caminho, te perguntarei da semente, e haverá na terra, o sulco, de onde esperarei brotar, e enfim, estarei em algum lugar?

- Talvez queiras a semente antes de saber sobre o chão que pisas e dele ouça o que pode nascer da terra!

- De fato, penso que poderá da minha carne, perpassar a veste da alma, de quiçá eu possa compreender a natureza do que penso.

- Fato este que deseje negociar? 
- Negociar o pensamento? Ou nessa terra, as formas de se trabalhar?

- Acaso o sol permita, haverá tempo em delírios do calor, de supor demasiado esforço de onde o arar esteja sobre o meu pensar? Talvez esse seja o delírio, que trará o sulco por onde a semente possa estar. Quem sabe?

- Custa - te por certo estar sobre a terra e dela nem sempre ouvir o ventre, por tão tecido denso, gestando ininterruptamente e arduamente seu fogo.

- Claro, o fogo. Como pude me esquecer, Elemento genitor, como fonte que jorra, mas da qual hoje preciso, encontrar ainda como ser. E todavia, então poderemos ser um?

- Um eu não diria, mas talvez, múltiplo dele, quem sabe.

- Negociemos então. Mas, poderá ser uma troca, ou teremos a necessidade do preço? Nascer haverá de conceber um valor? Esta será uma proposição de necessários argumentos para diagnóstico desse projeto de viver, onde quem sabe as medidas consultemos ao cosmo, ou mais próximo, o próximo!

-Bom será que o próximo esteja, nem tão longe ou que eu possa de sem fronteiras, o avistar, como do porto o além mar. De quem sabe a terra, esteja sobre os mesmos pés, e o caminho se torne o mesmo. Mas sobre o sol, será possível o que desejas. Ontem mesmo, encontrei o vazio, e não prenhe de si, esperava as cinzas, que nem mesmo servirão de adubo! Então pense, desejas tanto a igualdade, e como mostrar na forma de arar, o ventre dessa terra, que seus filhos se tornem a luta, cada qual a seu destino, mas que não desista. Será possível? Do que pode nascer o que não almeja brotar!? Então te pergunto, como poderá ser o amanhã.

Então seja esta a vontade que falta ao desejo, o quanto baste! Ou melhor, do que o desejo precisa para ser, mais do que o querer. Então que o assim, seja o onde o saber esteja como natureza orgânica do ser que pensa, em sociedade, para que possa nascer a cultura, desejo de conhecer a educação onde o significado desta abrace a vida, e não longe dela, se torne razão.

E não te esqueças urbano que sejas, entre tuas vielas, de naturezas repartidas, os espaços do saneamento, quer habite teu ambiente, sujeito! E sujeito que respiras, onde está a tua natureza? Por onde andas, na arquitetura da terra sobre medidas de espaço, a procura do pensamento?

- Do que podes fazer, tanto me perguntas? E porventura não será está a tua indagação, antes mesmo da plantação? Terreno baldio do mundo, estaremos até quando? Negociação. 
A troca. Quem sabe, natureza minha, mundo. Lugar de nós.

Mas, veja, como poderei eu que acabo de nascer, cidadão e posto feito terra, ou nela, melhor dizendo, trocar-me, se, estou como vim ao mundo, ser, e nem mesmo tenho o que oferecer a não ser a vida. E isso tem valor para mim, não posso claramente me desfazer dela.

- Haverá de ser somente isso, ou o que dela sabes? Acaso teu pensar e agir não será também da tua vida seus pertences?

- Queres negociar minha consciência?

Não! Apenas que o desejo de tua vida se torne, nesse valor, uma troca com a terra, lugar teu de nascimento, sem que te percas, mas que gere em uma relação o que te tornará, semente.

Haverá tempo de meus atos serem a imagem de meu próprio discurso, onde a palavra em silêncio se torna gesto. Fato este, sendo objeto do meu pensar. Abrigo de minha consciência, razão de minha alma.

E conta-se que Gaia ( terra), senhora de muitos frutos, haverá de contar seus filhos, e dependendo de quantas bocas houver, haverão de comer, ou da terra irão esperar, o que para todos saciará. Não havendo Gaia, de suportar, a fome de alguns, e a saciedade de outros.

-Pergunta-lhe o filho.

Como faremos então, dividiremos o pão, ou trabalharemos mais com o trigo?

Da terra nascerá, creia. E portanto, terás a tua resposta, se o que dividires, não seja o suficiente. Onde haverá de estar as tuas forças? Do que o trabalho nasce, que te saciará enquanto o próximo que da terra se nutre em igualdade.

O cultivo. O trabalho. Os frutos.

E, agora. Estando sobre a terra, que de tão vasta, perco-a de vista, e de lá de tão longe, parece um só oceano, de tão azul. Espaço.

Pescador, busca-me a solução, fui me aproximando, e comecei a ver, tantos lugares, que não sei mais onde poderei morar. Mas, me disseram que são muitas.

Precisarei distanciar-me para ver a terra, como um ponto, ou um oceano azul. Onde talvez a consciência desperte, do lugar de onde nem sequer sou capaz de ver um ser humano. origem) 
Quanto que uma imagem que nos representa em sociedade sendo esta objeto de manipulação está na interface dispondo sobre o mesmo lado, entrecruzamentos de dominação e subjugação, onde e apesar, o que engolimos sem questionar, ou sendo ainda, elemento de composição, temos a nossa parte em relação ao amortecimento que tanto criticamos como nem vendo, sendo ainda, poder de comunicação em massa. Onde mesmo não estando sobre linha de fronte do cotidiano, estamos sobre linhas cegas de guerras veladas em comunicação de um tempo que nos impõe ponderar o que de fato queremos se respirar, ou perder o ar, ou seria, a cidadania.

O rosto e a máscara social, sobre o tecido do existir, a pele de uma humanidade. Onde de fato estaremos como organismo e organização? Entre os tempos, a presença.

A aparente semelhança da segunda parte com o traçado de uma arqueologia, que busca no passado, em seus estratos, a feição autêntica de algumas formas e algumas práticas de comunicação hoje desaparecidas e degradadas. Quando na verdade o que buscamos é algo radicalmente diferente: não o que sobrevive de outro tempo, mas o que no hoje faz com que certas matrizes culturais continuem tendo vigência, o que faz com que uma narrativa anacrônica se conecte com a vida das pessoas. (BARBERO, 1997, pg18).

Apesar dos fatores históricos entre dicotomias de "povo" e intelectualizados", me parece que hoje estamos nos atravessando, campos justapostos que ainda com diferenças, podem aprender mutuamente cada qual com seu saber, entrecruzando de maneira a percorrerem seus sentidos de forma a proporcionar conhecimento mais amplo e de uma alcance não somente restrito a um determinado perímetro mas de maneira complexa e expansiva.

Interessante, observar como perspectiva dependendo do contexto, fazem com que, determinados saberes, possam não ser conhecimentos em sobrevivência ou adaptação ou mesmo, relações em espaços sociais que exerçam sobre perfis "cultos", uma outra necessidade de sentido a se encontrar sobre a forma do outro, este, o dito, popular. Isto fornece um dado, entre o que de maneira costumas colocamos como diferenças. Então, avaliando o cunho de um saber, enquanto necessidade e exercício concreto em relação ao espaço do viver, a divisão ocorre sobre elementos de uma equação mais ampla, onde o que suponho que me é normalmente irrelevante torna-se objeto de meu consumo, para compreensão por certa conjectura na qual esteja eu inserido e que me sendo, adversa de meu ambiente habitual, portanto, passo a englobar como estado de sujeito pleno, o outro que 
julgava distante, sem nem mesmo considerar reverberação social, pela constatação de que os saberes plurais, também são das diferenças.

Vivemos uma época em que me parece cada vez mais, que os distanciamentos que se aproximaram virtualmente, mesmo havendo criticas de posicionamentos cotidianos e concretos entre relações humanas, quiçá então seja, a globalização, os espaços se acercaram e deverão produzir entrelaçamentos e aproximações com mais ênfase cada vez de maneira a proporcionar entendimento e ainda, apesar de constatarmos um longo caminho a seguir, devemos considerar que como dito, do que queremos, entre a realidade e o que nos faz dela, discurso em opinião onde os direitos e deveres em sociedade são da negociação espaços onde não estamos apartados e somente representados sem nossa imagem, mas cada vez mais, estando cônscios de que a natureza do povo é a mesma do órgão público que o representa, enfim, o Estado como um todo. Sabendo claro que o discurso implementa uma parcela da realidade que cobrara seu destino, havendo de procurar as correspondências de maneira que o cotidiano demostre tanto como representação a própria imagem. Daí mais um fator do que é ressonância como duplo sentido de imagem, tanto o que são camadas visíveis do tecido social e não ausentes, assim como também, o que reverbera, justamente onde os lugares se aproximam.

Será possível que todavia, perguntemos para encontrar respostas, onde nasce o povo?

Território do saber, território político, território humano, social, de relações? Quantas vezes haveremos de nos perguntar para compreender o que nos constitui, entre partes, um todo?

Alguns rumos traçados:

O românticos chegam por três vias, nem sempre convergentes, à "descoberta" do povo. A da exaltação revolucionária, ou ao menos de seus ecos, dotando a chusma, o populacho, de uma imagem em positivo que integra duas idéias: a de uma coletividade que unida ganha força, um tipo peculiar de força, e a do herói que se levanta e faz frente ao mal. Uma segunda via: o surgimento, e exaltação também, do nacionalismo reclamando um substrato cultural e uma "alma" que dê vida à nova unidade política, substrato e alma que estariam no povo enquanto matriz e origem telúrica. E por último, uma terceira via: a reação contra a Ilustração a partir de duas frentes: a política e a estética. ( BARBERO, 1997, pg 13).

Ainda segundo o autor, o Romantismo traz a noção de cultura como imagem, do que é da população. 
Segue essa linha a releitura efetuada por Hobsbawm ao estudar as relações entre românticos e revolucionários, releitura que começa a abrir caminho também na América Latina. Assim, Morande propõe que, em sua relação com o povo, a renovação do conceito de cultura passa por um reestudo do conceito de Nação com a qual os românticos põem em jogo - frente ao racionalismo iluminista - "a valorização dos elementos simbólicos presentes na vida humana" e a partir dos quais "a pergunta pela cultura se converte na pergunta pela sociedade como sujeito". Dimensão que adquire hoje um relevo especial na hora de pensar a crise política e o sentido dos novos processos de democratização na América Latina e a necessidade então de "uma aprendizagem na dimensão da estruturação simbólica do mundo, assegurando a intersubjetividade das diversas experiências possíveis. ( BARBERO, 1997, pg 10).

Deslocamentos e rupturas, românticos e marxistas.

Politização que significa a explicitação da relação do modo de ser do povo com a divisão da sociedade em classes, e a historicização dessa relação enquanto processo de opressão das classes populares pela aristocracia e pela burguesia. Em síntese, marxistas e anarquistas compartilham de uma concepção do popular que tem como base a afirmação da origem social, estrutural da opressão como dinâmica de conformação da vida do povo. Frente aos ilustrados, isso significa que a ignorância e a superstição não são meros resíduos, senão efeitos da "miséria social" das classes populares, miséria que por sua vez constitui a contraparte vergonhosa e ocultável da nova sociedade. E frente aos românticos, isso implica descobrir na poesia e na arte populares não uma "alma" atemporal, mas as pegadas corporais da história, os gestos da opressão e da luta, a dinâmica histórica atravessando e fendendo o enganosamente tranquilo gerar-se da tradição.( BARBERO, 1997, pg 32).

A realidade como significado: Em Barbero, "O mundo da indústria incluía a participação artística do homem não só como espectador, mas também como ator, pois o conceito de beleza na obra de arte é substituído pelo desejo de significar".

Chaplin viu sempre o proletário sob os traços do pobre, dali surge a força humana de suas representações mas também sua ambiguidade política. Em um filme cuja máxima expressão será tempos modernos, é apresentado um proletário pré-político, homem com fome, torpe, golpeado continuamente pela política e contudo dotado de uma capacidade de significar de uma força representativa imensa, tanta que sua anarquia, discutível politicamente talvez represente em arte a forma mais eficaz de Revolução. ( BARBERO, 1997, pg 36)

Da negociação - Unidade em que termos?

A busca da unidade de termos os caminhos para andar, ou seja, oportunidades, educação.

Conhecimento como capacidade dentre o esclarecimento de uma ética comum, enfim, do 
que trata-se para não ter desvios observacionais é de direitos enquanto cidadania, ao menos de caminho, o resultado em variáveis e do empenho de cada um, se verifica nos efeitos, mas o que se deseja em unidade, não aniquila um existente para conviver um outro em nascimento na sociedade, mas que se possibilite modos de ação no corpo das estruturas sociais de maneira a possibilitar por onde ir, se o almejado é unidade de força de trabalho, em cada sentido se obterá um significado havendo de contribuir para os argumentos e propósitos e proposições claramente distribuídos em um viver melhor.

Contradições, espaços do contínuo. Entre o lastro do qual acreditamos que devemos estar atentos ao aprendizado que fornece, podendo estar em atualizações e alterações do tempo vigente e as características que emanam na sociedade em gerações novas, temos contradições e esforços de compreensão de ambos os períodos que podem vir a se complementar.

Democracia só de(para) alguns? Quando os desejos se tornam visíveis e concretos. Obter do discurso as suas práticas reais.

Entre meio do tecido, social,

O estado da massa não é amortecido, ou participativo desde que insipiente, o que se almeja é um estado entre meio, onde a participação de fato exerça seu direito em voz concreta de sua realidade informando, comunicando para que se estabeleça diálogos de compreensão, onde este posicionamento é objeto de engendramento de fato e verdadeiramente no corpo social. E mais ainda, não é um olhar de estado dominante para minorias em relação a lugar social, é um olhar de realidade estratégica social em 360, portanto assumindo que de todo ambiente se pode aferir conexões onde o desmembramento fatalmente terá o seu reflexo. Informação enquanto estado social quando parte de um modo de olhar a qual não me vejo pertença, isto cria um neblina da realidade, e sim, pode ser uma ilusão dentre o que de fato acontece, e também, então quando dizemos de comunicação entre as estruturas sociais, pode mesmo haver um certo receio de se instrumentalizar o por onde, refletir e assumir sua capacidade verdadeiramente participativa enquanto cidadania de um lugar quase ausente dos " ditos poderes" de perspectivas tanto do que é relativo aos ideias como do próprio auscultar da integridade do viver, alterando significativamente sua permanência que por alguns é vista como devendo ser imóvel, e isto esclarece certos pontos de vista, ao se aproximar do que e como vemos dentre o que queremos a realidade vigente. Elencar o diagnóstico de todos os ângulos da esfera social, reclama um certo trabalho de esclarecimento quanto a capacidade 
de nutrir com seus aspectos intrínsecos cada qual havendo de promover benefícios mútuos em tempo de progresso.

Do que acreditamos e do que nos fazem acreditar, no decorrer da história, o livre-arbitrio ficou um pouco desnutrido quanto a sua capacidade de avaliação, posto que se tem espaços da mente coletiva, ou individual que podem se tornar obscuras demasiadas a ponto de denegrir a capacidade de discernimento de indivíduos suscetíveis a se tornarem marionetes de uma necessidade, ou até mesmo causa. Porém, as consequências estarão em mesma medida, alcançando os possíveis algozes da liberdade.

Se a escolha é errônea, mas foi creditada ao indivíduo por si mesmo, é um fator, mas se a escolha equivocada se fortalece por induções, é de fato de considerar a repercussão que haverá de reflexo do posicionamento de quem foi, como indivíduo ou Estado, ato-movente dessa perda de consciência.

Preservar uma certa união somente por grupos, é restringir a capacidade de evolução e ainda mais, deteriorar a fonte que pode alcançar a multiplicidade de esforços benéficos quando em conexões ditas externas por alguns de toda sorte, ou de outros grupos, ou de outros territórios, enfim, o que se observa é se a união pretendida fica restrita ao objeto de alguns, deteriora-se a possibilidade de desenvolvimento, tendo claramente nas condutas de compartilhamento a necessária precaução de posturas lícitas, e que se atenham a devida seriedade quanto a escolhas e reverberações.

Até que, a multidão se fez visível.

Ortega explica que como teoria homem-massa, onde o homem realiza o percurso de como ele coloca, ir as suas entranhas, sair do anonimato, ou o " fundo do cenário social”, para protagonizar e se desenvolver na vida.

Existem conjecturas socias onde se aborda o sentido, como espécie de liberdade, e então nos vemos duplamente, aqui encontrando na liberdade, o que fizeram dela, tipos esvaziados de cerne como valor, e apenas preenchidos com deturpações de fato com o que creditamos ser liberdade, e ainda, além de tipo, a espécie como liberdade sendo até, artigo que tem preço, sobre o poder e a manipulação. E em se tratando de espécie, onde vamos investir, humanidade?

O refluxo ou via de mão dupla. O vomito social, e a consciência nacional? 
A soberba de creditar a predominância de um certo poder em relação a massa ou ao que é de relacionamento da face de um lugar social dito menor, ou minorias, e onde até a massa passa a ser integrada como apenas mais um fator de unidade manipulada, atualmente é um tanto quanto fator de risco, não considera-la como uma força que não esteja tão manipulada d(n)o hoje, podendo ter surpresas em um cotidiano alterado, nem que seja em processos concebidos esparsamente ao longo do tempo no qual deveremos não somente constatar, mas observar quanto pode passar a existir de uma realidade apartada mesmo que de escala relativamente que não poderia ser relegada, passando a consideravelmente ser elemento capaz de ou por liderança ou por grupos que vão se tornando cônscios e demostrando capacidades de instrumentalização social, realizar modificações significativas.

E dado que é impossível uma sociedade que chegue a completude unidade cultural, então o importante é que haja circulação. E quando existiu maior circulação cultural na sociedade de massa. ( BARBERO, 1997, PG 59)

Seguindo em possibilidades de pensar as modificações do espaço social:

Outra existência nas coisas. O vice-versa. A sensibilidade e as transformações sociais

E também como "modos de inscrição no cotidiano". Identificação e projeção. "Segundo Morin, a verdadeira mediação, a função de meio, que cumpre dia a dia, a cultura de massa: a comunicação do real com o imaginário. “Posicionamentos sociais e lastros históricos. Havendo de ter discernimento quando do caminho se estingue por natureza própria algo que não é conivente com a " sobrevivência, ou seja” passou a ser destituído naquele momento de sua função social, podendo ser visto como algo aniquilado, mas que todavia em conjeturas outras, podem ser até acessadas como fator eminente enquanto novas propostas em outro tempo. E continuam as visões sobre a realidade ou o que dela pode ser significado. Sobreposições - simulacros e veracidades.

Dos livros, da palavra, a necessidade de que a expressão seja a verdadeira ${ }^{370}$. O conhecimento deve ser livre tanto quanto e na medida da responsabilidade em relação à verdade, acesso integro ao entendimento como base de um lugar de expressão.

Dos efeitos da imagem e palavra, em utensílios sociais. Isto porque, ainda se encontra pessoas que fazem de um modo de desenvolvimento da sociedade, um poder de manipulação ou que deturpe, e para grande infelicidade isto regride a oportunidade de se encontrar novos

${ }^{370}$ MILTON, John. Consultar Areogagítica. Discurso pela liberdade de Imprensa ao Parlamento da Inglaterra. 
rumos, que a reflexão diante da expressão literária, do texto impresso, dito ou manifesto que de fato, faz do cotidiano um lugar que pode movimentar-se para além das horas, em sentido e compreensão.

Então, se passa a questionar qual a intenção ao não deixar livre e integro a passagem do conhecimento, seja livros, informação, comunicação. Claramente se a manipulação ocorre com má fé, deixa claro por certo que (é quase um perjúrio), as intenções são as mais prejudiciais possíveis, havendo de encontrar nisso alguma satisfação, claramente de entrave ao desenvolvimento de um outro ou camada social.

Atualizando o sistema - Da preocupação de épocas remotas, a presença hoje de notícias falsas e consequências. Escolhas, atos e reverberações.

Quem faz isso, claramente tem uma intenção vil, mas deve estar também ciente do prejuízo a que pode estar exposto se o leitor pudesse contribuir de alguma forma para uma reflexão, esta ficando a mercê dos jogos, sem a presença de uma consciência maior que poderia dialogar com o texto, mas enfim, se apresenta ao indivíduo, e a imprensa, ou internet, formas de comunicação escolhas, e depois as consequências.

Opinião pública. ${ }^{371} \mathrm{O}$ que hoje mobiliza um corpo de comunicação que esteja levando uma mensagem quer seja de uma insatisfação, de uma reverberação de uma necessidade da sociedade atual?

Mudanças - de quem para quem? Ação - realidade - ilusão. Expressão x Manipulação ( quanto que é de fato efusivo a expressão popular e quanto que lhe é apregoado como força por interesse já sendo algo manipulado )- manifestações recentes / verdade lógica.

Finalmente há o problema da mistificação da opinião pública, que se relaciona diretamente com as origens de sua expropriação e exploração. Pois é sempre ato decorrente em primeiro lugar por parte daqueles que agem em nome da sociedade, evocar a opinião pública como estuário de todas as suas ações. Seria como dizer que tudo se faz e tudo se executa em nome da opinião pública. ( AQUINO, 1986, pg. 11).

Face da sociedade.

A opinião pública é parte do processo de comunicação, porquanto pode ser entendida como um dos efeitos ao níveo da comunicação coletiva, pressupondo para tanto a existência de um estímulo, mensagem ou conteúdo de significados, produzido ou emitido por alguém e captado pelo todo ou por parte da sociedade. ( AQUINO, 1986, pg 12).

${ }^{371}$ Da série do álbum improviso. 
Se torna imprescindível diagnosticar os mecanismos da comunicação no tempo vigente, principalmente tendo em vista que, a fluidez não ocorre somente no sentido do efêmero, mas contundentemente na diluição dos papéis, ou seja, o receptor passou a ser emissor e as esferas privadas e públicas tornaram-se territórios cada vez mais engendrados por até mesmo no âmbito global pelo paralelo das redes se ter um campo amalgamado sem barreiras, portanto estamos derrubando outros murros, para além do de Berlim?
A pessoa que fala
o discurso que pronuncia
a pessoa que escuta
Quem
diz o que
a quem

A pessoa ( mundo ) Sujeito como discurso - fusão. Diz o que - passou a ser a conduta nela mesma / destino - outra fusão. Efeito - reverberação - mobilidade dos campos justapostos.

Quem diz o que em que canal a quem com que efeitos

Justaposições. Propósito do enunciador, ( caráter particular - ou de esfera geral ) - propósito final. Cabe aqui uma ressalva posto que um propósito deve ter em si um endereço de correspondência ( lembrando o conto ), no que diz respeito a uma geração - emissão que o propósito pode estar engendrado ( embutido ) no emissor mas não estar em correspondência ao propósito final ( provocando possivelmente ruídos ), e turbulência na eficiência da comunicação, para tal advogamos que nesse processo quanto mais e de fato o propósito for de cunho do âmbito geral, mais estaremos aptos a conjugar uma verdade, no tocante a um real propósito. ( tendo em vista ainda que quando a emissão ocorre ela já não mais é proeminente do ego mais sim de um outro ( $\mathrm{s}$ ). Sobre que condições ( cuidado com persuasão e manipulação ). Ambiente.

Cadeia de eventos suscetíveis, retórica social.? Hoje a presença do meio, como canal se apresenta na mais variada gama de linguagens, entre o que se quer dizer, para atingir um objetivo no âmbito de maior escala, de forma transparente como a responsabilidade dos tempos atuais exige de comprometimento do pensar com o agir, assumindo o percurso de emissão em comunicação tanto como fator externo, como interno, ou seja, um fluxo de relações. 
Empreender uma ação de capacitação para posteriormente colher os frutos em compreensão da emissão ou seja, direcionamento sem manipulação em liberdade de discernimento.

Agentes da interação: Aquino cita Maisonneuve, a respeito de interação social, considerando alienação de maneira que:

Ao tratar o problema da alienação, afirma que a interação social, respaldada numa relação entre a origem cultural e as características psicológicas de cada indivíduo acaba determinando a própria estrutura social em que se situam indivíduos do mesmo conjunto. O que pode ser entendido como uma decorrência da maneira como se opera a comunicação entre eles, entre cada um e o todo e entre o todo e a estrutura à qual pertencem. $\mathrm{Ou}$, em outras palavras uma decorrência da comunicação da processada sob os mais distintos aspectos, que tanto poderá instigar a participação, quanto servir de argumento à passividade, de vez que esta também pode ser entendida como um resultado da interação. ( AQUINO, 1986, p. 18).

$\mathrm{O} \mathrm{mu}(\mathrm{n})$ do no fone plugado no universo, in time do fato, entre causas e efeitos.

Ora, se comunicação, é , acima de tudo, interação, ou o processo pela qual ideias e sentimento se transmitem de indivíduo para indivíduo, estabelecendo a dinâmica social, e se a opinião pública resulta desse processo como um efeito de participação dos indivíduos da sociedade, claro que está no papel de decodificador enquanto interprete e influenciador de opiniões, é que vai determinar o gênero da manifestação de todo o conjunto, ( AQUINO, 1986, pg21).

Viver é comunicar-se. No diálogo da mente, estaria a persuasão ( razão - consciência mundo) sendo instrumento no contemporâneo de uma retórica do pensamento, direcionando ações, porém, particularmente no hoje, creio ser mais restrito quanto averiguação do real, com certa dificuldade apesar dos mais avançados meios de arquivos de toda forma, o lastro, tanto de história, memória, e este último sendo ainda mais duvidoso, restando portanto apesar da reverberação pregressa, o hoje, como fator primordial enquanto base de uma imagem que ainda que, sendo o argumento a ressonância, é o momento que passa a ser crucial dispondo sobre os moldes da busca de uma forma de veracidade, o que nos leva a possibilidade, in time de absorver, porém ainda, não de maneira efêmera mas capaz de desenvolver o momento em estágios profundos de compreensão, e até mesmo esses estágios sendo a matriz de um desenvolvimento em reverberação a posteriori.

Necessidade vigente e transparência, VERAcidade. Imagem como mundo em fronteiras de conexões. Emissão de pensamento e discurso em ato de engendramento, receptor e agente - 
tecnologias, alcance, direcionado em expansão. Destino: reverberação em conexões novas. Causa e efeito - Ressonância. A interpretação se aloja no contemporâneo em conexões que se entrelaçam sendo novas emissões, continuadamente, cadência.

Opinião pública - (RE)agente. Uma compreensão é ver que cada segmento social tem sua visão de mundo e outra é observar que é necessário o engendramento onde todos podem se ver como sociedade, ou seja, uma complexidade onde em suas visões colaboram para determinar o que é o povo ou os cidadãos que são de fato, o que nos constitui olhar. Porque de certa forma é um comodismo dizer que classes tem suas visões restritas, o que não quer dizer que não ocorra, ou que senão particulares, posto que ao menos se dizendo restritas são o que pode na verdade ser de escalas que se sobrepõem em modos de estar na sociedade, havendo de constar que cada espaço se apresenta apesar, não de maneira isolada e portanto, fazendo parte de um horizonte maior,

Poder e redes. Até que ponto as redes se entrecruzam com a opinião pública ( sendo ou fazendo parte dela ) e com as necessidades reais e manifestações cotidianas de carências a serem sanadas pelas ações de um poder que atenda de fato a demanda dos aspectos sociais.

Marca - 1.vestígios de um tempo 2; marca como sendo o que define o tempo.

Entre o ontem e o hoje.

Recapitulando, significa dizer que a permanente utilização da opinião pública, de forma imprópria acaba neutralizando, a capacidade de expressão de que se dispõe a sociedade.( AQUINO, 1986, p. 30)

Alerta-se sobre a necessidade de que a comunicação não seja somente unilateral, uma emissão que se reproduz como um estado de falta de diálogo, havendo a falta de resposta, pelo meio social, neste caso, da emissão dos representantes aqui neste caso, com o governo.

Avaliação de risco social, no decorrer de graves consequências por ações concebidas pelo que é dos fatores emocionais em detrimento de valor racional, movendo em certo ponto, massas que podem ser manipuladas, mas que acreditamos ser na sociedade vigente cada vez mais menos suscetíveis, dando acolhimento a informação esta sendo valor de reflexão. Amalgama contemporâneo - em construção. Matriz - (es ) em contínua construção.

Além de se buscar a razão no fator emocional, também deve-se diagnosticar o que envolve a capacidade de ser gerador, a emoção pode também ser agente de polo positivo ou negativo, no caso em estudo quanto a repercussões de ordem geral, quanto mais o diagnóstico foi 
eficiente quanto ao fato emocional, melhor será o discernimento para o caminho a seguir e a mensagem que eclodirá. Quanto maior a reflexão dos parâmetros desencadeantes da mensagem, mais lúcido e eficaz será o percurso do desafio a ser conquistado. Quanto a incógnita atual, a meu ver do fator cultural, em tempos de rede e diluição de territórios, será possível cada vez mais se considerar a eminencia de uma cultura sustentável.

Coloco a CULTURA SUSTENTÁVEL como algo fudamental no contemporaneo tempo, posto que não somente se faz necessário o despertar para o bios e nossa capacidade de gestão dos recursos do planeta, como também, e fortemente a capacidade de gerar e manter os recursos de uma mente ( no seu sentido mais amplo possível ( planetária ) que compreenda a organização de seus recursos do pensamento, como forma de agir, como valores a serem resgatados e forams de percepçção, e informação. Preservar e desnvolver valores éticos e estéticos em uma lógica de uma cultura sustentável implica em uma conquista de combaer uma exploração, ou melhor, combater um aviltre, combater as forças contrárias do pensamento evolutivo. Fomentar ações que prmovam o bem estar social é um dos fatores de uma cultura sustentável, é interagir com o pensamento saber equalizar o consumo, saber equalizar nossas ações, nossas escolhas,. O cuidado com os resíduos, no que se refere ao meio ambiente, é também em analogia, referente a nossa sociedade, a nossos sentimentos, a nossos propósitos.

Aqui cabe colocar a noção de Kostler de Hólon mais uma vez, onde cada DNA informacional, interagem como órgãos de células da sobrevivência. A mensagem (informação) como organismo. o que a faz perecer ou sobreviver em tempos latentes onde o curso do sangue da comunicação não pode e nem deve esvanecer.

Novos mecanismos podem possibilitar um outro poder mais atuante?

A condição humana - Cedo ou tarde haverá de vir o tempo, como observatório dele mesmo, auscultando seu eco em dizer do que almeja ainda ser existente e que tanto o faz perecer por não viver. Sejam por aspectos econômicos ou dilacerações sociais o fato é que a olhos nus se pode ver que ainda em toda fome de evolução não se conseguiu o desenvolvimento, almejado e pretendido. Mas, face a mesma face em entrecruzamentos de latência dos corpos existentes do organismo mundo, estão as histórias que permanecem dizendo que marcaram as nossas vestes, e mais do que as nossas vestes estão escrevendo a cena de nossa dramaturgia que esboça apenas ainda o desenho de sua jornada, esperando conter todos os gestos, emanados estão o público e atores como interpretes do mesmo palco, nas luzes do 
universo. Natureza da mensagem, o outro como compreensão. Se de minhas vestes sou teu corpo, compreendo-me tua voz em meu discurso, enlaçados em uma só mente, em desafios e propósito do bem ( ética - lógica - estética ) comum. Respeito a opinião do outro em possibilidades de acordo, desenvolvendo a cultura e o sujeito mundo.

\begin{abstract}
Partindo-se da definição de público como sendo a reunião de público devidamente organizados, munidos de suficientes informações sobre determinado assunto, em permanente discussão sobre o mesmo, na busca de um acordo comum, bem como na definição de opinião, tratada esta como arbítrio de consciência, tem-se condição de estabelecer natureza, características e funções da opinião pública. [...] “ Dir-se-ia em primeiro lugar, que a natureza da opinião pública está relacionada com um ingrediente cultural-racional, responsável pelo estabelecimento da controvérsia. A seguir, que a sua característica se relaciona com um ingrediente emocional-não racional responsável pela deflagração do debate. E, enfim, que a sua função, se refere a um ingrediente ambientalsocial, responsável pelo seu último produto, ou seja, o próprio acordo. ( AQUINO, 1986, pg 44)
\end{abstract}

Indivíduo como herdeiro de certas condições culturais - desenvolve-se em determinado meio social. A margem é parte do rio. Até que ponto no sujeito mundo atual somos frutos de um ambiente hibrido, conjecturado de conexões e refeito organismo volátil.

Este indivíduo vive, pensa e age de conformidade com a sua natureza, características e funções, e do mesmo modo, estabelece não só uma contiguidade fenomenológico-social quanto uma extensão interpretativa psicológica. O que equivale dizer que, mormente pelas conduções de individualidade das quais dispõe participa de maneira atuante num mesmo ambiente com outros indivíduos, conferindo a seu turno, a marca de sua participação, somando trações e amalgamando ideias. ( AQUINO, 1986, pg44).

Indivíduo e coletivo/ conjunto de indivíduos e em maior grau a instância do coletivo. O esboço, no contemporâneo de uma retórica do pensamento, direcionando ações, ou ainda que diante do entre-fluxos, que o pensar fosse a obra antes do croqui, de maneira mais fiel a um percurso originário atento ainda que em porém as suscetibilidades do entrelaçamento com a experiência da facticidade propriamente.

Uma observação quanto inclusive a importância do deslocamento e de sentidos compartilhados $\mathrm{O}$ que aparentemente não tem importância e de um primeiro momento não desperta interesse se absorvido de maneira mais integra ou seja, por facetas ainda a serem 
descobertas ou refeitas por conexões adjacentes podem tornar algo inicialmente não interessante em profundamente interessante, quase como o movimento de uma escultura ou das palavras do silêncio, como a paisagem que se está observando.

O contexto está sobre a nossa natureza a princípio como nossos olhos o veem, mas depois parte para ser descoberto como pensar e sentimento, transformando o que vemos, em mais do que sonhos, um outro lugar de passagem, para ser descrito sobre nossas ações que argumentam o existir sobre outro prisma, nas cores do universo, que podem ser possibilidades de um espaço a ser conquistado por todo aquele que da liberdade constrói sua opinião.

Porém, em relação ao indivíduo e ao âmbito geral, se encontra claramente a escala de amplitude de efeitos e repercussões.

Arbítrio e escolha. Pessoalmente me parece que arbítrio esteja mais direcionado ao interior do homem, como a sua liberdade sobre condições propriamente de sua gênese do existir, e a escolha, em distinção aqui, poderia se apresentar como sendo fazendo parte de um apesar de, ou seja, apesar do livre-arbítrio se apresenta, aqui sim engendrado por contexto e aspectos do âmbito mais propriamente do geral, o que podemos entender sendo o que se apregoa um caráter indivíduo-social. Nestes casos, podemos considerar situações em que o indivíduo tenha em si mesmo, uma resolução de pensar ( determinada ), porém, em escolha se submete ao contexto e ao convívio socialmente, e pode abster de sua condução mais propriamente em liberdade para condizer com uma escolha ainda que particular em um âmbito mais social. Essa escolha pode ter correspondência com o âmbito da decisão do arbítrio, ou se tornar um tanto quanto dispare posto que se desloca enquanto escolha para se apresentar como do âmbito geral, ainda que sendo discernimento. O que nos faz ir de encontro propriamente ao caráter do que pensamos abrigar escolhas éticas. Isso porque, até que ponto estaremos subalternos ou estaremos propensos a denegrir nosso ímpeto de livrearbítrio para atender a escolhas que são permeadas a esfera geral.

O indivíduo e o contexto social. O poder de uma ideologia penso que não deveria estar concentrado em manipular, subjugar, dominar, mas sim ao contrário, de se expor de forma a se tornar existente sem detrimento de outro pensar, de maneira que seus esforços estejam na sua própria manutenção com fatores que se lhe acerquem no decurso de seu próprio caminho. Por vezes uma ideologia, ou um percurso de ideias surgem, eclodem em 
decorrência de se contrapor mas esse caráter " crítico " não deve ser imposto como em derivação ( como na matemática ) mas sim, apenas como a força que o fez nascer, o fato $r$ desencadeador, mas não desencadeante em sentido que esteja cego para o que realmente desejava almejar, porque pode talvez se como força apenas contrário aí sim desencadear uma soma de forças que apenas consistam em dominação. Um pensar que surgiu apenas de uma contraposição deve ter bem claro as bases que o fez surgir para que não venha em por vir ter as mesmas características que o fez vir à tona, ou seja, de seu opositor. O que vale para governos, relações pessoais e em toda e qualquer forma de convívio social. Incongruência? Se é necessário uma intervenção da $\backslash \mathrm{ONU}$, por exemplo em uma situação hipotética, por não concordar com o rumo de uma Nação, e a intervenção se dá em auxílio aos seus constituintes, ao seu povo, ou seja poderemos nos defrontar com uma situação onde a Nação se apresenta em equívoco, mas o seu povo não e precisa de auxílio, então, como podemos discernir se justamente, uma NAÇÃO É CONSTITUIDA PELO SEU POVO. Nesse caso, poderíamos pensar que estaríamos lidando com desacordo em alcance interno do objeto, posto que a uma cisão ocorre entre a Nação e o que a constitui, porque uma Nação que se constitui integra pelo que a considera como tal, deve preservar acima de qualquer interesse de liderança o que não poderá subjugar seu povo, em primeira instância, e segundo, deverá estar como pátria conjugado a sua condição de integrante do mundo, e portanto, também não pode ferir os demais povos. Diversas culturas, em tempo de sujeito mundo, em redes e extensões de tecnologia colocam em xeque e expõe ao mesmo tempo conjecturas dos territórios real e virtual, como impasses do que se preserva e do que se deixa permear, em fluidez ou cadências, justaposições ou discordâncias, onde o deslocamento para o outro ( Hegel ) se torna ainda mais proeminente, em grande escala e sobre // de cognição ( virtual e real ), viabilizando em concretas ações o tempo de um conhecimento complexo, expansivo e que de fato seja sem fronteiras.

Poder e dominação. Necessidades como " agentes “ - despertam da realidade como discurso ( fato ), ocasionando movimento em direção a solução dos desafios, quer estejam em relações pessoais, empresas ou povos. Em tempo contemporâneo de estruturas adjacentes, ou seja, em rede par além da rede, poderemos conceber que o poder e a dominação passem a ser o que pressupõe maior capacidade de sanar as demandas de um todo ( mundo ), portanto em uma geografia compartilhada de intercâmbios se observe que o domínio se fará no entrelaçamento de desenvolvimento ainda que compartilhado de potencias ( não como nações ), que gerem recursos ( de diversas naturezas ), para tanto soluções como 
desenvolvimento do que promoverá o bem comum, de uma sociedade planetária mais justa. ( sem utopia). A meu ver, deixará de ser utopia por necessidade, ou seja, tem que ocorrer, em razão da própria sobrevivência. E, aproveitando o que muitos consideram utopias principalmente quanto a solidariedade, creio que o primeiro passo, e a compreensão que se de antemão prejulgamos ser uma concepção utópica, dessa maneira não se viabiliza a solução de nenhum desafio, portanto, a de se considerar que como princípio de ideal concreto se fortalecem as ações quando se acreditam em sua capacidade de existir.

O estudo dessa situação, em todos os seus níveis, possibilita entender melhor, não só a dominação como um fenômeno isolado mas principalmente a identificar a incorporação dos fatores que determinam e condicionam o arbítrio a cultura, de sorte a permitir que se relacione decisão- poder - liberdade - ideologia. ( AQUINO, 1986, pg49).

Ideologia de um poeta,

Para sobreviver

Não encontro meu teto, ainda que as águas o preencham, e eu navegue todas as manhãs e pelas noites quando por fim eu tenha nas estrelas o testemunho; da casa, do lar, das fomes desse ar que me faz, respirar para eu adentrar, sempre que todo dia se levante, ao despedirme de mim, ressurjo, outro seu. Onde morada minha, feito Prometeu, vê nos astros, o caminho da odisseia, memória do gesto que ficou marcado no lastro do teu verso, sentido comprometido apenas com os navegantes, recorrendo aos desbravadores, a terra de minha carne, que das aguas fez-se MAR.

E não é no meu engano que as lágrimas da força se recolhem, porque perderam a esperança, é do momento que espera que a eternidade por fim, enxugue o tempo do meu rosto que viu a tristeza passar onde despediu-se o coração, deixando por fim pulsar apenas no teu silêncio.

Ninho então é parede recoberta de minhas cinzas, trazendo minhas letras esquecidas para escrever os meus sentidos, nexos de uma nova razão.

Onde permaneço em pleno voo de minhas asas.

Poeta do pensamento

“[...] de acordo com um dos mais usados dicionários usados atualmente, ideologias diz respeito às ciências da formação das ideias tratado das ideias em abstrato, sistemas de ideias, sistemas segundo o qual a sensação e a única origem de nossos conhecimentos, conjunto das convicções e convenções filosóficas, religiosas, jurídicas, sociais e políticas relacionadas com a situação social dos seus representantes dentro da sociedade. Ou então ao pensamento teórico que pretende desenvolver-se sobre seus próprios princípios abstratos, mas que na realidade, é a expressão de fatos, principalmente social e econômicos, que não são levados em conta ou não 
são expressamente conhecidos como determinantes daquele pensamento [..] $\mathrm{O}$ que se tenta evidenciar com base na incorporação cultural dos instrumentos de poder e dominação, reflete o papel da ideologia como reflexo da realidade, na medida em que traduz, pelo processo histórico, os diferentes significados dessa realidade. De sorte que quanto mais constituída é a realidade, quanto mais é estável, mais o mito se torna explicável, surgindo como projeção mecânica e finalista dela mesma. [...] A constituição da realidade, o modo como se estrutura o conhecimento e a organização social tem muito a ver com o processo pelo qual se percebem os espaços individuais e coletivos. Insiste-se aqui em processo perceptivo, uma vez que a realidade quanto o repertório de conhecimentos e a organização do meio, deixam-se perceber mediante certos mecanismos de assimilação ou de rejeição que, entre outras características, dispõe daquela com a qual se tornam responsáveis por tomadas de decisão. Nesse campo emerge uma área de especial relevo, concernente ao aspecto da propriedade das decisões, que vale ser destacada. É precisamente o fator propriedade ou impropriedade das decisões tomadas estas em nome de algum objetivo que ferem ou interfere, o curso normal da vida do indivíduo em si, ou do grupo ao qual ele pertence. ( AQUINO, 1986, p. 50).

\subsection{Do que pode nascer do sonho.}

Do que pode nascer do sonho, um simples lugar ao sol. ${ }^{372}$

Ao que toque as palavras no encontro das notas,

Soará o gesto simples na mesma manhã

Nascendo conosco em seu através do tempo

As moradas das lutas de todo um porvir.

Sonhei onde os lugares foram perdidos

mas da alma ainda se pertenciam

sonhei que a solidão havia percorrido o amor

se desfeito da dor e encontrado o mundo

sonhei que as palavras eram fogo

repartiram-se pela voz do universo

criaram-se vida permanecendo liberdade.

sonhei que através das vestes do olhar

pode se ver a nudez calada

de um tempo que se despede

ao lado teu.

Aonde as tuas forças te erguerem saberás do que teu intimo sonho te acende a realidade

nas portas do teu sentimento que abriga o que deixaste ficar ao relento de tua alma.

desperta aonde a aparente insensatez pode te fazer mais lúcido

e a cada passo adentra o teu sentido que não te golpeia mais é pulso

a fazer das noites a mesma luz que é capaz de ver na escuridão do cosmo.

compreenderás talvez que a os grãos que fazem feixe podem varrer como poeira a imensidão das areias de teu caminhar nascente

\footnotetext{
${ }^{372}$ Composição para instrumento piano- A parte do destino. Do sonho entre a mensagem do caminho. Do sonho à realidade. Do sonho e o destino - Parte 1 . Dos sonhos e o destino, outro movimento. Segunda parte final da realidade. Esperança. Na face da luz.
} 
e na inocência não se perderá a razão, ainda que louco te pareça mas verás que de toda a criação o sonho pode dizer de uma verdade atravessando como marés a infinita e majestosa viagem onde todos os seres escrevem seu percurso de uma luta mítica participando da luta do viver que exerce uma força gladiadora como arenas incessantes de um dizer constante onde todos os filhos são gesto do impulso generoso do existir. ( SOUSA, 2015)

Quantas vezes eu morri com o meu coração ainda pulsando. ${ }^{373}$

Do que somos e o que queremos ser.

Todo que aprende, ensina a si mesmo

$$
\begin{aligned}
& \text { O caminho que deve percorrer } \\
& \text { para encontrar-se. }
\end{aligned}
$$

Sobre as mãos de Deus, a alma que serve.

Do que vemos no infinito?

Por onde avançamos e quando.... - atravessarmos os corações

De um coração à outro, esteja no lugar dos seus prantos ou desenganos, o teu e o meu recolhem-se onde a tristeza recebeu os dizeres seus do amor que protegeu até onde a palavra não se escondeu da felicidade. E o teu sorriso abraçou o que se pode compreender de um Paraíso. Que tua paz seja a minha, e desse gesto, nos encontraremos nos mundos, de onde possamos nos abraçar mais uma vez e descobrir a infinita razão de AMAR.

Conquistar do discurso o pensamento na prática da vida, o caminho do que queremos dentre o que somos. Os passos de nascer como liberdade atados ao umbigo do mundo, aprendendo a sobreviver sobre o solo que de nós pode conter as asas do corpo mas não o sentido da alma. Saber que na violência, esquecemos a nós mesmos, exerce ante a vida a consciência de despertar onde o primeiro passo é o perdão, e a ainda se observa o caminho de onde somente o amor pode estar nas gerações que não sofram injustiças a começar por cada um, cada ser,

\footnotetext{
${ }^{373}$ Composições Manhã de domingo - para a Floresta Brasileira e o entre nossas naturezas, humana e o planeta como um todo. E composição A Tarde. Composições série Belive. Todas em arquivo de audio. Composições - 1. Forças armadas; Justiça; Razão e Amor, Progresso.
} 
homem, mulher, ancião, ou criança, ser humano que existe sobre este planeta, exercendo o direito a ter a dignidade por princípio, a igualdade por verbo e a fraternidade por conduta, onde se poderá encontrar a paz de uma liberdade. Paz de presença humana como braços da humanidade tecidos por entre o espirito do universo.

Onde toda dor se ouve ainda que no silêncio.

Onde toda injustiça se ouve, ainda que no silêncio, mas também.

Onde toda a vida se ouve ainda que no silêncio porque é gerada na liberdade.

E será do tempo, a razão infinita da consciência.

A liberdade. A liberdade, o conhecimento, a consciência e a razão, e o que nos aproxima e ou o quando poderemos estar aptos a conceber uma revelação compreendida como conhecimento ligado a consciência, uma consciência vista para quem crê, como a presença do princípio do criador em cada um de nós, mas, para quem Nele não crê, então, como uma ordem do universo onde teremos a presença de um saber maior que a face que a humanidade compreende, então, sabendo que ainda neste mundo temos muitas vezes a bandeira de nos colocar como seres humanos que lutam pelo direito da liberdade, pergunto, direito da liberdade? $\mathrm{O}$ que entendemos como direito eu pergunto, porque ainda temos neste mundo, uma liberdade que compreende o ato, a conduta, ligado a um saber que se estabelece como conhecimento para praticar o quê? Violência de toda sorte? Violência de manipulação! Então como podemos entender uma liberdade enquanto ela não tem nos braços da razão a consciência. Como podemos entender a liberdade quando ela não tem sobre os braços da razão a consciência!? O que de fato entendemos como direito, o que de fato entendemos como liberdade? E o que de fato entendemos como conhecimento. Cada vez mais me parece que, o tempo do eterno se faz parte do momento, até para aquele que do conhecimento e consciência pode parecer ao mundo uma presença inocente, mas que é até instrumento de uma busca de um saber, e essa busca de um saber, justamente ao que é do eterno nos questiona à quem podermos demostrar, sendo o mundo de natureza tão diversa. Ou seja, do que fazemos com o conhecimento! Pode haver uma voz inocente, quando sabemos que estamos por vezes na vida, defronte a certos saberes que nos questionam depois, o que fizemos com eles? Amanhã, o teu porvir que construíste no teu passo que amanheceu contigo ao saber, ele mesmo te fará a arguição da tua alma nos teus atos, porque a pergunta do que fizeste com o saber que esteve a seu alcance, é sim também, a parábola da semente, ou de um tesouro, que não é somente se o guardas ou se o compartilhas, ou o que fazes 
com ele, mas do que desejas, quem és, e o que fazes. Portanto, a liberdade.... também é juízo de nós próprios, e repito, a liberdade, também é juízo de nós próprios, arguição de uma consciência maior que não necessariamente está somente em um momento somente, mas na ressonância, no que reverbera, e no que somos nós todos em uma presença eterna, infinita. Infinita não somente enquanto tempo, mas enquanto humanidade. Haveremos de saber, que de toda a revelação de um conhecimento que impropriamente possa estar sobre uma injustiça enquanto possamos crer que não são dignos de receber, porém, ainda como constatação de diferenças para que saibamos inclusive onde o joio ou o trigo estarão, ou do que nós fazemos com o que recebemos, talvez seja um caminho, para que ainda mesmo que aquele que, com o conhecimento não tenha agido bem, cometendo equívocos, possa ter a reflexão de si, enquanto continuo da própria liberdade, recuperando nele mesmo a consciência, e trazer a sua razão a presença de que o futuro ainda pode ser do presente um ato reflexionado e que muda e transpõe montanhas da sua própria natureza, esculpindo-se conhecimento, para alguns, aprendizado, isto quando não se tem o conhecimento por próprio mérito, por conduta em acordo e sentimento. Deus abraça seus filhos, sem distinção, sem distinção ele ama igualmente, e com todas as fibras da minha alma, eu tenho essa certeza, que não é minha, mas da crença que eu tenho Nele, então, sabemos que a nossa ignorância é muito grande para a sabedoria do criador, mas a nossa crença, é também um caminho. Um caminho que vai se estabelecer inclusive como uma capacidade de vigiar até mesmo os próprios passos porque a crença, não é uma questão abstrata, mas é uma fé concreta que me transforma em próprio ser vivente, é uma crença que é capaz de me dar valores como diretriz para que quando eu tenha um conhecimento eu possa saber inclusive o que do meu desejo e do meu querer e dos meus atos, eu posso ser.

Liberdade.... Liberdade... é um direito. O que é o direito ligado a face da liberdade? Eu não consigo ver um sentido de valor humano, sozinho.... eles se abraçam, eles se unem com todo o sentimento que é de um valor para uma humanidade edificada em bases solidas em relação ao bem maior, então, o que é o direito que não possa estar sobre a face da consciência? É tudo que é contrário as leis de um bem, ( bom e justo), bem no sentido de presença no universo que possa nos direcionar ao criador, ou que possa nos levar a um viver enquanto indivíduo e humanidade melhor. Então, o que é o direito .ligado a liberdade, ligado a razão, a consciência e a atos, e ao saber e conhecimento anteriores aos nossos? Liberdade é um direito? ! Sem dúvida. Então como posso compreender a infração do próprio direito em si, que por princípio o creio ligado ao bem, por origem até!? Eu, apenas vejo que a presença do 
direto, da liberdade, deve preservar enquanto consciência ou enquanto razão mesmo do homem, a presença dele na sua alma, porque a liberdade quando não é uma consciência , deixou de ser liberdade. Compreende? Então quando a liberdade não se abriga na razão do homem, principalmente ligada a consciência, ela não pode ser chamada de liberdade. Acaso seria então, direito meu em liberdade, fazer mal a um outro ser humano? Onde iríamos com isso? Não pode ser...

Não se pode crer que é direito meu por liberdade, agir assim, em atos de violência. Isto é um equívoco! Aonde pomos a nossa razão humana! Em deturpações de origem de sentido? Aonde pomos a razão humana, enquanto deturpamos sentidos, significados dos valores reais de uma humanidade. Isso não é ponto de vista, é denegrir e usurpar uma origem sagrada. A liberdade é sagrada. Sagrado é presença de tudo que vive. Porque aqui estamos tratando da liberdade que é participe do princípio do universo enquanto progressão de desenvolvimento e amor. É disso que estamos falando. Então, peço que sempre que tivermos a necessidade de um juízo em qualquer momento na vida, sobre atos, escolhas e sentimentos, que possamos saber reconhecer a origem e que um véu não esteja sobre meus olhos, de maneira não como a justiça mas de maneira a deturpar, ou do sentimento que eu não compreenda de fato como ele é, porque a razão humana é capaz de manipular até um sentido sagrado e isso não é ponto de vista, mas sim, o uso e emprego de tal saber e sentido para um fim que não condiz com a integridade daquele valor humano.

Por liberdade de expressão então eu poderia ferir, banalizar, usar de violência? Não. Na minha visão isso não pode ser parte de um sentido enquanto liberdade, abrigada em uma consciência. E se inclusive for muito difícil refletir sobre caminhos, aonde eu possa fazer, ver e sentir a justiça, sem que eu tenha que andar por caminhos que são contrários a mim, porque o mundo... o mundo é vil a ponto de nos depararmos com situações em que nos pareça que, para fazer justiça tenhamos que ir contra inclusive ao que acreditamos.... por exemplo, quando no âmbito social estamos cônscios de situações muito, muito injustas e que por vezes pode se escolher o caminho de um vandalismo, acreditando que isso possa alterar alguma coisa. Equívoco. Nós, temos que refletir. Os caros caminhos que não sejam contrários a essa integridade dos valores aos quais são constituídos em origem, tem que haver um meio, tem que haver um meio em que possam existir. E para aqueles que acreditam, até mesmo uma inspiração que seja capaz de dizer firmemente que pode e que a conduta não será contrária ao bem. Enfim, ninguém diz que é fácil. Lidamos com dificuldades e desigualdades, mas também, lidamos com portas, por onde o saber pode estar 
ligado ao amor e a uma consciência, e haverá sim, uma oportunidade que capacite o homem da sua verdadeira presença no mundo. Acreditar. Acreditar, não somente na própria crença, mas no outro. O que é difícil, porque é visto como inocente. Apesar de termos sim, que nos preservar ( porque ainda no mundo existe o mal). Por isso é tão difícil a harmonia. $\mathrm{O}$ equilíbrio não é fácil. Nem amar no sentido de compartilhar é fácil, quando lidamos com atrocidades que possam haver no mundo... porém ainda e mesmo assim aquele que pratica o bem, tem em si a razão e a consciência, talvez seja o ato proveniente da razão humana que diz a consciência que tudo ama e nada distingue, que ainda vivemos em um mundo desigual enquanto bem e mal, e portanto aquele que crê e que sabe que deseja e precisa agir no bem e acreditar no seu irmão, seja capaz de não desistir, seja capaz de não desistir. Mas, que aprenda, e repito, que aprenda a se proteger da maldade humana que ainda existe, não desistindo e sabendo que pode e deve ajudar o seu irmão. Desafio, desafio constante da humanidade, até que todos estejamos em igualdade. IGUALDADE. Porquê, estamos aqui.? Porque estamos aqui? Se não é para buscar essa igualdade, irmã da liberdade no sentido do amor maior. E então eu vos pergunto: o que o mundo ensina? O que aprendemos, o que vivemos, e o que nos tornamos? Que a face da eternidade esteja sempre presente no mundo como momento diante do eterno de maneira justa, porque nos seres humanos não somos, Senhor, capazes de compreender vossa sabedoria, mas buscamos cada vez mais, como razão necessária a presença da justiça, do bem, porque sabemos que a vida como preservação enquanto planeta precisa da compreensão que é o conhecimento de sermos uma humanidade, e humanidade não são alguns, humanidade, somos todos nós, portanto enquanto humanidade o que nós fazemos com a liberdade não é somente a minha, mas também a de meu irmão, portanto, não sejamos inocentes de nos crer apartados dos atos do meu irmão que não reconhece a consciência como presença na sua vida. Estejamos prontos para sermos continuamente obreiros entre o céu e a terra. Obreiros entre o ódio e o amor, obreiros, entre a paz e a violência, obreiros entre tudo que existe, para que possamos, possamos compreender, liberdade, igualdade e fraternidade. E eu vos rogo Senhor para que não nos esqueçamos do amor, o amor maior, que está presente na justiça, na liberdade, na fraternidade, na crença, no direito, e que ele possa ser, o verbo, a imagem como sentido, como significado na alma do nosso corpo habitando e permanecendo em nossas escolhas e condutas para que o amanhã seja presença reverberada no hoje, onde nos encontramos em distâncias que se aproximam e vos rogo para que a lembrança do que possamos compreender de direito enquanto justiça esteja sempre nos braços do amor e da consciência, e que do que nos parece desumano de alguma forma, encontre senão o corpo, a alma capaz 
de ver, o que o mundo ainda precisa conhecer de bem. E nesse momento agradeço por estar viva, e por acreditar. Acreditar.

Nesta tese já consideramos a necessidade humana do educar o pensamento, e neste momento, observamos ainda, quanto e principalmente, sabemos da utilidade da informação como comunicação e conhecimento, onde o educar é presença do canal que viabiliza e preserva onde e como haverá de estar a concretude da compreensão exposta como sabedoria, posto que já discernimos sobre as dificuldades sociais, isto porque poderemos encontrar usos do saber contrários a lei. Portanto caberia ao homem de bem, estar atento porque, devemos e precisamos para uma sociedade em desenvolvimento como um todo, planeta, considerar como base fundamental o esclarecimento, este sendo propriedade de valor humano como amalgamado a cognição, informação para um melhor viver como um todo, capacitando como já avaliamos, e propiciando caminhos segundo a participação cada vez maior do aprendizado como de fato e verdadeiramente consciência social, havendo de sempre e constantemente fornecer discernimento como auditoria interna do externo como mundo que transita entre os indivíduos e o povo, um organismo único, capaz de elucidar entre as diversidades e diferenças, onde e como a instrumentalização do saber, para que o equilíbrio não seja de maneira alguma prejudicado, havendo deturpação na ordem segundo ou melhor, por razão de que um benefício seja utilizado para o mal, então, é devido e necessário sempre a reflexão e ponderação, como virtude e ensinamento, mesmo até, como espaço do tempo onde o eterno certamente irá todavia se abrigar, isto dito desta forma, considerando que o conhecimento não é instante sem reverberar, portanto, se não der a terra um fruto, poderá julgar que é capaz de receber a semente, isto porque, teremos o tempo para fornecer o espaço que constitui como ele mesmo, a oportunidade que venha a eclodir o que veremos brotar como saber ligado ao desenvolvimento de consciência. Onde posso já dar um fruto, que virá a ser uma plantação? E onde ainda devo dizer que precisa preparar a terra? Não esquecendo que mesmo a árvore mais frondosa, e mais antiga pode em tempestade, ou violência, perder suas raízes, e morrer. Do mundo e da vida.

Portanto da liberdade, e da liberdade e conhecimento, haveremos de encontrar no mundo, o que pode nascer do sonho. Um sonho para todos. Um sonho, com justiça, paz, amor e vida.

Neste ponto, o sentido de responsabilidade social, ambiental, emocional, politica e humana, como diretrizes do que queremos, desejamos e de fato tornamos existente, como economia planetária, e gesto sensível do espírito do universo. 
Os mundos lógicos - * -Irmos até o outro é um movimento e trazer o outro até nós é outro.

Lógica paraconsistente

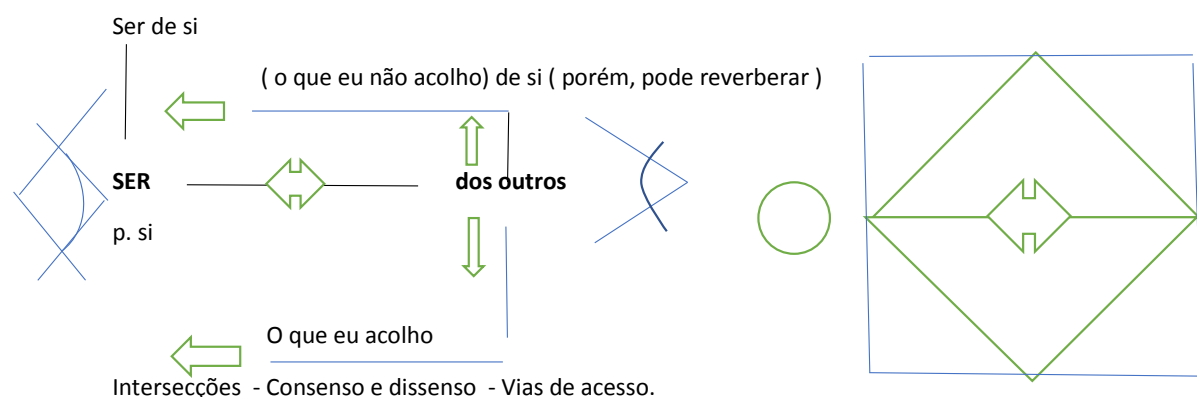

Intersecções - Consenso e dissenso - Vias de acesso.

Como simbologia:
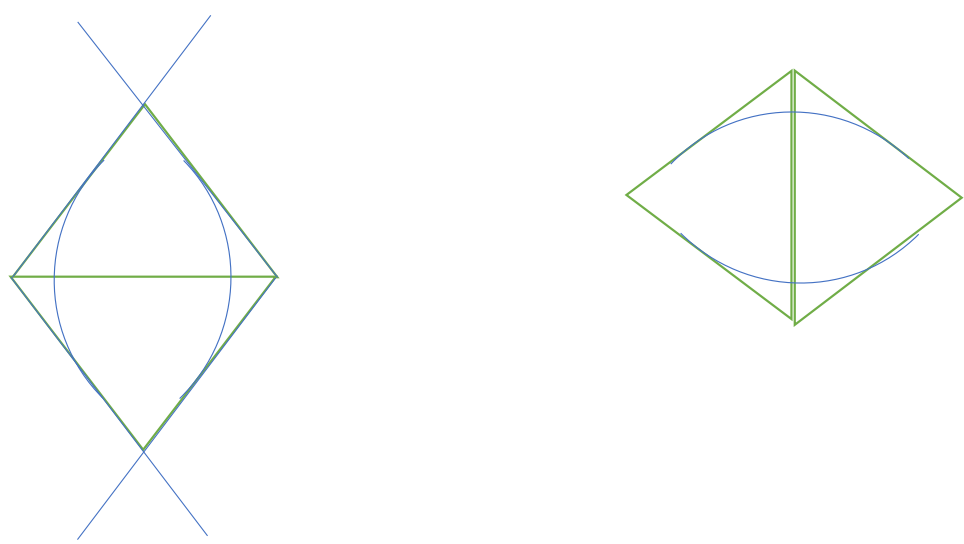

Esquadro e Compasso

Por onde vamos, o que vemos e o que fazemos.

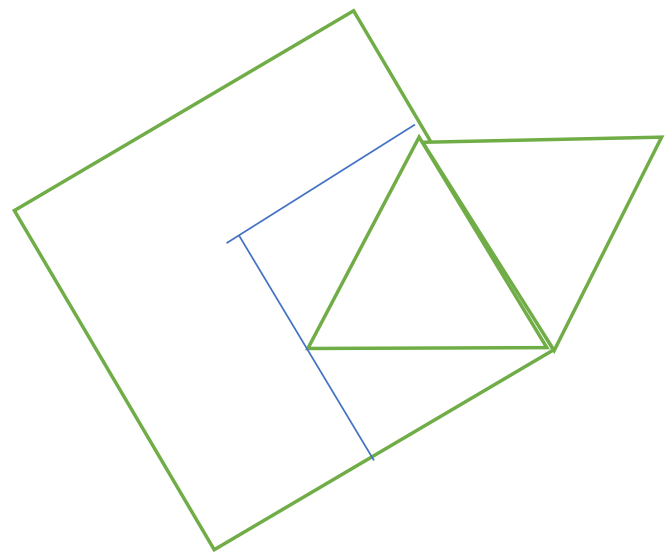

Dos sonhos e de ideais, por caminha o tempo, de nossa imagem, um pensamento: 
Do livro que está sendo escrito por mim, autora desta tese; Razões Submersas, o trecho que segue:

Sobre o tempo,

De uma guerra

Quer seja um segundo ou mesmo quantos anos, estejamos sobre uma pérfida luta onde deixamos de ser humanos. Quer sejam os destinos, desatados de seus próprios seres, estando a deriva sem mar e sem território, poderemos ver o tempo como a miséria da própria alma, sedenta e faminta de um outro lugar de onde os segundos repousaram por entre o que se vive, ainda de maneira digna.

Mas será todavia, um dizer este ao qual me entrego à revelia, pois a tormenta de uma guerra impõe a morte, e os destroços de qualquer alma, antes que mesmo se possa estar sobre o que restou do que chamamos, ser, mesmo que destituído do caráter humano. Quer seja um segundo, esse é eterno como a lágrima de quem quer que seja identidade que lastima seu lugar, porque se pode encontrar por toda parte. Por toda parte!

Então, se te perguntas como pode haver oh Deus em toda parte sofrimento!!!?

Identidade da crueldade, do despojo de para alguns, prazer em sentir a ferida do outro como sua pele sem compreender o que da gente, sente.

Mais uma vez o segundo passa, como o último e o primeiro, sendo passageiro da morte, efêmero gesto que se foi, para se encontrar como eterno?!

Eterno?!

Haverá ainda mais destemido corpo que da terra não sucumba por gerar em ser inóspito, violência, atrocidades, que do que paira sobre nós, é apenas um cenário.

O sentido? Quantos sabem em verdade que de tudo que em guerra desumana se luta, com o tempo, nem mesmo se sabe, pelo qual se vive?!

Nesse lugar, encontra o segundo com o tempo. Qual o meu lugar, do que vive a tanto tempo?!

- Lugar. Qual dele, o meu ou o seu?

- Pensei que fosse o mesmo.

- Estava eu querendo liberdade, ou qual era o destino de minha luta pela humanidade? Igualdade?

-Diga-me, onde me encontro que não seja o destino, um lugar nosso, VIDA, ou um existir que se perceba espaço de nosso tempo.

- Diga-me! 
- O tempo que soa como o ser do próprio vento, ausculta que do que se luta, pergunta: Como! Como ! Como !

- Então, esteja a tua luta no teu sentido como destino e caminho, porque se acaso o destino não esteja em seu caminho, não encontrarás, e da perda a primeira morte, será a própria da luta que se desfez em cinzas.

Quão corpo haverá do tempo que lute em dignidade e não por sofrimento.

E não por sofrimento!

Esqueces-te que se pode lutar com justiça?

As lutas não são somente, ganâncias pérfidas, são também generosidades de um horizonte onde ainda se pode ver o sol, lugar do cosmo de onde ainda procuramos razão.

Qual o tempo de uma luta?

O homem digno pode lutar por justiça, igualdade e amor uma vida inteira!!! E ainda por gerações como semente, e vida de seus ideais!

Qual o tempo de uma luta?

Haverá homens que julgam ser da vida a luta em desterro atroz, devassidão, mortes, desonra, um caminho este que se pergunta do como e quando: ACABOU?

Do mesmo estamos nós vivendo em sociedade sobre o que acreditamos, vivemos, ou ainda poderemos sonhar. Por onde vão os sonhos pelos quais desejamos lutar?

Desigualdade, fome, desnutrição, precariedades urbanas e humanas, infra estruturas,, dores, doenças.... Qual guerra ou luta, e como e onde, estaremos e nosso caminhar que não seja o destino esse olhar, de por onde estamos a passar sem mesmo SENTIR?

Amortizados estamos em velados segundos, esquecidos que o tempo é todavia, também, LUGAR DE HUMANIDADE!

5. O palco do mundo.

Da plena consciência dos direitos em existir, exerce o cidadão seus papeis no palco do mundo. Exaustivamente percorrendo uma gama infinita de dizeres em quantos forem a sua busca em personagens que na luta da sobrevivência tenha que exercer. Pais, filhos, profissionais, ser humano. Até mesmo este, o ser humano temos que aprender em como representar, em ambos sentidos, representar em dignidade o amago de existir, assim como representar como alma o corpo que se insere nas mais diversas faces do cotidiano em modos de sermos um espaço na sociedade. Nessa dramaturgia, realizamos a procura de sermos dignos do palco sagrado que é a vida, assumindo sejam qual forem os nossos momentos, a realidade que trazemos para a escolha do que queremos ser e representar. 
5.1. A experiência audiovisual, sinestesia explicita.

Da mão e do olho, o encontro do pensamento com a imagem, sons a percorrer o mesmo sentido. Quando a mão retoma meu corpo no desejo inalterado de escrever meu olhar, as folhas se tornam como o vento, tocando-me em pensamentos do horizonte o que antes de me debruçar sobre, arrebata de mim, o sonho dizendo-se uma possível face da realidade. Parto antes da viagem, como gestante do meu germe de observador que caminha antes dos trilhos do trem, vagante ilusionado do que parecia intrépido destino, mas que já me tinha por inteiro, seu fiel passageiro. Outubro era um mês onde as palavras me socorriam, carentes de se fazerem viver, por dizer de si, uma história minha. Alma-Ata era o destino no mapa do meu pensamento que necessitava recuperar as forças.

Colidir em si mesmo, com a brandura da neve e não se lembrar dos corpos enrijecidos e inertes da morte cavados na desesperança da tirania, não poderia ter outra forma se não a de suscitar imagens em resposta, dos diálogos esquecidos, como ímpeto inalterado de sobreviver. Também poderemos ser, o através do ímpio, dilacerando suas formas, pela força maior que reside em nosso pensamento, porque no decorrer dos tempos, existem muitas guerras travadas impunemente mesmo que sem armas. Mas, naquele tempo, por volta de 1942, haviam mortes marginalizadas em uma coação do estrangulamento da liberdade, haviam mortes expostas como face do possível, fazendo com essas mortes exaurir do tecido da humanidade um mundo apodrecendo, havia o estrangulamento dos direitos do existir, sufocando todo e qualquer direito a vida. Haviam máscaras duelando em territórios esquecidos da razão, e iludindo-se na não exposta verdade das lutas do poder econômico.

De alguma forma a neve das montanhas podem ser mais do que uma colisão de percepções e dialogar com o que precisa renascer, ganhar corpo e arder nas feridas. De alguma forma e sobretudo, temos que renascer ante a face do mesmo céu ainda que coberto de cinzas. De alguma forma ante a loucura de um fronte em qualquer parte ainda poderemos reagir. A arte como pulso do mundo, pode dizer o que lateja ainda que nos últimos suspiros ou mesmo que, agonizante. ( SOUSA, 2017, pg 1 ) 374

Assim sendo, o próprio ritmo do mundo se desenvolve impacientemente diante de nosso olhar, esteja em sons, cores, luzes ou sombras, morte ou vida, ressurgindo sempre como renascimento de uma energia capaz de ultrapassar as trevas e o mal, a tempestade de toda e qualquer natureza, porque seria impossível não viver, mesmo diante das lembranças das atrocidades, mesmo diante da corrosão dos corações e mentes, porque a regeneração pode ser feita e também está diante de nós, esperando que adentremos suas razões como elementos da equação da própria vida, até que geremos em nós, fractais de generosidade,

\footnotetext{
${ }^{374}$ Razões Submersas, trabalho em desenvolvimento para livro. Pesquisa histórica e de literatura.
} 
fraternidade, consciência, amor e liberdade em um ideal não de nações, mas de um mundo inteiro, para enfim, sobrevivermos, como irmãos, até que eu compreenda-me como todo e toda forma de existir.

Uma lógica entrelaçada no interior das imagens se faz eminente, aqui não como uma necessária ação e nem tão pouco como algo a ser relegado e esquecido, mas a montagem, aqui guarnecida, está no âmbito de uma reflexão interior de uma estrutura exposta sobre uma coesão entre emoção e justaposição. Sem extremos exaurimos um significado que se faz eminente na montagem pelo fato de emanar por esse ato, o que podemos compreender, o que poderemos imaginar, o que podemos indagar. O que deduzimos muitas vezes não condiz com o que está na representação e em possível, na verdade, então, para tal, talvez devêssemos desenvolver uma sagacidade ingênua de gênese capaz de exaurir dos sentidos de uma dedução o que também poderia ser outro, ou seja, deslocar-se, apreender outras vertentes, do mesmo fato, da mesma imagem, não como um inquérito, mas como uma reflexão que se demostre não dogmática e dessa forma, permita ser permeada por índices de outros dizeres.

Um certo caráter de automatismo se insere em deduções, precariamente incipientes no que condiz com verdades, ou com o que se quer de fato expressar na representação, e justamente neste particular se revela um pensamento sobre partes e o todo.

Cinema ou dimensões da física.... diálogos de sentidos cruzados

[...] a justaposição de dois planos isolados através de sua união não parece a simples soma de um plano mais outro plano - mas o produto. Parece um produto - em vez de uma soma das partes - porque em toda justaposição deste tipo o resultado é qualitativamente diferente de cada elemento considerado isoladamente. ( EISENSTEIN, 1947, p. 16 ) .

Para o fato de um processo de cognição, observa-se no espaço da imagem a oportunidade dos correlatos, pois sugere-se que podem se apresentar duas representações que por justaposição nos releva uma nova ideia. Claramente se coloca que as razões que nos levam a notar esse fato como relevante de importância ocorre justamente por acreditar que tanto o conteúdo como as possibilidades diagnosticadas em justapor são igualmente necessárias. $\mathrm{O}$ que surge da montagem de, inclusive, pelo que a conjecturou não ser relacionadas, pode tornar as mesmas correlatas. 
Talvez, diagnosticar qual seria o elemento unificador seja uma resposta cabível, mas sem olvidar que tanto o conteúdo dos planos isolados quanto a justaposição do que é independente entre si, porém, de fato, se verifica uma concreta necessidade de nos dirigirmos quanto ao que é do todo, do que pode unificar. Este ponto da reflexão nos remete ao que Arthur Kostler nos aponta sobre o holon ${ }^{375}$, sobre a capacidade integrativa e ao mesmo tempo auto-afirmativa.

A representação e a imagem podem ser discernidas como talvez o que posso compreender como forma e significado, e diante disto não nos podemos furtar ao que parece ser relevante, pois na imagem parece-nos que cabe ao surgimento de algo que informa, que gera um sentido, mas que deve para tal ser percebido para além da forma. Consideremos que para tal, um interessante e fundamental passo seja o das associações, relações que se estendem a cerca dos significados e que conduzem a uma rede de caminhos que podem nos revelar o destino de uma compreensão. Todo este processo que condensa uma aderência entre a representação e a imagem, denota a formação de uma realidade e de maneira que acreditamos também seja o modo de agir da formação das imagens pela arte, creio particularmente pelo modo com que no ato criador se depara o gesto do pensamento com estruturas e sentidos ( significados ), entrelaçados na obra.

A fusão da imagem pode-se dizer que está contida em um organismo que respira no ato de se encontrar em ressonâncias que permanecem entre o passado, através das referências latentes das lembranças como, índices referenciais, o presente, construindo uma realidade entre a representação, a forma como se apresenta e a imagem, como fusão condensando a lembrança, a informação presente que repercutiu no entre a lembrança, a forma, e o sentido.

Além disso, apesar de a imagem entrar na consciência e na percepção, através da agregação, cada detalhe é preservado nas sensações e na memória como parte do todo. Isto ocorre seja ela uma imagem sonora uma sequência rítmica e melódica de sons - ou plástica, visual, que engloba, na forma pictórica, uma série lembrada de elementos isolados. De um modo ou de outro, a série de ideias é montada, na percepção e na consciência, como uma imagem total, que acumula os elementos isolados " ( EISENSTEIN, 1947, p. 20 ).

\footnotetext{
${ }^{375} \mathrm{O}$ conceito de hólon foi desenvolvido por Arthur Kostler e podemos ler suas considerações a esse respeito no livro: As duas faces de Jano, onde considera holon, um elemento em analogia ao próprio corpo do ser humano, onde os órgãos desenvolvem seu funcionamento de forma particular mais integrado na totalidade, onde observa-se o comportamento de uma autonomia em conjunção a uma integralidade.
} 
No presente momento, em diálogo com o referido autor do sentido do filme, pondero mas reflexiono que ao referir-se que, “ uma obra de arte, entendida dinamicamente, é apenas este processo de organizar imagens no sentimento e na mente do espectador “, há de se considerar que no processo de criação ao qual, não diretamente, o espectador se integra, é possível e advirto que costumas uma organização dos sentimentos em imagens, sons, gestos, texturas, considerando que estejamos em um processo diagramático mental que percorre um horizonte que abarca os sentimentos de natureza interna para o lado externo, e nesse movimento se relacionam as afeições do sentimento em direcionamento, relações, semioses de maneira que se poderá concatenar o significado do sentimento, primeiridade ${ }^{376}$, qualidades nos termos de Charles Sanders Peirce, como também o significado da matéria ( códigos ), por exemplo, passos, planos, na dança - coreografia, como ainda da própria estrutura ( linguagens, dança - o movimento, ritmo, coreografia ), onde em diversas linguagens se pode verificar o engendramento entre código e linguagem.

Quem exerce o trabalho da arte, pode compreender que apesar dos códigos, e das linguagens, existe algo mais que deverá emergir para que de fato ocorra a arte, e esse algo mais pode ser compreendido como, a vida dos sentimentos, a sua revelação, isso o diferencia propriamente do simples ato mecanicista de executar as formas compostas pelos códigos das linguagens para, o emergir do sentimento, o ímpeto do espírito da própria qualidade (Primeiridade), que executa até mesmo para além do artista ou melhor, em comunhão com ele, a força da energia que é capaz de transmutar toda e qualquer realidade descortinando o próprio existir para ir no através dele até a interioridade e ressurgir no palco do mundo,

$\mathrm{O}$ ato contido de um ator, ou de um gesto de um bailarino também exerce sua força, e não somente em uma representação enfática pode se encontrar uma vida da cena, é algo mais que eclode e que talvez esteja no ato do querer, na entrega, como o que encontramos na forma da música que se entrelaça como nenhuma outra linguagem. Essa energia emerge do querer, da vontade de Shopenhauer ${ }^{377}$, ou mesmo, de uma sincronia do sentimento fazendo-se razão do

\footnotetext{
${ }^{376}$ O filósofo Charles Sanders Peirce em sua Fenomenologia descreve as categorias, como modo de ser do mundo, de maneira que a categoria da primeiridade corresponde ao que é livre, ao que é do sentimento, ao acaso, assim com a categoria da segundidade, corresponde a existência, ao que existe independentemente de nossa vontade, ao fato bruto, e a categoria da terceiriadade as regras, a tendência de se adquirir hábitos.

${ }^{377}$ Shopenhauer no livro, O mundo como vontade e representação, " A grandeza do mundo, que antes nos inquietava, agora repousa em nós: nossa dependência e, relação a ela é suprimida pela sua dependência de nós. Contudo isto não se apresenta imediatamente na reflexão, mas se revela como uma consciência apenas sentida de que, num certo sentido somos uma unidade com o mundo, sua incomensurabilidade mão nos oprime, mas nos eleva. " p. 39.
} 
movimento de seu próprio nascimento, do seu gesto interno no externo corpo da forma, da estrutura, da linguagem, como atmosfera capaz de engendrar-se no contínuo do universo.

Ponto de vista, o pensamento da perspectiva no ato da interpretação, como montagem, pode nos dizer que, mesmo ao tomarmos uma atuação longa sem cortes, encontraremos o pensamento da montagem, na própria interpretação, portanto, “ Mesmo se sua interpretação for toda tomada de um único ou mesmo de uma única poltrona da plateia de um teatro, apesar disso - num caso bem sucedido - a interpretação terá a qualidade de " montagem “.(EISENSTEIN, p.24). Absolutamente imprescindível recorrer neste momento, ao que Eisenstein nos revela sobre uma possibilidade de roteiro de filmagem, ao nos dizer sobre as notas de Leonardo da Vinci, e de minha parte considero de estrema sensibilidade perceber que os caminhos da pintura, da literatura e o cinema, são um viés do pensamento que o toma como faces da mesma interioridade, do mesmo sonho, do mesmo nascer e viver a existência. Devo, para não pecar por impropriedade de um conhecer, deixar destas palavras, parte desse caminho, aqui neste texto, parte do que escreveu Leonardo da Vinci. As notas eram sobre uma representação do Dilúvio pela pintura.

Que se veja o ar escuro, nebuloso, açoitado pelo ímpeto de ventos contrários entrelaçados com a chuva incessante e o granizo, carregando para lá e para cá uma vasta rede galhos de árvores quebrados, misturados com um número infinito de folhas. Que se vejam, em torno, árvores antigas desenraizadas e feitas em pedaços pela fúria dos ventos. Deve-se mostrar como fragmentos de montanhas, arrancados pelas torrentes impetuosas, precipitam-se nessas mesmas torrentes e obstruem os vales, até que os rios bloqueados transbordam e cobrem as vastas planícies e seus habitantes. Novamente devem ser vistos, amontoados nos topos de muitas das montanhas, muitas espécies diferentes de animais em tropel, aterrorizados e reduzidos, finalmente, a um estado de docilidade, em companhia de homens e mulheres que fugiram para lá com seus filhos. E, nos campos inundados, a superfície da água estava quase que totalmente coalhada de mesas, camas, barcos, e vários outros tipos de balsas improvisadas devido à necessidade e ao medo da morte, nos quais havia homens e mulheres com seus filhos, amontoados, gritando e chorando, apavorados com a fúria dos ventos, que encrespavam as ondas, fazendo-as girar como um poderoso furacão, carregando com elas os corpos dos afogados; e não havia objeto flutuando que não estivesse coberto de vários e diferentes animais, que haviam feito uma trégua e se amontoavam aterrorizados, entre eles lobos, raposas, cobras nos quais ainda havia vida. Serão vistos alguns grupos de homens, com armas nas mãos, defendendo os minúsculos pedaços de terra que lhes restaram dos leões, lobos e bestas predadoras que neles procuravam a segurança Ó tumulto aterrador se ouve ressoando pelo ar sombrio, rasgado pela fúria do trovão e dos raios que ele cospe e que o atravessam céleres, levando destruição, derrubando tudo o que se atravessa em seu caminho! Ó quantas pessoas podem ser vistas tampando os ouvidos com as mãos para calar o rugido feroz lançado através do ar obscuro pela fúria dos ventos misturados com a chuva, pelo intrépido dos céus e pelo 
chispar dos relâmpagos! Outras não se contentavam em fechar os olhos, mas, tampando-os com as mãos, uma em cima da outra, os cobriam, ainda mais apertados, para não ver o massacre impiedoso da raça humana pela ira de Deus......"( EISENSTEIN, 1947, p. 25).

O movimento na suposta obra imóvel, ou seja, o movimento com riqueza de detalhes na pintura, exala e exauri sentidos do olhar em uma trajetória.

Sobre certo aspecto poderemos sentir uma tormenta invadindo as águas de nosso pensar em torrentes inquietas de relações que almejam desesperadamente pelo ato criador, vir a existir, vir a tona dessas águas, e respirar com todos os sentidos e pelas portas abertas de todo espaço que o tempo possa habitar. Nesse frenesi encontra-se uma forte energia que agrega cada vez mais em intensidade o que chamamos de desejo. $\mathrm{O}$ desejo atreve-se aonde nem mesmo as frestas se permitem enxergar e ouvir, ele de forma arrebatadora desvenda os sonhos e a imagem de um imaginário que é nele mesmo, também, no dispêndio de seus esforços, realidade. Indubitavelmente, nesse desejo que corresponde ao ato gerativo de vir a existir, emerge de si a conexão com o contínuo de maneira que, o que envolve o desejo permaneça com tal força que se relacione em intensidade com tudo que o absorva, perceba ou seja de alguma forma atingido. Assim sendo, a volúpia não o deixa partir, mas segue com ele, nesse impulso de nascer, e permanecer, liberdade ainda que sobre o ápice da conquista dele mesmo e de quem se aproxima. Agora, o olhar que antecedeu a obra, invade os tecidos do mundo e deles tornou-se o próprio respirar, arfando cada vez mais por novas relações em semiose, para comunicar-se e então, permanecer do tempo que o fez, a eternidade em modo de viver. É o que o faz ser ainda que ele mesmo, outro também, porque já é tecido visível e vidente na carne do mundo, nos lembrando aqui de Mearleau Ponty, justapostos em uníssono na melodia de uma sonoridade em ressonância. O que vem a me dizer, sobre os olhos da mente ao ser parte do modo de cognição do próprio mundo, em processos análogos de compreensão, e por essa razão, encontro a poesia que me concede o direito de movimentar-me com os sentidos, me permite que ao abrir os olhos, minha alma desperte e meu espírito caminhe por lugares distantes sem desatar seu tempo ou seu espaço, mas compreendendo-se liberto na própria imensidão, com o horizonte inteiro a desbravar, com mapas de desejos nos oceanos encontrados ou perdidos esperando apenas que a navegação comece.

Em todo o processo a montagem é intrínseca posto que inclui no processo criativo a razão e o sentimento do espectador, onde os trilhos estão lá sendo percorridos ainda que não seja 
feita a viagem, “ A verdade pertence não apenas o resultado, mas também, o caminho. A investigação da verdade deve em si ser verdadeira, a verdadeira investigação é a revelação da verdade, cujos membros separados se unem no resultado. "(MARX, apud, EISENSTEIN, p. 27 ). De certo modo, se amalgama ao processo criativo e a obra, quando ele mesmo, o espectador, em seu âmago encontra-se com o sonho compartilhado pela imaginação do autor, ou do gesto criativo que de forma compartilhada conquista em reverberação os transeuntes da vida, porque a sensibilidade pertence a todo aquele que existe e reconhece no sentir outro, também a sua imagem, ainda que seja outra em relação a que ele adentrou intimamente experimentando a insaciável presença do desejo latente que pulsa e reconhece as entranhas de cada um em proximidade que jamais indiferente instiga a um novo conhecer.

O emergir, resgatar ou intensificar um sentimento, tanto na prática de uma cena, pelo ator, ou no momento de lidar com as qualidades ( primeiridade ) em uma alquimia dos sentidos ( caminho, sensório e significado ) do sentimento para a criação, podem exercer um redemoinho expansivo que compreenda lembranças, relações em rede de conexões que façam com que se possa atingir uma decantação do que aparece como a busca do que se almeja alcançar. Portanto, há de se convir da importância de compreender o como essa evocação ocorre. Neste ponto há um aspecto que penso poder colaborar para a investigação da evocação do sentimento que trata do que vem a ser a sinestesia- prefixo grego syn, com o significado junto, e aisthesis como sentido, sensação, percepção, compreendido como fusão do sensório, e a lei da mente ${ }^{378}$, fatores estes que se estendem ao que se desenvolve como justamente o conceito de sinequismo ${ }^{379}$, que por ser a doutrina que compreende o contínuo, as ideias se propagando e concatenando afeições e afetações.

Evidentemente, Peirce está articulando uma questão que passa, de modo claro, pelo sinequismo, a saber, sua doutrina do continuum. Em outras palavras, afirma ele que a ligação entre as idéias está sob um continuum na consciência. Uma idéia passada não estará nesta consciência valendo-se de uma operação de substituição, mas por efetiva ocorrência, ou seja, esta idéia se faz presente e deve ser ipso facto presente. Por conseguinte, o

\footnotetext{
378 Sobre a lei da mente, The Law of the mind de Charles Sanders Peirce em 1892, ” A análise lógica aplicada ao fenômeno mental mostra que há apenas uma lei da mente, que as idéias tendem a se espalhar continuamente e afetar outras que estão para elas em uma relação de afecção. Ao se espalhar, as idéias perdem intensidade e, particularmente, o poder de afetar outras, mas ganham generalidade e misturam-se com outras idéias. "(CP 6.104). Sobre a lei da mente também pode ser consultado, os artigos, Os Significados Pragmáticos da Mente e o Sinequismo em Peirce, Santaella, Revista Cognitio de Filosofia, 2002, n.3, p. 83-96, 2012 e O Amor Criativo como Princípio Heurístico na Filosofia de Peirce, de Ivo Assad Ibri, in Cognitio Revista de Filosofia, 6, n. 2, p. 187-199, jul./dez. 2005

${ }^{379}$ Sinequismo é uma palavra de origem grega que significa continuidade. O termo justamente aparece no texto de Charles Sanders Peirce sobre a lei da mente na série publicada no Monist entre 1890-1893. O Sinequismo ( CP. 6.202 ), pensamento da continuidade, justamente considera a integralidade.
} 
tempo que subjaz à consciência deve garantir que o presente está conectado com o passado por uma série de passos infinitesimais reais. Aquele continuum da consciência deve cobrir um intervalo de tempo no qual estamos imediatamente conscientes; ela não só é contínua num sentido subjetivo, mas, também, por ela ser imediata naquele intervalo infinitesimal de tempo, seu objeto é também contínuo. O sentimento de continuidade da consciência é, simultaneamente, a percepção8 direta da continuidade de de seu conteúdo.[...] No ver peirciano, a qualeconsciência, como ele a denomina, é uma consciência absolutamente presente na sua unidade. O sentimento, então, dessa unidade, é um sentimento vivo; é ele que acompanha a unidade de uma idéia complexificada pela junção de outras. Tal idéia mais geral não rompe aquela unidade primária da quale-consciência, uma vez que todas as idéias componentes estão absolutamente presentes num intervalo de tempo em que esta consciência se faz.” ( IBRI, 2005, p. 191 )

Se observarmos bem a sinestesia engendrada com relações dispostas em um diagrama que coabita com o que abordamos sobre a lei da mente, podemos compreender o que nos concede um meio cognitivo de um continuo de relações que integra tanto elementos não percebidos como pelo meio não usual de um imediatismo; revelar deslocamentos de sentidos que antes aparentemente distantes se fazem possíveis e nesse caminho emergem sentimentos adormecidos que podem expandir sua força e energia de sentimento.

As lentes mentais como Eisenstein se refere estão diante do interior como uma atitude cinematográfica de fragmentos e detalhes,

Nossa última pergunta foi como evocar os sentimentos vivos e as experiências emerjam do interior do ato. A pergunta anterior foi como evocar sentimentos do espectador uma imagem sentida emocionalmente. Em ambas as perguntas, os elementos estáticos, os fatores dados e os imaginados, todos em justaposição, criam uma emoção que emerge dinamicamente, uma imagem que emerge dinamicamente. Não consideramos isto, de modo algum, diferente, em princípio, do processo de montagem do cinema: aqui há a mesma concretização intensa do tema tornando-se perceptível através de detalhes determinantes, sendo o efeito resultante da justaposição desses detalhes a evocação do próprio sentimento. Quanto a verdadeira natureza dessas visões que aparecem diante do "olho interior" do ator, seus aspectos plásticos ( ou auditivos ) são completamente homogêneos com as características típicas do plano cinematográfico. Os termos fragmentos e detalhes, conforme aplicados, acima, a essas visões, não foram escolhidos ao acaso, já que a imaginação não evoca quadros completos, e sim propriedades decisivas e determinantes desses quadros. ( EISENSTEIN, 1947, p. 33 ).

Entre detalhes e fragmentos, observa-se como pode o ato do olhar cinematográfico de fato existir e não somente primeiros planos, médios ou plano geral. A literatura é prodigiosa 
nisso, exaurindo das palavras imagens que vem a tona, em justaposições realizando um episódio.

“[...]...Era tarde quando a porta se abriu, deixando a ausência entrar que se perdera da esperança, quando ouve-se um suspiro já onde não se respirava. Encontrou-se com o poeta que deitava-se nos versos de olhos fechados, ele que abre-se na presença do sofrer, resgata as forças quando desperta antes de sonhar. Atende ao gesto que entra com as mãos estendidas para recolher das palavras o som que se deixava ficar na lembrança do espaço, vazio. Fez-se lugar antes da tempestade, porque sentia-se o vento, a brasa do fogo e o percorrer insano, refugiando-se no corpo da folha incerta, que começa agora a escrever as primeiras linhas. Em um porto seguro. ( SOUSA, 2015 )

Planos: A porta que se abre ( quem entra é a ausência )/ O som do suspiro/( uma presença antes do poeta - a figura da própria ausência - pelo som ) O poeta ( entre o real e o imaginário - deitava-se nos versos de olhos fechados )/Mãos estendidas ( a busca )/Vento, brasa e fogo ( a inquietação do que viria a existir ) /Porto seguro ( as palavras - o pensamento ).

Todavia ainda se pode percorrer quais cores, que tonalidades encontrar no gesto dessas imagens de palavras, como esses deslocamentos entre um plano e outro podem ser a ação desses sentidos. E ainda, sobre emergir a presença da ausência ( o som que caminha no vazio sem corpo, corpo sendo o tecido da atmosfera que pulsa no seu existir ausente- me permitindo agora fazer a referência ao verso de Maiakovski ao dizer sobre o Vácuo onde Eisentein considera filmar as estrelas para enunciar o vazio, mas, fazendo com que a presença dele seja sentida ).

A experiência da ação pode ser revelada por índices das palavras percorrendo as imagens do sentimento, em prenúncios do que iremos percorrer, encontrar em compartilhamento dos sentidos compartilhados. Examino que lidar com imagens descritivas nos trás a possibilidade de determinados planos, porém, examinar as imagens de uma atmosfera que se mescla com uma descrição ela mesma sendo personagem em ação, me parece que possibilita um tom diferente, uma atitude de olhar cinematográfico que amalgama um outro tempo, um respiro do pensar os sentidos do sentimento. O que seria mais importante ao olhar, indago, pois seria talvez, uma escuridão de um ressinto.....antes da porta, do poeta e dos versos? O gesto de uma escuridão prenunciada pelo entardecer poderia ser um detalhe importante para o ritmo da imagem final das palavras nascendo, como a claridade de uma nova manhã? Ou ainda compreender o possível revelador dentre o que se oculta na noite para sonhar? A conduta expressiva é tão atuante como a própria cena, porque conduz o 
discernimento de o que se faz encontrar de fato existindo naquela imagem, e por qual caminho iremos desvelar o próprio olhar se conduzindo. $\mathrm{O}$ sentido, me parece, abarca a forma do como emergir e é justamente onde não apenas deve ser a "exposição-testemunho da mera informação”, mas sim, “ a exposição emocionalmente instigante “.”(EISENSTEIN, 1947, p. 34 ). Prodigioso é o exemplo de Puchkin, em seus poemas, tanto em como não ser mecanicista o modo de coincidir os planos e s trilhas musicais. No pensar da música e da imagem, podemos constatar a evidência de contra-ponto sonoro-visual, mas também nota-se o ênfase do som justamente no ênfase da representação, compreensível pela maneira como se realizaria uma montagem de um experiente olhar.

O olhar aproximado do modo de ser da literatura nos cede generosamente a sintonia plena do modo de ser da interpretação, em suma nos dizendo sobre uma igualdade presente no modo de ser da vida, onde a montagem exerce uma maneira de perceber o que observa-nos como expectador de nossos atos em detalhes e fragmentos de um porvir a ser registrado como nossa história em existir. Como, se o universo pudesse compreender o mundo como o grande palco, desenhando sua cena sobre os tempos, no espaço infinito da busca da compreensão dos sentidos em constante descoberta.

Anatomia dos sentidos. Sentidos amalgamados, no princípio, a constante. Processo investigativo da natureza dos fenômenos audiovisuais. O elemento unificador que funciona sendo um elo, a origem, se apresenta entrelaçado nos outros tantos elementos, como as variáveis plásticas, sonoras, dramáticas, formando uma imagem única, como no exemplo do Dilúvio, de Leonardo da Vinci.

Para encontrar a base de um posicionamento investigativo que paire sobre o conjunto e principalmente enquadre o próprio princípio em seus deslocamentos, poderemos compreender inicialmente o homem em suas emoções como percurso a ser desvendado, porém, penso que nos fenômenos auscultados da linguagem audiovisual, comporta uma amplidão de gestos para além do humano, onde no contemporâneo tempo se faz compreensível a sinestesia justamente também conjugando que tudo a sua maneira expressase e se transporta em meios de comunicação no aspecto de relação. Aqui o que queremos expor é justamente o fato de que compreender que a imagem de uma pedra, até mesmo sem determinar ainda em que tonalidade ela esteja envolvida, e nem tão pouco por que som, poderemos compreender que a pedra pode ser de mim o mesmo ser em imagem, posto que eu posso encontrar-me como a rigidez de uma forma de conduta, ou que eu possa ser a pedra a ser lapidada e ser a escultura a desvelar-se, portanto, seguimos com uma hipótese aqui 
cabível de que algo está sempre presente, tem um ambiente ${ }^{380}$, esperando ser descoberto, percebido, e além disso, compreendido como parte de meu ser.

Neste momento eu proporia um pequeno exercício de maneira a desenvolvermos uma possibilidade, e para tal, solicito que todo e qualquer que esteja lendo estas linhas imagine uma pessoa defronte a um lago, e esse lago permanece extremamente sereno, mais a imagem a qual se está contemplando é cercada pelos frames sonoros de uma relação com a imagem do som que é repleta de uma intensidade, força, movimento, que extrai da relação do momento que se continha a cerca da pessoa e do lago para ver a fresta por onde adentra um sentido a mais, repartido entre a imagem do pensamento, que revela estar em luta com a serenidade, porque a música dialoga de forma a estender o sentimento do sentido, tornando ainda a imagem, nela mesma, outra, desvelando o espaço em outro tempo, " contratempo ", diferentemente do imediato, mas que concede o olhar de uma multidão de elementos que podem nos dizer que no silêncio se encontram um infinito de palavras e que na serenidade pode se estar em uma luta feroz, ou em uma dor profunda, talvez como uma, "Nostalgia da luz". 381

Para a mais de identificar as formas dos sentidos em um trecho literário rico de imagens eu sinto que, podemos inquerir sobre como eles podem vir a tona, porém por ora,

É do Diário dos Goncourt - uma nota de pé de página, no registro de 18 de setembro de 1867: [...] Os membros resplandescentes de lutadores surgindo em plena luz. - Olhos desafiadores, - Mãos golpeando carne ao se agarrarem, - Suor com cheiro de animal selvagem - Palidez misturada a bigodes louros, - Carne machucada se avermelhando, - Dorsos suando como as paredes de pedra de um banho a vapor. -Avançando, arrastandose de joelhos, - Girando sobre as próprias cabeças, etc.( EISENSTEIN, 1947, p. 51 )

Os diferentes planos se entrelaçam com os diferentes sentidos, podendo ser compreendidos e percebidos de maneira a demostrar similitude aos processos mesmo da montagem.

\footnotetext{
${ }^{380}$ Para a reflexão do termo ambiente, como análise em conjunção, buscamos a referência do documentário A arvore da música, de Robert Cahen, onde se pode averiguar a relação existente do que se apresenta como propagação, ambiente, transdução e ressonância.

${ }^{381}$ No pensar o gesto da expressão do existir que ressona por caminhos do indagar contínuo a procura de respostas, que abarca sentimentos no decifrar do pensamento, sensibilidade e do viver, e da compreensão, do que encontra-se em latência a ser ainda descoberto, como referência em filmografia, consideramos neste ponto, o filme Nostalgia da luz de Patrício Gusman, assim como também, Thomás Edison: o mago da luz de Clarence Brown.
} 
A montagem vertical, acompanhada do modo de ser propriamente de uma partitura orquestral mais do que uma analogia nos mostra propriamente um modo de desenvolvimento de uma cognição que entrelaça movimentos expressivos estejam eles no drama, no movimento, na audição, na sombra, no tato, de uma forma que justaposições, diálogos, contrapontos e correspondências, ocorrem em uma progressão e em sequências que se fazem relações de ligações entre planos, e a de se ressaltar que mesmo quando os referimos a composição- montagem no caso do cinema mudo, a ligação de um plano ao outro ocorre nas linhas, estejam elas no crescente do êxtase, nos rostos ( vozes ). O que em suma pode-se aferir é justamente a capacidade de se obter tanto a construção da linha total como o movimento em cada parte. Aqui recorreremos ao caráter imagético das imagens fotográficas que justapostas, ou, em sequência que em conjunção a trilha sonora nos envolve no trabalho tão característico da montagem cinematográfica. O todo orgânico da imagem e do som é um árduo e prazeroso percurso realizado com percepções, diagnóstico, e um estar astuto para concatenar uma unidade ainda que permeada por momentos de uma complexidade fragmentada interdependente, disposta a uma coesão com as demais relações imbricadas na unidade.

Por vezes ainda que na ausência do som, mas na presença de um elemento de base, de uma gênese, de sua razão sensível, de sua integralidade, que é o ritmo, o movimento, podemos compreender, ver o som, senti-lo, nos ater a sua presença amalgamados por um sentido que se desprega de uma forma total mas que informa, e mais do que isso, o ritmo em sua unidade tem como agir em conformidade com o que compreendemos como som ainda que sem o processo habitual da audição, mas nos mostrando a capacidade de ser audível pelo próprio movimento, deslocamento, que opera em nós, em nossa percepção, o mesmo ser. Vejo a presença do som pelo seu elemento, a saber, o ritmo, o movimento ainda que desprovido do que consideremos propriamente som, podendo ser claramente um sentido ou uma sinestesia que abarca um movimento, portanto algo que pulsa de alguma forma, no cotidiano mundo, onde o tempo em alguma instância também pode ser instrumento em seu próprio porvir do movimento do universo, latejando e em nós engendrado como elemento orgânico também onde nosso gesto encena planos na existência, linhas, condutas de dramas e expressões, como algo muito interessante a ser diagnosticado, pois ser refere tanto a algo que está lá, porém sobre outra forma e também ainda a ser melhor inquerido como sendo um intervalo 
ressonante $^{382}$, como apontado por Macluhan no livro, A aldeia global. Talvez eu possa considerar a percepção do som sem propriamente seu corpo mas com o seu sentidosignificado que concede diante da propagação ${ }^{383}$, crateras de nós mesmos, expondo-se em revelações desapercebidas anteriormente, por vezes, por um outro modo de ser distante do habitual mas no cerne do seu âmago.

Particularmente, penso neste momento após alguns primeiros passos em imagens em movimento, concatenando o universo da dança e da música em gestos entrelaçados, em uma composição que caminharia por diagramas relacionados que se apresentariam sobre a seguinte forma em possível: O diagrama da imagem estaria disposto em ramos que poderiam em sua expansão demonstrar os elementos de base que ocorrem como fractais, ou elementos que ganham em informação e complexidade por suas interpostas relações. Um dos ramos seria o diagrama do ambiente, que antecede ao próprio percurso da cena, ele mesmo condensando aspectos elementares e em desenvolvimento ${ }^{384}$.

Os campos de sincronização ${ }^{385}$ nos fornece os dados de uma possível relação métrica de cadência, em diversas variações de combinações em sincopados e contrapontos de formas rítmicas em movimentos melódicos, podendo até mesmo incorporar elementos não correspondentes. As formas de sincronização diferentes são abarcadas pelo todo orgânico.

Creio ser um privilégio adentrar o pensamento de Karl von Eckartshause, Lafcadio Hearn, Renne Guilerré. Aqui apontamos, para elucidar o caminho ao qual estamos querendo elucidar, a parte interessante de uma carta em que Lafcadio Hearn escreve a seu amigo, Basil Hall Chamberlain onde, ele escrevem, “ Para mim as palavras têm cor, forma, caráter; elas têm rostos, partes, modos, gestos; elas têm temperamentos, humores, excentricidades elas tem matizes, tons personalidades. "( Hearn apud, Eiseistein, 1947, p. 62 ). Ainda nos debruçando pelas experiências de Hearn em sua busca nos deparamos com o oriente, derivando dos princípios do Yang e Yin e o cavalo dragão, um diagrama que conjuga propriedades de vários elementos da geometria da vida, cores, estações, fogo, agua, terra, ar

\footnotetext{
${ }^{382}$ Macluhan no livro La Aldea Global, "Se puede pensar en el intervalo resonante como un límite invisible entre el espacio visual y el acústico"

${ }^{383}$ Propagação com o significado da presença de algo que estava presente e eu não notava antes, e que é se reconhece pelo que pode gerar, aqui nos aproximando propriamente mesmo do que vemos na física como densidade de probabilidade. Em respeito a densidade de probabilidade, ver llya Prigogine, $\mathrm{O}$ fim das certezas. ${ }^{384}$ A reflexão apontada neste trecho diz respeito as pesquisas realizadas na Escola de Artes Dramáticas da Universidade de São Paulo, na sala 25.

385 Podendo sobre esse tema ser pesquisado o livro também de Eiseistein“ A forma do filme, em métodos de montagem, aqui claramente referindo-se a uma complexa polifonia, e uma percepção das partes como um todo.
} 
e notas musicais. Precisamente nos soa completamente contemporâneo no matiz da fluidez da diluição de fronteiras, justamente, a teoria de música ocular apontada por Karl von Eckarshausen, sobre palavras, músicas, cor e a expressão da alma:

Exatamente como os tons da música devem se harmonizar com as palavras do dramaturgo em um drama musical do mesmo modo as cores devem corresponder às palavras. Dou um exemplo para tomar isto mais compreensível. Escrevi um pequeno poema, que acompanho com minha música colorida, Ele diz: Palavras: Tristemente ela vagava, a mais adorável das donzelas...Música: As notas de uma flauta, plangentes. Cor: Oliva, misturado com rosa e branco. Palavras: ...em planícies floridas - Música: Alegre, tons crescentes. Cor: Verde, misturado com violeta e amarelobonino. Palavras: Cantando uma canção, feliz como uma cotovia. Música: Notas suaves, crescendo e gentilmente descrescendo em rápida sucessão. Cor: Azul marinho listrado com escarlates e verde-amarelado. Palavras: E Deus, no templo da criação, a ouve. Música: Majestosa, grandiosa. Cor: Uma mistura das cores esplêndidas - azul, vermelho e verde - glorificada pelo amarelo do amanhecer e púrpura - dissolvendo-se em verde claro e amarelo pálido..."( Eckartshausen, apud Eiseistein 1947, p. 60 )

A fusão que enaltece o modo de ser de diversas perspectivas engendradas a ponto de não ter pertencimento mecanicista ou dogmático quanto a processos e regras, mas um vasto horizonte perceptivo dissipativo. A evolução se tornou mais inserida em um pensar democrático no sentido de liberdade de estruturas de complexidade, considerando uma mobilidade diagramática para exaurir do sentimento, do próprio pensamento, suas densidades de possibilidades, bem próximo aqui do conhecimento da química e da física, como o que discerni Ilya Prigogine ${ }^{386}$ no livro, o fim das certezas, aqui propriamente relatado como viés da criação expondo-se em um pensar que busca a polissemia de caminhos, de seus elementos e de suas estruturas. Assim sendo demostrando uma nova maneira de ver o mundo, e em conformidade a esse modo de ver, as próprias revelações de se conceber o gerar, o produzir em potencializar significados como um processo em aberto, desencadeante em contínuas semioses, compreendidas como sendo capacidades de compreender a variação dos sentidos onde eles estiverem, produzindo conhecimento, ou seja, em uma introjeção de um estímulo a outro, nos quais os sistemas de signos modelizam movimentos de transformação, no entrelaçamento dos signos discretos na constituição dos signos contínuos ${ }^{387}$, multiplicando a linguagem, renovando os códigos. A geração apontada

\footnotetext{
${ }^{386}$ Ilya Prigogine, sobre as ilusões do tempo, as visões deterministas e a força criadora como descobertas de um mundo em construção.

387 Signo discretos se apresentam por serem decomponíveis em suas partes, e o signo contínuo, indecomponível e totalizante em conformidade ao que Yuri Lotman nos esclarece ao considerar a modelização do plano em mundo visível da vida, o contínuo, e mundo visível da tela, o discreto.
} 
acima como produção de sentidos está no que abordamos com relação aos sistemas dissipativos.

Das reverberações da cores, os sons em tonalidades. As estações das cores podem percorrer o caminho de nossa percepção por diversos matizes onde as cenas da vida se desatrelam do cotidiano modo de ver o mundo para pincelar as incertezas do efêmero e continuo gesto das intensidades dos impulsos do sentir, permeados pelas texturas dos gestos da alma. $\mathrm{O}$ que posso ouvir da claridade que se reconhece ao compartilhar a escuridão onde somente assim talvez eu compreenda a justaposição que me compreende como a luz interna que se faz mais viva quando anoitece. Talvez os sentidos do outono estejam no caminho de lhe ver chegar, como o silêncio que antecede a ausência ao desejar uma presença, fazendo-me encontrar sons que ecoam no espírito do tempo onde posso buscar o significado de um som pela ação do existir que mostra-se aberto ao que posso ver de olhos cerrados porque poderei sentir por diversos horizontes mas que guardam-se no que emerge de meu interior como o despertar translúcido de um devaneio. Poderei compreender talvez que o despetalar de folhas ao vento cobrindo a pele do solo possa adentrar o desvanecer do aroma que enaltece o gesto de partir renascendo, e nesse gesto do existir, por fim, eu poderei sentir no tecido do mundo as cores do outono, e assim sendo, partirá de mim as cores que ficaram rente a meus desejos transmutando-se de verdes sonhos em vigor para uma alquimia com siena natural que recobre de impressões do sol do caminho e sombras queimadas para amadurecer meu pensar que por estar em passagem toma voo de asas das cores da próxima estação, mas antes, em sua despedida reconhece as formas do vento que tocaram-lhe em dizeres do tempo passado latejando sobre os dia s e noites o que poderá ainda descobrir em seu devir de presenças e ausências onde cada gota de pigmento soa um oceano de sentimentos.

Se expandirmos os sentidos da cor em profundidade de campo interno, talvez, preservaremos sua liberdade interior porque decantando as possibilidades de significado, o entrelaçamento em face de profícuas relações alcança não somente cor, mas um alquimia de escalas cromáticas em sinestesia que aprofundam as suas existências, assim sendo o outono de cores terras poderá também ser revestido de um imenso azul da prússia com pigmentos de siena, porque o verde entardeceu em suas ranhuras abrindo-se para uma imagem que recolhe do azul do céu as próprias manhas do ontem, um tanto quanto em brumas estreladas percorrendo uma neblina que já prenuncia o inverno. A imagem da cor em sentidos pode encontrar-se com as palavras que se afeiçoam a caminhos que meu pensar adentra e dessa 
forma a liberdade de gênese das qualidades estariam preservadas e guarnecidas pelo estado de ressonância do que é em suma, propriedade latente do pulso da vida, o sensível.

Neste primeiro momento direcionamos a conduta de nossa compreensão para a cor e o interlúdio da imagem que condensa também a informação sonora pelo gesto, mas se auscultarmos o ambiente sonoro no mesmo momento do outono podermos ouvir as despedidas percorrer os graves ou sustenidos, porém, neste particular creio que sem nomear o que descreve o movimento, retomando Schopenhauer, deveríamos ficar em contemplação ouvindo as notas talvez de forma languida, mais próxima do andamento de um adágio ou moderato, para que cada grupo de notas, quiálteras ou arpejos, pudessem mostrar-se a cada deslocamento à memória do dizer estendendo-se como relações de lembranças transpassadas por toda a dramaturgia do gesto mais puro da alma, onde a vibração ultrapassa o ato para eclodir e emergir na natureza de todas as coisas, sublimando as formas para atingir metáforas de compreensão, onde as folhas podem ser como dedos a dedilhar o espaço escrevendo as palavras do ritmo cadenciado em nossa vontade de um querer que move o próprio princípio vital evolutivo rumo ao admirável.

Haveria um outono da Natureza que fosse do todo e de mim em parte a mesma natureza, no através dos meus sentidos? Quais cores te pertencem que tem em si a resposta da própria pergunta, onde possamos compreender que o tempo é companheiro e mesmo sendo passageiro, caminha na viagem conosco.

Desvelando as cortinas das cores, Wassily Kandinsky, percorre a narrativa dos seus personagens corporificados em sons, luzes, formas e cenas. Mais do que um aspecto psicológico das cores, prefiro me referir a seu modo de ser quanto a um agir de sentimentos das janelas da alma, por onde o carmim do fogo pode abrir asas e deitar-se no corpo esquecido de um lençol da manhã, onde o desejo se retirou e ainda que pelas luzes do dia que amanhece, se estende pela sombra do entardecer que ainda não se despediu, porque no interior ele permanece, sonho repartido da noite que adentrou. Assim posso ver a cor porque eu a ouvi nos gestos dos tecidos na voz do mundo. No palco da existência criamos no cotidiano de nossas cenas, sendo artistas todos nós, o texto do que procuramos, e indubitavelmente a dramaturgia se faz literatura dos significados onde "Para o que tende essa vida? Para quem se volta a alma angustiada do artista quando, também ela, participa de sua atividade criadora? O que ela quer anunciar? "Projetar a luz nas profundezas do coração humano, eis a vocação do artista”, escreveu Schuman” ( Kandisky, 1866, p. 30 ). 
$\mathrm{O}$ que soa, as notas ou a alma? Se nos acercamos da necessidade interior poderemos encontrar a vibração que eclode do aspecto puro do som que é a melodia do encantamento sensível de existir no que reverbera em cada aspecto da vida. As cores do café noturno de Vincent Van Gogh estão também no gesto pictórico, na forma de sua pincelada que encena a cor percorrendo as formas e o desejo da tonalidade, nos diálogos expressivos de um dizer sonoro que repercuti a angustia o desespero que um ambiente pode ultrapassar das telas à imagem do ambiente interno que sorve o café da paisagem que deseja dilacerar o corpo de um pensar para emergir uma possível alma liberta em outro ambiente ou todavia no através das cores, a noite se dissipa e retoma das estrelas a luz do caminho.

Entre matizes e Matisse, o explicito ato corporificado da cor aonde ela se apresente torna o sensível permeado por cadências de intensidades que caminham por significados em conjunção ou não, nas formas que abriguem essas mesmas palhetas dispersas pelo aspecto natural de sua interna identidade em um enigma do sonho ultrapassando a realidade em proliferação de dimensões. Mas ainda a mesma cor pode estar sobre matizes de uma gama infinita de densidade de probabilidades, no qual poemas vagam por minucias em descobertas, de variações do tema, em similitudes da cor e forma, da palavra e da música, do gesto encenado do próprio sentido que abarca o ser constituído em nuances a flor da pele exaurindo suas relações, em deslocamentos e permanências de si para sua presença no outro. Assim sendo, o amarelo estigmatizado por alguns, que pertence a um stacatto pode se revelar aproximado de um terra natural, uma sequência de uma planície que recolhe em um movimento moderato som acolhedor por ensurdecer o grito repartido pela natureza do olhar da sombra, observando o agora pálido amanhã do amarelo em planície de vales horizontes que prenunciam até mesmo os passos da noite ou o abraço tardio do sol. Pinceladas da mente transpassam planos e cenas, conjugando-se em diálogos imagéticos e sensórios em repercussões dos olhares das experiências do passado, presente e por vir. Ambivalências de sentido podem colidir e se expandir de forma a permanecer com as cores, como impacto ou reverberações adjacentes, exercendo sua energia conforme o que repercuti em cada outro dele mesmo como parte que o abrigou em outra forma ou pensamento. Em suma consideremos que a cor é um elemento que está em confluência com o objetivo visto que para tal informará certa percepção.

Composições em mobilidade diagramática. O pensar da obra se realiza em uma estrutura diagramática que conjuga elementos que agem em fluxos contínuos de interação. Algo que considero importante de ressaltar quanto a sonoridades e notas musicais em imagens de 
cognição é justamente sobre a voz do instrumento. Se faz necessário discernir que a mesma nota, ou sequência de notas tem sentidos diferentes se forem emitidos por um piano, ou por um violoncelo, ou uma harpa e assim por diante, porque a alma do som se aloja na voz do instrumento que emanados assumem o corpo que emite o sentido da sensibilidade. $\mathrm{O}$ violino chora as lágrimas da chuva de passadas gotas de orvalho despetaladas pelas naturezas do ser humano que dizem do sentido mazelas percorridas por agruras de caminhos vacilantes e exaustos matizes de cores em profunda dor encenadas nos compassos da vida ferida, mas que ainda encontra um gesto de estender a mão como o próprio deslizar do arco em passagens do que pode ainda renascer.

O verso do som pode ser da poesia o encantamento que soa em nosso pensamento até depois da última linha que ainda desenhará em nossa alma o gesto que ficou encenado pelo caminho na ressonância do movimento de nosso existir. A imagem tem um ritmo e o gesto tem uma intensidade, ambos em um ambiente que incorpora o movimento de ambos no cenário como tonalidades do que virá a emergir, e nesse entrelaçamento pigmentos do adágio me envolvem no tenro azul ou como uma bruma do amanhecer.

Reflexões em considerações conclusivas: $O$ tema desenvolvido neste texto não tem a pretensão de se esgotar, pelo contrário tem o desejo de permanecer em aberto para maiores profundas reflexões que o próprio campo fornece em estudos e pesquisas nas relações que existem entre as linguagens, o universo da imagem cinematográfica e propriamente o modo de ser da dramaturgia do palco do mundo. O modelizante pode ser observado como o que ordena o movimento dinâmico possibilitando o emergir da complexidade ${ }^{388}$ possibilitandonos diagnosticar também, como sendo uma orientação de uma perspectiva sistêmica nos indagando constantemente sobre a presença do que se modifica ainda que permanecendo. Ainda a ser aprofundado em outra oportunidade o aspecto cada vez mais evidente do arcabouço sistêmico que promove a compreensão em uma rede dialógica expansiva de diversos pontos de vista em perene construção, onde o movimento é ritmo do pensamento, entrelaçamento e convergência da comunicação.

5.2.A margem do som, amalgama da imagem, escritos de um tempo.

\footnotetext{
${ }^{388}$ Nos referimos ao que é exposto no artigo, Método, modelização e semiótica como ciência humana da professora Irene Machado publicado na Revista de Estudos semióticos, vol 9, n 2, pg. 77-87. Ver também o artigo, Inacabamento como modelo artístico do mundo, BAKHTINIANA, São Paulo, v.1 n 3, 82-98.
} 
Inquietou-me adentrando o pensamento, a imagem fazendo-se movimento, portanto, exercendo uma ação, que comunicava-se em, e através do ritmo, mas aparentemente, não havendo o som ( melodia ). O que posso compreender como som? Serei capaz de sentir em minha mente, sua unidade vibratória que em suma instância, se corporifique por uma presença do deslocamento, que inclui uma forma de tempo e espaço, existindo e inquirindo sobre uma gênese em um grau que exige uma sensibilidade, “ abstração " que se desconstrua de um modo habitual de olhar e de sentir, para emergir uma sensibilidade, alheia ao mecanismo de uma regra comum, ou até mesmo, poderá ser uma presença, tão natural que pode até mesmo passar despercebida?

O ritmo é um elemento sonoro, que desponta na equação da compreensão do som (e da música ), com importante significado, pois podemos nos aproximar dele, concebendo que o ritmo exerce ao se deslocar, um desenho ( caminho e design ) mostra seu espaço vibratório ( ou sonoro ), e ao se desenvolver se afeiçoa ao tempo, ludicamente ampliando o Cronos, com a presença do Kairos, coabitam tempos emanados em sentidos confluentes, posto que a vida segue o seu curso, e no organismo mundo muitos outros tempos de imagens vão se decompondo e compondo sua geografia. Como haver tanta presença no que se considerava ausente?

Penso que a reflexão apontada pela experiência da imagem ; do ritmo da imagem sem som , se aproxima mais da variável equacionaria ( Pitágoras- Harmonia das Esferas) que se apresenta na dimensão do fenômeno comunicacional de caráter ontológico, talvez como o que é abordado por Donald Andrews ${ }^{389}$ Como o ritmo exerce sua ação pragmática, sua conduta? Propriamente creio pelas configurações que dentre elas citamos, deslocamento, duração, intensidade, espaço e é nesse através que podemos adentrar seu modo de ser, que irá exercer relações diagramáticas, se desenvolvendo e agregando significados e informações em uma outra postura dele mesmo, sendo um movimento de seu "pensar" o desnudar-se ao passo que também se amplia. Difícil será conceber um pensar a um elemento sonoro, e ainda mais, desapropriado do humano, mas como meio da própria cognição do

\footnotetext{
${ }^{389}$ Donald Andrews em The Symphony of Life, aborda que em sua complexa teoria do universo vê em cada átomo um emanador de sons tônico, um minúsculo ressonador, e concebe coleções de átomos ( ou notas ) formando os acordes, conhecidos do físico como moléculas. Continuando a expandir-se em tamanho de dentro para fora, as moléculas se combinam pra formar os vários objetos e formas do mundo, de modo que cada objeto e cada ser vivo, é composto de grande número de moléculas, ou acordes, que dão ao objeto ou ser seu próprio "som" individual e complexo.
} 
viver, porém, em sintonia plena, com os aspectos do próprio contínuo, como útero do cosmo.

Se o modo de ser em processo cognitivo desponta para analogias entre o urbano corpo e o sujeito mundo em um amplo olhar em perspectiva, o movimento passa a ser expressão do ato de comunicação gerando relações como e para seu próprio existir. O próprio movimento égide do ritmo, se faz condição de sua expansão em informação rumo a natureza própria do rumo evolutivo, configurando a necessidade ( lógica ) da construção diagramática em uma geometria móvel do conhecimento.

Células urbanas no organismo do sujeito mundo. Odisseia contemporânea.

Caminhos do silêncio - Entre imagens.

Quantos silêncios podem haver, na difícil arte do viver, talvez a natureza nos revele, se pudermos olhar a voz com a profundidade do que é mais interno em cada ser. Um dia você partiu, deixou as folhas em branco, que pela perda ficaram cinzas. Mesmo assim, eu ainda the vejo, porque nas mesmas folhas eu escrevo e procuro o que o tempo me deixou como lembrança. Onde a esperança, nasce, faz-se o silêncio. Onde o mundo renasce, faz-se a voz, e onde a voz escreve as palavras do mundo, me perco porque se fez novamente cálido céu, onde somente encontro as plumas brancas, vestidas como o véu, cobrindo sua alma. Nunca partiste, por que me deixas-te o teu silêncio. ( Sousa, 2015)

Imagens como seres de Ovídeo em significação, repartidas em formas e unidas em ritmo, compasso que atravessa o tempo nele mesmo. E o que dizer então, frente as mídias, fractais ( Maldelbrot ) do modo de informar urbano ( e humano ) em adjacências ao construto do existir que não relega suas outras fontes de comunicar-se. Redes de diretrizes expansivas da criação do modo de ser do mundo, encontram matrizes ressoando os ecos das vibrações de todos os ritmos em compassos de todas as eras.

Que espaço em diagnostico me vejo e a qual pertenço ao adentrar sem ter partido, e possuir. A mente ávida do mundo exerce uma ressonância interna e externa em infinitas congruências, do enigma do viver.

O difícil - e o interessante- em desafio - a constante

Equação igualitária = posto que o simples é :

Por vezes um infinito complexo. 
Onde o nexo se reparte em incógnitas

Decifráveis em partículas variáveis do todo. ( Sousa, 2015)

As conexões dos sistemas integrados e expansivos, elaboram um continuo espaço em construção inacabada que consegue se estruturar em uma lógica de uma mobilidade, como um edifício e rede compartilhados. Poderemos talvez considerar que as conexões venham a ser bases que coabitem vetores e estruturas, como um ponto e linha, na geometria das ideias, inseridos em, “ forças geológicas”(Vernadsky, 1986). O som e a ressonância - estruturas e redes de significação e compreensão.

Quantas estruturas-mecanismos de sentido, significação se apresentam a nossos olhos e não são vistas, como o sangue dentro de nosso corpo que sabemos que nos faz viver, mas que submergem do tecido ( urbano ) pele, e ainda que presente em nossos gestos imbuídos de nosso pensar, são entre camadas, de uma amplitude de crescimento orgânica em sua natureza. O crescimento é ressonância e eco, ressonância como reverberação e multiplicidade de facetas, como Leonardo da Vinci, abrigando em seu design o entendimento da parcela - osso, para o cobrimento do todo - corpo.

O ritmo - deslocamento, fractais como seres de Ovídeo. Ecos de significação em estruturas dissipativas.

Desde os primeiros dias da biologia, filósofos e cientistas têm notado que as formas vivas, de muitas maneiras aparentemente misteriosas, combinam a estabilidade a estrutura com a fluidez da mudança. Como redemoinhos de água, elas dependem de um fluxo constante de matéria através delas, como chamas, transformam os materiais de que se nutrem para manter sua atividade e para crescer, mas, diferentemente dos redemoinhos ou das chamas, as estruturas vivas também se desenvolvem, reproduzem e evoluem. ( CAPRA, 1997, p. 147 )

No compasso da quietude ( adagio ) e do movimento ( andante ), a candeia nos acende o caminho traçado nos pensamentos de Prigogine, onde evocando Chiva, busca orientações de coreografar o tempo vigente. E refletindo nas ressonâncias, qual seria o elemento da equação que se revela fator de unidade em sua simplicidade, como um grão que pode ser um universo na imensidão do cosmo.

Uma pergunta não pode ficar sem resposta, ainda que seja uma interrogação.... 
Uma boa conversa, ainda que lúdica, pode interrogar a nós mesmos, e o diálogo com o mundo, pode ser uma perene e infinita, interrogação. O silencio tem o universo dentro dele. 390 Ensaios poéticos teatrais, tornam-se também corpo de um sentido ecoando sobre as coxias de um olhar do mundo.

5.3. Esferas em construção, Bethadh - a arvore da vida.

Planeta como semente do cosmo, que é possível ao se ver, crescimento interno, o que essa imagem nos diz? Como um planeta pode ser semente, ele não cresce, no cosmo, podem alguns responder. $\mathrm{O}$ que vemos, ou sentimos sobre o sentido do crescimento, desenvolvimento? Onde os significados podem estar como pensamento que encontra sentido na vida! Espaços em movimento, como o silêncio que nos fala, mas do que palavras, por vezes, estando na alma. $\mathrm{O}$ mundo cresce e se desenvolve enquanto raízes na sua história, e memória de sua existência, cresce sempre que acolhe de suas raízes o caminho dos valores humanos como seiva a estabelecer força por onde a humanidade se estabelecerá e erguerá como tronco, de lugares diversos como ramificações, culturas das mais diversas, onde crescerá e se desenvolverá com uma gama diversa de frutos, por onde o ar levará todavia mais uma vez a semente, germinando sobre a mesma terra, que é o território que unifica. Sobre anéis do tempo, criamos nosso espaço em movimento, imagens de nossas escolhas como indivíduos e sociedades que foram construindo a humanidade, que ainda precisa aprender a respirar e não ceifar suas raízes ou perecer como cárcere da liberdade, havendo todavia e porém, de sempre arcar com a responsabilidade de seus atos, onde o progresso, crescimento, deve ser visto como símbolo em significado da existência, sendo a busca de melhoria de vida para todos e não somente para uns.

Do livro: Ensaios Poéticos Teatrais.

Se a vida te cobre de ausência

Deixe ao menos a nudez da alma

Por onde atravessa o tempo

\footnotetext{
${ }^{390}$ De o 'Otelo, o mouro de Veneza', de Shakespeare. DESDÊMONA - "Eu fiz uma pergunta. Mereço uma resposta".OTELO - "Para que lhe servirá uma resposta, se não é para saber o que já sabe?"

DESDÊMONA - "Não me responda uma pergunta com outra".OTELO - "Melhor então é dizer nada".

DESDÊMONA - "Seu silêncio, então, será a melhor resposta".
} 
Dos dizeres que no cotidiano acalma

Feito paisagem da seca

Portas se abrem entre vagões sem trilhos

Sem destino por onde passar

Que não estejam sendo também lugar

A espera da gota recolhida no olhar

Que fincou na terra os pés da vida

Esperando o sangue como chuva

$\mathrm{Na}$ densa e árida paisagem

De onde apesar de oásis

Permanecerá do corpo

Ainda a mesma alma, nua

Se do desejo escritas a lua como sonhos

A ver o espaço na sociedade das ruas

Espere a calçada ou o outro lado por onde atravessar

Ainda que em cidade

A mesma busca árida por onde se ( encontrar ).

De quando em vez, o vento repousa

Tão tarde quanto manhã

Que ainda sonha mas por entre, tantas horas que caminha

Dos verdes sem matas

Açoite que do homem retratas

É a espera da natureza por viver

Onde retiraram a semente

A raiz e a própria terra

Mas, de quando em vez o vento repousa

E venta.

Sem saber como dizer, o sol deixa a terra amis quente que a chama,

Onde o fogo sagrado retoma a vida dos olhos que se abriram, acordam com o que ficou entre a noite. De quando em vez o suor passa a ser, a própria seiva do árduo trabalho que a fronte exala, ao gotejar como resistência, ao cadáver do animal que em distância pode ver. E dos ossos expostos, sabe que não poderá trazer a vida tamanha ferida do mundo, que da sede a carne fecundou a morte. 
Onde estamos, ou quando que não sejam ambos lugares nossos, entre cortados de retirar a pele sendo a própria terra, interior de nós.

Se avizinha o abutre! Como asas que ainda podem ser alguma sombra. Desavisado chega a ser, entre o tempo e o ser, exalando sabor sem pertencer. Olhos atentos, absortos pelo que se foi, e olhando à voltas, então me pergunto qual o desejo que está sobre os sobreviventes? Caça ou caçador, cidade e sobrevivente, natureza e homem, diálogos inocentes?

Abutre.

Ainda me olhas, me devora, antes mesmo do pico do sol. E nem mesmo caminha em voo apenas percorre meus gestos e se aproxima como a respirar pelos meus pulmões.

- Olha-me! Bem devagar esteve a se conter, em certo ponto a minha vida o detém, mesmo com a eminência de possível morte. Então, os segundos propensos da morte é tamanho que retarda o algoz e de como é o seu desatino, frente a boca sangrenta na falta da carne. Ainda é pouco. Ainda é pouco.

Lado a lado, como treliças de onde não se vê, o outro lado, estadias de um passado como volúpia de lugar ausente, que não mente e sente o quanto que o fel do sabor liberto está sobre o mesmo frio que se alimenta ou da morte ou da vida.

E, rompe-se, como a descobrir-se que não se fará distância para aquele que da alma sacia, o porvir. Inquieto, seja o sutil lugar que desafia estar o gosto do gozo da enxada como único ato, entre o viver e o morrer. Espaços de atravessar a rua, morada das avenidas, recolhendo os dizeres não ditos, como o olhar do abutre.

A enxada é a labuta do percurso, das intermináveis horas do trabalho, quer seja ele tecido ou tecendo a vista social, ou o prazo dependendo da imagem onde possa haver alguma paisagem que se possa olhar, algum lugar.

Lugar do poder

De ficar ou morrer

De quando em quando

O banco vazio a espera

Do tempo, seguiu-se nele mesmo, ontem.

Lugar do poder

Sobre domínios do sobreviver

Fazer insano de homens profanos

Ou direito sagrado usurpado por desumanos

Onde estaremos, abutre e eu? 
Lugar do viver

Entre lados opostos

Ou , mesmo lado

Quem sabe sobrepostos

Sobre coito doentio

A espera de que no cio

Ainda se possa dizer

Nasci do vazio.

E, pertencer, então nesse pérfido prazer

De naturezas compartilhadas

Entre viver e morrer

Apenas palavras e um dizer

Ou nem isso...... murmura o abutre. É o morrer....

Ou a vida do silêncio, que insiste em viver

E quem testemunhará, é o próprio cadáver, a distância o suficiente para se dizer, presente!

Será tempo suficiente, este que como despojo é adubo da vontade da terra que de alguma forma, deseja nascer. Entre a morte e a vida, haverá ainda outro testemunho?

Quem sabe do próprio punho que tanto cavou, ao como não fosse arar, mas de profundo encontrou o ar, que jorrava por algum lugar, água. Será desatino, delírio, ou a mão de Deus.!

Talvez quem sabe ouça o ventre do mundo, o mesmo que passou ao longe ou perto demais suficiente para destilar, em fenda o sulco de um destino. Ao trazer a água sobre a carne, desconfiado o abutre lança passos como a retirar a sede antes que a alma beba, a gota última que o seio da terra alimenta.

Então, terá selado, o futuro acorrentado ao passado, das asas a fraqueza em desejo tomba.

Pode o abutre ser sua própria carniça?

- Aproxima... devagar....

- Olho longamente para ele.

Sobre seus olhos gotejam lágrimas minhas! De meu peito e ainda não da terra, a vida torna-se realidade. Qual será então o destino, que sobreviveu a própria morte?

Murmúrios, murmúrios, murmúrios. 
Ainda ouço as asas, chão de terra batida arde, como a marcar fendas por onde passei.

Algo parece brotar, esgueira-se sobre o lugar uma passagem e no entre quem sabe, recolhe-se alimento.

Não, se retirar assim é prematuro, e sucumbirei mais uma vez, ao depois...

Então, estarei eu aqui olhando o nascimento, o que brotou crescer, ate que a possa devorar.

Mas, quão, estarei vivo(a) entre esse desejar que possa haver lugar assim, sem esmo lembrança, apenas talvez delírios, ou desatinos de quem ainda possa sobreviver.

Como o tempo parece infinito, quando se espera a vida, para poder não morrer...

- Estarei eu, até quando vivo também?....

Espero da semente, a árvore, poderei mais frutos comer? Ou será apenas sombra para eu morrer? E descansar, descansar...

O que é esse esperar que escolhe entre o meu viver, e o teu morrer, ou o até quando seja o tempo suficiente para que sobrevivamos. Gestação. Gestão de meus esforços. Entre nossos corpos. Individuo e sociedade. Desde quando a enxada está sobre o caminho?

Ou o caminho de viver, fez da terra para eu não morrer o trabalho de permanecer.

Permanecer...

Permanecer....

Permanecer....

Ah, Esse ser tão insistente!

Pensa ser gente!

Gente!

Gente!

Gente!

Ah quando sente, o pulso.

Pulso!

Pulso!

Pulso!

Bate a porta, quer entrar e então pergunta:

A vida ou a morte há de passar? 
Passar?

Passar?

Passar....

Por onde, se retiram a minha família, a minha moradia, e a minha vida.

Por onde, se retiram o meu trabalho, o meu desejo e o meu amor.

Por onde, se retiram o meu sonho, o meu suor, o meu destino.

Por onde se retiraram! ?Vírgula, coma de novo ${ }^{1} \mathrm{O}$ que comerei desgraçados, se não a própria face da alma, escrevendo e lendo o mesmo mundo!!!

Que foi ou será, redemoinho em crueldade, desumanidade, e onde foi parar a felicidade?

- O que é isso? Isso ! Isso ! Isso !

Não mais que isso, derramou, o pranto foi feliz ( cidade), onde o cinza do concreto, lápide do voo certo gemeu, mais uma vez.

Ouça.

Ouça

Ouça.

Dos porquês e razões perdidas, sofridos entre as feridas da mesma pele, tecendo...

Tecendo...

Tecendo....

As plumas do vento

Lamento, lamento, lamento....

Onde a composição soa, palavra por palavra, dizendo sentido permitindo viver.

Sentido

Sentido

Autoritária morte, do destino certo, que nasceu. Por fim, concreto novamente não abstrato, sentimento.

Espera-me.

Nada mais certo, espera-me a morte por onde passei como vida, vivendo, nascendo, nascente, gente, semente, água.

Escorre, sobre o sol, seca e morre

Morre... 
Morre...

Onde antes a alma bebia a sede por onde se refazia, sentia a vida.

Permanece, ou se foi, também...

Árvore da vida que me sacia. ( SOUSA, 2018)

Então como deve estar a terra, para que possa receber semente, ou deverei saber que também em todo momento tem-se a oportunidade de uma forma de conhecimento onde do próprio preparo se ensina e abre caminho.

5.4. Do poema da vida, inacabado e a dizer.

Em certo ponto, antes mesmo de um sentido, ou o próprio será o poema um sentimento, então eu te pergunto ainda que sabendo que da vida, o conhecimento como aprendizado, é eterno; estaremos compreendendo o sentimento de um viver, para conhecer o sentido? Hoje, amanhã ou do ontem, a imagem perpétua do instante se propaga, de onde posso ver ou ouvir um sentido que escreve o mundo segundo o qual pude perceber, mas dele é infinito o quanto outro nele esteja também significado, tanto que assim, mesmo o meu olhar se encontra no infinito, parte entre o que conheceu, impreciso e inacabado, poema do eterno. Isto, para não o fluxo do tempo segundo um passo após o outro, mas o passo como paisagem dele enquanto viver que não é meu, mas é do existir. E, como escrevi no início desta tese: a capacidade do homem de conhecer o seu caminho depende do quanto que dele não o conhece. A cada dia, o mesmo deve te parecer outro, assim sendo estarás, atento, e um passo após o outro, indagarás a consciência, para olhar sobre o conhecido com os olhos do desconhecido.

Assim sendo, a imagem que tens, não te pertence. A compreende, tendo-a em liberdade, dela segue o que vês, lês, diariamente escrevendo o mundo de maneira a estar nele sobre a responsabilidade de existir sobre o propósito no qual acredita e nessa razão estabelece o sentido. E no que acreditamos?

Entre o ponto e o contínuo, posso conhecer o sentimento e o sentido? Ou será todavia que estarei entre a geometria da vida, percorrendo com ela, para descobrir sua forma, modelagem do caminho. 
Para mim, verdadeiramente a vida é um poema, e um dia, me disseram, que não havia muito interesse. E logo eu, que de tudo que me apresenta o mundo, eu o sinto, como poema, por vezes recitando imagem, som, gesto, olhar, palavra, lugar, tudo. Então, onde haveria eu de escrever o mundo, se do jeito que eu via, ele não poderia ter espaço, porque o preço era baixo demais, o que seria então? Eu respeito que cada um sente e vê o mundo a sua maneira, mas também, eu tenho o direito de ver o mundo com a minha alma, e a poesia, quase como o desenho, nasceu comigo, como esse jeito de ver a vida, através do sentimento, retratado em traços como formas repassando lugares que habito por dizer. Então, descobri logo que não tinha muito lugar para existir,... diz a poesia. E então, ainda escrevo, e até mesmo o que não é poema, é poesia, e como pode ser isso? Algo como uma magia que fica entre algumas palavras, sabe, como a dizer... essa frase.... essa frase... parece um poema, é quando ela parece que brilha, cintila sobre o que pode haver de simplesmente natural, mas justo e propriamente é natureza tão antiga, talvez por isso esquecida, mas eu a vejo por todos os lados, então, o palco do mundo, também é seu lugar, entre gesto, manifesto, tudo que pra mim, se torna VERSO. É nesse lugar que de inacabado, encontro a vida, e é quando ela se torna sentido mesmo que solitário, ou ausente, esteja não somente como palavra, ou forma, mas gente, e além... de fato o que se sente. Chega a ser quase que, inconsequentemente parte da volúpia, como um prazer, mas que recebe a alquimia de revelar, por suas partes o que nasce de sagrado, podendo estar em tudo que representa, personagem sendo o próprio existir, face da alma em que tudo encontra uma chama que não se apaga, dentre o inacabado como mesmo um chamado, estando sobre cada elemento, dos que conhecemos e até mesmo, dos que não vemos, estando sobre mistérios, segredos, do que de tudo em parte se revela. E então retornando ao princípio, haverá lugar para o sentimento na vida, na qual travamos nossas lutas em sobrevivência, entre moradas difíceis de dilemas sociais, atrocidades e desigualdades... mas, então também não é este o lugar da expressão, da opinião, também podendo ser do sentimento o significado de um poema, o cotidiano, o mais humano, ou desumano, lugar de nós. Será justamente a razão de estar mais distante um sentimento que amortecidos estamos a consciência do que vivemos, dos fatos, das consequências, das correspondências entre o que somos, queremos e desejamos ser, também entre nós e o mundo? Em 1985, eu escrevia o pranto do poeta, aos doze anos de idade.

O poeta sofre

E está exausto de tanto sofrer;

Sofre... na sombra da sua face

No campo amargurado

$\mathrm{Na}$ chama do fogo apagado 
Nas lágrimas que o entorpecem,

No sonho que o adormece.

Sofre... pelas angústias mais tristes,

Pelo frio amor que o oprime,

Pelas pegadas que se tornam fúteis,

Pela madrugada que não vive

Mais que uma noite.

Sofre... no clarim matinal das manhãs,

No obscuro que vem e não parte,

$\mathrm{Na}$ origem que o passado encobriu,

No vento que permite seu temor,

Nas fúrias das multidões que os perseguem,

$\mathrm{Na}$ face que não o entende,

No caminho que quer prosseguir.

Sofre.... pelo mundo medíocre que o cerca

Pelos desamparados da luta,

Pela fé e justiça cruas,

Pelos pequenos na voz dos perdidos

Pela funesta cobiça humana,

Pela própria plenitude

Sofre... nos vadios ventos que se vão

Nos mares de chagas que se infestam

Nas condutas que não mais se assimilam

$\mathrm{Na}$ desgraça que procura

$\mathrm{Na}$ raça de todas as eras

No poder que o mata pelas ruas

Nas raízes que o prendem a esse rastro.

Sofre.... entre o medo dos inocentes

Pela linguagem agora sufocada

Pelas pedras vivas que o apunhalam

Pelo segredo que escalda sua certeza

Pela solidão entre quatro paredes

Pelo lugar que lhe impõe e lhe tomam

Sofre... por tudo que é efêmero

Pela fonte que já não mais o satisfaz

Pela profundeza que o recria a cada instante

Pelo fim que não terá uma história

Pelo princípio que o torna imenso

Pelo fato que o faz contínuo

Sofre... pela vulgaridade que vem do desprezo

Pelo voo ininterrupto das almas

Pelas rajadas de dentro de tudo

Pela bruma que entre sonhos adormece

Pelo aroma da nova aurora de paz

Sofre.... pelas almas que vagam

Por si mesmo e pelo seu destino. ( SOUSA, 1985)

Não como umbigo atado, mas vendo o mundo como um espaço dentro dele mesmo onde todos somos, parte dele, um território do viver. Espaço contemporâneo onde a escrita tem a propriedade de ser uma imagem que nos atravessa e atravessa o tempo, o sentido pode ser compartilhado como espaços por onde nos encontramos. 
E em 2016, em Folhas de Outono, o poema inacabado:

Ainda que sejam tuas as palavras infinitas

Vou continuar escrevendo, o poema, inacabado

Mesmo que me perca nesse olhar apaixonado

Onde pode o triste inverno, me dizer as dores

Onde pode as estrelas na luz de seus amores

Ainda que sejam teus o som do firmamento

Sentir o âmbar do teu pensamento

Na primavera a se colorir de flores

Ainda que seja teu este universo

Poderão ser estas as letras escondidas

Nas folhas da natureza repartidas

Suspiros do ( de um ) tempo em si disperso

Regresso que ainda se faz conhecer

Do poema da vida, inacabado e a dizer. ( SOUSA, 2016).

Do livro Diário da Manhã: De quantas forem os mesmos ardis de outrora, encarcerando a aurora, de onde se refaz o vento como própria liberdade. De tantas terras por onde passaram navegantes ou sejamos nós os mesmos viajantes tornando-nos ainda territórios por conquistar. Saibamos o quanto a natureza não esteja sobre os nossos bravos braços a recolher o insalubre destino de não lhe querer o quanto seja nosso abrigo e mesmo ser. Estando sobre os jornais do dia os mesmos que sem grafia os olhos liam. E diante da face não escondem a carne. E das fibras todavia, desejam ( a ) alma. E se assim ou somente seja esses os passos sobre o céu que de cinzas ou amanhecer estejam no mesmo lugar as tuas formas por dizer da liberdade ainda por conhecer.

Arrancar do sentido, a voz que o proclama. É amordaçar o próprio Verbo contido como gesto humano. Entre o existir o que proclamo do mesmo verso que não mais insano é a sempre busca da razão onde quer que ainda pulse um coração. Encandecendo a noite escura sobre nem mesmo o luar que as nuvens escondem, o fogo da terra como tambor do ventre, recolhe a atmosfera dos seus filhos por onde forem. E se da luta teus olhos da alma cravados estejam sobre tua alma, teu suor será e estará nas fibras da vida por onde o pulso não 
cessará, de ancorar os ideais da nação. Nação, terra do mundo, de seres que somos, humanos que ainda seremos, o quanto o amor possa verdadeiramente nos encontrar, Ungidos como pátria e lar do universo. Descabido quão possa te parecer esteja sempre como prumo o teu renascer, continua arguição de teu viver e ser, como origem infinita do amanhã.

Arguto se reparte o desejo na estação, quão lugar que se caminha enquanto se procura, a própria alma, ( que ) no corpo exausto se destina. E quão seja a sina, que das forças se ergue o que existe para que o destino não seja cruel, e não será, o quanto tua verdade nele, se fará, ante a espada que do véu corta, a realidade e a ilusão onde da morte finda, o coração.

Recebe do porvir a esperança onde esteja o quanto lamentos gorjeiam sobre os ruídos incandescentes de ardentes mordaças, que sufocam mais que as areais sobre pés, a não caminhar, que as águas possam banhar o gesto, que nesse silêncio esteve, sobre o testemunho do universo, a espera da lembrança, ser do teu verso, o teu viver, o reverso que da vida possa ser, a lágrima do mesmo oceano por dizer. E não deixes longe de teus braços o teu próprio trabalho que te faz viver.

Mesmo que saudades do tempo estejam na alma os dizeres da aurora, são de ti o mesmo suplício quando o porvir de teus sonhos demora. E que não tarda teus braços sobre minha alma, de onde meu corpo lhe sacia a vida, enquanto prazer tenhamos dos olhares que trocamos em infinitas carícias sem dizer.

Há tanto tempo, e que por vezes esse silêncio bastou.

E de quão for o sulco do teu desejo por entre o meu, estejamos nus perante a verdade, de sermos quem a veste da realidade nos faz, procura tua, em mesmo cálice de tua sede nua. $\mathrm{E}$ não há o que perdoar, mas sim amar, nesse deserto de compreensão, onde nem oásis haverá para se ver, ou passar enquanto apenas não seja sobre a vida, o fim. Acabou?

Qualquer açoite sobre que forma esteja no existir, repele a liberdade, essa que é do direito concebido dentre o ato da criação, onde Senhor, procuro a razão, e me faças teu, enquanto busca na minha consciência. Que eu não me perca, e dos teus sentidos, eu possa ver, ouvir, e tocar a tua pele do mundo onde eu enfim, possa viver e pertencer.

Saberá a vida o nosso querer, do mundo, um elixir, que se atravessa montanhas e novamente oceanos, mesmo que seja nos teus olhos, para que em teu corpo eu me derrame.

Escute o canto do silêncio, brada as vestes da manhã, sobre nossos sonhos que a contento, estou a desejar de ti, sobre o firmamento enquanto vivo, continuamente pelo ar que tú 
destilas no sabor de tuas vidas, território eterno que habitas sem dizer, sem pertencer, sendo o lugar, único destino desse teu amar.

Diga o quanto de teu porvir esteja no hoje, enquanto não mais que o segundo paire, o eterno, gesto que respira, a liberdade.

Voa.

Do que querem, desaguo antes e todavia em teus pesares, quando não bastem teus lugares para por onde eu atravessar, para ir-me a teu encontro.

- Do desejo do Adeus, fica a lembrança a desalinhar os fios tecendo como pavios, entre nós, a chama.

- A quanto os ponteiros não se mexem? A gaveta está prenhe, das linhas tuas, canetas sem escrivaninha servindo o cotidiano, mesmo como seja dos teus olhos sobre os meus, o não dizer que atravessa a morte, dizendo-me em contra-tempo, ao que sejas, teu que em mim também mora. Palavras de quantos forem, os diálogos incalculáveis dos relatos esquecidos que na imagem a eternizam o destino de terem acontecido.

- Caminha,

- Tú, caminhas dentre os passos do ventre teu, nascendo como multidão do silêncio de quem de si, é também, o que ouve, as vozes a confessar. Sendo o quanto das horas, passam como cumplices das memórias ateus do temp(1)o, para o qual tua palavra escreve.

- Ah! E teu suplício ou martírio não se desvanece por quanto horrorizado esteja a própria chuva a derramar-se sobre o solo, diante da terra como cinzas.

- Guarda, não o quanto deixe de ser meu, o teu destino que possa nos abraçar. E rente aos pés, as folhas gotejam, espécie de dizer. Lugar do ontem adoece enquanto outro de si mesmo aguarda convalescente cotidiano. E me olha longamente, como se a espera do mundo, não pudesse beijar, o profundo que de ti é superfície ao refletir como desejo de buscar-te, no mesmo mar.

Não me deixes portanto, tão insolentemente que eu perca quem tú és, e de minhas linhas o sentido não seja teu.

Encontramos por certo, tão alva como a manha, a alma que caminha. 
Ambiente vazio, pausada pena sobre a mesa, ou o caixa, procura o preço do existir, ainda e quanto se faça autoria do querer, onde o mesmo gesto esteja como o pensar, sendo o mesmo teu gesto de amar.

- Que o cotidiano, não me entregue solidão, quando passados tantos anos, por fim te reconheço!!!!

Olho agora após tanto e tanto, na tua alma, Abro a gaveta e está vazia, plena e repleta de ti,

De lá, tua palavra, nunca se retirou de meu pensar e muito menos de meu coração.

- Onde estão os meus escritos?

Amargo como teu gesto, o fel.

- Esqueces-te

- Tristeza

- Esqueceu

-Ame antes que padeça, ou amorteça os membros do sentimento, o mesmo lamento para te encontrar.

O mesmo destino enquanto tormento. Será de ti, a face do movimento, do quanto, todavia, há de amar.

Devolva-me.

De onde linhas, compulsivamente melancolia se derrama. De tantas confusos olhares a despedida. $\mathrm{O}$ quanto as almas sofrendo enxugam a ferida, sobre o sol que passa a ouvir. $\mathrm{O}$ grito da alvorada, de onde ... partir?

Esteja como o gesto de viver. Onde possa por fim haver, o consolo que na vida possa ser, mesmo que em triste agonia; mesmo que sobre os lábios seguia, o beijo recolhido do ardor que no silêncio se banha de toda a dor, ainda que e mesmo, saiba do prazer por onde for, de bradar o quanto seja a liberdade, a ( tua ) alma, e o ( meu) amor. Árvore da VIDA. 


\section{Conclusão}

Este trabalho se dispôs a uma pesquisa de cognição contemporânea entre os caminhos do modo de ser da música como presença da própria vida em ser de ressonância em sentido e presença sobre o ritmo do movimento da atualidade onde as questões humanas e sociais se apresentam sobre o que pautamos ser as dificuldades que nos distanciam ou nos aproximam do que somos e queremos ser, entre sonhos e realidades, ações e condutas onde o pensamento é matriz de um diálogo multidirecional realizando esforços de compreensão onde as relações partem do próprio indivíduo para a sociedade como um todo. Assumindo posturas de responsabilidade os caracteres da vontade humana se estabelece dentre uma bifurcação na busca ainda de uma possibilidade de encontro dos desejos e aspirações do indivíduo e a sociedade, assim como, sobre as condições da qual a realidade impõe sobre certo viés, escolhas sem alternativas, e ainda a reflexão sobre que mudanças haveremos de realizar para que as escolhas tenham ao menos a possibilidade de estarem sobre uma igualdade e liberdade para também possam assumir de maneira digna a cidadania como papel de sua dramaturgia exercendo a luta pelos seus direitos e deveres como seu maior papel. Tendo presume-se a característica de saber que, do que se almeja alcançar deve, portanto, realizar o caminho, havendo de ter no mesmo os elementos que estarão no destino. O sujeito ambiente percorre a busca de sua parcela da consciência como razão interna em presença no mundo, travando ininterruptas arguições de estados internos e externos na procura de soluções de propensos dilemas onde mesmo que se não houver consenso, que o respeito seja o prumo da busca, onde promova ao menos o equilíbrio entre forças. Considerando principalmente que a alquimia da vida se apresenta e mostra firmemente que é capaz de transformações, os valores humanos ainda que em diversidade de culturas, podem se aproximar cada vez mais sobre o que a música revela, como aprendizado, podendo soar como a mesma voz, o mesmo som. E considerando estes aspectos, podemos apresentar a vida como produto de nosso tempo, sendo uma postura assumida de identidade de pesquisa como objeto, explica-se que, isto em razão de por alguns ser depreciativo colocar a vida ou, e, o sujeito como produto, porém, e principalmente por essa razão tivemos a ressalva das considerações anteriores a essa colocação, e para esta pesquisa o que desejamos é considerar a lógica do consumo, creditando estar presente e permeada pelas condutas atuais em toda a sociedade, para tal em parte se fez pano de fundo também juntamente com a música do que poderemos investigar quanto a efetiva construção de uma vida melhor. Nos encontramos dentre o que em paralelo de sentido se mostra como pauta havendo de ser as como notas, os 
fatos, elementos do cotidiano na busca de uma harmonia, e ainda como podemos compreender, o que nos mostra o compasso sendo um caminhar, um com( passo) de cada vez, em sua diversidade, como modos de olhar, perspectiva também, e entre as divisões do compasso e as linhas, por onde vamos seguir, o esquadro, representado, e nessa simbologia questionamos o entendimento do que é pseudo efêmero, como um compasso, que segue, mas tem a capacidade de perpetuar-se em relações sonoras, em sentido, onde a obra como um todo ganha por fim, sua liberdade de movimento onde podemos conhecer o sentimento como razão abrigada em consciência trazendo o que reverbera mesmo que no "fim", determinado, reverberando na alma, espírito de nosso tempo, ressoando. Se possível fosse determinar para esse sentido, em poesia, uma palavra de imagem, esta seria, o IN(FINITO), espaços compartilhados, e até mesmo como ilustração desse significado, o movimento.

Partindo também que nosso tempo, se representa e constitui uma imagem, se faz uma arguição de como a mesma se constitui e para além, da sinestesia capaz de estar engendrada partícipe da multiplicidade em tempos globais, como modo diverso externo e interno como rede de conexões, estabelecidas com o propósito de c complexidade, mais expansão de sentido, compreensão, sendo instrumento em sinestesia de compartilhamento, de um caminho de conhecimento, em parte a imagem tonar-se metáfora como argumento lícito de caráter de uma civilização onde o deslocamento pressupõe eticidade, em lógica permeada por conexões em progresso, viabilizando maior entendimento, trazendo a imagem em sinestesia, como discurso refletindo o contemporâneo gesto de respeito a integridade humana com suas mais diferentes faces culturais, onde a sustentabilidade desse âmbito ocorre justamente na gestão do educar o pensamento, matriz em diagrama que reverbera atos plenos da esperança do que queremos para o amanhã, proporcionando a estética como beleza da vida enquanto produto de nosso existir.

Em especial como conclusão deste trabalho e pesquisa, como compreensão de que o conhecimento não se encerra, mas que deve inclusive ser continuo, a busca que teve início aqui, em desmembramento após o mestrado, se propõe a principalmente ter continuidade tanto como estudo como práticas de vida e no presente momento, se assegura na consciência de agradecimento pela oportunidade de aprendizado, pesquisa, e compreensão do que pode nascer do encontro na busca de um conhecimento como a própria inquietação do que é ou pode ser, um viver. De que maneira podemos estar cientes de nosso papel na sociedade, na universidade, nos caminhos traçados entre dificuldades e coragem, sobrepondo como marca de um tempo, este que aqui deixa uma pegada, sendo ainda areias onde quem sabe antes que 
as águas do oceano venham, esteja infinitamente o vento a escrever, o que, quem sabe o sentimento poderá ler, permanecendo comunicação translúcida: ressonâncias estéticas do contemporâneo.

Tem coisas que um homem pode não acreditar, mas o destino pode fazer com que ele acredite. ${ }^{391}$ 


\section{REFERÊNCIAS BIBLIOGRÁFICAS}

AUMONT, J. O olho interminável. Cinema e pintura. Trad. Eloisa Araujo Ribeiro, São Paulo: Cosac Naify, 2011.

ABAD, Gisela;BRAIDA, Frederico; Ponte, Raquel. Os sistemas híbridos do design: despertando os sentidos. V CIPED - 2009

ANHOLT, Simon. Branding places and nations In Brands and Branding, The Economist, 2004.

ADEODATO, Sérgio. Revolução silenciosa. In Revista Página 22, pg 43-47.

AQUINO, Victor, Facchinetti. Questões em Comunicação. Ética e Estética. São Paulo: Angellara, 2013.

ARISTÓTELES. Ética a Nicômaco. São Paulo: Martin Claret, 2004.

A política. São Paulo: Escala.

ALMEIDA, Fernando. Os desafios da sustentabilidade. Uma ruptura urgente. Rio de Janeiro: Elsevier, 2007.

ANDRADE, Mário de. O banquete. AQUINO, Eulinir de Fátima Silva Tomaz de. As faces do abandono. São Paulo: Editora Panorama, 2001.

ARANHA, Carmem S. G. Exercícios do olhar. Conhecimento e visualidade. Rio de Janeiro: FUNARTE, 2008.

AGOSTINHO, Santo. A cidade de Deus. Lisboa: Fundação Calouste Gulbenkian, 2008.

ALVES, Castro Alves. Obra completa. Rio de Janeiro: Editora Nova Aguilar, 1986.

ALVES, Rubem. A escola com que sempre sonhei sem imaginar que pudesse existir. Campinas: Papirus, 2001.

AMARAL, Aracy a . Amaral. Arte para quêe? A preocupação social na arte brasileira 1930-1970. Subsídio para uma história social da arte no Brasil. São Paulo: Studio Nobel, 2003.

BALZI, Juan José. O impressionismo. São Paulo: Editora Ática, 1992.

BARRETO Iná Futino; Crescitelli Edson. Resultados de marketing de relacionamento proposição de modelo por meio de mapeamento cognitivo. In Revista brasileira de gestão de negócios, São Paulo, v 17, n 58, p 1371-1389, out/dez 2015.

BRANT Leonardo. Um novo modelo de política para a cultura. Disponível no site: artecidadania.org.br. Acesso em 21 de setembro de 2005.

BAUMAN, Zygmunt; MAURO, Ezio. Babel entre a incerteza e a esperança. Rio de Janeiro: Zahar, 2016.

Janeiro: Zahar, 2013

A cultura no mundo líquido moderno. Rio de 
de janeiro: Zahar, 2011.

A ética possível num mundo de consumidores? Rio

BAYER, Raymond. História da estética. Lisboa: Estampa, 1978.

BERCHIOR, Camilo. Reciclando os sentidos. Edição do autor, 2014.

BRASSAI, Gilberte. Brassai, conversas com Picasso. São Paulo: Cosac Naify, 2000.

BRANT, Leonardo. Diversidade Cultural. Globalização e culturas locais: dimensões, efeitos e perspectivas. São Paulo: Instituto Pensarte, 2005.

BRITO, Lydia Maria Pinto. Gestão do conhecimento - instrumento apropriação pelo capital dos saber do trabalhador. In Cadernos de Educação Pelotas, pg 135-148, janeiro/ junho 2008.

BORNSTEIN, David. Como mudar o mundo. Empreendedores sociais e o poder das novas ideias. Rio de Janeiro: Record, 2005.

BOSI, Alfredo. Reflexões sobre a arte. São Paulo: Ática, 2001.

CAETANO Kati Eliana. Percursos das imagens e modalidades do sensível Revista Galáxia, n. 15 , p. 61-76, jun. 2008.

CRESCITELLI, Edson. Marketing promocional para mercados competitivos, planejamento implementação, controle. Ed. Atlas, 1996.

CRESCITELli, Edson; GALÃO, Fabiano Palhares. Planejamento e implantação da comunicação de marketing: uma análise comparativa entre teoria e prática. In REGE, São Paulo-SP. Brasil, v. 22, n 3, p. 435-452, jul/set 2015.

CRESCITELLI, Edson. Email Marketing: um estudo exploratório sobre o caso de uma consultoria empresarial. In Revista Gesta, v 4, n 3, ju-set, 2008, p 56-84.

CRESCITELLI, Edson. A importância do público interno na comunicação de marketing. In Facom n 15, p. 14-19.

Ikeda, Ana Akemi. Marketing de relacionamento. Entre fabricantes e vendedores do varejo. In Revista Administração em diálogo v 8, n1, 2006.

COSTA, Antonio Roque, Tallarico, Edson Gomes. Marketing promocional: descobrindo os segredos do mercado. São Paulo: Atlas, 1996.

CALÔ Adriana, GRAZIELA Brum. Senhoras obscenas. Antologia Poética. São Paulo: Benfazeja, 2016.

CANCLINI, Néstor García. Antropologia e estética da Iminência. São Paulo: Editora da Universidade de São Paulo, 2016.

Universidade de São Paulo, 2016.

O mundo inteiro como lugar estranho. São Paulo: Editora da

CAPRA, Fritjof. A teia da vida. São Paulo: Cultrix, 2006.

CARVALHO, Maria do Carmo Brant. Qualidade na educação. Disponível em http://www.cenpec.org.br/artigo_00.php acesso em 16-05-2005. 
CARVALHÃES, Maria Helena. Arte-cidadania: um novo lugar para a política pública de cultura. Disponível em endereço eletrônico no site artecidadania.org.br. Acesso em 21 de setembro de 2005.

CASCUDO, Luis da Câmara Cascudo. Civilização e Cultura. São Paulo: Global, 2004.

CARRASCOZA, João Anzanello. Do caos à criação publicitária. Processo criativo plágio e ready-made na publicidade. São Paulo: Saraiva, 2008.

CAUQUELIN Anne. Teorias da arte. São Paulo: Martins Fontes, 2005.

CASTELLS Manuel. A era da informação: Economia, sociedade e cultura. Vol. I. São Paulo: Paz e Terra, 1999.

CHARAUDEAU, Patrick. Discurso das mídias. São Paulo: Contexto, 2013.

CONTARINI Eugênia. Seminário Cultura e intolerância. Disponível em site do SESC Vila Mariana, evento realizado no período de novembro de 2003.

CONNOR Steven. Cultura pós-moderna. Introdução às teorias do contemporâneo. São Paulo: Loyola, 1989.

CÓRDOVA, Marly. Arte e educação. Disponível no site: artecidadania.org.br. Acesso em 21 de Setembro de 2005.

COSTA, Antonio Carlos Gomes da. A arte na constituição do humano. Disponível no site artecidadania.org.br. Acesso em 21 de setembro de 2005.

COVALESKI, Rogério. Intersecções artístico-comunicativas: o rompimento de fronteiras entre artes e comunicação. Trabalho apresentado em GP Publicidade - Epistemologia e Linguagem do XI Encontro dos Grupos de Pesquisa em Comunicação, evento componente do XXXIV Congresso Brasileiro de Ciências da Comunicação. 2011.

CURY Pedro João. Diálogos Pedagógicos Possíveis e Ambientais. Disponível no endereço eletrônico: http://www.futurasgeracoes.com.br/htm/arteeducacao3.htm Acesso em 27 de abril.

DAllan, Dalmo de Abreu. Cotidiano e Tolerância. Seminário Cultura e Tolerância. Evento realizado no SESC Vila Mariana em novembro de 2003.

DALI, Salvador. Diário de um gênio. Rio de Janeiro: Paz e Terra, 1989.

DIMENSTEIN Gilberto. Estamos nos iludindo infelizmente. Disponível em endereço eletrônico http://www1.folha.uol.com.br/folha/dimenstein/colunas/gd171103.htm Acesso em 20 de abril de 2005.

DRUCKER, F. Peter. A comunidade do futuro. São Paulo: Futura, 1998.

EISEISTEIN, S.. O sentido do filme. Trad.Teresa Ottoni, Rio de Janeiro: Zahar, 1990.

A forma do filme. Trad. Teresa Ottoni, Rio de Janeiro: Zahar, Ed,

2002.

Reflexões de um cineasta. Trad. Gustavo A. Doria, Rio de Janeiro:

Zahar, 1958. 
FEITOSA, Deisy Fernanda; BAIRON, Sérgio. O preço do olhar em tempos de convergência. Comunicon 2012.

FERRARA, Lucrecia . Design em espaços. São Paulo: Edições Rosari, 2002.

FLUSSER, Vilem. Hacia uma filosofia de la fotografia. México. D. F. Editorial Trillas, 1990.

GONZALEZ, Roberto Sousa. Governança Corporativa: o poder de transformação das empresas. São Paulo: Trevisan, 2012.

FIOSI, Carina. Arte no Centro, também para a comunidade do Centro. Disponível no site: artecidadania.org.br. Acesso em 16 de Setembro de 2005.

Ana Mae Barbosa avalia a Arte-educação de hoje no Brasil. Disponível no site artecidadania.org.br. Acesso em 21 de setembro de 2005.

Projeto Carmim: arte para transformação humana. Disponível no site artecidadania.org.br. Acesso em 21 de setembro de 2005.

GALEANO, Eduardo. As veias abertas da América Latina. Rio de Janeiro: Paz e Terra, 1983.

GARAUDY, Roger. Dançar a vida. Rio de Janeiro: Nova Fronteira, 1980.

GLEISER, Marcelo. A dança do Universo. São Paulo: Companhia das Letras, 2006.

GHIZZI, Eluiza Bortolotto. O processo perceptivo e os significados urbanos em tempo de globalização. In Revista Galaxia n 3. Pg 235-239, 2002.

GRENBERG Clement. Estética Domestica. Observações sobre arte e gosto. São Paulo: Cosac \& Naify, 2002.

GUINSBURG J; BARBOSA Ana Mae, org. O pós-modernismo.São Paulo: Perspectiva, 2005.

GALLICCHIO, Gisele. Simulacro e inclusão social. Disponível em Educação on line www.edicacaoonlinepro.br acesso em 12-05-2005.

HABERMAS, Jurgen. A Ética da Discussão e a Questão da Verdade. São Paulo: Martins Fontes, 2004.

HALL, Stuart. A identidade cultural na pós-modernidade. Rio de Janeiro: DP\&A, 2006.

HARR, Michel. A obra de arte. Ensaio sobre a ontologia das obras. Rio de Janeiro: DIFEL, 2007.

HARVEY, David. Condição pós-moderna. São Paulo: Loyola, 1989.

HEISENBERG, W.. Física e Filosofia.Tradução: Jorge Leal Ferreira, Instituto de Fisica de São Paulo: Editora Universidade de Brasilia, 1981.

A parte e o todo. Encontro e conversas sobre física, filosofia, religião e política. Tradução: Vera Ribeiro. Rio de Janeiro: Contra Ponto, 1996.

HENDERSON, Hazel. Além da Globalização. São Paulo: Cultrix, 2003. 
JARES, Xesus R. A educação para a paz como estratégia de aproximação das gerações. Congresso Internacional Co-Educação de Gerações, em Outubro de 2003.

JORGE, Ana Guimarães Jorge. Topologia da ação mental. São Paulo: AnnaBlume, 2006.

conhecimento. São Paulo: Paulus, 2011.

Introdução à percepção. Entre os sentidos $\boldsymbol{e} o$

JUNIOR, Hédio da Silva. Cotidiano e Tolerância. Seminário Cultura e intolerância. Evento realizado no Sesc Vila Mariana na cidade de São Paulo, em novembro de 2003.

IRWINE, William. Sobre el deseo. Nueva York: Oxford University Press, 2005.

KREMER, Nair. Deslocamentos. Experiências de Arte-Educação na Periferia de São Paulo. São Paulo: Edusp, 2003.

KUNSCH, Margarida M Krohling. Comunicação Organizacional: contextos, paradigmas e abrangência conceitual. Revista Matrizes V 8, n 2, jul/dez 2014, São Paulo.

KUNSCH, Margarida. Planejamento de relações públicas na comunicação integrada. São Paulo, Summus, 2003.

KOSTLER, A.. Janus. São Paulo: Melhoramentos, 1981.

KOSSOY, Boris. Herule Florence, a descoberta isolada da fotografia no Brasil. 3ed.

Revista. São Paulo: Edusp, 2006.

KOSSOY, Boris. Fotografia e história. São Paulo, 3ed. Revista. São Paulo: Ateliê Editorial, 2009.

KOSSOY, Boris. Realidades e ficções na trama fotográfica. 4ed revista. São Paulo: Ateliê

Editorial , 2009.

KOSSOY, Boris. Os tempos da fotografia: o efêmero e o perpétuo. São Paulo: Ateliê

Editorial, 2007.

LOTMAN, I. A estrutura do texto artístico. Tradução de M. C. V. Raposo e A. Raposo.

Lisboa: Estampa, 1978.

LIBÂNEO, José Carlos. A didática e a aprendizagem do pensar e do aprender - a teoria histórico-cultural da atividade e a contribuição de Vasili Davidov. In Revista Brasileira de Educação, n 27, 2004.

LACERDA, Osvaldo. Teoria Elementar da Música. São Paulo: Ricordi, 1961.

LIPOVETSKY, Gilles. O império do efêmero. A moda e seu destino nas sociedades modernas. São Paulo: Companhia das letras, 2009.

LINDSTROM, Martin. Brandsense: a marca multissensorial: Tradução Beatriz Affonso Neves. Porto Alegre: Bookman, 2007. 
O império do efêmero. A moda e seu destino nas sociedades modernas.

Tradução: Maria Lúcia Machado. São Paulo: Companhia das letras, 2009.

LIPOVETSKY, Gilles; SERROY, Jean. A estetização do mundo. Viver na era do capitalismo artista. São Paulo: Companhia das letras, 2015.

MACHADO, Irene. Escola de Semiótica. A experiência de Tartu-Moscou para o Estudo da Cultura. São Paulo: Fapesp, 2003.

MACHADO, I.Inacabamento como modelo artístico de mundo. Bakhtiniana: São Paulo, v. 1, n. 3, p. 82-98, 1o sem. 2010.

Método, modelização e semiótica como ciência humana. In Revista de

Estudos Semióticos. Vol 9 n 2, p. 77-87.

Espaço semiótico em diálogos e fronteiras. In Revista Casa Cadernos

de Semiótica Aplicada, V 13, n 1, p. 87-119, 2015.

Semiótica da comunicação: da semiose da natureza à cultura. In

Revista Famecos Porto Alegre V 17, n2 maio/agosto de 2010, pg 89-97.

MACHADO, João Luis. Cinema e Educação, um grande encontro. Disponível no site: Arte e cidadania.orb.br. Acesso em 21 de Setembro de 2005.

MACHADO Arlindo. A emergência do observador. In Revista Galaxia n 3 pg 227-234, 2002.

MARCONDES, Danilo. Filosofia, linguagem e comunicação. Metodologia da Filosofia e Análise da Linguagem. São Paulo: Cortez, ( ano )

MATTELART Michele, ARMAND. História das teorias da comunicação. São Paulo: Loyola, 1999.

MATOS Olgária. A educação na transformação da sociedade. Congresso Educação e Transformação Social realizado na cidade de Santos em maio de 2002.

MITSURO Yanaze - Gestão de marketing e comunicação- avanços e aplicações.. Saraiva, 2007.

Retorno de investimentos em comunicação - disfusão.

MESSEDER, Carlos Alberto e REIS, Patrícia Cerqueira. Cadeia Produtiva da Comunicação Contemporânea com o Mercado - as arenas da comunicação. CAEPM, São Paulo, 2009.

MEDINA, Cremilda. Caminhos do Saber Plural. Novo pacto da ciência 7. São Paulo: Eca 1999.

1995.

Sobre vivências. No mundo do trabalho. São Paulo: Eca/Usp: Cnpq A arte de tecer o presente. São Paulo: Summus, 2003. 
- São Paulo. pg 37-47.

Novas manifestações e velhos paradigmas. Ano 7 - n2 jul/dez 2013

Dialética da Malandragem (caracterização das Memórias de um sargento de milícias)" in: Revista do Instituto de estudos brasileiros, $\mathrm{n}^{\circ}$ 8, São Paulo, USP, 1970, pp. 67-89.

O povo e o personagem. São Paulo: Ulbra, 1996.

1993.

GRECO, Milton Do hemisfério sol. São Paulo: ECA/USP: Cnpq,

Casas da viagem. De bem com a vida ou afetos do mundo. São

Paulo: Edição do autor, 2012.

Guia das almas. São Paulo: CJE/ECA/USP, 1993.

Casa da Serra, 2018.

A arte de tecer afetos. Signo da relação 2 - cotidianos. São Paulo:

Ato Presencial. Mistério e transformação. São Paulo: Casa da

Serra, 2016.

Ciência e Sociedade. Mediações jornalísticas. São Paulo: Estação

Ciência: CCS/USP, 2005.

MACHADO, Irene. Diagramas, explorações no pensamento-signo dos espaços culturais. São Paulo: Alameda, 2016.

Romanini, Anderson. Semiótica da cultura e Semiosfera. São Paulo: Annablume/ Fapesp, 2007.

O que há de novo no século XX? Sobre o curso Arqueologia das mídias. In Revista Galáxia n 3, pg 201-206, 2002.

MAIA Verônica. Como o teatro pode ser inserido como ferramenta pedagógica e instrumento de fomento cultural na educação? Disponível em endereço eletrônico no site artecidadania.org.br. Acesso em 21 de setembro de 2005.

MAFFESOLI, Michel. A parte do diabo. Resumo da subversão pós-moderna. Rio de Janeiro: Record, 2004.

MATURANA, Humberto, VARELA, Francisco J. A árvore do conhecimento, as bases biológicas da compreensão humana. São Paulo: Palas Athena, 2001.

MALAGODI, Maria Eugênia, CESNIK, Fábio de Sá. Projetos Culturais. Elaboração, aspectos legais, administração, busca de patrocínio. São Paulo: Instituto Pensarte, 2004.

MARIZ Vasco. História da música no Brasil. Rio de Janeiro, Editora Civilização Brasileira, 1983.

MEIRELES, Cecília. Obra poética. Rio de Janeiro: Nova Aguilar, 1987.

MILTON, John. Areopagítica. Discurso pela liberdade de imprensa ao parlamento da Inglaterra. Rio de Janeiro: Topbooks Editora, 1999. 
MORAES, Vinícius. Poesia completa e prosa. Rio de Janeiro: Nova Aguilar, 1987.

MORIN, Edgar. Os sete saberes necessários à Educação do Futuro. São Paulo: Cortez, 2004.

MORIN, Edgar. A cabeça bem-feita. Repensar a reforma reformar o pensamento. Rio de Janeiro: Bertrand Brasil, 2010.

NASSAR, Paulo. Tudo é comunicação. São Paulo: Lazuli,

NAKAGAWA, Regiane Miranda de Oliveira. A publicidade $\boldsymbol{e}$ a retórica do entretenimento. Trabalho apresentado no NP15 Semiótica da comunicação, no VII Encontro de Núcleos de Pesquisa Intercom.

NEGRI, Marina. A estética publicitária impressa. Janeiro, 2012. In. Revista Estética n 7 USP disponível em www.usp.br/estética/

NEMES Lilia. Casa do Zezinho: 10 anos de arte, educação e participação cultural. Disponível no site artecidadania.org.br. Acesso em 21 de setembro de 2005.

NOVAES, Adauto. Org. Ética. São Paulo: Companhia das Letras: Secretaria Municipal de Cultura, 1992.

OLIVIERI, Cristiane Garcia Olivieri. Cultura Neoliberal, Leis de incentivo como política pública de cultura. São Paulo: Insituto Pensarte, 2004.

OLIVEIRA, Gabriela Ayer; PEREZ, Clotilde. Meeting Points: Eventos como estratégia de comunicação e Marketing. Intercom 2010.

OLIVEIRA, Braulio org. Gestão de marketing. Ed. Pearson, São Paulo, 2012.

PONTE, Raquel; BRAIDA Frederico; ABAD Gisela. Os sistemas híbridos do Design: despertando os sentidos. Congresso Internacional de Pesquisa em Design, 2009.

PEREZ, Clotilde e BAIRON, Sergio. Comunicação e Marketing. Editora Futura, 2002.

PEREZ, Clotilde. Consumidores mais complexos e exigentes. Um desafio ético e estético para as marcas contemporâneas. In Revista Eletrônica de Gestão de Negócios. 124-144 pg.

PEREZ, Clotilde; KHAUAJA Romeiro Motta Daniela, JORGE, Mariana Aiex. Semiótica Aplicada ao Marketing: Contribuições para a Gestão de Marcas. XXXI Encontro da ANPAD, Rio de Janeiro 22 a 26 de setembro de 2007.

POMPEU, Bruno; PEREZ, Clotilde. A ecologia das marcas: metáfora orgânicas do hipersigno. In Intercom 2013.

PORTO Marta. Brasil e o mito da caverna de Platão. Disponível em endereço eletrônico no site artecidadania.org.br. Acesso em 21 de setembro de 2005.

PRIGOGINE, I.. O fim das certezas: tempo, caos e as leis da natureza. Trad. Roberto Leal. São Paulo: Editora Unesp, 2011.

RAMOS, Roberto Carlos. A arte de construir cidadãos. São Paulo: Celebris, 2004.

RESTREPO, Luis Carlos. O direito a Ternura. Petrópolis: Vozes, 1998. 
ROMANINI, Vinícius. Design como comunicação: uma abordagem semiótica. in Design em Artigos.

RUAS Claúdia. Artes plásticas na educação: além do simples fazer... Disponível no site: artecidadania.org.br. acesso em 21 de setembro de 2005.

TAME, David. O poder oculto da música. São Paulo: Cultrix, 1984.

TOURAINE, Alain. Crítica da modernidade. Rio de Janeiro: Vozes, 1994.

TRINDADE Eneus. Propaganda, identidade e discurso. Brasilidade Midiáticas. Porto Alegre: Sulina, 2012.

TRIGUEIRO, André. Mundo sustentável. Abrindo espaço na mídia para um planeta em transformação. São Paulo: Globo, 2005.

VIGOTSKI, L.S. A formação Social da Mente. São Paulo: Martins Fontes, 2003.

WILlIAMS, Raymond. Cultura e sociedade de Coleridge a Orwell. Petrópolis: Camara Brasileira do Livro, 2011.

WINNICOTT, D. W. Privação e Delinquência. São Paulo: Martins Fontes, 2002.

WOLF, Mauro. Teorias das comunicações de massa. São Paulo: Martins Fontes, 2008.

SANTOS, Fausto dos. A estética máxima. Chapecó: Editora Universitária, 2003.

SANTOS, Fátima Aparecida dos. Design: a conexão do corpo com o ambiente e a sintaxe do pensamento humano. In revista Tríades, out 2010.

SANTAELLA, Lúcia. Por que as comunicações e as artes estão convergindo? São Paulo, Paulus, 2005.

Matrizes da linguagem e pensamento. São Paulo: Fapesp, 2015.

SILVA, Roberto da Silva. Os filhos do governo. São Paulo: Ática, 1998.

SILVEIRA, Isabel Orestes.. Design, Semiose e Ação comunicativa. In Revista Tríades dezembro de 2011, pg 1-16.

SILVA, Eduardo Duarte Gomes da Silva. Dimensões estéticas e políticas dos desejos de cidade: o humanismo de pequenas solidões. In revista Galáxia, São Paulo, n 20, p 176-187, $\operatorname{dez} 2010$.

SOUSA, CARINA GONZALEZ Y. Ágape arte como a vida. São Paulo: Instituto da Moda, 2016.

Moda, 2017.

Amanajé, contos e reflexões. São Paulo: Instituto da

Folhas de Outono. São Paulo: Instituto da Moda, 2016.

SHAKESPEARE, William. 42 Sonetos. Rio de Janeiro: Nova Fronteira, 2005.

SFEZ, Lucien. A comunicação. São Paulo: Martins, 2007.

STJERnfElZ, F. Diagrams as Centerpiece of a Peircean Epistemology. Transactions of the Charles S. Peirce Society. Summer, 2000, vol XXXVI, n 3. 
SETÚBAL Maria Alice, ÉRNICA Maurício. Porque educação é cultura? Disponível no endereço eletrônico: http://www.cenpec.org.br/artigo_01.php Acesso em 16 de maio de 2005 .

TEIXEIRA, Anísio, VIRGINIO Alexandre Silva. As pedras do caminho e o caminho das pedras o do processo de construção de uma cultura de justipaz. Disponível no endereço eletrônico: http://www.paulofreire.org/frontera_2.htm acesso em 13 de maio de 2005.

ULTRAMARI, Clovis. O fim das utopias urbanas. São Paulo: Pedroso Alvarenga, 2005.

VIANA Francisco. A reputação: a imagem para além da imagem. Coleção ABERJE. Vol 1. 2006.

VALCÁRCEL Amelia. Ética um valor fundamental. Eles e nós: estamos preparados para o multiculturalismo? Disponível no site Sesc Vila Mariana, de encontro realizado em 16 a 19 de outubro de 2001.

XAVIER, I, org. O cinema no século. Rio de Janeiro: Imago, 1996.

KIAN, Fátima Aparecida ( org). Direitos humanos e aspectos relevantes do direito. São Paulo: Pillares, 2016.

KREMER Nair. Deslocamentos, experiências de Arte-educação na periferia de São Paulo. São Paulo: Edusp, 2003.

WILliAMS Raymond. Cultura e Sociedade. São Paulo: Companhia Editorial Nacional, 1969.

WEERTHEIM Jorge. Por uma visão política da cultura. Disponível em : artecidadania.org.br. Acesso em 21 de setembro de 2005.

ZENONE, Luiz Claudio. Marketing Social. São Paulo: Thomson Learning, 2006. 